\title{
Reservations to UN-human rights treaties : ratify and ruin?
}

Citation for published version (APA):

Lijnzaad, L. (1994). Reservations to UN-human rights treaties : ratify and ruin? [Doctoral Thesis, Maastricht University]. Rijksuniversiteit Limburg. https://doi.org/10.26481/dis.19941216II

Document status and date:

Published: 01/01/1994

DOI:

10.26481/dis.19941216\|l

Document Version:

Publisher's PDF, also known as Version of record

\section{Please check the document version of this publication:}

- A submitted manuscript is the version of the article upon submission and before peer-review. There can be important differences between the submitted version and the official published version of record.

People interested in the research are advised to contact the author for the final version of the publication, or visit the DOI to the publisher's website.

- The final author version and the galley proof are versions of the publication after peer review.

- The final published version features the final layout of the paper including the volume, issue and page numbers.

Link to publication

\footnotetext{
General rights rights.

- You may freely distribute the URL identifying the publication in the public portal. please follow below link for the End User Agreement:

www.umlib.nl/taverne-license

Take down policy

If you believe that this document breaches copyright please contact us at:

repository@maastrichtuniversity.nl

providing details and we will investigate your claim.
}

Copyright and moral rights for the publications made accessible in the public portal are retained by the authors and/or other copyright owners and it is a condition of accessing publications that users recognise and abide by the legal requirements associated with these

- Users may download and print one copy of any publication from the public portal for the purpose of private study or research.

- You may not further distribute the material or use it for any profit-making activity or commercial gain

If the publication is distributed under the terms of Article $25 \mathrm{fa}$ of the Dutch Copyright Act, indicated by the "Taverne" license above, 
RESERVATIONS TO UN-HUMAN RIGHTS TREATIES RATIFY AND RUIN? 


\title{
A sales edition of this dissertation is published by Martinus Nijhoff Publishers, Dordrecht/Boston/London as \\ Vol. 38 in the Series entitled 'International Studies in Human Rights' in co-operation with the T.M.C. Asser Instituut, The Hague \\ ISBN 0-7923-3256-3
}

\begin{abstract}
Stichting T.M.C. Asser Instituut
Institute for Private and Public International Law, International Commercial Arbitration and European Law
\end{abstract}

22 Alexanderstraat, $2514 \mathrm{JM}$ The Hague, The Netherlands Tel. (0)70-3420300 - telefax: (0)70-3420359

The T.M.C. Asser Instituut was founded in 1965 by the Dutch universities offering courses in international law to promote education and research in the fields of law covered by the departments of the Institute: Private International Law. Public International Law, including the Law of International Organisations, Law of the European Communities and International Commercial Arbitration. The Institute discharges this task by the establishment and management of documentation and research projects, in some instances in co-operation with non-Dutch or international organisations, by the dissemination of information deriving therefrom and by publication of monographs and series. In addition, the Institute participates in the editing of the Yearbook Commercial Arbitration and in the editing and publishing of, inter alia, the Netherlands International Law Review and the Netherlands Yearbook of International Law.

The Institute provides the nine university law faculties in the Netherlands with a research assistant's post-graduate course in international and European law, and assistance to Asser College Europe, a partnership venture with eastern and central European countries which offers a framework for the organisation and implementation of research and educational projects. 


\title{
RESERVATIONS TO UN-HUMAN RIGHTS TREATIES
}

\author{
Ratify and Ruin?
}

\section{PROEFSCHRIFT}

ter verkrijging van de graad van doctor aan de Rijksuniversiteit Limburg te Maastricht, op gezag van de Rector Magnificus, Prof.dr H. Philipsen, volgens het besluit van het College van Dekanen, in het openbaar te verdedigen op vrijdag 16 december 1994 om 14.00 uur

door

Elisabeth Lijnzaad 


\title{
Promotores:
}

\author{
Prof.dr Th.C. van Boven
}

Prof.dr C. Flinterman

Beoordelingscommissie:

Prof.dr B.E.F.M. de Witte (voorzitter)

Prof.dr C.M. Chinkin (University of Southampton)

Prof.dr E.W. Vierdag (Universiteit van Amsterdam)

Mr A.W. Heringa 
ERWIN: Het probleem van de werkzaamheid van die conventies is hetzelfde als dat van de draagkracht die je kunst kan hebben, in termen van een intellectuele reflectie over de overbrenging van je materiaal.

[Geerten Meijsing, De venerische kunsten, Amsterdam 1989, 154]

\section{VOORWOORD}

Ook al zijn de gedachten van deze Erwin uit hun verband gerukt, het mag duidelijk zijn dat de consciëntieuze lezer een hele verhandeling over een betrekkelijk technisch volkenrechtelijk probleem wacht. Dit boek gaat over de werkzaamheid van conventies, en het is een overbrenging van mijn, misschien zelfs wel intellectuele, reflectie over het materiaal. Toch blijft het waarschijnlijk hocus pocus voor veel lezers en is het passend me, bij de aanvang van dit proefschrift te verontschuldigen voor de lengte ervan, en het feit dat de hoofdstukken over de vier te behandelen VN mensenrechtenverdragen in hoge mate uit taaie kost bestaan. Ter verontschuldiging aan de toegewijde lezer die oprecht van plan is deze hoofdstukken door te worstelen, moge dienen dat deze saaie kost minimaal even lastig was om te bestuderen. Sterker nog, VN documenten zijn in het algemeen weinig leuk, en zeker niet in deze hoeveelheden.

Een proefschrift schrijven is leuk en lastig. Beide indrukken strijden om de voorrang. Lastig, omdat dit proefschrift over een betrekkelijk ongrijpbaar probleem gaat. Ik heb soms gedacht me aan dit onderwerp te vertillen, welke indruk werd bevestigd door de geringe hoeveelheid literatuur op dit terrein. Er waren worstelingen met het begrip van het probleem, en met de structuur van dit verhaal. Soms had ik het liefst het begrip "object and purpose" uit mijn gedachten gebannen en het manuscript in de Maas gegooid.

Hoe lastig ook, het is tegelijkertijd een leerzame ervaring geweest: merken dat het niet slechts om het verzamelen van feitenkennis en het systematisch ordenen daarvan draait, maar dat ook creativiteit een belangrijke rol speelt. Het staat niet vaak in voorwoorden, maar zulke puzzels hebben hun eigen aantrekkingskracht: of je het wilt of niet, er gaat een zekere verslaving uit van een verzameling losse eindjes die in een systeem zouden moeten passen. Met losse eindjes duid ik hier voor het gemak het soms ondoorgrondelijke handelen van staten, in combinatie met ondoorzichtige regels van verdragenrecht als de "doel en strekking" regel aan. Er zou toch een systeem moeten zijn, een manier om het probleem van de voorbehouden bij mensenrechtenverdragen te begrijpen, leek mij. Na een fase van twijfel, een periode van het herschikken van materiaal in elke denkbare volgorde, ontstaat opeens (onder de douche, tijdens het boodschappen doen) inzicht over de juiste ordening. Nadat anderen kritiek hebben geleverd kan het verhaal aangescherpt worden, maar blijkt de kern intact te 
blijven. Er blijkt iets van de studeerkamerwijsheid te kloppen als anderen die aan een kritische toets onderwerpen. Het leerzame van zulke ervaringen staat ten onrechte nauwelijks in de belangstelling als er gesproken wordt over het ploeteren aan proefschriften, maar wat mij betreft is dat buitengewoon waardevol geweest. Ondanks de kwijtgeraakte documenten of in de computer zoekgeraakte stukken tekst die als laatste loodjes het afronden van een proefschrift tot een tergende bezigheid maken.

Het voorwoord is de plaats om familie en vrienden te bedanken voor hun steun bij het tot stand komen van een boek waar zij meestal niet veel leesplezier aan zullen beleven. Dat wil niet zeggen dat deze bedankingen daarom minder oprecht zijn, natuurlijk wil ik dierbaren, geliefden en andere vertrouwelingen op deze plek van mijn waardering laten blijken.

In de eerste plaats wil ik mijn ouders bedanken: zij wisten zeker dat er uiteindelijk een boek tot stand zou komen, ook al twijfelde ik daar soms aan. Voorzover ze daar prijs op stellen delen mijn broers en schoonzussen in diezelfde dank.

Een bijzonder woord van dank wil ik richten tot mijn paranimfen Liesbeth van Woerden en Malva Driessen. Liesbeth, omdat ze al zolang ik mij kan herinneren mijn beste vriendin en paranimf is. Toen we rondeleidsters waren; en nu we zogezegd volwassenen zijn. Malva, omdat het een genoegen is een kamergenote te hebben gehad waarmee even makkelijk over vrijers als over verdragen te praten is. Jullie beider vriendschap lijkt vanzelfsprekend, maar dit is nu eens een mooie plek om te zeggen hoezeer ik aan jullie beiden gehecht ben.

Daarnaast moeten mijn vroegere collega's in de vakgroep Internationaal en Europees Recht in Maastricht genoemd worden. Mijn promotoren Theo van Boven en Kees Flinterman wisten mij met hun grote kennis en ervaring op het gebied van de rechten van de mens af te houden van een al te positivistische benadering van het onderwerp van mijn proefschrift. Als buitengewoon liberale promotoren lieten ze mij een grote vrijheid in het bepalen van de reikwijdte en omvang van mijn onderzoek. Soms was dat lastig, bijvoorbeeld toen ik meende dat een vergelijking tussen dertien verdragen haalbaar was. Het heeft er in elk geval toe geleid dat ik ervarenderwijs zicht kreeg op de structuur en samenhang van het verhaal.

Het was een plezier samen te werken met Fons Coomans, Fred Grünfeld, Ingrid Westendorp en Harmen van der Wilt die elk op zijn of haar eigen wijze mijn wijsneuzige zekerheden ter discussie stelden. Tegenspraak vind ik altijd leuk. De sfeer in de projectgroep Mensenrechten maakte het mogelijk expertise op te bouwen op het onontgonnen terrein van internationaal recht en vrouwen. Het feministisch-juridisch discours stelt fundamentele uitgangspunten van het volkenrecht ter discussie, en ik heb het proefschrift regelmatig terzijde gelegd om aan die discussie deel te nemen. Ook de leden van de kerngroep Vrouw en Recht, en in het bijzonder Joyce Hes en Lucy Willems met wie ik het genoegen 
deel contractonderzoek te doen over zoiets belangwekkends als de conceptualisering van zachte boter wil ik bedanken voor de goede samenwerking. Aan de opeenvolgende student-assistenten van de vakgroep, met name Annette Brouwer en Judith Goossens, ben ik dank verschuldigd voor de nauwgezetheid waarmee ze lastige vragen voor me uitzochten. Kortom, Maastricht bleek een aangename omgeving om te wonen en te werken, niet in de laaste plaats door de informele sfeer aan de rechtenfaculteit.

Bert Vierdag heeft aan de wieg gestaan van mijn belangstelling voor het verdragenrecht. Ik herinner me met plezier zijn colleges verdragenrecht op vrijdagochtenden in de VN bibliotheek aan de Herengracht in Amsterdam, begin jaren tachtig. Wat op het eerste gezicht erg saai leek, bleek onder zijn leiding een fascinerend onderdeel van het volkenrecht. Ik ben blij dat zijn enthousiasme voor de bronnen van het volkenrecht, en het verdragenrecht in het bijzonder, zo aanstekelijk is geweest.

Tenslotte, een van de eerste schrijfsters over het probleem van voorbehouden bij het Vrouwenverdrag, Edith Oeser, heeft al gewaarschuwd voor de valkuilen op dit terrein. In 1988 schreef ze: "Every international law expert knows that reservations to multilateral treaties, notably human rights conventions, are very tricky." Als ik, ondanks haar waarschuwing, in die valkuilen terecht ben gekomen, is dat gelukkig vooral mijn eigen fout.

Maastricht, oktober 1994

Liesbeth Lijnzaad

1. E.Oeser, Legal questions in the Committee on the Elimination of Discrimination against women, in: 14 Bull. GDR Cttee. Human Rts. 1988, 86-98, at 93. 


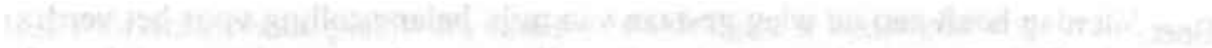
and

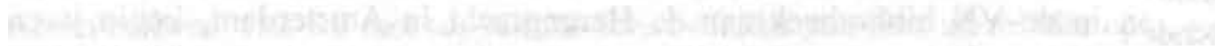

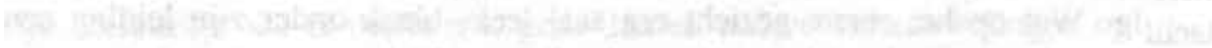

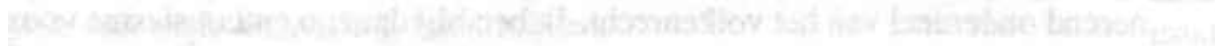

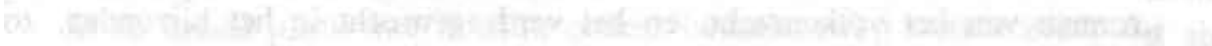

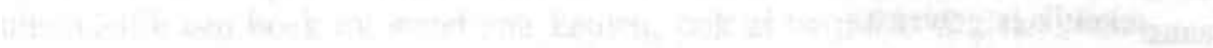

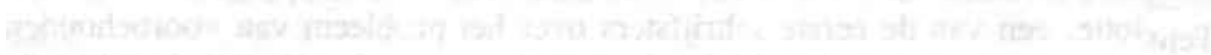

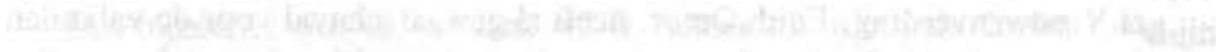

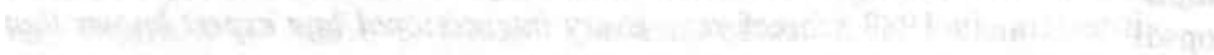
W,

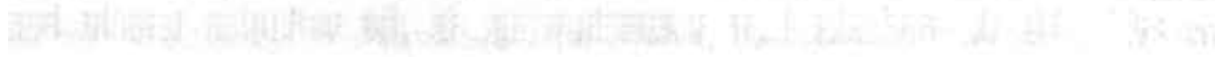

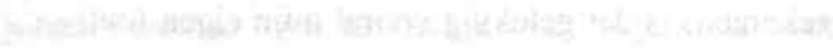

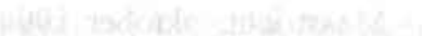

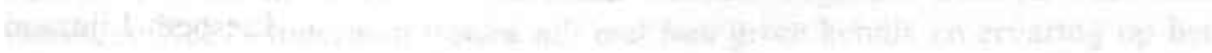

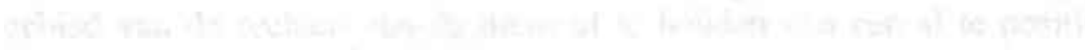

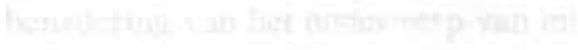

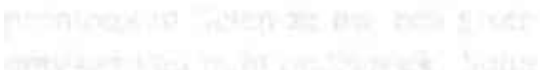

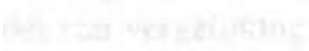

anding

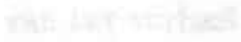

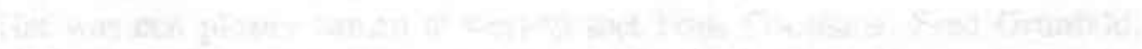

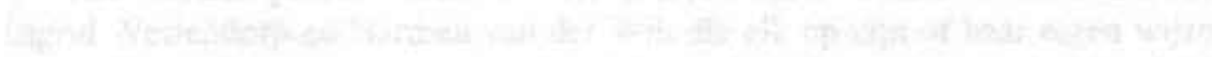

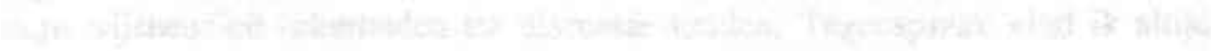

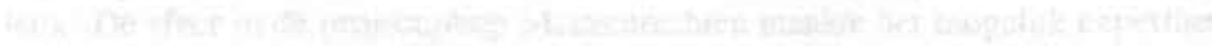

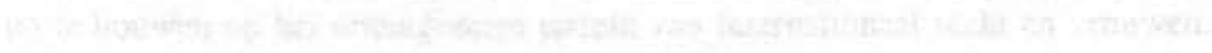

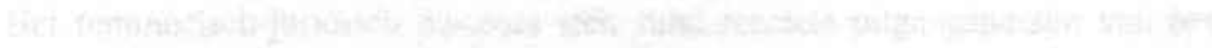

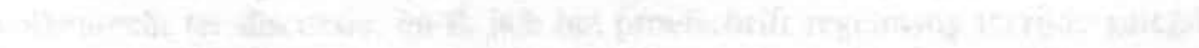

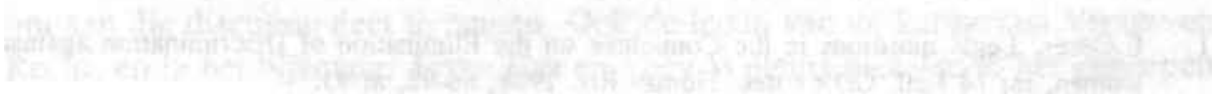


1. RESERVATIONS TO HUMAN RIGHTS TREATIES IN THE

AFTERMATH OF THE GENOCIDE CASE

1. THE OBJECT AND PURPOSE OF THIS STUDY 3

2. THE STRUCTURE OF THIS STUDY

PART II - Theoretical questions

2. THE LAW APPLICABLE TO RESERVATIONS

1. THE GENOCIDE CASE 15

1.1. The problem of reservations to the Genocide Convention 16

1.2. The Advisory Opinion on Reservations to the Genocide Convention

1.2.1. The (majority) Opinion 18

1.2.2. The Joint Dissenting Opinion $\quad 23$

1.2.3. The Individual Dissenting Opinion $\quad 25$

1.3. The Genocide Case reconsidered 26

2. THE DEFINITION OF "RESERVATION" 29

2.1. Definitions prior to the Vienna Convention $\quad 30$

2.2. The definition in the Vienna Convention 31

2.3. Definitions since the Vienna Convention 35

3. THE VIENNA CONVENTION SYSTEM

3.1. The formulation of reservations, article 19 VCLT 38

3.1.1. Explicit rules on reservations, articles $19 . \mathrm{a}$ and $19 . \mathrm{b}$

3.1.2. The content of article 19.c 39

3.2. Acceptance of reservations, article 20 VCLT 42

3.2.1. The acceptance of a reservation, articles 20.4.a and 20.4.c

3.2.2. Objections to a reservation, article $20.4 . \mathrm{b} \quad 43$

3.2.3. Tacit acceptance, article $20.5 \quad 45$

3.2.4. A priori acceptance, article $20.1 \quad 46$

3.3. The legal effects of reservations, article 21 VCLT 47

3.4. Withdrawal of reservations and objections, article $22=50$

3.5. Procedural aspects, article $23 \quad 50$

3.6. Treaty relations on the basis of reservations 50

3.6.1. The acceptance of compatible reservations 51

3.6.2. Objections to compatible reservations 51 
3.6.3. Incompatible reservations can be accepted

3.6.4. Objections to incompatible reservations

3.7. Reconsideration of the Vienna Convention system 53

4. THE RELEVANCE OF THE OBJECT AND PURPOSE RULE

4.1. Ex injuria non oritur ius 55

$\begin{array}{ll}\text { 4.2. Good faith } & 57\end{array}$

4.3. The importance of article 19.c 59

5. THE ISSUE OF INTERPRETATIVE DECLARATIONS

6. OF UNILATERALITY AND RECIPROCITY 65

6.1. Shades of unilaterality 65

6.2. The dialectics of reciprocity 67

6.3. Reciprocity as a creative force $\quad 69$

6.4. The supervisory side of reciprocity 70

7. THE TIME ELEMENT IN THE APPLICATION OF THE VIENNA CONVENTION

7.1. Questions of inter-temporal law in respect of the application of the Vienna Convention

7.2. Articles $19-23$ of the Vienna Convention as customary law

3. RESERVATIONS TO HUMAN RIGHTS TREATIES

1. REASONS FOR MAKING RESERVATIONS

2. THE "OBJECT AND PURPOSE" OF A HUMAN RIGHTS TREATY

2.1. Defining the object and purpose of a human rights treaty

2.1.1. Object and purpose in relation to the importance of human rights treaties

2.1.2. Object and purpose in relation to treaty-based human rights protection

2.1.3. Object and purpose in relation to the substance of a human rights treaty

2.1.4. Object and purpose in relation to ways and means of implementing human rights obligations

2.2. Monitoring the "object and purpose" obligation

2.3. The interpretation of human rights instruments: coexistence and coherence

3. THE QUEST FOR UNIVERSALITY

3.1. The universality of human rights law

3.2. The arithmetics of universality

3.3. A problem of tools

3.4. Reciprocity in human rights treaty law

4.1. European Convention for the Protection of Human Rights and Fundamental Freedoms 
4.2. American Convention on Human Rights 123

4.2.1. The Effect of Reservations case 124

4.2.2. Restrictions to the Death Penalty case 125

PART III - Reservations in practice

4. RESERVATIONS TO THE INTERNATIONAL CONVENTION ON THE ELIMINATION OF ALL FORMS OF RACIAL DISCRIMINATION

1. INTRODUCTION TO THE CONVENTION

1.1. Content of the Convention

1.2. The law applicable to reservations 132

1.3. Declarations and reservations 140

2. REACTIONS OF THE STATES PARTIES 147

$\begin{array}{ll}\text { 2.1. Objections } & 147\end{array}$

2.2. State Party meetings $\quad 148$

2.3. Withdrawal of reservations 148

3. PRACTICE OF THE COMMITTEE 149

3.1. Reporting procedure, article 9 CERD 149

3.2. Individual complaints, article 14 CERD 174

4. CONCLUSIONS REGARDING THE RESERVATIONS TO THE CONVENTION ON THE ELIMINATION OF RACIAL DISCRIMINATION $\quad 174$

4.1. The reservations 174

4.2. The role of States 178

4.3. The role of the Committee 179

4.4. Prospects 183

5. RESERVATIONS TO THE INTERNATIONAL COVENANT ON CIVIL. AND POLITICAL RIGHTS

1. INTRODUCTION TO THE COVENANT 185

1.1. Content of the Covenant 185

1.2. The law applicable to reservations 185

1.2.1. Reservations to the Covenant 185

1.2.2. Reservations to the Optional Protocol 196

1.2.3. Reservations to the Second Optional Protocol aiming at the abolition of the Death Penalty 196

$\begin{array}{ll}\text { 1.3. Declarations and reservations } & 198\end{array}$

1.3.1. The Covenant 198

1.3.2. Declarations and reservations relating to the Optional Protocol

1.3.3. Declarations and Reservations to the Second Optional Protocol aiming at the Abolition of the Death Penalty

2. REACTIONS OF THE STATES PARTIES 222 
2.2. State Party meetings

2.3. Withdrawal of reservations

3. PRACTICE OF THE COMMITTEE

3.1. Reporting Procedure, article 40 CCPR

3.2. Individual Complaints, the Optional Protocol 280

4. CONCLUSIONS

4.1. The reservations

4.2. The role of States

4.3. The role of the Human Rights Committee

4.3.2. Reservations under the Optional Protocol

6. RESERVATIONS TO THE CONVENTION ON THE ELIMINATION OF ALL FORMS OF DISCRIMINATION AGAINST WOMEN

1. INTRODUCTION TO THE CONVENTION

1.1. Content of the Convention

1.2. The law applicable to reservations

1.3. Reservations and declarations

1.3.1. Pacta sunt servanda

1.3.2. National legislation

1.3.3. Conflicting human rights

323

2. REACTIONS OF THE STATES PARTIES

2.1. Objections

2.2. State Party meetings

2.3. Withdrawal of reservations

2.4. Consultations in other forums

2.4.1. The Secretary General's survey

2.4.2. Discussions in the Third Committee (General Assembly)

2.4.3. A role for the International Court of Justice?

3. PRACTICE OF THE COMMITTEE

3.1. Reporting procedure

4. CONCLUSIONS REGARDING RESERVATIONS TO THE CONVENTION

4.1. The reservations

4.2. The role of States

4.3. The role of the Committee on the Elimination of Discrimination against Women

7. RESERVATIONS TO THE CONVENTION AGAINST TORTURE AND OTHER CRUEL. INHUMAN OR DEGRADING TREATMENT OR PUNISHMENT

1. INTRODUCTION TO THE CONVENTION AGAINST TORTURE

1.2. The law applicable to reservations 
2. REACTIONS OF THE STATES PARTIES $\quad 380$

$\begin{array}{ll}\text { 2.1. Objections } & 380\end{array}$

2.2. State Party meetings $\quad 384$

2.3. Withdrawal of reservations $\quad 385$

2.4. Other consultations $\quad 386$

3. PRACTICE OF THE COMMITTEE AGAINST TORTURE $\quad 386$

3.1. Reporting procedure, article 19 CAT $\quad 386$

3.2. Individual complaints, article 22 CAT 391

4. CONCLUSIONS REGARDING THE RESERVATIONS TO THE CONVEN-

TION AGAINST TORTURE

4.1. The reservations

4.2. The role of States

4.3. The role of the Committee against Torture

4.4. Prospects

PART IV - Conclusions

8. RESTORING THE RUINS, CONCLUDING REMARKS

1. SOME ESSENTIAL ISSUES

1.1. The universality debate

1.2. The lack of correlation between the law of treaties and human rights law

1.3. Reservations are not necessarily "wrong" 402

2. THE GENOCIDE CASE IN RETROSPECT

3. THE VIENNA CONVENTION RULES

404

4. RESERVATIONS IN PRACTICE

4.1. Role of the States Parties

4.2. Role of the supervisory Committees

4.2.2. The individual complaints procedure

4.3. The application of the "object and purpose" rule

5. A DRAFT RESERVATIONS CLAUSI:

6. PROSPEC'IS FOR THE FUTURE 


\section{ABBREVIATIONS}

ACHR

AdV

AFDI

AJIL

ALJ

BYIL

CalWILJ

CAT

CC

CCPR

CEDAW

CERD

C.HRY

CornelliLJ

D\&R

DenverJILP

ECHR

ECOSOC

EJIL

EuGRZ

GA Res

GYbIL

HarvILJ

HRLJ

HRQ

HRR

ICJ Rep

IC.LQ

ILC

ILR

IMCO

IowaLR

IsrYbHR

IYIL

JILP

MichJIL

MLR
American Convention on Human Rights

Archiv des Völkerrechts

Annuaire Français de Droit International

American Journal of International Law

Australian Law Journal

British Yearbook of International Law

California Western International Law Journal

Convention against Torture, and other cruel, inhuman or degrading treatment or punishment

Code Civil

Covenant on Civil and Political Rights

Convention on the Elimination of all forms of Dis-

crimination against Women

Convention on the Elimination of all forms of Racial

Discrimination

Canadian Human Rights Yearbook

Cornell International Law Journal

Decisions and Reports of the European Commission of Human Rights

Denver Journal of International Law and Policy

European Convention for the Protection of Human Rights and Fundamental Freedoms

Economic and Social Council

European Journal of International Law

Europäische Grundrechte Zeitschrift

United Nations General Assembly Resolution

German Yearbook of International Law

Harvard International Law Journal

Human Rights Law Journal

Human Rights Quarterly

Human Rights Review

International Court of Justice Reports

International and Comparative Law Quarterly

International Law Commission

International Law Reports

International Maritime Consultative Organisation

Iowa Law Review

Israel Yearbook on Human Rights

Italian Yearbook of International Law

NY University Journal of International Law and Politics

Michigan Journal of International Law

The Modern Law Review 


$\begin{array}{ll}\text { NILR } & \text { Netherlands International Law Review } \\ \text { NJB } & \text { Nederlands Juristen Blad } \\ \text { NJCM Bull. } & \text { NJCM Bulletin } \\ \text { NordicJIL } & \text { Nordic Journal of International Law } \\ \text { OP } & \begin{array}{l}\text { Optional Protocol to the Covenant on Civil and Political } \\ \text { Rights }\end{array} \\ \text { PYIL } & \text { Politic Yearbook of International Law } \\ \text { RBDI } & \text { Revue Belge de Droit International } \\ \text { RdC } & \text { Recueil des Cours de l'Académie de Droit International de } \\ & \text { la Haye } \\ \text { RDH } & \text { Revue des Droits de l'Homme } \\ \text { RGDIP } & \text { Revue Générale de Droit International Public } \\ \text { RIAA } & \text { Reports of International Arbitral Awards } \\ \text { RSCDPC } & \text { Revue de Science Criminelle et de Droit Pénal Comparé } \\ \text { SOP } & \text { Second Optional Protocol (aiming at the abolition of the } \\ & \text { death penalty) to the Covenant on Civil and Political Rights } \\ \text { SYbIL } & \text { Soviet Yearbook of International Law } \\ \text { TILJ } & \text { Texas International Law Journal } \\ \text { UNTS } & \text { United Nations Treaty Series } \\ \text { VaJTL } & \text { Vanderbilt Journal of Transnational Law } \\ \text { VCLT } & \text { Vienna Convention on the Law of Treaties } \\ \text { VJIL } & \text { Virginia Journal of International Law } \\ \text { YaleJIL } & \text { Yale Journal of International Law } \\ \text { YbECHR } & \text { Yearbook of the European Convention on Human Rights } \\ \text { YbILC } & \text { Yearbook International Law Commission } \\ \text { YJWPO } & \text { Yale Journal of World Public Order } \\ \text { ZAÖRV } & \text { Zeitschrift für auslandisches öffentliches Recht und } \\ & \text { Völkerrecht } \\ \text { ZfRechtspolitik } & \text { Zeitschrift für Rechtspolitik } \\ & \end{array}$




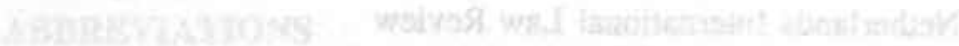

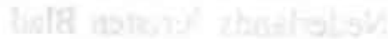

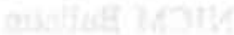

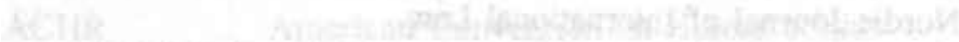

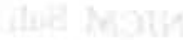

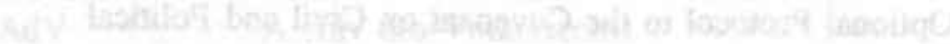

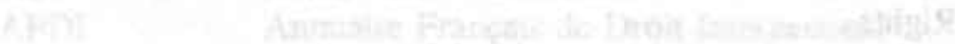

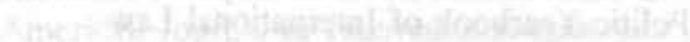

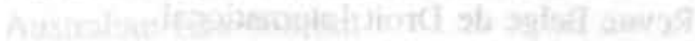

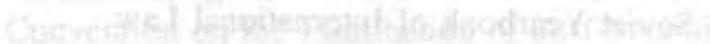

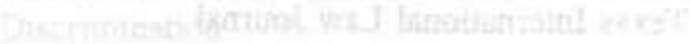

IfHP f'

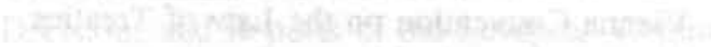


PART I

INTRODUCTION 


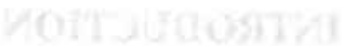




\section{RESERVATIONS TO HUMAN RIGHTS TREATIES IN THE AFTER- MATH OF THE GENOCIDE CASE}

\section{THE OBJECT AND PURPOSE OF THIS STUDY}

When embarking on a study of reservations to human rights treaties, one could be tempted to consider it a hopeless puzzle. By making reservations, States frequently undermine essential rules, and indeed essential human rights guarantees. On reading the Bangladeshi reservation to the Women's Convention $^{1}$, indicating that it will implement this convention in accordance with Islamic Sharia law, the advocates of women's rights cannot but be extremely sceptical about the possible contribution of the Convention (as amended by the reservation) to the improvement of the situation of women in Bangladesh. Similarly, the reservation made by the Yemen Arab Republic excluding articles 5.c (political rights), 5.d.iv (right to marriage), 5.d.vi (right to inherit) and 5.d.vii (right to freedom of thought, conscience and religion) on acceding to the Convention on the Elimination of Racial Discrimination ${ }^{2}$ seems to destroy the aim of the Convention, that is the elimination of racial discrimination with respect to the entitlement to human rights.

These are two examples, but going through the lists of reservations many more appear. The impression is that many States, when ratifying, at the same time ruin the treaty. Reservations restrict the potential domestic effect of a human rights treaty, and a large number of reservations made by a great many States will turn a human rights instrument into a moth-eaten guarantee. Reservations to human rights instruments are questionable, they instantly create a feeling of unease. It does not seem proper to exclude provisions from a treaty obviously meant to protect people, as human rights treaties are ${ }^{3}$.

Yet, this is a black-and-white picture. It is too simple to consider all reservations suspect, and to take all reserving states to be acting in bad faith. Though the "bad guys" in the following will be the reserving States Parties with their incomplete and fragmented implementation of human rights instruments, their attitude is not necessarily worse than that of States that ratify and fail to implement the obligations. Through a reservation partial implementation is explicit, and usually legitimate. Ratifying the complete treaty and failing to implement it, which constitutes a breach of treaty, may go largely unnoticed. The effects may not be significantly different for the beneficiaries, however.

Reservations are a relatively new issue in the law of treaties. It was only during the interbellum that the number of reservations increased, and the interna-

1. New York, 18 December 1979.

2. New York, 21 December 1965.

3. M.Coccia, Reservations to multilateral treaties on human rights, in: 15 CalWIL.J 1985, 151, at 16:"..the terms 'reservation' and 'human right' appear to contradict one another." 
tional community felt the need to reflect on their legal effects. At the time, the law of treaties was relatively simple and straight-forward, the number of participating States was relatively small and the number of issues dealt with in international law was relatively limited. In such a situation it was possible to cope with the odd State that wanted to opt out of particular provision in a treaty.

Human rights law developed after the Second World War; and the Genocide case of the International Court of Justice was to focus the attention on the intricacies of the relationship between the option provided by the law of treaties to make reservations, and the protection of human rights through treaties. The majority opinion on Reservations to the Genocide Convention, indicating that "object and purpose of the treaty" would be the future yardstick for dealing with reservations, provided a rule that seemed adequate at first sight. More than thirty years after the Advisory Opinion, the question of reservations to human rights instruments reappeared when the reservations to the Women's Convention seemed to fundamentally restrict the potential impact of this convention.

Reservations can be made, and indeed are frequently made where it concerns human rights treaties. Thus, it is necessary to study the rules of the law of treaties on reservations, in order to see if and how these general rules can be applied to reservations to human rights treaties, and to see how reservations have been dealt with in practice under a number of human rights instruments. At first sight the Vienna Convention on the Law of Treaties' rule on the "object and purpose of the treaty", reflecting the Genocide Opinion, seems to provide a clear yardstick for dealing with the issue of reservations to human rights treaties. However, the rule is transparent and opaque at the same time, and proves to be distinctly confusing when applied in practice.

The book's preoccupation (that is, the author's preoccupation) with the law of treaties as a framework for reference must be mentioned. Whether or not the author is a self-confessed prisoner of the Vienna Convention on the Law of Treaties will be for the reader to decide. Focusing on the law of treaties' aspects of the problem was prompted by the fact that the subject of this research lies at the intersection of the law of treaties and human rights law. If one were to follow the dogmas and theories in either field, this would lead to the conclusion that reservations are the necessary consequence of the structure of the present day law of treaties, even if an unpleasant consequence; or alternatively, that reservations are a sign of the superficial interest states take in the international protection of human rights. Be this as it may, to stop at either conclusion would be very simplistic, and could not lead to any improvements in the present situation.

The initial object of this study was the problem of reservations to the Women's Convention. Reservations seem to have turned this Convention into a weak instrument, seemingly unable to contribute to the goals it was designed for: the elimination of discrimination against women. Reservations to the Women's 
Convention worried my colleague the late Loes Brünott, who suggested a study of these reservations be undertaken. Although the question of the validity and legality of reservations poses itself forcefully with respect to the Women's Convention, it was thought useful to widen the scope and include other human rights instruments as well ${ }^{4}$. A comparison of the practice under other instruments could lead to an exchange of strategies. The concept of international human rights law as a coherent and interdependent set of rules has contributed to this choice, as well as the issue of the universality of human rights law, which is a focal point in the research conducted by the Centre for Human Rights at the University of Limburg.

There has always been an implicit suggestion", also in the Genocide Opinion", that allowing reservations contributes to increasingly universal acceptance of human rights instruments. Yet, this depends on the sacrifices in terms of substance, necessary to attain the goal of universality. The question that should be asked is whether the emphasis on universality is at the expense of the integrity of the treaty, and thus of the protection of the substantive rights therein. To rephrase LeBlanc's remark: "Has the willingness of the majority [in the Genocide Opinion, EL] to compromise the integrity of a convention in the hope of achieving universality been to no avail?"7?

Little has been written about reservations to human rights instruments concluded within the United Nations. The issue has primarily arisen with respect to the European Convention for the Protection of Human Rights and Fundamental Freedoms ${ }^{8}$, obviously prompted by the imaginative case-law of European Commission and European Court in recent years. The differences between regional and world-wide systems of human rights protection need not be elaborated upon here. It may suffice to say that the non-comparability of the supervisory mechanisms would have made it complicated to present an overview of the ways to deal with reservations. I therefore chose to discuss the impact of reservations to human rights treaties concluded within the United Nations. Universality as a guiding principle also pointed to the study of instruments concluded under the aegis of the United Nations.

Originally this study focused on the legality of far-reaching reservations and the exact scope of the obligation not to make reservations contrary to "the object

4. As H.Charlesworth, C.Chinkin and S.Wright, Feminist approaches to international law, in 85 AIIL. 1991; 613-645 at 634 wrote:"No single approach ean deal with the complexity of international legal organizations, processes and rules, or with the diversity of women's experiences within and outside those structures."

5. J.K.Gamble. Reservations to multilateral treaties: a macroscopic view of state practice, in: 74 A.IL 1980, $372-394$ at 372; C. Logan Piper. Reservations to multilateral treaties: the goal of universality, in: 71 lowaLR 1985, 295-322 at 298.

6. Reservations to the Convention on the Prevention and Punishment of the Crime of Genocide. 28 May 1951. ICJ Rep. 1951 15-55, at 21-22. 23-24.

7. L.J.LeBlanc. The United States and the Genocide Convention, Durham 1991 (hereailer: LeBlanc. Genocide Convention), at 218.

8. Rome. 4 November 1950. 
and purpose of the treaty". As research progressed, other issues emerged. A question that became increasingly important was simply whose problem reservations are. If related to foreseeable impact, one would assume that it was the problem of the individuals in the reserving States. However, the public at large has little knowledge of these intricate legalistic questions. Reservations lead to the unilateral exclusion, or restriction of provisions of a human rights instrument, that might be of a very fundamental nature. In spite of this unilateral action, the law of treaties views reservations, at least theoretically, as consensual agreements to modify or restrict the obligations under a treaty. States use the possibility to make reservations, yet only a few states react explicitly to reservations incompatible with the object and purpose. This being the case, it is interesting to see if and how the relations between the States Parties to a treaty could influence the occurrence and impact of reservations. If reservations are basically consensual, the other States Parties have a role to play. But it was not only the inertia of States that has led to the detrimental impact of reservations. As will become apparent in the discussion of the supervisory practice under four major UN human rights treaties, it also took a long time before the supervisory Committees developed a way of treating reservations.

Thus, the aim of this study has been to analyze the reservations to four human rights treaties, concluded within the United Nations, in the light of the rules on reservations in the contemporary law of treaties. I have tried to see reservations within the dynamic framework of contemporary human rights law, keeping in mind the rather static rules of the law of treaties. Merely indicating the intricacies of the lack of correlation between the law of treaties and human rights law is a descriptive activity; the challenge is to find solutions within, and possibly outside of, the existing system. This necessarily leads to compromises of sorts, and the choices made are based upon the goals of human rights law, as well as on the understanding of treaty law as a set of instrumental rules. It has been my intention to look for patterns in the way the reservations are dealt with under these treaties, with the aim of finding useful tools to improve the monitoring. I have sought for theoretical and practical possibilities to reduce the impact of reservations. This necessarily implies taking a stand on matters of substance, even if a point of view is indeed personal.

In spite of the understandable wish to be able to present a complete theory on reservations to human rights treaties, this will not be possible. Rather than pretending to strive for an all-embracing theory, this study will highlight a number of problems, and indicate solutions for such problems. Yet, approaches overlap, and in view of the intricacies of the issue this could not be prevented.

To my mind, these overlaps are not necessarily a disadvantage. In a number of cases a variety of solutions has been presented. By doing this, I have not only tried to indicate the complexity of the problem, but also to suggest solutions based on different points of view. In particular this approach can be seen with the discussion of the question what the "object and purpose" of a human rights instrument might be, and when discussing possible ways to reduce the detri- 
mental impact of so-called sharia'h reservations to the Women's Convention". A sketchy overview of theory and practice has merits of its own, it might be a starting point for some further study into the matter.

A quotation frequently used when writing about reservations, is the phrase by Ruda in his Cours ${ }^{10}:$ "The question of reservations has been one of the most controversial subjects of contemporary intemational law." This study does not pretend to solve the fundamental questions in this field. This book about reservations to human rights treaties emphasizes that there may be more controversies than available solutions. However, the uncertainty as to the rules applicable to reservations to human rights treaties, and the way in which such reservations have been dealt with in practice has proved to be a challenging and rewarding subject for research.

The relevance of this study also depends to a large extent on its usefulness for international practice. Consequently, while an analytical overview may provide insight into the mechanisms that play a role with respect to reservations, some further steps should be taken and suggestions might be made that could influence the practice. Keeping this in mind, the ideas presented in the final chapter of this book are fairly pragmatic. At any rate, they are decidedly influenced by my perception of the exigencies of international human rights practice. An attempt will be made to point out how a more strict policy with regard to reservations and interpretative declarations could be followed. In particular this will lead to suggestions as to how States Parties, in their capacity as reserving States as well as objecting states, could reduce the detrimental impact of reservations. The focus should however probably be on the supervisory Committees and their possibilities, as the States Parties themselves caused the problem in the first place. An important question dealt with, is whether the supervisory organs of the human rights instruments have any influence in the matter of reservations and if so, how they could use this in a diligent way.

As a final remark, it should be kept in mind that this study is necessarily incomplete because of the focus on international practice. It goes without saying that, as the major goal of human rights protection is the improvement of the position of individuals under the jurisdiction of the States Parties to human rights instruments, it would be equally, if not more, interesting to look at the impact of reservations on the protection at domestic level. For various reasons it is not possible to lift the veil of the international obligation; largely of course because it would be almost impossible to study all the systems of domestic implementation. Yet with an overview of the international position, detailed studies on the domestic relevance of reservations might be facilitated. 
It is necessary to clarify the choices that have been made to present the findings of my research. The first part deals with the theoretical aspects of the problem. Discussing the general rules on reservations was a necessary starting point. The second chapter thus deals with the Genocide case, which is the basis for the present day rules on reservations. Though the Genocide case is discussed in depth, an overview of the ensuing discussions in the General Assembly $^{11}$ and the International Law Commission ${ }^{12}$ has been omitted. A number of books dealing specifically with the developments in the law on reservations since the Genocide case has been published ${ }^{13}$, and re-examining such developments would not have led to new insights. An analysis of the system of the Vienna Convention on the Law of Treaties turns attention to the present day situation of dealing with the existing reservations under contemporary law. The chapter also deals with a number of related issues concerning the concept of reservations in the general law of treaties and the meaning of the "object and purpose" rule. The third chapter focuses on the specific issue of reservations to human rights treaties, the ideas appearing in human rights literature, as well as a number of prevalent assumptions. An attempt is made to indicate the substantive content of the "object and purpose" rule when applied to human rights treaties. The way in which reservations are dealt with under the European Convention and the American Convention ${ }^{14}$ is indicated briefly in order to sketch the approaches under regional instruments.

The second part of this study consists of an inquiry into the rules on reservations in four UN human rights instruments, and their application in practice. These are the Convention on the Elimination of all forms of Racial Discrimination, the Covenant on Civil and Political Rights, the Convention on the Elimination of all forms of Discrimination against Women, and the Convention against Torture. Thus, two general human rights instruments and two nondiscrimination conventions are dealt with.

The Covenant on Civil and Political Rights is a general instrument, a backbone of the UN human rights system. The Convention against Racial Discrimination and the Women's Convention are in many respects a lex specialis to the

11. Leading to GA Res.598 (VI), 2 January 1952; and GA Res.1452 A and B, 7 December 1959.

12. First report by Lauterpacht. A/CN.4/63 (1953):

Second report by Lauterpacht, A/CN.4/87 (1954);

First report by Fitzmaurice, A/ CN.4/101 (1956):

First report by Waldock, A/CN.4/144. A/CN.4/144/Add.1 (1962):

Fourth report by Waldock, A/CN.4/175 (1965).

13. Most notably F.Hom, Reservations and Interpretative Declarations to Multilateral Treaties, Amsterdam 1988; P.H.Imbert, Les réserves aux traités multilatéraux, Paris 1979 (hereafter: Les réserves); R.Kühner, Vorbehalte zu multilateralen völkerrechtlichen Vertrüge, Berlin 1986.

14. San José, 22 November 1979. 
Covenant on Civil and Political Rights; from a practical point of view it will be useful to see if and how the practice under a general instrument can be relevant to more specific instruments dealing with non-discrimination. The Convention on the Elimination of Racial Discrimination has similarities with the Women's Convention, and has been extensively used for reference during the drafting of the latter instrument. Thus the practice concerning reservations under the CERD could provide for useful and comparable information on the way in which reservations were dealt with under the Women's Convention. Moreover the CERD contains a reservations' clause, and suggestions are frequently made that this clause might be included into the Women's Convention $^{15}$.

In studying the Genocide Case, my impression was that the simplicity of the questions asked in the request for this Advisory Opinion, has produced rules on reservations that may be easily applicable to single-purpose treaties, but are hard to apply to multifarious instruments. This has led to the inclusion of the Convention against Torture in this study. It is interesting to find out whether the "object and purpose" rule developed with respect to the Genocide Convention could also be a useful yardstick with respect to another single-purpose treaty, such as the Convention against Torture. In relation to this Convention, reservations aiming at the operation of the supervisory procedures have highlighted other problems with respect to the general interest, as opposed to the reciprocal interest, with regard to human rights instruments.

It is necessary to explain why other UN human rights instruments have not been dealt with. Reservations to the Covenant on Economic, Social and Cultural Rights are not discussed. This is because reservations to this instrument, which is in general based upon a gradual implementation of the rights mentioned, are in general of a different nature. The Vienna Convention rules focus on exclusion or modification of the legal effect of a provision, but do not seem to have taken into account the legal effect of provisions with an inherent flexibility such as provisions with respect to gradual implementation. Though the legal effect of reservations to the Covenant on Economic, Social and Cultural Rights raises interesting questions, it is a separate issue that will not be dealt with here. Another reason for not discussing reservations to the Covenant on Economic, Social and Cultural Rights lies in the over-all size of this book. Adding the practice under another treaty would have made this book too bulky, and the work too long. Yet the choice, it must be admitted, is debatable as the implementation of "classical" human rights can also depend on the availability of financial means. Moreover, a number of provisions in the Women's Convention are clearly social rights rather than civil or political rights. 
The Convention on the Rights of the Child has not been dealt with because of the fact that it had not been finalized at the time this study began ${ }^{16}$.

The four conventions that are dealt with all provide for a supervisory mechanism which is largely comparable, with periodic reporting to an independent Committee of experts. Obviously there are differences with respect to the substantive rights, and to a lesser extent also with respect to the supervisory procedures. The inclusion of the individual complaints procedure under the Optional Protocol to the Covenant may provide useful information on the impact of reservations for individuals. Reference to the way in which reservations are dealt with under the Optional Protocol may be useful for similar procedures under article $14 \mathrm{CERD}$ and article $22 \mathrm{CAT}$, or a possible future individual complaints procedure under the Women's Convention. The information gathered has led to some overall conclusions that will be presented in the final chapter. In fact, insight into the practice suggests that an exchange of strategies in dealing with reservations between the supervisory Committees might improve their success in reducing the impact of reservations.

In order to facilitate comparison, these four treaties are dealt with on the basis of a unified scheme, in which information is grouped under standardized headings. In each case the particular law on reservations applicable to the instrument is dealt with after an introduction to the instrument. The following section deals with the actions undertaken by the States Parties. Firstly the reservations are dealt with, grouped per article, which provides insight into the acceptance (or lack of acceptance) of substantive provisions. Then the objections and the withdrawals are described. The following section analyses the way in which reservations have been treated under the instrument's supervisory system. First, an overview is given of the way in which reservations have been discussed in the reporting procedure, this information is grouped per state. This enables the reader to see the consistency (or lack of consistency) with which the supervisory Committees have dealt with the reservations made by a reporting State over the years. As no state complaints have been made, a discussion of this procedure has been omitted. In the chapter on the Covenant on Civil and Political Rights the cases under the Optional Protocol in which reservations and interpretative declarations were discussed are then dealt with. This is followed by conclusions with respect to the applicable rules on reservations, the actions of States Parties, of the supervisory organs, as well as a tentative outlook on future developments.

This scheme has the advantage on focusing on the interplay between reserving States, other States Parties and the respective Committees in the matter of reservations. Though it is possible to look at reservations as static statements with respect to the law applicable to the reserving State, I would venture to suggest that the supervisory mechanism has stimulated a dynamic approach to human rights, in which a reduction of the impact of reservations should be 
included. While the protection of human rights is expanding and becoming an increasingly interrelated system, this should also encompass the issue of reservations. Another obvious reason for looking at the dynamic side of treatybased human rights protection is the fact that States Parties and the Committees share a responsibility for reducing the impact of reservations. While it is clear that from a purely formal point of view this responsibility lies with the States Parties, one may by now safely submit that the Committees have to play a vital role in the issue.

However, no scheme is perfect and the scheme used in the discussion of reservations to four major UN human rights treaties also has its flaws. I chose to discuss the role of the treaty bodies, omitting the work of the political organs of the UN. Thus, while the scheme focuses on the steps taken by States and Committees as the main actors in this field, it is at the same time largely incapable of illustrating the interplay when other actors take an interest in the issue of reservations. This is most obvious with respect to the way in which the ongoing discussion in the United Nations with respect to reservations to the Women's Convention is presented. This discussion moved back and forth between a number of organs (most notably the meeting of States Parties and the Third Committee of the General Assembly), and this dynamic element seems to be absent in the presentation of the information. This study focuses on the work of the treaty bodies, and does not deal in detail with the work of political organs of the United Nations.

The section on the practice with respect to the four human rights treaties covers all material available for public use $\mathrm{e}^{17}$, since the beginning of the supervisory procedures up until $1992^{18}$. On the other hand, I have sometimes not stuck to this final date, in case new information was of particular importance to this study. An example is the reaction by the Human Rights Committee to the questions raised by Austria, which had to be included, because of the importance of an explicit statement by the Committee on the issue of reservations.

The attitudes of the States Parties, the primary actors in this field, have only been considered through their identifiable acts. Motives to act, and more importantly, motives not to act have not been considered in depth. Though this is by no means impossible, it might be more within the field of political science than within that of law. However, the acts that never take place, in this case all the times that a detrimental reservation was made without any apparent reaction from the other States parties, remain the most intriguing. Especially so when the law attaches legal effect to such cases of inertia.

17. It should be noticed that initially the periodic reports to the Committee on the Elimination of Racial Discrimination were not published for general use, nor were their summary records. General publication began with the seventeenth session.

18. In particular, the information sent to the General Assembly by the different Committees in $1992(\mathrm{~A} / 47 / .$.$) has been used as the final list. This in general covers the sessions in$ early 1992 and related material. 
The concluding chapter presents pragmatic solutions for the problem of reservations to human rights treaties. In particular some suggestions are given as to how the notion of "object and purpose" could be made operational with respect to human rights. On the basis of a comparative analysis of the four treaties, a number of strategies the supervisory Committees could use in order to reduce the detrimental impact of reservations is presented. And finally, as the problem is largely due to the absence of good reservations clauses in human rights treaties, a draft clause is presented. Thus I hope to have indicated that possibilities to restore the ruins caused by incompatible reservations to human rights treaties do indeed exist. 
PART II

THEORETICAL QUESTIONS 


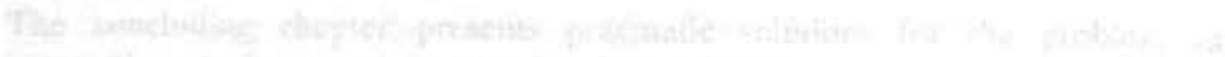

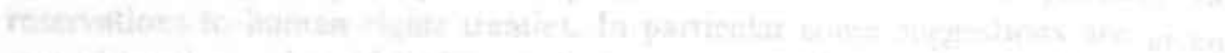

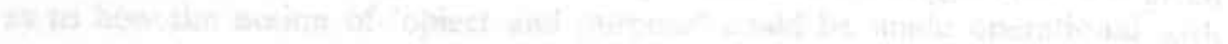

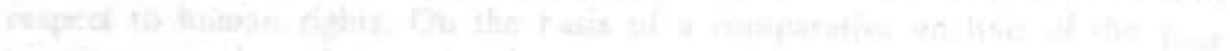

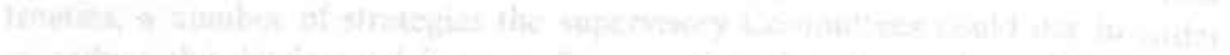

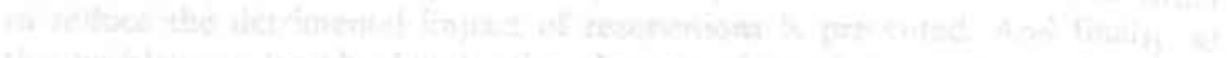

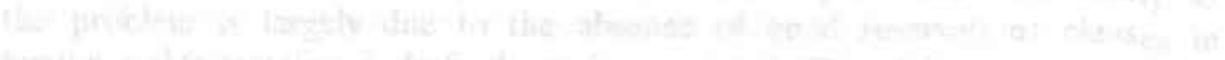
Q

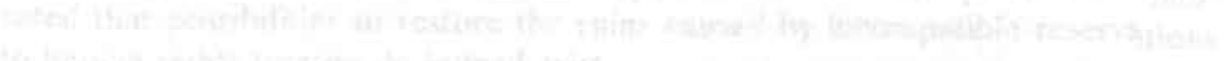

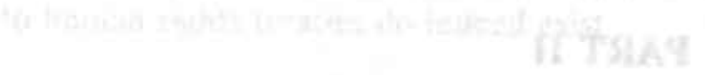

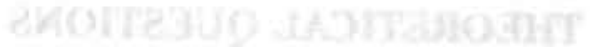




\section{THE LAW APPLICABLE TO RESERVATIONS}

\section{THE GENOCIDE CASE}

The Genocide Case stands at the beginning of the development of the contemporary theory on reservations. It was only when a difference of opinion arose about reservations to the Convention on the Prevention and Punishment of the Crime of Genocide ${ }^{1}$ (hereafter: the Genocide Convention), that the intricacies of the question of reservations to human rights treaties became apparent. This is why a book on reservations to human rights treaties must necessarily begin with a discussion of the Genocide case. The case sketches the problem of combining universality and integrity in the field of human rights law, which will be one of the focal points of this thesis.

Yet, as this study focuses on the contemporary law and practice, the historical discussion will accordingly not be a lengthy one. After a short overview of the events that led to the request for an Advisory Opinion, the Opinion as well as the Dissenting Opinions will be discussed followed by a presentation of the reception of the Opinion by legal scholars. Consequently a thorough discussion of the then contemporary law of treaties in respect of reservations has been omitted, as this is not the main issue of this study. Neither will the reception of the Opinion as such be dealt with. The goal of this presentation is to highlight the questions that arose in the Genocide case in majority and dissenting opinions, as these issues will recur in the discussions about reservations to human rights treaties.

The Advisory Opinion of the International Court of Justice of May 1951 concerning Reservations to the Convention on the Prevention and Punishment of the Crime of Genocide ${ }^{2}$ was epoch-making, and has been of decisive importance for the development of the rules on reservations in the law of treaties in general, as well as specifically the law applicable to reservations to human rights treaties. Yet, the novelty of the legal problem at the time of its occurrence may have prevented a thorough analysis of the consequences the Advisory Opinion would have. With hindsight there is reason to seriously doubt the merits of this Opinion, in fact it may even be a very unfortunate dictum.

1. GA Res.260A (III); 9 December 1948.

2. Reservations to the Convention on the Prevention and Punishment of the Crime of Genocide, 28 May 1951. IC.J Rep. 1951 15-30; dissenting opinion Guerrero, McNair, Read and Hsu Mo idem at 31-48: and dissenting opinion Alvarez idem at 49-55. 


\subsection{The problem of reservations to the Genocide Convention}

Reservations to human rights treaties are a relatively new problem in international law. In general one might say that the issue arose with the emergence of treaties that are not mutually and reciprocally advantageous for States. While it had been possible to find solutions to the question of reservations in the customary law of treaties, the issue of reservations to human rights treaties only appeared when international law turned its attention to the protection of the individual ${ }^{3}$. The specific nature of human rights treaties does not easily fit in with straight-forward contractual law, which is what the law of treaties basically was. Fundamental differences are that these are law-creating treaties (as opposed to contractual treaties), and that the primary beneficiaries of the treaty are the individuals under the jurisdiction of the State. In the following, the matter of reservations to human rights treaties will prove to be one of an overriding incompatibility between the basic premises of two distinct lields of international law.

This being the direct cause for the Advisory Opinion on reservations to the Genocide Convention, it is necessary to consider the state of international law on reservations at the time. In the early nineteen fifties various rules existed side by side. When the question of reservations to the Genocide Convention arose, the parallel existence of the above mentioned systems created great confusion.

In traditional international law the integrity of the treaty was of decisive importance. Reservations had to be accepted unanimously by all States parties to the treaty before a reserving State could be considered a party to the treaty. An accepted reservation would thus lead to a modification of the treaty binding on all States parties. In this system the integrity of the treaty prevailed and emphasis was put on acceptance and objection as expressions of consent or refusal to be bound.

The practice of the Pan-American Union (and its successor the Organization of American States) was a very different one. On the basis of article 6.3 of the 1928 Havana Convention, the rule applied that each single State Party to a treaty had to decide for itself whether or not to accept a reservation. Maximum participation to a treaty was the major aim. States could become Parties to a treaty in spite of objections raised against their reservations. The treaty would however only enter into force between reserving and accepting States, as treaty relations are established on the basis of reciprocity".

In the information supplied to the International Court yet another rule appeared. The Eastern European states claimed that the right to make reservations was vested in the sovereignty of states, and reservations would consequently not protection of minorities.

4. Ruda, op.cit. at 115-133. 
require acceptance. This theory did not seem to be supported by extensive practice, contrary to the integrity system and the universality system mentioned before.

Drafting the Genocide Convention was one of the first projects undertaken by the United Nations, and it was clearly a reaction to the atrocities that took place during the second world war. In GA Resolution 96(I) ${ }^{5}$, it was stated that the United Nations intended to condemn and punish Genocide as a crime under international law. The Convention was adopted unanimously by the General Assembly in $1948^{\circ}$, and entered into force in January 1951.

The Convention consists of nineteen articles, articles I-VII contain substantive provisions dealing with the incrimination of genocide, the obligation to legislate in order to implement the Convention and rules on prosecution either before a domestic tribunal or before an international tribunal, as well as rules on the extradition of persons charged with genocide. The latter part of the convention contains rules on the involvement of the United Nations with the suppression and prevention of Genocide, as well as a dispute settlement procedure (article IX) and final clauses.

According to article XIII, the Convention would enter into force ninety days after the receipt of the twentieth ratification or accession. However, a number of the first twenty states to ratify had made reservations to article IX of the Convention $^{7}$, and other States objected to these reservations ${ }^{8}$. It should be noted that article IX of the Genocide Convention met with a great number of reservations, twenty-three states ${ }^{9}$ made a reservation in respect of this provi$\operatorname{sion}^{10}$, and twelve States objected to reservations excluding article $\mathrm{IX}^{11}$. The different views on article IX would trigger the changes in the law on reserva-

5. Dd.11 December 1946.

6. GA Res. 206A(III), dd.9 December 1948.

7. Bulgaria (accession 21 July 1950), the Philippines (ratification 7 July 1950) and Ukrainian SSR (accession on 31 July 1950) all made reservations concerning article IX prior to the entry into force of the Convention.

8. Prior to the entry into force Australia objected to the reservation of Bulgaria and the Ukrainian SSR: Ecuador objected to the reservations of Bulgaria and the Ukrainian SSR, and Norway objected to the reservation by the Philippines.

9. Albania, Algeria, Argentina, Bulgaria, Byelorussian SSR, China, Czechoslovakia, Democratic Yemen, German Democratic Republic, Hungary, India , Mongolia, Morocco, Philippines, Poland, Rumania, Rwanda, Spain, Ukrainian SSR, USSR, United States, Venezuela and Viet Nam.

10. In 1989 Hungary, Byclorussian SSR, Ukrainian SSR and the USSR withdrew their reservations to article IX of the Genocide Convention.

11. Australia, Belgium, Brazil, China, Cuba, Ecuador, Greece, Netherlands, Norway, Sri Lanka, United Kingdom; Cuba withdrew its objections in 1982.

Reservations and Understandings issued by the United States on ratification of the Genocide Convention will not be discussed, although the compatibility of these with the object and purpose of the Convention is highly questionable. The United States ratified the Convention in 1988 , some 37 years after its entry into force. 
tions, as the reservations to this provision led to the Advisory Opinion on the Genocide Convention.

The Convention does not contain a reservations clause and when reservations were made, the depository circulated the reservations asking for the views of the States Parties to the Convention. In the traditional unanimity system this was a logical procedure, however the Soviet Union questioned this, as it went beyond the authority of the depository in article XVII of the Convention. The reservations were objected to, but Guatemala and Ecuador indicated that they intended to apply the Latin-American system, in which a State may be a party to a treaty without establishing treaty-relations with States Parties that had objected to its reservation. The Secretary General then asked the General Assembly how to proceed, in particular with respect to establishing whether enough States had ratified for the Convention to enter into force.

After discussions in the General Assembly, it was decided to take action consisting of three different steps ${ }^{12}$. First of all, an Advisory Opinion of the International Court of Justice was requested, consisting of three related questions. Secondly, the International Law Commission was invited to study the matter of reservations in its work on the law of treaties, both from the point of codification as well as the point of view of progressive development of international law. The request to give priority to this study did not prevent the whole project, that would become the Vienna Convention on the Law of Treaties, from being concluded in 1968 , some eighteen years later ${ }^{13}$. Third step in the General Assembly Resolution was to instruct the Secretary General to continue his practice as a depository without prejudice to the legal effect of objections to reservations received pending decisions by the International Court, the International Law Commission or the General Assembly.

\subsection{The Advisory Opinion on Reservations to the Genocide Convention}

\subsubsection{The (majority) Opinion}

A number of States had raised preliminary objections to the Court dealing with the question of reservations to the Genocide Convention. Certain States had indicated that a difference of opinion on the matter of reservations was a dispute and should not be the subject matter of an Advisory Opinion ${ }^{14}$. After mentioning this, the Court set out to emphasize that the request for an Opinion should in principle not be refused. It indicates that in this case both the General Assembly which drafted the Convention and the Secretary-General who is the depositary of the Convention have an interest in knowing the legal

12. GA Res.478 (V), 16 November 1950.

13. The General Assembly referred the question of reservations to treaties in general to the International Law Commission. The ILC upheld the unanimity rule. Due to the influence of the Advisory Opinion, the views of the ILC rapidly slid into oblivion.

Yearbook of the International Law Commission, 1951-II, 130.

14. ICJ Rep. 1951 at 19-20. 
effects of reservations, and of objections to reservations to the Genocide Convention.

Other objections to the Court dealing with this request for an Advisory Opinion are that the General Assembly is interfering with the Convention, as interpretation is a right pertaining to the States Parties. The Court indicates that the General Assembly not only drafted the Convention but also that express provisions of the Convention associate the General Assembly with the Convention ${ }^{15}$. These are rights parallel to the General Assembly's rights under the Charter. Another objection has been that the Advisory Opinion would be bypassing article IX of the Genocide Convention, the dispute settlement procedure. The Court rejects this objection on the grounds that the procedure in article IX is only available for Contracting Parties, and the matter of reservations and objections is a preliminary issue to the right in article IX.

The Court explicitly indicates that its opinion is limited to the Genocide Convention, stressing that the General Assembly had referred the general question of reservations to the International Law Commission ${ }^{16}$. The Court then goes on to note that the questions put to it are purely abstract, and do not refer to reservations or objections made to the Convention.

The questions before the Court were the following:

I. Can the reserving State be regarded as being a party to the Convention while still maintaining its reservation if the reservation is objected to by one or more of the parties to the Convention but not by others?

II. If the answer to Question I is in the affirmative, what is the effect of the reservations as between the reserving State and:

a) The parties which object to the reservation?

b) Those which accept it?

III. What should be the legal effect as regards the answer to Question I if an objection to a reservation is made:

a) By a signatory which has not yet ratified?

b) By a State entitled to sign or accede but which has not yet done so?

The first question put to the Court raises an apparently general issue. The Court states two guiding principles at the beginning of its discussion. First of all "[I]t is well established that in its treaty relations a State cannot be bound without its consent, and that consequently no reservations can be effective against a State without its agreement thereto". This is merely a repetition of the general pacta sunt servanda rule. Then the Court goes on to say that a "multilateral convention is the result of an agreement freely concluded upon its clauses and consequently none of the contracting parties is entitled to frustrate and impair, by means of unilateral decision or particular agreements, the

15. Cr. article XIII Genocide Convention.

16. ICJ Rep. 1951 at 20 :"The questions thus having a clearly defined object, the replies which the Courts called upon to give to them are necessarily and strictly limited to that of the Convention". 
purpose and raison d'être of the convention." This is directly related to the notion of the integrity of the convention, "a notion which in its traditional concept involved the proposition that no reservation was valid unless it was accepted by all the contracting parties without exception, as would have been the case if it had been stated during the negotiations"17. It should be noted that the Court points at the fact that the notion of the integrity of the treaty is a notion of traditional law of treaties, indicating that it is directly inspired by the contractual concept of treaties ${ }^{18}$.

However, there may be reasons for a more flexible application of the principle of integrity, such as the universal character of the United Nations under whose auspices the Convention was drafted; and the fact that the Convention itself envisages a wide degree of participation in article $\mathrm{XI}^{11}$. Extensive participation has always lead to flexibility is what the Court says. This is reinforced by the fact that the Convention itself was the product of a number of majority votes in the General Assembly. The Court states that "[T]he character of a multilateral convention, its purpose, provisions, mode of preparation and adoption, are factors which must be considered in determining, in the absence of any express provision on the subject, the possibility of making reservations, as well as their validity and effect." ${ }^{20}$ This is the guiding principle in case the treaty itsclf does not indicate how to deal with reservations.

Then the Court looks at the discussions during the drafting and concludes that making reservation was considered to be possible, and moves on to determine which reservations may be made and what kind of objections may be made. The solution to this question is within the Convention itself, it requires universal participation. From the General Assembly's determination to condemn and punish Genocide, it follows that the Convention was intended to be universal in scope. Moreover the Convention was adopted for a purely humanitarian and civilizing purpose. It is a convention in which the states have no interests of their own, there is no perfect contractual balance between the rights and duties of states.

This leads to the conclusion that it has been the intention of the General Assembly that as many States as possible should participate in the Convention. The complete exclusion of a particular state would not only restrict the scope of application of the convention but also detract from the authority of the principles laid down in the Genocide Convention. And, it is inconceivable that the contracting States had in mind that an objection to a minor reservation would have such a result. On the other hand it is equally inconceivable that the Contracting states would sacrifice the very object of the treaty in order to secure as many participants as possible. This leads to the central phrase in the Advisory Opinion "The object and purpose of the Convention thus limit the 
freedom of making reservations and that of objecting to them". These are the relevant paragraphs of the Advisory Opinion:

\begin{abstract}
"The object and purpose of the Genocide Convention imply that it was the intention of the General Assembly and of the States which adopted it that as many States as possible should participate. The complete exclusion from the Convention of one or more States would not only restrict the scope of its application, but would detract from the authority of the moral and humanitarian principles which are its basis. It is inconceivable that the contracting parties readily contemplated that an objection to a minor reservation should produce such a result. But even less could the contracting parties have intended to sacrifice the very object of the Convention in favour of a vain desire to secure as many participants as possible. The object and purpose of the Convention thus limit both the freedom of making reservations and that of objecting to them. It follows that it is the compatibility of a reservation with the object and purpose of the Convention that must furnish the criterion for the attitude of a State in making the reservation on accession as well as the appraisal by a state in objecting to the reservation. Such a rule of conduct must guide every State in the appraisal which it must make, individually and from its own standpoint, of the admissibility of any reservation.
\end{abstract}

Any other view would lead either to the acceptance of reservations which frustrate the purposes which the General Assembly and the contracting parties had in mind, or to the recognition that the parties to the convention have the power of excluding from it the author of a reservation, even a minor one, which may be quite compatible with those purposes $^{21}$."

Finally the Court explicitly mentions that it strongly disagrees with the suggestion that a State may become a party while making any reservation it chooses, on the basis of its sovereignty, thereby criticizing the theory advanced by the Eastern European States. Such an emphasis on sovereignty would disregard the object and purpose of the Convention ${ }^{22}$.

The International Court concludes that because of the abstract character of question I, no answer can be given. It states:"[T]he appraisal of a reservation and the effect of objections that might be made to it depend upon the particular circumstances of each individual case ${ }^{n 23}$. Consequently, the Court did not answer the question in general, and merely indicated along which lines states should decided about their position when confronted with reservations.

The Court then moves on to discuss the second question which reads:"If the answer to Question I is in the affirmative, what is the effect of the reservations as between the reserving State and a) The parties which object to the reservation?; b) Those which accept it?

21.

ICI Rep. 1951 at 24.

22. ICJ Rep. 1951 at $25-26$.

23. The Court's answer to the first question is:

"[A] State which has made and maintained a reservation which has been objected to by one or more of the parties to the Convention but not by others, can be regarded as being a party to the Convention if the reservation is compatible with the object and purpose of the Convention; otherwise, that State cannot be regarded as being a party to the Convention." 
The Court begins by re-emphasizing the fact that the appraisal of the validity of reservations and the reaction thereto is a right exercised individually and from the point of view of the individual states. It says that "[E]ach state objecting ... will or will not, on the basis of its individual appraisal within the limits of the criterion of the object and purpose ... consider the reserving state to be a party to the Convention"24. This is the phrasing that created confusion with respect to the reasons for objecting as well as the consequences of objections.

The system drawn up by the Court in answering question II is a confusing one $^{25}$. It appears to expect a general notion of object and purpose to arise out of the treaty, and the State Parties will consequently act in accordance with that general notion. The Court emphasizes the good will of States in respect of the object and purpose of the Convention ${ }^{20}$. The Court then goes on to discuss the consequences of a divergence of view on the compatibility of a particular reservation. The Court's answer to the second question is:

"a) [I]f a party to the Convention objects to a reservation which it considers to be incompatible with the object and purpose of the convention. it can in fact consider that the reserving State is not a party to the Convention.

b) [I]f, on the other hand, a party accepts the reservation as being compatible with the object and purpose of the Convention, it can in fact consider that the reserving State is a party to the Convention."

The third question put before the Court is as follows: What should be the legal effect as regards the answer to Question I if an objection to a reservation is made a) by a signatory which has not yet ratified?; b) by a State entitled to sign or accede but which has not yet done so?

The third question deals with the possible impact of reservations prior to ratification, which was an issue surrounded by confusion at the time. The Court notes that the right to become a party to the Convention is not a very clear notion, and elaborates on the rights of a signatory state that has not yet ratified. The Court concludes that the signatory State is entitled to object, and may indeed do so when ratifying.

The Court's answer to the third question is:

"a) [A]n objection to a reservation made by a signatory state which has not yet ratified the Convention can have the legal effect indicated in the reply to Question I only upon ratification. Until that moment it merely serves as a notice to the other State of the eventual attitude of the signatory State:

24. ICJ Rep. 1951 at 26.

25. ICJ Rep. 1951 at 26:"The disadvantages which result from this possible divergence of views - which an article concerning the making of reservations could have obviated - are real ..."

26. ICJ Rep. 1951 at 27:"It must clearly be assumed that the contracting states are desirous of preserving intact at least what is essential to the object of the Convention; should this desire be absent, it is quite clear that the convention itself would be impaired both in its principle and in its application." 
b) $[A \mid n$ objection to a reservation made by a State which is entitled to sign or accede but which has not yet done so is without legal effect."

\subsubsection{The Joint Dissenting Opinion}

The dissenting Opinion of Judges Guerrero, McNair, Read and Hsu Mo consists of three distinct parts in which the state of international law as regards reservations is discussed, the majority opinion is criticized and some thoughts concerning the universality - integrity dilemma are voiced. The joint dissent may be characterized as a scholarly approach to the problem of reservations, and the thoroughness of McNair can be read between the lines.

The joint dissent begins by stressing that the possibility should not be overlooked that the Advisory Opinion might have a wider effect than merely giving expert advice to the General Assembly on the issue of reservations to the Genocide Convention ${ }^{27}$. With hindsight this has indeed been the case.

The first part consists of a discussion of the international legal rules concerning reservations available at the time. There is no legal vacuum, consent is the basis for treaty obligations, and this is equally the case with respect to reservations ${ }^{28}$. Unanimous consent of all the parties to a treaty is necessary before the reservation can be effective and the reserving State will become a state party.

The four judges elaborate in a scholarly way, in order to establish the customary law with respect to reservations, and point to the opinion of learned authors as well as the practice both within the League of Nations and the United Nations ${ }^{20}$. It could be suggested that this was just administrative practice, but it is indicated that exceptions to the rule of unanimous consent were formulated by parties to a treaty in express provisions. This is followed by an overview of specific rules on reservations, such as the Pan-American Union practice and article 64 ECHR. These are all examples of an a priori agreement between States Parties that particular rules, other than the unanimity rule, would be applicable. The judges conclude that:

"The fact that there is a recognized method of ear-marking in advance and by agreement those provisions against which a reservations will be permitted is the strongest possible evidence that the governments negotiating the Genocide Convention did not contemplate giving to intending parties a unilateral right of making reservations deemed by them to be incompatible with the purpose of the Convention. ${ }^{-30}$

Then the judges turn their attention to the way in which the issue of reservations was dealt with during the drafting of the Genocide Convention. Although the matter was considered, it was decided not to include a reservations clause, 
on the assumption that the unanimity rule, which was the applicable law at the time, would apply in case reservations were made ${ }^{34}$.

The second part of the Joint dissenting Opinion consists of a thorough critique of the rule formulated by the majority. For those rereading the dissent from the perspective of reservations to human rights instruments, it is striking that the majority of problems that were to arise in the application of the Court's "object and purpose" rule are already mentioned by the four judges.

The judges doubt if there is any reason to assume that the drafting States agreed with "object and purpose" as a yardstick for the acceptance of reservations. In fact the criterion itself would in all likelihood lead to problems. The judges note that

"[T]his attempt to classify reservations into "compatible" and "incompatible" would
involve a corresponding classification of the provisions of the Convention into two
categories - of minor and major importance; when a particular provision formed part of
"the object and purpose of the Convention", a reservation made against it would be
regarded as "incompatible", and the reserving State would not be considered as a party
to the Convention; when a particular provision did not form part of "the object and
purpose", any party which considered a reservation made against it to be compatible
might regard the reserving state as a party."

The distinction between compatible reservations and incompatible reservations is unacceptable for the dissenting judges, firstly because it is a new rule for which no evidence can be found in practice or legal literature. Moreover, the rule cannot be deduced from the intentions of the states that negotiated the Genocide Convention. In fact it is unlikely that the General Assembly would have accepted this new rule with respect to reservations without explicitly mentioning it in the treaty itself ${ }^{33}$.

The second argument against the rule developed by the majority is that the "object and purpose" rule will be difficult to apply in practice. The dissenting judges wonder about determining the exact content of "object and purpose" of the Genocide Convention. They indicate that the individual application of the compatibility criterion by the States Parties will lead to confusion, an objective determination by a judicial organ would be preferable but may not be feasible. Moreover there may be uncertainty about the date of entry into force, in sum the new rule is not a "reliable means of solving the problems"

The third part of the joint dissenting opinion is rather brief and consists of an obiter dictum about the importance of integral acceptance, rather than universal acceptance. It is stated that there is no evidence that the drafting States "desired to secure wide acceptance of the Convention even at the expense of 
the integrity or uniformity of its terms, irrespective of the wishes of those states which have accepted all the obligations under $i^{n{ }^{n 35}}$. In fact the four judges conclude that the nature of the Genocide Convention should lead to an strict application of the prevailing rules. They say:

"It is therefore not universality at any price that forms the first consideration. It is rather the acceptance of common obligations - keeping step with like-minded states - in order to attain a high objective for all humanity, that is of paramount importance. Such being the case, the conclusion is irresistible that it is necessary to apply to the Genocide Convention with even greater exactitude than ever the existing rule which requires the consent of all parties to any reservation to a multilateral convention." ${ }^{26}$

\subsubsection{The Individual Dissenting Opinion}

The other dissenting opinion is by Judge Alvarez, who does not agree with the majority view, but whose views are even more contrary to the Joint dissent. This dissenting Opinion may be characterized as a forward-looking view on the development of international law, in fact it is in certain respects a legal programme.

Alvarez begins by indicating that there are no precise rules available to solve the problem of reservations to the Genocide Convention. Important developments are taking place in international law, and these would lead to the abandonment of traditional rules, in spite of the fact that the Court has a task in applying rather than developing law ${ }^{37}$. Since the Second World War, international law has seen the creation of treaties with a character distinct from traditional treaties. For instance, treaties establishing international organizations, establishing new and important principles of international law, and conventions regulating matters of social and humanitarian interest. These are universal treaties, aiming at the general interest; formulated by the General Assembly and adopted by a majority vote. In fact these treaties result from legislative functions assumed by the General Assembly of the United Nations. Consequently, these conventions must be interpreted with a view to the future $e^{38}$.

Reservations must not be made to these instruments, as that would be contrary to the general and social interest they aim at. In order to achieve a wide acceptance of these instruments, the drafters should aim at a less ambitious pact, rather than a more elaborate pact to which numerous reservations would be made. The reservations made to the Genocide Convention could be explained by the fact that the reserving States did rely on old-fashioned ideas on multilateral conventions ${ }^{39}$. Seeking a solution to the reservations problem, as the majority did, by distinguishing between compatible and incompatible

35. 
reservations would not lead to a satisfactory solution. The best solution would be to explicitly state that reservations were not allowed. As this was not the case, three possibilities arose:

- if the reservations were not accepted by at least one state, the reserving State would not be a party to the Convention;

- if the majority of states accepted the reservation, the Convention would be modified accordingly; the States not accepting the reservation would not be partics to the modified Convention;

- if the reservation was accepted by some states and objected to by other States; there would be no Convention at all.

\subsection{The Genocide Case reconsidered}

After the Genocide Opinion, two different views were expressed by UN organs. The International Law Commission suggested that the traditional unanimity rule be maintained ${ }^{40}$; whereas the General Assembly instructed the Secretary General to communicate all reservations to the States Parties to a particular treaties so that the States Parties could decided upon their legal consequences $^{41}$. Decisions about the effect of reservations would henceforth be taken by the States Parties individually. The discussion about India's reservation on acceding to the 1948 IMCO Convention ${ }^{42}$, lead to the conclusion that the Secretary General was to apply the Genocide rule not only to treaties concluded after the Genocide opinion, but to any treaty for which he performed depository functions ${ }^{43}$.

40. I.Sinclair, The Vienna Convention on the Law of Treaties. 2nd Ed. Manchester 1984 at 58-59.

41. GA Res.598 (VI), 12 January 1952.

42. Convention on the International Maritime Consultative Organisation. Geneva 6 March 1948

43. See A/C.6/SR.614- SR.617; A/PV.847 and GA Res.1452 A and B (XIV), 7 December 1959 indicating that the rules in GA Res.598 (VI) should be applied to all reservations. 


\begin{tabular}{|c|c|c|c|}
\hline $\begin{array}{l}\text { PHILOSOPHY OR } \\
\text { ISSUE }\end{array}$ & Judge ALVAREZ & MAJORITY & MINORITY \\
\hline $\begin{array}{l}\text { World order perspec- } \\
\text { tive }\end{array}$ & $\begin{array}{l}\text { New international } \\
\text { order }\end{array}$ & $\begin{array}{l}\text { Legitimacy of old or- } \\
\text { der but flexible rules }\end{array}$ & State sovereignty \\
\hline Reservations & $\begin{array}{l}\text { None permitted; } \\
\text { convention deals with } \\
\text { social issues }\end{array}$ & $\begin{array}{l}\text { Permitted if compati- } \\
\text { ble with "object and } \\
\text { purpose" }\end{array}$ & $\begin{array}{l}\text { Traditional unanimi- } \\
\text { ty rule; consent of } \\
\text { other parties requi- } \\
\text { red }\end{array}$ \\
\hline Convention coverage & $\begin{array}{l}\text { Universality would } \\
\text { occur eventually }\end{array}$ & $\begin{array}{l}\text { Premium on univer- } \\
\text { sality }\end{array}$ & Universality desired \\
\hline $\begin{array}{l}\text { Integrity of provisi- } \\
\text { ons }\end{array}$ & $\begin{array}{l}\text { Implied emphasis on } \\
\text { integrity of conven- } \\
\text { tion's provisions }\end{array}$ & $\begin{array}{l}\text { Compromise on inte- } \\
\text { grity of convention's } \\
\text { provisions }\end{array}$ & $\begin{array}{l}\text { Priority on integrity } \\
\text { of convention's pro- } \\
\text { visions }\end{array}$ \\
\hline Judicial role & Judicial activism & $\begin{array}{l}\text { Modified judicial } \\
\text { activism }\end{array}$ & Judicial self-restraint \\
\hline
\end{tabular}

As has been demonstrated by LeBlanc ${ }^{\dagger}$ in his very enlightening scheme, the majority opinion lies between the joint dissent and the individual dissent, in as much as it seeks to combine the aims of universality and integrity. The joint dissent is clear on the importance of integrity, and the need to uphold the traditional system in order to do this. Alvarez' dissent is equally clear on the merits of the American system and the way in which it promotes participation. The dissenting opinions point out easy ways to solve the reservations issue, but they are conflicting and each solution has rather foreseeable disadvantages.

The majority tries to solve the problem by combining the opposing doctrines. It presents "object and purpose" as an objective core within the treaty, a goal shared by the drafting States. This notion is a yardstick to be used when considering the acceptability of reservations, or the need to make objections will have to be applied by each state individually. Probably Shelton is right in emphasizing that the application of the objective rule of object and purpose by States Parties is related to the fact that the Genocide Convention does not contain an elaborate supervisory system, as compared to modern human rights treaties ${ }^{45}$.

The approach used by the Court is fairly persuasive at first sight. The system drawn up suggests that it is possible to combine concern about the object and purpose with the need for universal participation. The Court wants to have it both ways, and suggests that this is feasible. However, in spite of explicitly mentioning concern for the integrity of the instrument, little is done to follow-

44. This table is a copy of table 9.2 by L.J. LeBlanc in his book The United States and the Genocide Convention; Durham 1991 at 215.

45. D.Shelton, State Practice on Reservations to Human Rights Treaties, in: CHRY 1983, 205-234 at 229 . 
up on that concern ${ }^{46}$. The Advisory Opinion made the balancing of universality and integrity look possible, probably as a direct result of the singlemindedness of the Convention and the non-core nature of the dispute settlement provision. Object and purpose as an objective notion applied subjectively by the states, here one of the fundamental problems of this thesis unfolds itself. "Object and purpose" seem the most obvious yardstick, at the same time, it is the most impossible yardstick.

As we will see further below, the Genocide case has had a great impact on the Law of Treaties, and in particular on the drafting of the Vienna Convention. Looking back at the issue that was at stake in the Genocide case, the impact may be far greater than the issue dealt with would merit.

The Genocide Convention, and thus the Advisory Opinion, are not entirely comparable to the human rights treaties that will be dealt with below. Two elements should be stressed in this respect. The Genocide Convention is, by comparison with the later human rights treaties, a simple convention. It can be considered a single-purpose treaty: the object and purpose of the convention are to outlaw Genocide. Compared with later treaties, the Covenant on Civil and Political Rights for instance, the Genocide Convention is monolithic. The single-mindedness of the Convention, I would like to suggest, facilitated the ICJ's clear views on "object and purpose". With hindsight, the simplicity of the Convention may have been deceptive.

The second remark is related to the particular reservations that were the cause for the Advisory Opinion. The question that led to the Advisory Opinion, the option to make reservations to the dispute settlement clause in article IX, may be a rather peripheral question. Certainly, the Genocide Convention does not have a specific supervisory system, dispute-settlement is the only available procedure. One wonders whether the role of the International Court as the supervisory organ could be an important one. It was only in 1993 that the Convention was invoked before the Court ${ }^{47}$, and it would not seem that the Court has a potentially important role to play. Reservations to that provision may not undermine the Convention's raison d'être, the outlawing of genocide. Supervisory structures such as the ones pertaining to the four treatics to be discussed in the following were to be developed in the nineteen sixties. I would contend that the nature of the reservations at stake, although the

46. H.Golsong. Les Réserves aux Instruments Internationaux pour la Protection des Droits de I'Homme. In: Les Clauses Echappatoires en matière d'Instruments Internationaux relatifs aux Droits de l'Homme. Bruxelles 1982, 23-42. writes at 28:"Malheuresement, cette même Court n’a pas traduit ses nobles considérations au cas soumis et a appliqué son critère de manière trés terre-à-terre, en disant que le but et lobjet de la Convention sont essentiellement le souci d'y voir participer le plus grand nombre possible d'Etats. On en parle donc plus des fins supérieures de la convention: l'objet et le but a été réduit á se souci de universalité."

4?. Application of the Convention on the Prevention and Punishment of the Crime of (ienocide (Bosnia and Herzegovina v. Yugoslavia (Serbia and Montenegro)). 
questions before the Court did not deal with the specific reservations, also reinforced the feeling that "object and purpose" would be a practical criterion.

After this anecdotal introduction to an Advisory Opinion that was a turning point in the development of the law on reservations, we will turn our attention to the law itself.

\section{THE DEFINITION OF "RESERVATION"}

Both before and after drafting the Vienna Convention on the Law of Treaties $^{48}$ writers have discussed reservations without precisely defining them $^{49}$. They are dealt with in a matter of course way, and one wonders why so little attention has been given to defining reservations. Even if reservations were a clear and unambiguous concept in the law of treaties ${ }^{50}$, it remains necessary to define them before embarking on a study of reservations to human rights treaties.

The reason for bringing up the importance of a definition is the vital role it plays in understanding a legal phenomenon and the law applicable to it. Definitions are supposed to give an unambiguous explanation of the phenomenon to be explained, the definiendum. It is replaced by the definiens, a set of words that clarify the definiendum ${ }^{51}$. As law does not use a formal language, definitions will always employ ordinary language. This may give rise to uncertainties, because language is often imprecise and constantly changing. Apart from this, our knowledge may be inadequate to completely understand the definiendum, which also leads to imprecise definitions. And finally the possibility has to be taken into account that those drafting a definition intentionally employed vague terms, leaving room for further elaboration when using the definition. Thus a phenomenon might be defined in ambiguous terms, or the

48. Vienna Convention on the Law of Treaties. 23 May 1969, entry into force 27 January 1980, henceforth: Vienna Convention or VCLT.

49. D.Kappeler, Les réserves dans les traités internationaux. Bäle 1958, at 15. suggests that the majority of the authors present rather subjective delinitions.

50. V.F. Gubin. The Soviet Union and Reservations to multilateral Ireaties(summary), in: SYbIL 1959. 141-143 at 142:"Despite its more than half a century's existence, problems arising from this conception and its legal nature remain among those which have been least studied. [...] One of the reasons for this is the fact that reservation is constantly confused with other concepts indicated by the same word.": Imbert, Les Réserves at 11:"Les études relatives à la nature juridiques des réserves ont été extrêmement nombreuses; mais aucune n'apporte une réponse vraiment satisfaisante;"; and Kühner, op.cit. at 8: "Leider wird der Terminus "Vorbehalt" in der völkerrechtlichen Literatur und der Vertragspraxis häufig auch im umgangssprachlichen Sinne verwendet."

51. Horn, op.cit. at 38: "Through the standard type of definition, the word to be defined, the definiendum, is replaced by the definiens. a combination of usually simpler words the meaning of which is assumed to be clear." 
terms may in a later stage prove to be imprecise. In practice an imprecise definition may however have some advantages because of its flexibility ${ }^{52}$.

\subsection{Definitions prior to the Vienna Convention}

In the nineteen fifties and nineteen sixties, after the Advisory Opinion in the Genocide case, a number of books dealing specifically with the law of reservations were published. These in depth studies give insight into the way in which the nature of reservations was perceived, and give an overview of the definitions used in legal doctrine up until then.

Looking at the elements authors ${ }^{53}$ consider to be relevant characteristics, there is consensus about the unilateral nature of reservations ${ }^{54}$. States act on their own initiative, aiming at a favourable modification of the treaty regime. Reservations are made after the authentification of the text of the treaty when no means of changing rights and duties other than reservations are available. Whether or not reservations are treaty clauses, the authors agree on the fact that acceptance of reservations is necessary. This follows from the contractual

52. Horn, op.cit. at 38 .

53. K.Holloway, Les réserves dans les traités internationaux. Paris 1958 (hereafter: Holloway, Les réserves); K.Holloway, Modern trends in treaty law. London 1967 (hereafter: Holloway: Modern trends): M.Khadjenouri, Réserves dans les traités internationaux, Genève. 1953: Kappeler, op.cit. The focus has been on these books, as a detailed survey of the different definitions used prior to the Vienna Convention is beyond the scope of the present study.

Other definitions may be found in e.g:

R.L.Bindschedler, Vorbehalt, in: K.Strupp, H.J.Schlochauer (eds.), Wörterbuch des Volkerrechts, Vol.III, Berlin 1962 at 785-787.

G.G.Fitzmaurice, The Law and Procedure of the International Court of Justice, 19511954, 33 BYIL 1957, at 272-293.

P.Guggenheim, Traité de droit international public, Tome I, 2ieme Ed.aug. Genève, 1967, at 166-167.

H.Kelsen, Principles of international law; 2nd Ed., New York 1966. R.W.Tucker(ed.), at 470-472.

A.D.McNair. The Law of Treaties, Oxford, 1961, at 158.

L.Oppenheim, International law, a treatise: 8th Ed., Oxford. 1967. H.Lauterpacht(ed.); par.517a at 913-916.

M.Soerensen, Manual of public international law: London 1968. C.Parry(ed.), par.4.184.21 at $194-198$.

54. Holloway, Les réserves, at 103 states:" .une réserve est considéréc comme étant une déclaration formelle par laquelle un Etat stipule la limitation unilatérale des effets du traité à son égard, soit en excluant certaines dispositions, soit en les modifiant de façon à diminuer ou à restreindre ses obligations en vertu du traité, dans sa forme définitive."; Kappeler, op. cit. at 16 writes:"La réserve est une acte juridique d'un Etat qui se propose de participer à un traité international. Elle intervient après la conclusion du traité, établit un régime spécial en faveur de l'Etat qui la propose et constitue la condition sous laquelle il est prêt à participer à la convention."; and Khadjenouri, op.cit. at 12 states: "La réserve est une clause conventionelle émanant de l'initiative d'une ou de plusieurs parties (ou futures parties) et instituant un régime juridique dérogatoire au régime normal du traité." 
nature of treaty law. An accepted reservation creates a legal regime distinct from the original treaty, which will be applicable to the reserving state.

When looking at socialist international legal theory prior to the Vienna Convention, the definition used is strikingly different ${ }^{55}$. A reservation is a unilateral formal declaration made by a State at the signing, ratification or acceptance of a treaty, which will bring about a change in the treaty relation between the reserving state and the other states parties. A reservation is a condition for becoming a party to the treaty. Its legal force lies in the unilateral declaration by the reserving state, acceptance by other States Parties is not necessary. This follows from the fact that the right to make reservations is supposedly inherent in the concept of state sovereignty.

The main difference between the socialist doctrine and the traditional doctrine concerned the appreciation of the unilateral character of reservations. Both doctrines held different views on the contractual nature of treaty law and the emphasis put on sovereignty as the sacred core of the state's international existence. These views prevailed at the time the dralting of the Vienna Convention on the Law of Treaties took place ${ }^{50}$.

\subsection{The definition in the Vienna Convention}

The VCLT contains a definition of reservations in article 2.1. $\mathrm{d}^{57}$, an article called "Use of terms", which reads: 'For the purposes of the present Convention'. The meaning of article 2 within the Convention limits the validity of the description used in article 2.1. $\mathrm{d}^{58}$. Horn traces this restrictive approach by the drafters of the Vienna Convention back to a mistake about the nature of definitions, stating that definitions of the stipulative kind (such as article 2.1.d)

55. S.B.Filippov, Ogovorki v teorii i praktike mezdunardnych dogovorov (Reservations in the theory and practice of international treaties) Moscow, 1958: as restated by E.Göttling. Vorbehalte zu internationalen Verträgen in der sowjetischen Völkerrechtstheorie und Vertragspraxis, Hamburg 1967, at $28-34$ and Th.Schweisfurth. Der internationale Vertrag in der modernen sowjetischen Völkerrechtstheorie. Köln 1968, at 248-251; Gubin, op.cit. at 142. On Gubin's theory: Götling. op.cit. at 34-41 and Schweisfurth, op.cit., at 248-249.

Unfortunately none of the works mentioned has been read in the original language. Acknowledging the difficulties of using second-hand information, the author feels that leaving out socialist legal doctrine altogether would have constituted an omission.

56. The Vienna Conference on the Law of Treaties met from 26 March to 24 May 1968. and continued from 9 April to 22 May 1969.

57. Cf. the definitions of reservations in article 2.1.j of the Vienna Convention on Succession of States in respect of Treaties. Vienna 23 August 1978. Trb.1989, 51; and article 2.1.d of the Vienna Convention on the Law of Treaties between States and International Organizations or between International Organizations, Vienna 21 March 1986, Trb.1987, 136.

58. Horn, op.cit. at 40:"..,the Vienna Convention does not answer the question whether there may exist different concepts of reservation.": Ruda, op.cit. at 105 "...does not pretend to prejudge the question or give a doctrinal definition." 
need not necessarily be universally and absolutely valid ${ }^{59}$. Article 2.1.d is an analytical definition of the kind "per genus proximum et differentiam specificam". This is a definition that gives general characteristics and then narrows the definiendum down by indicating specific features.

Article 2.1.d reads:

\begin{abstract}
"reservation' means a unilateral statement, however phrased or named, made by a State, when signing, ratifying, accepting, approving or acceding to a treaty, whereby it purports to exclude or to modify the legal effect of certain provisions of the treaty in their application to that State".
\end{abstract}

Looking more closely at the definition in article 2.1.d it contains both objective and subjective criteria which merit further analysis.

"(R)eservation means a unilateral statement.."

A reservation is a statement external to the treaty made on the initiative of the reserving State. It will have to be a formal declaration according to article 23.1 of the Vienna Convention.

The element of unilaterality has lead to confusion. Reservations are peculiar because of the fact that they are made unilaterally, are accepted or objected to unilaterally (although this may hardly be noticeable in multilateral treaty practice), and ultimately function in a reciprocal way ${ }^{60}$. It is the single-sided initiative of the reserving State that is meant here ${ }^{61}$. As Imbert quite aptly states, reservations may be unilateral but that does not mean that they are discretion$\operatorname{ary}^{62}$.

\title{
"..however phrased or named.."
}

This part of the definition is widely acclaimed as indicating that the substance of the declaration is decisive. A substantive criterion will be used to decide whether a particular statement is a reservation or not. As will be seen below, this formulation is of particular relevance when the legal nature of interpretative declarations is the issue $e^{63}$.

59. Horn, op.cit. at 40:"There is absolutely nothing in the notion of stipulative definitions that would imbue them with universal and absolute validity".

60. Imbert, Les Réserves at 12: Sinclair, op.cit. at 51-52.

Cf. the International Court of Justice in the Anglo-Nonwegian Fisheries ease, ICJ Rep. 1951, at 132:"although it is true that the act of delimitation is necessarily a unilateral act, because only the coastal state is competent to undertake it, the validity of the determination with regard to other States depends upon international law."

61. As Imbert puts it, op.cit., at 11:"Acte unilatérale au moment où elle est formulée, la réserve semble cesser de l'être dans son exercice:(..) d'où la difficulté de trouver un qualificatif qui puisse s'appliquer à l'ensemble de phénomène."; or Kühner, op.cit. at 13 qualifies reservations as "einseitige, empfangbedürftige Willenserklärung".

62. Imbert, Les Réserves at 12.

63. D.W.Bowett, Reservations to non-restricted multilateral treaties, in:48 BYIL 1976/77 6792 at 68: Kühner, op.cit. at 15-17; Sinclair, op.cit. at 52-54: and Ruda, op.cit. at 105-106. 


\section{"..made by a State.."}

This element restricts the definition to the Vienna Convention, which only deals with treaties between States. The condition of a State being the initiator of a reservation has no value outside the scope of the Vienna Convention ${ }^{64}$, as in modern international law other subjects of law, such as international organizations, can also be endowed with ius contrahendi ${ }^{65}$.

"..when signing, ratifying, accepting, approving or acceding to a treaty,.."

The moments at which reservations might be made inserts a temporal restriction into the definition. It raises the question as to whether the list is exclusive or whether this only states the most common examples. Various authors have extensively argued that the list is incomplete, and this is convincing if one compares the moments indicated in article 2.1.d to the means of expressing consent to be bound in article $11 \mathrm{VCLT}^{6}$. Practice shows that making a reservation at another point in time does not necessarily imply the invalidity of the reservations ${ }^{67}$.

\section{"..whereby it purports to exclude or to modify.."}

This is the crucial element in the definition. It deals with the very essence, the aim with which States make reservations. According to article 2.1.d the intention behind a reservation may either be to exclude or to modify.

The intention to exclude certain obligations from the complete package of obligations and rights presented by a treaty, has traditionally been the stimulus for making reservations. There is no difference of opinion on 'the intention to exclude' as an element in the definition of reservations.

This is different where it concerns the second element, the intention to modify. Here the opinions differ due to the fact that modify is a verb with a rather broad meaning. It might imply a change by way of extension, or a change by way of restriction. Obviously the term "modify" in its restricted sense fits into the concept of reservations.

64. See articles 1 and 2.1.a VCLT.

65. Kühner, op.cit at 17-18: R.Szafarz. Reservations to multilateral treatics, in: 3 PYIL 1970, 293-316. at 295 .

Cf. the 1986 Vienna Convention on the Law of Treatics between States and International Organizations or between International Organizations.

66. Horn. op.cit. at 41-44; Kühner, op.cit. at 18-22 and discussing the completeness of the enumeration at 20-21; Szafarz, op.cit. at 295.

67. Edwards, op.cit. at 383 ; Horn, op.cit. at $41-42$ presenting a rather bold example of flexibility as concerns the temporal restrictions: G.Gaja. Unruly treaty reservations, in: Le Droit International à l'heure de sa codification (Etudes en lhonneur de Roberto Ago), Vol.I, Milano 1987 (hereafter: Gaja. Unruly reservations). 305-330, at 310-313 discussing reservations made after ratification; and M.Nowak. UNO Pakt bürgerliche und politische Rechte und Fakultativprotokoll, CCPR Kommentar. Kehi 1989 at xoy about the Netherlands intention to withdraw from the Covenant on Civil and Political Rights, in order to ratify with a reservation to articie 26 immediately after withdrawal. 
Extending the modification is problematic. An extending reservation is supposedly a statement through which the reserving state commits itself to obligations going beyond the obligations following from the treaty. It would be a mistake to take these statements to be reservations, they are merely unilateral declarations through which a state unilaterally binds itself ${ }^{\text {tix }}$. They do not bring about additional obligations for the other states parties as they can only be bound through their consent ${ }^{69}$. Extensive reservations do not function reciprocally ${ }^{70}$ and the rules on the acceptance of reservations are a fortiori not applicable ${ }^{71}$.

It seems that the term "modify" has deliberately been chosen so as to avoid deciding on the issue of the extensive reservations ${ }^{2}$. It remains to be seen whether this has been a wise decision, as it evidently created the impression that the Vienna Convention in fact recognized this concept ${ }^{73}$. Modification should be understood as implying restrictive modification, which is an explanation in line with customary law ${ }^{74}$.

\section{"..the legal effect of certain provisions of the treaty.."}

This phrase deals with the intended consequences of a reservation, and its formulation has lead to discontent. Essentially the question is whether the obligations following from a treaty can directly be traced back to individual provisions of the treaty, or that in certain cases obligations may follow from the structure of the treaty and the interplay of the provisions. Imbert has pointed to the inadequacy of the formulation, stressing that the intention is not so much the exclusion and restriction of provisions, hut the exclusion and restriction of obligations ${ }^{75}$. Hom has argued that the argument is of lesser relevance as the definition deals with the legal effects of certain provisions ${ }^{76}$. It goes without saying that obligations are among the legal effects of treaty provisions.

Another aspect of the reference to "legal effects" is that the definition thus encompasses a wide variety of declarations. The legal effect of the provisions of any treaty is based on its entry into force between ratifying state and all other states parties, for the whole territory of the state concerned, for all the issues

68. Horn, op.cit. at 90; and Ruda, op.cit. at 107.

69. Holloway, Les Réserves, at 104; Imbert, Les Réserves at 16: Kühner. op.cit. at 25.

70. Horn, op.cit. at 88.

71. Horn, op.cil. at 88

72. Kühner, op.cit. at 23-24; and Sinclair, op.cil. at 54.

73. Szafarz. op.cit. at $294:$... that the term "modification" contained in this description is to be understood as covering also the possibility of "limitation": and at 295:"(T)he term "to modify" appearing in the conventional definition contains implicitly not only the possibility of limitation but also of extension or any other change. Opponents of the conception of extensive reservations do not take into account a situation in which the reserving state simply widens its rights (and not its obligations). increasing by the same token the obligations of its partners. Reservations introducing a change other than simple limitation or extension also appear in practice.".

74. Ruda, op.cit. at 107; Sinclair op.cit. at 54.

75. Imbert, Les Réserves at 14-15; Kühner, op.cit,, agreeing with Imbert at 23; and Szafarz expressing similar doubts, op.cit. at 296-297.

76. Horn, op.cit. at $45-46$. 
within the scope of the treaty from the moment of entry into force onwards. The obligation pacta sunt servanda covers not only the substantive elements of a treaty but includes all these elements. Unless, of course, the treaty provides otherwise. In case a state wishes to exclude substantive provisions it stands to reason that a reservation is in order. Any other restriction on the legal effects of a treaty, be it ratione loci, ratione temporis or ratione personae must also be assumed to be a reservation ${ }^{7}$. There are no criteria clearly distinguishing these restrictions from substantive restrictions ${ }^{78}$, they equally hamper the entry into force of the treaty in its fullness.

\section{"..in their application to that State"}

The final wording of the definition in article 2. I.d stresses the individualist nature of reservations. They may lead to a change in the applicable treaty, but only in relation to the reserving State ${ }^{79}$. This has quite often been understood to mean restriction and modification of the obligations of the reserving state only, which is a mistake in view of the reciprocal nature of the law of treaties ${ }^{(s)}$. Either the acceptance of, or the objection to a reservation can have consequences for the other State(s). Clearly reservations do not change the content of the treaty itself, or the treaty relations between the other states parties to the treaty as indicated in article 21.2 VCLT.

\subsection{Definitions since the Vienna Convention}

Since the conclusion of the Vienna Convention, other definitions have been advanced by legal scholars, but we shall not deal with them ${ }^{R 1}$. What is perhaps more relevant is that the Vienna Convention definition has been relied upon in a number of cases, involving treaties anterior to the Vienna Convention, in which

77. Presenting the opposite argument. Horn op.cit, at 98-110.

78. Horn. op.cit. at 98 merely writes that a distinction is necessary without explaining what the distinction is based on.

79. Ruda, op.cit. at 107:"..it is to the obligations of the reserving State and not those of the other States that the reservation must refer."

80. See article 21.3 VCLT.

81. Imbert, Les Réserves, at 18:"Une réserve est une déclaration unilatérale, quel que soit son libellé ou sa désignation, faite par un Etat quand il signe, ratifie, accepte ou approuve un traité ou y adhère. ou quand il fait une notification de succession à un traité, ou à tout autre moment prévu par le traité, par laquelle il vise à limiter ou à restreindre le contenu ou la portée des obligations découlant pour lui du traité." Szafarz, op.cit. at 294:"(A) reservation is a formal declaration made unilaterally by a subject vested with ius contrahendi in the meaning of international law when initialling. signing or depositing a document of ratification, approval. acceptance, accession. succession. territorial application or prolongation of a multilateral agreement. whereby it purports outright or by way of specific interpretation to exclude, to limit, to change or to extend the legal effect of certain provisions of the agreement as applicable to this subject or to a part of its territory or to a territory dependent on it." And at 296 a definition of reservations sensu largo. 
article 2.1.d VCLT was invoked as a definition with general validity, thereby ignoring the restrictive clause "For the purposes of the present Convention".

In the case on the delimitation of the Continental Shelf between the United Kingdom and France ${ }^{82}$, the Court of Arbitration referred to article 2.1.d VCLT, which had been accepted by both parties as a correct definition of a reservation $^{83}$. The Court used article 2.1.d VCLT when dealing with the British contention that the third French reservation to article 6 of the 1958 Geneva Convention on the Continental Shel $f^{34}$ was in fact not a reservations but an interpretative declaration ${ }^{85}$.

Similarly, in the Temeltasch case ${ }^{86}$ the European Commission on Human Rights explicitly referred to article 2.1.d VCLT as a tool for distinguishing between reservations and interpretative declarations; after concluding that the European Convention itself did not contain a definition of reservations ${ }^{87}$. Using the definition in article 2.1.d VCLT as a yardstick for establishing whether or not a certain declaration is in fact a reservation is in fact, is confirmed in the Belilos decision of the European Commission ${ }^{88}$. In the ensuing case before the European Court of Human Rights, article 2.1.d VCLT is hriefly referred to, but is not used by the Court as a consequence of the approach it takes to dealing with the Swiss declaration ${ }^{80}$.

These examples from judicial practice, as well as the fact that learned authors in general seem to agree about the application of article 2.1. $d^{\left(x_{1}\right.}$ seem to agree about its validity. It would thus appear that article 2.1.d VCLT has been received as the contemporary definition of "reservation".

82. First decision 30 June 1977; 54 ILR 1979, 6-10, 31-45.

83. Award, par.55.

84. 499 UNTS 311.

85. Award, par.55 reads:"The Court thinks it sufficient to say that, although the third reservation doubtless has within it elements of interpretation, it also appears to constitute a condition imposed by the French Republic on its acceptance of the delimitation regime provided for in Article 6."

86. Temeltasch v. Switzerland, case 9116/80. 5 May 1982; D\&R 31 (1983) at 120-153; to be discussed Chapter 3, par.4.1.1 infra.

87. Par.69-73.

88. Belilos v. Switzerland, case 10328/83, 8 July 1985; D\&R 44 (1985). The Belilos decision will be discussed in Chapter 3, par.4.1.2 infra.

89. Belilos v. Switzerland, 29 april 1988, ECHR Ser.A, No.132; par.42. The Belilos case will be discussed below in Chapter 3, par.4.1.3.

90. Edwards, op.cit. at 364-367; Gaja, op.cit. at 307-309; Sinclair, op.cit. at 75. 
The intention when codifying the law of treaties must have been to make the law more easily applicable and more readily available ${ }^{91}$. Whereas the Vienna Convention on the Law of Treaties may be clear on most parts of the law of treaties, it certainly is not on reservations. Authors writing on the subject of reservations explain the origins of articles 19-21, without giving much attention to the difficulties surrounding their application in practice. The drafting history does of course account for the peculiarities and ambiguity of the text. Yet, an analysis of the significance of the VCLT's provisions on reservations should go beyond anecdotal drafting history. More insight is needed in the rules the VCLT lays down through its ambiguous and fragmented provisions.

This paragraph will especially focus on the rules relating to reservations to a treaty which does not contain a reservations clause. Article 19.c, which is applicable in this case, lays down the requirement of the compatibility of the reservations with the object and purpose of the treaty, as a basis for the admissibility of a reservation. This raises the question of how and by whom this rule is safeguarded. The various forms of acceptance, described in article 20, do not mention a link between admissibility and acceptability. One might thus wonder what the legal value of the compatibility rule is. The VCLT does not appear to make much difference, in article 21 , between the formal legal effects of the acceptance of a reservation, or objections to a reservation. As objections very often produce a legal effect similar to acceptance, maintaining the distinction between acceptance and objections in the VCLT might be questioned.

In the following the relevant provisions of the VCLT, articles 19-23, will be dealt with. The discussion of article 19 will demonstrate the apparent inadequacy of the compatibility rule. The changed role of both acceptance of and objections to reservations will become clear when discussing article 20. The legal effects of acceptance and objections, and the small distinction between them, will appear when discussing article 21. A schematic overview of the various reactions possible to a formulated reservation will be presented.

Further below, the remaining functions of acceptance and objections are dealt with, as well as the relevance of the compatibility rule of article 19.c. This will lead to the conclusion that the rules on reservations in the Vienna Convention are not as incomplete and inoperative as is often suggested. In spite of the ambiguous text, and though this may not have been intended when drafting the VCLT, the rules now provide for more, and more varied reactions to reservations.

91. See Preamble to the Vienna Convention. 7th paragraph:"Belicving that the codification and progressive development of the law of treaties achieved in the present Convention will promote the purposes of the United Nations set forth in the Charter,...; S.Rosenne, The Temporal Application of the Vienna Convention on the Law of Treaties, in: 4 CornelIILJ 1970, 1-24 at 18; Sinctair, op cit at 1-4. 


\subsection{The formulation of reservations, article 19 VCLT}

A reservation is a unilateral statement made by a State when expressing its consent to be bound. Whereas the drafting of treaties tends to be an increasingly multilateral process; the expression of consent to be bound remains a unilateral act. This is a consequence of the consensual nature of the law of treaties. As a matter of principle, a State cannot be bound in its treaty relations without consenting to them. Consequently reservations can only be effective against a State which has accepted them. When the reservation is accepted, the treaty as modified will be binding on the reserving and the accepting State.

This consensual element in the law on reservations is hidden in the word 'formulate' at the opening of article $19^{92}$. The article dealing with admissibility reads:

"A State may, when signing. ratifying, accepting, approving or acceding to a treaty, formulate a reservation unless:

a) the reservation is prohibited by the treaty:

b) the treaty provides that only specified reservations, which do not include the reservation in question, may be made, or

c) in cases not falling under sub-paragraphs a) and b), the reservation is incompatible with the object and purpose of the treaty."

'Formulate' means 'propose' in article 19.a and 19.c, which implies that the state informed of such a proposed reservation should decide whether or not to accept it. This is not the case with reservations within the category of 'only specified reservations' mentioned in article 19.b. The States parties to the treaty are supposed to have accepted the reservations within the scope of this paragraph beforehand.

Article 19 describes the situations in which a reservation may be formulated, it deals with the issue of admissibility. Article 19.a and article 19.b point to treaty provisions dealing with reservations. In those cases the states parties have developed an explicit rule on the admissibility of reservations. Article 19.c is a residual rule, covering all the cases not dealt with by article 19. a and article 19.b.

Provisions on reservations should ideally be incorporated in the treaty itself $f^{93}$. If it is envisaged that reservations might be made, it would be best if rules about reservations were laid down in the treaty itself rather than leaving the matter undecided, and let the individual states decide. A reservations clause provides for more clarity if parties state beforehand whether and on what conditions reservations may be made. The problems that may be avoided during the drafting by not discussing a reservations clause, are likely to reappear at the time of ratification. Frequently reservations clauses are absent, in which case the compatibility rule of

92. Sinclair, op.cit. at 51; Ruda, op.cit. at 105 .

93. C. GA Res.546(VI), Inclusion in the draft International Covenants on Human Rights of provisions regarding reservations; GA Res.598(VI), Reservations to multilateral conventions. 
article 19.c applies. The present paragraph will mainly deal with this provision extensively, the other admissibility rules will only be referred to only briefly.

\subsubsection{Explicit rules on reservations, articles 19.a and 19.b}

Article 19 VCLT begins with the presumption that reservations may be made ${ }^{94}$. This general acceptance of reservations is then limited by a number of cases in which reservations may not be formulated, as mentioned in paragraphs a - c. Though article 19.c will prove to be of overriding importance for this study, it is useful to begin by looking at paragraphs $a$ and $b$ of the provision first.

Article 19.a is a straight forward rule, it refers to a rule in the treaty itself which indicates that reservations may not be made. In case the State Parties have dealt with the issue, there is clearly no need for an additional rule in the Vienna Convention".

Some States Parties use an other approach to the issue of reservation, by indicating that particular reservations may be made. Article 19.b VCLT states that only if the treaty provides that only specified reservations may be made, no other reservations are allowed. The issue here is the fact that in order to restrict the reservations that may be made, the treaty itself will have to indicate that these are indeed the only reservations that may be made. The inclusion of the word "only" as a result of an amendment by Poland ${ }^{*}$ did, enlarge the scope of article 19.c which now also encompasses treaties indicating that specified reservations may be made. It must be assumed that the reservations falling within the scope of article 19.b, the group of only specified reservations, are identical to the reservations expressly authorized in article $20.1 \mathrm{VCLT}^{97}$.

From the point of view of the monitoring of reservations, articles 19.a and 19.b have the advantage of being transparent rules decided upon by the future State Parties at the time of the drafting. They are guidelines for the depository as to which reservations may or may not be accepted and consequently which ratifications containing reservations may or may not be registered.

\subsubsection{The content of article 19.c}

The inclusion in article 19.b of the word 'only' (only specified reservations ... may be made) limited the scope of this provision. At the same time it broadened the scope of article 19.c which encompasses the following $\operatorname{cases}^{98}$ :

- treaties allowing reservations in a very broad manner.

- treaties not prohibiting reservations other than the ones explicitly prohibited (article 19.a).

- treaties not expressly authorizing reservations other than the ones exclusively specified (article 19.b).

94. Imbert, Les Réserves at 86-90; Ruda, op.cit. at 180.

95. Kühner, op.cit. at 124-125.

\%. Ruda, op.cit. at 181-182; Szafarz, Reservations at 299-300.

97. Kühner, op.cit. at 148-153; and Anglo-French Continental Shelf para.39.

98. Cf. Kühner, op.cit. at 132-134; Szafarz, op.cit. at 300. 
- treaties not prohibiting reservations other than the ones explicitly prohibited and not expressly authorizing reservations other than the ones exclusively specified (articles $19 . \mathrm{a}$ and b).

- treaties containing no reservations clauses at all.

The rule contained in article 19.c caused confusion and disagreement. It has to be pointed out that although article 19.c uses the same phrase as the International Court of Justice in the Advisory Opinion on the Genocide Convention, the rule is not the same". The Advisory Opinion dealt with "object and purpose" as a criterion for both the formulation of reservations and objections to reservations ${ }^{100}$. In the VCLT system "object and purpose" apply only to the formulation of reservations ${ }^{101}$.

The contemporary differences of opinion concentrate on two things, the meaning of "object and purpose" and the observance and monitoring of article 19.c.

Firstly, there is disagreement about the meaning of "object and purpose". Are "object and purpose" objective criteria, and could incompatibility thus be established objectively? Or are they mere subjective notions? The VCLT implies that every treaty has an object and purpose ${ }^{102}$, and implies furthermore that this can be determined. Some authors doubt this, saying that it is an uncertain notion and an unworkable criterion in view of the differing intentions of the States parties ${ }^{103}$. It might be suggested that object and purpose may point to goals external to the treaty, for instance aims in the fields of politics, economics or social development. In addition to that, the object and purpose of the treaty are likely to change in the course of time ${ }^{104}$.

It must be assumed that States, when expressing consent to be bound by a treaty do so because they wish to attain the goal at which the treaty aims. The character of a treaty, its purpose and indeed its raison d'être are the very reason for the expression of consent to be bound. This does not mean that ascertaining the object and purpose of a particular treaty is in all cases an easy task ${ }^{105}$. It should be borne in mind that there are few treaties with an object and purpose as obvious as the Genocide Convention, in the Advisory Opinion on which the criterion was developed. The "object and purpose" rule leads to a necessary

99. Coccia, op.cit. at 30.

100. ICJ Rep.1951. at 24:"The object and purpose of the Convention thus limit both the freedom of making reservations and that of objecting to them." See par.1.2.1 supra.

101. Coccia, op.cit. at 9; Sinclair, op.cit. at 61 .

102. There is also uncertainty as about the relation between "object" and "purpose"; see Coccia, op.cit. at 23, and G.Teboul. Remarques sur les Réserves aux Conventions de Codification, in: 86 RGDIP 1982, 679-717, at 695-696.

103. Teboul, op.cit. 695-701, and presenting an example at 698-701.

104. Teboul, op.cit. at 697; and see Chapter 3, par.2 infra. Object and purpose of a human rights treaty.

105. Teboul, op.cit. at 701 . 
distinction between core and non-core obligations. In most cases this will be a matter of thorough interpretation ${ }^{106}$.

The observance of article 19.c led to another controversy. Opinions differ as to whether the admissibility of a reservation depends on its acceptability (to another State party) or whether admissibility and acceptability are two distinct notions. The source of the problem is the fact that the VCLT states that only compatible reservations may be formulated ${ }^{107}$. Yet, the drafting conference in Vienna deliberately omitted possible methods for determining the compatibility of a proposed reservation ${ }^{108}$. Thus article $19 . \mathrm{c}$ is a rule of law without explicit safeguards.

The majority of writers conclude that, though compatibility is an objective criterion, it will ultimately be the States parties who will decide upon the acceptability of a given reservation ${ }^{109}$. Article 19.c introduces compatibility as a basis for admissibility and leaves it at that. States do not explicitly decide on admissibility when accepting a reservation ${ }^{110}$, but if they do, they would subjectively apply a theoretically objective notion"'. As ultimately acceptability alone is relevant for the validity of a ratification containing a reservation, these authors doubt the value of article 19. $\mathrm{c}^{112}$. It will be clear that this line of thought easily ignores article 19.c, or at least turns it into a phantom provision on practical grounds.

106. Coccia, op.eit. at 24 :" It is a preliminary legal issue to be solved as a matter of treaty interpretation."

107. Imbert, Les Réserves at 93:"Il convient surtout de souligner l'absence d'indication sur la façon dont doit être appreciée la compatibilité d'une réserve". Also J.K.Koh, Reservations to Multilateral Treaties: How International Legal Doctrine Reflects World Vision. 23 HarvilJ 1982/83, 71-116, at 98.

108. Ruda, op.cit. at 182, discussing collegiate systems.

109. Coceia, op.cit. at 23-24; Imbert, Les Réserves at 140; Kühner, op.cit. at 136; Ruda, op.cit. at 190; Szafare, op.cit. at 300.

110. Imbert, Les Réserves at $\%$.

111. Ruda, op.cit. at 182: Teboul, op.cit. at 694.

112. Inbert. Les Réserves at 136:"..revient à affirmer que lacceptation dune réserve est indépendante des conditions de recevabilité: n'est-ce pas reconnaitre que ces dernières sont inutiles ou tout au moins illusoires?".

Kühner, op.cit. at 147:"Die Unterscheidung zwischen zulässigen und unzulässigen Vorbehalten ist insoweit sinnlos.",

Ruda, op.cit. at 190:"These simple conclusions justify our regarding Article 19. subparagraph(c) as a mere doctrinal assertion...".

Szafarz. op.cit. at 301:".., the rule expressed in paragraph (c) of Article 19 has (in practice) no legal value of its own.".

Coccia, op.cit. at 30 , adds that the voluntary character of art.19. is explained by the fact that this rule could only be imperative if it were ius cogens. 
Others claim that this interpretation of article 19.c is a misconception. A distinction must be made between admissibility and acceptability ${ }^{113}$, which is reflected in articles 19 and 20 VCLT. Thus a proposed reservation theoretically passes a twofold test. Admissibility is the first requirement, and only admissible reservations may be formulated ${ }^{114}$. Reservations within the scope of article 19.b are per se admissible ${ }^{115}$, all other reservations are subject to the compatibility rule. Determining the compatibility of a reservation is a matter of legal interpretation, in which "object and purpose" are objective criteria. In the absence of provisions concerning the determination of compatibility in the VCLT, States parties have to rely on the treaty in question ${ }^{116}$. The second step eventually leading to a valid reservation is that of acceptance (article 20). This involves a purely subjective act, in which States parties may act out of political motives ${ }^{117}$. Incompatible reservations are nullities ${ }^{118}$ and the acceptance of such a reservation would be a breach of treaty ${ }^{119}$.

This theory is be clearly impractical, it is impossible to find out whether states believed a reservation to be incompatible and thus unacceptable in a system in which tacit consent is the major form of acceptance.

\subsection{Acceptance of reservations, article 20 VCLT}

The article opens with specific cases such as expressly authorized reservations (article 20.1), reservations to treaties with a limited number of negotiating states (article 20.2) and reservations to a constituent instrument of an international organization (article 20.3). Article 20.4 comprises the basic rules concerning reservations: namely the consequences of reservations as well as the consequences of objections. It is basically this provision that lays down the pattern of future treaty relations. Tacit consent is regulated in article 20.5, the article thus implying the possibility of explicit consent.

Articles 20.2 and 20.3 will not be dealt with in the following, the order in which the other paragraphs of article 20 are deal with is related to their relevance to the present subject.

113. Bowett, op.cit. at 80 :"Not only is the test for non-acceptance quite different, but the effect of the objection will vary according to whether the reservation is regarded as impermissible or, in the alternative, permissible but objectionable and therefore opposable to the objecting State." Idem Coccia op.cit. at 24: Teboul,op.cit. at 691.

114. Bowett, op.cit. at 83:"The contradiction in the conduct of a Party which 'accepts' a reservation which it acknowledges to be contrary to the object and purpose of that same treaty is self-evident."

115. Bowett,op.cit. at 71 .

116. Bowett,op.cit. at 80 .

117. Bowett,op.cit. at 87.

118. Bowett,op.cit. at 82-84, Koh,op.cit. at 83.

119. Bowett,op.cit. at 83 . 


\subsubsection{The acceptance of a reservation, articles 20.4.a and 20.4.c}

Article 20.4.a. specifies that acceptance means a reservation has the effect it aims at. It reads:

"In cases not falling under the preceding paragraphs and uniess the treaty otherwise provides:

a) acceptance by another contracting State of a reservation constitutes the reserving State a party to the treaty in relation to that other State if or when the treaty is in force for those States;

b) ....

c) an act expressing a State's consent to be bound by the treaty and containing a reservation is effective as soon as at least one other contracting State has accepted the reservation"

The unilateral proposal to modify treaty obligations needs to be accepted in order to establish the desired change in treaty relations. It should be noticed that article 20.4.a does not mention the conformity of the reservation with the criteria in article 19 VCLT as a precondition for acceptance of the reservation ${ }^{130}$. Acceptance in the VCLT system is a bilateral matter. Consent to be bound on condition of the acceptance of the reservation is effective only in relation to the accepting state. The VCLT thus lays down a flexible system concerning reservations ${ }^{121}$. The flexibility lies in the fact that the acceptance of all States parties is not required, as the treaty enters into force between the reserving State and each State that accepts the reservation. Theoretically the multilateral treaty breaks down into numerous bilateral treaties, in which states are hound by the original treaty as modified by accepted reservations and reservations objected to. As will be seen below, on the basis of the rule of tacit acceptance (article 20.5) there will probably always be entry into force for the reserving state ${ }^{122}$.

\subsubsection{Objections to a reservation, article 20.4.b}

Objections to a reservation do not preclude the entry into force of the treaty between the reserving and the objecting State. It is only when the objecting State definitely expresses a contrary intention that entry into force will not take place. Article 20.4.b reads:

"(A)n objection by another contracting State to a reservation does not preclude the entry into force of the treaty as between the objecting and reserving States unless a contrary intention is definitely expressed by the objecting State:"

120. Coccia, op.cit. at 23; R.Cook. Reservations to the Convention on the Elimination of All Forms of Discrimination Against Women (hereafter: Cook. Women's Convention), in: 30 VJIL 1990, 643-716, at 656.

121. Kühner, op.cit. at 157-159; Ruda, op.cit. at 189; Szafarz, op.cit. at 310.

122. Imbert, op.cit. at 141. 
As has been discussed by various authors ${ }^{123}$, it was a proposal of the Soviet Union that reversed the presumption of objections implying non-entry into force ${ }^{124}$. It is doubtful whether this provision is a codification of customary law preceding the Vienna Conference ${ }^{125}$.

Bowett ${ }^{126}$ understands the provision to be a logical rule, in his view an incompatible reservation is a nullity, there can thus be no problem in accepting entry into force on the basis of a compatible reservation. A more realistic view would be to see article 20.4.b. as an adaptation of the law of treaties to contemporary international practice. The fact that objections do not preclude the entry into force is a consequence of the exigencies of multilateral treaty-making. The rule concerning objections is the complement of the VCLT's flexible system, in which the treaty is in force in different modes between various states. The Vienna Convention attaches the least possible weight to objections, preserving as much of the treaty as possible ${ }^{127}$. It favours reservations to the absence of treaty relations. If objections would preclude entry into force, the coherence of the flexible system of treaty relations provides would fall through.

Practical though the system may be, it must be noticed that the flexibility, and the favourable approach to reservations, has changed the roles of the reserving and the objecting States. It is not the reserving State that needs to legitimize its position, the onus is on the objecting State whose actions will be a visible step outside of the flexible system.

Only where an objecting State explicitly expresses the intention no treaty relations will be established. This intention has to be expressed explicitly, it has to be incontestable ${ }^{128}$. Objections may be made to all reservations, as States are free to accept or refuse the proposed modification of the treaty ${ }^{129}$.

The objecting State decides upon entry into force. As precluding entry into force can easily be understood as an unfriendly act, it is said that the VCLT thus favours reservations ${ }^{130}$. On the other hand it should be kept in mind that the same unfriendly reaction used to be expressed previously by objecting. The

123. Imbert, Les Réserves at 153-156; Kühner, op.cit. at 179-182: Ruda, op.cit. at 193; Sinclair, op.cit. at 62; Szafarz, op.cit. at 306-308; A.N. Talalajew. Das Recht der internationalen Verträge, Berlin 1977 at $72-73$.

124. It would appear that few participants at the Vienna Conference perceived the consequences of accepting the inclusion of the word not (..does not preclude entry into force..). The inclusion of not in article 20.4. b was part of an East West trade-off according to a spokesman in the Netherlands Ministry of Foreign Affairs.

125. Coccia, op.cit. note 189 at 36; Imbert, op.cit. at 155; Kühner, op.cit. at 180-182; Ruda, op.cit. at 193; Szafarz, op.cit. at 306-307.

126. Bowett, op.cit. at 86 .

127. Imbert, op.cit. at 159 ; Koh, op.cit. at 102.

128. Kühner, op.cit. at 183; Szafarz, op.cit. at 309.

129. Kühner, op.cit. at 187; cf. T.O.Elias, The Modern Law of Treaties, Leiden,1974, at 28, saying:"..are clearly inadmissible, but also are objections to reservations which are wholly compatible with the object of the treaty.", apparently confusing the consequences of art.20.1 and art.20.4.b.

130. Imbert, op.cit. at 158; Kühner, op.cit. at 182-183; Sinclair, op.cit. at 62. 
VCLT merely added an extra element to the reactions possible to proposed reservations. While previously an objection implied no entry into force, the preclusion of entry into force now has to be explicit.

A variety of opinions exist on whether States have to state their reasons for precluding entry into force. Kühner and Szafarz share the opinion that States are required to provide motives ${ }^{131}$, while Bowett considers this only necessary in case of incompatibility ${ }^{132}$. In his view the above mentioned freedom of acceptance does not imply a duty to motivate objections ${ }^{133}$. Coccia does not think that reasons for objections have to be provided, or that objections should be restricted to object and purpose ${ }^{134}$

While article 20.4.b states that the intention not to enter into treaty relations has to be explicit, there is a difference of opinion concerning the necessity to explicitly exclude entry into force in case of incompatible reservations ${ }^{135}$. Bowett says they need not be objected to as they are null and void ${ }^{136}$, while Szafarz claims that stating that a reservation is incompatible, or contrary to ius cogens would per se prevent entry into force ${ }^{137}$. Kühner doubts this as concerns compatibility ${ }^{138}$ but goes further saying that acceptance of reservations contrary to ius cogens is impossible ${ }^{139}$. Objections to a reservation contrary to ius cogens are a fortiori not needed to prevent this reservation having effect.

\subsubsection{Tacit acceptance, article $\mathbf{2 0 . 5}$}

Article 20.5 lays down the rule of tacit consent stating:

"(F)or the purposes of paragraph 2 and 4 and unless the treaty otherwise provides, a reservation is considered to have been accepled by a State if it shall have raised no objection to the reservation by the end of a period of twelve months after it was notified, or by the date on which it expressed its consent to be bound by the treaty, whichever is later."

Thus tacit acceptance of reservations takes place either at the moment a State expresses its consent to be bound without objecting to reservations previously made; or after a period of twelve months in which no objection has been raised.

132. Bowett, op.cit. at 87.

133. The view, it must be stressed, is intimately tied to the scheme he sets up explaining articles 19-23 VCLT.

134. Coccia, op.cit. at 26, 33.

135. See supra, par.3.1.

136. Bowett, op.cit. at 83 .

137. Szafarz, op.cit. at 309.

138. Kühner, op.cit. at 183.

139. Kühner, op.cit. at 146; and of. articles 53, 64 VCLT. 
Article $\mathbf{2 0 . 5}$ provides a workable solution by interpreting 12 months of silence as acceptance of the reservation ${ }^{100}$. This time limit provides certainty about the entry into force of the treaty for the reserving State as it is very likely that at least one State will tacitly accept the reservation (article 20.4.c) ) $^{141}$. It maintains the principle of the law of treaties that States can only be bound by their consent $^{142}$. Interpreting silence as consent is a way of fitting the increasingly lax practice into the rules of treaty law. Thus the system of inconspicuous tacit consent in fact promotes the increase of treaty relations in a spectacular way, it reinforces the flexible system set up under articles 20.4.a and 20.4.c. Tacit consent is a presumption, States not accepting a reservation will have to object. The time limit article 20.5 sets is arbitrary but dispositive. States may decide upon another time limit in the treaty, which would render article 20.5 inapplicable. The time span of one year seems appropriate but it may always be too short for the Ministries of Foreign Affairs and too long for the reserving state ${ }^{143}$.

Tacit acceptance is more important than explicit acceptance in contemporary practice. This is influenced by various facts such as the reluctance to overtly state acceptance $^{144}$ or the tardiness of States in reacting to reservations ${ }^{145}$.

\subsubsection{A priori acceptance, article 20.1}

Article 20.1 provides for a priori acceptance for reservations expressly authorized. It reads:

"A reservation expressly authorized by a treaty does not require subsequent acceptance by the other contracting States unless the treaty so provides."

The article deals with specified reservations as mentioned in article $19 . b^{146}$. The phrasing however is different ${ }^{147}$, which must be taken to be the result of inaccurate drafting. As the link between article 19.b and article 20.1 is not very apparent, article 20.1 caused some confusion. It has been taken to cover not only the cases within the scope of article 19.b but also those of article 19.c. Thus reservations compatible with object and purpose of the treaty would be a priori accepted once their compatibility is established.

140. Cf. the ninety days time limit in article 20.1 CERD: A. Cassese, A new reservations clause (Article 20 of the United Nations Convention on the Elimination of All Forms of Racial Discrimination), in: Recueil d'études de droit international en hommage à Paul Guggenheim, Geneve 1968, 266-304 at 297.

141. Imbert,op.cit. at 142:"La seule différence est constituée précisément par le délai du consentement tacite...c'est à dire plus par une question de temps que par la présence ou absence d'une condition particulière à remplir."

142. Imbert. Les Réserves at 142:"Théoriquement le principe du consentenent aux réserves deneure, mais dans la pratique, on est très proche du système... suivant lequel l'Etat réservataire est partic au traité dès l'instant où il formule sa réserve."

143. Imbert, op.cit. at 107; in respect of CEDAW: Clark, op.cit. at 302. 312-314.

144. Kühner, op.cit. at 154 .

145. Imbert, op.cit. at 104; Sinclair, op.cit. at 63.

146. Kühner, op.cit. at 129-130, 149.

147. Cf. art.19.b "only specified reservations", art.20.1 "expressly authorized". 
The Inter-American Court of Human Rights took this point of view in an Advisory Opinion requested by the Inter-American Commission on Human Rights $^{148}$. The question was at what time the American Convention on Human Rights would enter into force for a State making a compatible reservation. Taking article 20.1 literally $^{149}$, the Court understood compatible reservations to be expressly authorized, which a priori acceptance implied instant entry into force. The Advisory Opinion is based on the wording of article $20.1^{150}$, and the Court's interpretation is sound in view of the interpretation rules laid down in article 31.1 VCLT. However, in view of the drafting history it misapprehends the relation between articles $19 . \mathrm{c}$ and $20.1^{151}$. In that line of thought, a correct solution would have been entry into force after twelve months ex article 20.4.c jo. article 20.5. It has to be pointed out though, that in spite of theoretical inadequacies, this solution is a very desirable one from the point of view of human rights protection ${ }^{152}$.

\subsection{The legal effects of reservations, article 21 VCLT}

The legal effects of reservations and objections are dealt with in article 21 . Whereas article 20 sketches the consequences of acceptance of and objections to reservations, article 21 gives a detailed account of the treaty relations established on the basis of accepted reservations and reservations objected to. As a basic notion of the law of treaties, the article underlines the concept of reciprocity ${ }^{153}$. States intending to modify their treaty relations will face the same modifications by other States against them ${ }^{154}$. The modification thus established will only be valid between the States concerned, as provided in article 21.2.

148. Inter-American Court of Human Rights. The Effect of Reservations on the Entry into Foree of the American Convention on Human Rights (Arts.74 and 75), AdvisoryOpinion OC-2/82 of September 24. 1982; Series A No.2; discussed in Chapter 3 , par.4.2.1 infra.

149. The application of the Vienna Convention is based upon article $75 \mathrm{ACHR}$.

150. Paragraph 36 of the Advisory Opinion reads:" The Court notes, in this connection, that Articie 20.1 in speaking of "a reservation expressly authorized by a treaty," is not by its terms limited to specific reservations. A treaty may expressly authorize one or more specific reservations or reservations in general. If it does the latter, which is what the Court has concluded to be true of the Convention, the resultant reservations, having been thus expressly authorized, need not be treated differently from expressly authorized specific reservations. The Court wishes to emphasize, in this connection, that unlike Article 19.b, which refers to "specific reservations". Article 20.1 contains no such restriction, ...."

151. Kühner, op.cit. at 150-151.

152. This apparent contradiction between the law of treaties and the exigencies of human rights Jaw underlines the impression that the law on reservations can not be applied strictly to human rights treaties.

Kühner, op.cit. at 152, puts it like this:"Das Gutachten fusat letzendlich auf der zutreffenden Erkenntnis dass das Vorbehaltregime der WVK auf Verträge zum Schutze der menschenrechte nicht zugeschnitten ist."

153. See the discussion of reciprocity in par.6 infra.

154. Cf.articles 21.1.a and 21.1.b, as well as article 21.3 final phrase. 
Article 21.1 deals with modifications on the basis of an accepted reservation, and the great similarity between this provision and the one on the effects of an objection not precluding entry into force must be noted. Article 21.1.a reads:

"A reservation established with regard to another party in accordance with articles 19 , 20, 23; a) modifies for the reserving State in its relations with that other party the provisions of the treaty to which the reservation relates to the extent of the reservation;...",

while article 21.3 states:

"[W]hen a State objecting to a reservation has not opposed the entry into force of the treaty between itself and the reserving State, the provisions to which the reservation relates do not apply as between the two States to the extent of the reservation."

This parallel has lead many authors to question the difference between acceptance and objections not precluding entry into force ${ }^{155}$. The distinction between acceptance and objections disappeared as far as the legal effects are concerned. It has even been suggested that objections not precluding entry into force are an atypical form of acceptance ${ }^{156}$.

From a practical point of view this might seem convincing. An objection not precluding entry into force may eventually be the reason the treaty will enter into force for the reserving State, failing acceptance of its reservation by other States parties. Thus articles 20.4 .b jo. 21.3 are complementary to article $20.4 . \mathrm{c}^{157}$.

The authors are somewhat puzzled about the reasons why objections should be made when these will have the same effects as acceptance. In the Vienna Convention the decisive element for the establishment of treaty relations based on reservations is the statement on entry into force. Objections no longer preclude entry into force, only the expressed intention to preclude entry into force does so. This does not mean, however, that objections not precluding entry into force are without significance. States may use objections to express their disagreement with a reservation, without precluding the establishment of treaty relations. Such objections may be political declaration ${ }^{158}$ but it is also conceivable that States may want to object so as to prevent the possible formation of customary law opposable to them, on the basis of the reservation.

Apart from the question of whether the Vienna Convention rules could be applied to an earlier treaty such as the 1958 Geneva Convention on the Continental Shelf $\mathrm{f}^{\text {s9 }}$, the issue of the legal effect of reservations and objections to such

155. Clark, op.cit. at 310; Coccia, op.cit. at 35; Imbert, Les Réserves at 157; Koh, op.cit.at 102-103; Kühner, op.cit. at 184; Sinclair; op.cit. at 76; Szafarz, op.cit. at 311.

156. Clark, op.cit. at 310 ; Kühner, op.cit. at 184 , saying:".läge es dann nicht sogar nahe, den einfachen Einwand als besondere atypische Forn der ausdrücklichen Annahme anzusehen?"

157. Kühner, op.cit. at 184; Szafarz, op.cit. at 310.

158. Imbert, Les Réserves at 157.

159. See about this question par. 7 infra. 
reservations was one of the important questions dealt with by the arbitral tribunal in the United Kingdom - France Continental Shelf Case ${ }^{160}$. In particular the meaning of the phrase "to the extent of the reservation" in article 21.3 was dealt with.

It is necessary to sketch the situation with which the arbitration dealt with. The United Kingdom had ratified the Convention in 1964; France ratified in 1965 making a declaration containing five interpretative statements, that might in part be reservations. The fifth declaration dealt with article 6.1 and 6.2 , about the determination of boundaries on the Continental Shelf ${ }^{161}$. It refers to "special circumstances" in particular areas along the French Atlantic and North Sea coasts. The goal of the reservation ${ }^{162}$ was to establish that in these areas the boundary would not be determined using the equidistance principle laid down in article 6. Early 1966, the United Kingdom objected to this French reservation, stating that it was unable to accept the reservation to article 6 .

The question asked what the effect of the reservations was. France contended that the effect of reservations and objections was that the 1958 Convention was not applicable between itself and the UK. Alternatively, the whole Convention except for article 6 would apply. Hence pre-existing customary law would apply to fill the legal gap. The United Kingdom argued that objections to reservations did not preclude the entry into force of the Convention. In the alternative, the reservation with respect to article 6 was not permissible within the system of the 1958 Convention, and thus invalid. The Convention as a whole therefore was binding upon both States.

The Court indicates that the effect of the objection is to render the reservation non-opposable for the United Kingdom, as much as the reservation prevented the United Kingdom from invoking article 6 against France. This however does not lead to total inapplicability of article 6 between France and the United Kingdom, the Court stresses. "It is to render the Article inapplicable as berween the two countries to the extent, but only to the extent of the reservations; and this is precisely the effect envisaged in such cases by Article 21, paragraph 3 of the Vienna Convention on the Law of Treaties. " 163

The phrase "to the extent, but only to the extent" is a clear formulation of the principle that the scope of legal effect of reservations and objections should be construed narrowly, and that reservations should be interpreted restrictively.

160. Delimitation of the Continental Shelf (United Kingdom of Great Britain and Northern Ireland and the French Republic) Award 30 June 1977: in: 54 IL.R 1979 at 6-10, 38-53.

161. Article 12 of the 1958 Convention on the Continental Shelf indicates that reservations may be made to articles other than article 1 to 3 .

162. The Court had established that the declaration was a reservation. see par. 54-55; also discussed in par.2.3 supra.

163. Award, para.61. 


\subsection{Withdrawal of reservations and objections, article 22}

Article 22 VCLT lays down the rule that in general reservations may be withdrawn at any time, and that the consent of the State that had earlier accepted the reservations is not required, unless otherwise agreed. The rule in article 22.1 does favour the withdrawal of reservations by attaching no conditions to withdrawals, which is a practical and pragmatic approach. Yet, if reservations are considered to be additional bilateral agreements, it is rather unsystematic not to require the consent of the accepting State for the withdrawal by the reserving State.

Similarly, objections may be withdrawn at any time. It should be noted that the withdrawal of objections is extremely rare, if not non-existent.

The provision contains in paragraph 3 some rules with respect to the moment at which the withdrawal of reservations and objections becomes operative, which is usually at the moment notification is received.

\subsection{Procedural aspects, article $\mathbf{2 3}$}

The final provision in the section on reservations in the Vienna Convention deals with the procedural aspects of reservations. Paragraph 1 indicates that reservations, express acceptance and objections must be formulated in writing, and must be communicated to the States Parties and the States entitled to become State Parties. The withdrawal of a reservation, or of an objection to a reservation should also be formulated in writing says article 23.4. Stressing that these steps should be in writing will come as no surprise given the fact that reservations and objections lead rules of law in the shape of lex scripra ${ }^{1 \omega}$.

Paragraph 2 stresses that reservations made when signing subject to ratification, need to be confirmed at the moment of expressing consent to be bound. Objections to, or express acceptance of reservations formulated prior to expressing consent to be bound, do however not require confirmation according to article 23.2 VCLT.

\subsection{Treaty relations on the hasis of reservations}

In view of what has been said about the provisions on reservations, it is useful to give an overview of the treaty relations possible on the basis of reservations falling within the scope of article 19.c. This matter might be best explained using a diagram in which the three different aspects articles 19-21 mention (compatibility, acceptability and legal effects) are incorporated.

It must be assumed that any reservation is either compatible or incompatible (section I). States parties have to react to any reservation, and they only have two

164. G.Gaja, Reservations to treaties and the newly independent States (hereafter: Gaja, Reservations). IYIL 1975, 52-68 at 58 suggests that the withdrawal of reservations may be implicit. We will not discuss this possibility here. as it seems to be a very limited exception to the general practice. 
options. Either they accept the reservation or object to it (section II). Furthermore they will have to decide on the legal effects either decision on acceptability will have. Acceptance, whether explicit or tacit, implies entry into force; whereas objections may or may not lead to entry into force (section III).

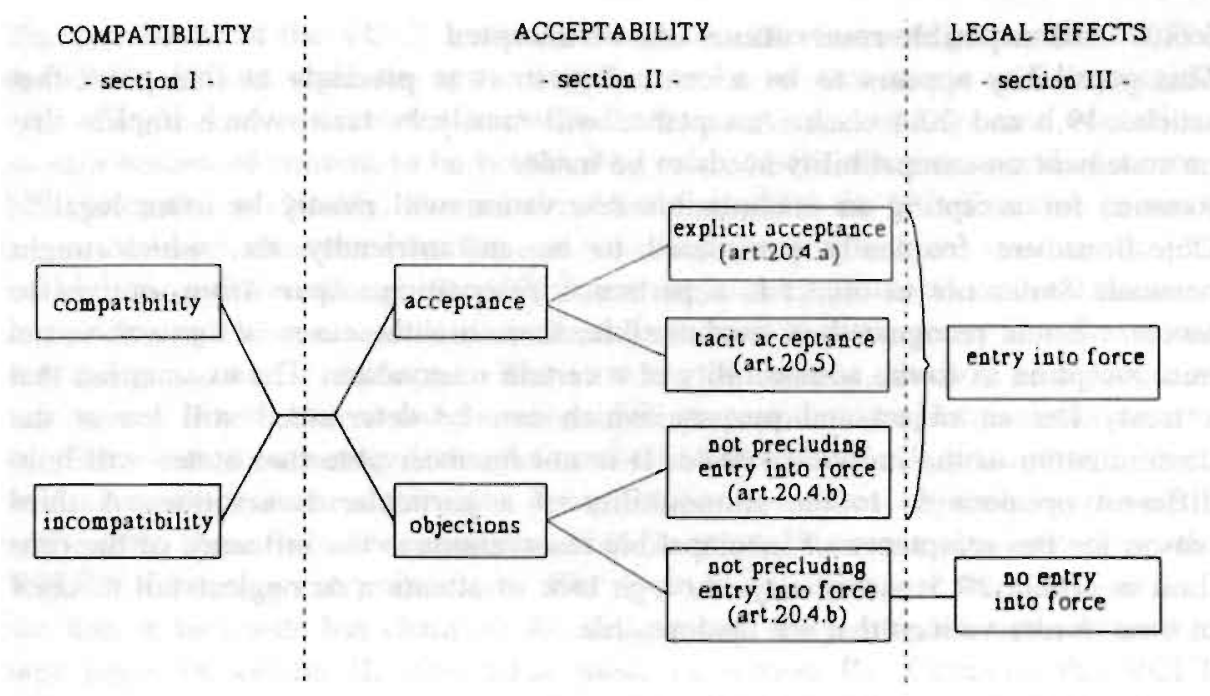

Using the diagram, the following situations can be described:

\subsubsection{The acceptance of compatible reservations}

This is a case which needs little explanation: once a reservation is compatible there appears to be no reason not to accept the reservation. Acceptance can be either explicit (article 20.4.a), which is increasingly rare, or tacit (article 20.5).

\subsubsection{Objections to compatible reservations}

Whether States have a duty to accept all compatible reservations, as some authors assert ${ }^{165}$, is a question which arises in the second combination. Acceptability, it is recalled, is foremost a subjective matter ${ }^{160}$. Whereas the Genocide case stresses compatibility as a rule for reservations and objections this is not the case in the Vienna Convention. States may have all sorts of reasons not to want to enter into treaty relations with an other State on the basis of reservations. Here the link between objection and entry into force needs to be stressed. In order not

166. Clark. op.cit. at 303; Coccia, op.cit. at 33; Shelton, op.cit. at 228. 
to establish treaty relations with a reserving State, a State will have to object, and state explicitly that entry into force will be precluded.

It is hard to see why a State objecting to a compatible reservation would not oppose entry into force if it were not for laxity or lack of precision in applying article 20.4.b. Even if the use of this possibility is not very clear, it is not impossible.

\subsubsection{Incompatible reservations can be accepted}

This possibility appears to be a contradiction. It is precisely at this point that articles 19.c and 20.4 clash. Acceptance will mostly be tacit, which implies that no statement on compatibility needs to be made.

Reasons for accepting an inadmissible reservation will mostly be extra legal ${ }^{167}$. Objections are frequently considered to be an unfriendly act, which might persuade States not to object to a particular reservation. Apart from motives to accept what is recognized as inadmissible, there are the cases of ignorance and misconception as to the admissibility of a certain reservation. The assumption that a treaty has an object and purpose which can be determined still leaves the determination to the individual State. It is not inconceivable that States will hold different opinions as to the admissibility of a particular reservation. A third reason for the acceptance of incompatible reservations is the influence of the time limit in article 20.5; states may, through lack of attention or neglect fail to react in time to reservations that are inadmissible.

\subsubsection{Objections to incompatible reservations}

This causes few problems and may somehow seem as self-explanatory as the case mentioned under 1 . States objecting have the opportunity to choose between entry into foree and preventing entry into force. It must be assumed that the decision on the entry into force is related to both the weight the objecting State attaches to the incompatibility of the reservation, and to the character of the treaty the reservation is made to.

Thus an objection not preventing entry into force will often be a statement concerning the state of the law ${ }^{168}$, while the objecting State has no direct interest in thoroughly reciprocal treaty relations. This explains objections based on inadmissibility of a reservation, not precluding entry into force of human rights treaties ${ }^{160}$.

Objections preventing entry into force are the ultimate consequence of the compatibility requirement in article 19.c. This reaction may be encountered if the reservation is contrary to the object and purpose of the treaty, or is a violation of

167. Clark, op.cit. at 304, 307; Ruda, op.cit. at 190.

168. Thus preventing both confusion and the creation of customary law opposable to the objecting state, based on an incompatible reservation.

169. See for instance objections by the Federal Republic of Germany, the Netherlands, Mexico and Sweden to reservations made to the Convention on the Elimination of all Forms of Discrimination against Women; Multilateral treaties deposited with the Secretary-General ST \LEG\SER.E\11. 
ius cogens ${ }^{170}$. The preclusion of entry into force is also likely to appear in the case of so-called contract-treaties ${ }^{171}$, which aim at mutually reciprocal benefits. The objecting State then reacts to the disequilibrium caused by the reservation by precluding entry into force.

\subsection{Reconsideration of the Vienna Convention system}

The provisions of the VCLT on reservations are not as unambiguous as would be desirable. At first sight the system appears to be an incomplete and impractical one. The law on reservations traditionally focused on acceptance and objections as expressions of consent to be bound. The role of both acceptance and objections has changed considerably, as a result of the distinction the VCLT makes between acceptance and objections on the one side, and entry into force on the other. It will be noticed that though the VCLT maintains the traditional contrast between acceptance and objections, the important distinction between entry into force and non-entry into force is obscure. The vital element in any reaction to a proposed reservation is whether or not the treaty will enter into force between the reserving State and the reacting State. As has been shown in the diagram above, there will in most cases be entry into force, except for when objections precluding entry into force have been made. This is what is commonly known as the VCLT's favouring entry into force. However, using the same diagram, one will see that in fact little has changed: the decision on entry into force which used to take place in section II, now takes place in section III. Claiming the VCLT favours entry into force fails to perceive that it has merely extended the points on which a State considering a reservation will have to react.

Article 20 makes a distinction between acceptance and objections on the one side and (non)entry into force on the other. It is often said that this distinction deprives acceptance and objections of all legal significance ${ }^{172}$. This view however, cannot be shared. In the VCLT's system States are required to react in a twofold way to a reservation. Firstly they express approval or disapproval with the reservation by accepting it or objecting to it. Explicitly stating disapproval with a reservation may preclude the establishment of a particular interpretation of the treaty, or the formation of customary law on the basis of a reservation opposable to the States parties ${ }^{173}$. Then they indicate whether or not the treaty

170. States may use objections in this way to stress their disapproval of reservations contrary to ius cogens, the reservations thenselves, it must be stressed. are void ab initio; Kühner at 146: articles 53, 64 VCLT.

171. S.Rosenne. Developments in the Law of Treaties 1945-1986, Cambridge 1989, at 182 defining the traité-contrat:".the treaty consists of a series of reciprocally operating rights, duties and benefits, the treaty being more or less synallagmatic and reflecting a do ut des adjustment of concrete interests."

172. Coccia, op.cit. at 36; Cook, Women's Convention, at 6.56.

173. P.H.Imbert, Reservations and human rights conventions(hereafter: Imbert, HRR) in: 6 HRR 1981. 28-60, at 37 writes in respect of human rights treaties that "..it is possible to offer resistance to the interpretation of a provision which might result from reservations and. in a general way, to uphold a principle." 
will enter into force between themselves and the reserving State. Accepted reservations and reservations objected to will lead to reciprocal modification of the treaty between reserving and reacting State. The modifications will not take place between the other States parties to the treaty, which leads to what Coccia adequately calls a patchwork of different rights and obligations ${ }^{174}$.

Still, neither acceptance nor objections are irrelevant facts. They have a significance of their own, though they no longer determine or preclude the establishment of treaty relations between the reserving and the reacting State. Acceptance, be it explicit or tacit, implies the approval of the State reacting to a reservation. A state that accepted a theoretically incompatible reservation will be estopped from invoking the incompatibility at a later stage. Objections, on the other hand, voice the disapproval of a State with a reservation. This disapproval does not necessarily preclude entry into force. The main function of objections, it is suggested, may be that they preclude a particular interpretation of the treaty from gaining influence. States may attempt to establish a generally accepted interpretation of the treaty by way of a reservation ${ }^{175}$. By objecting to such a reservation the objecting State may influence the (non)acceptance of this interpretation by other States parties, or by organs executing the treaty. The issue of preventing a particular interpretation of the treaty, plays an even more important role when the objections aim at precluding the creation of customary international law on the basis of a reservation. Preventing a particular interpretation of the treaty does not necessarily require preclusion of entry into force. Moreover, objecting on the grounds of incompatibility allows the option of bringing up the matter of compatibility at a later stage, for instance as an issue in a dispute settlement procedure. While there may not be a need to preclude entry into force, an objection may safeguard future action with respect to the incompatibility.

This is why it might said that the Vienna Convention has in fact broadened the scope of possible reactions to reservations. The diversity of reactions to both compatible and incompatible reservations within the scope of the VCLT may historically be the result of compromise solutions and imprecise drafting. Yet, the law on reservations is not as incomplete as it seems to be at first sight. In fact it provides a comprehensive system of reactions to a proposed reservation. The law of treaties now gives States more, and more varied possibilities to react to reservations than it previously did. It must be assumed that this will eventually lead to more clarity, in particular on the practical consequences of reservations to treaties which do not contain a reservations clause.

174. Coccia, op.cit. at 9.

175. This may be a so-called interpretative declaration which because of its characteristics falls within the scope of art.2.1.d VCLT.

See on this issue: D.M.McRae, The legal effects of interpretative declarations, in: 50 BYIL 1978, 155-173. 


\section{THE RELEVANCE OF THE OBJECT AND PURPOSE RULE}

With the emphasis on the practical aspects of the law on reservations in the previous paragraphs, the question that comes to mind is whether the lack of procedural safeguards for article 19.c, leads to its uselessness.

Compatibility appears to be an objective criterion, and if it were to coexist with the subjective and consensual character of treaty law, reservations would be subject to a double test. The authors have tried to explain article 19.c by either giving it the greatest possible impact, stating that any reservation incompatible with object and purpose would be a nullity ${ }^{176}$; or by claiming that article 19.c is a mere doctrinal assertion which is irrelevant in view of the system of tacit acceptance the convention promotes ${ }^{177}$.

The occurrence of incompatible reservations might be explained by the exigencies of international relations and national politics. The reasons for formulating incompatible reservations are beyond the scope of this book, and are not dealt with. Yet, one wonders whether this difference of opinion is all there is to article 19.c. The discussion has been narrowed down to the compulsory character of article 19.c, which makes it impossible to see the value of the provision. Article 19.c is a logically necessary rule, designed to prevent States, when expressing consent to be bound, from undermining the very raison d'être of the treaty by making a reservation incompatible with the object and purpose of that same treaty. What is the relevance of article 19.c and can it only be explained by choosing sides with either of the opposing schools of thought? As will be shown below, the value of article 19.c extends beyond both points of view in a theoretical as well as in a practical way.

\subsection{Ex injuria non oritur ius}

The question of the (tacit) acceptance of reservations (supposedly) contrary to the object and purpose of a treaty might also be viewed from another angle, the principle of ex injuria non oritur ius. It is submitted that, without referring to it, the theory proposed by Bowett actually relies on this maxim. The rule reflects the basic understanding that States may not benefit from their own wrong (be it omissions or negligences), and no profits should derive from illegal acts ${ }^{178}$.

Ex injuria non oritur ius rule is a notion that could be classified as a general principle of law, and is as such a secondary source of international law under article 38.1.e of the Statute of the International Court of Justice. Moreover, the ex injuria rule is theoretically necessary in any legal system. Yet, in spite of the self-evident nature of this maxim, few authors devote attention to the practical

176. Bowett, op.cit. passim; G.Triggs. Australia's ratification of the International Covenant on Civil and Political Rights: Endorsement or Repudiation?. in: 31 ICLO 1982, 278-306.

177. See par.3.1.2 supra.

178. G.Fitzmaurice. The General Principles of International Law considered from the standpoint of the rule of law; in: 92 RdC 1957 II, 5-222 (hereafter: Fitzmaurice, General Principles) at 117. 
consequences of the rule. Brownlie considers it to be a rule that does not provide a safe guide to the solution of specific problems ${ }^{179}$. In discussing the question of whether international law ever validates illegality, Fitzmaurice focuses on the consensual nature of international law ${ }^{180}$ by stressing that illegal acts are not validated by the sheer fact of taking place, but because other States do not react. As long as acts contrary to international law do not meet with objections and protests on the part of other States, one cannot claim that it is illegality that produces legal consequences. It is rather the lack of reaction, or acquiescence, that legitimizes a previously illegal act ${ }^{181}$. The relevance of Fitzmaurice's point of view is that it underlines the fact that, although states appear to act unilaterally on the international plane, international law is an essentially consensual system. Acquiescence replaces explicit consent, and those that acquiesce are equally responsible for the rule that is being be created.

Transplanting this theory to the problems surrounding the enforcement of article 19.c VCLT, the position is as follows: article 19.c itself indicates that reservations contrary to object and purpose are illegal. Yet, reservations that are formulated need to be accepted, the Vienna Convention is build upon the traditional system. What is confusing about the Vienna Convention system is the fact that rule stipulating the illegality (namely the "object and purpose" criterion in article 19.c) is immediately followed by a provision formalizing the mechanism of acquiescence, in fact strengthening it, the system of tacit acceptance (in article 20.5). The rule of tacit acceptance is a mechanism that can lead to legitimizing acts contrary to rules of international law, even stronger than the functioning of acquiescence described by Fitzmaurice.

However, tacit acceptance is not necessary and in case an incompatible reservation is made States have the possibility to react by way of objections. It would seem that claiming the incompatibility of a reservation after having accepted it tacitly is a case of venire contra factum proprium. Tacit acceptance leads to estoppel with respect to the compatibility issue.

It is submitted that our understanding of article 19.c reflects the certainty with which the object and purpose rule was proclaimed in the Advisory Opinion the Genocide Convention. This detracts attention from the international legal mechanism of acquiescence that may legitimize a previously illegal act, which is in fact (although not very explicitly) reinforced by the system of tacit consent in article 20.5. Consequently, although the question has been raised above, the problem of acting contrary to article 19.c, which frequently happens as we shall see further on, is not a problem about the ex injuria non oritur ius rule. It is the problem of inactive states, whose laxity leads to the acceptance of reservations contrary to object and purpose. The responsibility for incompatible reservations is thus shared by reserving and accepting States.

181. The functioning of acquiescence in international law will not be discussed here. 


\subsection{Good faith}

Another interpretation of the rule in article 19.c would be that it is an obligation akin to the principle of good faith ${ }^{182}$. This is a rule emphasizing the need for trust and confidence amongst states in international legal relations. The rule seeks to promote foreseeability. The obligation to act in good faith is a rule of international law, laid down amongst others in article 2.2 of the Charter of the United Nations ${ }^{183}$. It is reinforced by the reference to this obligation, and the following elaboration, in the Declaration on Principles of International Law concerning the Friendly Relations and Co-operation among States ${ }^{184}$.

The interesting point is that the obligations assumed in accordance with the Charter must be understood to include promoting and encouraging respect for human rights and fundamental freedoms mentioned in article 1.3 of the Charter. This stresses that States should act in good faith, especially in respect of human rights treaties concluded under the aegis of the United Nations.

The obligation to act in good faith is a two-sided obligation. First of all it is a rule binding upon States covering the period of negotiations of a treaty up until the ratification ${ }^{185}$. This explains the necessity of the "object and purpose" rule in article 19.c of the Vienna Convention, it is an elaboration of the rule that ratifications (including the reservations attached) ought to take place in good faith.

At this point it interesting to note that the International Court has stressed that good faith is a rule that also applies to unilateral acts ${ }^{186}$. In the Nuclear Tests case, the International Court concluded that States could rely on a unilateral declaration by France, because of its binding nature being based upon good faith $^{187}$. A similar line of argument is to be found in the Nicaragua case in respect of the withdrawal of the declaration of acceptance of the compulsory jurisdiction of the Court by the United States ${ }^{188}$. Though it has been stressed

182. Cook, Women's Convention at 678-679.

183.Article 2.2 reads:"|A]Il members, in order to ensure to all of them the rights and benefits resulting from membership, shall fulfil in good faith the obligations assumed by them in accordance with the present Charter."

184. GA Res.2625 (XXV), 24 October 1970.

185. Cf. article 18 VCLT, see about this provision Sinclair, op.cit. at $42-44$.

Coccia, op.cit. at 25 speaks of an obligation to refrain in respect of article 19.c; Cook. Women's Convention at 678.

186. Cf.G.Schwarzenberger, The fundamental principles of international law; in: 87 RaC 1955 I. 195-383: at 323.

187. Nuclear Tests case (Australia v. France), ICJ Rep.1974, 253: par.46:"Just as the very rule of pacta sunt servanda in the law of treaties is based on good faith, so also is the binding character of an international obligation assumed by unilateral declaration."

188. Case concerning Military and Paramilitary Activities in and against Nicaragua (Nicaragua v. United States of America), ICJ Rep.1984;

par.60 reads:"..the declarations, even though they are unilateral acts, establish a series of bilateral engagements with the other states accepting the same obligation of compulsory

(continued...) 
that while appearing to be unilateral, reservations are actually restrictions based on consent ${ }^{189}$, the similarity between a reservation and the declaration under the Optional Clause of the Statute of the International Court is remarkable. Reservations, even though they are formulated unilaterally, establish a series of bilateral engagements with other States accepting the same obligation; reservation and acceptance lead to a network of engagements in which. according to the ICJ, the principle of good faith plays an important role.

The other side of the principle of good faith may prove to have more practical importance in respect of reservations. Given the obligation described above. states must be assumed to have acted in good faith in the exercise of their rights under international law 190 .

Good faith is a guideline as to how obligations should be executed, and places restrictions on the State's discretion to choose between options it may have in the fulfilment of its obligations ${ }^{191}$. The presumption of good faith will act as a guiding principle in the application and the interpretation of obligations ${ }^{192}$. While the interpretation of a treaty is necessary for its application, the same holds true for reservations. Article 19.c will be a guideline for this interpretation, states are presumed not to have formulated reservations incompatible with the object and purpose of the treaty because they are supposed to have acted in good faith when formulating reservations.

It is submitted that this assumption is not only relevant for the other States Parties, but that it is of fundamental importance for the work of the supervisory bodies under human rights treaties. The presumption that accepted reservations are not incompatible, will lead to an interpretation restricted by the limits of compatibility. Thus broadly formulated, technically incompatible reservations will not have the sweeping effect their authors intended. States will in all probability never mention an intention to make an incompatible reservation, and are indeed not supposed to have Jone so. Good faith, in the shape of article 19.c VCLT, thus limits the influence that accepted incompatible reservations may have.

188.(...continued)

jurisdiction, in which the conditions, reservations and time-limit clauses are taken into consideration. In the establishment of this network of engagements, which constitutes the Optional Clause system, the principle of good faith plays an important role;...

par. 63 reads:" $[B]$ ut the right of immediate termination of declarations with an indefinite duration is far from established. It appears from the requirements of good faith that they should be treated, by analogy, according to the law of treaties,..."

189. See par.3.2, par.3.6 supra.

190. This point was stressed by the Belgian representative during the drafting of article 2.2 of the Charter: A.Cassese, International Law in a Divided World. Oxford 1988 (hereafter: Cassese. International Law) at 154: Cook, Women's Convention at 649-650.

191. Cassese, International Law, at 152 writes that the principle of good faith "merely conveys the idea that international subjects must not take advantage of their rights (or discharge their obligations) in such a way as to thwart the purpose and object of legal rules." This is not a particularly helpful point of view in respect of article 19.c VCLT, but it goes to show that there is a distinct similarity in both notions.

192. Cook, Women's Convention at 649-650. 


\subsection{The importance of article 19.c}

The law of treaties is a set of rules regarding the formalities through which rules become rules of international law. It is merely instrumental to the regulation of the substance of the treaty. A reservation formulated by one State and accepted by another will become binding on both States. The fulfilment of formalities is not enough: article 19.c points to the substance of the treaty. The article states what is in fact an essential element of the law of treaties: parties not only consent to the text of a treaty but also, and foremost, to the common intention expressed in that text. Expressing consent to be bound by a treaty, while at the same time denying the raison d'être of the treaty by formulating a reservation incompatible with the object and purpose of the treaty is, at the very least, contradictory ${ }^{193}$.

Article 19.c is both a logical necessity as well as a realistic requirement, the formalities of the law on reservations may not be used to serve other purposes than the ones they were designed for. Reservations incompatible with the object and purpose of the treaty are clearly beyond the instrumental scope of the law, and may therefore not be formulated. This is why article 19.c may be seen to underline the instrumental character of the law of treaties.

\section{THE ISSUE OF INTERPRETATIVE DECLARATIONS}

Interpretative declarations seem to obstruct the rules on reservations. There is an impression that states use the front of interpretative declarations when wanting to make reservations. Interpretative declarations do not reveal the author's default when applying a treaty, or are not such a sign of bad faith as reservations are ${ }^{194}$. Additionally there is confusion about the appropriate reaction to these 'reservations in disguise', it is not clear when to react and how to react if one intends to preclude the declaration from obtaining binding force ${ }^{105}$.

One of the aims when drafting the definition of reservations as laid down in article 2.1.d of the Vienna Convention was that it would also encompass statements known as interpretative declarations, which in some case are assumed to have the same legal effects as reservations ${ }^{196}$. The definition in article 2.1.d stresses the substance of reservations, namely their excluding or restricting effect, irrespective of the name attached to the declaration.

Before dealing with the possible similarity between interpretative declarations and reservations, the onus will be on their distinctive characteristics, and on the role of interpretation in treaty law. Taken at face value reservations and interpretative

193. L.Lijnzaad, Paradoxale universaliteit, of de beperkingen van het verdragenrecht, in: Universaliteit van mensenrechten, fundanenteel en controversicel, Th.van Boven, C.Flinterman (eds.), Leiden 1992: 7-17 at 10.

194. Kühner, op.cit. at 15-16.

195. McRae, op.cit at 158, Sinclair, op.cit at 53-54.

196. Bowett,op.cit. at 68; Hom, op.cit. at 236. Sinclair, op.cit. at 52-54. 
declarations have little in common ${ }^{197}$. Reservations restrict the legal effect of a treaty for the reserving state, a restriction that comes into force the very moment the reservation is accepted by other States Parties. Interpretation is another matter, it takes place once the treaty has entered into force and it is essential for the application of the treaty. Interpretative declarations thus unilaterally clarify the content of (a particular provision of) a treaty.

It is necessary to recall the role of interpretation in treaty law ${ }^{198}$. The application of generally formulated principles requires the interpretation of the rule. This can best be described as a process in which is sought to determine what in this particular case would be the rule following from the general norm. Interpretation is not an independent process, it is initiated because of the occurrence of a particular issue. It establishes a rule which is more precise, more detailed and more suitable than the abstractly formulated norm. Interpretation is the transition from the text of a treaty to treaty practice. The constant recurrence of interpretation is demonstrated by the fact that often reservations and interpretative declarations themselves need to be interpreted.

The interpretation of a treaty should take place according to the general rules for the interpretation of treaties ${ }^{199}$. The principle stated by Vattel as: "IIJl n'est pas permis d'interpréter ce qui "n'a pas besoin d'interprétation" is supposedly the leading rule ${ }^{300}$. A number of other rules are regularly mentioned such as the supposition that the plain meaning of the terms in a provision is used, and the rule expressio unius est exclusio alterius ${ }^{201}$.

197. Horn, op.cit. at 237:"An interpretative declaration is an interpretation, which is distinguished from other interpretations by its form and by the moment it is presented. A reservation is a modification of the norm system expressed in a treaty. It is distinguished from other forms of modification because of its formal and temporal characteristics, as for example, formal amendments and superession by new treaties regulating the same subject-matter." and at 238:"So reservations and declarations form completely distinct categories of acts due to their different functions. A reservation affects the norm - an interpretative declaration operates on the norm formulation; their objects are distinct."

198. MeNair. The Law of Treaties, Oxford 1961 at 365 puts it like this:"...the duty of giving effect to the expressed intention of the parties, that is their intention as expressed in the words used by them in the light of the surrounding circumstances.", and P.Reuter. Droit International Public, Paris 1976. Sième ed.rev. at 124 writes:"Interpréter consiste à retrouver la volonté du ou des auteurs d'un acte juridique. Interpréter un accord instrumenté dans un texte consiste donc, en se soumettant d'abord au texte, à retrouver la commune volonté de ses auteurs."

199. Questioning the cxistence of general rules and suggesting that choosing particular rules of interpretation in fact influences the result of the interpretation: Brownlie, op.cit. at 626-627.

200. This may be doubted, as the conclusion that there is no need for interpretation usually follows the interpretation of the treaty. On this point Sinclair, op.cit. at 116.

201. On the issue of the interpretation of treaties amongst others: McNair, op.cit. Chapters $\mathrm{XX}$ and XXI; H. Lauterpacht, Restrictive interpretation and the principle of effectiveness in the interpretation of treaties, 26 BYIL. 1949 at 48-85: M.K.Yasseen, L'interpretation des traités d'apres la Convention de Vienne sur le droit des traités. 151 RdC 1976 III, 9-114. 
Articles 31-33 of the Vienna Convention deal with the interpretation of treaties $^{202}$. Article 31.1 reads:

A treaty shall be interpreted in good faith in accordance with the ordinary meaning to be given to the terms of the treaty in their context and in the light of its object and purpose.

The intentions of the states parties as laid down in the treaty are what is sought for in article 31 , which is known as the objective approach to treaty interpretation. The article indicates elements used in the process of interpretation, but does not (and cannot) give the ultimate rule as to how interpretation should take place ${ }^{303}$. The elements indicated (good faith, ordinary meaning, context and object and purpose of the treaty) are together the one single general rule of interpretation, albeit that they indicate the order in which to proceed. From a technical point of view, articles 31-33 are applicable to treaties that have entered into force.

It stands to reason that prior to ratification of a treaty, states study its provisions to determine whether they can accept the treaty as it is, or would like to exclude or restrict some of its provisions, thus wanting to make reservations. States will interpret the treaty for domestic purposes, supposedly along the lines of articles 31-33 of the Vienna Convention.

The impact of a treaty and the way in which its provisions will work out cannot always be estimated in advance. It may well be that there are provisions the content of which is not clear at first sight. There may be broadly formulated provisions, or provisions formulated in such a way as to find a compromise solution during the drafting, thus hiding the fact that no solution had actually been reached. Moreover, states may want to preclude unpredictable changes in interpretation due to technical or scientific changes in the subject-matter of the treaty, or may want to suggest a preferred interpretation to supervisory organs.

The precise obligations following from a treaty cannot always be determined before hand. It is then that the quite understandable wish to make interpretative declarations at the ratification of a treaty arises. States indicate the desired interpretation of a provision. The interpretative declaration is an opinion as to how a provision ought to be understood. It is nothing more than a unilateral statement addressed to other states parties and to possible supervisory organs. While the declaration itself has no direct legal effect, either for its author or the other states parties, its aim is obviously to arouse support for the interpretation proposed.

Yet, distinctions between reservations and interpretative declarations are not always as clear as sketched above. Let alone the matter of the legal difference between the effects of reservations and interpretative declarations, both could be seen on a sliding scale from the definite exclusion of unacceptable provisions at 
the one end, to suggesting a preferred interpretation of a provision at the other end. In between both lies a grey zone of cases in which states advocate a certain interpretation of a provision, but if that particular interpretation is not accepted they want to exclude the provision altogether. In such a case the need to exclude a provision has not yet arisen, for it may well be that the interpretation proposed will eventually turn out to be the authoritative interpretation. On the other hand states feel impelled to be careful, for once the authoritative interpretation is established, it will usually be too late to make a reservation.

This is the dilemma surrounding interpretative declarations. States do make interpretative declarations that not only purport to advance an interpretation favoured by the declaring state, but that also condition their acceptance of the treaty. They accept the treaty provided that their particular interpretation will be accepted $^{204}$. These declarations have been called "qualified interpretative declaration" 20.5 , and should, according to McRae, be treated as reservations. Although this seems to provide a distinctive criterion, one wonders who it is to decide whether a statement is a "mere interpretative declaration" or a "qualified interpretative declaration". States may be supposed to be unambiguous in their statements, but quite often the intention of the declaring state will not he clear $r^{206}$.

Proposing a specific interpretation as a condition for the acceptance of (a provision of) the treaty does not lead to problems once it is established that the proposed interpretation is the same as the authoritative interpretation. With hindsight, the interpretation given by the declaring state has been the correct one from the start. But if it is established, on the other hand, that the authoritative interpretation differs from the one propused by the declaring state, the conditional aspect of the declaration regains importance. For once it is determined how a provision should be interpreted, the declaration turns into a reservation. A qualified interpretative declaration has two sides to it: it gives an interpretation of a provision, and, at the same time, it is a potential reservation once it is established that the interpretation is not accepted ${ }^{317}$.

This possibility of transition refines the theory of interpretative declarations, and does justice to the uncertainty that led to formulating an interpretative declaration $^{308}$. Horn, in developing this theory, stresses that it should be an authentic interpretation that plays a decisive role in the transition ${ }^{200}$. For authentic interpre-

204. McRac, op.cit. at 160.

205. Horn, op.cit. at 238-242, and MeRae, op.cit. at 155-173.

206. On the ambiguity of interpretative declarations: Gaja. Unruly resenvations at $319 ;$ Kühner op.cit at 31: and Szafarz op.cit. at 297.

207. Horn, op.cit, at 242.

208. Horn, op.cit at 239:"However, if some other interpretation is judged to be the correct one, and the declaration turns out to be a derogation from the norm system as established it would fulfil the requirements for being considered a reservation."

209. Horn, op.cit. at 239: This is the case once the parties have agreed upon an authentic interpretation through diplomatic negotiations; or have concluded a supplementary agreement on interpretation; or when a dispute concerning the interpretation of the treaty has been settled through judicial settlement or arbitration in a manner binding on all parties, which seldom occurs. "(my italics, EL). 
tation puts an end to the uncertainty about a provision, and indicates whether or not the potential reservation has become an actual reservation. He supposes that after an authentic interpretation that runs contrary to an interpretative declaration, the declaring state will express its intention ${ }^{210}$ : will the potential reservation live on as a reservation or will the declaring state abide by the authentic interpretation. He suggests that once the authentic interpretation is established, and the declaring state has clarified its position, the rules on acceptance of reservations would be applicable 211 .

This theory has been confirmed by the European Court on Human Rights in the Belilos-case ${ }^{212}$. It involved an interpretative declaration concerning article 6.1 of the Convention for the Protection of Human Rights and Fundamental Freedoms made by Switzerland on ratification of the Convention ${ }^{23}$. While the declaration maintained the interpretation of article 6.1 of the Convention as it stood at the time of ratification ${ }^{214}$, case-law had developed in another direction, as indicated by the Court in the Albert and Le Compte-case ${ }^{215}$ judgment. The declaration clearly ran contrary to the contemporary interpretation of the Convention at the time the events in the Belilos-case occurred.

When the European Commission on Human Rights dealt with the case, it considered the declaration a mere interpretative declaration, basically because Switzerland had made both reservations and declarations at the time of ratification, and the Commission assumed that the distinction made by the author state was decisive ${ }^{216}$. The Court on the other hand seems to agree with the Swiss contention that the declaration substantially fitted the definition of reservations in the Vienna Convention, and should be considered a reservation ${ }^{21}$. Although the Vienna Convention is not mentioned, the Court implicitly relied on its definition

210. Horn, op.cit. at 239:"This will depend on whether the declaring state is still willing to maintain its divergent interpretation. The declaring statc will presumably in many cases submit to the authoritative interpretation and abandon its own declaration."

211. Horn, op.cit. at 240.

212. The case is noteworthy in many respects, and will be discussed in Chapter 3, par.4.1.3 infra. On this case: H.J.Bourguignon. The Belilos Case: New Light on Reservations to Multilateral Treaties, in: 29 VJIL 1989 at 347-386; J.M. van der Velde, Zwitserse interpretatieve verklaring en artikel 64 . Noot by Belilos arrest, in: 13 NJCM Bull. 1988, at 464-481; and idem, De reaktie van de Zwitserse regering op het Beli!os arrest, in: 13 NJCM Bull 1988, at 597-601.

213. Switzerland deposited its instrument of ratifieation on 28 November 1974; the declaration concerning art.6.1 reads:" The Swiss Federal Council considers that the guarantee of fair trail in Article 6, paragraph 1 of the Convention, in the determination of civil rights and obligations or any criminal charge against the person in question is intended solely to ensure ultimate control by the judiciary over the acts or decisions of the public authorities relating to such rights or obligations or the determination of such a charge."

214. Ringeisen-case, 16 July 1971, ECHR Ser.A vol.13.

215. 10 February 1983, EC.HR Ser.A vol.58.

216. The Commission furthermore indicated that, had the declaration been a reservation, it would have been invalid for lack of compliance with article 64 of the Convention.

217. Belilos judgement, para.49. After deciding this, the Court found the declaration to be an invalid reservation for failing to fulfil the requirements of article 64 ECHR. 
of reservations, mentioning the fact that states quite often make interpretative declarations without clearly distinguishing them from reservations, and stressing that the nomenclature is of lesser importance:"In order to establish the legal character of such a declaration, one must look behind the title given to it and seek to determine the substantive content. In the present case, it appears that Switzerland meant to remove certain categories of proceedings from the ambit of Article 6 para. 1 and to secure itself against an interpretation of that Article which it considered too broad." 218 Thus there is an authoritative interpretation of the interpretative declaration made by Switzerland, and it found the declaration to be a qualified interpretative declaration.

The Swiss government even took the next step envisaged in the system designed by Horn, and made a statement clarifying its position concerning the legal effect of its declaration after the Belilos-case. This follow-up declaration met with disapproval $^{219}$, but it demonstrated that Horn had a point in assuming that states might like to clarify their position once it is established that an interpretative declaration is actually a reservation.

Although the Belilos judgement of the European Court on Human Rights is the perfect example for the theory of transitional interpretative declarations, its practicality should not be over-estimated. The author feels that this theory may have a very limited utility, for it is based on the existence of an authority endowed with the capacity to give an authentic interpretation of the treaty. Wellorganized, solid structures of supervision are relatively rare in international law. In the field of human rights treaties, various questions arise such as the identity of an authority competent to given an authoritative interpretation 230 , and the form in which this interpretation should take place ${ }^{221}$. Further below an attempt will be made to answer these questions, based on the practice of the treaties under consideration.

218. Van der Velde, Zwitserse interpretatieve verklaring at 479 . holds a different view. He thinks the Court did not give its opinion on the status of the declaration and instead argued the other way round, setting out to scrutinize the fulfilment of the requirements applicable to reservations in article 64 ECHR.

219. Van der Velde, De reaktie at 599-601, clearly outside the theory of interpretative declarations and the possibility of transition, maintains that a qualified interpretative declaration that decisively is a reservation cannot be made at any other moment that ratification. This prohibits Switzerland from making another, more specified declaration. Bourguignon, op.cit. at 383-384, has an even more black outlook, suggesting that the impossibility of making an(other) reservation would lead to Switzerland renouncing the treaty completely.

220. For instance, tan the supervisory committees be deened to give an authentic interpretation of the provisions of the Covenants if they are generally considered to be quasijudicial bodies? Or should this be up to the meeting of States Parties?

221. To name but a few questions: can this interpretation take place during discussions between representatives of the states parties reporting and members of the Committees, in the individual complaints procedures, or do general comments by a Committce provide interpretation with enough authority? 
Moreover it cannot be predicted when, if ever, a case involving the provisions mentioned in a qualified interpretative declaration will be authentically interpreted $^{222}$. Nor is it desirable that the parties should discover that an interpretive statement is a reservation at some arbitrary moment in the future. That is, on the assumption that whenever an authentic interpretation is given, it is clear what the implications will be for the interpretative declaration. As mentioned above, declarations are quite often formulated in vague and ambiguous terms. After the authentic interpretation the declaring state would supposedly indicate whether it intends to maintain its declaration as a reservation, which would be the starting point for the acceptance as described in article 20.5 of the Vienna Convention $^{223}$. One wonders whether this system is suitably transparent, and whether it will establish certainty concerning the status of interpretative declarations at all. Basically a declaration cannot exclude or restrict the legal effect of provisions of the treaty. It should be understood that in cases where a state wishes to exclude or restrict the legal effects of a treaty, an interpretative declaration cannot be used. Nor can it be expected that an interpretative declaration used in such cases will have the legal effect of a reservation. It is not subject to the procedure of tacit acceptance ${ }^{24}$ because it is apparently not a reservation.

\section{OF UNILATERALITY AND RECIPROCITY}

\subsection{Shades of unilaterality}

Although the Vienna Convention is theoretically clear about it ${ }^{25}$, the impression of reservations being unilateral acts remains. Perhaps not so from a technical point of view, but it appears that as reservations favour the reserving states, they are detrimental to the interests of the other states parties. There are three stages at which this supposed unilaterality casts its shadow: the making of a reservation, the acceptance of a reservation and the legal effects of a reservation.

Taking the moment when reservations are made, the initiative in making a reservation originates with the reserving state ${ }^{226}$. Formulating a reservation is obviously a unilateral act, but it remains to be seen whether reservations differ in

222. Horn, op.cit at 239:"Before any authoritative interpretation is achieved a situation of uncertainty will prevail and we are not able to fell whether the declaration has a modifying effect or not."

223. Horn, op.cit. at 240-242 passim.

224. Article 20.5 VCLT, discussed in par.3.2.3 supra.

225. Discussing the unilaterality issue prior to the Vienna Convention: G.C.Fitzmaurice, The Law and Procedure of the International Court of Justice 1951-1954, treaty interpretation and other treaty points, in:33 BYIL 1957, 203-293.

226. Imbert, Les Réserves at $\mathbf{1 2}$.

C. the International Court of Justice in the Anglo-Norwegian Fisheries case (ICJ Reports 1951, at 132):"although it is true that the act of delimitation is necessarily a unilateral act, because only the coastal state is competent to undertake it, the validity of the determination with regard to other States depends upon international law." 
this respect from other actions in the field of treaty law. Breach of treaty, proposed amendments, or suspension of the treaty are all acts that originate in one (or some) of the states parties. In this respect reservations are not unique.

As concerns the unilateral validity of reservations, socialist international law held for a long time that the validity depended merely on the fact that the reservations were made by a State, in whose sovereignty their validity was vested ${ }^{227}$. The main criticism of this theory has been that it neglects reciprocity as a comerstone of treaty law. The theory is outdated now, as fundamental changes have taken place 228 . Moreover, the Vienna Convention in article 20.4 set up a system in which acceptance is necessary, although it greatly favours the reserving state and turns acceptance into an implicit, if not symbolic, act.

The third issue is the unilateral impact of the reservation. The changes in treaty relations brought about by the reservation are supposed to be advantageous for the reserving state ${ }^{229}$. The state would have ameliorated its position substantively. It stands to reason that the preservation or the improvement of a position is a forceful incentive in making reservations. Yet, according to article 21.1 of the Vienna Convention the reservation leads to mutual, reciprocal changes in treaty relations ${ }^{230}$. Although the reservation may be prompted by particular interests of the reserving state, it automatically implies equivalent changes in the rights and duties of the accepting state.

The rule laid down in article 21.1 seems balanced. But looking at either the differences in the content of the treaties or the different character of the provisions, its consequences differ ${ }^{231}$. In the case of traités-contrats, the impact of the mutual restriction will depend on the balance of obligations and rights laid down in the treaty. The content of the treaty determines whether the retributionary exclusion based on article 21.1 is of any significance. Reservations to trairéscontrats are likely to have repercussions on the balance of substantive reciprocity underlying the treaty, but it does not necessarily have to be the case ${ }^{232}$. An active interest in the reservations made, and an inclination to object are to be expected.

\section{Coccia, op.cit. at 27; and see par.2.1 supra.}

228. R.A.Mullerson, Sources of international law: new tendencies in Soviet thinking, in:83 A.IIL 1989, 494-512; and I.I.Lukashuk. The principle pacta stunt servanda and the nature of obligation under international law. in:83 AJL 1989, 513-518.

229. Horn. op.cit. at $91: " A$ reservation seems at first glance to have a self-relating quality".

230. Horn, op.cit. at 92:"The distinct rule of reciprocal invocation is intended to reintroduce a balance into the legal relations between the reserving and the confronted states."; and at 96 asserting that "all reservations do somehow create obligations for the confronted states".

231. E.Decaux, La réciprocité en droit international, Paris 1980 at 73 severely criticizing article 21:".la Convention de Vienne a négligé toutes ces difficultés, pour se contenter de l'affirmation rassurante de la réciprocité des réserves. Comme si une solution unique était possible, indépendamment de la diversité des traités, des réserves et des parties. La simplicité de l'article 21 est donc trompeuse."

232. Horn, op.cit. at 92:"Reservations will in the standard case circumseribe the correlate rights of the other parties and widen their correlate obligations". 
The question is whether the reciprocal exclusion of rights and obligation serves any purpose in a traité-lo $i^{233}$, and in particular in a human rights treaty. For the objective nature of a human rights treaty makes it pointless, if not undesirable, for a State Party to react to a reservation by way of restricting its own obligations towards the reserving state. There is no impetus to do so, as the actual disadvantages of the reservation fall within the sphere of the individual subjects of national law in the reserving state, well beyond the influence of any balance struck by substantive reciprocity within the treaty. Moreover, the conviction underlying the adherence to the treaty, the fact that states decidedly undertake to guarantee the human rights of persons under their jurisdiction is in itself almost in contradiction to taking the option of mutual restriction that the law of treaties offers. In sum, reciprocal reservations thus turn out to be basically unilateral modifications. The absence of subjective rights may on the whole undermine the interest in the reservations made, and will seriously hamper the willingness to object.

\subsection{The dialectics of reciprocity}

The supposed unilateral nature of reservations dealt with above, has focused our attention on the opposite, the issue of reciprocity. The law of treaties operates on the basis of reciprocity. It is a common, although not necessarily correct, assumption that the law of treaties is comparable to the law of contract ${ }^{234}$. Presenting the law of treaties as a set of rules, based on the necessity of regulating the way in which agreements are made ${ }^{235}$ contains a certain amount of everyday logic. Reciprocity is a mechanism of international law, and even more so of treaty law, that acts as a stabilizing factor. It is understood as providing a balance between the interests of both parties. Through unilateral acts the equilibrium function of reciprocity is demonstrated. Each time a unilateral act disturbs the balance, reciprocity seems to establish a new equilibrium.

233. Rasenne, Developments, at 182 defining the raite-ioi:".the treaty consists of a series of generalized, and not particularly reciprocal. statements of standards, noms, rules, rights. and benefits which the contracting partics (or perhaps it might better be expressed as 'standard-creating parties') postulate."

234. A.D.McNair, The functions and differing legal character of treaties, in:11 BYIL I930, 100-118, at 106:".we must be on our guard against the assumption that merely because treaties have borrowed from private law contracts their form and the source of their binding force, all the rules as to formation, validity, interpretation. and discharge of contracts are equally applicable to treaties."

Rosenne, Developments, at $187:{ }^{\prime \prime}$.it is a matter of increasing urgency to liberate international legal theory from the restraints imposed by the historical background of a general law of contracts as a jurisprudential notion, and especially from the experiences of domestic private law.."

235. J.Dehaussy, Le problème de la classification des traités et le projet de convention établi par la Commission du Droit International des Nations Unies, in: En hommage à Paul Guggenheim, Genève 1968, 305-326 at 305:".le traité est. en quelque sorte. un $<<$ moule $>>$ juridique qui confère aux normes que les sujets du droit des gens s'accordent pour y <<couler > >. un caractère - pour eux, au moins - obligatoire." 
The issue of reciprocity is directly related to the perception of treaties as bilateral agreements (and in case of a multilateral treaty, a bundle of bilateral agreements ${ }^{236}$. Pacta sunt servanda and do $u$ tes are still the basis for bilateral obligations. The commonplace understanding is that parties to a treaty will have been able to find a balance between their interests, by way of giving and taking. Shared interests and mutual benefits are the basis for an agreement.

Legal scholars have repeatedly indicated that there is much doctrinal uncertainty about reciprocity ${ }^{237}$. When discussing reciprocity, they commonly quote either biblical ${ }^{238}$ or philosophical views ${ }^{239}$ on the necessity of an element of retribution in social and legal relationships.

Reciprocity is a mechanism that creates a balance of rights and duties ${ }^{200}$. Whether or not the balance struck is a good one from the point of view of morality is irrelevant in this respect ${ }^{241}$. It is the mechanism of give and take, that plays a role in many spheres of life. It is superfluous to elaborate at length on the provenance of the phenomenon reciprocity, but it is said to provide stability in primitive societies ${ }^{242}$. In law it lies at the very basis of contracts, and indeed of treaties.

In this respect, there is a similarity between a primitive legal system and the structure of the international legal order. Although the international legal order has developed from its nineteenth-century preoccupation with sovereignty and the absolute freedom to act deduced from it, it still lacks a central legislator, a compulsory judicial system and an authority endowed with the power to enforce the law.

236. Decaux, op.cit. at 53-56; at 54:"Le droit international étant un droit relationnel est, par là-même, un droit réciproque". Dehaussy, op.cit. at 312:"..les conventions multilatérales générales s'analysent comme faisant naître un réscau de relations juridiques entre les Etats parties, pris deux à deux." M.Virally, Le principe de réciprocité en droit international contemporain, in: $122 \mathrm{RdC} 1967 \mathrm{III}, 5-67$, at 25: "A première vuc, en effet, parce qu'elle exprime lidée de retour, la reciprocité paraît concerne, par nature, une rélation bilatćrale. Or on voit qu'elle a aussi sa place dans les traités multilatéraux. Elle affecte alors les rapports juridique établi entre une partie quelconque et chacune des autres parties, prises individuellement (ou. dans certains cas, l'ensemble de ces dernières).

237. Amongst others Virally, op.cit. at 9:"Or il est assez inquićtant, à propos d'une notion si communément utilisée dans la pratique internationale, une absence presque complète d'études doctrinales. comme si une sorte d'instinct en avait détourné les juristes."

238. Deuteronomy 19:21.

239. Decaux, op.cit. giving a survey of philosophical thinking on reciprocity at 2-7.

240. L.L.Fuller. The morality of law. New Haven. rev.ed. 1969. at 19-27 discusses the relationship between reciprocity and duty: writing at 22:"If it is true that duties generally can be traced to the principle of reciprocity. it is also true that the reciprocity out of which a given duty arises can be visible, as it were, in varying degrees. At times it is obvious to those affected by it: at others it traces a more subtle and obscure course through the institutions and practices of society."

241. B.Simma, Das Reziprozitätselement im Zustandekommen völkerrechtlicher Verträge, Berlin 1972, at 49.

242. Simma, op.cit. at $17-24$. 


\subsection{Reciprocity as a creative force}

Historically bilateral treaties were predominant, and their conclusion clearly demonstrated the importance parties attached to reciprocity. Signature and ratification took place at the same moment, symbolizing the equality of parties as sovereign states and the fact that parties were formally bound towards one another ${ }^{243}$. As the law developed and multilateral treaties came to flourish, the necessity of formal reciprocity remained. Every treaty is based on formal reciprocity (albeit sometimes in a residual form) ${ }^{244}$. It is this formal side of reciprocity that has been laid down in the Vienna Convention. Formal reciprocity establishes the validity of the treaty. From that moment onwards execution is not merely an obligation for the contracting state but also a right for its co-contractant. Yet, it is also the time at which reservations, restricting the fullness of the consent to be bound, are made.

The raison d'être of any treaty is the fact that states have taken an interest in its substance. The content of the treaty is supposedly what really matters to the parties $^{245}$. During the negotiations states will try to find a balance between their interests and the interests of their co-contractants. By accepting obligations towards another contracting state, the first state in return receives benefits in the shape of obligations incumbent on its counterpart ${ }^{246}$. This involves giving and taking, bargaining, a complex process of trading concessions for benefits ${ }^{247}$. In the interplay that leads to the formulation of the text, states have the opportunity to weigh the profits of the treaty against its costs. In terms of reciprocity this implies that states will search for a balance between the respective benefits on both sides. States do not necessarily have a balanced set of rights and obligations under the treaty ${ }^{248}$. Substantive reciprocity is not mandatory, it is quite possible for states to be bound by obligations that are not matched by reciprocal obligations incumbent on their counterparts ${ }^{249}$. Correlativity is a logical necessity, whereas substantive reciprocity is a possibility ${ }^{260}$.

243. Decaux, op.cit. at 56-58, and Simma op.cit. at 55-66 elaborating on the various aspects of formal reciprocity.

244. Decaux, op.cit. at 58:"La reciprocité formelle des engagements reste done essentielle, même si matériellement aucune réciprocité n'est nécessaire."

245. M.Lachs, Some Thoughts on the Role of Good Faith in International Law, in: Declarations on principles, Liber amicorum Röling, Leyden 1977, 47-55: at 48.

246. As Virally, op.cit. at 5 puts it:"...elle (reciprocity, EL) ne joue plus comme un frein, mais comme un moteur,...".

247. Decaux, op.cit. at 57:"La réciprocité d'un traité est inséparable de la négociation: e'est la réciprocité des concessions qui prépare la réciprocité des obligations."

248. Simma, op.cit.at 68 and 70 ; Virally op.cit.at 59.

249. The supposed necessity of substantive reciprocity played a role in the diseussion on socalled "unequal treaties". On this issue: Decaux, op.cit.at 17-40: Simma, op.cit.at 68-73 and Virally, op.cit. at 58-61.

250. Horn, op.cit. at $92-93$ presenting schemes of correlate rights and duties; Simma, op.cit. at $52-54$ presenting correlativity and reciprocity in a scheme. 
The balance between the wishes of the states negotiating the treaty can be found in two different ways ${ }^{251}$. One way of establishing reciprocity is to agree to identical treatment ${ }^{252}$. The treaty will then provide for identical rights and identical obligations for all the states parties. Basically, this kind of reciprocity leads to the equality of all states parties under the treaty regime ${ }^{253}$. On the other hand, it should be noted that identical treatment does not necessarily imply that all parties to the treaty will have to make the same sacrifices, or will obtain the same benefits from the treaty ${ }^{254}$.

Yet, equality is not always the best possible solution. It may be that differing interests lead to a balance of differing obligations (and rights) for the various parties. For instance, in commercial treaties one party may provide goods whereas its counterpart will in return provide investments. Although these are reciprocal obligations, they are not identical. Reciprocity is reached through equivalent obligations ${ }^{255}$.

\subsection{The supervisory side of reciprocity}

Apart from law-creating aspect of reciprocity, it also has a role in the observance of treaties. States are obliged to fulfil their obligations under a treaty. In the absence of a compulsory international judicial system, states themselves have to take responsibility for the observance of treaties. They have the right to react to breaches of treaty, and may do so. This assumption is however based on (the probability of) substantial harm to the interest of a reacting state. Foreseeable harm will prompt states to demand the fulfilment of treaty obligations. But then, not all obligations have a direct bearing on a state's interest, not all obligations involve benefits that may cause substantial losses when breached ${ }^{256}$. Examples of such obligations may either be provisions leading to obligations applicable between a state party and persons under its jurisdiction, such as human rights, or a treaty laying down an objective legal regime. In case of violations, states may not notice the violation, or may not feel tempted to react. For after all, reactions to breaches are not mandatory. Moreover, if it concerns a provision of a multilateral treaty one might wonder which state should take action. An injured state would be most likely to initiate any action but unfortunately the injured state can often not be identified ${ }^{25 ?}$.

251. Virally, op.cit. at 30 questioning this distinction:"Il n'y a pas vraiment, au surplus, de choix à faire quant à la façon de réaliser la réciprocité: tout dépend de ce qui est échangé."

252. Virally, op.cit. at 23-29.

253. Virally, op.cit. at 25.

254. Virally, op.cit. at 32 warns that reciprocity through identity may have "trompe-l'oeil" effects.

255. Virally, op.cit. at 31.

256. Cr. Barcelona Traction case, ICJ Rep.1970 at 32; see Clark, op.cit. at 316-317.

257. On this issue see K.Sachariew. State responsibility for multilateral treaty violations: identifying the "injured State" and its legal status: in 35 NILR 1988, 273-289; and M.T.Kamminga, Inter-state accountability for violations of human rights, Leiden 1990. 
Non-observance of treaty obligations endangers the balance of substantially reciprocal rights and duties, and may stimulate action aimed at restoring observance by the defaulting state. It follows from the principle of do ut des that a party is no longer bound towards its co-contractant if the latter does not honour its treaty obligations. Basically states can react towards the defaulting state by either demanding that it fulfils its obligations, or by suspending or terminating the treaty in accordance with article 60 of the Vienna Convention. Reciprocity is thus an element in the internal dynamics of the treaty, promoting the observance of obligation $\mathrm{s}^{258}$.

Yet, an impediment for the functioning of reciprocity as a mechanism promoting compliance with human rights treaties is the fact that article 60.5 Vienna Convention cuts off one of the traditional measures available to the injured state in case of non-fulfilment of obligations, the termination or suspension of the treaty as a consequence of its breach. For, and rightly so, the Vienna Conference found it to be imperative that the breach of a treaty with a humanitarian character should not endanger the protection of the individual. Thus, even if states would have wanted to react on breaches of treaty by terminating a treaty, this is in some cases impossible in view of the Vienna Convention ${ }^{359}$.

Reactions to reservations can similarly be understood as being prompted by reciprocity. Whether states will react to a reservation (if at all) will depend on the way in which the reservations affects the State's interest, or reduce the substantive benefits expected from the treaty ${ }^{2(x)}$. Expressing consent to be bound is a moment at which the supervisory aspect of reciprocity ought to play a role. Misunderstanding this stage as one involving merely formal reciprocity diverts attention from a fundamental issue, namely that reservations do imply changes in the substance of the treaty. Reservations affect the substance of the treaty and thus involve questions of substantive reciprocity. Reciprocity might be supposed to create an active interest in the reservations made among the states parties. By failing to perceive the possibilities of 'preliminary' supervision, in the form of a choice between acceptance and objections, states do not fully utilize the available ways of safeguarding the substance of the treaty. It is submitted that misjudging the impact of reservations on the substance of a treaty, and disregarding the tools

258. Decaux, op.cit. at 63:“A mi-chemin de la simple réciprocité formelle et de la réciprocité matérielle, il y a donc une réciprocité juridique. un do ut des qui porte non sur le contenu de l'obligation, mais sur le mécanisme de lobligation."

259. E.Schwelb. The Law of Treaties and Human rights. In: 16 AdV 1973 1-27, at 14-27; Sinclair, op.cit. at 190; and E.Suy, Droit de traités et droits de l'homme, in: Vötkerrecht als Rechtsordnung, Internationale Gerichtsbarkeit, Menschenrechic. Festschrift fur Hermann Mosler, Berlin 1983, 935-947 at 939-942.

260. Clark, op.cit. at 317 writes:"In making reservations to reciprocal rights treaties, parties are necessarily aware of the reaction they may provoke from other states and must suffer the consequences of that reaction, such as losing the benefit of a provision, as well as being freed from the obligations it imposes. Derogations from the norms of a human rights instrument can be effected by a reserving state at comparatively little cost." 
treaty law offers, are among the reasons why reservations to human rights treaties pose problems.

\section{THE TIME ELEMENT IN THE APPLICATION OF THE VIENNA CONVENTION}

The rules on reservations contained in the Vienna Convention on the Law of Treaties will be considered essential guidelines in the matter of reservations to Human Rights treaties. Before doing so it is necessary to investigate whether these rules are actually applicable, either in general, or specifically in respect of the Human Rights Conventions dealt with that have no specific rules on reservations ${ }^{201}$.

So far the Vienna Convention has been ratified by seventy states, which is clearly no universal acceptance ${ }^{262}$. Moreover, even if the Convention were universally accepted, this would still not lead to the conclusion that it would be applicable to treaties concluded prior to its entry into force, unless it is established that the Convention is indeed nothing but a codification. And, although the Vienna Convention was intended to be a codification of the pre-existing customary Law of Treaties, it is doubtful whether this was the case with its provisions on reservations ${ }^{263}$. Both are problems concerning the application of the Vienna Convention with a distinct time-element.

\subsection{Questions of inter-temporal law in respect of the application of the Vienna Convention}

The first question to be dealt with, is the matter of inter-temporal law proper. Little has been written about the inter-temporal law of treaties, and it is a rather technical issue $e^{364}$. Yet, it is necessary to consider this theoretical problem, given the important role the VCLT will play in the following. In this study the question of the inter-temporal application of the VCLT is particularly relevant in respect of the Covenant on Civil and Political Rights ${ }^{265}$, which entered into force in 1976, that is prior to the entry into force of the Vienna Convention in $1980^{206}$. Could States, or could the Human Rights Committee, rely on the Vienna Convention rules in respect of reservations to the Covenant?

261. CCPR, CEDAW, CAT.

262. ST/LEG/SER.E/11, 31 December 1992.

263. Edwards. op.cit. at 365.

264. A.Bleckmann, Die Nichtrückwirkung völkerrechtlicher Vertrüge, in: 33 ZAóRV 1973, at 38-55; G.E. do Nascimento e Silva, Le facteur temps et les traités: 154 RdC 1977 I, 215 298 at 265-295; Rosenne, The temporal application, passim.

265. This is on the assumption that the reservations clause in the Convention on the Elimination of Racial Discrimination provide a complete set of applicable rules.

266. Entry into force of the Covenant on Civil and Political Rights: 23 March 1976; entry into force of the Vienna Convention on the Law of Treatics 27 January 1980. 
With the gradual development of international law, and the co-existence of ancient and contemporary rules of law, there are rules concerning the application rules dating from another period ${ }^{267}$. The maxim tempus regit actum ${ }^{268}$ has been refined in the Islands of Palmas case, where the arhitrator distinguished between the validity of the rule according to the law at the moment of its creation, and the subsequent application of the rule $e^{269}$. The rule in the Islands of Palmas case stresses the development of international law as a dynamic, and continuous process ${ }^{270}$ that has an impact on the interpretation of rules in the course of time. What is important in the Islands of Palmas case is the fact that the interpretation of rules is subject to the law as it stands at the moment of interpretation. This point was forcefully repeated in the Advisory Opinion on the Legal Consequences of the Continued Presence of South Africa in Namibia, when the Court stressed that the interpretation of obligations created within the League of Nations, would take place taking the contemporary international legal system into account ${ }^{271}$. The case has been disclaimed as being an example of dynamic interpretation, and thus contrary to the general rules on the interpretation of treaties $^{272}$. However, apart from being an elahoration of the rule in the Islands of Palmas case, it might be suggested that it is a goal-oriented, rather than dynamic, approach that is used in the Legal Consequences of the Continued Presence of South Africa in Namibia case.

Article 4 of the Vienna Convention explicitly indicates that it "applies only to treaties concluded by states after the entry into force of the present Convention

267. It should be noted that most of the cases concerning intertemporal law deal with questions of territory, which are to a great extent factual problems, whereas the application of secondary rules such as the rules on reservations in the Vienna Convention are of quite a different nature.

268. Bleckmann, op.cit. at $40-41$.

269. Islands of Palmas arbitration, 1928 (Netherlands v United States), 2 RIAA 1949, reads: "As regards the question which of different legal systems prevaiting at successive periods is to be applied in a particular case (the so-called intertemporal law), a distinction must be made between the creation of rights and the existence of rights. The same principle which subjects the act creative of a right to the law in force at the time the right arises, demands that the existence of the right, in other words its continued manifestation, shall follow the conditions required by the evolution of the law"

270. G.Schwarzenberger, International Law, 3rd Ed.London, 1957 at 21-24.

271. Legal consequences of the continued presence of South Africa in Namibia (South West Africa) notwithstanding Security Council Resolution 276 (1970); ICJ Rep.1971, 15.

Par.53 reads:"That is why, viewing the institutions of 1919 , the Court must take into consideration the changes which have occurred in the supervening half-century, and its interpretation cannot remain unaffected by the subsequent development of law, through the Charter of the United Nations and by way of customary law. Moreover, an international instrument has to be interpreted and applied within the framework of the entire legal system prevailing at the time of interpretation."

272. Cf. article 31 VCLT.

See A.Verdross, B.Simma; Universelles Völkerrecht. Theorie und Praxis: 3.Auft. Berlin 1984: par.782 at $497-498$. 
with regard to such States ${ }^{\text {273 }}$. This should be read as meaning that the VCLT as a treaty will only apply to treaties concluded after its entry into force, the Vienna Convention as a codification of customary law does obviously apply to treaties predating the VCLT. Hence one would conclude that it is not possible to apply the Vienna Convention to the CCPR, unless the rules on reservation were binding under customary law.

The problem of the inter-temporal law of treaties is, to a certain extent, an academic problem. In the Continental Shelf arbitration, the Court relied upon the VCLT with respect to a dispute arising before the conclusion of the Convention. The United Kingdom had ratified the 1958 Convention on the Continental Shelf in 1964, France had ratified with reservations in 1965 and the United Kingdom had objected in 1966 . While stating that the case needs to be decided in the light of the law in force at the time the dispute arose, the Court indicates that the changes in the law were primarily related to the rules applicable when the treaty did not contain a reservations clause (article 19.c VCLT). This issue does not arise with respect to the Continental Shelf convention which does contain a reservations clause in article $12^{274}$. Be this as it may the Court's opinion is somewhat in contrast with its application of the definition of article 2.1.d. $\mathrm{VCLT}^{275}$, and of article 21.3 VCLT wit respect to the scope of reservation and objection $^{276}$. In particular it cannot be said that article 21.3 was a codification of pre-existing law ${ }^{277}$, applying this provision does not seem to fit in the Court's decision to apply the law in force at the time the dispute arose.

Similarly, when the HRC and other supervisory bodies used notions from the VCLT in dealing with reservations, no state objected. In particular it is striking that non-parties to the VCLT did not object, as these would be the most likely ones to do so. The reason for this, apart from the fact that there is no obligation to react, is probably the fact that the pre-existing rules on reservations lacked clarity and would therefore not be readily invoked by the non-parties to the VCLT. In spite of the clarity on the "object and purpose" rule, the Genocide case did not provide any substantial rules on how to treat reservations, the VCLT as a set of rules thus filled the vacuum. In this respect Rosenne has pointed out that codification has a consolidating effect on the law. irrespective of its formal status $^{2 \pi}$.

273. Cl. article 28 VCl.T. See about article 4 VCL.T:Rosenne. The Temporal Application, at 5-12; Sinclair, op.cit. at 8-9.

274. Award, para.38:"Accordingly, the evolution of the law of reservations between 1951 and 1966 has only marginal interest in the present connection".

275. Award, para.55.

276. Award, para. 61 .

277. Ci. Kuhner, op.cit. at 211-218; and Imbert. Les Réserves at 260.

278. Rosenne, The Temporal Application, at 19 writes:".the written text usually has the general effect of making the law more clear that it was in its unwritten state and the positive text will take the place of usage even regardless of its formal status as being in force ${ }^{n}$ or not. The new text has a profound influence upon the future development of the law and upon the practice of States and of the international organizations." 


\subsection{Articles $\mathbf{1 9 - 2 3}$ of the Vienna Convention as customary law}

Secondly, the question arises as to whether there are sufficient indications to consider the VCLT's regime on reservations as customary law ${ }^{279}$. This question is prompted by the fact that there are substantial difference between the states parties to the Vienna Convention and the human rights treaties dealt with. It would clearly be confusing to distinguish between the states that are parties to the Vienna Convention, and those that are not, but this may be necessary unless it is established that article 19-23 of the Vienna Convention are applicable as customary law ${ }^{380}$. Moreover, taking into account the ICJ's decision in the North Sea Continental Shelf cases, there has to be considerable proof for the assumption that a convention would become binding upon a third state through customary law, shortly after its entry into force ${ }^{281282}$.

On the basis of case law following the entry into force of the Vienna Convention, and in particular the United Kingdom-French Continental Shelf arbitration ${ }^{283}$ and the Belilos case before the European Court of Human Rights $5^{284}$, it may be concluded that the VCLT's provisions on reservations are taken to be binding as customary law ${ }^{285}$. The relevance of these cases is the fact that they concern treaties concluded long before the drafting of the Vienna Convention took place. In the United Kingdom-France Continental Shelf case, a declaration made when ratifying the 1958 Geneva Convention on the Law of the Sea was of crucial importance. Not only was this convention concluded long before the VCLT was drafted, France had consistently refused to ratify the Vienna Convention ${ }^{286}$.

279. Edwards, op.cit. at 365; Sinclair, op.cit. at 13-14.

280. Cf. articles 34 and 38 VCLT.

281. North Sea Continental Shelf cases (Federal Republic of Germany v. Denmark; Federal Republic of Germany v. the Netherlands), ICJ Rep. 1969 , par. 28 reads:

"In principle, when a number of States, ..... have drawn up a convention specifically providing for a particular method by which the intention to become bound by the régime of the convention is to be manifested - namely by the carrying out of certain prescribed formalities (ratification, accession), it is not lightly to be presumed that a state which has not carried out these formalities, though at all times able and entitled to do so, has nevertheless somehow become bound in another way."

Rosenne. The Temporal Application at 20-21. suggests that the Continental Shelf case only has a limited value in respect of the VCLT as the Court's reasoning focused on one single provision of the 1958 Convention on the Continental Shelf, a provision that was de lege ferenda rather than being lex lata or an emerging customary rule. He suggests that the case should be read as a warning against the euphoria prompted by successful codification conference.

282. Entry into force Vienna Convention on the Law of Treaties 27 January 1980; Entry into force Convention on the Elimination of All Forms of Discrimination against Women 3 November 1981; Entry into force Convention Against Torture 26 June 1987.

283. 54 ILR 1979. 6-10.

284. To be dealt with in Chapter 3, par.4.1.3 infra.

285. Coccia, op.cit. at 11-15; Edwards, op.cit. at 366.

286. O.Deleau, Les Positions Françaises à la Conference de Vienne sur le Droit des Traités, in: 15 AFDI 1969, 7-23; Sinclair, op.cit. at 68-77. 
With respect to the Belilos case, it should be noted that the ECHR was concluded in 1953, the Court used article 2.1.d VCLT to fill a gap in the ECHR's rules on reservations ${ }^{377}$. Additionally it is pointed out that non-parties and international organizations have incorporated the Vienna Convention into their treaty practice, thereby giving great importance to the VCLT rules ${ }^{288}$.

This all leads to the conclusion that though these provisions were progressive development rather than codification at the time of drafting the Vienna Convention, they have by now accepted as the law to be applied to reservations ${ }^{289}$.

287. It should be noted that Switzerland ratified the Vienna Convention in 1990, some time after relying on the VCLT rules with respect to reservations in the Temeltasch and Belilos cases under the ECHR.

288. Coccia, op.cit. at 15-16; Edwards. op.cit. at 365-366.

289. Edwards, op.cit. at 365 writes that "..the rules of customary law regarding reservations were sufficiently uncertain that it was best to think of the Vienna Convention rules as de lege ferenda in 1969. However. in the twenty years that have elapsed since the Vienna Convention was opened for signature, the rules regarding reservations stated in that treaty have come to be seen as basically wise and to have introduced desirable certainty.": similarly Sinclair, op.cit. at 13-14. 
After discussing the general law of treaties issues that reservations tend to bring up in the previous chapter, it is now time to turn to the specific issue of reservations to human rights treaties. In the following chapters the practice of four conventions will be dealt with extensively, at this point a number of theoretical issues will be dealt with, which will serve as background information for part II of this thesis.

Although I would have preferred to have been able to present a complete and systematic theory about reservations to human rights, this will not be possible. Consequently the paragraphs, while all discussing aspects of this issue, are not necessarily interrelated.

\section{REASONS FOR MAKING RESERVATIONS}

Before embarking on the legal aspects of reservations to human rights treaties, it is useful to look at the considerations that play a role for states when they make reservations. There is a distinct feeling that reservations should not be possible', which puts the onus of being a "bad guy" on the reserving State. This may be the simplest way to see the reservations issue, but there is more to it than mere unwillingness.

A number of considerations would be relevant in respect of the ratification of any treaty. States may have substantive interests that they don't want to compromise when ratifying a treaty ${ }^{2}$. Reservations may be the direct result of a failure to bring legislation into conformity with convention standards. Traditionally, reservations have been expressed to the dispute settlement clauses (the so-called Slavic reservations $)^{4}$, and to provisions about the territorial application (the socalled colonial clause) ${ }^{5}$. Political problems have also lead to reservations, such as the unacceptability of treaty relations with a particular State ${ }^{6}$.

Looking specifically at human rights treaties, the position of developing countries may lead to reservations, prompted by the lack of expertise in the Ministry of

1. Coccia, op.cit. at 16; Imbert, HRR at 28; vd Velde, Voorbehouden ten aanzien van de ECRM, 354.

2. Edwards, op.cit. at 363; O.Schachter. M.Nawaz, I.Fried, Towards wider acceptance of UN treaties, a UNITAR study, (hereafter: Schachter es.) New York 1971 at 155.

3. Edwards, op.cit. at 363; Schachter es., op.cit. at 155.

4. The dispute settlement clause in article IX of the Genocide Convention was the reason for the Advisory Opinion. Cf. Edwards, op.cit. at 363; Schachter cs. op.cit. at 155.

5. Edwards, op.cit. at 363 ; Schachter es. op.cit. at 155.

6. E.g. reservations excluding the recognition of Isracl. objecting to the validity of the ratification for West-Berlin (prior to the dissolution of the GDR), or the ratification for the Falkland Islands/ Maivinas; cf. Schachter cs. at 155-156. 
Foreign Affairs' or, more seriously, hy the lack of financial means that makes it impossible to attain a particular goal set in a human rights treaty. Though it may be assumed that these reservations will generally be made in respect of social and economic rights, the attainment of civil and political rights often also requires financial means ${ }^{8}$.

A number of reservations are directly related to the problems foreseen at the implementation of the human rights treaty in the domestic legal order ${ }^{9}$. This category can be explained by the fact that by their very nature human rights instruments intend to operate in a field in which the State used to be the sole legislator ${ }^{10}$. In giving rules meant to govern the relationship between the state and the individuals under its jurisdiction, it is foreseeable that a collision between these rules and preexisting domestic rules may occur. The most obvious examples are rules of constitutional law that are inconsistent with the treaty ${ }^{11}$, other examples relate to the division of power in the state. In this respect the federal clause is widely used to emphasize that it is not within the power of the central authority to legislate in the fields mentioned by the treaty ${ }^{2}$. In general, when legislation needs to be adapted as a consequence of ratification, reservations may occur so as not to anticipate the legislative authority of parliament ${ }^{13}$. Other reasons for reservations dealing with legislation are the cases in which it is perceived that treaties conflict, and states feel the need to indicate a priority'.

In these case it may seem evident that states do not want to change their obligations under the constitution, or under other international instruments by accepting obligations under a human rights treaty. Yet it is more of a policy decision, than an issue of conflicting rights. If ratitication of a human rights treaty is considered to be desirable, the necessary legislative changes could he made prior to ratification, thereby excluding the need for reservations. In fact, this should be advocated, given the time it takes to withdraw reservations, if ever they are with-

7. Coccia, op.cit. at 20; similarly with respect to the reservation by Germany to article 7 ECHR: J.A.Frowein, Reservations to the European Convention on Human Rights, in: Protecting Human Rights: the European Dimension; F. Matscher. H. Petzold eds. Köln usw. 1988, 193-200 at 195 .

8. Coccia, op.cit. at 20.

The reservations to article 14.6 CCPR by Guyana, Malta, and Trinidad and Tobago about compensation for miscarriages of justice, are a case in point.

9. Coccia, op.cit. at 19-22; Schachter cs., op.cit. at 30-31.

10. It has been said that human rights treaties jeopardise the sovereigniy of the States parties, but introducing the issue of sovereignty in this discussion docs not lead to a better insight. See: Imbert, HRR at 30.

11. Sec for instance the Mexican reservations to articles 13 and 25.6 CCPR, both referring to the Constitution.

12. For example the federal reservation by the United States in respect of the CCPR; Edwards, op.cit. at 363.

13. Discussing reservations as a consequence of parliamentary involvement with treatymaking: Edwards op.cit. at 363-364.

14. Examples of such an approach are for instance the reservations of Austria to articles 19 . 21,22 CCPR in relation to article 16 ECHR, or the Irish reservation to article $11.1 . . \mathrm{b}, \mathrm{c}$ and $d$ CEDAW in relation to European Community legislation. 
drawn. On the other hand it must be acknowledged that a policy to ratify without (or with only a few) reservations may lead to very late ratifications because of the prior legislative work ${ }^{15}$.

Another reason for making reservations to a human rights treaty mentioned frequently, has to do with the uncertainty of the obligations accepted under a treaty. The drafting process may have led to provisions that are not completely clear, that may be compromise solutions, hiding disagreement behind general formula. But more important, states try to shield their domestic human rights situation against the dynamic forces of a treaty ${ }^{16}$. The practice of human rights treaties has demonstrated in the past twenty odd years that their dynamic force, together with the functioning of supervisory organs ${ }^{17}$, is a powerful way of improving and extending human rights protection. The existence of a supervisory organ, and the procedures vested in it, will in the course of time lead to an additional set of rules, interrelated to the rules formulated in the treaty itself. The interpretation of a treaty in the discussion of the state reports, the interpretation of a treaty by the Committees in an individual complaint procedures, and the interpretation of a treaty through the formulation of general comments and general recommendations ${ }^{18}$ all compose what is known as the acquis, the system created through the human rights convention. The legal nature of the acquis cannot be determined in detail. Though the application of the treaty necessarily requires the Committee to interpret the instrument, there is a thin line between interpretation and the creation of additional rules to fill lacunae. In a way. the existence of a supervisory organ, and its practice, undermine the certainty about the obligations that parties to a treaty have. Attempts to restore certainty through reservations are therefore understandable.

Imbert ${ }^{19}$ has in this respect referred to the "explanation" made by the: Netherlands in relation to its reservations to the Covenant on Civil and Political Rights $^{30}$, in which it indicates that although a number of its reservations may

15. The Dutch ratification of the Convention on the Elimination of All Forms of Discrimination against Women would seem to be a case in point. The Convention was submitted for ratification to Parliament on 23 April 1985: the consideration were concluded with the acceptance of the law of approval on 2 July 1991. The Netherlands ratified (without reservations) on 23 July 1991, whereas the Convention had been opened for ratification on 1 March 1980, and had entered into force on 3 September 1981.

About this lengthy process see: L.Lijnzaad, Het kussen van een kikker, in: 7 Nemesis 1991, 5-17 at 5; and J.H.J. de Wildt. Het Internationaal Verdrag inzake de uitbanning van alle vormen van Discriminatie van Vrouwen, in: 41 Ars Aequi 1992, 259-266 at 259.

16. Coccia, op.cit. at 21-22; Cook, Women's convention at 650; Imbert. HRR at 30-31; Shelton, op.cit. at 208.

17. Cook. Women's Convention at 673.

18. General Comments in articles 9.2 CERD, 40.4 CCPR. and 19.3 CAT, General Recommendations in article 21 CEDAW.

19. P.H.Imbert, Les Réserves à la Convention Européenne des Droits de l'Homme devant la Commission de Strasbourg (hereafter: Affaire Temeltasch). in: 87 RGDIP 1983, 580625, note 20 at 588; and Imbert. HRR at 31 .

20. To be discussed Chapter 5, par.3.1 infra. 
actually not be necessary because of the concurrence between the Netherlands interpretation and the (authoritative) interpretation (by the Human Rights Committee), it "wishes to ensure in all cases that the relevant obligations arising out of the Covenant will not apply to the Kingdom, or will apply in the way indicated". This is a clear example of a "better safe than sorry" approach.

This is a most intriguing issue that clearly demonstrates the kind of problems that arise because of the dynamic nature of human rights law and the static nature of the law of treaties. After all, can the States parties be supposed to have accepted the acquis as it will develop in the years following their ratification? The Netherlands is an example of a state that seriously considered withdrawing from the Covenant on Civil and Political Rights and re-ratifying with a reservation to article 26, because of the fact that the acquis, in particular on article 26, ran counter to its interests ${ }^{21}$. Had the future interpretation of this provision been known beforehand, a reservation would no doubt have been made ${ }^{22}$.

A further matter on the same lines, is the position of states that become parties a long time after entry into force, and disagree with the interpretation developed by the supervisory organ in the period preceding its own ratification. These states may want to exclude some of the interpretations established in the course of the treaty's existence. The position of the United States and Switzerland with respect to article $26 \mathrm{CCPR}$ is a case in point, both made reservations explicitly providing an interpretation that the Committee does not adhere $t^{23}$. This will theoretically lead to two distinct and parallel interpretations of a provision, operative within the one system, which is in itself not a positive development. On the other hand the question does arise if the ratification of a human rights convention, including the supervisory system it establishes and the roots of the development of an acquis that are present in the treaty, does not require a necessary submission to the acquis as it will develop, or will have developed. Such reservations aim at two essential elements in human rights treaty law, namely the idea of the progressive development of human rights, and the important role of the supervisory organs in that respect.

\section{THE "OBJECT AND PURPOSE" OF A HUMAN RIGHTS TREATY}

Given the absence of explicit rules on the admissibility of reservations in various human rights treaties ${ }^{24}$, and the inclusion of clauses referring to the object and

21. See M.Driessen, J.Parlevliet, Internationale Escapades (Opinie), in: 63 NJB 1988, 357; P.Kooijmans, Preadvies voor de Emancipatieraad, 17 March 1988.

22. Cf. the Swiss declaration following the judgenent in the ECHR-Belilos case see: Bourguignon, op.cit. at 384-385; and J van der Velde. De Reaktic van de Zwitserse regering op het Belilos arrest, in: 13 NJCM Bull.1988 at 597-601. For a discussion see par.4.1 infra.

23. Similarly, Frowein, op.cit. at 194, 199; and J.A.Frowein. W.Peukert, Europaische Menschenrechtskonvention (EMRK Kommentar), Kehl 1985 at 488 about the reservation of Liechtenstein on the ratification of the ECHR.

24. CCPR, CAT 
purpose rule ${ }^{25}$, the question as to what "object and purpose" are, is of great importance. Looking at the discussions in legal literature about the object and purpose of human rights treaties and the monitoring of compliance using that notion, one cannot but be struck by the limited range of the ideas. It would seem that "object and purpose" disappeared in the discussion of monitoring, in which field greater certainty seems to be available. I would like to suggest that poor reflection on the actual meaning and content of the notion of "object and purpose" prevents any actor on the international plane (be it a State, be it a member of a supervisory organ) from adequately reacting to blatantly incompatible reservations. In other words, there is no point in saying that "object and purpose" is a useless notion, without at least first trying to get a grip on the notion.

Few attempts have been made to develop a theory on the content of the object and purpose rule in respect of human rights treaties. The absence of doctrine in this field is understandable when one considers the problems that arise in seeking the concrete content of the rule. To understand these problems it is necessary to return to the Genocide case. When the Court spoke about the object and purpose of the treaty that was to be the yardstick for both reservations and for objections $^{26}$, there was not any doubt about the object and purpose of the treaty under consideration. The aim of the Genocide Convention is the banning of genocide. In view of the clarity of this purpose, there would be few cases in which doubts could arise about the compatibility of a reservation to the Genocide Convention. Reservations should be measured according to whether or not they would hamper the banning of genocide. The rule developed in respect of this single-purpose treaty causes serious problems when applied to subsequent human rights treaties, that are more elaborate, more diversified and more detailed. It is submitted that as a result of the Genocide case, the rule developed has the disadvantage of being extremely simplistic.

In the following an attempt will be made to clarify the possible content of "object and purpose" of a human rights treaty. Given that this key notion in the VCLT system is renown for its inherent vagueness, it is necessary to try and detail its content. However, little certainty can be found and the scheme presented has therefore the character of an exploration. The second matter dealt with will be the way in which the rules on reservations are to be monitored. After that the possibilities of the "object and purpose" rule as an interpretation rule will be discussed.

\subsection{Defining the object and purpose of a human rights treaty}

It has been suggested that the object and purpose of a human rights treaty would be rather limited and would encompass the prohibition of reservations contrary to 
ius cogens $^{27}$, erga omnes obligations as indicated by the International Court in the Barcelona Traction case ${ }^{2 x}$, and rules that are international crimes on the basis of the work of the International Law Commission on State responsibility ${ }^{29}$. Similarly reservations to provisions that are a mere codification of rules of customary law do not undermine the validity of the customary rule ${ }^{30}$. Another important suggestion is the inadmissibility of reservations contrary to provisions of the Charter of the United Nations ${ }^{31}$. Though these may seem to be a logical translations of the object and purpose rule, one might wonder whether it does in fact apply in these cases. To my mind, acting contrary to ius cogens is prohibited per $s e$, this does not require any additional prohibition under the guise of object and purpose $e^{32}$. Acting contrary to the Charter of the United Nations is a breach of treaty for member states of the United Nations under the priority rule of article 103 of the Charter, and here again it is hardly necessary to rely upon the object and purpose rule of article 19.c VCLT. Consequently "object and purpose" would still be an empty shell.

Sometimes the whole treaty is equated with its "object and purpose". If a treaty prohibits discrimination, each and every provision contributes to the goal of the treaty, and is thought to be part of its "object and purpose". Similarly, the protection and promotion of human rights has been understood to be the object and purpose of a human rights treaty. But foregoing the distinction between core obligations and other obligations implies a complete prohibition on the making of reservations, within the VCLT system as it stands today. Article 19.c would be a redundant rule as the matter would be dealt with in article 19.a. That would not only be an unrealistic approach, it would also render the "object and purpose rule" pointless as it would lose its distinctive significance.

Both positions sketched above amount to an "object and purpose" without any distinctive content. The claim that a particular reservation is contrary to object

27. In general: Coccia, op.cit. at 16. Shelton. op.cit at 208-209: in respect of the CCPR: J.F.Hartman, Working paper for the Committee of Experts on the Article 4 Derogation Provision, in: 7 HRO 1985, 89-131 at 114; in respect of CEDAW: Cook, Women's Convention at 655 .

28. Barcelona Traction, Light and Power Company (Belgium v. Spain) (second phase), ICJ Rep. 1970, par.33-34:".. an essential distinction should be drawn between the obligations of a State towards the international community as a whole. and those arising vis-à-vis another State in the field of diplomatic protection. By their very nature the former are the concern of all States. In view of the importance of the rights involved, all States can be held to have a legal interest in their protection; they are obligations erga omnes."

29. Coccia, op.cit. at 17, refers to article 19 of the Draft Articles on State Responsibility.

30. Th.Meron. Human rights and humanitarian norms, Oxford 1989 at 11-12. Meron suggests that such reservations do not involve questions of incompatibility as the "object and purpose" rule focuses on the substance of the treaty.

31. In respect of the CCPR: R.Higgins, The United Nations still a force for Peace, in: 52 MLR 1989 (hereafter.Higgins, MLR), 1-21 at 14; and Shelton, op.cit. at 227; and objections to the Indian reservation to article I CCPR by France. Germany and the Netherlands.

32. Articles 53.64 VCLT. 
and purpose is easier made than substantiated. The notion presupposes the possibility of distinguishing between the full (text of a) treaty and its essential goals, if "object and purpose" is to have a meaning at all. It implies a distinction between all obligations in the treaty and the core obligations that are the treaty's raison d'être. It is quite possible that reservations are made that do not touch upon object and purpose, but remain on the fringe. Although they restrict the legal effect of provisions of the treaty, they will not be as harmful as the reservations contrary to object and purpose, and consequently they are not forbidden. A substantial number of reservations to non-core rights accumulated, can however have an equally detrimental effect, which should be kept in mind ${ }^{33}$. The value of the prohibition of reservations contrary to object and purpose will depend on the selection made between fringe reservations and more serious ones.

An issue overshadowing this discussion is that distinguishing between core and non-core rights seems to reduce the authority of the non-core rights. Distinguishing implies a hierarchy of human rights norms. This is contrary to the view that human rights norms are a coherent set of rules protecting the fundamental freedoms of people, in which all component norms have the same importance ${ }^{34}$. The rules in the VCLT, the "object and purpose" rule in particular, presuppose the option of distinguishing between the obligations in the treaty and the "core" obligations, irrespective of the problems surrounding the application of this rule. Though it must be assumed that "object and purpose" necessitates distinguishing among the Treaty's norms, there are no rules available as to how this should be done. Detecting the core obligations is a matter of interpretation, and it is by no means an exercise the VCLT itself provides adequate tools for. Articles 31 and following deal with the interpretation of the treaty, but the distinguishing process is not dealt with.

In writing about the various international human rights instruments, authors have indicated specific provisions that they consider to belong to the treaty's core obligations. These will be dealt with in the chapters on the various treaties. For the present purposes I would like to suggest that the chances of reservations conceming the final clauses, the dispute-settlement clauses included, to be contrary to the object and purpose of a human rights treaty are extremely small. Such reservations will consequently not be discussed in the following chapters dealing with four human rights treaties. This is based on the assumption that such reservations will in general not detract from the improvements in human rights protection aimed at in the treaty. However, it should be noted that the Genocide case in fact dealt with the compatibility of reservations to the dispute settlement

33. Clark, op.cit. at 314-315; and compare Cook, Women's Convention at 679 about de minimis reservations.

34. Cr.Th.Meron. On a hierarchy of International Human Rights, in: 80 AJIL 1986, 123(hereafter: Meron, Hierarchy); and D.Sullivan, Gender equality and religious freedom:Towards a framework of conflict resolution. in: 24 JILP 1992, 795-856 at 817. 
provisions in article IX of the Genocide Convention ${ }^{35}$. It serves to say that this case is not comparable to the human rights treaties that will be discussed below, as the Genocide Convention does not contain an elaborate supervisory system ${ }^{36}$. It must be noticed that though 'object and purpose' has become a catch phrase, it is a negative obligation. The rule is that reservations should not be contrary to the object and purpose of a treaty, there is no obligation for them to be in conformity with object and purpose. This may seem a twist of words but it is not without importance. One of the consequences of object and purpose as a negative obligation is that theoretically there is no need to determine the substantial content of the norm, it is mainly necessary to see whether a reservation is contrary to a but vaguely determined object and purpose.

When discussing the object and purpose of a human rights treaty, a number of rules are mentioned in the literature that are supposedly part of the object and purpose. As far as they are categorical claims, indicating that a particular kind of rule will always be part of a convention" object and purpose", it is useful to consider them in general. In the following I will present these claims, and my views, under four categories. In spite of the systematic flaws, these four angles may provide more insight in the kind of issues appearing under object and purpose. The categories are merely presented as an exploration of ways to deal with this intriguing question.

\subsubsection{Object and purpose in relation to the importance of human rights treaties}

It may be suggested that "object and purpose" is not only based on an intrinsic comparison between the various provisions of a treaty, but should also take into account the importance of the framework of international human rights law in general. This implies considering the relevance of improvements that a treaty brings, in comparison to pre-existing human rights in the shape of customary law or soft law. Relevant characteristics of human rights instruments are the fact that the rules laid down are meant to apply in the relations between the State and the individuals under its jurisdiction. Moreover, such instruments frequently provide for a supervisory mechanism that will monitor the implementation of the treaty. It is contended that the importance of the codification of human rights law as such is an aspect to be weighed in determining the "object and purpose" quality of particular provisions.

\section{- domestic legislation -}

An essential characteristic of human rights instruments is the obligation to implement a human rights treaty in domestic legislation ${ }^{37}$. This obligation has led to reservations safeguarding domestic legislation that are almost stereotypes of reservations to a human rights treaty. The question is whether it is permissible to

35. Cf.LeBlane, Genocide Convention, at 203-204 expressing the contrary opinion, and emphasizing the importance of the dispute settlement provision.

36. Cr. Shelton, op.cit. at 229.

37. Article 2 CERD, article 2 CCPR, article 2 CEDAW, article 2 CAT. 
formulate reservations so as to protect existing legislation against any changes that may become necessary as a consequence of ratification of the Covenant. The aim of treaty-based human rights protection is clearly to achieve an improvement in protection, rather than a stand-still through the consolidation of the national status quo. Moreover, States do not provide certainty about their obligations towards their co-contractants. A reference to domestic legislation in a reservation would seem to suggest that the author state has complete liberty in changing its legislation. Legislation is after all a matter outside of the scope of traditional international law. Being a party to a human rights instrument (with or without reservations) restricts the liberty to legislate from the point of view of substance. Legislation cannot restrict human rights any further than a convention allows. In practice it will be more complex to assess whether new domestic legislation is more restrictive as compared to prior legislation, and this in itself is a convincing argument for discouraging the use of generally formulated "domestic legislation" reservations.

In practice, different forms of this approach are discernable in reservations to human rights treaties. The first category is that of States who claim that their national legislation is in conformity with the treaty. Usually such reservations focus on a specific provision of national legislation. Such declarations do seem somewhat superfluous as conformity is an obligation, following the expression of consent to be bound. But rather than stressing the obvious, the intention is to determine compatibility. Compatibility is established through a formal declaration, thereby shielding the domestic situation from international interference. If the reservation is accepted, there cannot be any doubt as to the compatibility of national legislation with the requirements of a convention. Consequently, the other States Parties will have to scrutinize the domestic legislation of the reserving State in order to establish whether or not they agree with the assumed compatibility, and would intend to object to the reservation ${ }^{38}$. It is easy to see that this will not be an attractive approach, and may even be considered interference with domestic affairs. Yet, one might say that these reservations are an explicit invitation to undertake this, for if legislation were compatible, there would not be a need to indicate compatibility by way of a reservation.

The second eategory of minimalist reservations is more explicit about the intentions of the ratifying State, it merely indicates that national legislation will

38. Clark, op.cit. at 311 writes:"It should be considered a dereliction of treaty obligations for parties not to specify which conflicts berween the treaty and national law they will resolve in favour of national law". And similarly ACHR Advisory Opinion OC $3 / 83$. Restrictions to the Death Penalty, par.65 reads: A contrary approach might ultimately lead to the conclusion that the State is the sole arbiter of the extent of its international obligations on all matters to which its reservations relates, including even all such matters which the State might subsequently declare that it intended the reservation to cover." 
prevail over the rules in the treaty in the case of conflict ${ }^{39}$. Two cases can be distinguished: states may exclude a particular provision on the grounds that it is not in accordance with domestic law. In such cases the state will usually indicate precisely what is excluded, which is preferable. A more detrimental form of reservation stressing the prevalence of domestic law are statements formulated generally. Reservations emphasizing the predominance of religious law (Sharia'h, for instance) or traditional custom belong to the same category. They leave compliance with the treaty to the reserving State's discretion, it will depend on the obligatory value of social or religious systems. These statements restrict the possible impact of the treaty even further. If national legislation prevails one might wonder why a State took the trouble of becoming a party to a human rights treaty at all. It would appear that the promotional aspect of ratification prevails. What stays in mind in an international context is the ratification, the fact that implementation at national level is sloppy will go unnoticed.

It should be asked whether reservations giving prevalence to domestic legislation is compatible with the object and purpose of a human rights treaty, and in particular with the obligation to implement it in the national sphere. The general rule in the law of treaties in this respect is article 27 VCLT, which has also been referred to in this respect ${ }^{40}$. The provision indicates that states may not rely on domestic law for a failure to perform a treaty, and reads:

"A party may not invoke the provisions of its internal law as justification for its failure to perform a treaty. This rule is without prejudice to article $46^{41}$."

At the drafting Conference in Vienna there has not been much discussion about this provision, which was proposed by Pakistan and subsequently added to the draft Convention on the Law of Treaties. The only reason why the matter had not been dealt with in the ILC Draft was that the Commission felt that the matter belong to the topic of State responsibility. Given the inclusion of article 27 in the Vienna Convention the matter lies apparently at the intersection of the law of treaties and the law of state responsibility $y^{2}$. The particular question that we are facing, the relation between the VCLT provisions on reservations (and their application to human rights treaties), and article 27 VCLT has not been dealt with at the Conference.

39. O.Schachter, The Obligation to Implement the Covenant in Domestic Law, in: L.Henkin, The International Bill of Rights, the Covenant on Civil and Political Rights, New York 1981, 311-331(hereafter: Schachter, Obligation to implement): writes at 321:"The clarity and candour of these statements may seem commendable in comparison with questionable claims of conformity made by some governments."

40. In respect of CEDAW: Cook, Women's Convention, at 706: in respect of CCPR: O.Schachter, The obligation to give effect to the Covenant on Civil and Political Rights, in 73 AJIL 1979, 402-405 at 405; Triggs, op.cit. at 284-285, 291.

41. Article 46 VCLT has no relevance in this respect. it deals with the invalidity of a treaty concluded in manifest violation of internal law on the competence to conclude treaties.

42. About the drafting of article 27 VCLT: Sinclair, op.cit. at 84 . 
The starting point must be the assumption that the Vienna Convention contains a coherent set of rules on the law of treaties. Consequently there should not be a conflict between articles 19-22 and article 27. It should be recalled that the articles 19-22 are in part II of the Convention, entitled Conclusion and Entry into Force, whereas article 27 is in the general section of Part III, entitled Observance, Application and Interpretation of Treaties. While article 19 gives rules about which reservations are permissible and which reservations are prohibited, article 27 gives a rule on the observance of treaties. The fact that article 27 is not a lex specialis to article 19.c follows from the structure of the Vienna Convention. Chronologically, both provisions apply in a different phase of the treaty's existence. From that point of view it would seem to be logical for article 27 not to contain elements of a rule applicable in the earlier part of the treaty's existence. Or, to put it differently, if there is a prohibition on making minimalist reservations safeguarding domestic legislation, that rule should be in Part II of the Vienna Convention. It should be emphasized that though article 27 VCLT is a mandatory rule of international law, reservations are a legitimate exception to the rule ${ }^{43}$.

The answer would seem to be that reservations giving prevalence to national legislation are, as such, a legitimate way to indicate that the treaty will not be implemented in full. Reservations are an international legal method for restricting the application of a convention. A state using that method does not rely on domestic law but on a legitimate exception to article 27 VCLT by making a reservation safeguarding its position. Such reservations necessarily imply a reservation to article 2 CCPR and similar provisions, even if this is not expressly indicated.

An element to be taken into account is the fact that reservations merely indicating which provisions are not applicable, will usually have the same background. Although not mentioning that domestic legislation is the reason for excluding a particular provision, this will usually be the effect it has. The fact that human rights instruments have to be implemented in the national legal system is the obvious reason for this. Looking at the matter of domestic legislation as a grounds for making reservations in this way. demonstrates that the actual question is about the relevance of an explicit or implicit reference to domestic legislation ${ }^{\text {th }}$.

It is contended that, as the VCLT system stresses an approach focusing on the substance of the reservation ("however phrased or named") this would lead to a similar approach to the "domestic legislation" reservations. Consequently, what matters is the scope of the reservation and this is what should be clarified. The

43. Article 27 could only be relevant in respect of reservations if it were a rule of ius cogens, which is not the case.

44. Underlining a different point of view: CFlinteman. ERieter: Nederland en de Amerikaanse voorbehouden bij het Internationaal verdrag inzake Burger- en Pọlitieke Rechren. in: 17 NICM Bull. 1092. $961-970$ (hereafter:Flinterman Ricter N.ICM Bull.) at 967. 
answers and clarifications provided to the supervisory Committee by the reserving State should lead to a "translation" from a "domestic legislation" reservation to a reservation to a particular provision of a treaty. This does show that, from a practical point of view, these reservations are undesirable as the substance is hidden behind the "domestic legislation" formula. They raise a smoke screen between the supervisory organs and the domestic implementation. Uncovering the substance of the reservation will depend on the agility of the Committee, which is not necessarily the best way to limit the scope of reservations. A reservation indicating what it is that is excluded, is to be preferred.

To claim that reservations referring to domestic legislation are contrary to the object and purpose per se, would put undue emphasis on the formal aspects of such a reference, whereas the Vienna Convention stresses object and purpose as a notion related to the substance of the obligation. What is wrong about domestic legislation reservations is their smoke screen effects, the substance of the reservation is hidden behind formal reference to domestic legislation. Although I do consequently not support the view that these reservations are per se contrary to object and purpose, they may, and usually will, be incompatible under the rule of precision, dealt with infra.

\section{- supervision -}

A distinctive characteristic of human rights treaties, at least of the ones that will be considered in this study, is that they all create a mechanism for the supervision of the implementation of the obligations laid down in the treaty. This is directly related to the use of the law of treaties as a method of creation of human rights law. Through these organs a process of supervision is established that has stimulated the progressive development of human rights law. The creation of supervisory organs has greatly added to the improvement of domestic human rights protection. The continuous scrutiny through periodic reporting, and also the individual complaints procedures, have an impact that could not be achieved without using the law of treaties as a tool for the attainment of human rights.

The supervisory system is explicitly protected in article 20.2 CERD Ch $^{\text {ts }}$ and a similar rule was contemplated during the Jrafting of the Women's Convention* Though the various supervisory procedures may he optional, it would appear that the functioning of the organs, and indeed their very existence are core elements in the human rights system protected under the "ohject and purpose" rule.

\subsubsection{Object and purpose in relation to treaty-based human rights protec- tion}

This category of reservation is hased on the obligation not to ohstruct the treaty law side of a convention. Acting in contravention of general rules of the law of treaties is contrary to the object and purpose of any treaty. 
The group of reservations that, because of their impact on the formal aspects of a treaty, are contrary to object and purpose, consists of two different kinds of reservations. In fact, though theses categories of reservations are mentioned here, similar reservations would probably be contrary to the object and purpose of any kind of treaty, be it a traité-contrat or a traité-loi.

\section{- precision or ambiguity -}

A number of reservations do not indicate the provision at which they are aimed. General and unrestricted reservations entail much uncertainty about the extent to which a State making such reservations will be bound by the obligations contained in the treaty. They are contrary to the very idea of lex scripta, the importance attached to explicit and written agreements. Apart from that, these reservations cast doubt on the State Party's intention to comply with the treaty ${ }^{47}$.

Given the nature of human rights treaties, the impact of such vague reservations can be very detrimental for the individuals the treaty seeks to protect. This is why the European Court in the Belilos case ${ }^{48}$ stressed that precision about the scope of the reservation was an evidential factor that contributed to legal certainty. Though this was said in relation to the explicit rule in article 64 ECHR, there is no reason why this requirement should have a more limited relevance in the absence of explicit rules on reservations. Consequently, precision about the scope of the reservation would seem to be included in the "object and purpose" notion.

\section{- federal reservations -}

It has been suggested that domestic legislation reservations are in particular necessary for federal states ${ }^{49}$, who have a internal structure that may make it more complicated to implement a human rights treaty. The implementation of human rights treaties touches upon issues traditionally within the power of the component parts of the State, rather that under the authority of the central government. The two states to have formulate such reservations in respect of the CCPR, Australia ${ }^{50}$ and the United States ${ }^{51}$, are federal States ${ }^{52}$. Australia entered a similar reservations in respect of the right to paid maternity leave in article 11.2 CEDAW. As such, the position of federal States and their reliance on domestic constitutional legislation could be covered by what has been said about domestic legislation before.

General reservations stressing the prevalence of domestic law are frequently explicitly referring to, or implicitly based upon, the domestic constitutional

48. See for a discussion par.4.1.3 infra.

49. Triggs, op.cit. at 284-285.

50. About the Australian reservation see: Triggs, op.cit.

51. Schachter, Obligation to Implement; M.D.Craig. The International Covenant on Civil and Political Rights and United States Law: Department of State Proposals for preserving the Status Quo, in: 19 HarvILJ 1978, 845-886 at 845, 868-880.

52. On the other hand this may be a mere coincidence, similarly minimalist reservations in respect of the Women's Convention have been made by predominantly unitarian States. 
system, which is more a matter of structure than a question of substance. Although the implementation of substantive rights lies behind these rules of structure $^{53}$, it is almost impossible to track down the actual impact on the various rights. The grounds for making these reservations are not only the domestic division of power between the state and its component parts, but may also be national constitutional rules about the implementation of international law in the domestic system, as in the case of the self-executing nature of international obligations in the United States ${ }^{54}$.

Whereas the application of the object and purpose rule in substantive matters is quite complex, international legal theory at the moment provides little guidance for the application of the principle to rules of structure. The only possibility would seem to be application of the object and purpose rule on the basis of estimated effect, which would in turn lead to an interpretation of the impact of the reservation on the implementation of the individual substantive rules in the domestic legal system.

Other arguments against the federal reservations are less forceful. A number of authors suggest that federal reservations might be construed as contrary to object and purpose because of the fact that they would lead to a situation in which nonfederal States would be bound to a higher degree than federal States having made a federal reservation 55 . This argument is in a way tautological, it is evident that non-reserving States are always bound to a greater extent that reserving States. The fact that other federal states have ratified without such reservations also indicates that the matter is not specific for federal states.

Another reason for the suggestion of a conflict with object and purpose is that the aim is to create a general minimum international standard of human rights, and federal states should not be allowed to depart from that aim that easily. While these may be reasons for disapproving of a federal reservation, it is questionable whether this amounts to saying that the reservation is detrimental to the core obligations. A minimum international standard is not necessarily the same as the complete content of a human rights instrument ${ }^{56}$.

53. Craig. op.cit. at 871 .

54. In the 1978 proposal to ratify the CCPR, the transmittal message tohe t U.S.Congress indicated that the reservations and understandings were meant to "harmonize the treaties with existing provisions of domestic law". A similar argument can be found in the Transmittal letter for the 1992 Ratification.

There is a direct relation with the American constitutional system in which treaties may be self-executing. If the reservation were not made, the content of the Covenant could overrule the fundamental rights in the Constitution. In order to prevent that, a declaration indicating that the Covenant would not be self-executing in domestic law was issued, so as to be sure of a restricted influence of the Covenant.

Craig. op.cit. at 853-862; Flinterman, Rieter, NJCM Bull. at 967.

55. Craig. op.cit. at 870 ; Triggs, op.cit. at 291.

56. Craig, op.cit. at $870-871$ : Triggs, op.cit. at 291. 


\subsubsection{Object and purpose in relation to the substance of a human rights treaty}

The third group of reservations are the ones contrary to the object and purpose of the treaty in as much as its content is concerned. As stated above, given the fact that the 'object and purpose' rule is formulated as a negative rule there is no obligation, much less a possibility to determine object and purpose in any objective way. Apart from an authoritative statement by the States Parties or an interpretation by the International Court on the basis of provisions on dispute settlement ${ }^{57}$, it will be up to the Committees to indicate what is and what is not contrary to the object and purpose.

\section{- non-derogable rights -}

There are different ways of looking at rights to which derogations are not allowed $^{58}$. The first interpretation is that these are rights from which derogations cannot be justified by the necessities of any conceivable situation of public emergency. The emphasis is on public emergency, and the fact that this situation cannot legitimize the suspension of the rights listed in article $4.2 \mathrm{CCPR}^{59}$. The other interpretation is that these are core rights whose fundamentality is compelling per se. In this view, the nature of the rights protected is stressed. This evidently amounts to saying that these non-derogable rights belong to the Covenant's object and purpose ${ }^{60}$. The gist of relying on non-derogability as an indication of object and purpose of the Covenant is that, if derogations are not permitted, reservations are a fortiori not permitted either.

The theory of non-derogable rights belonging to the object and purpose of a human rights treaty has been strengthened by the Opinion of the ACHR Court in the Death Sentences case, where it stated that "a reservation which was designed to enable a State to suspend any of the non-derogable fundamental rights must be deemed to be incompatible with the object and purpose of the Convention.." Though the Court instantly qualified its own opinion, by stating that "the situation would be different if the reservation sought merely to restrict certain aspects of a non-derogable right without depriving the right as a whole of its basic purpose. " ${ }^{61}$, this probably just indicates that no definite rules can be given on the issue of "object and purpose". To my mind, this statement does not seriously hamper the understanding of non-derogable rights as core rights.

57. Article $22 \mathrm{CERD}$, article $29 \mathrm{CEDAW}$, article $30 \mathrm{CAT}$.

58. Hartman, op.cit. at 113; L.Henkin. The Covenant on Civil and Political Rights, in: U.S. Ratification of the Human Rights Treaties, R.B.Lillich (ed.) Charlottesville 1981, 20-26 at 23-24; Suy, op.cit. at 943-947.

59. See for a discussion of article 4 as a core obligation Chapter 5, par.1.2.1 infra.

60. Henkin, op.cit. at 23; Shelton, op.cit. at 209, 227; Suy, op.cit.at 944.

61. ACHR Advisory Opinion OC $3 / 83$, Restrictions to the Death Penalty, par.61; discussed in par.4.2.2 infra.

About this Opinion, see: Buergenthal, op.cit. at 23-25; Clark, op.cit. at 319-320. 


\section{- non-discrimination -}

It could very well be argued that the prohibition of discrimination is a core obligation in human rights law. The fact that this prohibition appears four times in the CCPR ${ }^{62}$ is proof of the importance of the obligation, which is stressed by the fact that the international community also drafted two specific instruments aimed at the elimination of discrimination, the CERD and the CEDAW.

However, it would seem that the more the prohibition of discrimination becomes all-encompassing, the more it loses its "object and purpose" potential. The detailed rules in the CERD and the CEDAW that seek to eliminate discrimination in a wide variety of situations, illustrate that discrimination is a multifarious mechanism. At the same time there is the risk of diluting the prohibition of discrimination as a core obligation because of the non-availability of a criterion to distinguish between the cases in which discrimination is prohibited.

To illustrate this, two examples may prove the point. At first sight the object and purpose of the Convention on the Elimination of All Forms of Racial Discrimination would appear to be the banning of racial discrimination. However, looking at the specific provisions, this interpretation of "object and purpose" proves to be too imprecise, too indiscriminate. If a State were, for example, to exclude article 5.f CERD by way of reservation, would that reservation be incompatible? The provision deals with the guarantee of access to places and services for use of the general public, such as transport, hotels, restaurants, café's, theatres and parks. It is beyond doubt that being refused entry to a restaurant on the basis of one's race is discriminatory and offensive, but is protection of this right really at the core of the prohibition of racial discrimination? Similarly, the Convention on the Elimination of All Forms of Discrimination against Women in article 9.2 deals with women's equal rights in respect of the nationality of their children. A reservation excluding this provision might lead to a situation in which mother and children would not only have different nationalities, but in which the children would legally be strangers in her own country. This may be offensive, annoying and painful for the mother, but could it on the other hand be assumed that article 9.2 CEDAW is a "core" right, as article 9.1 CEDAW would seem to be?"

In both cases there may be good reasons to consider the rights mentioned as noncore rights. However, when distinguishing between the whole of the treaty obligations and the core obligations, one easily makes a subjective choice ${ }^{4}$. It would appear that this is caused by the generality of "object and purpose" at first sight (prohibition of racial discrimination, prohibition of discrimination against women), that cannot be translated into a more adequate, concrete yardstick. Consequently one could easily disagree and argue that, on the contrary, the rights discussed above are core rights.

63. Clark, op.cit. at 320 , suggests that this might be based on the fact that article 9.2 CEDAW could not be considered a non-derogable right. 


\section{- scope of discrimination -}

Given the necessity of distinguishing that is implied in "object and purpose" as a criterion, one way of addressing the issue in respect of the non-discrimination treaties, would be to look at the area in which the core of discrimination lies ${ }^{65}$. In this respect, it might be argued, for instance, that the position of women in the family is an essential source of discriminatory practices in other fields. Thus it could be concluded that reservations to articles 15 and 16 CEDAW would be unacceptable. Yet, this might be a rather subjective choice, another evaluation of the sources of women's discrimination might lead to another "object and purpose".

If "core" is understood to point to the source of the discrimination, this might even lead to a further conclusion in respect of CEDAW, the fact that social and cultural patterns of conduct of men and women are the origin of women's discrimination. Consequently, article 5 CEDAW should be considered to belong to the Convention's object and purpose. At the same time it is one of the convention's most complicated provisions with a goal that may well be beyond what law could realistically achieve, and very few reservations have been made to this provision.

\subsubsection{Object and purpose in relation to ways and means of implementing human rights obligations}

A variety of questions follow from the issues that occur in the human rights practice in relation to the way in which the obligations will be implemented.

\section{- obligations of means, or obligations of result -}

Another question to be answered is whether "object and purpose" refers to the goal of the treaty, or deals with the means of achieving this goal as well ${ }^{60}$. This is particularly relevant in cases in which states hold different views on how to attain a certain goal, or in cases involving conflicting rights. States may make reservations and indicate that they still intend to realize the treaty's object and purpose albeit by other means. This demonstrates the relevance of the question.

It would seem to serve no purpose at all to condemn reservations in cases in which states claim to achieve the same end by other means. In fact it may be that emphasizing the obligation of result and thereby perhaps being flexible with the explicit obligations of means (cf. the discussions about article 4 CERD or 20 CCPR between the respective Committees and the reserving States) may contribute to universality, as a difference of opinion on the ways to achieve a goal does not necessarily conflict with the integrity of the treaty. Effective implementation is what matters, although it must be noticed that obligations of means are more precise and facilitate monitoring of the achievement of the goals set in a treaty, as compared with obligations of result.

66. See about this issue: Schachter. The obligation to give effect at 462. 


\section{- the relevance of travaux préparatoires -}

One of the obvious suggestions would be to look in the travaux préparatoires of a human rights instrument in order to find out more about the core of a particular treaty. This would seem to be emphasized in that the VCLT also refers to the travaux as a supplementary means that may be used in the interpretation of treaties ${ }^{67}$. Reference to the travaux is an approach typical for a treaty-lawyer.

Yet the question arises as to whether using the travaux is a method that does justice to the progressive aspirations of human rights law ${ }^{68}$. With its over-all focus on the progressive development of human rights protection, and with the increasing importance of the acquis developed in respect of human rights treaties this would seem to be a rather retroactive approach. The use of travaux as an element in the interpretation of treaties refers to the static nature of the law of treaties, that may not be suitable for human rights law.

\section{- the dynamic principle -}

A following question in the same train of thought would then be whether it is conceivable that the "object and purpose" itself changes in the course of time. This is an intriguing question because of its suggestion of flexibility. The assumption is based on a parallel with the development of the acquis, and its increased importance. This argument concerning object and purpose is rare, but it is in line with obligations to progressively eliminate discrimination ${ }^{69}$. In respect of the American reservation to article $6 \mathrm{CCPR}$ on the abolition of the death penalty it has been argued that this is contrary to the General Comments of the Human Rights, and therefore contrary to object and purpose ${ }^{\text {to }}$.

The disadvantages of such an approach are to be noted: if it would be accepted that the object and purpose of a treaty could change in the course of time, a

67. Article 32 VCLT; $c f$. Cook, Women's Convention, at 661 .

68. Raising a similar issue in respect of the Travaux of the ECHR: R.Kühner. Vorbehalte und auslegende Erklärungen zur Europäischen Menschenrechtskonvention (hereafter: MRK), in: 42 ZAöRV 1982, 58-92 at $72-73$.

69. Cook, Women's Convention, at 661-662.

70. C.Flinterman, E.Rieter, De Verenigde Staten en het BUPO Verdrag: de rol van Nederland (hereafter: Flinterman. Rieter NJB), in:67 NJB 1992, $935-936$ write at 935:"Dit voorbehoud bij artikel 6 BUPO-verdrag. waarin het recht op leven is neergelegd, druist rechtstreeks in tegen de tekst van artikel 6 BUPO-verdrag. die gebaseerd is op de wenselijkheid van de afschaffing van de doodstraf; tegen de 'general comments' van het Mensenrechtencomité (het toezichthoudend orgaan onder het BUPO-verdrag) waarin ondermeer wordt gesteld dat staten verplicht zijn de oplegging van de doodstraf te beperken en dat de doodstraf slechts in zeer uitzonderlijke omstandigheden kan worden opgelegd en tegen ontwikkelingen in het intermationaal recht in het algemeen, zoals blijkt uit de totstandkoming van het Tweede Facultatief Protocol bij het BUPOverdrag (New York, 1989) dat voorziet in de afschaffing van de doodstraf. Het Amerikaanse voorbehoud lijkt derhahe in strijd ic zijn met 'loonwerp ch docl van het BUPO verdrag. "(my emphasis, EL).

The authors were probably focusing on the subsiantive issue of the abolition of the death penalty, rather than the intricate question of the flexibility of "object and purpose". 
reservation made at the beginning of the treaty's existence might be compatible ex tunc whereas a similar reservation made twenty years later would not be compatible. The problems which could arise would in a way be covered by the acceptance of the latter reservation under the permissive rule of article 20.5 VCLT, but in the interpretation of a reservation used by a supervisory organ the changed content of object and purpose would play a role.

\section{- social relativism -}

A final point of view that has appeared in relation to the object and purpose of human rights treaties is the view that compatibility is a relative notion, and that the specific circumstances of countries will have to be weighed. In suggesting this with respect to the Women's Convention, Cook writes that compatibility is not only a function of the interpretation of the treaty as a whole, but also from sociopolitical measurements of effects of reservations on women".

It is a line of reasoning that clearly fits into the tradition in feminist legal theory of looking at the reality behind the rules, and as such it must be appreciated. However it would appear that this theory is neither based on a realistic perception of the embarrassment at international level of looking into the socio-political structure of the reserving States, otherwise known as the internal affairs of a State, nor of the possibilities for either States Parties or supervisory Committees to research the background of reservations in such great depth.

\subsection{Monitoring the "object and purpose" obligation}

The "object and purpose" rule has been of limited relevance in treaty practice, if measured by the number of objections made to reservations to human rights treaties $^{72}$. Though, as indicated before, it is not obligatory for incompatible reservations be objected to $^{73}$, or that objections necessarily imply incompatibility $^{74}$, the small number of objections is striking. The vague content, and the difficulties in substantiating the "object and purpose" notion must be one of the major reasons for this.

71. Cook, Women's Convention at 680 , writes:"[T]o propose the compatibility of reservations is specific to the circumstances of individual countries, and that countries with such features as a large differential literacy rate between men and women or with many households headed by women are different from other countries, suggests that legal determination of compatibility arises not from the Convention per se, but from specific applications of treaty provisions to individual countries." And similarly with respect to religious law: Sullivan, op.cit. at 810 writing:"The extent to which religious law may be applied without restrictions based on other human rights will vary with the substantive content of the law, and with the scope of its application ratione materiae and ratione personae."

72. As Bourguignon writes with respect to Imbert emphasis of States as the sole actors with respect to the determination of compatibility, at $369:^{*}$. .the final refutation of M.Imbert's insistence on the process of acceptance and objection is that it simply has not worked."

73. See Chapter 2, par.3.6.3 supra.

74. See Chapter 2, par.3.6.2 supra. 
Coccia, emphasizing that there is no difference between general multilateral treaties and human rights treaties, states that the object and purpose rule does not prevent the acceptance of reservations contrary to object and purpose ${ }^{75}$. Acceptance of an incompatible reservation precludes the invocation of incompatibility at a later stage, objections provide an option for further discussion about the reservation, but given the small number of objections, the incompatibility rule must be assumed to have lost relevance ${ }^{76}$.

Disappointed with the lack of reaction by states to incompatible reservations, Shelton writes that "another mechanism for review and decision on legality must be developed"77. Supervisory organs established by the human rights treaties would be qualified for such a task, because they are composed of independent experts, and these organs are committed to ensuring an effective implementation. Shelton recalls that at the time of the Genocide decision, no international supervisory mechanisms existed, indicating that this lead to the question about compatibility being brought before the Court. In spite of the fact that an attempt by the Committee on the Elimination of Racial Discrimination to establish broad powers to deal with the compatibility issue failed ${ }^{78}$, she perceives more possibilities in this field for the Human Rights Committee. This is based on an analysis of the differences between the competence of the CERD Committee and the HRC in the respective treaties, and because of the fact that unlike the CERD, the CCPR does not contain a reservations clause ${ }^{79}$.

The discussion on monitoring the "object and purpose" obligation seems to have focused on two distinct options, namely the choice between the traditional system in which the other States Parties play a decisive role, and the so-called institutional system, in which an institution, supervisory organ or judicial organ has a final say. Whereas the first option has not led to a limitation of incompatible reservations, the legitimacy of the second system is questioned when a human rights instrument does not explicitly give such authority to the supervisory organ.

Let us look at the role supervisory organs might play in this respect. An explicit decision on compatibility would appear to be impossible with respect to the UN human rights instruments, other than through the dispute-settlement procedure. There are no other procedures by which incompatibility could be authoritatively

75. Coccia, op.cit. at 34 writes:"an argument may be made that the object and purpose of a human rights treaty must be interpreted in a more rigorous manner, given the particular obligations involved. Yet, because the incompatibility rule does not apply when States accept reservations, such rigorous interpretation must, in any event, yield to the acceptance of States. As a result, from a practical viewpoint the primary issue concerning treaties on human rights is not whether reservations are incompatible with the object and purpose of the treaty, but whether States do, in fact, object to reservations made in regard to such treaties."

76. Coccia, op.cit. at 33-34.

77. Shelton, op.cit. at 229.

78. Shelton, op.cit. at 229 , and see Chapter 4, par.1.2 infra.

79. Shelton, op.cit. at 230-231. 
established, a fact also emphasized by the Office for Legal Affairs in their advice to both the CERD Committee and the CEDAW Committee ${ }^{80}$. It should be kept in mind that neither the European Convention nor the American Convention are comparable to the UN Human rights systems as far as the authority of the Committees to discuss reservations is concerned. Clarity such as can be achieved under the ECHR and the ACHR will clearly not be available.

However, this does not restrict the authority of a supervisory organ to discuss the compatibility of a reservation if this comes up in the course of its work. It would not be realistic to assume that a reservation precludes every discussion of the reservation. Like a treaty, a reservation needs interpretation before application. On the basis of the assumption that all reservations made are compatible with the object and purpose, a supervisory organ is fully entitled to interpret a reservation restrictively, as it were assuming its compatibility ${ }^{81}$. This is an important, albeit somewhat obscure way of getting a grip on the issue of reservations, fully in line with the task of a supervisory organ in monitoring the compliance with the human rights instrument. And this has indeed been taking place under the UN human rights treaties, as we shall see below.

Imbert suggests that a choice between monitoring of the "object and purpose" rule by the States Parties or by the supervisory organs is necessary, but fails to indicate why this is the case ${ }^{82}$. I do not understand why both methods could not be employed to limit the detrimental impact of incompatible reservations. Without doubt it is the primary responsibility for States to refrain from making a reservation contrary to object and purpose of a treaty. The mirror responsibility of the other States Parties consists of monitoring the reservations made, and if necessary objecting to incompatible reservations. If the traditional mechanism does not function adequately, institutional monitoring of reservations as part of the supervisory work may be a useful complement to the traditional rules. My understanding of ways to monitor the compatibility of reservations would be that, though States have the right and indeed the obligation, to respond explicitly to incompatibility, the supervisory organs have a parallel right following from their role within the supervisory system $^{83}$.

80. Advice to the CERD Committee in: UN Juridical Yearbook 1976 (ST/LEG/SER.C/14) at 219-221: advice to the CEDAW Committee in: A/39/45, Vol.II, Ann.II.

81. See par. 2.3, The interpretation of reservations infra.

82. P.H.Imbert, in: Europaischer Menschenrechtsschutz, I. Maier (ed.), Heidelberg 1982; at 170 states:"Allgemein meine ich, dass man zwischen zwei Systemen der Beurteilung von Vorbehalte wählen muss: zwischen der Zustimmung der Verıragsstaaten oder dem Eingriff der Kontrollorgane ausserhalb der für die stillschweigende Zustimmung gesetzten Frist. Beide Systemen können zusammen schwerlich funktionieren, denn die Möglichtkeit einer emeuten Prüfung durch die Kontrollorganen schwächt zwangsläufig das ist das mindeste, was man dazu sasgen kann - die Zustimmung. die die Vertragsparteien vorher erteilt habe. Man muss also wählen."

83. Similarly van der Velde, Voorbehouden at 359 writing about the ECHR system: ${ }^{n e e l e e r}$ lijkt het er op dat zij (the European Commission on Human Rights, EL) in plaats van

(continued...) 
Putting too much emphasis on the steps that supervisory organs could take with respect to incompatible reservations, would seem to turn the whole problem into an issue beyond the influence of states, within the field of action of supervisory organs only. This would certainly be a misconception as it is based on the admission that states are not the best guardians of the "object and purposen of treaties they themselves create. In my view the primary responsibility for dealing with the negative impact of reservations is first of all one belonging to the states parties to a treaty ${ }^{84}$. A supervisory organ has the secondary and complementary responsibility, the existence of a supervisory organ cannot be an excuse for not fulfilling the obligations under article 19.c VCLT and parallel provisions of other treaties.

\subsection{The interpretation of human rights instruments: coexistence and coherence}

Frequently reservations need to be interpreted, in particular when the supervisory organs discuss the periodical reports of the reserving States. They have to try and establish the scope of the restriction or exclusion created by a reservation. States may not always formulate their reservations in a comprehensible way; may purposely formulate vague statements; and, like any written document, reservations may suffer from the recurring vagueness of language. Consequently reservations will have to be interpreted, presumably in accordance with article 31 VCLT. This provision, like article 19.c VCLT, refers to the object and purpose of the treaty as a yardstick for the interpretation of a treaty.

The interpretation of reservations may be a useful starting-point for restricting the detrimental impact of some reservations. The prohibition of reservations contrary to the object and purpose of a treaty is not merely a rule laid down in the Vienna Convention, it is also a logical necessity. Not only is there be a good faith obligation not to undermine the very essence of the treaty one is concluding, such a policy also saps the value of the consent necessary for the conclusion of a treaty. Sweden has elaborated on this aspect of the prohibition to undermine the object and purpose when objecting to reservations to the CEDAW ${ }^{85}$. A conse-

\section{3.(...continued)}

een exclusieve bevoegdheid van de verdragsstaten een parallele toetsingsbevoegdheid van zowel de verdragsorganen als de staten aanwezig ziet."

84. Imbert. HRR, at 46 writes: "What purpose is served by making everything depend on a hypothetical decision by the Commission, the Court or the Committee of Ministers, as though prior consideration could not be given to a resenation at the time it was formulated?" (my emphasis, EL).

85. The objection reads:" .. the reason why reservations incompatible with the object and purpose of a treaty are not acceptable is precisely that otherwise they would render a basic international obligation of a contractual nature meaningless. Incompatible reservations, .., do not only cast doubt on the commitments of the reserving states to the objects and purposes of this Convention, but moreover, contribute to undermine the basis of intemational contractual law. It is the common interest of states that treaties to 
quence of the obligation contained in article 19.c is the presumption that States Parties never intended to act contrary to the object and purpose of the treaty they ratified. In international law there is a general presumption that States in their international relations act in accordance with good faith, implying a presumption that reservations are supposed to have been made in conformity with the existing rules, thus not being contrary to "object and purpose"

In a number of cases, it will be apparent that the presumption of reservations being compatible with object and purpose is scarcely more than a legal fiction. However, I would like to contend that it is a useful presumption. To refute the presumption, a state will have to admit that it acted contrary to a general rule underlying international relations, and will moreover have to indicate explicitly that it intended to act contrary to the object and purpose of the very treaty it was ratifying, which casts a nasty shadow on its reliability as a State Party. States will never explicitly concede that they purposely made an incompatible reservation.

Returning to the interpretation of reservations, this will mean that a supervisory committee may, on the basis of general international law, assume that a State intended to make a compatible reservation, and thus interpret a reservation in a restrictive sense, thereby limiting the detrimental scope of the reservation.

A second, and perhaps more daring approach would be to take into account the whole body of human rights law as it stands today. Although specific instruments may deal with specific fields of human rights protection, these instruments may be seen as elements in a general body of law. Within this hody of law various rights have been articulated in different instruments. The point to be made is that the different human rights instruments do not merely coexist, but that they are a coherent set of rules, in spite of the diversity of sources. Human rights instruments themselves point to this coherence, in the shape of the provisions stressing the continued availability of better protection under other rules. These are provisions such as articles 5 jo. $46 \mathrm{CCPR}$, article $23 \mathrm{CEDAW}$, or article 1.2 CAT. Up until now, these provisions have been thought to be directly relevant for the individuals under the jurisdiction of the states, and have not played a significant role in the work of the supervisory organs. To my mind, these provisions should be made operational, and should indeed be used by the supervisory organs to legitimize an approach based upon the coherence of human rights law.

Coherence implies that the obligations (including reservations) under one treaty will have to be consistent with obligations under another treaty incumbent on the reserving State. The majority of states have ratified more than one human rights instrument. Although there is no explicit obligation to act in a coherent way on an international level, the international obligations in the field of human rights

85.(...continued)

which they have chosen to become parties also are respected, as to object and purpose, by other parties."

ST/LEG/SER.E/11.

86. See Chapter 2, par.4, The relevance of the object and purpose rule. 
law must be interpreted on the basis of the assumed coherence of a State's obligations. In fact, reservations to one treaty can very often be construed as breaches of another treaty.

This line of reasoning has been proposed by Mexico when it objected to reservations to the CEDAW ${ }^{87}$. The acceptance of general obligations would seem to preclude the restriction of these obligations in specific cases or for specific groups $^{\mathrm{kx}}$. The advantage of this approach to reservations is that the vague notion of object and purpose is substantiated with reference to other human rights obligations. Obligations already accepted by the reserving state become a yardstick for its reservations under other instruments.

In the following scheme, an attempt has been made to draw up a scheme indicating disparities in the obligations of States under the four human rights instruments to be dealt with below ${ }^{k 9}$. Though this scheme only refers to four conventions, it might be enlarged to include obligations concluded under the aegis of specialized agencies, such as ILO and UNESCO, or regional instruments ${ }^{90}$.

\begin{tabular}{|l|l|l|l|}
\hline States & CCPR & CERD & CEDAW \\
\hline Austria & art. 12.4 & [art. 5.d.ii] & \\
\hline Belgium & art. 23.2 & [art. 5.d.iv] & $\begin{array}{l}\text { [art. 16.1.a, } \\
\text { 16.1.b, 16.2] }\end{array}$ \\
\hline Cyprus & [art. 23.4, 24.3] & & art. 9.2 \\
\hline Egypt & [art. 23.4, 24.3] & & art. 9.2 \\
& [art. 23.4] & & \begin{tabular}{l} 
16.1.g, 16.1.h \\
\hline
\end{tabular} \\
\hline
\end{tabular}

87. The objections reads:" .., it is inconsistent with these contractual obligations (the objection mentions the UN Charter, the Universal Declaration of Human Rights, the CC.PR as well as the Covenant on Economic, Social and Cultural Rights) previously assumed by ... for its Government now to claim that it has reservations, on the same subject, about the 1979 Convention.

ST/L.EG/SER.E/11. And similarly Lijnzaad, Het maken en breken van internationaal recht voor vrouwen, reactie op 'Onder Voorbehoud'(hereafter: Lijnzaad, Maken en breken), Nemesis 1993, at 211-214.

88. This idea of coherence implies a restrictive application of general rules of contract law, such as the lex specialis or lex posterior rule.

89. This table merely gives an impression of some discrepancies with respect to reservations to various conventions. The articles in bold are reservations, the articles between brackets are parallel provisions without reservations in other instruments.

90. Similarly Cook, Women's Convention at 682 . 


\begin{tabular}{|c|c|c|c|}
\hline States & CCPR & CERD & CEDAW \\
\hline FR Germany & $\begin{array}{l}\text { art. } 19 \\
\text { art. } 21 \\
\text { art. } 22 \\
\text { [art. } 25 . c \text { jo. 26] }\end{array}$ & $\begin{array}{l}\text { [art. 5.d.viii] } \\
\text { [art. 5.d.ix] } \\
\text { [art. 5.d.ix, } \\
\text { 5.e.ii] }\end{array}$ & art. 7.h \\
\hline Iceland & art. 8.3.a & & [art. 11.1.c] \\
\hline Iraq & $\begin{array}{l}\text { [art. 2.1, 2.2, } \\
\text { art. 26] } \\
\text { [art. 23.4, 24.3] }\end{array}$ & & $\begin{array}{l}\text { art. } 2 . f, 2 . g \\
\text { art. } 9.2\end{array}$ \\
\hline Jamaica & [art. 23.4, 24.3] & & art. 9.2 \\
\hline Jordan & $\begin{array}{l}\text { [art. 23.4, 24.3] } \\
\text { [art. 23.4] }\end{array}$ & & $\begin{array}{l}\text { art. } 9.2 \\
\text { art. 16.1.c, } \\
\text { 16.1.d, 16.1.g }\end{array}$ \\
\hline Luxemburg & $\begin{array}{l}\text { art. } 19.2 \\
\text { art. } 20.1 \\
\text { [art. 25.c jo. } \\
\text { art. 26] }\end{array}$ & $\begin{array}{l}\text { [art. 5.d.viii] } \\
\text { [art. 4.a, 4.h] }\end{array}$ & art. 7 \\
\hline Malta & art. 19 & [art. 5.d.viii] & \\
\hline Mauritius & [art. 23.4] & & art. $16.1 . g$ \\
\hline Netherlands & $\begin{array}{l}\text { art. } 12.1,12.2 \\
\text { art. } 12.4\end{array}$ & $\begin{array}{l}\text { [art. 5.d.i, } \\
5 . d . i i] \\
\text { [art. 5.d.i, } \\
\text { 5.d.ii] }\end{array}$ & \\
\hline New-Zealand & art. 22 & $\begin{array}{l}\text { [art. 5.d.ix, } \\
\text { 5.e.ii] }\end{array}$ & \\
\hline
\end{tabular}




\begin{tabular}{|l|l|l|l|}
\hline States & CCPR & CERD & CEDAW \\
\hline $\begin{array}{l}\text { Republic of } \\
\text { Korea }\end{array}$ & art. 22 & $\begin{array}{l}\text { [art. 5.d.ix, } \\
\text { 5.e.ii] }\end{array}$ & art. 9 \\
[art. 23.4, 24.3] & art. 23.4] & art. 16.1.g \\
\hline $\begin{array}{l}\text { Trinidad and To- } \\
\text { bago }\end{array}$ & art. 12.2 & $\begin{array}{l}\text { [art. 5.d.i, } \\
\text { 5.d.ii] }\end{array}$ & \\
\hline Tunesia & art. 21 & [art. 5.d.ix] & art. 9.2 \\
& [art. 23.4, 24.3] & art. 23.4] & 16.1.c, \\
& art. 12.1 & $\begin{array}{l}\text { [art. 5.d.i, } \\
\text { [.d.ii] }\end{array}$ & [art. 5.d.i, \\
\hline United Kingdom & a.d.ii] & [art. 7.b, 7.c] \\
\hline
\end{tabular}

Some differences exist between the Convention on the Elimination of Racial Discrimination and the Covenant. But there are really striking examples of disparities between obligations under the Covenant on Civil and Political Rights, to which no reservations have been made, and identical obligations under the Women's Convention swamped with reservations. The obvious remark would be that the Covenant happens to be the Men's Convention. A strategical approach to the reservations issue uses the unqualified acceptance of obligations under the Covenant as relevant for the scope of reservations to the Women's Convention.

An overview such as this may facilitate the work of the Committees, who could question the differences in obligations under the different treaties. The Human Rights Committee could for instance, question Iraq on the implementation of articles 2 and 26 CCPR (to which no reservations have been made), in view of the Iraqi reservation to article 2.f and 2.g CEDAW and the obligation to withdraw discriminatory penal legislation. The Women's Committee could ask the same question, based on the expert knowledge the Committee members may have about the Covenant. Similarly, Cook has argued that in fact the supervisory bodies may look at relevant case law under other human rights instruments, in 
order to interpret human rights obligations". This may have some additional advantages in terms of access to supervisory procedures.

It will be quite obvious that in order to tum this theory into a tool for practical use, the supervisory Committees will have to gain more insight into the coherence of contemporary human rights law. But this is perhaps a small problem that could be solved easily with expert advice, and could be facilitated by adequate servicing of the supervisory organs.

\section{THE QUEST FOR UNIVERSALITY}

The universality of human rights law is a complex matter. Dealing with the issue, one is struck by the confusion of tongues surrounding it. The universality of moral, ethical and religious values is intermingled with ideas about the feasibility of universally binding legal rules. Far from pretending to provide a solution, attention ought to be given to the question whether the universality of human rights law is a goal that can be attained within the realm of the law of treaties. Do reservations affect the quest for universality, and if so, are there possibilities of redressing this?

\subsection{The universality of human rights law}

When discussing the universality of human rights law, the first matter that comes to mind is the question whether human rights are based on a concept of human dignity shared by all cultures ${ }^{92}$. Although human rights are embodied in treaties drafted within the framework of the United Nations, the issue is whether their validity is based on universal ethical, moral or religious convictions. Leamed authors have at length elaborated on this question, but it would seem to be beyond the abilities of lawyers, as lawyers, to assess the validity of moral judgments ${ }^{93}$.

91. Cook, Women's Convention at 710 .

92. M.Bertrand, Universality, in: Is Universality in jeopardy?, United Nations Department of Public Information, New York 1987, 21-33 at 23:"For universality to exist, there should be a common political view of the world, in other words, universal acceptance of the same values and of the institutions capable of guaranteeing them. .; and R.J.Dupuy, L'universalité des droits de l'homme, in:Studi in onore di Giuseppe Sperduti, Milano, 1984, 541-556, at 541:"..la question de savoir si le droit international donne des droits de l'homme une vision suffisament rassemblée, suffisamment unifiée pour pouvoir convier tous les hommes à les respecter."

93. The discussion has focused on three related issues concerning universality, namely the existence of a shared concept of human rights. the influence of western individualism on human rights law, and finally the question whether the Universal Declaration as a whole has universal validity.

On the matter of the shared concept of human rights amongst others: Th.C. van Boven, Politisation et droits de l'homme, in: Les organisations internationales entre l'innovation et la stagnation, N.Jéquier,F.Muheim(eds.), Lausanne, 1985 125-138, at 126-127; Dupuy, op.cit. at 542; H.Gros Espiell, The evolving concept of human rights, in: Human rights, 
The assumption of the universality of human rights is inspired by the conviction that these rights should be available for all. To ensure this, human rights instruments should be binding at a global level. The fact that various human rights instruments have been drafted within the framework of the United Nations and have been widely ratified has been taken as proof for the existence of universally shared values ${ }^{94}$. When drafting human rights instruments it may be assumed that states use this opportunity to determine the common core of values upon which human rights are based. Yet, it is not mandatory to lay down rights based on shared concepts of human dignity, the substance of the treaty may very well be the result of negotiations.

Assuming that the protection of human rights would be guaranteed once all states have ratified every human rights treaty demonstrates the naiveté of lawyers. This means interpreting formal universality as substantive universality, which need not be the case. Behind being a party to a human rights treaty lies the question of which provisions the state is actually bound by. Reservations obviously restrict the rights laid down in human rights instruments. Although a large majority of the states may be formally bound by a treaty, it will not be equally binding on all states parties and the substantive rights will not be available for all.

The question ought to be raised as to what is exactly meant by the quest for universality. The desire for human rights to be available for all, would seem to stretch well beyond the simple adherence to a human rights treaty. This is merely formal universality. An additional requirement is the integral acceptance of the rights laid down in the treaty. Universality need not, after all, be satistied by a purely formalistic approach, substantive guarantees are of primordial importance. Global adherence alone is a rather meagre form of universality.

93.(...continued)

thirty years after the Universal Declaration. B.(i.Ramcharan(ed.). The Hague 1979, at 41-65: L.Kühnhardt, Die Universalität der Mensehenrechte. München 1987 passim; C.Tomuschat. Is Universality of Human Rights Standards an Outdated and Utopian Concept?. in: Das Europa der Zweiten Generation, Gedächtnisschrift für Chr. Sässe, Kehl 1981, 585-609.

On the so-called "western" influence on the contemporary concept of human rights: P.R.Baehr. Toepassing van universele mensenrechtennormen, in: 40 Internationale Spectator 1986, 85-92 at 86; Cassese. International Law at 299.

On the validity of the Universal Declaration amongst others: The Universal Declaration of Hluman Rights: its significance in 1988. SIM Special no.9 (december 1988) passim: P.Alston. The United Nations and the elliptical notion of the universality of human rights, in: Is Universality in jcopardy?. United Nations Department of Public Information, New York 1987, 51-65 at 53-56.

94. Alston, op.cit. at 59:".. a claim which, although sometimes assumed (1) exist, could never reasonably made. That is that the United Nations approach to human rights represents a common denominator of all of the world's cultural traditions and ethical values and that the notion of rights is as decply rooted in each of the world's major cultural traditions as it is in Western Enlightenment culture." 
This broader approach to universality adds another perspective to the discussion. For universality, understood as global adherence and integral acceptance faces two different hurdles. Not only does universality require persuading all states to become parties to human rights treaties, the integral acceptance of the treaty is an equally important goal of human rights policys. Both requirements of the broader concept of universality, it is contended, conflict with the basic premises of the law of treaties, the fact that states can only be bound by what they explicitly agree to. This is precisely were the quest for universality and the issue of reservations meet.

\subsection{The arithmetics of universality}

Apart from the fact that there are a number of understandable reasons for making reservations dealt with above, there is also a widely held view that reservations are a necessary correlate of the wish to establish a universal protection of human rights ${ }^{96}$. In my view this is a rather limited interpretation of universality ${ }^{97}$, but the point to be discussed here is whether the assumption that reservations are the necessary price for ratification is valid.

The argument is as follows: given the desirability of universal adherence to human rights treaties and given the fact that the situation in the countries differs a great deal ${ }^{98}$, reservations may provide for a mechanism to modify the obligations in the treaty. The advantage is that states that do not yet completely fulfil the norms set by the treaty, will be within its scope. Being a party will ensure supervision, and encourages the improvement of the domestic human rights situation ${ }^{99}$. This line of reasoning stresses the importance of adherence, on the assumption that being a state party to a particular treaty will prompt the withdrawal of reservations in the future. This view is underlined by the suggestion that to reason otherwise, by demanding full adherence and excluding reservations, leads to an elitist treaty with only a few States Parties living up to the treaty's standards, which is contrary to the aim of universality.

The question to be raised is whether it has indeed been true that the reservation option has led to universal adherence. This was after all the argument for being lenient on the reservations issue. When looking at the figures for the treaties to be dealt with in this study, they are not very persuasive ${ }^{100}$.

95. Cook, Women's Convention at 644-645, 649; Lijnzaad, Paradoxale universaliteit, at 7.

96. Schachter es. at 147 write that:"It is reasonable to assume that the right to make reservations to multilateral treaties facilitates their wider acceptance."

97. Lijnzaad, Paradoxale universaliteit, at 7.

98. Schachter cs. at 147; Shelton, op.cit. at 208.

99. A.Byrnes, The "Other" Human Rights Treaty Body: The Work of the Committec on the Elimination of Discrimination Against Women, in: 14 YaleJIL 1989 (hereafter: Byrnes, The work of the Committee), 1-67 at 56: Cook, Women's Convention at 686.

100. Cr. Lijnzaad, Paradoxale universaliteit, at 13-14. Schachter es. write at 147:"It has been said that the assumption that reservations facilitate ratifications and accessions lacks statistical confirmation." 
By 31 December 1992, 166 States were member of the United Nations and thus eligible to express consent to be bound by these instruments ${ }^{101}$. The following figures indicate that in spite of the fact that rather liberal rules on reservations applied, adherence is far from universal. ${ }^{102}$

$\begin{array}{lll}\text { CERD } & 130 \text { ratifications } & 47 \text { reservations } \\ \text { CCPR } & 100 \text { ratifications } & 44 \text { reservations } \\ \text { CEDAW } & 110 \text { ratifications } & 51 \text { reservations } \\ \text { CAT } & 64 \text { ratifications } & 26 \text { reservations }\end{array}$

The other presumption is that being a state party to a human rights treaty, under the wings of the supervisory organs, will lead to a gradual improvement of the implementation of the complete treaty and to the withdrawal of reservations. Let us look at the withdrawal figures, this will be done more in depth in the following chapters, but for now the following figures may serve as an indication that the number of withdrawals does not substantiate this line of reasoning. ${ }^{103}$

$\begin{array}{llr}\text { CERD } & 130 \text { ratifications } & 10 \text { withdrawals } \\ \text { CCPR } & 100 \text { ratifications } & 6 \text { withdrawals } \\ \text { CEDAW } & 110 \text { ratifications } & 12 \text { withdrawals } \\ \text { CAT } & 64 \text { ratifications } & 8 \text { withdrawals }\end{array}$

The idea that reservations are a necessary price for universal participation has been reinforced by publications that have suggested that the impact of reservations does not pose great problems in practice. On the basis of a so-called macroscopic approach, Gamble indicated that the average state made less than one reservation per treaty in recent years ${ }^{104}$. This conclusion appears to be reassuring. With less than one reservation per state per treaty, one is indeed inclined to consider the reservations issue a minor problem.

Yet, there are reasons to doubt whether this approach does not suffer from the inaccuracies of arithmetic. When looking specifically at human rights treaties the figures are significantly different. In her article Shelton concludes that $20 \%$ of the States ratified human rights treaties with reservations, and in fact $13 \%$ of the States made substantive reservations as opposed to procedural reservations ${ }^{105}$. Not only does this show that the figures can be deceptive. Shelton also stresses

101. ST/LEG/SER.E/11.

102. These figures are the number of states that made reservations. and include reservations to dispute settlement clauses, that are not dealt with.

103. These figures are withdrawals per country, and could thus include the withdrawal of a number of reservations.

104. Gamble, op.cit at 372; vd Velde, Voorbehouden at 354. Similarly Schachter es. op.cit. at 154-155.

105. Shelton, op.cit. at 225-226. 
the importance of the substance of the reservation. Substance is what "object and purpose" is all about, it is a rule about the quality of the reservation. This is even more the case given the "object and purpose" of human rights law in general.

To sum up, it must be concluded that, however persuasive the argument is that reservations facilitate ratification, it is not absolutely valid. Whereas the Court in the Genocide case was able to combine both universality and integrity because of the single-mindedness of the Genocide Convention ${ }^{106}$, this will probably not be possible with respect to more recent human rights treaties. Moreover with the law on reservations favouring universal acceptance in article 20.5 VCLT, and with the supervisory Committees acting as the guardians of human rights instruments, it can only be expected that the solution will be some kind of compromise.

On the other hand it has been suggested that those States that take their human rights obligations seriously make reservations, whereas a great many states that ratify without reservations do not have the slightest intention of living up to their obligations in the domestic sphere ${ }^{107}$. This should indeed be kept in mind when criticizing reserving States. For the individual in a state, it will probably make little difference whether a restriction of human rights is legitimized through a reservation or not.

\subsection{A problem of tools}

The problem of reservations to human rights treaties is that of the choice of a wrong tool ${ }^{108}$. From the outset, with the idea that an International Bill of Rights should be drafted, a deliberate choice was made for lex scripta $a^{109}$. This is understandable, as treaties have the advantage of providing accessible and possibly detailed rules. Moreover, it will be clear which states are bound by the rules. Using treaties for the formulation of human rights does however also have a number of disadvantages ${ }^{110}$. The negotiations may be heavily influenced by considerations not related to human rights, the final text suggests genuine consensus, but may in fact be a compromise solution. By using the methods of the law of treaties the distinctive characteristics of this set of instrumental rules will influence the possibility of achieving universality in a broader sense.

To understand this, some reflection on the origins of the Law of Treaties is necessary. Historically the law of treaties developed as a tool for states to formalize their agreements. Initially it concerned only bilateral agreements, laying down reciprocal subjective rights. It is necessary to keep this initial orientation in mind as the number of states parties to treaties expanded. As the 
international legal community grew ${ }^{111}$, states began to conclude multilateral treaties, considering them a bundle of parallel bilateral treaties ${ }^{1 / 2}$. Whereas the law was able to cope with the changes involving the growing number of states parties $^{113}$ to multilateral treaties, it was much more complicated to adapt to the changing content of the treaties ${ }^{114}$.

The fundamental change in the content of treaties was brought about by the emergence of both objective legal regimes and traités-lois. Treaties like these lay down obligations of a general nature stemming from global considerations rather than the states parties' subjective interests. This changing content might have necessitated a reconsideration of the foundations of treaty law ${ }^{115}$. However, international law stuck to a traditional method of law creation, incorporating as far as possible new developments in the content of the treaties ${ }^{116}$. It is submitted that the problems arising in relation to reservations to human rights treaties are among other things, a consequence of the fact that while the content of treaties changed, the method of creating law through written agreements remained the same ${ }^{117}$.

The method suitable for the creation of universally valid and integrally binding law would be customary international law. It is basically universally binding, and every rule of law is integrally binding on every state ${ }^{118}$. But this is not suitable in the case of international human rights law ${ }^{119}$. Its creation takes a relatively

11. Discussing the changes in the structure of international relations; G.J.H van Hoof, Rethinking the Sources of International Law, IJsselstein 1983, at 65-71.

112. An approach upheld in the Vienna Convention, see: Rosenne, Developments at 82-83. and by the same author Bilateralism and Community Interest in the Codified Law of Treaties (hereafter: Rosenne, Bilateralism), in: Transnational Law in a changing society, W.Friedmann cs.(eds.), New York 1972, 202-227.

113. van Hoof, op.cit. at $69-71$

114. van Hoof, op.cit. at 68-69.

115. On the attempts to classify treaties: Rosenne. Developments at 181:"The underlying assumptions seem to be, ... e either that there is no unitary law of treaties applicable in its ensemble for every purpose to every treaty ... or that such a unitary law of treaties does exist, but the application of its detailed rules and precepts will vary, and some of its precepts might even disappear entirely, according to the classification into which a given treaty falls.".

116. Rosenne, Bilateralism, at 226:".the Vienna Convention on the Law of Treaties, when placed in the context of the totality of public international law as it is today, goes a long way towards reconstituting the law of treaties in such a manner that, alongside the bilateralism which really is the essence of contractual law and jurisprudence, the existence of broader interests is not only acknowledged but actually accorded a recognized place in the law."

117. Rosenne, Developments at 83-84:"..the codification (the Vienna Convention, EL) as a whole still reflects the law as it developed in the relatively compact and relatively homogeneous international community before the effects of self-determination 1919 and of the massive decolonization of the 1960 s could be felt."

118. With the exception of the doctrine of the "persistent objector", see Norwegian Fisheries case, IC.I Reports 1951.

119. Van Hoof, op.cit., discussing the disadvantages of the methods of customary law at 113116, and of treaty law at 119-130; Lijnzaad, Paradoxale universaliteit at 14-15. 
long time, and the rules that will eventually come into existence may not be specific enough. The creation of supervisory organs, such as the various committees monitoring the implementation of human rights covenants, is certainly not possible within the process creating international customary law. Moreover, participants in the creative process of international customary law very often feel that they can not influence the process.

In sum, neither method of creating international law is suitable for the achievement of both demands, the requirement of global adherence as well as the aim of integral acceptance. Customary international law is inadequate because of its opaque creative process and the lack of precision in the rules of law thus created. Treaty law is unsuitable because of the liberty it traditionally leaves states and the consequences this has for the quest for universality. This must lead to the conclusion that the aim of universality in the broader sense, that is global adherence and integral acceptance, will probably always be hampered by the limited possibilities the methods of creation of international law, and treaties in particular, offer.

Although the question of reservations to human rights treaties presents itself as a technical legal question, there is also another reason for the conflicts between the law of treaties and human rights law. Looking at the problem from a different angle, it could be rephrased as one of differing morality.

The foundation of the law of treaties is basically still the plain and simple rule of do ut des, elaborated on above. It is the morality of obligation, sticking to one's promise and acting as agreed ${ }^{120}$. It is the elementary morality on which any legal system is based, a system of reciprocal restraint through bilateral agreements. Human rights law is based on a different morality, the morality of aspiration $^{121}$. It is forward-looking, aimed at promoting the well-being of mankind. It implies efforts and restraints from the actor controlling the power that might endanger human rights, namely the state. It is the morality of a refined legal system that seeks to attain predetermined goals.

Having sketched the differing moralities of both the law of treaties and human rights law it becomes clear that attaining the goals of human rights law, within the field of aspirations, will be difficult when the only tool available is one of obligations. The traditional law of treaties is not the best possible tool but unfortunately it is the only available one ${ }^{122}$. As the whole international legal system is geared towards obligations the only possibility of realizing an aspiration (such as the aspiration of universal human rights) is through redressing it as an obligation. Hence the "treatyfication" of human rights law.

120. Fuller, op.cit. at $19-27$.

121. Fuller, op.cit. at 15-19.

122. McNair. The functions and differing legal character of treaties, writes lucidly about the defectiveness of treaties, at 101:".. the only and sadly overworked instrument with which international society is equipped for the purpose of carrying out its multifarious transactions." 
Behind the formal aspect of treaty obligations lie usually materially obligatory elements. That is the actual strength of traités-contrats, not only are they formally obligatory there is also a reciprocal substantive obligation. Call it do ut des or not, it is essentially the reason the system functions. The absence of substantive reciprocity within human rights treaties leaves them without an internal supervisory mechanism ${ }^{123}$.

\title{
3.4. Reciprocity in human rights treaty law
}

What then, has happened to reciprocity in human rights treaties? As described above, substantive reciprocity together with a certain amount of interest on the part of the states involved, seem the best guarantee for monitoring the fulfilment of treaty obligations. Seeing that reciprocity can be of such vital importance in the various stages of a treaty, it is necessary to look at the question of whether there is a reciprocal relationship at the basis of a human rights treaty.

These treaties differ from the "standard" treaty as far as the content and the beneficiaries of the norms are concerned. The question of the reciprocity of human rights treaties has been dealt with in relation to the objective nature of the obligation $^{124}$.

With respect to Genocide Convention, the International Court stated that:

\begin{abstract}
The Convention was manifestly adopted for a purely humanitarian and civilizing purpose. It is indeed difficult to imagine a convention that might have this dual character to a greater degree, since its object on the one hand is to safeguard the very existence of certain human groups and on the other to confirm and endorse the most elementary principles of morality. In such a convention the contracting states do not have an interest of their own; they merely have, one and all, a common interest, namely, the accomplishment of those high purposes which are the raison d'être of the convention. Consequently, in a convention of this type one cannot speak of individual advantages or disadvantages to States, or of the maintenance of a perfect contractual balance between rights and duties ${ }^{n 12 s}$
\end{abstract}

Similarly the European Commission on Human Rights, in the procedure of Austria versus Italy ${ }^{126}$ stated that:

".. the purposes of the High Contracting Parties in cuncluding the Convention was not to concede to each other reciprocal rights and obligations in pursuance of their

123. Fitzmaurice. The law and procedure of the International Court of Justice 1951-1954, at 280 writing ahout the Genocide case: ".the Court was fully aware that the Genocide Convention was of the normative type, and did not operate reciprocally by way of any benefits moving between the parties inter $s c$ on which an objection to a reservation could bite:"

124. See T.Buergenthal, The advisory practice of the Inter-American Human Rights Court (hereafter:Buergenthal. Advisory practice), in: 79 A.IIL 1485. 1-27 at 20-23.

125. ICJ Rep. at 23.

126. Austria v. Italy. Application $788 / 60,4$ European Yearbook on Human Rights 1961, at 138. 
individual national interests but to realize the aims and ideals of the Council of liurope.." "..the obligations undertaken by the High Contracting Parties in the I uropean Convention are essentially of an objective character, being designed rather to prutect the fundamental rights of individual human beings from infringements by any of the lligh Contracting Parties than to create subjective and reciprocal rights for the High Contracting Parties."

In the same vein the American Court in the Effects of Reservations case $1: 7$ emphasized that:

"..modern human rights treaties in general.... are not multilateral treaties of the traditional type concluded to accomplish the reciprocal exchange of rights for the mutual benefit of the contracting States. Their object and purpose is the protection ol the basic rights of individual human beings irrespective of their nationality, both against the State of their nationality and all other contracting States."

The quotations may illustrate that the object of human rights treaties is not the exchange of reciprocal obligations, although these are formally still underlie the treaty, but objective obligations towards the individuals under the jurisdiction of the states parties ${ }^{128}$.

Although they are the beneficiaries of a treaty, civilians are not party to the treaty ${ }^{129}$. The provisions are of an objective nature, suggesting a validity well beyond the bounds of reciprocity. The substantive provisions of the treaty will have to be fulfilled between a state and its subjects, whereas the treaty obligations are between the different states parties. The fact that the actual beneficiaries of the conventions are civilians rather than states, together with the objective nature of the rights might suggest that no exchange of benefits between the ratifying states ever took place. This is incorrect. The most essential benefit is the fact that human rights will be regulated at intemational level. This a benefit to the international community at large, which has also been the aim of the participating states. A human rights treaty is, like any other treaty, the result of negotiations. There are often other benefits involved in negotiating and acceding to a human rights treaty. These will not be retributions in the shape of favourable provisions in an international legal instrument, but may take the form of extra-legal remunerations, such as an improvement of the state's international standing, the proof of being a respected member of the international community.

127. Effects of reservations, OC-2/82, para.29.

128. Dupuy, op.cit. at 551:".le principe de la réciprocité sur lequel se fonde tout le droit international classique, est écarté. On veut créer, par les conventions affirmant les droits de l'homme. un ordre juridique objectif, ou comme dit la Conmission liuropéenne des droits de l'Homme, un ordre juridique communautaire. C'est dire que l'on ne se trouve pas en présence d'un système de nature contractuelle. Un ctat ne peut pas subordonner le respect par lui des droits de l'homme au respect de ceux-ci par sun cocontractant. On ne marchande pas avec les droits de l'homme. Ce n'est pas le "do ut des". "est ordre juridique objectif qui est mis en place; cest une légalité qui est la mème pour tous." Clark, op.cit at 318 , points to major conceptual differences in this respect. 
As described above, formal reciprocity is vital for every treaty's existence ${ }^{130}$. The Vienna Convention lays down formal reciprocity, creating a formal balance between the rights and obligations of the states parties to a treaty. At the same time a substantive balance may be completely absent. As concerns reservations, the Vienna Convention system is equally formalistic. When the reserving state restricts its obligations, the recipient states are equally allowed to do so towards the reserving state. A reservation to a human rights treaty may harm people under the jurisdiction of the reserving state, and will only affect moral rights appertaining to the other states. A reciprocal restriction on obligations on the basis of article 21.1 of the Vienna Convention thus serves no purpose. When one analyzes these aspects of reciprocity, the problem of reservations to human rights treaties becomes clear. Although the acceptance of reservations is dealt with as a matter of formal reciprocity (both in the Vienna Convention and in doctrine), it has a tremendous impact on the substance of the treaty. This fact has never provoked much attention, or action on the part of the States concerned. The absence of directly detrimental consequences of reservations for the other States Parties, enhanced by the tacit acceptance in article 20.5 VCLT, leads to states accepting the reservations.

\section{OTHER HUMAN RIGHTS INSTRUMENTS}

Focus on a number of human rights treaties concluded under the aegis of the United Nations has been a deliberate choice. The reasons for this choice have been explained before. Nevertheless, the experience in dealing with reservations under other human rights treaties, in particular the regional systems, may provide useful background information. The conditions for dealing with reservations are obviously quite different, but there is a great similarity between the substantive rights protected at world level and at regional level. Regional practice may provide useful insights for reducing the impact of reservations at global level. In the following the rules and case-law on reservations to the European Convention and the American Convention will be dealt with briefly. This is not meant to be an exhaustive discussion, but merely an illustration of a relevant practice ${ }^{\mid 3 !}$.

\subsection{European Convention for the Protection of Human Rights and Fundamental Freedoms ${ }^{132}$}

The European Convention for the Protection of Human Rights and Fundamental Freedoms (henceforth:ECHR) is the oldest regional system for human rights protection. It was created under the aegis of the Council of Europe, and the 
rights under the Convention as well as the additional Protocols can in general be classified as civil and political rights. The ECHR's twin, the European Social Charter ${ }^{133}$ contains social and economic rights, and has a incomparable supervision system.

The supervisory system of the European Convention consists of a European Commission of Human Rights ${ }^{134}$ and a European Court of Human Rights ${ }^{135}$. Individual petitions may be received by the Commission, provided that the State Party against whom the complaint is addressed has accepted this competence of the Commission. Under article 24 a state party may begin proceedings against another State Party on allegations of breach of the Convention. The State involved and the Commission may refer a case to the Court.

During the drafting of the European Convention on Human Rights (henceforth: ECHR) the question of reservations was discussed. It was felt to be within the nature of the Convention that reservations would not be allowed without restrictions, and it was also suggested that a qualified majority should accept the reservations formulated ${ }^{136}$. None of these intentions materialized, and article 64 now reads:

"1. Any state may, when signing this Convention or when depositing its instrument of ratification, make a reservation in respect of any particular provision of the Convention to the extent that any law then in force in its territory is not in conformity with the provision. Reservations of a general character shall not be permitted under this Article.

2. Any reservation made under this Article shall contain a brief statement of the law concerned."

On the basis of this provision, the ECHR's reservations system consists of the following rules. Reservations of a general character are prohibited in article 64.1. The obligation to make a specific reservation appears twice in the provision: not only are reservations of a general character prohibited in the second sentence, the article also speaks of a reservation in respect of a particular provision of the Convention in the first sentence. A second requirement is that the reservation is based upon legislation in force in the reserving State the time of ratification, a rule which is also to be found in the first paragraph of the provision. This is reinforced by the second paragraph that indicates that the reservation should be accompanied by a brief statement of the law concemed. The provision prohibits the formulation of general reservations, and at the same time it provides information on the relevant legislation to the Convention's supervisory organs as well as the individuals under the protection of the Covenant ${ }^{137}$.

133. Turin, 18 October 1961; Entry into force 26 February 1965.

134. Articles 19.a, 20-37 ECHR.

135. Article 19.b, 38-56 ECHR.

136. Bourguignon, op.cit. at 356-360; P.van Dijk, G.J.H.van Hoof, De Europese Conventie in Theorie en Praktijk, Nijmegen 1982, at 517-518; Golsong, op.cit. at 30-31; Imbert, HRR, at 43-44; Imbert, Affaire Temeltasch, at 613-615; Kühner, MRK at 70-73; J.M. van der Velde, Voorbehouden ten aanzien van de ECRM, in: 12 NJCM Bull.1987, 353-365, at 356-357.

137. Frowein and Peukert, op.cit. at 490 ; Kühner, MRK, at $80-81$. 
The system laid down in the Convention itself is remarkably formal, it does not focus on the substance of the reservation. In terms of the Vienna Convention it must be understood as a system under article 19.a VCLT, article 64 indicates which reservations are prohibited ${ }^{138}$. It has however also been suggested that in addition to this, the object and purpose rule of article 19.c VCLT would also be applicable $e^{139}$. The application of article 64 is not explicitly regulated by the European Convention, and the question could be raised as to whom the Convention refers in the second sentence of the first paragraph of article 64, where it reads that reservations of a general character shall not be permitted ${ }^{100}$. Two issues need to be raised in this respect. Does article 64 ECHR fall within the scope of the tacit acceptance rule of article 20.5 of the Vienna Convention? If that is the case there would, according to Imbert, not be room for scrutiny by the Convention's supervisory organs at the end of the twelve months period ${ }^{|s|}$. Golsong on the other hand stressed that the VCLT is not equipped to deal with human rights treaties ${ }^{142}$. The authority of the supervisory organs is based upon the nature of the Convention and its intention to create a European ordre public, and the objective obligations following from the Convention. The fact that the Convention provides for supervision re-enforces the importance of a determination by organs within the system, rather than the States ${ }^{133}$.

A further problem in this respect is the uncertainty arising if the supervisory organs could, even after a long period of time, determine that a particular reservation was invalid. This would be a rather haphazard determination depending on the cases brought before the Commission if and when they were submitted. It might lead to reservations heing declared invalid twenty years after being made, which is contrary to the requirement of legal certainty ${ }^{1 / 4}$. However, van Dijk and van Hoof are quite right in stressing that the situation in respect of reservations does not differ from other situations in which a violation of the Convention is established years after its entry into force. Such declarations will only have an ex nunc effect.

Questions about reservations have arisen in the individual complaints procedure. The Commission usually decides on inadmissibility ratione materiae when the violation complained about is covered by a reservation. In such cases a rule is invoked that is not hinding upon a state, which leads to inadmissibility 14.5 . If however the scope of the reservation is unclear, and in cases in which an

138. Bourguignon, op.cit. at 355 .

139. Van Dijk/van Hoof, op.cit. at 518; Kühner, MRK, at \$2-\$7.

140. Golsong, op.cit. at 31 .

141. Imbert. HRR at 44; Imbert. Affaire Temeltasch, at 616.

142. Ciolsong. op.cit. at $37-41$.

143. Frowein and Peukert, op.cit. at 400491: Golsong. op.cit. at 33-34.

141. Van Dijk and van Hoof, op.cit. at 523: Frowein and Peukert, op.cit. at 491; Golsong op.cit. at 34-35; Imbert, Aftaire Temellasch, at 616-617.

145. Frowein and Peukert, op.cit. at $491-492$. 
interpretative declaration is invoked, the matter will be usually be declared admissible and decided on the merits.

In order to implement the Convention, and the reservations made thereto, interpretation is necessary. The initial practice with respect to the reservations has been remarkable liberal ${ }^{146}$. There are a great number of examples in which the Commission interpreted the State's intention in such a way as to construct a situation in which a state validly relied upon a reservation. This at times meant ignoring the fact that a reservation did not refer to a specific provision, or did not indicate the relevant legislation ${ }^{147}$. In other cases new legislation was understood to be under the scope of prior reservations, whereas the gist of this rule seems to be that "new" legislation cannot be safeguarded by "old" reservations.

However wisely article 64 was applied by the European Commission on Human Rights in the past, the nineteen eighties brought a dramatic change in the way in which reservations were dealt with. This change of season was heralded in a decision on admissibility where the Commission stated that it had "now come to the opinion that, in view of the various questions which may be raised by the scope of a reservation and its compatibility with Article 64 of the Convention, its previous decisions on this matter could be usefully reconsidered. ${ }^{148}$.

In the following a number of recent cases will be discussed in greater detail, especially so because of their relevance for the subject of reservations to human rights treaties in general. A number of preliminary remarks may be useful for the understanding of these cases. On ratification of the European Convention in 1974, Switzerland had made two interpretative declarations, both leading to important case law on reservations and interpretative declarations to the European Convention, with an importance possibly extending beyond the scope of the ECHR itself.

Switzerland ratified in 1974, which is twenty-four years after the ECHR was opened for ratification and twenty-one years after it entered into force. Consequently it had had the opportunity to reflect on the dynamics of the European convention's system, including the fact that whereas States often favoured a restrictive interpretation of a provision, the supervisory organs might use an extensive interpretation ${ }^{149}$.

The fact that Switzerland is a federal state in which the cantons have a high degree of autonomy also played a role in the formulation of reservations and declarations. It was clear that Switzerland did not want to change parts of its domestic legislation that were within the autonomy of the cantons, as a consequence of the ratification.

146. Bourguignon, op.cit. at 360; Frowein, Reservations at 196; Kühner, MRK, at 73-74.

147. Van Dijk, Van Hoof, op.cit. at 519-520.

148. X.v.Austria, case 8180/78, 10 May 1979; D\&R 20 (1980), 23-28, at 27-28

About this decision: Imbert, HRR, note 98 at 59; Shelton, op.cit. at 232.

149. B.Wagner, L.Wildhaber, Der Fall Temeltasch und die auslegenden Erklärungen der Schweiz, in:10 EuGRZ 1983, 145-149 at 145. 


\subsubsection{The Temeltasch case (Commission) ${ }^{150}$}

Switzerland had made an interpretative declaration with respect to article 6.3.c and e, dealing with the right to free legal aid and the right to free assistance of an interpreter. The interpretative declaration was made because in a number of cantons, as well as under federal penal law, the costs of interpretation could be included in the legal fees, even in the case of acquittal. Free assistance of an interpretor was a temporary right during the procedure. The issue of interpretation costs had been regulated in a different manner in the multilingual legal system of Switzerland. Freedom to use one's own language is restricted by the rules on the official language of the canton. When the declaration was made in 1974 there was no intention to change the system of compensation for interpretation fees ${ }^{151}$. Since then, a similar German rule on translation fees had been determined not to be "free" as required in article 6.3 .d by the European Court of Human Rights in the case of Luedicke, Belkacem and Koç in $1978^{152}$.

Temeltasch, a Dutch national, had been apprehended on charges of carrying drugs. In the ensuing procedure he was acquitted, but had to pay legal fees related to the interpretation. He invoked the rule in article 6.3.e ECHR, as interpreted by the Court in the Luedicke case, but the Swiss Federal Court pointed at the interpretative declaration made by Switzerland ${ }^{153}$. The question before the Commission on Human Rights is thus whether the Swiss declaration can be invoked in this case, and in particular if it is a valid reservation under article 64 of the Convention.

First of all the Commission established its authority to interpret the declaration, which is based on the specific nature of the European Convention ${ }^{154}$, as well as on the existence of supervisory organs with the specific task of overseeing the implementation of the Convention. In its determination that the declaration was a reservation the Commission used article 2.1.d VCLT, given the fact that the ECHR itself did not contain a definition of reservations. In order to establish the intention of the author state, the Commission studied the discussions in the Swiss Parliament to come to the conclusion that the intention had been to exclude the applicability of a wider interpretation of the provision (such as would be given by the Court in the Luedicke case a few years after the Swiss ratification). More-

150. Temeltasch v. Switzerland, case 9116/80, 5 May 1982; D\&R 31 (1983) at 120-153.

151. Ignoring article 64.2 ECHR had been a deliberate choice, based on domestic political considerations. On the backgrounds of the interpretative declaration to article 6.3.e see:Imbert. Affaire Temeltasch, at 591-593; Kühner, MRK, at 67-69; Van der Velde, Zwitserse interpretative verklaring en artikel 64 EVRM at 481; Wagner/Wildhaber, op.cit. at 146-147.

152. 28 November 1978, ECHR, Ser.A, vol.29 (1978), at 20.

153. The declaration reads:"Le conseil fédéral suisse déclare interpréter la garantie de la gratuité de l'asssistance d'un avocat d'office et d'un interprète figurant à l'article 6 , para. 3 lettres $c$ et $e$, de la convention comme ne libérant pas définitivement le bénéficiare du paiement des frais qui en résultent."

154. Para.62-65. 
over, it is noticed that at the time, no authoritative interpretation of the provision existed, had this been the case a formal reservation would have been made ${ }^{155}$.

Having established that the Swiss interpretative declaration should be understood to be a reservation, the Commission briefly deals with the prohibition of a general reservation, which is not at stake in the case itself $f^{156}$. The rule is interpreted to prohibit either a reservation not indicating which provision of the Convention it is aiming at, or in general a reservation of which the scope is unclear $^{157}$.

The second rule in article 64 ECHR, the obligation to provide a brief statement of the legislation concerned, had not been fulfilled by Switzerland, which claimed that its federal structure and the variety of legal rules applicable in the cantons made it impossible to fulfil this obligation ${ }^{158}$. With respect to the absence of information on the relevant legislation, the Commission concluded that the absence of such information in itself would not nullify the reservation, but that the impact of this omission depended on the scope and clarity of the provision the reservation referred to. Consequently, as the rule in article 6.3.e is a clear rule, with a well determined scope, the absence of information on the relevant Swiss legislation in this particular case did not lead to the invalidity of the reservation 159. The interpretative declaration was considered to be a valid reservation, in spite of the non-fulfilment of the obligations under article 64.2 by Switzerland.

The Temeltasch case established the Commission's authority to deal with reservations and interpretative declarations, on the basis of the essential characteristics of the European Convention ${ }^{160}$. Using the definition of article 2.1.d VCLT in order to determine whether the declaration is a reservation seems a practical solution. However, the extensive use of Swiss sources on the nature of the declaration must be criticized ${ }^{161}$.

155. Para.74-82.

156. Para.84.

157. Frowein. Peukert, MRK Kommentar at 489-490; R.Kühner, Die "auslegende Erklärung" der Schweiz zu Art.6 Abs.3 lit.e der Europäischen Menschenrechiskonvention (hereafter: Kühner, Auslegende Erklärung), in: 43 ZAöRV 1983, 829-833 at 832.

158. Wagner/Wildhaber, op.cit. at 149; para.85 Teneltasch case.

159. Para.88-9l.

160. The extensive arguments by Imbert against the authority of the Commission to deal with the validity of the interpretative declaration as a reservation will not be dealt with here. See Imbert, Affaire Temeltasch, at 613-621.

Cf.Kühner, Auslegende Erklärung, at 829.

161. We shall not discuss the issue of referring to debates in a national parliament in order to establish the intentions behind an interpretative declaration. Though this may be possible with the framework of the European Convention, it must be doubted whether this would be a realistic line of action for supervisory organs at world level. Apart from the question whether the reasons for formulating an interpretative declaration are to be considered an internal affair of a state, and the likelihood of translation problems restricting the use of parliamentary records, the point may be raised that the "however phrased or named" formula in article 2.1.d VCLT should be interpreted in accordance with article 31 VCLT. 
It has been stressed by Imbert that the "however phrased or named" formula has been written for cases of doubt. He questions whether there could be any doubt in this case, as Switzerland had made two reservations and two interpretative declarations, thereby clearly expressing itself on the intended legal effect ${ }^{162}$. Indeed, one can agree with Imbert that the Commission ought to have attached greater weight to the distinction made by Switzerland itself.

Furthermore, in dealing with Temeltasch' interpretation fees, the Commission used the opportunity to clarify its understanding of the prohibition on general reservation, even if the case did not call for such points of view. The legal effect of the absence of statements on the legislation falling within the scope of the reservation, depends on the scope of the provision that the reservation aims at. This would seem to be a rule that is more lenient than the actual wording of article 64.2 ECHR, and it might be understood as a concession towards the understandable problems of federal states in gathering such information. However, the suggestion that the Commission's point of view turns article 64.2 into a mere formal requirement must be contradicted ${ }^{163}$, as would be emphasized in the Belilos case.

Ultimately the Swiss declaration leads to a peculiar situation. An interpretative declaration as such does not have to fulfil the criteria of article 64, that is the prohibition of general reservations and the obligation to provide a statement of the law concerned. But then, in the Temeltasch case the interpretative declaration was considered to be a reservation under article 2.1.d VCLT, as a consequence of developments in the case law on a provision the declaration dealt with, which in turn puts the whole declaration under the scope of article 64 ECHR including its formal requirements.

This would hypothetically prompt cautious States to make interpretative declarations that fulfil the requirements of article 64 . But by then, the distinctions between declarations and reservations would have become completely blurred.

\subsubsection{The Belilos case (Commission) ${ }^{164}$}

An interpretative declaration had also been made by Switzerland to article 6.1 ECHR dealing with the right to a fair and public hearing on the determination of civil rights and obligations or on criminal charges, within a reasonable time by an

162. Imbert, Affaire Temeltasch, at 594 writes:"Mais les mots ["however phrased or named" in article 2.1.d, EL] que nous avons soulignés ont été introduits pour couvrir le cas de déclarations ambiguës; ils n'ont jamais signifié qu'un Etat pouvait, à tout moment, revenir sur la qualification expresse d'une de ses déclarations ni qu'il soit toujours légitime de répondre à une telle demande..... Dans la présente affaire, on a en fait permis à un Etat de transformer une déclaration interprétative en réserve".

163. Wagner/Wildhaber, op.cit. at 149.

164. Belilos v. Switzerland, Case 10328/83; 8 July 1985; D\&R 44 (1985). 
independent and impartial tribunal established by law ${ }^{165}$. The Swiss legal system does not contain a general guarantee of access to a remedy before an impartial and independent tribunal, and in a number of cases matters involving civil rights or criminal charges would first be dealt with by an administrative authority. There would be a final appeal before a judicial tribunal, but part of the procedure might take place before administrative authorities. Moreover the cantons were the legislative authorities responsible for these procedures, rather than the federal government ${ }^{166}$.

Prior to the Swiss ratification the European Court of Human Rights had given a wider interpretation to the notion "civil rights and obligations" in article 6.1 ECHR in the Ringeisen case ${ }^{167}$, than Switzerland intended to accept, relying on the interpretation of the provision given by Fawcett on behalf of the Commission before the Court in the Ringeisen case. According to Switzerland two interpretations of the provision were possible, and as there was no intention to adhere to a wider interpretation, a restrictive interpretative declaration was made.

The case concerned Mrs Belilos, a Swiss national, who took part in an unauthorized demonstration in Lausanne, and was convicted and fined by the Police Board, which is an administrative authority. Determinations on questions of fact could not be reviewed in appeal by a judicial authority. She claimed that the procedure before the Police Board violated her right to a fair trial under article 6.1 ECHR as the Police Board was not an impartial body, and because she could not appeal on the determination of facts.

The question before the Commission was thus whether Switzerland could rely on the interpretative declaration it had made in respect of article 6.1 ECHR as a reservation. Since the Temeltasch case there was no doubt that the Commission had authority to deal with the interpretation of the Swiss declaration.

Again the Commission used a twofold test. First the question as to whether the declaration is a reservation is addressed. At the time of ratification Switzerland had made two reservations and two interpretative declarations. Most remarkably, this combination of statements is taken by the Commission to be proof of the intention not to make a reservation. It forcefully argues: "IIff a state makes reservations and interpretative declarations at the same time, an interpretative declaration will only exceptionally be able to be equated with a reservation. ${ }^{n 168}$. Consequently, by distinguishing, Switzerland itself indicated that the interpretative declarations were not to have the legal effects of reservations.

165. The declaration reads:" The Swiss Federal Council considers that the guarantee of fair trial in article 6, paragraph 1 of the Convention, in the determination of civil rights and obligations or any criminal charge against the person in question is intended solely to ensure ultimate control by the judiciary over the acts or decisions of the public authorities relating to such rights or obligations or the determination of such a charge."

166. Wagner, Wildhaber, op.cit. at 145-146.

167. Judgement 16 July 1971, Ser.A no.13.

168. Report Belilos, para.102; apparently echoing Imbert's opinion quoted in note 162 supra. 
This could have concluded the matter, but the Commission then set out to review the declaration as though it were a reservation, and holds it to the test of article 64 ECHR. Here the Swiss declaration fails on both criteria. First of all, it does not fulfil the requirement in article 64.1 of not being a general reservation. The declaration is formulated too broadly, in particular the terms "ultimate control by the judiciary" leave a lot of uncertainty about the scope ${ }^{169}$. Moreover the declaration did not contain a statement of the law concerned as required by article $64.2^{170}$. Consequently the declaration as a reservation would not be a valid reservation under article 64 of the Convention. This determination reinforces the Commission's earlier view that the declaration was not a reservation on the basis of the distinguishing principle ${ }^{171}$. In the absence of a reservation the Commission is of the opinion that Switzerland violated article 6.1 ECHR.

The theory of distinguishing, as proposed by the European Commission has, surprisingly, not received much acclaim. This is probably due to the fact that it was not upheld by the Court in its decision in the Belilos case.

The fact that the author State itself deliberately chose to distinguish and the legal effects of such a choice have, to my mind, not received enough attention. The argument of the Commission is based on the ipse dixit rule, or otherwise on the expressio unius rule. Under the former one is bound by one's own words, whereas under the latter expressing the one means excluding the other. Both are maxims of the Law of Treaties that underscore the Commission's decision ${ }^{172}$. Additional arguments are the fact that the rule in article 2.1.d, as recalled by Imbert, was meant to provide solutions in cases of doubt which supposedly did not exist in the present case ${ }^{173}$.

It has been said that applying the rule of distinguishing to declarations and other statements made in respect of the ECHR would lead to uncertainty ${ }^{174}$. The ipse dixit argument used by the Commission is rebutted by the fact that States have political reasons for not being explicit about the intentions underlying their declarations. This may be the case, but this line of reasoning would seem to be extremely permissive towards the author states. Political reasons for the nomenclature of a declaration are necessarily within the responsibility of the author

169. Para.108-111.

170. Para.112-118; this appears to be a striking difference with the decision in the Temeltasch case, where the absence of a statement of the relevant law was excused, because of the clear scope of the obligation. I understand the difference to lie in the wide field of application of article 6.1 as opposed to article 6.3.c.

171. Para.118-119.

172. Cf.article 31.1 VCLT.

173. Imbert, Affaire Temeltasch, at 594:"La question peut etre posée de savoir si, dans un cas semblable, il convenait de rechercher, apres coup, qu'elle avait pû etre la véritable intention de l'Etat."; and similarly about article 2.1.d VCLT Sinclair, op.cit. at 54:[1]t seems that the declaring State's own characterization of its statement as a "declaration" rather than a "reservation" should be accepted."

174. R.St.J.Macdonald, Reservations under the European Convention of Human Rights, in:21 RBDI 1988, 429-450, at 439. 
state, and the question is whether this is so at the expense of certainty, that, as indicated by the Commission is an important motive for the ECHR's rules on reservations.

And more interesting, as the rule of distinguishing, used by the Commission in the Belilos case, has solid roots in general international law, its applicability may very well extend beyond the scope of the European Convention. It is contended that this rule will in particular be a useful rule to deal with reservations and interpretative declarations to other human rights instruments.

\subsubsection{The Belilos case (Court) ${ }^{175}$}

The Belilos case was then brought before the Court, both by the Commission and by Switzerland. It was the first case in which the Court pronounced on the validity of a reservation.

The Court established its authority to deal with the Swiss declaration on the basis of articles 45,49 and 19 ECHR, in a rather brief paragraph ${ }^{176}$. Switzerland never raised the issue of competence as a preliminary objection and the Court merely indicates that it is competent ${ }^{177}$.

An explicit determination of the nature of the statement does not take place, and the Court proceeds to deal with the criteria in article 64 ECHR straight away. This is a remarkable procedure if compared to the Commission's twofold approach of first determining whether the declaration is a reservation, and after that whether the reservation is valid under articles 64 ECHR. The fact that the Court discusses the intention of the author State is of great importance (thereby echoing article 2.1.d VCLT), but then sets out to discuss the declaration as though it were a reservation.

With respect to article 64.1 , it is indicated that a general reservation means a reservation couched in terms too vague or broad for it to be possible to determine their exact meaning and scope", which is an objective determination on the basis of the text of the reservation. The Swiss declaration did not fulfil this criterion $^{178}$.

Switzerland had not fulfilled the obligation under article 64.2 ECHR of providing a statement of the relevant law either, and was literally reprimanded by the Court. This requirement is both an evidential factor and contributes to legal certainty, the provision is a condition of substance for reservations. Practical difficulties, such as the cantonal legislation in Switzerland, cannot justify ignoring this requirement ${ }^{179}$.

This leads to the conclusion that the Swiss interpretative declaration concerning article 6.1 ECHR failed to meet the requirements of article 64 ECHR, and was

175. Belilos case, 29 april 1988; ECHR Ser.A, Vol.132.

176. Para.50.

177. Bourguignon, op.cit. at 365-371; Macdonald, op.cit. at 442-443; van der Velde, Zwitserse verklaring at 478 .

178. Par.55.

179. Par.59. 
therefore an invalid reservation. It was added that this invalidity did not touch upon the fact that Switzerland was bound by the Convention ${ }^{180}$.

The importance of the judgement in the Belilos case is that the Court quite clearly indicates that it is competent to deal with the validity of reservations, thereby excluding them from the exclusive authority of other States parties during the twelve months period prescribed by article 20.5 VCLT. This concluded a rather lengthy academic discussion on the question whether the Court had any authority in this respect or whether the whole matter depended on the way in which the states parties reacted to reservations, as had been argued forcefully by Imbert.

The way in which the Court treats the reservation is not persuasive. One fails to see why it was impossible to state the legal effect of the statement at the very beginning, it would appear that Switzerland made a lot of effort to emphasize its intention of making a reservation, or a qualified interpretative declaration falling within the scope of article 2.1.d VCLT. In fact it is peculiar that Switzerland, relying as it did on a minority opinion in the Commission on the Ringeisen case prior to its ratification, did not foresee the problems ${ }^{181}$.

For no apparent reason the Court did not follow the Commission's line of distinguishing, and following the distinction made by the author State itself. This is to be regretted as distinguishing would provide a useful approach to cases in which a State has made both reservations and interpretative declarations. The Court's judgement confines the issue of the Swiss declaration to the ECHRsystem, thereby restricting its rule to that system.

A final point to be made deals with the theory of severance in relation to the invalidity of reservations. In case a reservation is considered invalid, it has to be considered what the legal effects will be. If the acceptance of the reservation was an imperative condition for the consent to be bound of the author state, it would be logical that the invalidity of the reservation also invalidates the consent to be bound. It may be assumed that in such cases, states do take the precaution of formulating reservations rather than empty statements ${ }^{182}$. If on the other hand the interests in the reservation are minor, compared to the interests of being a State Party, the invalid reservation will merely be struck off the list and the obligations of the author state will increase accordingly. This latter solution was chosen by the Court in saying that there is an overall willingness on the part of Switzerland to be bound by the treaty. However, stating that the declaration is an invalid reservation does in itself not change the legal situation in Switzerland,

180. Par.60.

181. Could not the fact that Switzerland relied upon a minority opinion in the Commission, as expressed by Fawcett, that was not subsequently carried by the Court, be considered a fachum proprium that it cannot rely upon in order to turn its interpretative declaration in to a reservation?

182. Bourguignon, op.cit. at 382. 
where cantonal legislation will have to be brought up to Convention standards ${ }^{183}$.

The ECHR practice has proved that the role of supervisory organs can be of great importance with respect to reservations. On the other hand article 64 ECHR is not a perfect rule. In particular the second criterion, relating to any law in force, may lead to an undesirable situation in the long run. The provision lacks a mechanism for the reservations to be withdrawn, it appears to be static. After all it would seem to be reasonable for the reserving State to eventually change its legislation in order to be able to withdraw the reservation. There is no impetus to do so, under article 64, which is reinforced by the absence of a system of periodical reporting to a supervisory body. There are no ways of suggesting the withdrawal of an outdated reservation referring to a law that could easily have been changed since the ratification. States Parties might suggest withdrawal to other States Parties, but that could hardly be called a system.

\subsection{American Convention on Human Rights}

The American Convention on Human Rights was concluded under the aegis of the Organisation of American States ${ }^{184}$. The ACHR covers by and large civil and political rights, an additional Protocol covering social, economic and cultural rights was adopted in $1988^{185}$.

Reservations to the ACHR are subject to the rules laid down in the Vienna Convention ${ }^{186}$, in accordance with article 75 , which reads:

"This convention shall be subject to reservations only in conformity with the provisions of the Vienna Convention on the Law of Treaties signed on May 23, 1969."

The supervisory organs are the Inter-American Commission on Human Rights ${ }^{187}$ and the Inter-American Court on Human Rights ${ }^{188}$. The supervisory system consists of individual petitions (article $44 \mathrm{ACHR}$ ) and if the competence of the Commission is recognized, so are inter-state complaints (article 45). If these procedures do not lead to a satisfactory solution, a State or the InterAmerican Commission can bring the case before the Court (article 61 ACHR). One of the striking advantages of the ACHR's practice is the possibility of Advisory Opinions, which has greatly contributed to shaping the doctrine on reservations to human rights treaties. The Advisory authority makes it possible to put legal questions before a body with considerable authority. The Inter-American

183. See supra Chapter 2, par.5 The issue of interpretative declarations.

184. San José, 22 November 1969; entry into force 18 July 1978.

185. San Salvador, 17 November 1988, the protocol has not yet entered into force.

186. The ACHR and the VCLT are contemporaries, which leads Golsong to the conclusion that article 75 ACHR was drafted in the euphoria of the Vienna Convention. Golsong, op.cit. at 31-32.

187. Articles $34-40$ ACHR.

188. Articles 52-60 ACHR. 
Court has the authority give Advisory Opinions on the interpretation of the ACHR or other human rights instruments (article 64.1), as well as Advisory Opinions on the compatibility of domestic law with these instruments (article $64.2)^{189}$.

\subsubsection{The Effect of Reservations case ${ }^{190}$}

The second Advisory Opinion given by the Inter-American Court, at the request of the Commission, deals with the question of what point in time that a State becomes a party to a treaty when it has made a reservation.

After dealing with some preliminary issues, such as the fact that the request covers the interpretation of articles 74 and 75 of the Convention, and the fact that these issues had traditionally been dealt with by the depository and the individual States, the Court declares itself to be competent on the basis of article 64 jo. 33.b ACHR. The Inter-American Commission is competent to ask for the Opinion, based on its legitimate institutional interest to know whether or not a State is a member to the ACHR ${ }^{191}$.

In answering the question before it, the Court indicates that the reference in article 75 ACHR to the Vienna Convention, means a reference to article 19.c $\mathrm{VCLT}^{192}$. It is recalled that the drafting States intended to create a flexible system on reservations ${ }^{193}$. Then the Court turns its attention to the applicable rule in article 20 VCLT, which is dealt with by way of deduction. Article 20.2 is not applicable because the ACHR is not about the exchange of reciprocal rights, nor is article 20.3 applicable. The Court indicates that article 20.4 VCLT is equally reflecting traditional multilateral and reciprocal agreements. It then recalls the nature of human rights instruments and their goal of creating a legal order for the common good, thereby quoting from the case of Austria v. Italy under the $\mathrm{ECHR}^{194}$, the Genocide case, the preamble of the ACHR, and stressing the relevance of the right of individual complaint. The conclusion is that it would be manifestly unreasonable to apply article 20.4 VCLT, which would postpone entry into force of the ACHR until its acceptance by another State Party ${ }^{195}$. Thus article 20.1 is applicable, while it speaks of "expressly authorized reservations" this is not limited to specific reservations. Reservations compatible with the object and purpose of the convention (article 19.c VCLT) are expressly authorized $^{196}$, and while states Parties may have a legitimate interest in barring incompatible reservations this is not the case with compatible reservations.

189. See about article 64 ACHR: Buergenthal, Advisory Practice at 3-15.

190. Advisory Opinion 4 September 1982, OC-2/82; also published in 3 HRLJ 1982, 153-165.

191. Par.14-16.

192. Par.22.

193. Par.23-25.

194. Case $788 / 60$, Yearbook IV (1961).

195. Par.34.

196. Par.36-37. 
As indicated earlier, there is room for some doubt as to the adequacy of applying article 20.1 in relation to article 19. VCLT $^{197}$, but the solution presented by the Court is by all means adequate for a human rights instrument.

\subsubsection{Restrictions to the Death Penalty case ${ }^{198}$}

While the previous case dealt with a purely formal aspect of the law on reservations, this Advisory Opinion dealt with substantive issues, namely a reservation to article 4.4 (prohibition of capital punishment for political offenses or related common crimes) which is a non-derogable right under article 27.2 of the Convention. The request for an Advisory Opinion was based upon a difference of opinion between the Inter-American Commission and Guatemala, the reserving State. In particular the Commission raised two issues. Firstly, it did not consider the extension of the categories of crimes for which the death penalty could be imposed legitimate, invoking article 4.2 ACHR. This issue will not be dealt with in the following. The second point of contention was the fact that Guatemala had made a reservation to article $4.4^{199}$, and had subsequently increased the number of cases for which the death penalty could be applied.

Guatemala contended that it had not accepted the authority of the Court, as the necessary declaration under article 62 ACHR had never been made, which lead to a complicated procedural dispute on the admissibility of the request for an Advisory Opinion, as well as on the question how to establish whether the request was admissible or not. However, the Court finds that the absence of a recognition of jurisdiction is irrelevant in respect of Advisory Opinions, and the Court only has to establish that the author of the request is entitled to submit such a request ${ }^{200}$.

In order to answer the questions about article $4 \mathrm{ACHR}$ it is necessary to interpret the provision, in accordance with the Vienna Convention. The Court states that in respect of human rights treaties objective interpretative criteria are more appropriate then subjective criteria relying on the intent of the Parties ${ }^{201}$. This, together with articles 29 and 30 ACHR, leads to the conclusion that the purpose of article $4 \mathrm{ACHR}$ is the strict limitation of the death penalty. Consequently,

197. See about the law of treaties perspective Chapter 2, par.3.2.4 supra.

198. Restrictions to the Death Penalty (arts.4(2) and 4(4) American Convention on Human Rights), OC-3/83, 8 September 1983.

199. The Guatemalan reservation reads:"The Government of the Republic of Guatemala, ratifies the American Convention on Human Right, signed in San José, Costa Rica, on the 22nd of November 1968, making a reservation with regard to Article 4, paragraph 4 of the same, inasmuch as the Constitution of the Republic of Guatemala, in its article 54 , only excludes from the application of the death penalty, political crimes but not common crimes related to political crimes."

200. Par.21-25.

201. Par.50 (p.77) reads:"In the case of human rights treaties, ... . objective criteria of interpretation that look to the texts themselves are more appropriate than subjective criteria that seek to ascertain only the intent of the Parties". 
article 4.2 contains an absolute prohibition on applying the death penalty for crimes that were not previously punishable with life ${ }^{202}$.

Turning to the question about the reservation to article 4.4, the Court refers to its earlier Opinion on the Effect of Reservations, and turns to the question of whether the reservation is compatible with the object and purpose of the treaty. This determination is directly related to article 27 ACHR, dealing with nonderogable rights, the Opinion reads:

"Article 27 of the Convention allows the States Parties to suspend, in time of war, public danger, or other emergency that threatens their independence or security, the obligations they assume by ratifying the Convention, provided that in doing so they do not suspend or derogate from certain basic rights, among them the right to life guaranteed by Article 4 . It would follow therefrom that a reservation which was designed to enable a State to suspend any of the non-derogable fundamental rights must be deemed to be incompatible with the object and purpose of the Convention and, consequently, not permitted by it. The situation would be different if the reservation merely sought to restrict certain aspects of a non-derogable right without depriving the right as a whole of its basic purpose. Since the reservation referred to by the Commission in its submission does not appear to be of a type that is designed to deny the right to life as such, the Court concludes that to that extent it can be considered, in principle, as not being incompatible with the object and purpose of the Convention. ${ }^{\text {2203 }}$

The issue of non-derogability as an indication of the object and purpose of a treaty is dealt with by the Court in a rather ambivalent manner. The initial impression is non-derogable must mean incompatible, yet in the very next sentence the far-reaching scope of this statement is restricted by the emphasis put on the restriction of certain aspect of the non-derogable right ${ }^{\text {pnd }}$. The Opinion is indecisive which is rather unfortunate. In fact the Opinion is contradictory, which might be attributed to the fact that the Court may not have perceived the contradiction in its own Opinion.

The Court then goes on to stress that reservations should be interpreted in accordance with the Vienna Convention, and then deals specifically with the Guatemalan reservation. The relevant rules of articles 4.2 and 4.4 have clearly a different meaning, article 4.2 prohibits the extension of capital punishment, whereas article 4.4 prohibits capital punishment for political and related common crimes. Read together, both provisions merely guarantee the continued application of the death penalty to erimes other than pcitical and related common crimes. The Court firmly states that a reservation to one provision does not also cover another provision that is not mentioned in the reservation. The reservation

202. Par.59.

203. Par.61.

204. In particular the following part of par.61 of the Advisory Opinion:"It would follow therefrom that a reservation which was designed to cnable a Stac to suspend any of the non-derogable fundamental rights must be decmed to be incompatible with the object and purpose of the Convention and, consequently, not permitted by it. The situation would be different if the resenation merely sought to restrict certain aspects of a non-derogable right without depriving the right as a whole of its basic purpose." 
relates to article 4.4, and this excludes the possible modification or restriction of article $4.2 \mathrm{ACHR}^{205}$. Guatemala failed to manifest its rejection of article 4.2 in order achieve its goals.

The application of the VCLT is an obligation for the Court, and it has come to some remarkable solutions. The Inter-American Court has used its advisory jurisdiction with great agility, in particular in distinguishing between the VCLT rules relevant for reciprocal treaties, and the rules necessary for human rights instruments.

This Opinion stresses the need for a restrictive interpretation of reservations, based upon objective criteria related to the nature of human rights law. Though the Court initially stressed the relevance of article 4 being a non-derogable right, this element does not play an important role towards the end of the Opinion. Moreover the latter part of par.61 would seem to qualify the initial strong stance on non-derogability by qualifying the prohibition, referring to restrictive rather than exclusive reservations ${ }^{206}$. 
In

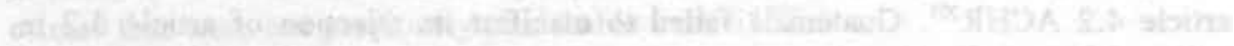

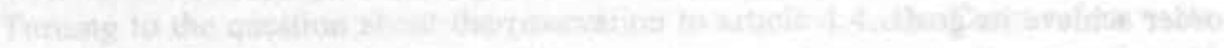

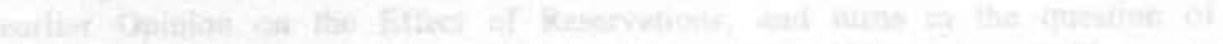

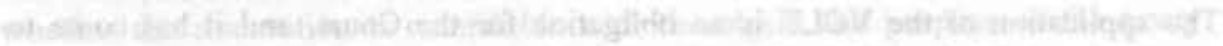

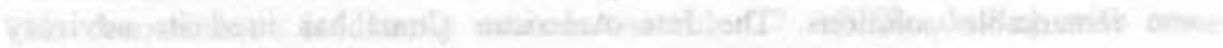

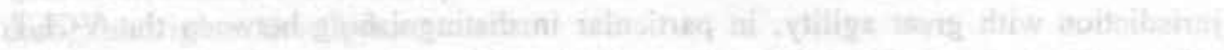

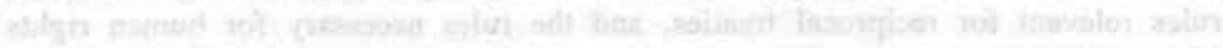

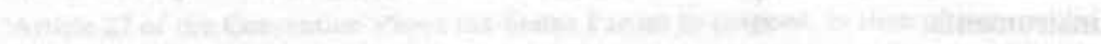

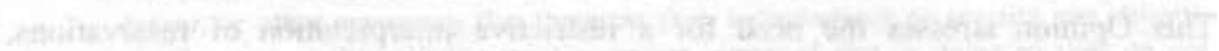

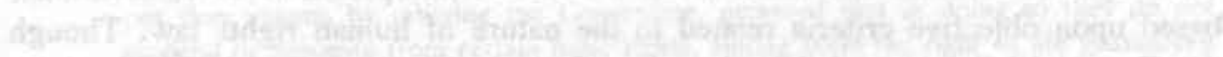

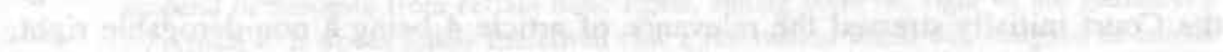

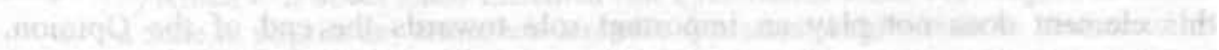

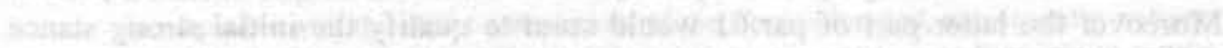

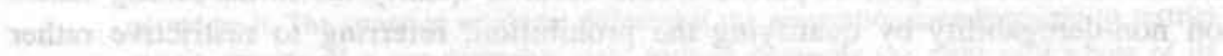

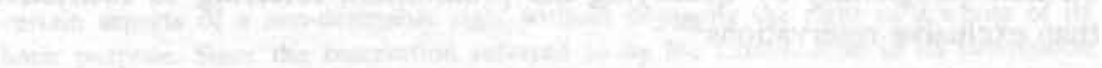

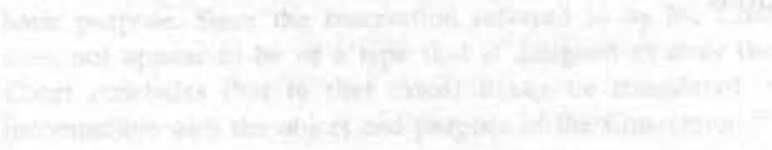

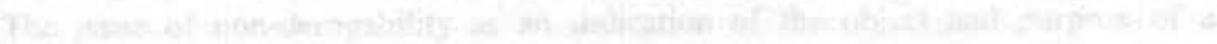

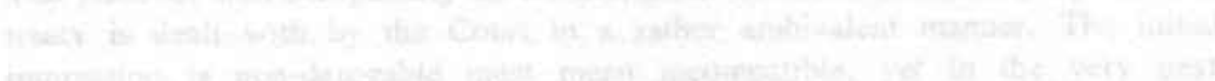

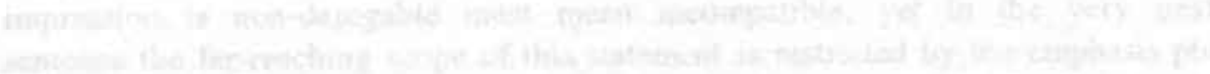

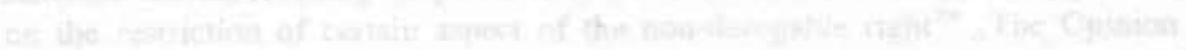

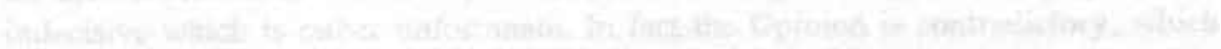

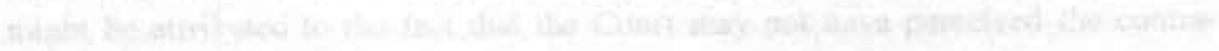

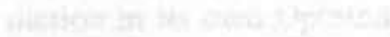

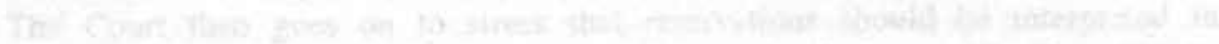

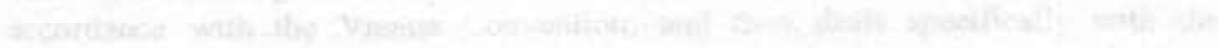

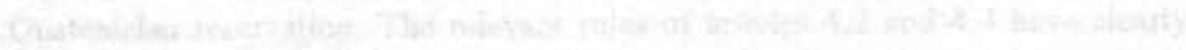

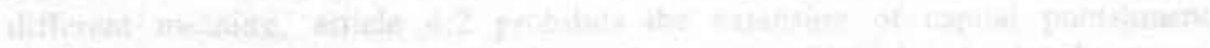

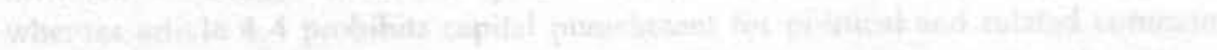

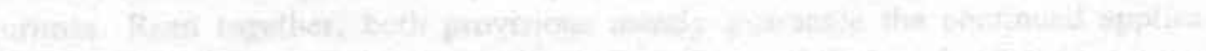

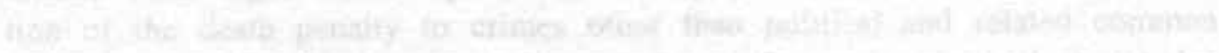

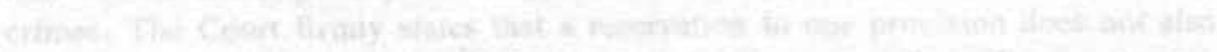

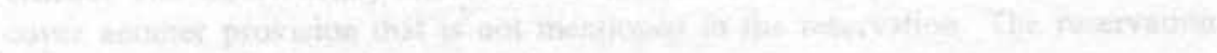

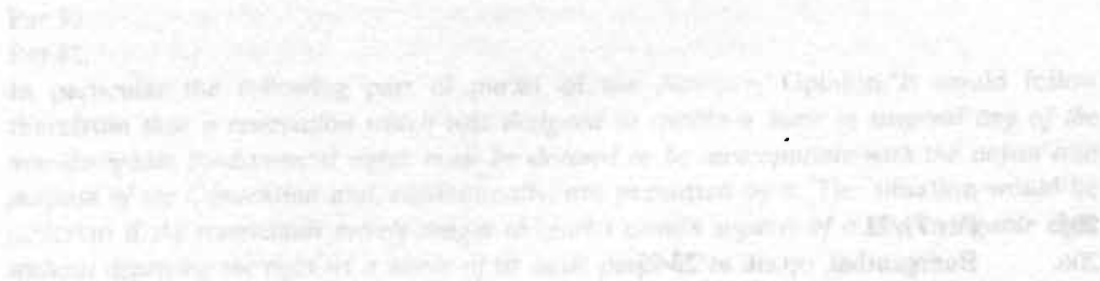


PART III

RESERVATIONS IN PRACTICE 


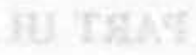

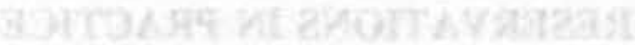




\section{RESERVATIONS TO THE INTERNATIONAL CONVENTION ON THE ELIMINATION OF ALL FORMS OF RACIAL DISCRIMINA- TION}

\section{INTRODUCTION TO THE CONVENTION}

\subsection{Content of the Convention ${ }^{1}$}

The International Convention on the Elimination of All Forms of Racial Discrimination (hereafter:CERD) consists of three parts, dealing with substantive law, the supervisory mechanism and the final clauses.

The first part lays down substantive rules. In article I racial discrimination is defined as "any distinction, exclusion, restriction or preference based on race, colour, descent, or national or ethnic origin which has the purpose or effect of nullifying or impairing the recognition, enjoyment or exercise, on an equal footing of human rights and fundamental freedoms in the political, economic, social, cultural or any other field of public life". Sections 2 and 3 indicate that distinctions in the sphere of citizenship and nationality are allowed, provided that they are not discriminatory. Section 4 deals with affirmative action, which is permitted, but should be abolished once the objectives of such a policy have been attained.

Article 2 contains the condemnation of racial discrimination, and lists a number of duties the States Parties undertake in the field of governmental activities, and within society at large. Article 3 condemns segregation and apartheid, whereas the following article specifically deals with racist propaganda, and racist organizations. The right of equality before the law is laid down in article 5 which also contains a list of the rights which ought to be guaranteed: civil and political rights as well as economic, social and cultural rights. As a complement to this provision, article 6 provides for effective protection within the domestic legal system. In article 7 , States Parties set themselves the task of combatting prejudices.

The second part of the Convention deals with the supervisory mechanism ${ }^{2}$; to

1. UNTS 660, 195; GA Res. 2106A (XX). 21 December 1965. See for the history of the Convention:N.Lerner. The U.N. Convention on the Elimination of all Forms of Racial Discrimination, Alphen aan den Rijn, 1980, at 1-6: Th. Meron. Human Rights Lawmaking in the United Nations, Oxford 1986 at 7-9; W.M.Reisman. Responses to Crimes of Discrimination and Genocide: An Appraisal of the Convention on the Elimination of Racial Discrimination: in:1 Denver JILP. 1971. 29-14 at 43-44: and E.Schwelb. The International Convention on the Elimination of All Forms of Racial Discrimination, in: 15 ICLQ 1966, 996-1068 at 997-1000.

2. Schwelb, op.cit. at 1032-1044.

About the supervisory system in general:T.Buergenthal, Implementing the UN Racial Convention, in: 12 TILJ 1977. 187-221: K.Das, Measures of implementation of the 
this end a Committee on the Elimination of Racial Discrimination consisting of impartial experts is set up under article 8. The following article provides for the procedure in which States Parties report on the implementation of the Convention. In articles 11 to 13 the procedure of State complaints is laid down, followed by the optional individual complaints procedure in article 14 and the advisory function of the Committee with regard to petitions from inhabitants of the Trust and Non-Self-Governing Territories in article $15^{3}$.

The third part contains the so-called final clauses, of which the provision on reservations, article 20 , is the most relevant within the present framework.

\subsection{The law applicable to reservations}

As a consequence of the Advisory Opinion in the Genocide case, the General Assembly had recommended that when drafting multilateral conventions, the insertion of a reservations clause should explicitly be considered ${ }^{5}$. In the Third Committee views differed on the possible content of a reservations clause. Certain states wanted to enumerate the articles to which reservations would be prohibited. Poland proposed articles 1 to $5^{6}$, and Ghana, Mauritania and the Philippines wanted to add articles 8 to $14^{7}$. If these proposals had been adopted reservations to essential rules of substantive law and supervision would have been forbidden, probably creating a very transparent system. However no agreement could be reached, and the Convention was forwarded to the General Assembly without a provision on reservations, at the suggestion of Canada ${ }^{8}$.

In the General Assembly an amendment was proposed, which led to the insertion of article $20^{9}$. Not all participating States were equally pleased with the provision. France felt the two-thirds rule introduced political elements, and the United States favoured a judicial decision on the matter of compatibility ${ }^{10}$.

\section{2.(...continued)}

International Convention on the Elimination of All Forms of Racial Discrimination with special reference to the provisions concerning reports from States Parties to the Convention, in: 4 RDH 1971, at 213-263: and J.L.Gomez del Prado. United Nations Conventions on Human Rights: The Practice of the Human Rights Committee and the Committee on the Elimination of Racial Discrimination in Dealing with Reporting Obligations of States Parties, in: 7 HRQ 1985, at 492-513.

3. Lerner, op.cit. at 86-88; Schwelb, op.cit. at 1045-1046.

4. Lerner, op.cit. at 95-97; Schwelb, op.cit. at 1055-1057, 1058.

5. GA Res. 598 (VI), 12 January 1952 reads:

"1. Recommends that organs of the United Nations, specialized agencies and States should, in the course of preparing multilateral conventions, consider the insertion therein of provisions relating to the admissibility or non-admissibility of reservations and to the effect to be attributed to them;

2. ...."

6. A/C.3/L.1272; A/6181, par.191.

7. A/C.3/L.1314; A/6181, par. 192 .

8. A/6181, par.193-194.

9. GAOR 1965, 20th session; A/L.479; A/PV.1406, 21-12-1965.

10. Lerner, op.cit. at 96. 
Article 20 contains rules on the making of reservations, their withdrawal and the duties of the Secretary-General of the United Nations (acting as the depository of the Convention) $)^{11}$ in this field, as well as rules on the admissibility of reservations. Though, at first glance, the article appears to provide a transparent system, it does in fact rather beg the question.

Article 20 reads:

1. The Secretary-General of the United Nations shall receive and circulate to all States which are or may become Parties to this Convention reservations made by the States at the time of ratification or accession. Any State which objects to the reservation shall, within a period of ninety days from the date of the said communication, notify the Secretary-General that it does not accept it.

2. A reservation incompatible with the object and purpose of this Convention shall not be permitted, nor shall a reservation the effect of which would inhibit the operation of any of the bodies established by this Convention be allowed. A reservation shall be considered incompatible or inhibitive if at least two-thirds of the States Parties to this Convention object to it.

3. Reservations may be withdrawn at any time by notification to this effect addressed to the Secretary-General. Such notification shall take effect on the date on which it is received.

- article 20.1 -

The first paragraph of the provision deals with the procedural aspects of making reservations. Reservations made shall be circulated by the depository, not only to States Parties but also to possible future States Parties ${ }^{12}$. This last group of addressees is somewhat surprising, as they do not seem to have a legal interest in this particular information. Only the objections made by States Parties will be relevant for the two-thirds rule mentioned in paragraph 2 of that same provi$\operatorname{sion}^{13}$. Objections by other States cannot be taken into account, unless they ratify within three months after the reservation has been made ${ }^{14}$.

Even if the number of objections remains below two-thirds of the ratifying States, these objections may be a valuable indication of the opinion of the other States Parties, and might lead to the withdrawal of a reservation.

Objections to reservations are expected to reach the depository within ninety days after the communication of the reservation. The rule in article 20.1 is unclear about the point in time from when onwards the ninety days period starts. The provision reads:".. the date of the said communication..". Given the fact that the

11. See article 17.2 CERD.

12. See about this policy also a memorandum by the Office of Legal Affairs to the Depuly Director of the Division of Human Rights, Practice followed by the depositany regarding communications the nature of which is unclear, in the casc of comcentions providing for a specific procedure to be applied in respect of resenaions, in: UN Juridical Yearbook 1975 (ST/LEG/SER.C/13), par.8 at 206-207.

13. A.Cassese, A new reservations clause, Article 20 of the United Nations Convention on the Elimination of All Forms of Racial Discrimination: in: Recucil d'ctudes de droit international en hommage à Paul Guggenheim. Genève. 1968, 260-304. at 278.

14. Cr. Cassese op.cit. at 277-279. 
period is relatively short, this must surely be understood as the date of the reception of the said communication by the potential objectors. It should be noted that the Vienna Convention on the Law of Treaties allows for a period of twelve months in article 20.5, and seems to point to the moment of reception of the reservation, reading: "..after it was notified of the reservation. ${ }^{15}$. In any case, the period of ninety days presupposes an active and attentive policy on the part of the States Parties. Although the drafters may have had this in mind, it is questionable whether this short period does justice to the time-consuming handling of such communications in Ministries of Foreign Affairs ${ }^{16}$. This will probably take considerably more time.

Apart from the question of whether the period of ninety days is sufficient for the formulation of objections, there is the intriguing matter of the difference in timelimits in articles 19 and 20 . While article 19 provides for the entry into force after thirty days ${ }^{17}$; article 20 allows for a period of ninety days in which the other States Parties may object to reservations. The question is at which point in time the Convention will enter into force for the reserving State which has made a compatible reservation. As Cassese puts it: "The problem arises because par. 1 of Art. $19 \ldots$ is ill-coordinated with art. 20, so that the application of these two articles could lead to absurd consequences. ${ }^{18}$

Prior to the entry into force of the Convention, the two-thirds rule of article 20.2 could not be applied for lack of States Parties able to react. The point is whether the reserving state can be included in the list of twenty-seven States Parties necessary for the entry into force of the Convention. Or should a substantial number of objections from other States Parties, at the very moment of entry into force, establish that the reservation is incompatible, thus precluding entry into force for all the ratifying States? On the other hand, waiting for twenty-seven ratifications without reservations could mean that the entry into force of the CERD would have been postponed for a long time. Such an interpretation would be contrary to the Convention's objective of protection against racial discrimination which is best served by a speedy entry into force of the Convention.

In a rather elaborate discussion of this problem Cassese ${ }^{19}$ suggests three methods of interpretation that might provide a solution for the logico-grammatical puzzle created by both provisions. He concludes that an extensive interpretation

15. See Chapter 2, par.3.2.3 supra for a discussion of article 20.5 VCLT.

16. Cassese seems to think that three months is an acceptable time-span, quoting another example of a three months period, op.cit. at 296-297.

17. Article 19 reads:

"1. This Convention shall enter into force on the thirtieth day after the date of the deposit with the Secretary-General of the United Nations of the twenty-seventh instrument of ratification or instrument of accession.

2. For each State ratifying this Convention or acceding to it after the deposit of the twenty-seventh instrument of ratification or instrument of accession. the Convention shall enter into force on the thirtieth day after the date of deposit of its own instrument of ratification or accession."

18. Cassese, op.cit. at 285.

19. Cassese, op.cit. at 285-298. 
of the notion of States Parties in article 20.2, as meaning not only states for which the CERD is in force, but also states that have expressed their consent to be bound, provides a workable rule. Enlarging the group of states implies a more rapid determination of the entry into force. However, when reservations have been made, the delay of ninety days to establish compatibility will always occur. In actual practice the Secretary-General took a pragmatic approach in the matter of the entry into force of the Convention in relation to ratifications to which reservations had been attached. When the twenty-seventh ratification was deposited by Poland on 5 December 1968, two previous ratifications containing reservations were still in their ninety-day period, another ratification containing reservations had not yet been circulated and the Polish ratification itself also contained a reservation. Thus the Secretary-General issued a statement indicating that although twenty-seven ratifications had been received, he was not in the position to determine whether or not the Convention had entered into force. Three months later the Secretary-General notified the interested states that the Convention had entered into force on 4 January 1969, according to article 19.1 CERD $^{30}$.

The solution is a practical one, the depository waited ninety days, according to article 20.1 , in order to establish if the number of objections to any of the reservations would prevent a ratifying State from becoming a party to the Convention. As this was not the case, the Convention entered into force retroactively a month after the reception of the twenty-seventh ratification. Though the entry into force of the CERD took place without problems, the issue is clearly the consequence of imprecise drafting.

Another point that needs to be made in view of article 20.1 , is that the ninety day rule is biased towards states that become parties at a later point in time. As objections can only be made within the ninety day period following the making of a reservation (the provisions reads: "within a period of ninety days from the date of the said communication,.."), states ratifying after that period of time will not have the opportunity to formulate objections relevant to the determination of the compatibility of a reservation. A reservation is compatible if the number of objections falls short of the two-thirds requirement three months after it has been made, even if at a later stage the number of objections of subsequent States Parties would be substantially higher.

20. The statement reads:"It appears from the provisions of article 20 of the Convention that it would not be possible to determine the legal effect of the four instruments in question (the ratifications containing reservations for which the ninety-day period had not yet expired, EL) pending the expiry of the respective periods of time mentioned in the preceding paragraph.

Having regard to the above-mentioned consideration, the Secretary-General is not at the present time in a position to ascertain the date of entry into force of the Convention." ST/LEG/SER.E/11, 31-12-1992, at 110. 
- article 20.2 -

The core rule on reservations to the CERD is article 20.2. It provides for a generic prohibition rather than prohibiting specified reservations.

Reservations incompatible with the object and purpose of the Convention are prohibited as are reservations inhibiting the operation of any of the bodies established by the Convention. Whether reservations belong to either category is established on the basis of the number of objections made. Though it is not explicitly mentioned, the gist of article 20.2 is that incompatible reservations are not accepted, and that the reserving state is thus forced to either withdraw its reservation, or withdraw its ratification ${ }^{21}$. It must be stressed, on the other hand, that even if a reservation is accepted, it is not necessarily compatible. The two-thirds rule merely establishes acceptance on the assumption of compatibility 2 .

It needs to be recognized that the protective value of the two-thirds rule diminishes as more states become parties to the CERD. Though the rule remains unchanged, the number of states necessary to establish incompatibility according to 20.2, two-thirds of the ratifying states, necessarily increases ${ }^{23}$. Thus the rule has an intrinsic flexibility that implies a loss of control, proportional to the growing number of States Parties ${ }^{24}$.

The rule that reservations may not be incompatible with the object and purpose of the Convention is a reflection of the Court's opinion in the Genocide case. The notion of "object and purpose" seems self-evident, but it raises the question what the precise object and purpose of the CERD are.

The elimination of racial discrimination is clearly the purpose of the Convention, but does that imply that reservations to any of the substantive provisions are prohibited? In such case, the proposal by Poland would have been a more transparent rule. Yet, the interpretation of the notion of "object and purpose" is left completely to the States Parties. The object and purpose rule is a guideline for the formulation of objections, but not necessarily a touchstone. That is, apart from the case in which a difference of opinion on the compatibility of a reservation is taken to the Intemational Court of Justice, according to article 22 CERD $^{25}$.

21. This is again underlined in interpretative declarations made by Fiji, Tonga and the United Kingdom, which read:"In addition it interprets article 20 and the other related provisions of Part III of the Convention as meaning that if a reservation is not accepted the State making the reservation does not become a Party to the Convention."

22. B.Graefrath, Menschenrechte und internationale Kooperation (usw.), Berlin (DDR) 1988 , at 70 .

23. A particularly striking example of this problem is the number of objections necessary to establish the incompatibility of the reservation of the Yemen Arab Republic, for a discussion of the objections see infra section 2.1.

24. Cf. Clark, op.cit. at 298 discussing the two-thirds rule as a solution for reservations to the Women's Convention.

25. Cassese, op.cit. at 276-277, and CERD/C/SR.553. 
What ultimately matters is the number of objections, not the reasoning behind them. Article 20.2 is skilfully drafted, while suggesting that the content of the CERD is of overriding importance the actual determination lies in the hands of the States Parties who should, but need not, decide upon the basis of that criterion.

The prohibition of reservations that would inhibit the operation of a body established by the Convention seems to be an objective rule. Here, as with the object and purpose criterion, the two-thirds rule applies. While this rule might be acceptable with respect to the content of the Convention, it has quite a different role as far as the supervisory system is concerned. Cassese disagrees with linking the two elements, and putting both of them under the aegis of the two-thirds rule. It might even be claimed that the creation of a supervisory system is one of the objects of the CERD, and in that respect this second notion is superfluous ${ }^{26}$.

The issue raises two points, first of all the question which are the bodies concerned, and secondly precisely which reservations are prohibited.

Article $\mathbf{2 0 . 2}$ refers to "any of the bodies established by this Convention". These are the Committee on the Elimination of Racial Discrimination (article 8 CERD) and the ad hoc Conciliation Commission (article 12). The jurisdiction of the International Court of Justice is clearly outside of the protective scope of article 20.2 , even if the Court performs a dispute settlement function related to the CERD, according to article $22^{27}$.

The protection deals with the operation of the bodies, and it might be a matter for discussion if this were understood to include the whole of part II of the Convention which contains all the available procedures within the framework of the CERD. If this extensive interpretation is correct, then the substance of the proposal by Ghana, Mauretania and the Philippines has in fact been realized.

Article 20.1 does not indicate that objections need to be confined to the grounds mentioned in paragraph 2 , but seems to imply $\mathrm{it}^{28}$. Both provisions are interwoven and a sound interpretation takes into account the context of the provi$\operatorname{sion}^{29}$. The basic assumption is that states establish treaty-relations on the basis of the Convention with every other ratifying state. The only reason to rebut this assumption are the dangers implied in undermining the object and purpose of the CERD, or the supervisory functions of the bodies established by the CERD. Where the (two-thirds) majority of ratifying States feel that this danger is imminent, the Convention shuts like an oyster. During the drafting, the reasoning of the International Court of Justice in the Genocide case was referred $\mathrm{to}^{30}$. The

26. Cassese, op.cit. at 276.

27. Schwelb, op.cit. at 1056.

28. Schwelb, op.cit. at 1056.

29. Article 31.1 VCLT.

30. Cassese, op.cit. at 275-276. 
Court explicitly stated that States, when objecting, should do so on the basis of the object and purpose criterion ${ }^{31}$.

A related issue is whether states need to indicate the reason for their objection. Article 20.1 merely requires the expression "that it does not accept it". The application of article 20.2 seems to require mentioning the incompatibility, but on the other hand the assumption might be that states only object when either of the two interests are at stake.

States do have the liberty to formulate other objections, such as the ones based on the non-recognition of particular states or other political considerations. Clearly these can not be taken into account when determining if two-thirds of the ratifying states have objected ${ }^{32}$. In that respect only objections dealing with the grounds mentioned have any relevance.

Given the two-thirds rule, the question instantly arising is what the relevance is of objections not amounting to a total of two-thirds of all the States Parties. The intention of such objections is clearly to indicate discontent about reservations made, but what is their legal significance once it is established that a particular reservation is compatible pursuant to article 20.2?

As a consequence of the acceptance of the reservation as compatible, the reserving state becomes a party to the CERD. The issue is whether treaty relations will be established between the reserving state and the objecting state. In discussing this problem, Cassese presents two option $s^{33}$.

Firstly, as the objections have been the result of considering the reservation from the perspective of object and purpose, they must be considered sufficiently serious. Consequently the least an objecting State might expect, is not to establish treaty-relations with the reserving state. Yet, this seems to conflict with the Convention's desire for universal participation and is therefore not considered an attractive solution. On the other hand, this might be a matter of purely legalistic significance, as the reserving state will ultimately be bound towards its citizens, and the treaty-relations underlying the validity of a human rights convention are to a certain extent of a minor importance.

The other line of reasoning, not shared by the present author, holds that as a consequence of the determination that the reservation is compatible, the objections lose relevance and treaty-relations are established in spite of prior objections. The main argument is that this does justice to the notion of effective participation $^{34}$, which seems to amount to a strict monitoring of the integrity of

31. ICJ Reports 1951, at 26:"As no State can be bound by a reservation to which it has not consented, it necessarily follows that each State objecting to it will or will not, on the basis of its individual appraisal within the limits of the criterion of object and purpose stated above, consider the reserving State to be a party to the Convention."

32. Cassese, op.cit. at 277.

33. Cassese, op.cit. at 280-285.

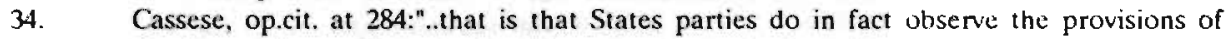
the Convention; with a view to this a complex control machinery for the Convention was provided which States parties are moreover forbidden to evade by appending reservations." 
the Convention. The problem with this line of reasoning is that the State's intentions as they concern the establishment of treaty relations become purely superficial, without consent making any actual difference for the application of the Convention.

In the course of the work of the Committee on the Elimination of Racial Discrimination, some questions arose as to whether the Committee itself had a role to play in respect of reservations ${ }^{35}$. Three questions were put to the Office for Legal Affairs, dealing with the legal effect of interpretative declarations, the authority of the Committee to decide upon compatibility, and a last question about reservations made after ratification.

The second question is clearly relevant for the scope of article 20.2, the Office for Legal Affairs states that, as the Committee is not a representative organ of the States parties it does not have the competence to decide upon compatibility. The memorandum reads:

"When a reservation has been accepted at the conclusion of the procedure expressly provided for by the Convention (article 20) - even a unanimous decision - by the Committee that such a reservation is unacceptable could not have any legal effect.".6

This line of reasoning clearly follows the structure of article 20 , as well as the individualized approach to compatibility in the Genocide case. Shelton suggests that the advice also relies on the maxim expressio unius est exclusio alterius, states never meant to grant this authority to the Committee ${ }^{37}$. Yet, it may be doubted whether the categorical denial of the potential role of the Committee (could not have any legal effect), can be maintained in the future. The memorandum relies on a static role of the Committee, whereas future developments will indicate that a more dynamic approach is possible.

\section{- article 20.3 -}

Withdrawal of reservations is a simple matter, all that is needed is a communication to the Secretary General which will have immediate effect. This seems to imply effectiveness from the moment of reception of the withdrawal onwards ${ }^{38}$. Apparently, no specific acceptance by other States Parties is needed, which is similar to the rule laid down in article 22.1 of the Vienna Convention.

35. Legal effects of statements of interpretation and other declarations made at the time of ratification or accession. UN Juridical Yearbook 1976 (ST/LEG/SER.C/14) at 219-221; also reflected in CERD/C/SR.286. at 216-218.

36. ST/LEG/SER.C/14, par.8 at 221 .

37. Shelton, op.cit. at 229-230.

38. Cf. article 22.3.a VCLT. 


\subsection{Declarations and reservations}

Declarations and reservations to the CERD can be divided into a number of groups. Not all of them are equally important and will be dealt with ${ }^{39}$. The reservations and declarations not elaborated upon are the statements dealing with the non-recognition of Israel $^{50}$, Taiwan ${ }^{41}$ or Rhodesia ${ }^{42}$. Furthermore thirteen states declared their objections to participation-clauses articles 17 and 18 of the CERD, stating that these provisions are discriminatory ${ }^{43}$. Article 22 dealing with dispute-settlement and including the option of unilaterally referring a dispute to arbitration and eventually to the International Court of Justice, met with a great number of reservations ${ }^{44}$.

In their acceptance of the Committee's power to receive individual communications (article 14 CERD) some of the States Parties have restricted their acceptance to cases not dealt with by another international body of investigation or settlement. Though sometimes formulated as a reservation, they are in fact qualified acceptances ${ }^{45}$, and are not dealt with below ${ }^{46}$.

The other reservations and declarations deal with the CERD's substantive provisions, or with the much discussed advisory function in respect of the right of petition for inhabitants of Trust and Non-Self Governing Territories in article 15 of the Convention. In the following these declarations and reservations will be

39. 9 States (including the former German Democratic Republic, not mentioned in ST/LEG/SER.E/11) "objected" to the ratification of the Convention by Government of Democratic Kampuchea (described by Byelorussia as "the Pol Pot clique of hangmen"), indicating that the People's Republic of Kampuchea was the only legitimate actor on behalf of Kampuchea/Cambodia. Though this is an objection in the literal sense, it is by no means an objection in the legal sense, as it does not refer to a reservation. Strange enough the Secretariat has listed the Kampuchea objections under the heading of objections in its publication ST/L.EG/SER.E/11.

40. Reservations by Bahrein, People's Democratic Republic of Yemen, Irac, Kuwait, Libyan Arabic Jamahiriya, Syrian Arab Republic, United Arab Emirates and United Arab Republic (subsequently withdrawn by Egypt on 18-1-1980).

41. Reservation by China, and a number of communications from other States; see ST/LEG/SER.E/11, note 3 at 111 .

42. Reservation by the United Kingdom.

43. 8 States made reservations dealing with both articles 17 and 18 , while 5 States made reservations only dealing with article 17.

44. Schwelh, op.cit. at 1054-1055,1056.

29 States made reservations in respect of article 22. in the meantime 7 States have withdrawn their reservation (ST/LEG/SER.E/11). After its accession to the CERD on 29-12-1981. China formulated a reservation to article 22 on 13-1-1982. The Secretary General seems to think that this is still acceptable; see ST/LEG/SER.E/11 at 101 . C. article 2.1.d VCLT.

45. Declarations by Denmark, lceland, Norway and Sweden formulated as "reservations", and declaration by Italy formulated as "understanding".

46. The Committee considers these declarations to be reservations. see CERD/C/SR.346 and SR.457-458.

About the issue of concurrent human rights procedures see: Schwelb, op.cit. at 10461048. 
discussed. It should be noted that all reservations have been accepted, as the number of objections never amounted to two-thirds of the States Parties.

- article 1 -

Article 1 of the CERD defines racial discrimination as "any distinction, exclusion, restriction or preference based on race, colour, descent, or national or ethnic origin which has the purpose or effect of nullifying or impairing the recognition, enjoyment or exercise, on an equal footing of human rights and fundamental freedoms in the political, economic, social, cultural or any other field of public life ${ }^{m 7}$. The following paragraphs deal with the non-applicability of the Convention in the field of citizenship, nationality or naturalization, and with special measures.

The only reservation to article 1 has been made by the United Kingdom. It holds that neither the Commonwealth Immigrants Acts, 1962 and 1968 nor their application involve any discrimination within the scope of article 1.1 of the CERD, and it reserves its right to continue to apply the Acts ${ }^{4 R}$. The reservation is remarkable in as much as it seems to formulate, by way of reservation, a fact that has already been provided for in article 1.2, namely that distinctions, restrictions or preferences between citizens and non-citizens are allowed ${ }^{49}$.

The reservation raises the fundamental point of who is to determine whether or not domestic legislation is in conformity with the demands of the Convention. In the opinion of the United Kingdom, the reserving state can declare that conformity exists, and given the acceptance of the reservation the fact is established amongst the States Parties to the Convention.

Another question concerning this reservation is the position of future legislation, and in particular laws amending the Commonwealth Immigrants Acts. The United Kingdom's reservations suggests that its legislator will act within the limits of CERD, which is an obligation to be found in article 2.1.a of the Convention. But conformity with the Convention should be established by the States Parties, and in the subsequent practice of the Committee. Through its reservation the United Kingdom has become the sole judge of the conformity of its legislation with the CERD.

- article 2 -

Article 2 deals with the obligation to take measures in order to eliminate racial discrimination, and with special measures for the development and protection of

47. Lerner, op.cit. at 28-32; D.Mahalic and J.Gambee Mahalic. The Limitation Provisions in the International Convention on the Elimination of All Forms of Racial Discrimination, in: 9 HRQ 1987, 74-101 at 78-82: K.J.Partsch. Die Konvention zur Beseitigung der Rassendiskriminierung, in: Vereinte Nationen 1971, 1-8 and 46-53, at 2; Schwelb, op.cit. at $1003,1006-1007$.

48. K.J.Partsch, Elimination of Racial Discrimination in the Enjoynent of (ivil and Political Rights, in:14 TJIL 1979, 191-250 (hereafter: Partsch. TILJ) suggests at 212, that this reservation in fact deals with article 5.d.i of the CERD. frecdon of movement.

49. Meron, op.cit. at 44-46. 
specific racial groups ${ }^{50}$. Two reservations have been made with respect to article 2 of the CERD, by Fijis ${ }^{31}$ and by Tonga. The reservations are remarkably similar and purport to exclude the school system from the aegis of articles 2, 3 and 5.3. $v^{52}$.

The link with article 2 would seem to be the governmental influence on education, whereas the relation between articles 3 and 5.e.v and educational matters is more obvious. From the wording of the reservation it is not clear whether it aims at the whole provision, the negative obligations contained in paragraph 1 , or the special measures dealt with in paragraph 2.

The obligation to eliminate racial discrimination in the field of education within the CERD is a double-sided one. The Convention guarantees equality in the enjoyment of the right to education and training (article 5.e.v), which is enforced by the general prohibition of segregation (article 3 ). Racial discrimination is not only prohibited, there is an obligation "to adopt immediate and effective measures, particularly in the fields of teaching, education .. with a view to combating prejudices which lead to racial discrimination .." (article 7). It would stand to reason that in case states cannot accept the obligations laid down in articles 2, 3, and 5.e.v, they would a fortiori find it impossible to accept obligations of the kind laid down in article 7 . With respect to that provision, no reservations have been made however.

- article 3 -

The reservations of Fiji and Tonga to article 3, in combination with articles 2 and 5.e.v have been dealt with above.

- article 4 -

Article 4 CERD is a notoriously controversial provision, trying to reconcile the rights of freedom from racial discrimination with freedom of expression and association. The provision may be taken to be an elaboration of the obligation laid down in article 2.1.d, though it must be noticed that its discriminationconcept differs from the definition laid down in article $1^{53}$. The article obliges states to adopt measures such as penalizing the dissemination of ideas on racial superiority (article 4.a), prohibiting organizations promoting racial hatred (article 4.b) and preventing the promotion of racial discrimination by public institutions

50. Lerner, op.cit. at 36-39: Mahalic, op.cit. at 82-88.

51. Previously, when the United Kingdom had ratified CERD, it had made a similar reservation on behalf of Fiji. On 11 january 1973. Fiji succeeded to the CERD, and, while redrafting them, affirmed the reservations made on its behalf by the United Kingdom. See ST/LEG/SER.E/11.

52. The reservations read:".. or that the school system of Fiji/fonga may not fulfil the obligations referred to in articles 2,3, or 5.3.v, the Government of Fiji reserves the right not to implement the aforementioned provisions of the Convention / the Kingdom of Tonga reserves the right not to apply the Convention to Tonga.

About these reservations see Partsch, TJIL, at $211-212$. 


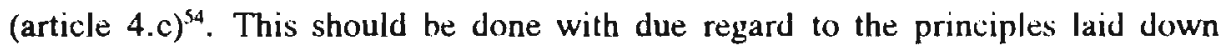
in the Universal Declaration on Human Rights and the rights laid down in article 5 CERD, according to the introductory phrase of article 4.

Twelve states made declarations dealing with the content of article 4 , and according to Partsch three groups of statements can be distinguished $\$$. The first group of statements refers to national constitutions and the human rights guaranteed therein ${ }^{56}$. The second group of declarations indicate how states intend to interpret the provisions of the CERD, and must he taken to be genuine interpretative declarations. These States indicate and stress in particular that they will interpret the CERD in line with other human rights documents mentioned ${ }^{57}$. They all point to the fact that the obligation in article 4 .a and 4.6 could easily encroach upon rights such as the freedom of association or the freedom of expression.

The third group of statements would seem to have the characteristics of reservations, for these states indicate that they will fultil their obligation to enact the required legislation should they feel that the need arises ${ }^{5 \%}$. The fulfilment of treaty obligations thus depends on national legislative considerations, which is contrary to the rule that parties should honour their treaty-ohligations, independently of the internal situation.

Australia made a different reservation, indicating that it could not yet fulfil its obligation to penalize racial discrimination according to article 4 .a, but it sought to do so at the first opportunity.

- article 5 -

Article 5 of the CERD presents itself as a genuine human rights catalogue. This can be deceiving, the gist of the provision is the prohibition and elimination of

54. Lerner, op.cit. at 47-53; Mahalic, op.cit, at 89-101; Schwelb, op.cit. at 1021-1025;

55. Partsch, TILJ, at 213-214; and CERD/C/SR.326 par.21 and SR.348 par.49.

56. Reservation upon signature of the United States of America. sce for a discussion under "Constitutions" infra at....

57. Austria (".the right to freedom of opinion and expression and the right to freedom of peaceful assembly and association may not be jeopardized"). Belgium ("..must be reconciled with the right to frecdom of peaceful assembly and association"). France (".releasing the States parties from the obligation to enact anti-discrimination legislation which is incompatible with the freedoms of opinion and expression and of peaceful assembly and association..") and Italy (".the obligations deriving from article 4 are not jeopardizing the right to freedom of opinion and expression and the right to freedom of peaceful assembly and association..").

In a subsequent communication to the depository of the CERD, France explicitly underlined that its statement had been an interpretation of article 4 , and did not purport to limit its obligations under the Convention: ST/LEG/SER.E/11, at 112.

58. Antigua and Barbuda (".where it is considered that the need arises to enact such legislation.."), Bahamas, Barbados, Fiji. Malta. Nepal. Papua New Guinea ("..that some legislative addition to, or variation of the existing law and practice. is necessary to give effect to the provisions of article 4."), Tonga and the United Kingdom.

Though Guyana and Jamaica do not explicitly mention article 4 in their reservations, the scope of their "Constitutional" reservation may be taken to include the obligation to legislate in article 4. 
racial discrimination and the guarantee of equality before the law. The list of human rights that should be enjoyed on the basis of equality is not exhaustive, given the use of the word "notably" in the opening paragraph".

The reservations of Fiji and Tonga to article 5.e.v has been dealt with supra under article 2. The third state to make a reservation with respect to article 5 was Yemen $^{60}$. The then Yemen Arab Republic acceded to the Convention making a reservation concerning article 5.c and 5.d.iv, vi and vii. The reservations are striking as Yemen purports to exclude the Convention's protection against racial discrimination where it concerns political rights (article 5.c), the right to marriage (article 5.d.iv), the right to inherit (article 5.d.vi) and the right to freedom of thought, conscience and religion (article 5.d.vii). It is a far-reaching statement that can probably only be understood within the light of the Yemen domestic legal system. At face value it definitely seems to run contrary to the very intention of article 5 as such, the rule of equality before the law. There is apparently only fragmentary equality in Yemen. This particular reservation is the only substantive reservation to which objections have been made ${ }^{61}$.

- article 6 -

France and Italy indicate that the question of remedies is governed by ordinary law, and Italy adds that the same goes for claims for reparations. The CERD leaves the implementation of article 6 , be it through ordinary law, or through

59. Lerner, op.cit. at 55-60; Partsch, TILJ, 195-201: Schwelb, op.cit. at 1025-1027.

60. On the political aspects of the merger see: Keesings Historisch Archief Maart 1990, 174175: Augustus 1990, 551-553; R.Schmidt, Zu einigen Aspekten der Vereinigung beider jemenitischer Staaten, in: 19 Asien, Afrika, Lateinamerika 1991. 293-304.

The merger of the Yemen Arab Republic and the People's Democratic Republic of Yemen poses fascinating questions to the law of treaties. In its letter to the Secretary General of the United Nations (ST/LEG/SER.E/11, at 9) Yemen indicates that it will succed to the treaty obligations of both states, and must be considered bound from the date of the first ratification by either state onwards.

The question thus arises whether this statement merely refers to the commencement of the obligation, or purports to establish that the new Republic of Yemen will be bound on exactly the same conditions as were laid down in the first ratification, abandoning the reservations in the later ratification. Article 31 of the Vienna Convention on Succession of States in Respect of Treaties. [Vienna 23 August 1978] does unfortunatcly not give any guidance in this matter.

Yet, with respect to the ratification of the CERD it does make a difference. The People's Democratic Republic of Yemen acceded to the Convention on 18 Octoter 1972, making reservations to article 17 and 18 , article 22 and to the recognition of Israel. The Yemen Arab Republic, on the other hand, acceded to the Convention on 6 April 1989. making a reservation in respect of article $5 . c$ and 5.d.iv, vi and vii.

The Secretariat does not seem to know how to handle this matter. The reservations made by the People's Democratic Republic of Yemen (date of accession: 18-10-1972) are printed in full, with a note indicating that both states have in the meantime merged. Under the heading "Objections" the objections to the reservation by the Yemen Arab Republic (date of accession: 64-1989) are listed. That particular reservation itself has disappeared to the category "Notes". The whole presentation clearly lacks transparency. To be discussed infra par.2.1. 14 states have objected. 
special procedures, to the States Parties. The essential obligation is to ensure that an effective remedy is available ${ }^{62}$.

Fiji, Nepal, Malta, the United Kingdom and Tonga make literally the same interpretative declaration, elaborating on the meaning of the words used in the provision $^{63}$. One might wonder whether the interpretation of 'satisfaction' as "redress effective to bring the discriminatory conduct to an end", as the second part of the declaration reads, does justice to the notion of an effective remedy for an individual victim ${ }^{64}$. But the declaration intends to widen the scope of the notion of 'satisfaction', as it reads "including...". In sum, this can therefore be considered an interpretative declaration.

\section{- Constitutions -}

Three groups of "constitutional" declarations can be distinguished. A group of six States mentions that their constitutions guarantee the fundamental rights and freedoms to every person; that the constitutions prescribe judicial procedures in the event of a violation of those rights, and that acceptance of the CERD does not imply acceptance of obligations going beyond the constitutional limits ${ }^{65}{ }^{66}$. These declarations are remarkably similar and suggest close cooperation when drafting the text. A second group of declarations lists the rights protected in the constitution, and underlines that the CERD does not require legislation incompat-

62. Lerner, op.cit. at $60-62$.

63. The reservations of Fiji. Nepal, Malta, the United Kingdom and Tonga read:"..interpret(s) the requirement in article 6 concerning 'reparation or satisfaction" as being fulfilled if one or other of these forms of redress is made available, and interprets 'satisfaction' as including any form of redress effective to bring the discriminatory conduct to an end."

64. C. Lerner, op. cit. at 62.

65. Antigua and Barbuda, Bahamas, Barbados, Guyana, Jamaica, and Papua New Guinea.

66. Papua New Guinea acceded to the CERD on 27 january 1982, but its declaration dates from 22 february 1982 (ST/LEG/SER.E/11). There does not seem to be any need for the application of rule that reservations can only be made at the very moment of accession. which follows from article 2.1.d VCLT, to interpretative declarations but the presentation of this particular statement is question-begging.

The Secretary-General mentions that "[T]he resenation was circulated..on 22 February 1982". It is unusual for the Secretariat to qualify any of the declarations made by a State party to a treaty. And if it is a reservation, the Secretary-General should have monitored compliance with article 2.1.d VCLT, which is a rule of customary law.

However, in a strange misconception of the content of the law on reservations, the Secretary-General writes (op.cit. note 6 at 118):"None of the States concerned having objected to the reservation by the end of a period of ninety days after the date when it was circulated by the Secretary-General, the said declaration is deemed to have been permitted in accordance with the provisions of article 20.1 (of the CERD, EL)."

This statement on the conformity with article 20.1 CERD is not to be found elsewhere in the overview of the reservations made. The assumption underlying article 2.1.d is that reservations can only be made (and afterwards accepted) at the moment of accession. Subsequent reservations intend to unilaterally change the treaty, which is per se impossible. Hence, reservations made after accession should not be circulated and can a fortiori not be accepted. Obviously, the depository fell into the "silence-trap" of article 20.5 VCLT. 
ible with the constitution ${ }^{67}$. It should be noted that the rights listed do not cover the whole content of article 5. A third declaration merely mentions that the CERD does not contain an obligation to introduce judicial procedures going beyond those provided in the constitution ${ }^{68}$.

In order to determine the legal status of such declarations it is necessary to see whether they purport to restrict any of the rights and obligations contained in the CERD. By claiming that their constitution is in accordance with CERD standards, these reserving states become the sole judge of their compliance with in particular article 6 . They may or may not comply with the Convention, but this can not any longer be a matter for discussion as the only yardstick for compliance is the constitution. This is precisely why these declarations must be seen as reservations. The States reserve to themselves the right to supervise compliance, and may unilaterally change their obligations under the CERD by changing their constitution.

The reserving States interpret the CERD as not containing an obligation to introduce judicial procedures other than the ones established in their constitution. One might wonder whether explicitly mentioning the relevant provisions of the Convention might not have been better and clearer. The declarations seem to be related to the obligations contained in articles 4,5 and 6 of the Convention. Article 5 is a non-exhaustive list of human rights that have to be guaranteed on a non-discriminatory basis, whereas article 4 and 6 each deal with "judicial processes". But apparently only the obligations under article 6 are meant as the majority of authors of the "constitutional" reservations have also made reservations to article $4^{6 *}$.

It might be argued that extending procedural possibilities aimed at the elimination of racial discrimination cannot be incompatible with any constitution. All the Convention demands in article 6 is "effective protection and remedies" and the right to seek "just and adequate reparation or satisfaction". The protection of the right to equality and all the human rights protected by the Convention does not necessarily require new procedures, as long as the available procedures fulfil the CERD requirements.

\section{- article 15 -}

This provision reaffirms the right of petition for the inhabitants of Trust and Non-Self-Governing Territories to which GA Resolution 1514(XV) applies"

67. Nepal, and the United States in a reservation upon signature, mentioned in ST/LEG/SER.E/11.

See about the United States ratification of the CERD: C.Ferguson, International Convention on the Elimination of All Forms of Racial Discrimination. in: U.S.Ratification of the Human Rights Treaties, with or without reservations? R.Lillich ed., Charlottesville, 1981, at 41-46: N.L.Nathanson, E.Schwelb. The United States and the United Nations Treaty on Racial Discrimination, Washington, 1975.

68. Guyana.

69. Antigua and Barbuda, Bahamas, Barbados, Nepal and Papua New Giuinea.

70. Cf. articles 86-91 Charter of the United Nations. 
and indicates that the Committee will receive all relevant information and petitions dealing with problems of racial discrimination ${ }^{71}$. It is the only provision of the supervisory system to which reservations have been attached. The United Kingdom, Tonga and Fiji indicate that the provision is discriminatory in as much as it provides for a petition procedure which is not available for States without such territories ${ }^{2}$. It is noteworthy that the right of petition is a right of people according to General Assembly Resolution $1514(\mathrm{XV})$, whereas the reserving states speak of a right pertaining to States. Though this might be a logical construction within state-centred international law, it does not seem to do justice to the "rights of people" concept in human rights law. Moreover, the right to petition may have similarities with the individual complaints right, and nothing seems to prevent the reserving states from making the declaration as required in article 14 CERD.

France indicates that it maintains its position with respect to Resolution 1514$(X V)^{73}$. The French declaration raises the question whether it is sound drafting to refer to a resolution in a convention, for both legal instruments have a different nature. Apart from that, the construction used in article 15 seems to suggest that those States Parties who voted against the said Resolution but ratified the CERD, have in the meantime changed their views on the Resolution. Whatever the merits of this discussion, France is the only state to explicitly indicate its position with respect to both Resolution $1514(\mathrm{XV})$ and the Convention. It remains a puzzle whether the statement is an interpretative declaration or a reservation as it is hard to determine whether the content of article 15 reinforces Resolution 1514 as such, that is as a General Assembly resolution, or whether the previously non-binding content of the Resolution has been transformed into a rule of law through its incorporation in the Convention.

\section{REACTIONS OF THE STATES PARTIES}

\subsection{Objections}

Objections have only been made to the reservation to article 5 made by the Yemen Arab Republic ${ }^{74}$. Though it is not clear whether the reservation is still operative $^{75}$, it needs to be mentioned that 14 States made the effort to object ${ }^{76}$. There may be some doubt about the validity of the objections, apart from the fact

71. Lemer, op.cit. at 86-87 and 121-130; Schwelb, op.cit. at 1031. 1045-1046.

72. Lemer, op.cit. at $87-88$.

73. Schwelb, op.cit. at 1046: see also A/C.3/SR. 1368 and A/66181, par.166.

74. The "objections" to the ratification of the Convention by Democratic Kampuchea have been dealt with supra in par.1.3.

75. See supra par.1.3.2.

76. The only other objection to be mentioned is the Pakistani objection to the Indian reservation concerning article 22 , the dispute settlement provision. The objection was received on 24 February 1969. and therefore within the time-limit of article 20 . It is published in the "Notes" section of the document ST/LEG/SER.E/11. 
that they clearly did not amount to two-thirds of the States Parties ${ }^{n}$. Looking at the points in time when the objections were made, we see that while the reservation had been made at accession on 6 April 1989, five objections had been made by the end of July 1989, another seven by the end of August 1989 and two more reservations by the end of September $1989^{78}$.

If "from the date of the said communication" in article 20.1 CERD is taken to mean from the moment of accession onwards, 5 July 1989 would have been the deadline. If that is the case, Sweden is the only state to have objected in time. If some time is allowed for the administrative handling and forwarding of the reservation to the States Parties and the moment of dispatching is decisive, it would depend on the time taken over these steps. Assuming that the Secretariat needs a month for the handling, 5 August 1989 would be a deadline, and by then seven States had objected. A further possibility would be to take the moment of reception as the starting point, a line that also seems to be followed in article 20.5 VCLT. In that case the time-limit set in article 20.1 becomes fairly flexible and unpredictable. In any case, the least the Secretariat could do is to indicate why the objections listed are considered to have been received in time.

Thus the objections to the far-reaching reservation made by the former Yemen Arab Republic prove the point made before, that it is highly questionable whether the time-limit set in article 20.1 is realistic. Apart from the question of whether States intend to object, there is also the problem of the relatively short period available for the objections.

\subsection{State Party meetings}

The States Parties have never discussed the issue of reservations in their meetings.

\subsection{Withdrawal of reservations}

Denmark was the first State to withdraw a reservation which dealt with the implementation of the CERD on the Faroe Islands. It had ratified the CERD on 9 December 1971 (entry into force on 8 January 1972) and was able to withdraw

77. The Yemen Arab Republic ratified on 6-5-1989, when 127 States were party to the CERD. The $2 / 3$ rule would at the time have required 84 objections!

78. Australia (8 August 1989). Belgium (8 August 1989), Canada (10 August 1989), Denmark (10 July 1989), Finland (7 July 1989), France (20 September 1989), Germany (8 August 1989), Italy (7 August 1989), Mexico (11 August 1989), the Netherlands (25 August 1989), New Zealand (4 August 1989), Norway (28 July 1989). Sweden (5 July 1989 ) and the United Kingdom (4 Augrust 1989) objected.

On 30 April 1990 Czechoslovakia objected to the reservation by the Yemen Arab Republic, but failed to do so in ninety day period provided for in article 20.1 CERD. This may explain why the Secretariat reproduced the Czechoslovakian objection in the "Notes" section of the ST/LEG/SER.E/11. This objection however would have been within the time-limit set by article 20.5 VCLT. 
the reservation within the following year on the enactment of implementative legislation on the Faroe Islands.

Within five years after ratification Tonga, on 28 October 1977, was able to withdraw part of its reservations, namely those relating to article 5.c in respect of elections, and articles 2, 3 and 5.e.v in so far as they relate to education and training. The text of the notification of withdrawal indicates that it is only a partial withdrawal, and implies maintaining the reservation in other fields than the ones mentioned. Article 5.c deals also with political rights other than the right to participate in elections, such as taking part in Government, the conduct of public affairs and access to public service. The scope of articles 2 and 3 of the CERD is clearly much broader then education and training, and only article 5.e.v is literally restricted to this particular field.

In 1980 Egypt withdrew a declaration made in respect of the non-recognition of Israel, but that declaration had not been not a reservation stricto sensu.

In the aftermath of the political changes at the end of the ninety-eighties, the USSR, Byelorussian SSR, the Ukrainian SSR, Hungary, Bulgaria, Czechoslovakia and Mongolia withdrew their reservations to article 22, the provision concerning dispute-settlement by the International Court of Justice ${ }^{79}$.

\section{PRACTICE OF THE COMMITTEE}

\subsection{Reporting procedure, article 9 CERD}

The periodic reports submitted to the Committee in accordance with article 9, have for a long time been classified as restricted documents, and the same has been the case with the Committee's summary records. This situation lasted until the fifteenth session in 1977, when the issue of classification and distribution of documents of the Committee was dealt with, and steps were taken to have the reports as well as the summary records published as documents for general distribution from the seventeenth session onwards ${ }^{50}$. Documents from the earlier sessions of the Committee are thus not completely available.

\section{Antigua and Barbuda}

The Constitution of Antigua and Barbuda entrenches and guarantees to every person in Antigua and Barbuda the fundamental rights and freedoms of the individual irrespective of race or place of origin. The Constitution prescribes judicial processes to be observed in the event of the violation of any of these rights, whether by the State of by a private individual. Acceptance of the Convention by the Government of Antigua and Barbuda does not imply the acceptance of obligations going beyond the constitutional limits nor the acceptance of any obligations to introduce judicial processes beyond those provided in the Constitution.

79. Withdrawals of the USSR (3 March 1989), Byelorussian SSR (19 April 1989), Ukrainian SSR (20 April 1989), Hungary (13 September 1989), Bulgaria (24 June 1992), Czechosiovakia (26 April 1991) and Mongolia (19 July 1990). See ST/LEG/SER.E/11.

80. CERD/C/SR.351, par.51-66; CERD/C/SR.352, par.1-12. 
The Government of Antigua and Barbuda interprets article 4 of the Convention $s$ as requiring a Party to enact measures in the fields covered by subparagraphs (a), (b) and (c) of that article only where it is considered that the need arises to enact such legislation.

Antigua and Barbuda ratified the Convention in 1988, and the initial report would have been due in 1989 . So far, no reports have been received ${ }^{81}$.

\section{Australia}

The Government of Australia ...declares that Australia is not at present in a position specifically to treat as offenses all the matters covered by article 4(a) of the Convention. Acts of the kind there mentioned are punishable only to the extent provided by the existing criminal law dealing with such matters as the maintenance of public order, public mischief, assault, riot, criminal libel, conspiracy and attempts. It is the intention of the Australian Government, at the first suitable moment, to seek from Parliament legislation specifically implementing the terms of article $4(a) . "$

In discussing the first Australian report ${ }^{82}$, the Committee stressed the temporary nature of the Australian statement ${ }^{83}$ and was eager to know when legislation would be forthcoming ${ }^{84}$. As Australia had indicated in its report that the provision was partially covered by existing legislation such as the Racial Discrimination Act 1975, the Committee inquired about the exact scope of this Act ${ }^{85}$. In reply the Australian representative explained the content of penal legislation that might be applicable, and underlined that existing legislation "went a long way towards satisfying the requirements of article 4.a of the Convention", and stated that the Government was considering "what additional legislation, if any, was required"86. This last statement is striking, as Australia had indicated its intention to legislate, on the basis of its own assessment that existing legislation did not cover the Convention.

In the second Australian report, the focus is on the possible conflict between article 4 and 5 , and the matter of the temporary non-applicability has become one of conditional non-applicability ${ }^{87}$. The issue was discussed by the Committee as though the reservation did not contain a temporal restriction. The Committee stressed the mandatory nature of article 4 , as it had done before with respect to similar reservations. Only committee-member Dayal underlined that Australia itself had already indicated that legislation did not go far enough, and hoped that it would enact the necessary legislation ${ }^{88}$.

81. A/46/18, at 15 .

82. CERD/C/R.85/Add.3.

83. CERD/C/SR.330, par.12 (Bahnev); and CERD/C/SR.335, par.7 (Sayegh).

84. CERD/C/SR.330, par.S (Nettel) and par.12 (Bahnev).

85. CERD/C/SR.329, par.5I (Lamptey), and par.67 (Dayal); and CERD/C/SR.335, par.7 (Sayegh).

86. CERD/C/SR.335, par.27, 34 and 36 (Australia).

87. The report, CERD/C/16/Add.4 at 20, reads: ${ }^{n}$.. the matter (implementation of article 4.a, EL) will be kept under review to sec whether specific legislation in the area is desirable".

88. CERD/C/SR 443, par.79 (Dayal). 
Australia in its third report underlined that in view of other human rights obligations, it did not intend to fulfil its legislative obligation under article $4 . a^{89}$, and acknowledged the possible deficiency of its legislation on the control over dissemination of racist ideas and the prohibition of racist organizations. In the Committee discussion emphasis is laid on the fact that the Australian declaration was not merely a reservation but also a commitment to future legislation which appeared to have been forgotten by Australia ${ }^{90}$.

In the thirtieth session, the Committee again focuses on the intention expressed by Australia in its declaration to put legislation implementing article 4 .a before Parliament at the first suitable moment. The report does not deal with article 4 , nor does it mention the reservation"1. By then, it had been nine years since Australia ratified and expressed this intention and nothing appeared to have happened in the meantime, which was an omission?2. In reply to the questions about Australia's reservation to article 4 .a the representative indicates that it is the subject of public debate, the outcome of which would be reflected in the next report ${ }^{93}$.

The fifth report expresses sympathy for article 4 and mentions that work is being undertaken in the area of article 4.a, but it would appear that no conclusion had yet been reached ${ }^{94}$. In introducing the report the representative mentions an Australian declaration linking article 4 to the rest of the Convention and stressing that legislative action would have to be compatible with freedom of speech $^{95}$. While this appears to reflect a new policy, the statement may in fact be a reformulation of the reservation. The hope was expressed that the next report would contain more information on the implementation of article $4 \%$. The rejoinder to this observation merely listed the available remedies in criminal law against acts of violence ${ }^{97}$.

The sixth report mentions that the Racial Discrimination Act 1975 partially fulfils the obligations under article 4; and indicates that a 1983 Recommendation to remove the reservations was still under consideration ${ }^{98}$. The combined seventh and eighth report elaborates on the reservation to article 4 , indicating that it is partially a reservation and partially a statement of intent. The reservation had been made because the Race Discrimination Act 1975 did not specifically meet the requirements of article $4 . a$. The result of the National Inquiry into Racist Violence would lead to review of the necessity of the reservation ${ }^{99}$. In the

89. CERD/C/63/Add.3.

90. CERD/C/SR.556, par.7 (Ingles).

91. CERD/C/88/Add.3.

92. CERD/C/SR.677, par.31 (Partsch), par.38 (Shahi), par.57 (Karasimeonov), par.59 (Sherifis).

93. CERD/C/SR.679, par.69 (Australia).

94. CERD/C/115/Add.3, par.135-137.

95. CERD/C/SR.816, par.21 (Australia).

96. CERD/C/SR.816, par.51 (Vidas).

97. CERD/C/SR.817, par.21 (Australia).

98. CERD/C/146/Add.3, par.67-69.

99. CERD/C/194/Add.2; par.172-180. 
Committee meeting the question is again raised when Australia would fulfil its commitment to withdraw the reservation and prepare the necessary legislation $^{100}$. The representative indicates that he would convey the questions concerning article 4 to the Government ${ }^{101}$.

\section{Austria}

"Article 4 of the International Convention on the Elimination of All Forms of Racial Discrimination provides that the measures specifically described in sub-paragraphs (a), (b) and (c) shall be undertaken with due regard to the principles embodied in the Universal Declaration of Human Rights and the rights expressly set forth in article 5 of the Convention. The Republic of Austria therefore considers that through such measures the right to freedom of opinion and expression and the right to peaceful assembly and association may not be jeopardized. These rights are laid down in article 19 and 20 of the Universal Declaration of Human Rights; they were reaffirmed by the General Assembly of the United Nations when it adopted article 19 and 21 of the International Covenant on Civil an Political Rights and are referred to in article $5(d)$ (viii) and (ix) of the present Convention."

In discussing the first Austrian report ${ }^{102}$ the Committee inquired about the purpose of the declaration, asking whether it was in fact a reservation ${ }^{103}$. The representative of Austria stressed that the statement was merely an interpretative declaration, indicating the interdependence of certain human rights. Freedom of expression should not be exercised contrary to the Convention, yet the Convention should not be interpreted as restricting all freedom of expression ${ }^{104}$. This explanation must be taken to be authoritative, coming from the author of the declaration. The Chairman of the Committee pointed out that article 4 refers to the Universal Declaration of Human Rights, which contains in article 29 the prohibition against using rights and freedoms contrary to the purposes and goals of the United Nations ${ }^{105}$.

The Austrian declaration is dealt with matter-of-factly in the thirteenth session, mainly providing an explanation on the scope of the declaration ${ }^{106}$. In the seventeenth $^{107}$ and twenty-first ${ }^{108}$ session it is not dealt with at all. And in the twenty-fifth ${ }^{109}$ session it is again emphasized that no interpretative declaration should keep a state from complying with article 4 .

The sixth periodic report by Austria discusses the implementation of article 4 at length ${ }^{10}$. It points out that incitement to a hostile act is punishable and thus

100. CERD/C/SR.915, par.54 (Wolfrum), par.82 (de Gouttes); SR.916, par.19 (Shahi).

101. CERD/C/SR.916, par.36-37 (Australia).

102. CERD/C/R.50/Add.6 and CERD/C/R.6\%/Add.1

103. CERD/C/SR.187, at 64 (Aboul Nasr).

104. CERD/C/SR.187 at 64-65 (Austria).

105. CERD/C/SR.187, at 65 (Haastrup).

106. CERD/C/R.77/Add.4, and CERD/C/SR.273 at 70 (Sayegh). CERD/C/SR.274 at 77 (Austria).

107. CERD/C/19; CERD/C/SR.367 and SR.368.

108. CERD/C/48/Add.6 and CERD/C/SR.459.

109. CERD/C/75/Add. 9 and CERD/C/SR.560-561.

110. CERD/C/106/Add.12, par.48-57. 
broadly covers the scope of article $4 . \mathrm{a}$; article $4 . \mathrm{b}$ is covered by legislation on associations; and the role of public authorities in article 4.c would also seem to be covered by penal law.

Without mentioning the declaration, the combined seventh and eighth periodic report describes the available remedies in case of an infraction of article $4^{\prime \prime \prime}$. The discussion of the Austrian report is remarkably brief, Committee members referring to article 4 are directed to the sixth report in which the implementation of article 4 was dealt with ${ }^{112}$.

\section{Bahamas}

"Firstly the Government of the Commonwealth of the Bahamas wishes to state its understanding of article 4 of the International Convention on the Elimination of All Forms of Racial Discrimination. It interprets article 4 as requiring a party to the Convention to adopt further legislative measures in the fields covered by paragraphs (a), (b) and (c) of that article only in so far as it may consider with due regard to the principles embodied in the Universal Declaration set out in article 5 of the Convention (in particular to freedom of opinion and expression and the right of peaceful assembly and association) that some legislative addition to, or variation of existing law and practice in these fields is necessary for the attainment of the ends specified in article 4. Lastly, the Constitution of the Commonwealth of the Bahamas entrenches and guarantees to every person in the Commonwealth of the Bahamas the fundamental rights and freedoms of the individual irrespective of his race or place of origin. The Constitution prescribes judicial processes to be observed in the event of the violation of any of these rights whether by the State or by a private individual. Acceptance of this Convention by the Commonwealth of the Bahamas does not imply the acceptance of obligations going beyond the constitutional limits nor the acceptance of any obligations to introduce judicial processes beyond those prescribed under the Constitution."

The first report ${ }^{113}$ is rather brief, and the chairman of the Committee suggested that this was the consequence of the far-reaching reservation relating to the constitution $^{1 / 4}$. The discussion goes hardly any further than stressing the need for a complete report on the implementation of the Convention.

The second report by the Bahamas lists the articles of the Convention and indicates whether or not action has been taken to fulfil the obligation ${ }^{1 / 5}$. The Committee urged the Bahamas to reconsider its reservations, suggesting that it was possible to adopt new legislation or to change the constitution ${ }^{16}$.

The third report by the Bahamas ${ }^{17}$ elaborated on the three elements of the reservation, adding that it "does not consider its reservation an impediment to its obligations to fulfil its obligations pursuant to its becoming a party to the Convention". The main reason for this point of view was that the practices addressed in article 4 of the Convention did not occur in the Bahamas. Moreover 
the Bahamas were considering legislation to implement both this Convention and the Convention on the Suppression and Punishment of the Crime of Apartheid. The Committee stressed that its interpretation of article 4 as a mandatory obligation did not imply that it considered that racism existed in the Bahamas ${ }^{118}$. Yet, the statement was also called an interpretative declaration by another member of the Committee, who on that basis agreed with the Bahamas that its reservation(!) was not an impediment to the implementation to the Convention ${ }^{119}$. In his reply the representative of the Bahamas merely repeated his Governments position with respect to the obligation to legislate under article $4^{130}$.

In 1991, in its procedure for states that are overdue in reporting, the Committee also dealt with the Bahamas. The rapporteur recalls the way in which the reservation to article 4 had been dealt with earlier, and reiterates the view that the reservation was not an impediment for the fulfilment of the obligation under article $4^{121}$.

\section{Barbados}

The Constitution of Barbados entrenches and guarantees to every person in Barbados the fundamental rights and freedoms of the individual irrespective of his race or place of origin. The Constitution prescribes judicial processes to be observed in the event of the violation of any of these rights whether by the State or by a private individual. Accession to the Convention does not imply the aceeptance of obligations going beyond the constitutional limits nor the acceptance of any obligations to introduce judicial processes beyond those provided in the Constitution.

The Government of Barbados interprets article 4 of the said Convention as requiring a Party to the Convention to enact measures in the fields covered by sub-paragraphs (a), (b) and (c) of that article only where it is considered that the need arises to enact such legislation."

In the opinion of the Committee's rapporteur"22 the "statement" concerning article 4 left Barbados ${ }^{123}$ the liberty to implement the provision as it saw fit. The reservation concerning the constitution falls within the field of application of article 6 and is even more categorical than the previous one. All the Committee could do was to estimate the impact of the reservation in the absence of a representative of Barbados. It would in particular be interesting to know how the Barbados Parliament had used its powers under section 24 (6) of the Constitution. In discussing the initial report of Barbados Committee-members felt that the reservation to article 4 almost nullified the ratification of the CERD ${ }^{124}$, though the report seemed to suggest that the reservation was unnecessary ${ }^{125}$. At the end

119. CERD/C/SR.610, par.27 (Ingles).

120. CERD/C/SR.610, par.28, 29 (Bahamas).

121. CERD/C/SR.926, par.10 (Sadiq Ali).

122. CERD/C/SR.204 at 51 (Sayegh).

123. CERD/C/R.50/Add.11.

124. CERD/C/SR.204 at 52 (Ancel).

125. CERD/C/SR.204, at 52 (Calouski). 
of the discussion, the Chairman raised the question as to whether the declaration concerning article 4 was a reservation or an interpretation ${ }^{136}$. He added "[I]f the latter, it would conflict with the Committee's view", thereby underlining that the Committee ought to have dealt with that preliminary question first.

The reservations are extensively dealt with in the discussions of the second periodic report by Barbados ${ }^{127}$, which is a perfect example of the confusion surrounding reservations. Barbados itself created part of the confusion by stating that article 4.a and 4.c are in fact covered by Barbadian national legislation ${ }^{138}$. This seems to narrow down its interpretative declaration to article 4.b, in spite of the wording of the statement ${ }^{129}$. The Committee elaborated upon the relationship between articles 4 and $5^{13.0}$ and underlined the mandatory character of article $4^{131}$. There was however no consent on the status of the Barbadian declaration (phrased as "..interprets.."), and moreover the Committee was not familiar with the Barbadian constitution ${ }^{132}$. Consequently, no determination could be made as to Barbados' fulfilment of its obligations under article $4^{133}$. Finally, it was suggested that Barbados be asked for additional information ${ }^{134}$. In its compilation (third, fourth and fifth) periodic report ${ }^{135}$ Barbados underlined the primordial role of its constitution in the domestic legal system, thereby implicitly explaining its reservation. Given the fact that racial discrimination was absent, there was no need for article 4 legislation. In its discussion the Committee was disturbed by the fact that the report did not contain clarifications about the scope of the reservation referring to the Barbadian constitution, which had explicitly been asked for. Though the report indicated that certain provisions in the constitution were considered to be sufficient, the Committee stressed that secondary legislation to that effect was no less vital. And again it was emphasized that the obligation to legislate in accordance with article 4 was mandatory ${ }^{136}$.

126.

CERD/C/SR.204 at 53 (Haastrup).

127. CERD/C /R.77/Add.6.

128. Unfortunately the Committee does not deal with the legal effect of such a restrictive statement by a State Party in its periodic report. This may have been influenced by the absence of a representative from Barbados.

129. CERD/C/SR.272 at 49 (Partsch), 51 (Valencia Rodrigucz), 53 (Sayegh, Pahr). 55 (Blishchenko), 58 (Sayegh, Nabavi).

130. CERD/C/SR.272 at 50 (Bahnev). 53 (Sayegh).

131. CERD/C/SR272 at 53 (Pahr), 55 (Blishchenko), 56 (Lamptey). and 57 (Kapteyn).

132. CERD/C/SR.272 at 54, Committee-member Ingles says:"It (the Committee,EL) could not criticize Barbados for having made a reservation with regard to that article, if in fact it was a reservation. Nor could it eriticize Barbados for having interpreted the article, if it was simply a case of interpretation;..." The difference of opinion continues at 55 (Nabavi), 58 (Aboul-Nasr) and 59 (Haastrup).

133. CERD/C/SR.272 at 54 (Ingles), 57 (Partsch), 59 (Haastrup).

134. CERD/C/SR.272 at 50 (Bahnev), 53 (Pahr), 57 (Kapteyn), 59 (Blishchenko) and 60 (Kapteyn).

135. CERD/C/75/Add.7.

136. CERD/C/SR.557, par.40 (Sherifis), par.46 (Valencia Rodriguez). 
The sixth periodic report by Barbados contains very limited information on the implementation of article 4; and no information about the reservation at all ${ }^{137}$. The seventh periodic report does not contain any information on the reservation to article 4, it merely refers to the Public Order Act ${ }^{138}$. In her introduction, the Committee rapporteur indicates that there was evidence that the Public Order Act did not cover the whole scope of article $4^{139}$. In the absence of a representative from Barbados, there was hardly any discussion with respect to the substance of the report.

\section{Belgium}

In order to meet the requirements of article 4 of the International Convention on the Elimination of All Forms of Racial Discrimination, the Kingdom of Belgium will take care to adapt its legislation to the obligations it has assumed in becoming a party to the said Convention.

The Kingdom of Belgium nevertheless wishes to emphasize the importance it attaches to the fact that article 4 of the Convention provides that the measures laid down in subparagraphs (a), (b) and (c) should be adopted with due regard to principles embodied in the Universal Declaration of Human Rights and the rights expressly set forth in article 5 of the Convention. The Kingdom of Belgium therefore considers that the obligations imposed by article 4 must be reconciled with the right to freedom opinion and expression and the right to peaceful assembly and association. Those rights are proclaimed in article 19 and 21 of the Internationale Covenant on Civil and Political Rights. They have also been stated in article 5 subparagraph (d)(viii) and (ix) of the said Convention.

The Kingdom of Belgium also wishes to emphasize the importance which it attaches to respect for the rights set forth in the European Convention for the Protection of Human Rights and Fundamental Freedoms, especially in articles 10 and 11 dealing respectively with freedom of opinion and expression and freedom of peaceful assembly and association.

In discussing the declaration the question is asked whether Belgium ${ }^{140}$ could not have gone further in the incrimination of organizations, referring to the obligation in article $4 . b^{141}$. Another member of the Committee points to the rules laid down in articles 29 and 30 of the Universal Declaration, which provide the option of restricting fundamental rights ${ }^{142}$. In his answer the Belgian representative indicated that there were options for preventing and prohibiting activities contrary to the public order, at the same time underlining the hesitation in using that legislation ${ }^{143}$.

The Belgian statements were not dealt with by the Committee when discussing the second periodic report in the nineteenth session ${ }^{14}$, or the combined third

138. CERD/C/131/Add.13, par.9-10.

139. CERD/C/SR.890, par.5 (Sadiq Ali).

140. CERD/C/R.85/Add.5.

141. CERD/C/SR.365, par.53 (Dechezelles).

142. CERD/C/SR.365, par.58 (Partsch).

143. CERD/C/SR.366, par.1-2 (Belgium).

144. CERD/C/16/Add.2 and CERD/C/SR.423. 
and fourth report in the twenty-ninth session ${ }^{145}$. Belgium is overdue in reporting, the Committee has yet to receive the fifth through eighth reports ${ }^{146}$.

\section{Fiji}

-To the extent, if any, that any law relating to elections in Fiji may not fulfil the obligations referred to in article $5(\mathrm{c})$, that any law relating to the land in Fiji which prohibits or restricts the alienation of land by the indigenous inhabitant may not fulfil the obligations referred to in article $S(\mathrm{~d})(\mathrm{v})$, or that the school system of Fiji may not fulfil the obligations referred to in articles 2,3 , or $S(e)(v)$, the Government of Fiji reserves the right not to implement the aforementioned provisions of the Convention."

Firstly the Government of Fiji wishes to state its understanding of certain articles in the Convention. It interprets article 4 as requiring a party to the Convention 10 adopt further legislative measures in the fields covered by paragraphs (a). (b) and (c) of that article only in so far as it may consider with due regard to the principles embodied in the Universal Declaration set out in article 5 of the Convention (in particular to freedom of opinion and expression and the right of peaceful assembly and association) that some legislative addition to, or variation of existing law and practice in these fields is necessary for the attainment of the end specified in the earlier part of article 4 . Further, the Government of Fiji interprets the requirement in article 6 concerning 'reparation or satisfaction' as being fulfilled if one or other of these forms of redress is made available and interprets 'satisfaction' as including any form of redress effective to bring the discriminatory conduct to an end. In addition it interprets article 20 and the other related provisions of Part III of the Convention as meaning that if a reservation is not accepted the State making the reservation does not become a Party to the Convention.

The Government of Fiji maintains the view that article 15 is discriminatory in that it establishes a procedure for the receipt of petitions relating 10 dependent territories whilst making no comparable provision for States without such territories.

The initial report of Fiji was very brief and incomplete ${ }^{147}$, but the Committee was forgiving, saying that Fiji was facing many problems in the aftermath of its gaining independence ${ }^{148}$.

In discussing Fiji's second report ${ }^{149}$, Committee-members stressed the need to reconsider the necessity of maintaining the reservation concerning article 5.c in respect of electoral law ${ }^{150}$.

In its third periodic report Fiji itself deals with the reservations maintained at succession $^{151}$, and underlines their necessity ${ }^{152}$. The large number of reservations by Fiji is extensively discussed by the Committee, and the State is urged to withdraw its reservations, or at least to indicate the envisaged duration of the reservations. The Committee is specifically concerned with the Fijian reservation

145.

CERD/C/88/Add.5 and CERD/C/SR.663-665.

146. See $A / 46 / 18$.

147. CERD/C/R.03/Add.1; CERD/C/R.69.

148. CERD/C/SR.185 at 15 (Dayal), 21 (Haastrup).

149. CERD/C/17/Add.2.

150. CERD/C/SR.420, par.53 (Partsch), 56 (Bahnev).

151. CERD/C/G4/Add.4.

152. The report reads:"In particular it is likely, to say the least, that the reservation and declarations will continue to provide some protection as a condition of the succession for Fiji in the considerable future." 
concerning the electoral system in relation to article $5 . \mathrm{c}^{153}$. And it is stressed that inequalities as special measures may, under article 2.2 , only be of limited duration. Concerning the declaration with respect to article 4 , the chairman of the Committee indicated that in the absence of a "more authoritative" interpretation of the Convention by the International Court of Justice, the interpretation by the Committee of the said provision should have prevalence over the State's interpretation $^{154}$.

While listing its reservations at the beginning of its fourth report, Fiji repeated that "the reservation and declarations will continue to provide some protection as a condition of the succession for Fiji in the considerable future"155. The Fijian representative introducing his country's report at the twenty-ninth session, explained that apart from article 5.c, the rest of that provision was protected through the constitution. The reservation concerning article 5.d.v was necessary in view of the land tenure system and the reservation to article 5.e.v could be explained by article 2.2 of the Convention ${ }^{156}$. In its discussion of this Fijian report, the Committee contradicted the opinion of the reporting State that it had sufficiently implemented article 4, and again urged it to legislate along the lines of that provision and withdraw the reservation. Given the efforts in the field of education the Committee felt that the reservation to article 5.e.v was no longer necessary, and the reservation concerning political rights in article 5.c was not covered by article 1.4 of the Convention. There was a general call to review the reservations, which had been made at succession, some ten years earlier ${ }^{157}$. And again there was confusion about accepted reservations considered incompatible by some Committee-members ${ }^{158}$. In his reply the Fiji representative merely dealt with the matter of article 4 in relation to article 5 .

In 1991, the Committee again considered the previous reports of Fiji in its procedure dealing with overdue reports. The rapporteur recalls that doubts had been expressed with respect to the extensive number of reservations made by $\mathrm{Fiji}^{159}$. Another Committee member suggests that Fiji be invited to withdraw the reservations, even if under article 20 CERD the reservations had been accepted. He expresses regret about the way in which the two thirds rule on

153. Committee-member Partsch mentioned that an Indian member of the House of Representatives needed more votes to be elected than a Fijian member, CERD/C/SR.553, par. 12 .

154. CERD/C/SR.553, par.18 (Ingles).

155. CERD/C/89/Add.3

156. In the report it reads "..the comprehensive fundamental rights guarantecd to the individual of any race by the Constitution must be read together with the reservations and declarations, thus purely and simply, in the Fiji context its electoral, land and educational laws and systems cannot be regarded as racial discrimination or a perpetuation thereor".

157. CERD/C/SR.629, par.32 (Karasimeonov).

158. CERD/C/SR.629, par.36 (Ingles), 42 (Shahi), 43 (Houshmand).

159. CERD/C/SR.925, par.64 (Wolfrum). 
incompatibility operates, as it meant that the Fijian reservations that were contrary to the spirit of the convention had been accepted ${ }^{160}$.

\section{France}

With regard to article 4, France wishes to make it clear that it interprets the reference made therein to the principles of the Universal Declaration of Human Rights and to the rights forth in article 5 of the Convention as releasing the States Parties from the obligation to enact anti-discrimination legislation which is incompatible with the freedoms of opinion and expression and of peaceful assembly and association guaranteed by those texts.

With regard to article 6 , France declares that the question of remedy through tribunals is, as far as France is concerned governed by the rules of ordinary law.

With regard to article 15, France's accession to the Convention may not be interpreted as implying any change in its position regarding the resolution mentioned in that provision.

In a reaction to the initial French report ${ }^{161}$, a Committee-member doubted whether the reservation concerning article 6 was really responsive to the requirements of that article ${ }^{162}$. The reservation concerning article 15 was dealt with as a matter of object and purpose of the Convention, with a Committee-member stressing that a difference of opinion on the wording of Resolutions should not keep France from supporting sanctions against Rhodesia or restricting investment in Southern Africa ${ }^{163}$. Importance should be attached to the objectives, rather than the expressions used in the resolutions.

In discussing the second report of France ${ }^{164}$, the only issue dealt with is the interpretative declaration concerning the scope of article 4. Committee-member Partsch praised the French approach as "Roman Legal Elegance", because the declaration took the Universal Declaration of Human Rights into account as well as article 5 of the CERD ${ }^{165}$.

The declarations made by France have not been dealt with subsequently ${ }^{166}$, however the ninth and tenth reports are overdue ${ }^{167}$.

\section{Guyana}

The Government of the Republic of Guyana do not interpret the provisions of this Convention as imposing upon them any obligation going beyond the limits set by the

160. CERD/C/SR.925, par.81 (Ferrero Costa).

161. CERD/C/R.33/Add.6 and CERD/C/R.33/Add.11.

162. CERD/C/SR.207, at 83 (Sayegh).

163. CERD/C/SR.207, at 87 (Lamptey).

164. CERD/C/R.65/Add.11.

165. CERD/C/SR.326 at 120-121 (Partsch).

166. Third report dealt with at the twentieth session; CERD/C/18/Add.3 and CERD/C/SR.438, 439. Fourth report dealt with at the twenty-third session; CERD/C/65/Add.2 and CERD/C/SR.509, 510. Fifth report dealt the twenty-eighth session; CERD/C/90/Add.3 and CERD/C/SR.627, 628. Sixth report dealt with at the thirty-second session; CERD/C/117/Add.2 and CERD/C/SR.732, 733; Eighth report dealt with at the thirtyseventh session CERD/C/148/Add.3 and CERD/SR.832-833.

167. See $A / 46 / 18$ at 14 . 
Constitution of Guyana or imposing upon them any obligation requiring the introduction of judicial processes going beyond those provided under the same Constitution.

Guyana has ratified the Convention in 1977 and its initial report would have been due in 1978. So far, neither the initial report nor the six subsequent reports have been received by the Committee ${ }^{168}$.

\section{Italy}

(a) The positive measures, provided for in article 4 of the Convention and specifically described in sub-paragraphs (a) and (b) of that article, designed to eradicate all incitement to, or acts of, discrimination, are to be interpreted, as that article provides, "with due regard to the principles embodied in the Universal Declaration of Human Rights and the rights expressly set forth in article $5^{n}$ of the Convention. Consequently, the obligations deriving from the aforementioned article 4 are not to jeopardize the right to freedom of opinion and expression and the right to freedom of peaceful assembly and association which are laid down in articles 19 and 20 of the Universal Declaration of Human Rights, were reaffirmed by the General Assembly of the United Nations when it adopted article 19 and 21 of the International Covenant on Civil and Political Rights, and are referred to in articles 5 (d)(viii) and (ix) of the Convention. In fact, the Italian Government, in conformity with the obligations resulting from Article 55 (c) and 56 of the Charter of the United Nations, remains faithful to the principle laid down in article $29(2)$ of the Universal Declaration, which provides that "in the exercise of his rights and freedoms, everyone shall be subject only to such limitations as are determined by law solely for the purpose of securing due recognition and respect for the rights and freedoms of others and of meeting the just requirements of morality, public order and the general welfare in a democratic society.

(b) Effective remedies against acts of racial discrimination which violate his individual rights and fundamental freedoms will be assured to everyone. in conformity with article 6 of the Convention, by the ordinary courts in the framework of their respective jurisdiction. Claims for reparation for any damage suffered as a result of acts of racial discrimination must be brought against the persons responsible for the malicious or criminal act which caused such damage.

The only matter dealt with by the Committee in its sixteenth session is the socalled "reservation" in Italy's declaration under article $14^{169}$. The reason behind such a "reservation" was explained both by the Italian representative presenting the first report and by a Committee-member'to.

The interpretative declaration concerning article 4 and 6 were reaffirmed in its second report ${ }^{17}$, which stressed the availability of ordinary courts for obtaining the redress mentioned in article 6 , and underlined the absence of a necessity to legislate on the basis of article 4 given the fact that racial discrimination was virtually absent in Italy. Discussions in the Committee's twenty-first session

168. A/46/18, at 8 .

169. To the extent that the matter complained about is not already dealt with in another international procedure. See for a discussion par.1.3 supra; ef. the decision of the Committee of Ministers of the Council of Europe decision mentioned in 13 YbECHR 1970, 70-77.

CERD/C/R.95/Add.1 and CERD/C/SR.346, par.40 (Sayegh).

170. CERD/C/SR.347, par.26 (Italy), 29 (Partsch).

171. CERD/C/46/Add.1, at 7,9-10. 
focused on the "reservation" in Italy's declaration on the basis of article $14^{172}$. There was concern about the availability of this procedure, and it was stressed that the "reservation" added the extra requirement of the matter not being dealt with by any other international supervisory organ. The reservation was unnecessary restrictive. The Italian representative indicated that the reservation followed the recommendation of the Council of Europe and underlined that very few states had up until then made the declaration according to article $14^{173}$.

At the twenty-ninth session a small remark was made about a provision in Italian law dealing with the implementation of article $4^{174}$.

The sixth periodic report by Italy does not provide any new information about the implementation of articles 4 and 6 CERD $^{175}$, and the combined seventh and eighth report does not contain any specific information either ${ }^{176}$. The reservations are not discussed by the Committee ${ }^{177}$.

\section{Jamaica}

The Constitution of Jamaica entrenches and guarantees to every person in Jamaica the fundamental rights and freedoms of the individual irrespective of his race or place of origin. The Constitution preseribes judicial processes to be observed in the event of the violation of any of these rights whether by the State or by a private individual. Ratification of the Convention by Jamaica does not imply the acceptance of obligations going beyond the constitutional limits nor the acceptance of any obligations to introduce judicial processes beyond those prescribed under the Constitution."

In the discussion of the initial report ${ }^{178}$ by Jamaica, its reservation regarding the prevalence of the national constitution led to serious debate among Committeemembers. A need for more detailed information concerning the provisions of the Convention affected by the reservation was felt. Did it cover the obligations in articles 2.1.c and $4^{170}$ ? It was noted that the constitution seemed to allow for discriminatory practices that would otherwise be prohibited by the Convention, in spite of the statement that human rights are guaranteed in Jamaica ${ }^{180}$. The question was raised as to whether the reservation only referred to the present constitution or also to future constitutions ${ }^{181}$. Members were curious about the reason for making such a general reservation ${ }^{182}$. and urged Jamaica to withdraw $i t^{183}$. The most remarkable statement in the discussion was that of Committeemember Ingles: "..although the reservation had met with no objections from States

173. CERD/C/SR.458, par.o (Italy).

174. CERD/C/104/Add.2; CERD/C/SR.671. par.26 (Partsch).

175. CERD/C/156/Add.1, par.27, 39.

176. CERD/C/182/Add 2.

177. CERD/C/SR.880, par.1-53.

178. CERD/C/R.33/Add.9.

179. CERD/C/SR.178, at 72 (Dayal, Lamptey).

180. CERD/C/SR.178 at 66 (Valencia Rodriguez). 67 (Warzazi) and at 74 (Ingles).

181. CERD/C/SR.178, at 73 (Kapteyn).

182. CERD/C/SR.178, at 67 (Valencia Rodriguez) and at 73 (Haastrup).

183. CERD/C/SR.176 at 67 (Valencia Rodriguez, Warzazi). 
Parties under article 20 paragraph 2, of the Convention and could therefore be considered as satisfactory to them as not being incompatible with the Convention, the Committee had a dury to examine whether Jamaica was in fact complying with its obligations under the Convention ${ }^{n 184}$.

The representative of Jamaica answered the questions raised. The prevalence of the constitution over international law is a rule of Jamaican law, and the reservation was intended to guarantee this with respect to the CERD ${ }^{185}$. In clarifying the scope of the reservation, the representative implied that article 4 was not affected as it was amply covered by the constitution ${ }^{186}$. The reservation did not prevent Jamaica from eliminating racial discrimination in the country, since there was none.

In its thirteenth session the Committee stressed that the reservation should not undermine the mandatory nature of articles $4 . a$ and $4 . b^{187}$. Committee-member Ingles underlined that "it was for the Committee to determine whether the provisions of the constitution of that country were compatible with the Convention ${ }^{\text {1128. }}$. This line of reasoning can of course only be followed if the statement were an interpretative declaration. Again, the Committee did not seem to have access to the constitution referred to ${ }^{189}$. The Jamaican representative presenting the second periodic report ${ }^{190}$ maintained that the reservation "in no sense prevented.. from complying with the provisions of the Convention"19!

In its third report Jamaica stressed that "the reservation is certainly not designed to weaken the Convention"192. The Committee was intrigued by this statement and wondered in what respect the Convention and the constitution were inconsistent. Examples were requested of obligations in the Convention not covered by the constitution ${ }^{193}$. There was confusion about the acceptability of the reservation. Some members suggested that it is merely a declaration ${ }^{194}$, though other Committee-members emphasized that the reservation had already been accepted $^{195}$. The fact that the reservations of the Bahamas and Barbados were quite similar to the Jamaican reservation was mentioned, and it was supposed that the reservation was the consequence of extreme caution on the part of the reserving State.

184. CERD/C/SR.176 at 74 (Ingles).

185. CERD/C/SR.178 at 74-75 (Jamaica).

186. CERD/C/SR 179 at 76 (Jamaica).

187. CERD/C/SR.274 at 81 (Valencia Rodriguez.).

188. CERD/C/SR.274 at 81 (Ingles).

189. CERD/C/SR274 at 82 (Ingles), 83 (Partsch) and 85 (Sayegh).

190. CERD/C/R.65/Add.6 and CERD/C/R.69/Add.6.

191. CERD/C/SR.274, at 84 (Jamaica).

192. CERD $/ \mathrm{C} / 23$, at 2.

193. CERD/C/SR.386, par.2 (Nabavi), 6 (Vatencia Rodriguez), 22 (Hollist), 27 (Nettel).

194. CERD/C/SR.386, par.12 (Sayegh), 24 ((Videla Escada); CERD/C/SR.387, par.7 (Lamptey).

195. CERD/C/SR.386, par.27 (Nettel). 29 (Bahnev); CERD/C/SR.387, par.2 (Devetak). Committee-member Goudiam even suggests attracting the attention of the States Parties to the Jamaican reservation in relation to article 20.2 CERD, clearly ignoring the content of article 20.1 CERD, CERD/C/SR 386, par.15. 
In his reply the Jamaican representative underlined his country's adherence to the basic obligation to eliminate racial discrimination, which explained why the reservation was not meant to weaken the Convention. He stated that the implementation of article 4 was restricted by section 25 of the Jamaican constitution, whereas there was no constitutional obligation to act upon the rights laid down in article $5^{196}$.

In the fourth periodic report by Jamaica ${ }^{197}$ its reservations are not explicitly dealt with. It was however indicated that the Jamaican Government was giving consideration to the observations made by the Committee at its consideration of the prior report. In the discussions during the twenty-first session of the Committee the task of reconsidering the reservation and consequently reviewing the constitution was considered a difficult one, though some Committee-members asked whether the Convention had become part of domestic law of Jamaica ${ }^{198}$. The introduction to the combined fifth, sixth and seventh report by Jamaica ${ }^{199}$ elaborated on the content of the Jamaican constitution, and indicated that in spite of the conviction that it provided sufficient protection against racial discrimination, the Government has decided that a law specifically implementing article 4 should be enacted. After that the reservation would be withdrawn. The intention to enact legislation on the basis of article 4 was praised by the Committee in its thirty-second session ${ }^{200}$. Jamaica is overdue on its eighth through tenth reports ${ }^{201}$.

\section{Malta}

"The Government of Malta wishes to state its understanding of certain articles in the Convention.

"It interprets article 4 as requiring a party to the Convention to adopt further measures in the fields covered by sub-paragraphs (a), (b) and (c) of that article should it consider, with due regard to the principles embodied in the Universal Declaration of Human Rights and the rights set forth in article 5 of the Convention, that the need arises to enact 'ad hoc' legislation, in addition to or variation of existing law and practice to bring to an end any act of racial discrimination.

"Further, the Government of Malta interprets the requirements in articie 6 concerning 'reparation or satisfaction' as being fulfilled if one or other of these forms of redress is made available and interprets 'satisfaction' as including any form of redress effective to bring the discriminatory conduct to an end."

Though the Committee emphasizes that article 4 is mandatory, there is hardly any discussion in the eighth session about Malta's interpretation ${ }^{2 / 2}$. In the thirteenth

197. CERD/C/18/Add 8 .

198. CERD/C/SR.463, par.8 (Dechezelles), 11 (Ordonez).

199. CERD/C/117/Add.4.

200. CERD/C/SR 741, par.54 (Cremona). 58 (Sherilis), 60 (Yutzis), 63 (Song); CERD/C/SR.742, par.2 (Cicanovic), 3 (Shahi). 5 (Sadiq Ali), 12 (Partsch), 13 (Karasimeonov).

201. See $A / 46 / 18$ at 12 .

202. CERD/C/R.33/Add.8 and CERD/C/SR.154, 155. 
session the Committe does again not deal with the declarations concerning articles 4 and 6 made by Malta ${ }^{\text {no3 }}$.

In the discussion about the third periodic report of Malta ${ }^{304}$, it was asked whether the declaration concerning article 4 is a reservation or not. If the latter is the case, then there is need to adopt the legislative measures as provided for in article 4. In his reply the representative of Malta at the twenty-fifth session does not deal with the absence of article 4 legislation ${ }^{305}$.

The declaration was barely dealt with in subsequent sessions ${ }^{206}$. The seventh periodic report of Malta reiterates the reservations made at ratification, stressing that legislation could be made should the need arise $e^{2 n 7}$.

In the combined eighth and ninth report, Malta indicates that there is little to add with respect to articles 4 and 6 CERD $^{3 \times}$. In his introduction to the report. the rapporteur mentions that a difference of opinion with respect to the mandatory nature of article 4 remained between Malta and the Committee ${ }^{-n 9}$, a view which is reinforced by other Committee members ${ }^{210}$. The Maltese representative said he had nothing to add to the views expressed in the report ${ }^{21}$, and points at the fact that Malta had not been the only State to make a reservation to article 4.

\section{Nepal}

The Constitution of Nepal contains provisions for the protection of individual rights, including the right to freedom of speech and expression, the right to form trade unions and associations not motivated by party politics and the right to freedom of professing his/her own religion; and nothing in the Convention shall be deemed to require or to authorize legislation or other action by Nepal incompatible with the provisions of the Constitution of Nepal.

"His Majesty's Government interprets article 4 of the said Convention as requiring a Party to the Convention to adopt further legislative measures in the fields covered by 2sub-paragraphs (a), (b) and (c) of that article only in so far as His Majesty' Government may consider, with due regard to the principles embodied in the Universal Declaration of Human Rights, that some legislative addition to, or variation of existing law and practice in those fields is necessary for the attainment of the end specified in the earlier part of article 4.

"His Majesty' Government interprets the requirements in article 6 concerning 'reparation or satisfaction' as being fulfilled if one or other of these forms of redress is made available; and further interprets 'satisfaction' as including any form of redress effective to bring the discriminatory conduct to an end."

203. CERD/C/R.65/Add.10 and CERD/C/SR.288; the report by Malta mainly contained additional information dealing with article 7 to which no reservations had been made.

204. CERD/C/65/Add5; CERD/C/SR 552, par.26 (Ingles).

205. CERD/C/SR.552, par.29-36 (Malıa).

206. CERD/C/90/Add.8, 9, 11 and CERD/C/SR.632.

207. CERD/C/117/Add.6, par.6-7.

208. CERD/C/171/Add.2, par. 16-19, par.21

209. CERD/C/SR.897, par.43 (Vidas).

210. CERD/C/SR.897, par.46 (Banton), par.49 (Yutzis), par.51 (Ferrero Costa).

211. CERD/C/SR.897, par.52 (Malta). 
Though the Committee, at its eighth session, felt that more information about the application of articles 4 and 6 in relation to the Nepalese constitution might be welcome. the first report ${ }^{212}$ was generally considered to be satisfactory. The reservations made were not explicitly dealt with ${ }^{2 ! 3}$.

The third report by Nepal ${ }^{1 / 4}$ was limited to information about the provisions to which no reservations or declarations had been attached. In the discussion the chairman indicates that Nepal had only made one reservation dealing with article 22, taking the declaration concerning the constitution to be an interpretation. The other statements were also considered to be interpretations and the wish was expressed that Nepal would soon enact legislation satisfying the requirements of article $4^{215}$.

In its fourth report Nepal repeated its reservations regarding article 4 and its constitution $^{216}$. The Committee suggested that Nepal should withdraw its reservations, and stressed the need for legislation implementing article 4 . It was after all for the Committee to decide whether the protection afforded in Nepal was sufficient on the basis of the CERD, and not merely up to the Nepaltse Government $t^{217}$.

The combined sixth till eighth report of Nepal mentions the reservation concerning article 4, and indicates that the consideration that Nepalese legislation is sufficient is at the origin of the reservation ${ }^{218}$. This same view is expressed in the general reservation referring to the Nepalese Constitution ${ }^{19}$. The declaration with respect to article 6 is not mentioned. Committee nembers expressed regrets about the reservations made, and wondered whether they were reservations stricro sensu or interpretative declarations ${ }^{3}$. The representative from Nepal indicates that he will refer the issue of the withdrawal of the reservation to article 4 to the Government ${ }^{221}$.

\section{Papua New Guinea}

The Government of Papua New Guinea interprets article 4 of the Convention as requiring a party to the Convention to adopt further legislative measures in the fields covered by subparagraphs (a), (b) and (c) of that Article only in so far as it may consider with due regard to the principles embodied in the Universal Declaration set out in article 5 of the Convention that some legislative addition to, or variation of existing law and practice in these fields is necessary to give effect to the provisions of

\section{CERD/C/R.33/Add.7 and CERD/C/SR.154.}

213. The Nepalese reservations were not subject to discussions for the Committee in its tenth session; CERD/C/R.65/Add.2 and CERD/C/SR.210 at 109-114. In the discussion about the second periodic report the reservations and declarations were not dealt with either; CERD/C/R.88/Add.10 and CERD/C/SR.366.

214. CERD/C/65/Add.6.

215. CERD/C/SR.553, par.41-44 (Ingles)

216. CERD/C/148/Add.1.

217. CERD/C/SR.787, par.8 (Braunschweig), par.9 (Aboul Nasr), par.12 (Partsch).

218. CERD/C/148/Add.1, par.6-7.

219. CERD/C/148/Add.1, par.8-9.

220. CERD/C/SR.787, par.8 (Braunschweig); par.9 (Aboul Nasr); par. 12 (Partsch).

221. CERD/C/SR.787, par.24 (Nepal). 
article 4. In addition, the Constitution of Papua New Guinea guarantees certain fundamental rights and freedoms to all persons irrespective of their race or place of origin. The Constitution also provides for judicial protection of these rights and freedoms. Acceptance of this Convention does not therefore indicate the acceptance of obligations by the Government of Papua New Guinea going beyond those provided by the Constitution, nor does it indicate the acceptance of any obligations to introduce judicial process beyond that provided by the Constitution."

In the New Guinean initial report ${ }^{22}$ the declaration regarding article 4 is labelled a reservation, and there is an explanation about the rights protected in the constitution, maintaining the reservation dealing with its primordial role. The Committee stressed that, in spite of assurances from the State that no racial discrimination existed, there was still an obligation to legislate on the basis of article 4. Papua New Guinea was urged to withdraw the reservation, and if discrimination does not exist there would seem to be no reason for maintaining $\mathrm{it}^{223}$.

The second till fifth report of Papua New Guinea are overdue ${ }^{224}$.

\section{Tonga}

Reservations

To the extent, if any, that any law relating to elections in Tonga may not fulfil the obligations referred to in article 5.c [withdrawn 28 October 1977), that any law relating to land in Tonga which prohibits or restricts the alienation of land by the indigenous inhabitants may not fulfil the obligations referred to in article $5(\mathrm{~d})(\mathrm{v})$, or that the school system of Tonga may not fulfil the obligations referred to in articles 2, 3, or 5.e.v [withdrawn 28 October 1977], the Kingdom of Tonga reserves the right not to apply the Convention to Tonga."

Declarations

"Secondly the Kingdom of Tonga wishes to state its understanding of certain articles in the Convention. It interprets article 4 as requiring a party to the Convention to adopt further legislative measures in the fields covered by sub-paragraphs (a), (b) and (c) of that article only in so far as it may consider with due regard to the principles embodied in the Universal Declaration set out in article 5 of the Convention (in particular to freedom of opinion and expression and the right of peaceful assembly and association) that some legislative addition to, or variation of existing law and practice in these fields is necessary for the attainment of the end specified in the earlier part of article 4. Further, the Kingdom of Tonga interprets the requirement in article 6 concerning 'reparation or satisfaction' as being fulfilled if one or other of these forms of redress is made available and interprets 'satisfaction' as including any form of redress effective to bring the discriminatory conduct to an end.

In addition it interprets article 20 and the other related provisions of Part III of the Convention as meaning that if a reservation is not accepted the State making the reservation does not become a Party to the Convention."

"Lastly the Kingdom of Tonga maintains its position in regard to article 15. In its view this article is discriminatory in that it establishes a procedure for the receipt of petitions relating to dependent territories whilst making no comparable provision for States without such territories. Moreover. the article purports to establish a procedure applicable to dependent territories of States whether or not those States have become 
parties to the Convention. His Majesty's Government have decided that the Kingdom of Tonga should accede to the Convention, these objections notwithstanding because of the importance they attach to the Convention as a whole."

The reservations Tonga made 225 did not seem to be known to the Committeemembers who, during the eighth session, complained about the availability of information on the reservations ${ }^{226}$. A procedural discussion on the role of the UN Secretariat in preparing a document for the Committee containing the reservations followed, passing over the substance of the Tongolese reservations. The remarkable statement by Committee-member Sayegh that ".. the Committee was not bound by such reservations, the report of the State Party concerned might be affected by them ${ }^{\text {2227 }}$ was not discussed.

Discussions about the report of Tonga ${ }^{228}$ in the ninth session were fragmental, mainly because the initial report had been incomplete ${ }^{229}$ and the additional report was not any better. The large number of reservations made by Tonga seemed to suggest that the country was fully aware of the content of the CERD, and reservations should temper the Committee's approach ${ }^{230}$. At the same time the question was raised as to whether Tonga had made a declaration or a reservation, and what the legal effect of a declaration would be $e^{231}$. It is quite remarkable that the representative of the UN Secretariat indicates which parts of the statement are considered a reservation, and which parts a declaration ${ }^{232}$.

The second periodic report of Tonga ${ }^{233}$ was dealt with by the Committee in an elaborate manner. As Committee-member Sayegh quite aptly states:"..the Kingdom of Tonga, despite its small population, was the State which formulated the largest number of reservations, observations and objections relating to the Convention." 234 There is still uncertainty about the status of the various statements made by Tonga. Though the information provided by the UN Secretariat distinguishes between reservations and declarations, Tonga in its report relies on a reservation concerning article 4 , published as a declaration ${ }^{235}$. This led to confusion about the classification of the statement $t^{36}$, and clarification on the

225.

226.

227.

228.

229.

230.

231.

232.

233.

234.

235.

236.
CERD/C:R.50/Add.1 and CERD/C/SR.156.

CERD/C/SR.156, at 132 (Tómko), 133 (Sayegh), 134 (Haastrup, Partsch), 135 (MacDonald).

CERD/C/SR.156 at 133 (Sayegh).

CERD/C/R.50/Add.1 and CERD/C/R.50/Add.10.

CERD/C/R.50/Add.1, dealt with supra.

CERD/C/SR.194 at 120 (Partsch).

CERD/C/SR. 194 at 124 (Aboul-Nasr).

CERD/C/SR.194 at 124, referring to CERD/C/R.72. The Secretariat had left that distinction to be determined by the States Parties, after the Genocide affaire and the India-IMCO question; see Chapter 2, par.1.3 supra. The determination by a member of the Secretariat would seem to exceed the authority of a civil servant.

CERD/C/5.

CERD/C/SR.278 at 121 (Sayegh), on the same issue: CERD/C/SR.278 at 125 (Blishchenko).

CERD/C/5 par.13.

CERD/C/SR.277 at 119 (Valencia Rodrigues), 120 (Partsch): CERD/C/SR.278 at 121

(Sayegh), 124 (Nabavi, Ingles), 127 (Dayal), 128 (Lamptey) and 129 (Warzazi). 
part of both the depository and the State was needed ${ }^{237}$. It was stressed that Tonga should take into account that the Committee considered the United Kingdom's statement with respect to article 4 unacceptable ${ }^{238}$. Furthermore there is discussion about the scope of the reservation to article 5 , and the necessity of making such a reservation ${ }^{239}$. It was felt that reservations to article 2 and 3 in respect of the educational system were probably unnecessary given the information provided in the report ${ }^{240}$. A Committee-member wonders why Tonga referred to article 20 in a declaration ${ }^{261}$, and members complained about the non-availability of the legislation referred to in the report ${ }^{242}$. Finally it was suggested all reservations and declarations be reconsidered ${ }^{243}$.

On 27 October 1977 Tonga had withdrawn part of its reservations. In the consideration of the third periodic report by Tonga ${ }^{24}$, members of the Committee praised the State for the withdrawal of the reservations concerning articles 5.c and 2,3 and 5.e. $\mathrm{v}^{245}$; without discussing the remaining reservations.

The discussion of the fourth report did not take place in the presence of a representative of that State ${ }^{246}$. There was discussion of the fact that the Tongan interpretation of article 4 left the determination of the necessity to legislate to the State itself, which was too subjective in the eyes of the Committe ${ }^{247}$, and contrary to the obligation in article 29 of the Universal Declaration. The need to enact legislation implementing article 4 was again stressed.

In subsequent sessions the reservations were barely dealt with ${ }^{248}$. The eighth report by Tonga was strikingly brief and did not mention the reservations made $^{249}$. In their consideration of the report, the Committee expressed concern about the implementation of article $4 \mathrm{CERD}^{250}$. As no representative from Tonga is present, these remarks were not contradicted.

\section{United Kingdom}

"Firstly, in the present circumstances deriving from the usurpation of power in Rhodesia by the illegal regime, the United Kingdom must sign subject to a reservation of the right not to apply the Convention to Rhodesia unless and until the United Kingdom informs the Secretary General of the United Nations that it is in a position to ensure that the

237. CERD/C/SR.277 at 120 (Partsch).

238. CERD/C/SR.278 at 127 (Dayal).

239. CERD/C/SR.277 at 119 (Valencia Rodrigues); SR.278 at 125 (Blishchenko) and 127 (Dayal).

240. CERD/C/SR.278 at 127 (Dayal) and 128 (Lamptey).

241. CERD/C/SR.278 at 124 (Nabavi).

242. CERD/C/SR.278 at 125 (Blishchenko), 126 (Brin Martinez) and 129 (Nabavi).

243. CERD/C/SR.278 at 125 (Blishchenko).

244. CERD/C/30.

245. CERD/C/SR.393, par.23 (Partsch), 24 (Valencia Rodriguez).

246. CERD/C/75/Add.3.

247. CERD/C/SR.551, par.3, 7, 8 (Partsch) and 22 (Bahnev), 24 (Ingles).

248. CERD/C/106/Add.5 and CERD/C/SR.656; CERD/C/131/Add.1 and CERD/C/SR.728; CERD/C/158/Add.5 and CERD/C/SR.838.

249. CERD/C/158/Add.5.

250. CERD/C/SR.838, par.22 (Yutzis), par.24 (Partsch), par.28 (Lamptey). 
obligations imposed by the Convention in respect of that territory can be fully implemented."

"Secondly, the United Kingdom wishes to state its understanding of certain articles in the Convention. It interprets article 4 as requiring a party to the Convention to adopt further legislative measures in the fields covered by sub-paragraphs (a), (b) and (c) of that article only in so far as it may consider with due regard to the principles embodied in the Universal Declaration set out in article $S$ of the Convention (in particular to freedom of opinion and expression and the right of peaceful assembly and association) that some legislative addition to, or variation of existing law and practice in these fields is necessary for the attainment of the end specified in the earlier part of article 4. Further, the United Kingdom interprets the requirement in article 6 concerning 'reparation or satisfaction' as being fulfilled if one or other of these forms of redress is made available and interprets 'satisfaction' as including any form of redress effective to bring the discriminatory conduct to an end. In addition it interprets article 20 and the other related provisions of Part IIl of the Convention as meaning that if a reservation is not accepted the State making the reservation does not become a Party to the Convention."

"Lastly the United Kingdom maintains its position in regard to article 15. In its view this article is discriminatory in that it establishes a procedure for the receipt of petitions relating to dependent territories whilst making no comparable provision for States without such territories. Moreover, the article purports to establish a procedure applicable to dependent territories of States whether or not those States have become parties to the Convention. Her Majesty's Government have decided that the United Kingdom should sign the Convention, these objections notwithstanding. because of the importance they attach to the Convention as a whole."

"[..] the United Kingdom does not regard the Commonwealı Immigrants Acts, 1962 and 1968 , or their application, as involving any racial discrimination within the meaning of paragraph 1 of article 1 , or any other provision of the Convention, and fully reserves its right to continue to apply those Acts."

"Lastly, to the extent if any, that any law relating to election in Fiji may not fulfil the obligations referred to in article 5 (c), that any law relating to land in Fiji which prohibits or restricts the alienation of land by the indigenous inhabitants may not fulfil the obligations referred to in article 5 (d) (v), or that the school system of Fiji may not fulfil the obligations referred to in articles 2,3 or 5 (c) (v), the United Kingdom reserves the right not to apply the Convention to Fiji."

In the eighth Committee-meeting attention focused on the interpretative declaration concerning article 4 , the reservation concerning Rhodesia and the question of the reporting obligation for dependent territories in view of articles 9 and 15 of the Convention, considering the reservation made to article $15^{51}$. There is a notable difference of opinion on the extent to which the Committee is empowered to deal with reservations. While Partsch thought the Committee should take the reservations into account ${ }^{32}$. Sayegh "maintained the position that reservations by a State Party or several States Parties to the Convention were not binding upon the Committce when it made its own interpretation of provisions" 253 . It should be noted that these opinions are not necessarily contradictions, as the Committee may very well establish its own interpretation, but will evidently have to take into account the reservation made in its dialogue with the reserving State. 
On the other hand, Committee-members pledged some restraints, implying that the Committee should accept the reservation as it stoof ${ }^{54}$.

The deliberations in the Committee focused on different aspects of the article 4 reservation. There was discussion about the conformity of certain sections of the Race Relations Act 1965 with article 4 in conjunction with the reservation ${ }^{25 s}$. The question was whether the restrictions in the Race Relations Act were adequately covered by the reservation or whether the restrictions in the Race Relations Act went further than provided for in the reservation ${ }^{256}$. In that respect the discussion as hampered by the fact that Committee-members had not established an interpretation of article 4 themselves ${ }^{257}$. In the eyes of Committee-member Sayegh there were two questions in this respect: first, does article 4 make legislation compulsory, and secondly were there limits on the obligation to outlaw racism ${ }^{288}$. The representative of the United Kingdom was unfortunately not in a position to reply to these specific questions ${ }^{259}$.

The reservation concerning the applicability of the Convention in Rhodesia was discussed by Committee-member Haastrup who underlined that the seizure of power was illegal and that the United Kingdom should still be considered responsible for the application of the Convention in that particular territory ${ }^{260}$. The reservation would seem to be practical as much as it indicates that it is beyond the State party's influence to guarantee the observance of the Convention in Rhodesia ${ }^{261}$.

The third issue deals with the obligation to report about the implementation of the Convention in dependent territories. The reporting obligations under article 9 of the CERD do extend to dependent territories, and such information might be dealt with under article 15 if not under article 9. The power of the Committee under article 15 could not be restricted by reservations, according to Committeemember Partsch ${ }^{262}$. He was probably hinting at the question of whether this provision created rights and obligations for the States Parties or merely provided the Committee with the authority to deal with such petitions.

The Chairman opened the discussion of the second periodic report ${ }^{263}$ by questioning the validity of the United Kingdom's statement regarding article 4 . He suggested that the interpretation could not be a valid reservation as it had not been classified as such by the Secretariat. If it was meant to be a reservation, the United Kingdom should have acted in accordance with article 20 and should have made a formal reservation ${ }^{2 k 4}$. Committee-member Kapteyn takes a more

254. CERD/C/SR.158 at 158 (Haastrup, MacDonald).

255. CERD/C/SR.157 at 152 (Dayal).

256. CERD/C/SR.156 at 139 (Sayegh).

257. CERD/C/SR.157 at 148 (Ingles).

258. CERD/C/SR.156 at 139 (Sayegh): CERD/C/SR.158 at 159 (Sayegh).

259. CERD/C/SR.158 at 159 (United Kingdom).

260. CERD/C/SR. 156 at 136 (Haastrup).

261. As emphasized by the British representative, CERD/C/SR. 158 at 163.

262. CERD/C/SR.157 at 151 (Partsch).

263. CERD/C/R.70/Add.34.

264. CERD/C/SR.248 at 14 (Haastrup). 
balanced approach, considering it a "non-binding statement expressing a legal

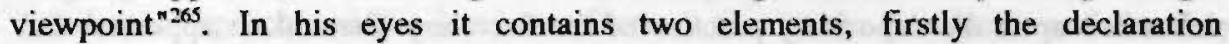
repeats what has already been said in the opening paragraph of the provision itself: the elimination of racial discrimination should not completely curtail the freedom of association or the freedom of expression. The second element of the declaration, the suggestion that it is for the United Kingdom to determine the scope of article 4, was worrying. This could only be the case if the United Kingdom had made a formal reservation, which it did had not ${ }^{206}$. Kapteyn's opinion is seconded by Sayegh, who however feels that the United Kingdom should clarify its position concerning the legal nature of the statement ${ }^{26}$. Committee-member Valencia Rodriguez drew the attention to article 2.1.d of the Vienna Convention on the Law of Treaties, emphasizing that the intention of the state is of decisive importance. Hence it is necessary to establish if the statement concerning article 4 was meant to modify the legal effect of the provision. If that was the case it would be a reservation and the Committee would not have the competence to deal with the matter ${ }^{268}$. Committee-member Ortiz Martin took the statement to be an interpretative declaration and thought it was up to the Committee to interpret the Convention, not to the States Parties ${ }^{269}$. Kapteyn, in a later session endorsed the request of Committee-member MacDonald to ask the United Kingdom for a clarification as regards its position with respect to the statement ${ }^{270}$. Aboul-Nasr seemed to differ with his colleagues on the extent of the Committee's power to interpret the Convention ${ }^{271}$ and suggested bringing the matter of the British statement before the Court of Justice ${ }^{272}$.

265. CERD/C/SR.248 at 15 (Kapteyn).

266. Kapteyn eloquently makes short work of the British declaration:"The second element in the United Kingdom's interpretative statement, ..., which maintained that the exclusive right to determine the scope of the obligations under article 4 rested with each State party, was both dangerous and disturbing. and, morecover. would be true only if the United Kingdom had made a formal reservation and not just an interpretative. statement. In the absence of a formal reservation, it rested with the Committec rather than the United Kingdom Government to determine whether or not a State party..... was fulfiliing its obligations under article 4 . Unless and until the interpretation of the scope: of those obligations had been the subject of a decision by the International Court of Justice under article 22 of the Convention or of an advisory opinion of the Court requested by the General Assembly, the Committec, as the guardian of the Convention, was fully competent to interpret and apply the Concntion. In so doing, the Committee had the duty to allow States parties a measure of discretion so as to enable them to take into account their legal and cultural traditions..." CERD/C/SR.248 at 15.

267. CERD/C/SR.248 at 17 (Sayegh).

268. CERD/C/SR.248 at 19 (Valencia Rodriguez).

269. CERD/C/SR.249 at 30 (Ortiz Martin).

270. CERD/C/SR.249 at 31 (Kapteyn).

271. CERD/C/SR.249 at 31 (Aboul-Nasr).

272. It should be noted that according to article 22 CERD. only disputes between States Parties can be brought before the Court. The other option would be the request for an Advisory Opinion on the grounds of article 96 of the UN Charter, hut that requires the involvement of either the Security Council or the General Assembly. given the fact that 
At the twelfth session, the deputy director of the Division of Human Rights elaborated upon the depository practice of the Secretary General. It appeared that States did not follow a very consistent practice with regard to the labelling of their statements. Some declarations proved to be reservations and vice versa; if doubt arose the Secretary General sought further clarification from the State concerned $^{273}$. In reply to a question by Valencia Rodriguez, the deputy director indicated that only the reservation concerning Rhodesia had been circulated in accordance with article 20 , implying that the statement concerning article 4 had not been deemed a reservation ${ }^{274}$.

In replying to the remarks made by the Committee-members, the United Kingdom representative skilfully evaded reference to the declarations made, merely dealing with issues that had occurred under the Race Relations Act $1968^{275}$.

In the discussions of the fourth periodic report by the United Kingdom ${ }^{276}$ all attention was devoted to the declaration concerning article 4, and the assumption that the State was free to decide upon the necessity to legislate. Committeemember Partsch elaborated on a distinction he had made before ${ }^{277}$ and indicated that there were three groups of statements concerning article 4. Firstly there was the reservation by the United Kingdom to the extent that article 4 would only be applied as far as it was compatible with national legislation ${ }^{27}$. A second group consists of "objective interpretative statements" in which Governments stated that they would enact legislation so far as it was compatible with the Universal Declaration on Human Rights, amongst them the declarations by Austria, France and Italy. The United Kingdom's declaration was labelled a subjective reservation, in which the adoption of legislation is depending on considerations of necessity relating to the Universal Declaration and article 5 of the Convention. The issue, in the eyes of Partsch, is whether a subjective reservation could be made in the form of an interpretative statement. Or, in other words, was the statement in fact a reservation, and could it be formulated as an interpretative declaration?

In spite of the elaborate discussion the United Kingdom representative did not feel tempted to give his point of view. The whole issue was ignored in his reply ${ }^{279}$.

In the discussion in the eighteenth session about the fifth periodic report of the United Kingdom ${ }^{200}$, all attention was devoted to the declaration concerning article 4. A Committee-member asked how the United Kingdom felt about

272.(...continued)

the Committee does not belong to the group of organs mentioned in article 96 paragraph 2.

273. CERD/C/SR.249 at 31-32 (Das).

274. CERD/C/SR.249 at 32 (Das).

275. CERD/C/SR.249, at 33-36 (United Kingdom).

276. CERD/C/R.90/Add.30.

277. CERD/C/SR.348, par.49 (Partsch).

278. A reservation upon signature, the United States have so far not ratified the CERD.

279. CERD/C/SR.349, par.8-19.

280. CERD/C/20/Add.17 and CERD/C/20/Add.26. 
banning Nazi organisations, indicating that there was a conflict between the freedom of speech and the freedom of association on the one hand, and the duty to combat racism on the other hand. In his reply, the United Kingdom representative qualified the declaratory statement concerning article 4 as being a reservation, which consequently led to a discussion about the qualification of all the statements made by the United Kingdom. There was uncertainty about the relevance of the qualification of a particular statement in relation to its legal effect $^{281}$.

In its repor ${ }^{322}$ the United Kingdom explicitly dealt with the issue of incitement to racial hatred in response to earlier questions by the Committee. It elaborated on the functioning of the 1976 Race Relations Act, though the reservations to article 4 were not mentioned. The Committee noticed that the United Kingdom was reviewing the Public Order Act 1936 with a view to reconciling the freedom of expression with the obligations under the Convention, and the hope was expressed that the views of the Committee would be taken into account. The Committee maintained an opinion different from the United Kingdom on the interpretation of article $4 . b^{233}$. In his reply the United Kingdom representative stressed that his Government felt that the issue of incitement should be solved through free debate ${ }^{384}$.

In discussing the sixth report of the United Kingdom ${ }^{285}$ in its twenty-seventh session, the issue of the prohibition of racist organizations according to article 4 was again taken up by the Committee. The Chairman suggested that the delay in revising the Race Relations Act and the Public Order Act in order to bring them into conformity with article $4 . \mathrm{b}$ might be related to the British interpretative declaration on article 4 . The Committee maintained that article 4 was not discretionary but mandatory. The representative of the United Kingdom held that the interpretative declaration was based on the fact that the right already existed in common law, and the United Kingdom did not want to be obliged to legislate ${ }^{286}$.

The eighth report mentions with respect to article 4 that the Public Order Act 1936 was under review, while indicating implicitly why legislation in accordance with article 4 CERD had not been made ${ }^{237}$. The reservations are not mentioned, and with respect to article 6 available remedies are only dealt with briefly $y^{3 \bar{k}}$.

The introduction to the ninth periodical report of the United Kingdom indicates that legislation with respect to incitement to racial hatred will be reinforced ${ }^{289}$.

281. CERD/C/SR.398, par.29 (Lamptey); CERD/C/SR.390, par.23 (United Kingdom), 43 (Sayegh), 44 (Nettel).

282. CERD/C/60/Add.13 and Add.24.

283. CERD/C/SR.488, par.41 (United Kingdom).

284. CERD/C/SR.488 par.41 (United Kingdom).

285. CERD/C/91/Add.24.

286. CERD/C/SR.605, par.27 (Dechezclles) and CERD/C/SR.606. par.14 (Ingles), 16 (United Kingdom).

287. CERD/C/118/Add.7, par.28-29.

288. CERD/C/118/Add.7, par.44.

289. CERD/C/149/Add.7, par.4. 
The report discusses article 6 by outlining the role of the Commission for Racial Equality, and the assistance it may provide to individuals under the Race Relations Act 1976. In its discussion of the British report during the thirty-fourth session, there was a difference of opinion about the extent to which the State and the Committee could use a differing interpretation of article 4.6 of the Convention. On the other hand there was sympathy for the British intention to implement parts of article 4 through the Public Order Act $1986^{20}$.

The opening paragraph of the tenth report indicates that the Public Order Act 1986, containing provisions within the scope of article 4 CERD came into effect in $1987^{291}$. The section about article 6 CERD again refers to the role of the Commission for Racial Equality. The report by the dependent Territories ${ }^{292}$ does not deal with the reservations. The eleventh report quite bluntly does not contain a paragraph on the implementation of article 4 CERD $^{-03}$.

The tenth and eleventh report are dealt with jointly by the Committee. The country rapporteur mentions in his introduction that the United Kingdom had not yet fully implemented article 4.b. The United Kingdom had made a unilateral declaration which was not a reservation, and should thus reconsider its position ${ }^{224}$. Moreover, the rapporteur asked why the United Kingdom had not yet withdrawn its reservations ${ }^{295}$. The questions raised are however not dealt with by the British representatives ${ }^{2 *}$.

\subsection{Individual complaints, article 14 CERD}

Reservations have not been dealt with in the small number of cases under the individual complaints procedure.

\section{CONCLUSIONS REGARDING THE RESERVATIONS TO THE CONVENTION ON THE ELIMINATION OF RACIAL DISCRIMI- NATION}

\subsection{The reservations}

In his article about the reservations clause of the CERD ${ }^{207}$, Cassese lists three important innovations contained in article 20. For the first time the "object and purpose" criterion was laid down in a treaty, thereby using the decisive notion from the Genocide case. There was a prohibition on undermining the supervisory 
system of the Convention by way of reservations. An objective procedure was provided to establish whether the reservations made were contrary to either criterion. Some twenty years later it is useful to consider these innovations again, and to see if practice has turned out to be as satisfactory as Cassese thought it would be.

The Convention established a system in which the determination of compatibility is objective, given the Genocide case, this is an improvement to a situation in which the depository feels obliged to interfere. The "two-thirds rule" has been the most important element of the rule on reservations in the Convention on the Elimination of all Forms of Racial Discrimination. The rule creates pseudoobjectivity, as all States Parties decide themselves about the compatibility and the final determination is mere arithmetic. There are presumably few States who actually decide about the compatibility of reservations and the need to object. It would seem that the majority of the States just do not react. It is the passage of time that establishes compatibility rather than an explicit determination. In view of this governmental inertia the problem of the "two-thirds rule" being a rather flexible rule ${ }^{298}$ turned out to be of little weight in actual practice.

The two distinct criteria of object and purpose, and the operation of the supervisory bodies have not been very relevant. Given the fact that the supervisory system of the Convention, which became the prototype for supervision of human rights treaties within the United Nations, was new at the time, a need was felt to protect. The protection of the operation of the bodies established by the Convention is in itself a positive achievement. As it happened no reservations aiming at the supervisory system have been made, which might be explained by the explicitness of article 20.2 on this issue.

As to the object and purpose-rule, the present author does not share Cassese's enthusiasm for its incorporation in the Convention. Originating from the typical single-purpose treaty the Genocide Convention is, it is a question-begging rule when applied to a treaty with such a multifarious content as the CERD. Though the Convention aims at eliminating racial discrimination, the obligations are so diverse (see e.g. article 5 CERD) that it will be hard to establish which rules do or do not belong to the Convention's object and purpose. This does not mean that the criterion of object and purpose is inadequate; it merely underlines that it will be complicated to apply the notion. Though the Convention indicates that the criterion is "object and purpose", States may want to use this as a guise for objections based on purely political considerations. Additionally, the pseudoobjectivity of the determination, as mentioned above, plays a role.

Cassese furthermore notices that the use of the collegiate system in the CERD must be seen in the light of the tendency to protect the integrity of the vital provisions and basic obligations of a treaty. Another example of this tendency, he 
writes, is "the listing of provisions to which reservations cannot be appended" 29 .

With hindsight this analysis appears to be incorrect. The fundamental difference between the system laid down in article 20 CERD and a specific rule on prohibited reservations is the moment upon which the determination of compatibility takes place. It must be assumed that when deciding upon those provisions of a treaty to which reservations may not be made, States have the object and purpose of a treaty in mind. The determination of compatibility is formalized beforehand and the depository of the treaty merely acts on the explicit instructions provided in the treaty. It will be the treaty itself that indicates which reservations are, or are not allowed ${ }^{300}$. In the long run, a specific provision on reservations seems the best method for safeguarding the object and purpose of a treaty. A system which calls for a separate determination by the States Parties every time a reservation is made, leaves room for political opportunism and laxity.

Turning our attention to the reservations made to the Convention on the Elimination of all Forms of Racial Discrimination it is noteworthy that out of the 133 States Parties ${ }^{301}$, only 16 States made reservations or interpretative declarations concerning the CERD's substantive positions ${ }^{302}$.

These appear to revolve around the issue of conflicting rights and obligations. The controversy between article 4 and its obligation to legislate, and the rights guaranteed in article 5 is one example of this question. A less obvious example is the reference to the constitutions of States Parties and the protection granted to domestic legislation in a number of reservations.

As article 4 is the focal point of reservations to the CERD, it is necessary to establish the precise content of the obligation. It deals with the prohibition of racist propaganda (par.4.a), racist organisations (par.4.b) and governmental involvement in racist activities (par.4.c). A closer look shows that the three paragraphs contain a number of rules, put together on the basis of the issue involved. Authors differ about the number of obligations contained in article $4^{303}$.

Clearly there is a serious risk of a clash between the freedom from discrimination on the one hand and the freedom of expression and freedom of association on the other hand. The drafters of the provision have attempted to anticipate problems by including the so-called "due regard clause". The introductory phrase of the provision underlines that these goals should be achieved, keeping both the Universal Declaration on Human Rights and article 5 of the Convention in mind.

300. Cf. articles 19.a and 19.b VCL.T.

301. ST/LEG/SER.E/11 (31-12-1992).

302. Or 17, depending on the reservations made by the Yemen Arab Republic.

303. C. Lemer, op.cit. at 49-51; Mahalic, op.cit.at 93-101: K.J.Partsch. Die Strafbarkeit der Rassendiskriminierung nach dem Internationalen Abkommen und die Verwirklichung der Verpflichtungen in nationalen Strafrechtsordnungen, in: GYbIL. 1977, 119-138, at 123-124. 
From the outset there has been an awareness that problems could arise, which led to an obligation to reconcile these possibly conflicting rights. Consequently, apart from the specific obligations to penalize on the basis of the paragraphs a-c, there is a general obligation to balance these obligations with the Universal Declaration and article 5 of the CERD. Thus neither the States Parties, nor the Committee are right in assuming that either the duty to penalize and take legislative action, or the duty to guarantee freedom of expression or freedom of association should prevail.

The provision and its aim of balancing the irreconcilable have been criticized for various reasons. For some it is necessarily either freedom from discrimination (at the expense of freedom of expression or association) or the other, adding that the CERD is mistaken in encroaching upon the traditional rights of freedom of expression and association ${ }^{304}$. The apparent prevalence of freedom from discrimination is seen as a major deficiency in the Convention as a whole, whatever the desirability of the elimination of racial discrimination.

Another criticism of article 4 focuses on the fact that the provision deletes an element of the definition of racial discrimination given in article 1 . While the definition mentions the "effect or purpose" as an element in the discrimination that is to be fought, this element is completely absent in article 4 and its obligation to implement legislation. Consequently there is the risk that article 4 will lead to the penalization of acts that might hypothetically lead to racial discrimination without this actually taking place. This risk is at any rate present in par.4.a and its prohibition of "dissemination of ideas based on racial superiority or hatred" where there is clearly no need to establish if this dissemination in fact had the purposes or effect as mentioned in article 1.1

One might wonder whether the reservations made are the actual problem or whether the provision itself is the bone of contention. Article 4 is the result of a compromise in which the introduction purports to balance human rights while at the same time paragraphs a and b stress the obligation to penalize racist propaganda and racist organisations. With hindsight a provision with fewer imperfections would have done more justice to the Convention's goals of eliminating racial discrimination. Ultimately the conclusion must be that article 4 , however important its goals, is an unfortunate provision because of its formulation. Thus reservations may not have been completely unexpected ${ }^{205}$.

Another problem is raised by the reservations referring to national constitutions. Using these reservations, States not only unilaterally establish that their domestic situation is in conformity with the obligations under CERD, but also put future legislation beyond the reach of the Convention and its supervisory Committee.

of course it is necessary for States to consider the relationship between their international obligations and their domestic legal system prior to entering into the 
obligations laid down in the CERD. In case of conflict, the traditional policy has been to make a reservation and in that respect there would not appear to be anything wrong with these statements. On the other hand, it should be stressed that human rights instruments are dynamic and aim at improving protection for individuals. From that point of view, these reservations are too static. Moreover, it should be made clear that by emphasizing their constitution as a ground for restricting obligations under the CERD, States explicitly indicate that the protection afforded under their Constitution is less than that under the Convention. Such an approach is surely contrary to the high ideals frequently included in constitutions.

The issue of the domestic legal system and its rules on the prevalence of international law is of no relevance in this respect. It is up to the States Parties to ensure the compatibility of national and international obligations. Raising national standards in order to match intemational standards is a viable altemative for the reservations.

Reservations to the CERD are, in the eyes of Meron ${ }^{306}$, the direct result of different opinions about the Convention's scope. The Convention is the product of deficient drafting, it is the result of the wishes of the majority in the General Assembly and consequently contains rules that are not acceptable for democratic States ${ }^{307}$. Meron assumes that direct interference with private life in a way incompatible with democracy leads to reservations, instantly adding that other democratic States have for various reasons failed to make reservations. In actual fact, the emphasis on "democratic States" seems to me to be a gross exaggeration of the motives behind the reservations.

Furthermore Meron explains that reservations are the result of the CERD adopting "maximalist" goals, this idealism influences the willingness to accept obligations $^{308}$. He feels that the Convention is overzealous, and will not be able to reach its high goals. It is probably a matter of personal taste whether a human rights document should strive for the highest possible goals, or should restrict itself to realistic

goals that can within reason be achieved. Part of the discussion is thus one between the opposites of realism and idealism.

\subsection{The role of States}

States do not seem to have played an important role with respect to the issue of reservations. Only very few states managed to withdraw their reservations, and few states did object to the reservations of the Yemen Arab Republic.

The fact that objections to article 4 reservations have not been made, may in a way weaken the Committee's strong stance on the obligation to legislate con- 
tained in the provision. Objections might have supported this approach. One might say that the interest states take in the Convention is focused on its domestic implications rather then the international obligations entered into on ratification.

\subsection{The role of the Committee}

The Committee on the Elimination of Racial Discrimination has the longest experience with the supervisory system common to the UN Human Rights treaties, and its consideration of reservations and declarations may indicate the possibilities of a supervisory organ with regard thereto. In his evaluation of the Committee's function in the first six years of its existence, Buergenthal is optimistic about the achievements of the Committee in exploring the possibilities of the reporting procedure as a means of supervision ${ }^{309}$. The way in which the Committee has used its opportunities has turned the reporting obligation into a serious instrument for monitoring the implementation of the Convention. On the other hand, when one looks specifically at the way in which the Committee has dealt with the matter of reservations, a number of contentious issues have arisen over the years. In contradistinction to the general evaluation, there is no reason for optimism as far as reservations are concerned.

The determination of the actual status and legal effect of a particular declaration is theoretically left to the author State. But States are in the habit of not expressly indicating the nature of their declaration, probably with a view to interpreting its legal force at a later point in time. Sometimes called "interpretation", declarations are referred to as "reservations" in discussions with the Committee. The discussion of the legal force of a particular statement is a recurring one in the Committee's work. However, the Committee appears to be at a loss on the law applicable to reservations and the reservations made. Not only is there a lack of knowledge about the CERD's own system ${ }^{310}$, and consequently a great trust in the wisdom of the UN Secretariat ${ }^{3 \prime \prime}$, there is also great lack of insight into the intricacies of interpretative declarations ${ }^{312}$.

As it may be hard to establish at face value what the exact purpose of a statement is, the role of the Committee becomes of primordial importance. The activities of a supervisory organ, such as the Committee on the Elimination of Racial Discrimination, necessarily imply a certain amount of interpretation of the statements made by the States Parties, in order to establish the precise obligations binding upon them.

309. Buergenthal, The UN Racial Convention at 218-221.

310. E.g. CERD/C/SR.176 (Jamaica); CERD/C/SR.248 (United Kingdom); CERD/C/SR.386. 387(Jamaica); CERD/C/SR.629 (Fiji).

311. See CERD/C/SR.194 at 124; CERD/C/SR.249 at 31-32; CERD/C/SR.277 at 120.

312. E.g. CERD/C/SR.187(Austria); CERD/C/SR.194(Tonga); CERD/C/SR.204(Barbados); CERD/C/SR.248(United Kingdom); CERD/C/SR.272(Barbados); CERD/C/SR.274(Jamaica); CERD/C/SR.277(Tonga): CERD/C/SR.348(United Kingdom); CERD/C/SR.386, 387 (Jamaica): CERD/C/SR.398, 399(United Kingdom); CERD/C/SR.552(Malta); CERD/C/SR.553 (Nepal); CERD/C/SR.610(Bahamas). 
Moreover, there is a lack of continuity in the Committee's discussions with the reserving States. Concern about a particular reservation in one session is followed by complete silence about the same reservation when the next report is dealt with $^{313}$. This suggests inadequate servicing of the Committee as well as a lack of interest on the part of the Committee-members. It appears to lack a institutional memory as far as reservations are concerned.

The Committee's authority to determine the legal effect of a particular statement remains unclear to the Committee. There is a tendency to rely on the steps taken by the Secretary-General acting as depositary for the Convention. It should be noted that the Genocide-case, if anything, established that the determination of the acceptability of reservations was a matter for the States Parties to decide ${ }^{314}$.

From what transpires in the Committee's discussions, the Secretary General only circulates declarations explicitly labelled "reservation" to the other States Parties, in accordance with article $20.1^{315}$. It is impossible to understand why the Secretary General did not circulate all the interpretations, declarations and reservations made, but that is what transpired. Consequently, the States Parties never had the opportunity to object to reservations made under the guise of interpretation, as they had not been circulated. Obviously it would be a misinterpretation of article 20 to consider these statements as accepted reservations.

The problem is thus the authority to decide upon the legal effect of interpretative declarations and other statements of an uncertain nature. There are Committeemembers who consider the Committee to be empowered to make such a determination, whereas others emphasize that this is within the authority of the States Parties only $y^{316}$.

The right approach would seem to be the following. When ratifying, States may make reservations and in practice also make interpretative declarations. Whereas the former have a direct bearing upon the consent to be bound expressed by the State inasmuch as they restrict the obligations under the treaty, the latter merely suggest an interpretation of the treaty that might not be shared by other States Parties or by the Committee. However, if this interpretation is particularly important for the ratifying State, it has the option of choosing the form of a (binding) reservation.

In the case of a statement of an uncertain nature, the analysis of the intention might be influenced by the formulation and the language used. This may lead to a comparison between the original obligation and the interpretation offered that will give insight into the authors intentions.

313. See for instance, CERD/C/SR.210(Nepal); CERD/C/SR.366(Nepal); CERD/C/SR.393.

314. See for a discussion of the Genocide case, Chapter 2, par.1.2 supra.

315. E.g. CERD/C/SR.194(Tonga); CERD/C/SR.249(United Kingdom); CERD/C/SR.277(Tonga).

316. E.g. CERD/C/SR.157, 158(United Kingdom); CERD/C/SR.156(Tonga); CERD/C/SR176(Jamaica); CERD/C/SR.248, 249(United Kingdom); CERD/C/SR.274(Jamaica); CERD/C/SR.629(Fiji). 
When a State has made various statements labelling some explicitly as reservations, the Committee would be well advised to follow the line of reasoning used by the European Commission on Human Rights in the Belilos case ${ }^{317}$. This theory of distinction is not necessarily restricted to the European Convention, though Graefrath ${ }^{318}$ is right in emphasizing that its practice is not per se applicable, or even transferable, to other Human Rights Conventions. It should be underlined that the theory of distinction, basically amounts to the principle of expressio unius est exclusio alterius, which is in line with the rules for the interpretation of treaties ${ }^{319}$.

Another approach used by the Committee in its discussion with the reserving States is to ask for clarification and for information about the scope of the statement, and about the author's intention ${ }^{320}$. There is a risk that this approach might introduce complete subjectivity into the field of reservations. It may seem odd for the author state to determine the legal effect of a particular statement, perhaps years after ratification. This would be very undesirable from the point of view of legal certainty. Yet, if such a request were to be addressed to a State which had made a distinction between reservations and interpretations, as indicated above, confusion could not arise. After all if the statement was meant as a reservation, it should have been labelled as such, the author state itself would bear the "risk" of the ensuing confusion.

On the other hand such a request will probably lead to a clarification from the author state which would at least be an authoritative clarification, as long as it is within the limits of interpretation. Should a difference of opinion arise as to the correct interpretation, or the permissible interpretation, then the Committee has clearly stated that its interpretation of the Convention is more authoritative than the interpretation by a particular State Party ${ }^{321}$. This would seem to follow logically from the Committee's central role in the supervisory system, and the extensive knowledge about the Convention it has consequently gathered.

The best way to settle a difference of opinion on the precise interpretation of the Convention finally would be to take the issue to the International Court of Justice, in accordance with article 22 of the Convention. This can only be done after negotiations have taken place, or after using the dispute settlement procedures available in the Convention. It must be stressed that article 22 deals specifically with a dispute between two or more States Parties; this definitely excludes the possibility of the Committee bringing the dispute before the Court. Another impediment would be the number of reservations made to article 22 it-

317. Belilos vs Switserland, European Commission of Human Rights; discussed in Chapter 3, par.4.1.2 supra.

318. Graefrath, op.cit., at 74-75.

319. Cf. articles 31-33 VCLT.

320. See for instance: CERD/C/SR.187(Austria); CERD/C/SR.398-399(United Kingdom).

321. C. Meron, op.cit. at 49; and CERD/C/SR.553(Fiji). 
self ${ }^{322}$. Accordingly, authoritative interpretation of the Convention by the International Court must be considered a theoretical, if not hypothetical possibility.

Apart from the rather inconclusive discussions about interpretative declarations, the Committee frequently asked States to reconsider reservations, or more explicitly, to withdraw reservations. This has not had a very impressive effect, only one state managed to withdraw a substantive reservation.

The work of the Committee is seriously hampered by a lack of knowledge of the legal systems and the legislation of the States Parties. Quite frequently the impact of a reservation can only be seen in its true proportions within the perspective of the existing legal system. This is in particular the case with the implementation of articles 4,5 and 6 .

The Committee's experience in discussing reservations and declarations concerning articles $4 . a$ and $4 . b$ has not been particularly fortunate. Its concern about the implementation of these provisions, and the obligation to legislate contained therein has been politely ignored ${ }^{323}$. Though the introductory phrase of the provision suggests that a solution to the apparent controversy is possible, this may seriously be doubted when looking at the provision itself and the state practice as reported to the Committee.

Over the years, the issue of article 4 reservations has acquired the character of a symbolic discussion in which points of view are exchanged but never changed. The views of States concerned and of the Committee differ on this provision, and on the basis of the reservations made there is absolutely no need, even less an obligation, to implement the provision. It is precisely when the implementation of a controversial provision is at stake, that CERD's supervisory system's lack of force becomes apparent. It is not only the somewhat ritualized discussion about the reservations made, there is also the well-established fact that States that did not enter a reservation have, in fact, not implemented the provision either. Here the Committee has also lacked strength to improve the implementation of the provision. Better drafting might have prevented this highly unsatisfactory situation.

The most striking example of the Committee's powerlessness with regard to the obligation to legislate in accordance with article 4 is the Australian reservation. That State itself indicated the intention to legislate at the first suitable moment, and has so far not been able to fulfill this unilateral obligation. After doubting the need to legislate in one session ${ }^{324}$, the temporal restriction has become a genuine reservation in the eyes of its author in the next session of the Committee ${ }^{325}$. In spite of the clear wording of the reservation, the Committee has not been able to persuade the State to honour its commitment. 
It appears from the reports that legislation giving effect to article 4 of the Convention is frequently absent. The Committee therefore decided to deal with it in its first General Recommendation ${ }^{326}$. It merely held that the Committee had noticed the absence of the legislation implementing article $4 \mathrm{a}$ and $\mathrm{b}$, and suggested states should give attention to supplement their legislation with the required provisions.

A while later the matter was again raised hy Committee-member Partsch under the heading of "Obligations of States Parties under article 4.an ${ }^{\text {n32? }}$

A problem related to the issue of the article 4 reservations dealt with before, is constituted by the reservations referring to national constitutions. Though the group of States that made these reservations is not very large, the reservations can have a very restrictive effect on the implementation of the CERD in the domestic legal system.

Unfortunately the Committee has not been successful in dealing with this particular group of reservations. First and foremost this appears to be the consequence of insufficient knowledge about the content of the constitutions ${ }^{328}$ and the functioning of the various national legal systems ${ }^{329}$ on the part of the Committee. It is obvious that the Committee cannot know everything, but it could be a good deal more strict with the States that fail to provide such information, even if asked by the Committee. Another explanation might be that, as constitutions are at the hasis of national legal systems, the Committee is reluctant to overtly question their compatibility with the CERD. Discussions with reserving States revolve around the exact scope of the reservation ${ }^{36}$ and the relationship between the CERD and the constitution ${ }^{331}$. So far only one State has been persuaded by the Committee to consider withdrawing its reservation, and legislation to that end appears to be in progress ${ }^{332}$.

\subsection{Prospects}

Given the great similarity between the reservations made and the fact that they have frequently been discussed between the States Parties and the Committee, there does not seem to be any prospect of a general withdrawal of the article 4 reservations. The discussion has not led to either of the opponents changing their views, thus withdrawal is very unlikely. It should be kept in mind that, though the Committee has a clear stance on the obligations under article 4 , a number of non-reserving States have not implemented the provision either. This may lead to

328. CERD/C/SR.154(Nepal); CERD/C/SR.178(Jamaica); CERD/C/SR.272(Barbados); CERD/C/SR.274(Jamaica).

329. CERD/C/SR.179(Jamaica); CERD/C/SR.463(Jamaica).

330. CERD/C/SR.274(Jamaica); CERD/C/SR.349(Bahamas); CERD/C/SR.386(Jamaica).

331. CERD/C/SR.557(Barbados).

332. CERD/C/SR.463(Jamaica); CERD/C/SR 742(Jamaica). 
the conclusion that the actual situation in the States Parties to the CERD falls short of the written obligation. The reservations are an indication of a fundamental difference of opinion amongst the States Parties about the obligations under article 4 and the need to legislate ${ }^{333}$.

The prospects as regards other substantive reservations, such as the article 1 reservation of the United Kingdom, and the articles 2, 3 juncto 5.3.v reservations of Fiji and Tonga may be slightly better. The Committee may be able to persuade these States in a constructive dialogue to withdraw these particular reservations by stressing their rarity and the public opinion impact they have. Tonga, as has been mentioned before, has already withdrawn a part of its reservation.

The declarations concerning the wisdom of formulating article 15 as it appears in the Convention have by now lost their importance. Not only has the number of Trust and Non-self governing Territories drastically decreased, the declarations have not been discussed by the Committee at all.

Another possibility might be a more assertive approach towards the article 4 and the constitutional reservations. The Committee might reconsider its prior discussions with the States concerned and draw up a standardized approach towards interpretative declarations along the lines indicated in par.4.3 supra. Using such an approach, the majority of States Parties relying on reservations formulated as "interpretation" may be confronted with the fact that their interpretation has not been accepted so that they are bound by the original obligations in the Convention. Though this line of reasoning gives the Committee the option of dealing with the matter more assertively, it will doubtless run into the general problem of the non-implementation of article 4 . 


\section{RESERVATIONS TO THE INTERNATIONAL COVENANT ON CIVIL AND POLITICAL RIGHTS}

\section{INTRODUCTION TO THE COVENANT}

\subsection{Content of the Covenant}

The Covenant on Civil and Political Rights' is an extensive catalogue of "first generation" human rights and fundamental freedoms, drafted in the ninety-sixties together with the International Covenant on Economic, Social and Cultural Rights. These two conventions, together with the Optional Protocol to the Covenant on Civil and Political Rights, completed the International Bill of Rights, work on which began in 1948 with the proclamation of the Universal Declaration of Human Rights by the General Assembly.

The International Covenant on Civil and Political Rights (hereafter: CCPR) consists of six parts. Part I establishes the right to self-determination for all peoples. Part II deals with fundamental notions essential for the functioning of the Covenant, such as the principle of equal treatment, the obligation to guarantee the rights in the Covenant to any person, and the derogation clause in article 4. Part III contains the Covenant's substantive provisions. It is a catalogue of civil and political rights, and encompasses such notions as the right to life, the prohibition of torture, slavery and arbitrary arrest as well as freedom of movement, freedom of thought and freedom of opinion and expression. The Covenant's supervisory system can be found in Part IV, which sets up the Human Rights Committee (hereafter: HRC). Part V of the Covenant contains rules on interpretation, and Part VI contains the final clauses ${ }^{2}$. The individual complaints procedure, an additional supervisory procedure can be found in the Optional Protocol (hereafter: OP). And in 1989 a second Optional Protocol aiming at the abolition of the Death Penalty ${ }^{4}$ was adopted (hereafter: SOP), adding the prohibition of capital punishment to the Covenant's system.

\subsection{The law applicable to reservations}

\subsubsection{Reservations to the Covenant}

The Covenant itself does not contain an explicit rule on reservations, though

1. UNTS 999 at 171; UNTS 1057 at 407; entry into force 23-3-1976.

2. D.McGoldrick, The Human Rights Committee, Its Role in the Development of the International Covenant on Civil and Political Rights, Oxford 1991, at 18-20.

3. GA Res.2200A (XXI); entry into force 23 March 1976.

4. GA Res.44/128, entry into force 11 July 1991. 
the matter was discussed extensively during the drafting', particularly because the General Assembly had requested the inclusion of a reservations clause following the discussions about reservations to the Genocide Convention ${ }^{6}$. Views differed to a great extent ${ }^{7}$, the Soviet Union contended that reservations should be allowed as this was a right inherent in State sovereignty, whereas Chili and Unuguay stressed that universal respect for human rights should lead to a complete prohibition of reservations $s^{8}$. The United Kingdom favoured a system that combined the system of article 64 ECHR and article 20 CERD, in which reservations to the extent that domestic law was not in conformity with the Covenant would be admissible provided that two-thirds of the States Parties accepted the reservations or did not object?. China, Egypt, Lebanon and the Philippines suggested that the criterion should be the "object and purpose of the treaty", with disputes about compatibility being referred to the International Court of Justice ${ }^{10}$.

The Commission on Human Rights was ultimately unable to draft a reservations clause that could be agreed upon, and indicated that it was difficult to apply the "object and purpose" criterion to the Covenant with its far-reaching and detailed provisions. Moreover, using that criterion would make it necessary to create safeguards against possible abuse. It was understood that the absence of a reservations clause did not imply that any reservation was permitted, as general international law would apply"1. Thus the "object and purpose" rule of article 19.c VCLT would seem to be applicable ${ }^{12}$, though it must be kept in mind that the Covenant was adopted by the General Assembly on 16 December 1966, that is to say before the adoption of the Vienna Convention on the Law of Treaties ${ }^{13}$.

Clearly this raises the ever intriguing question of what the object and purpose of the Covenant might be. The protection of civil and political rights is a very general notion, and it is unlikely that the States Parties meant all of the Covenant

5. R.Higgins, Derogations under Human Rights Treaties (hereafter: Higgins, BYIL), in: 48 BYIL 1976/77, 281-320 at 317-319; McGoldrick. op.cit. 16; V. Pechota, The Development of the Covenant on Civil and Political Rights. in: The International Bill of Rights, L.Henkin ed., New York 1981, 32-71 at 52-54; Suy, op.cit. at 943-944.

6. GA Res. 546 (VI).

7. A/2929, p.382-389.

8. E/CN.4/L.354.

9. E/CN.4/L.345 \& Add.1

10. E/CN.4/L/351.

11. E.Sichwelb, The International Covenants on Human Rights, in: A.Eide, A.Schou, International Protection of Human Rights, 144; Stockholm 1968.

12. Craig, op.cit. at 851; Golsong. op.cit. at 31-33 passim; B.Graefrath, Menschenrechten und internationale Kooperation usw., Berlin(DDR) 1988, 69-85; Higgins, BYIL at 318319; Higgins, ML.R at 11; McGoldrick, op.cit. at 16; Nowak, op.cit. at XXIII-XXV.

13. See for a discussion of the inter-temporal law of treaties, supra Chapter 2, par.7.1.

The Vienna Convention on the Law of Treaties was adopted on 23 May 1969, entered into force 27 January 1980; the Covenant on Civil and Political Rights was adopted 19 December 1966 and entered into force 23 March 1976. 
's substantive provisions to be part of its object and purpose. Two theories regularly appear in literature concerning reservations to the CCPR.

First of all, it has been suggested that article 4 of the Covenant ${ }^{14}$, the derogations clause, is an indication of its object and purpose. Discussions during the drafting of the Covenant, when the Commission was still considering the possibility of including a reservations clause, focused on the importance of article 4 . It was suggested that reservations to that provision would not be acceptable ${ }^{15}$. Article 4 reads:

\begin{abstract}
"1. In time of public emergency which threatens the life of the nation and the existence of which is officially proclaimed, the States Parties to the Present Covenant may take measures derogating from their obligations under the present Covenant to the extent strictly required by the exigencies of the situation, provided that such measures are not inconsistent with their obligations under international law and do not involve discrimination solely on the grounds of race, colour, sex, language, religion or social origin.

2. No derogation from articles $6,7,8$ (paragraphs 1 and 2), 11, 15, 16 and 18 may be made under this provision.

3. Any State Party to the present Covenant availing itself of the right of derogation shall immediately inform the other States parties to the present Covenant, through the intermediary of the Secretary-General of the United Nations. of the provisions from which it has derogated and of the reasons by which it was actuated. A further communication shall be made, through the same intermediary, on the date on which it terminates such derogation."
\end{abstract}

For present purposes the important aspect of the provision is the suggestion that the Covenant's "object and purpose" is discernable in the list of non-derogable rights in article 4.2. Yet, discussions about this provision have primarily focused on the circumstances under which derogation is legitimate ${ }^{16}$. In the General Comment on article 4 of the Covenant ${ }^{17}$, the HRC also focused on the operational side of the provision, rather than the substantive rights that may be derogated from ${ }^{18}$.

There are different ways of looking at rights from which derogations are not allowed $^{19}$. The first interpretation is that these are rights from which derogations cannot be justified by the necessities of any conceivable situation of public emergency. The emphasis is on public emergency, and the fact that this situation cannot legitimize the suspension of the rights listed in article 4.2. The other interpretation is that these are core rights whose fundamentality is compelling per

14. Henkin, op.cit. at 23: Higgins, MLR, at 15 writes:"There is a certain surface attractiveness to this idea."; McGoldrick, op.cit. par.7.13 at 305: Suy. op.cit. at 943 writes: Dans la mesure ou lart. 4 peut être assimile à une clause de réserve, on peut considerer que les parties ont clairement exprimé leur volonté d'interdire certaines réserves, et qu'aller a lencontre de cette intention serait incompatible avec le droit des traités."

15. Higgins, BYIL, at 318; Suy, op.cit. at 943-944.

16. Hartman, op.cit.; Higgins, BYIL at 283-288; J.A.Walkate. The Human Rights Committee and Public Emergencies, in: 9 YJWPO 1982, 133-146.

17. General Comment 5/13.

18. Walkate, op.cit. at 140-141.

19. Hartman, op.cit. at 113; Henkin, op.cit at 23-24; Suy, op.cit. at 943-947. 
se. In this view, the nature of the rights protected is stressed. This evidently amounts to saying that these non-derogable rights belong to the Covenant's object and purpose ${ }^{20}$. The gist of relying on article 4 as an indication of object and purpose of the Covenant is that, if derogations are not permitted, reservations are a fortiori not permitted either.

Article $4.2^{21}$ protects the right to life; the prohibition of torture, slavery and servitude; the prohibition of imprisonment on the grounds of the inability to fulfil a contractual obligation, the ban on ex post facto laws, the right of recognition as a person before the law, and freedom of thought, conscience and religion. The right to life must be considered a rule of ius cogens, whereas the prohibition of torture and slavery are both rules of ius cogens and conventional law ${ }^{22}$. Moreover, there is a great similarity between the non-derogable rights in various human rights instruments $\mathrm{s}^{23}$. The right to life, the prohibition of torture, slavery and servitude and the prohibition of ex post facto legislation also appear in European and American regional instruments ${ }^{24}$. The right to a judicial personality, and freedom of conscience and religion appear both in the CCPR and in the American Convention ${ }^{25}$. The uniformity of human rights protection in times of emergency would seem to underline its fundamentality, and points to a certain opinio iuris concerning non-derogable rights. Yet, it should be noted that article 18 itself allows for limitation in paragraph $3^{26}$ and is apparently not as absolute as its listing in paragraph 2 of article 4 would seem to suggest. And the prohibition of imprisonment because of inability to fulfil contractual obligations as a non-derogable right under the Covenant, is the odd one out ${ }^{27}$.

Another non-derogable right appears in a somewhat hidden form in article $4.1^{2 x}$. The location of the prohibition of discrimination within article 4 has been the subject of discussion, during the drafting it has been alternatively in paragraphs 2 and 1. Article 4.1 echoes the general non-discrimination clauses in articles 2.1 and 26 of the Covenant, yet it is much more restrictive as concerns which kind of discrimination is forbidden. Whereas article 2.1 and 26 also prohibit discrimination on the ground of political or other opinion, national origin, property, birth or other status, there is no protection against such discrimination in article 4.1 . In

20. Henkin, op.cit. at 23; Suy, op.cit.at 944.

21. See for the drafting history M.J.Bossuyt, Guide to the"Travaux Préparatoires" of the International Covenant on Civil and Political Rights, Dordrecht 1987 at 91-96; Hartman,op.cit. at 115-118.

22. Cf. International Agreement for the suppression of the White Slave Trade (1904); International Convention for the Suppression of the White Slave Traffic (1910); Convention against Torture and Other Cruel. Inhuman and Degrading Treatment and Punishment (1984).

23. Cf. article 15.2 European Convention on Human rights and Fundamental Freedoms; article 27.2 American Convention on Human Rights.

24. Articles 2, 3, 4.1 and 7 ECHR; articles 4, 5, 6, 9 ACHR.

25. Articles 3 and 12 ACHR.

26. Hartman, op.cit, at 114.

27. Hartman, op.cit. at 113 ; Meron, op.cit. at 92.

28. Bossuyt, op.cit. at 86-87; Hartman, op.cit. at 113,118; McGoldrick, op.cit. par 7.11 at 304. 
the situation in which States may want to rely upon article 4, discrimination solely on the ground of race, colour, sex, language, religion or social origin is prohibited. This might be explained by the fact that particular situation demands the use of a more restricted prohibition of discrimination. Another possible conclusion might be that the grounds enumerated in article 4.1 are the core of the prohibition of discrimination, and would therefore fall within the Covenant's object and purpose. This would seem to be underlined by the fact that the prohibition of discrimination has brought about the creation of separate international instruments such as the Convention on the Elimination of Racial Discrimination and the Convention on the Elimination of All forms of Discrimination against Women. Additionally, it might be pointed out that an identical list appears in the American Convention ${ }^{29}$.

It might be suggested that when making a reservation to a provision mentioned in article 4.2, or to the core elements of the prohibition of discrimination in article 4.1 a State may be supposed to act contrary to the object and purpose of the Covenan $^{30}$. This must be seen as a rebuttable presumption ${ }^{31}$, in as much as an additional explanation or a reference to applicable national legislation may contradict the presumption ${ }^{32}$.

Yet, one might wonder whether article 4 is the only indication of the Covenant's object and purpose. Not only has this provision been written for the exceptional situation of public emergency, it is conceivable that other rights are also of fundamental importance, in spite of the fact that they may be derogated from in an emergency situation. There is, after all, a conceptual difference between the temporary nature of derogations and the legitimate non-compliance based on reservations ${ }^{33}$.

Apart from the non-derogable rights, a number of other Covenant provisions have been referred to as belonging to its object and purpose. Higgins suggests that reservations to article 14.1(public sentences) and article 14.3.d(public trials) are impermissible ${ }^{34}$. The Netherlands and Portugal in their objections to the Algerian reservation suggest that article 23.4 (equality in marriage) is a rule of

29. Article 27.1 ACHR.

30. However, while Germany and the Netherlands objected to the Trinidad and Tobagan reservation aiming at article 4.2 , neither explicitly mentions non-derogability as the reason for objecting. The objecting States merely indicate that a reservation is incompatible with object and purpose of the Covenant .

31. Henkin, op.cit. at 24.

32. Suy, op.cit. at 944 .

33. Higgins, BYIL at 315; Suy, op.cit. at 944 writes:"Ne s'agit-il pas en fait d'un faut problème resultant d'une confusion entre conditions d'application (possibilité pour un Etat partie de modifier l'application du Pacte) et de conditions de participation (obligations pour un Etat partie de respecter un minimum de normes, même en cas de danger public)."

34. Higgins, MLR, at 15 . 
object and purpose ${ }^{35}$. Reservations to articles 14.5(right to review), 14.7(ne bis in idem) and 22(freedom of association) are unacceptable to Czechoslovakia and the Netherlands on the grounds of object and purpose ${ }^{36}$.

Other suggestions about reservations contrary to object and purpose of the Covenant have been reservations to provisions reflecting ius cogens ${ }^{37}$, or provisions contrary of the Charter of the United Nations ${ }^{38}$. In both cases such reservations would not be acceptable for other reasons either, in the first case because of the binding force of ius cogens obligation $s^{39}$, and in the second because of article 103 of the Charter which itself stipulates the priority of this constitutional instrument. Reliance upon article 19.c VCL.T may therefor be unnecessary.

Another issue frequently mentioned in respect of object and purpose of the Covenant is the obligation to implement the Covenant in domestic legislation, an obligation laid down in article 2 of the Covenant. It should be noted that this minimalist approach is particularly useful for those states who want to stress, for domestic purposes, that no obligations are taken up on the ratification of the Covenant. The advantages of such ratifications are that being a State Party to a human rights convention implies a certain propriety. There will not be an obligation to legislate along the lines of the Covenant, as the reservation has excluded the need to do so, and ratification will be purely symbolical. The question is whether it is permissible to formulate reservations so as to protect existing legislation against any changes that may become necessary as a consequence of ratification of the Covenant. The aim of treaty-based human rights protection is clearly to achieve an improvement in protection, rather than a standstill through the consolidation of the national status quo. Such declarations thus cast doubt on the intentions of the ratifying state, as there does not appear to be an intention to live up to the aspirations of the Covenant, in spite of the expression of consent to be bound.

In practice, different forms of the minimalist approach are discernable in reservations to human rights treaties, and the Covenant in particular. The first category is that of States who claim that their national legislation is in conformiry with the treaty. Usually such reservations focus on a specific provision of national legislation. Such declarations do seem somewhat superfluous as conformity is an obligation, under article 2 CCPR, following the expression of consent to be bound. But rather than stressing the obvious, the intention is to determine compatibility. Compatibility is established through a formal declaration, thereby shielding the domestic situation from international interference. If the reservation

35. It is striking that both States did not object to the reservation made by Korea to that very same provision.

36. Objections to a reservation by Korea.

37. Hartman, op.cit. at 114.

38. Higgins, MLR at 14; and objections to the Indian reservation to article I by France, Germany and the Netheriands.

39. see articles 53,64 VCLT. 
is accepted, there cannot be any doubt as to the compatibility of national legislation with the requirements in the Covenant. Consequently, the other States Parties will have to scrutinize the domestic legislation of the reserving State in order to establish whether or not they agree with the assumed compatibility, and would intend to object to the reservation. It is easy to see that this will not be an attractive approach, and may even be considered to be interference with domestic affairs. Yet, one might say that these reservations are an explicit invitation to undertake this, for if legislation were compatible (as it should be under the Covenant) there would not be a need to indicate this by way of a reservation.

The second category of minimalist reservations is more explicit about the intentions of the ratifying State, it merely indicates that national legislation will prevail over the rules in the treary in the case of conflict ${ }^{t 0}$. Two cases can be distinguished: states may exclude a particular provision on the grounds that it is not in accordance with domestic law. In such cases the state will usually indicate precisely what is exclude, which is preferable. A more detrimental form of reservations stressing the prevalence of domestic law are statements formulated generally. These statements restrict the possible impact of the treaty even further. If national legislation prevails one might wonder why a State took the trouble of becoming a party to a human rights treaty at all. It would appear that here again the promotional aspect of ratification prevails. What will stick to mind in the international sphere is the ratification, the fact that implementation at national level is sloppy will go unnoticed.

The question should be asked as to whether reservations giving prevalence to domestic legislation are compatible with the CCPR, and in particular with the obligation to implement the covenant in the national sphere, as laid down in article 2. The general rule in the law of treaties in this respect is article 27 $V C L T$, which has also been referred to in this respect ${ }^{41}$. The provision indicates that states may not rely on domestic law for a failure to perform a treaty, and reads:

"A party may not invoke the provisions of its internal law as justification for its failure to perform a treaty. This rule is without prejudice to article $46^{4:}$."

At the drafting Conference in Vienna there was not much discussion about this provision, which was proposed by Pakistan and subsequently added to the draft Convention on the Law of Treaties. The only reason why the matter had not been dealt with in the ILC Draft was that the Commission felt that the matter belong to the topic of State responsibility. Given the inclusion of article 27 in the Vienna Convention the matter lies apparently at the intersection of the law of treaties and

40. Schachter, The Obligation to Implement writes at 321:"The clarity and candour of these statements may seem commendable in comparison with questionable claims of conformity made by some governments."

41. Triggs; op.cit. at 284-285, 291.

42. Article 46 VCLT has no relevance in this respect, it deals with the invalidity of a treaty concluded in manifest violation of internal law on the competence to conclude treaties. 
the law of state responsibility ${ }^{A 3}$. The particular question that we are facing, the relation between the VCLT provisions on reservations (and their application to human rights treaties), and article 27 VCLT has not been dealt with at the Conference.

In respect of reservations, the starting point must be the assumption that the Vienna Convention contains a coherent set of rules on the law of treaties. Consequently there should not be a conflict between articles 19-22 and article 27 . It is necessary to recall that the articles 19-22 are in part II of the Convention, entitled Conclusion and Entry into Force, whereas article 27 is in the general section of Part III, entitled Observance, Application and Interpretation of Treaties. While article 19 gives rules about which reservations are permissible and which reservations are prohibited, article 27 gives a rule on the observance of treaties. The fact that article 27 is not a lex specialis to article 19.c follows from the structure of the Vienna Convention. Chronologically, both provisions apply in a different phase of the treaty's existence. From that point of view it would seem to be logical that article 27 does not contain elements of a rule applicable in the earlier part of the treaty's existence. Or, to put it otherwise, if there is a prohibition on making minimalist reservations safeguarding domestic legislation, that rule should be in Part II of the Vienna Convention. It should be underlined that though article 27 of the Vienna Convention is a mandatory rule of international law, reservations are a legitimate exception to the rule. If Triggs' line of reasoning were followed, any reservation referring to domestic legislation would be illegal per $s^{44}$.

The answer would seem to be that reservations giving prevalence to national legislation are, as such, a legitimate way to indicate that the treaty will not be implemented in full. Reservations are an international legal method to restrict the application of a convention; a state using that method does not rely on domestic law but on a legitimate exception to article 27 VCLT by making a reservation safeguarding its position. Such reservations necessarily imply a reservation to article 2 CCPR, even if there does not appear to be an obligation to indicate this expressly. Given the fact that article 27 itself cannot be considered an explicit prohibition on minimalist reservations, it is unlikely that this general rule of international law would implicitly be protecting the object and purpose of a treaty.

An element to be taken into account is the fact that reservations merely indicating which provisions will not be applicable, will usually have the same background. While not mentioning that domestic legislation is the reason for excluding a particular provision, this will usually be the case. The fact that the Covenant has to be implemented in the national legal system is the obvious reason for this. Looking at the matter of domestic legislation as a grounds for making reserva- 
tions in this way, demonstrates that the actual question is about the relevance of an explicit or implicit reference to domestic legislation ${ }^{45}$.

It is contended that, as the VCLT system stresses an approach focusing on the substance of the reservation ("however phrased or named") this would lead to a similar approach to the "domestic legislation" reservations. Consequently, what matters is the scope of the reservation and this is what should be clarified. The HRC will ask for clarifications about the scope of the reservation in its discussions with the author States, and justitiably so $^{26}$. The answers and clarifications provided by the author State will lead to a "translation" of the reservation from a "domestic legislation" reservation to a reservation to a particular provision of the Covenant.

This does show that, from a practical point of view, these reservations are undesirable as the substance is hidden behind the "domestic legislation" formula. Uncovering the substance of the reservation will depend on the agility of the Committee, which is not necessarily the best way to limit the scope of reservations. A reservation indicating what it is that is excluded, is to he preferred.

A more important point in this respect, is the fact that a reference to domestic legislation in a reservation would seem to suggest that the author state has complete liberty in changing its legislation. Legislation is after all a matter outside of the scope of traditional international law. It is contended that being a party to a human rights instrument (with or without reservations) restricts freedom to legislate from the point of view of substance. Legislation cannot restrict human rights any further than the Covenant allows. In practice it will he more complex to monitor whether new domestic legislation is more or less restrictive as compared to prior legislation, and this in itself is a convincing argument for discouraging the use of generally formulated "domestic legislation" reservations.

It has also been suggested that domestic legislation reservations are in particular necessary for federal states ${ }^{47}$, which have a internal structure that may make it more complicated to implement a human rights treaty. The implementation of human rights treaties touches upon issues traditionally within the power of the component parts of the State, rather than under the authority of the central government. The two states to have formulated such reservations in respect of the Covenant, Australia ${ }^{48}$ and the United States ${ }^{49}$, are federal States ${ }^{50}$. As such, the position of federal States and their reliance on domestic constitutional

45. Underlining a different point of view: Flinterman, Rieter, NJCM Bull. at 967.

46. This is without doubt within its mandate on the basis of article 40 of the Covenant.

47. Triggs, op.cit. at 284-285.

48. About the Australian reservation see: Triggs, op.cit. passim

49. Schachter, op.cit. at 311-331; Craig, op.cit. at 845, 868-880.

50. On the other hand this may be a mere coincidence, similarly minimalist reservations in respect of the Women's Convention have been made by predominantly unitarian States. 
legislation could be covered by what has been said about domestic legislation before.

On the other hand, the position of federal states is covered by an explicit provision in the Covenant, article 50 . It reads:

"The provisions of the present Covenant shall extend to all parts of federal States without any limitations or exceptions."

It has been suggested that federal reservations are contrary to the implicit prohibition on federal reservations in article 50 of the Covenant ${ }^{51}$, and are therefore contrary to the object and purpose of the Covenant ${ }^{52}$. To give some perspective to this discussion it is necessary to refer to the drafting of the Covenant. At the time, the possible problems of federal states were discussed, but an accommodation was explicitly rejected by the acceptance of article 50 CCPR as it stands now. The other drafting States quite explicitly mentioned that, while understanding Australian and American problems, they did not want weaken the obligation to implement the Covenant in the whole of the country ${ }^{53}$.

The "object and purpose" rule has a strong tendency to focus on the substance of international instruments, dating back to the Advisory Opinion in the Genocide case. General reservations stressing the prevalence of domestic law over the Covenant are frequently explicitly referring to, or implicitly based upon, the domestic constitutional system, which is more a matter of structure then a question of substance. Although the implementation of substantive rights lies behind these rules of structure ${ }^{54}$, it is almost impossible to track down the actual impact on the various rights in the Covenant. The grounds for making these reservations are not only the domestic division of power between the state and its component parts, but may also be national constitutional rules about the implementation of international law in the domestic system, as in the case of the selfexecuting nature of international obligations in the United States ${ }^{55}$.

Whereas the application of the object and purpose rule in substantive matters is quite complex, international legal theory at the moment provides little guidance

51. Henkin, op.cit. at 23; Pechota, op.cit. at 51 .

52. Craig, op.cit at 869-871; Triggs, op.cit. at 291.

53. Bossuyt. Travaux Préparatoires" at 761-767; Craig, op.cit. at 868-870; Graefrath, op.cit. at 77-79; Nowak, op.cit. at 681-683; Pechota, op.cit. at 49-51: Triggs, op.cit. at 285-286.

54. Craig. op.cit. at 871 .

55. In the 1978 proposal to ratify the Covenant, the transmittal message to the U.S.Congress indicated that the reservations and understandings were meant to "harmonize the treaties with existing provisions of domestic law". A similar argument can be found in the Transmittal letter for the 1992 Ratification.

There is a direct relation with the American constitutional system in which treaties may be self-executing. If the reservation were not made, the content of the Covenant could overrule the fundamental rights in the Constitution. In order to prevent that, a declaration indicating that the Covenant would not be self-executing in domestic law was issued, so as to be sure of a restricted influence of the Covenant.

Craig, op.cit. at 853-862; Flinterman, Rieter, NJCM Bull. at 967. 
for the application of the principle to rules of structure. The only possibility would seem to be application of the object and purpose rule on the basis of estimated effect, which would in turn lead to an interpretation of the impact of the reservation on the implementation of the individual substantive rules in the domestic legal system.

As the acceptability of a clause on federal reservations was discussed extensively, with the participating States expressing different opinions on the matter, one cannot conclude that the absence of a formal option amounts to a prohibition of federal reservations, because they are contrary to object and purpose. This would be unrealistic, given the rules in the Vienna Convention, but also in view of the drafting history of article 50 CCPR ${ }^{56}$.

Other arguments against the federal reservations are less forceful. A number of authors suggest that federal reservations might be construed as contrary to the object and purpose of the Covenant because they would lead to a situation in which non-federal States would be bound to a higher degree by the Covenant than federal States having made a federal reservation ${ }^{57}$. This argument is in a way tautological, it is evident that non-reserving States are always bound to a greater extent that reserving States. The fact that other federal states have ratified without such reservations also indicates that the matter is not specific for federal states.

Another reason for the suggestion of a conflict with object and purpose of the Convention is that the aim is to create a general minimum international standard of human rights, and federal states should not be allowed to depart from that aim that easily. While these may be reasons for disapproving of a federal reservation, it is questionable whether this amounts to saying that the reservation is detrimental to the core obligations underlying the Covenant. A minimum intemational standard is not necessarily the same as the complete content of the Convention $^{58}$.

Ultimately the problem is one of distinguishing between core and non-core obligations. Constructing the Covenant's object and purpose as has been done above is a legalistic exercise, it must be kept in mind that the decision about the acceptability lies in the hands of the other States Parties to the Covenant.

This brings us to the fundamental question how the Committee should deal with reservations and declarations. On the basis of the Vienna Convention system the States Parties decide on the validity and acceptability of reservations. The determination, as has been explained before, is an individual decision by the States Parties based on the objective "object and purpose" notion".

Yet, when reservations and declarations appear in the work of the Committee, be it in the reporting procedure or under the Optional Protocol, it does seem necessary for the Committee to have an opinion on the statements and on their 
impact on the substance of the Covenant. It stands to reason that the Committee can only discuss a State's compliance with the Covenant if it takes the reservation into account, and if necessary interprets $i^{60}$. The interpretation of declarations forming an integral part of a State party's obligation, would seem to be a logical step in the work of the Committee under article 40.4 of the Covenant. Article 31 of the Vienna Convention should be the guiding principle in this respect ${ }^{61}$.

\subsubsection{Reservations to the Optional Protocol}

The Optional Protocol does not have a specific provision on reservations either, and reservations are consequently subject to the general system as laid down in article 19.c of the Vienna Convention. Two points need attention when considering reservations and declarations to the Optional Protocol. First of all the Protocol is a separate international instrument, a treaty in its own right. This can best be seen in the need for states to explicitly express consent to be bound in order to establish obligations under the Protocol. In spite of the fact that it is an instrument technically distinct from the CCPR, it is intimately related to the Covenant on substantive issues as well as supervision. It is impossible for a State to ratify the Protocol without being party to the Covenant, according to article 1 OP. From this it follows that the direct relation between Protocol and Covenant must be considered as essential for the Protocol, belonging to its object and purpose.

A second issue in the same vein is that the Protocol purports to establish a supervisory procedure additional to the two procedures under the Covenant. The purpose of establishing a procedure is its functioning, and clearly a reservation should not seriously hamper the procedure, as a matter of object and purpose.

\subsubsection{Reservations to the Second Optional Protocol aiming at the abolition of the Death Penalty}

Unlike the Covenant and the Optional Protocol, the second Protocol ${ }^{62}$ does have a specific provision on reservations. Article 2 reads:

"1. No reservation is admissible to the present Protocol, except for a reservation made at the time of ratification or accession that provides for the application of the death penalty in time of war pursuant to a conviction for a most serious crime of a military nature committed during wartime.

2. The State Party making such a reservation shall at the time of ratification or accession communicate to the Secretary-General of the United Nations the relevant provisions of its national legislation during wartime.

3. The State Party having made such a reservation shall notify the Secretary-General of the United Nations of any beginning or ending of a state of war applicable to its territory."

60. Higgins, MLR at 17; Suy, op.cit. at 944.

61. McGoldrick, op.cit. at 24; Nowak, op.cit. at 22.

62. D.Breillat. L'abolition mondiale de la peine de mort. A propos de $2 e$ Protocole facultatif se rappportant au Pacte internationale relatif aux droits eivils et politiques, visant a abolir la peine de mort, in: RSCDPC 1991, 261-278; G.J.Naldi, The prohibition of the death penalty in international law, in: 38 NIL.R 1991, 373-384 at 375-376. 
The rule in article 2.1 SOP belongs to the category described in article 19.b VCLT, it indicates that only specified reservations may be made. These are reservations that provide for the application of the death penalty in time of war pursuant to a conviction for a most serious crime of a military nature committed during wartime. Apart from indicating which reservation is allowed, the provision creates the obligation to communicate the relevant legislation to the depository of the Second Protocol. This would seem to be a constituent element in the legitimacy of the reservation. Without the provision of wartime legislation, the reservation cannot be validly made. Furthermore, the reservation will only function in exceptional circumstances, the beginning and end of which have to be notified to the Secretary General. A reservation to the SOP is only a dormant restriction, which will have to be invoked by notification. Consequently, notification determines the legitimacy of the use of capital punishment during wartime. It should be noticed that as an "article 19.b VCLT" provision, article 2 SOP is somewhat unusual within the VCLT system. At the drafting of article 19, the Vienna Conference felt that the determination whether reservations were acceptable was to be left to the depository under paragraphs a and b, whereas the States Parties would have to decide individually in the case of article 19.c. The background of this choice were the India-IMCO discussions in which the evaluation of compatibility by the depository led to much discussion ${ }^{63}$. It was felt that the involvement of the depository should be restricted to a purely formal consideration of whether or not a particular reservation was prohibited by the treaty, or whether it belonged to the explicitly specified reservations mentioned in a treaty.

It would appear that without further qualification in the Second Protocol, the notion of "a most serious crime of a military nature" leaves room for interpretation by the Secretary General ${ }^{64}$. Does this formula refer to the grave breaches of the Geneva Conventions and Additional Protocols, does it refer to the crime of genocide? The way the reservations clause is formulated now, it calls upon the Secretary General to appreciate the seriousness of the crime referred to in article 2.1 , and in the legislation supplied under article $2.2 \mathrm{SOP}$. It might be questioned whether the Secretary General is capable (and willing) to do this, the HRC would seem to be distinctively better equipped to do so. It is obvious that the other elements "application of the death penalty in time of war" and "a conviction for a .. crime .. committed during wartime" will be easier to establish.

In respect of the reservations it is also necessary to focus on article $6.2 \mathrm{SOP}$, which reads:

"2. Without prejudice to the possibility of a reservation under article 2 of the present Protocol, the right guaranteed in article 1. paragraph 1 of the present Protocol shall not be subject to any derogation under article 4 of the Covenant."

63. See Chapter 2, par.1.3 supra about India's reservation to the 1948 IMCO Convention.

64. Breillat, op.cit. at 273. 
At first sight the provision merely reiterates the possibility of making reservations in accordance with article 2 SOP, and introduces article 1 SOP as an addition to the list of non-derogable rights in article 4.2 CCPR.

However, logically this provision undermines the supposed "object and purpose" nature of article 4 CCPR discussed before. As article 1 SOP is a non-derogable right, and if the reasoning concerning article 4 CCPR and article 19 VCLT is to be followed, reservations would be impermissible. Yet articles 6.2 juncto 2 SOP indicate that reservations to a non-derogable right (i.c. article 1 SOP) are indeed possible. The theory reflected above concerning article 4 CCPR would seem to be undermined as the consequence of sloppy drafting. From a systematic point of view, this rule is somewhat unfortunate.

\subsection{Declarations and reservations}

\subsubsection{The Covenant}

- article 1 -

Article 1 deals with the right of peoples to self-determination and to the free disposal of their natural wealth and resources. Algeria interprets article 1 as not impairing the right of control over natural wealth and resources, which seems to be a repetition of article 1.2. Both France and the United Kingdom stress that the obligations under the United Nations Charter ${ }^{65}$ will prevail over article 1 of the CCPR in cases of conflict, on the grounds of article 103 of the Charter. This declaration merely repeats what would be the case given the rule laid down in article 103 anyway ${ }^{66}$. India declares that the words "the right to self-determination" in the provision only apply to peoples under foreign domination, and do not apply to people in a sovereign independent State ${ }^{67}$. Higgins notices that the Indian declaration attaches conditions to the exercise of the right not to be found in the Charter of the United Nations ${ }^{68}$. And the HRC in its General Comment indicates that the right implies the need to provide for constitutional and political guarantees for its exercise ${ }^{69}$. The declaration would appear to be a rather restrictive interpretation, which is actually meant as a reservation ${ }^{\text {to }}$.

65. In particular articles 1 and 2 of the Charter. and for the United Kingdom also article 73.

66. It should be noted that the Charter speaks of "the principle of self-determination"(articles 1.2 and 55), whereas the Covenant speaks of "the right to self-determination". See Nowak, op.cit. at 14.

67. Discussing the character of the provision Nowak, op.cit. at 16-17: about the right to selfdetermination in a multi-ethnic State idem at 21; McGoldrick op.cit. at 15, at 247-249 and 253-254.

68. Higgins, MLR at 14.

69. General Comment 12/21, du.12-4-1984.

70. Three states objected to the Indian reservation, see par.2.1 infra, saying that it attached conditions to the right of self-determination not to be found in the Charter itself. See Higgins, MLR at 13; McCroldrick, op.cit. at 248.

A similar interpretation of article 1 appears in a periodic report by Sri Lanka, CCPR/C/14/Add.6 par.2. 
Article 1.3 refers to States Parties having the responsibility for Non-Self-Governing and Trust Territories, and their obligation to promote the right to selfdetermination. With respect to that provision Algeria emphasizes that it considers the maintenance of the state of dependence of certain territories contrary to the Charter of the United Nations and contrary to GA Resolution $1514(\mathrm{XV})^{7}$; whereas Roumania stresses that the provision is contrary to GA Resolution $2625(\mathrm{XXV})^{7}$. Apparently these states want to give prevalence to the Resolutions mentioned, thereby enlarging the scope of the provision ${ }^{73}$.

\section{- article 2 -}

Article 2 of the Covenant contains the non-discrimination rule, the obligation to take the necessary steps to implement the Covenant in the domestic legal order using the means indicated in the provision and the obligation to provide for an effective remedy in case of violations ${ }^{74}$.

Belgium reserves the right not to apply article 2 with respect to the succession to the throne, a reservation probably only dealing with article 2.1 , and the prohibition of a distinction based on sex or birth ${ }^{7576}$.

Australia and Germany made reservations dealing with article 2.1. Australia emphasizes that article 2.1 juncto articles 24.1, 25 and 26 should not hamper legislation designed to achieve the equal enjoyment of the rights in the Covenants for some classes in Australian society. The interpretative declaration aims at safeguarding positive action. It should be noted that the HRC only explicitly dealt with positive action in respect of women in General Comment $4 / 13^{77}$. Germany stresses that the articles 2.1 , together with 19,21 and 22 should be applied within the scope of article 16 of the European Convention on Human Rights, a provision that deals with the imposition of restrictions on the political activity of aliens ${ }^{78}$. The reservation aims at the co-ordination of treaty obligations conceming the position of aliens in human rights law. As the HRC stressed in General Comment $15 / 27^{79}$, the rights laid down in the CCPR are equally applicable to aliens,

71. Cf. the French reservation concerning article 7 Optional Protocol which also refers to GA Res.1514(XV). Declaration on the Granting of Independence to Colonial Countries and Peoples.

72. Declaration on Principles of International Law concerning Fricndly Relations and Cooperation among States, GA Res.2625 (XXV).

MeGoldrick indicates that it has been argued that this Resolution uses a much narrower coneept of self-determination than the Covenant does, op.cit at 248.

73. Nowak, op.cit. at 7-8.

74. Schachter. The obligation to give effect at $462-263$.

75. Though it has been published that the reservation has in the meantime been withdrawn (Opzij. Oktober 1991, at 38), this withdrawal has not yet appeared in either ST/LEG/SER.E/11 or CCPR/C/2/Rev.3.

76. Cf. General Comment $4 / 13$.

77. General Comment 4/13.

78. Article 16 of the European Convention reads:"Nothing in the articles 10,11 , and 14 shall be regarded as preventing the High Contracting Partics from imposing restrictions on the political activity of aliens."

79. General Comment 15/27. 
except for the distinction indicated in article 25 of the Covenant. The reservation of Germany goes beyond this provision, putting greater restrictions on the political activity of aliens.

It appears from the Committee's consideration of the initial report of the United Kingdom that its reservation concerning "the preservation of service and custodial discipline" is also related to article $2^{80}$.

Australia had also made a reservation concerning article 2.2 and 2.3 in relation to its federal constitutional system ${ }^{81}$. While accepting its obligations under the Covenant for the State as a whole, it reserved the right to give effect to articles $2.2,2.3$ and 50 , subject to article $2.2^{82}$. Given the formulation of the declaration it must be considered to have been a reservation. Behind this intricately formulated declaration there is concern that Australia cannot guarantee a swift and timely adaptation of existing legislation to Covenant standards by all its component parts. Australia is both committed and cautious, and emphasizes the prevalence of article 2.2, which, it should be noted, does not contain a time-limit for the taking of the "necessary steps". These steps may not take a very long time as that would be a misinterpretation of the Covenant ${ }^{83}$, gradual implementation is not the method used by the Covenant.

The reservation made at ratification on 13 August 1980, was withdrawn on 6 November 1984 when a new statement on the same issue of implementation in a federal state was delivered in the shape of a declaration ${ }^{84}$. It has been suggested that this revised statement, which reinforces the impression that the reservation had not been meant as a reservation stricto sensus. ${ }^{85}$, was the direct result of objections to the reservation ${ }^{80}$.

Though a reference to article 2.2 or article 50 is not included, the United States entered a similar understanding dealing with its federal structure ${ }^{87}$. The understanding is more sweeping than the Australian one, and while maintaining

80. CCPR/C/SR.70, par.22 (United Kingdom).

81. Gracfrath, op.cit. at 77-79.

82. For the text of the reservation sec par.3.1 infra.

83. Nowak op.cit. at 60-61.

84. The dectaration reads:"Australia has a federal constitutional system in which legislative, executive and judicial powers are shared or distributed between the Commonwealth and the constituent States. The implementation of the treaty throughout Australia will be effected by the Commonwealth, State and Territory authorities having regard to their respective constitutional powers and arrangements concerning their exercise."

85. About the apparent intentions behind the labelling of the initial statement Triggs, op.cit. at 292-294: McGoldrick op.cit. at 271.

86. International Covenant on Civil and Political Rights. Explanation of Proposed Reservations, Declarations and Understandings (hereafter: US Explanation) at 11.

87. The understanding reads:"The United States understands that this Convention shall be implemented by the Federal Government to the extent that it exercises legislative and judicial jurisdiction over the matters covered therein and otherwise by the state and local governments; to the extent that state and local governments exercise jurisdiction over such matters, the Federal Government shall take measures appropriate to the Federal system to the end that the competent authorities of the state or local government may take appropriate measures for the fulfilment of the Convention." 
the responsibility for implementation at federal level, implementation at state or local level becomes less certain as a result of the wording chosen. The official explanation attached to list of reservations and declarations for discussion in the U.S.Senate mitigates the statement, stating that "even though the Covenant will apply to state and local authorities, it will be implemented consistently with U.S. concepts of federalism." Further onwards it reads "..the intent is not to modify or limit U.S. undertakings under the Covenant but rather to put our future treaty partners on notice with regard to the implications of our federal system concerning implementation. ${ }^{288}$, and the explanation itself indicates a similarity between the US statement and the revised Australian declaration ${ }^{89}$.

\section{- article 3 -}

Article 3 stresses the equality of men and women in the enjoyment of civil and political rights. Belgium is the only State to have made a reservation with respect to article 3 , in relation to article 2 and 25 and the right to succession, discussed above.

\section{- article 4 -}

Article 4 contains the possibility to derogate from the obligations in the Covenant in times of public emergency. Given the fact that derogation as such runs contrary to the purpose of protecting people against the power of a State, such possibilities are necessarily exceptional, and should be interpreted restrictively ${ }^{90}$.

Israel made a reservation regarding article 4.1 as a whole, indicating that the state of emergency has been in force since 1948, which "constitutes a public emergency within the meaning of article $4.1^{1191}$. One cannot ignore the fact

88. US Explanation at 10-11.

89. Flinterman, Rieter, NJCM Bull at 966.

90. Cf.General Comment $5 / 13$.

91. The Israeli declaration reads:

"Since its establishment, the State of Israel has been the victim of continuous threats and attacks on its very existence as well as on the life and property of its citizens.

These have taken the form of threats of war, of actual armed attacks. and campaigns of terrorism resulting in the murder of and injury to human beings.

In view of the above, the state of emergency which was proclaimed in May 1948 has remained in force ever since. This situation constitutes a public emergency within the meaning of article 4.1 of the Covenant.

The Government of Israel has therefore found it necessary, in accordance with the said article 4 , to take measures to the extent strictly required by the exigencies of the situation, for the defence of the State and for the protection of life and property, including the powers of arrest and detention.

In so far as any of these measures are inconsistent with article 9 of the Covenant, Israel thereby derogates from its obligations under that provision."

In ST/LEG/SER.E/11 this declaration is printed in the "Derogations" section, in CCPR/C/2/Rev. 3 it appears both as a declaration, and as a derogation. 
that this statement is somewhat circular: according to article 4.1 the public emergency (which would seem to include "the state of emergency") may on certain conditions justify a derogation from the obligations under the Covenant. A state of emergency cannot in itself be a public emergency that gives the rights of derogation. Apparently Israel meant to establish the existence of a public emergency without fulfilling the requirements of article 4.1. The public emergency is established through a reservation, evading the Covenant's procedure. This explains the absence of notifications of derogation in accordance with article 4.3 by Israel.

By using a reservation the derogation has acquired an indefinite duration, withdrawal will be a unilateral act within the power of the author state ${ }^{92}$. The Covenant's notification procedure, with the requirements in article 4 , stresses the overriding character of the derogation as a temporal exception. Article 4 is an exceptional rule in the Covenant, and must be assumed to protect the Covenant's object and purpose $e^{93}$. The reservation goes a lot further than the provision allows, especially as far as the duration of the derogation is concerned. The exception is turned into the rule, one can therefore within reason claim that this reservation is contrary to a core obligation in the Covenant.

France has made a reservation regarding article $4.1^{24}$. It is a rather technical declaration, dealing with the concordance between the requirements for derogations in times of public emergency, such as formulated in article 4.1, and the circumstances in French legislation concerning the declaration of the state of siege or the state of emergency. The French reservation holds its legislation to be meeting the requirements in article 4.1. Higgins suggests that this reservation is unacceptable because it purports to exclude international supervision on the issue of the compatibility of national legislation in the field of article $4^{95}$.

In a second statement on article 4.1 France states that its constitutional criterion of "measures required by the circumstances" the Covenant's criterion of "to the extent strictly required by the exigencies of the situation". It appears that the French Constitution is more permissive than the Covenant in the evaluation of situations that necessitate to establishing a state of emergency. The intention of the reservation is clearly to evaluate the situation on the basis of domestic requirements rather than the requirements in the Covenant.

The United States issued an understanding as concerns article 4.1 , indicating that the prohibition of discrimination in the latter part of the provision does not preclude measures that may have a disproportionate effect on persons of a

93. See par.1.2.1 supra.

94. McGoldrick, op.cit. at 304-305.

95. Higgins, MLR at 16-17.

96. See article 16 of the French Constitution. 
particular status. The understanding seems to restrict the scope of the provision to direct discrimination, as opposed to indirect discrimination considered to be covered by articles 2.1 and 26 of the Covenant. The aim appears to be to achieve an interpretation that is common to the US domestic system and the Covenant. In particular it is indicated that there is a difference between the open-endedness of the Covenant's anti-discrimination provisions and the American system of prohibitions related to specific statuses ${ }^{97}$. It should be noted that the prohibited distinctions in article 4.1 are much more restrictive than the non-discrimination rule in articles 2.1 and 26 , in respect of which the United States issued an understanding ${ }^{98}$. Given the aim of excluding the legal effect of article $4.1^{\infty}$, Flinterman and Rieter take the understanding to be a reservation ${ }^{100}$. Yet as the United States has made both reservations and declarations, the Belilos theory of distinguishing is applicable ${ }^{101}$. Consequently, the understanding is an interpretation that need not be followed by the HRC.

Trinidad and Tobago made a reservation dealing with article 4.2 , the list of provisions from which derogations are not allowed ${ }^{102}$. The reservation is somewhat hermetic, as it refers to the Trinidad and Tobagan Constitution without indicating which rights are dealt with ${ }^{103}$. The reservation seems to imply that derogation from the rights listed in article 4.2 is possible, as this is apparently a possibility under its Constitution ${ }^{104}$. Contrary to the exceptional character of the provision, with its list of provisions that may not be derogated from, the reservation presents a highly uncertain derogation system. This is not acceptable because of the precision and detail with which article 4 has been drafted. Consequently a vague reservation of this kind must be assumed to be contrary to the object and purpose of the Covenant ${ }^{105}$.

97. U.S. Explanation at 6-7. Cf. McGoldrick, op.cit. par.7.11 at 304.

98. Cf. Nowak, op.cit. at $93-94$.

99. Cf. article 2.1.d VCLT.

100. Finterman, Rieter, NJCM Bull. at 966.

101. The Belitos case, and the importance of the European Commission's opinion in this case is discussed in Chapter 3, par.4.1.2 supra.

102. Suy, op.cit. at 945, writes that the reservation is in fact an interpretative declaration:"Bien que formulée en termes similaires, le déclaration de la Trinité-et-Tobago dans l'instrument figurait sous la nubrique "réserve". A la demande de Secrétariat, le Gouvernement de la Trinité-et-Tobago a alors indiqué qu'il s'agissait seulement d'une déclaration interprétative."

This fact is only reported by Suy, and has in any case not lead to a change in the presentation of the declaration in UN documents.

103. The reservation reads:" ${ }^{n}$. since section $7(3)$ of its Constitution enables Parliament to enact legislation even though it is inconsistent with sections (4) and (5) of the said Constitution."

104. McGoldrick, op.cit. par.7.17 at 306-307.

105. Cf. CCPR/C/SR.765, par.16-18 (Higgins). 


\section{- article 6 -}

Article 6 is the Covenant's provision on the right to life, and it is one of the non-derogable rights listed in article $4.2 \mathrm{CCPR}^{106}$. The prohibition of capital punishment as an elaboration of the right to life led to the conclusion of the Second Optional Protocol in 1989.

Norway entered a reservation concerning article 6.4 , the right to seek pardon or commutation of the sentence in case of a death sentence. The reservation does not give any information on the backgrounds, and was withdrawn within four-and-a-half year after the Norwegian ratification ${ }^{107}$.

In a declaration about article 6.5 , the prohibition of the death sentence for crimes committed by person below the age of eighteen, or the execution of the death sentence on pregnant women, Ireland indicates that legislation to give effect to the provision has not yet been introduced, but states that it will have regard to its obligation under the Covenant to advise commutation of such sentences. In contradistinction to what the Irish statement suggests, article 6 (and paragraph 5 in particular) points to the right for the convict to seek pardon or commutation of sentence. The intention has probably been to indicate that in spite of the absence of legislation, there is a overall willingness to be most restrictive in carrying out the death sentence ${ }^{108}$. In that respect the declaration merely explains the domestic implementation of the Covenant in spite of the absence of legislation. The declaration, read together with article 2.2 of the Covenant suggests its own withdrawal in due course. It must be considered to be a unilateral obligation to legislate and abolish the death penalty.

Without explicitly mentioning article 6.5 , the United States ${ }^{100}$ reserves the right to impose capital punishment on persons below eighteen years, only excluding the category of pregnant women ${ }^{110}$. The Covenant does not contain a general prohibition on the death penalty, yet it excludes this sentence for crimes committed by persons under eighteen and the execution of this sentence on pregnant women.

In the previous proposal to ratify the Covenant in 1978 the reservation had excluded article 6.5 completely. The administration now indicates that in contemporary practice pregnant women are not executed ${ }^{\prime \prime \prime}$. The explanation

106. Cr. Naldi, op.cit. at 373-375.

107. Withdrawn 12 December 1979.

108. Cf.General Comment 6/16, par.6.

109. The reservation reads:"The United States reserves the right, subject to its Constitutional constraints, to impose capital punishment on any person (other than a pregnant woman) duly convicted under exiting or future laws permitting the imposition of capital punishment, including such punishment for crimes committed by persons below eighteen years of age."

110. It should be noted that the protection for the mother only lasts until the end of the pregnancy, cf. Meron, op.cit. at 99-100; Nowak, op.cit. at 129-130.

111. Craig, op.cit. at $881-882$; Henkin, op.cit. at 24. 
indicates that the reservation dealing with the execution of minors is in conformity with recent Supreme Court decisions ${ }^{112}$.

The General Comment on article 6 explicitly reiterates that the Covenant itself does not abolish the death penalty ${ }^{113}$. Desirable though a general prohibition of capital punishment may be, it can at present not be considered to be included in the object and purpose of the Covenant ${ }^{144}$. The drafting of the Second Optional Protocol is more than proof of this interpretation. That is why the contention that the American reservation stressing the permissibility of capital punishment should be regarded as contrary to the object and purpose of the Covenant ${ }^{115}$, cannot be accepted. Article 6.5 itself however, prohibiting the execution of minors is non-derogable right, and reservations excluding that provision must be assumed to be contrary to the object and purpose of the Covenant.

Another problematic aspect of the American reservation is that it explicitly mentions the permissibility of capital punishment under future legislation ${ }^{116}$. Clearly future legislation must be restricted by the limits set by the Covenant (together with the article 6.5 reservation). In article 6 , as underlined by the General Comment on this article, there is a general tendency to abolish the death penalty ${ }^{117}$. Increasing the number of cases in which the death penalty may be imposed is contrary to the spirit of the provision, and is in general contrary to the obligation to implement the CCPR.

- article 7 -

Article 7 is the prohibition of torture and of cruel, inhuman or degrading treatment. It is a non-derogable right under article 4.2 of the Covenant, and the prohibition has been elaborated in the Convention against Torture, and other Cruel, Inhuman and Degrading Treatment or Punishment ${ }^{118}$.

In an interpretative declaration the United States indicates that it considers itself bound by article 7 on the assumption that "cruel, inhuman and degrading treatment or punishment" has the same meaning as "cruel and unusual treatment" in the fifth, eight and fourteenth amendment to the Constitution. The declaration has the shape of a reservation giving prevalence to domestic legislation. In the explanation it is indicated that this interpretation is in line with a similar interpretation foreseen at the ratification of the Convention against Torture. It is furthermore explained that the interpretation is a reaction to the views of the Human Rights Committee about the length of judicial proceedings and the consequences this could have in cases involving capital punishment; the same goes for the views taken by the Committee on issues

112. Naldi, op.cit. at 380-384.

113. General Comment 6/16, par.6.

114. Naldi, op.cit. at $373,378$.

115. Flinterman, Rieter, NJB at 935; Flinterman, Rieter, NJCM Bull, at 964.

116. Flinterman, Rieter, NJCM Bull., at $\mathbf{9 6 3 .}$

117. Cf. preamble Second Optional Protocol, third paragraph.

118. GA Res. 39/46, entry into force 26 June 1987. 
such as corporal punishment and solitary confinement ${ }^{110}$. Clearly, as a State adhering to the Covenant almost 25 years after it was first opened for ratification, the United States used the opportunity to react on the views and practice of the Human Rights Committe ${ }^{120}$. This raises the interesting question of the authority of the Human Rights Committee's interpretation of the Covenant in relation to subsequent ratifications.

\section{- Article 8 -}

Article 8 deals with the prohibition of slavery, servitude and compulsory labour. The first two paragraphs on slavery and servitude are non-derogable rights.

Iceland made a reservation in respect of article 8.3.a, the prohibition of forced or compulsory labour. It indicates that there is a provision of Icelandic law to the effect that a person who is not the main provider may be sentenced to work in a labour facility to satisfy arrears in support payments for children. It should be noted that this is not an issue under the (non-derogable) right laid down in article 11 CCPR, the inability to fulfil a contractual obligation, as this is an obligation under national law ${ }^{121}$.

- article 9 -

Article 9 is the Covenant's provision on arbitrary arrest. A large number of States made reservations with respect to article 9. France made a reservation to the effect that articles 9 and 14 will have no bearing on the enforcement of disciplinary rules in the army. India indicated that article 9 will be applied in consonance with sections of article 22 of the Indian Constitution. Israel derogates from the obligations under article 9 in relation to the existence of the state of emergency, suggesting that it does not precisely know to what extent the state of emergency measures deviate from the guarantees in article 9. These general reservations to article 9 as a whole all indicate the prevalence of domestic legislation over the safeguards provided for prisoners and detainees. As a consequence of the vagueness of the reservations it is hard to establish which rights and what protection are exactly excluded.

In a reservation dealing specifically with article $9.3^{122}$, Finland also refers to domestic legislation, indicating that under its legislation administrative authorities may take decisions on arrest and imprisonment after which some time may pass before a decision is taken in court. It should be noted that article 9.3 calls for prompt access to a judge, the Finish reservation speaks of "a certain time lapse". Austria interpreted articles 9 and 14 as not prohibiting the measures in its Administrative Procedure Acts and in the Financial Penal Act. In spite of the lack of detailed information on the content of this legislation, it appears that this reservation also purports to safeguard the delay in access to a 
court $^{123}$. Article 9.3 speaks of prompt access to a judge, and General Comments $8 / 16$ interprets this as "delays must not exceed a few days" ${ }^{\text {"24 }}$.

Five states made reservations concerning article 9.5 , the right to compensation for miscarriages of justice. Italy indicates that it considers this right to be restricted to the cases of arrest and detention contrary to article 9.1, arbitrary arrest or ex post facto procedures. It should be noticed that article 9.5 deals with any kind of unlawful arrest of detention, implying that this is not necessarily restricted to the rights guaranteed in the Covenant and includes illegality under domestic law as much as illegality under international law ${ }^{125}$. In its interpretative statement Mexico indicates that a right to compensation exists for procedures as a result of false accusations. Apparently what is meant is a right against the accuser, which is not necessarily excluded in article $9.5^{126}$. In the understanding issued by the United States the right of compensation is also considered to be enforceable against either governmental entities or the individual responsible. Moreover the compensation is subject to reasonable requirements in domestic law. India is the one State to indicate plainly that no right of compensation for the victims of unlawful arrest exists.

- article 10 -

Article 10 is the provision dealing with the treatment of accused and convicted persons. The majority of reservations and declarations made with respect to article 10 focus on paragraph 2 , and its obligations to separate the accused from the convicted, and to separate adults from juveniles. Two issues appear in the declarations, first of all the capacity problems that strict separation might cause, and consequently some States indicate that they feel that this an objective to be implemented progressively. On the other hand there is the consideration that sometimes separation is not beneficial to juveniles. It is noteworthy that the HRC is quite uncompromising on the rules laid down in article 10.2, as can be seen in General Comment 9/16 127 .

In a reservation concerning article 10.1 and withdrawn in 1984, Australia stated that provisions of the Covenant are without prejudice to the rules for the preservation of custodial discipline in penal establishments ${ }^{128}$.

With respect to article 10.2.a, Ireland and Australia ${ }^{120}$ indicate that they consider separation an objective to be achieved progressively. Belgium states that it will interpret the provision in conformity with the Council of Europe Standard Minimum Rules for the Treatment of Prisoners ${ }^{130}$, and indicates

123. Nowak, op.cit. note 103 at 185.

124. Cf. General Comment 8/16, par.2.

125. Nowak, op.cit. at 189.

126. Nowak, op.cit. at 190.

127. General Comment $9 / 16$, par.2

128. Triggs, op.cit. at $295-296$.

129. Triggs, op.cit. at 296.

130. Resolution (73) 5 of the Committee of Ministers of the Council of Europe, 19 January 1973. 
that under certain circumstances communal activities for accused and convicted persons are possible. The Netherlands entered a reservation indicating that it does not want to be considered bound by the provision, as "ideas about the treatment of prisoners are so liable to change ${ }^{1131}$. It is noticeable that the Netherlands is the only State to have formulated this opinion in a reservation. The United Kingdom reserves the right not to apply article 10.2.a to Gibraltar, Montserrat and the Turks and Caicos Islands. And the United States indicates that under "exceptional circumstances" the menace constituted by an individual must be considered included, and states that the accused may waive their right to separation.

The separation of juveniles and adults in article $10.2 \mathrm{~b}$ is clearly meant to be to the benefit of the juveniles ${ }^{132}$. But States do feel that the obligation is too absolute, and indicate that they may deviate from the general rule if that is more beneficial, or if there is a lack of suitable prison facilities. Australia ${ }^{133}$, Finland, Iceland, the United Kingdom, and Switzerland all indicate that they have a policy of separation, but cannot agree with a general and absolute rule to that effect. The availability of adequate prison facilities is mentioned in the declarations of New Zealand, the United Kingdom and Trinidad and Tobago. Without further elaboration Norway and the United States entered a reservation to articles 10.2.b concerning juvenile convicts and 10.3 .

Article 10.3 deals with reformation and social rehabilitation as the essential aims of the penitentiary system. A number of States link the latter part of this provision to article 10.2.b and the protection of juveniles ${ }^{1.4}$, overcoming the distinction between accused and convicted juveniles. The United States issued an understanding indicating that article 10.3 does not diminish other aims of the penitentiary system, such as deterrence, incapacitation and punishment ${ }^{135}$. It would seem that the main goal of the understanding is to shelter the American prison system from criticism by the States Parties or the Human Rights Committee ${ }^{136}$.

- article 11 -

Article 11 contains the prohibition of imprisonment on the ground of the inability to fulfil contractual obligations, and it is listed in article 4.2 of the Covenant as a non-derogable right. Congo made a reservation to this provision, indicating that it is incompatible with domestic legislation which allows for imprisonment as enforcement measures for the payment of debts over a certain

131. In the same vein Craig, op.cit. 882-883; Nowak, op.cit. at 201.

132. Nowak, op.cit. at $199-200$.

133. Australia twisted the criterion of benefit around, stating "accepted only to the extent that such segregation is considered by the responsible authorities to be beneficial to the juveniles or adults concerned." (emphasis added, EL); Triggs, op.cit. at 296.

134. Australia, Austria, Belgium, Denmark, Finland, Luxembourg. Netherlands, New Zealand, Norway, Sweden, Trinidad and Tobago, United Kingdom, United States.

135. Nowak, op.cit. at 200-201.

136. Craig, op.cit. at 882-883; Flinterman, Rieter, NJCM Bull. at 966-967. 
amount of money when the debtor has acted in bad faith. The reservation indicates that imprisonment is possible for debts exceeding the amount of 20,000 CFA francs, logically speaking one may assume that through the process of inflation the number of debtor cases within the ambit of the reservation will only grow with the passing of time and the deterioration of the economy in Africa. Thus, while a rule of domestic law is involved, it is a rather flexible rule in which the value of money has a decisive role ${ }^{137}$. Without any further explanation as to the reason for making the reservation, the United Kingdom claims the right not to apply article 11 in Jersey.

On the face of it, these are ordinary reservations indicating the prevalence of national legislation over the Covenant's rules. The seriousness of these reservation, lies in the fact that article 11 is a non-derogable right, and therefore belongs to the core-obligations underlying the Covenant. It should be noted that this has however not led to an abundance of objections on that ground $^{138}$.

\section{- article 12 -}

Article 12 is the provision that deals with liberty of movement and the right to leave and return to one's country.

India issued a general declaration that the provision shall be applied in conformity with a provision in its Constitution. The Netherlands reserved their right to consider the Netherlands (the so-called "Kingdom in Europe") and the Netherlands Antilles as separate territories for the purpose of article 12.1 and as separate countries for the purpose of articles 12.2 and 12.4 , clearly with the purpose to retain the power to restrict these rights between the component parts of the Kingdom ${ }^{139}$. The United Kingdom made similar reservations with respect to article 12.1, indicating that territory in the provision would apply to each of the territories of the United Kingdom and its dependencies separately. In respect of article 12.4 the United Kingdom explicitly indicates that their acceptance of the provision is subject to the continued application of existing immigration legislation, which also amounts to restricting the application of

137. Cr. CCPR/C/SR 732, par.59 (Dimitrijevic).

138. See supra par.1.2.1: only Belgium and the Netherlands objected to the Congolese reservation referring to article 11 as a non-derogable right. No objections were made to the UK-Jersey reservation to the same non-derogable right.

C. Higgins, MLR at 15; Nowak op.cit. at 205.

139. It is remarkable that the Netherlands felt the need to make a reservation concerning article 12.2 (the right to leave any country), whereas the Unitcd Kingdom did not make such a reservation. Both states intended to safeguard their power of restricting intraterritory movement.

The parliamentary papers concerning the law of approval for the Covenant (Memorie van Toelichting bij de Goedkeuringswet) indicate that the difference between "country". in articles 12.1 and 12.4 CCPR and the usual term "state" prompted the reservation. TK 1975-1976, 13932 (R 1037) at 23-24. 
article 12 between the component parts of the State ${ }^{140}$. Given the general phrasing of the provision, reservations are necessary if the rights of people from colonies and dependent territories need to be restricted ${ }^{141}$. Switzerland reserved the application of article $\mathbf{1 2 . 1}$ to those foreigners having a valid residence permit for a particular canton, thereby excluding the nation-wide scope of the provision ${ }^{142}$. Article 12 contains a general rule on liberty of movement once someone is lawfully present within the territory. Consequently a reservation is necessary if there are geographical restrictions to a residence permit. Trinidad and Tobago reserve the right not to apply article 12.2 because of the fact that persons wanting to travel abroad must furnish tax clearance certificates first. In somewhat exceptional reservations dealing with article 12.4 Austria reserves the right to maintain the expulsion of the House of HabsburgLorraine, and Italy does the same for some members of the House of Savoy. It would appear that Austria and Italy were not certain whether the expulsion might not be consider arbitrary.

- article 13 -

The expulsion of aliens lawfully within the territory of a State is surrounded by procedural guarantees in article 13 of the Covenant. Decisions about the expulsion itself are protected by other provision of the Covenant, article 13 merely deals with the execution of the expulsion decision and the right of appeal against such a decision ${ }^{143}$. Finland indicated by way of a reservation that its legislation was not in conformity with this provision, and was able to withdraw the reservation some ten years later ${ }^{1+4}$. France made a plain reservation that the provision would not derogate from any domestic instrument concerning the entry and sojourn of aliens in France. The reservation of Iceland is much more restricted and indicates that legislation on the matter of objecting to the expulsion decision is not in conformity with the Covenant. India indicates that it will apply domestic law to foreigners in respect of article 13, thereby apparently indicating the non-conformity of Covenant and Indian legislation on this point. Non-conformity is also the case with the legislation of Malta, the reservation however appears to be a temporal one, as it seems to express a willingness to make the necessary legislative changes in the

140. Higgins, BYIL, note 4 at 319.

141. Nowak, op.cit. at 211.

142. The Swiss reservation reads:"The right to liberty of movement and freedom to choose one's residence is applicable, subject to the federal laws on aliens which provide that residence and establishment permits shall be valid only in the canton which issues them."

Though paragraph 6 of General Comment 15/27, would seem to suggest that the Swiss reservation is acceptable, this is contradicted by Nowak, op.cit. at 211-212.

143. Cr. General Comment 15/27, par.10.

144. See infra par.2.4 
future ${ }^{145}$. Mexico mentions the non-compatibility of its Political Constitution with article 13, and the United Kingdom reserves the right not to apply article 13 (and the right of review provided therein) for a deportation order in Hong Kong.

- article 14 -

Article 14 is the Covenant's long and extensive due process provision. A considerable number of reservations have been made, most of them safeguarding domestic legislation against the influence of the Covenant. Ireland indicates that its military law on minor offenses may not in all respects be in conformity with article 14.

With respect to the earlier part of article 14.1 , publicity of the trial ${ }^{146}$, Austria indicates that this will be subject to the Federal Constitution Law. Switzerland indicates that pre-trial penal procedures before an administrative authority will not be public. Neither will civil procedures be public, depending on cantonal legislation.

Concerning the latter part of article 14.1, the obligation to make public criminal judgments ${ }^{147}$, Belgium asserts that its system, which does not allow for derogations from the principle mentioned, is in conformity with the Covenant. Denmark indicates that its legislation allows for the exclusion of the press and the public to a greater extent than the Covenant appears to do. In a reservation withdrawn ten years after ratification Finland reserved the right to keep certain sentences secret, based on considerations other than the ones mentioned in the latter part of article $14.1^{148}$. With respect to public sentencing Switzerland indicates that, depending on cantonal legislation, the judgement will not be delivered in a public hearing but communicated to the parties in writing ${ }^{149}$.

Malta made a reservation with regard to article 14.2 , the right to be presumed innocent ${ }^{150}$. It interprets the provision as not prohibiting legislation that imposes upon any person the obligation of proving particular facts, which is contrary to the intention behind the provision.

Article 14.3, the minimum guarantees in a penal procedures, attracted many reservations. Australia made a reservation to article 14.3.b indicating that adequate facilities does not mean the provision of the same facilities to the prisoner as to the prisoners legal representative ${ }^{151152}$.

145. The Maltese reservation reads:"The Government of Malta endorses the principles laid down in article 13. However, in the present circumstances it cannol comply entirely with the provisions of this article."

146. See first part of article 14.1; cf. McGoldrick op.cit. at 402-403, Nowah, op.cit. at 261-264 and General Comment $13 / 21$ par.6.

147. Nowak, op.cit. at 264-267.

148. About the reservations by Denmark and Finland. Higgins, ML.R at 13-14.

149. Cl. Nowak, op.cit., at 261 and 264-266, and General Comment 13/21 par.6.

150. McGoldrick op.cit. at 403-404; Nowak, op.cit. at 267-268 and General Comment 13/21 par.7.

151. McGoldrick op.cit. at 406: Triggs op.cit. at 296. 
Fourteen States made reservations regarding article 14.3.d, and emphasize two of the most important obligations under that provision ${ }^{153}$. With respect to the right to be tried in his presence, Australia, Austria and the Netherlands indicate that it remains possible to exclude the defendant from the procedure on the grounds of disturbance and improper conduct ${ }^{154}$. Venezuela reserves the right to apply its in absentia procedure for offence against the res publica. Germany made a reservation in respect of its Revisionsgericht procedure, indicating that it is for the Court to decide whether the defendant held in custody is to appear before the court. Australia, Barbados, Finland, Gambia, Guyana, and the United Kingdom all indicate that they cannot guarantee free legal assistance, while Switzerland indicates that legal assistance does not relieve the beneficiary from the obligation to pay the ensuing fees. Italy indicates that it considers domestic legislation permitting a defendant to conduct his own defence to be compatible with article 14.3.d. The United States focuses on the free choice of counsel, indicating that a court may appoint a counsel in the case of indigence, and stating that the rule does not apply when the defendant is able to pay for alternative counsel or when imprisonment is not imposed ${ }^{155}$.

The United States is the only State to have made a reservation in respect of article 14.3.e, indicating that this provision does not prohibit the obligation to show that a witness is necessary for the defense ${ }^{156}$. Switzerland made a reservation in view of article 14.3.f, to the extent that free assistance from an interpreter does not relieve the defendant from the obligation to pay the ensuing fees ${ }^{157}$.

The United States made a reservation to article 14.4 and its special treatment for juveniles, linked with paragraphs 2 (b) and 3 of article 10 , dealt with supra ${ }^{158}$.

The right to a review by a higher tribunal in article 14.5 met with a variety of reservations all dealing with specific rules of domestic law ${ }^{159}$. Italy, Belgium, the Netherlands and Switzerland all exclude this right in view of procedures concerning persons holding a public office, held in first instance before the

152.(...continued)

152. Though $C C P R / C / 2 /$ Rev. 3 indicates that this reservation has been withdrawn, the section on withdrawals in the same document merely mentions the Australian reservation to article 14.6 to be withdrawn. The present situation is consequently uncertain.

153. McGoldrick, op.cit. at 408-409; Nowak op.cit. at 272-274 and General Comment 13/21. par.11.

154. Triggs, op.cit. at 297, 299-302.

155. The reservation reads:"The United States understands that subparagraphs $3($ b) and (d) of article 14 do not require the provision of a criminal defendant's counsel of choice when the defendant is provided with court-appointed counsel on the grounds of indigence, when the defendant is financially able to retain alternative counsel, or when imprisonment is not imposed..."

156. Craig, op.cit. at 883-884; McGoldrick op.cit. at 409; Nowak op.cit. at 274-275 and General Comment 13/21 par.12.

157. McGoldrick op.cit. at 409-410; Nowak op.cit. at 275-276 and General Comment 13/21 par. 13. See for a discussion of the Temeltasch case see Chapter 3, par.4.1.1 supra.

158. MeGoldrick, op.cit. at 410-411; Nowak, op.cit. at 277-279 and General Comment 13/21 par.16.

159. MeGoldrick, op.cit. at 411-412; Nowak op.cit. at 279-281. 
highest jurisdictional authority ${ }^{160}$. Trinidad and Tobago reserve the right to continue the application of its system of leave to appeal as a specific requirement in a number of cases. Norway and Denmark merely exclude article 14.5, with the latter indicating that its domestic legislation differs from the obligations under the Covenant. Considerations of domestic legislation also led to the reservations of France ${ }^{|6|}$, Germany, and Korea. Austria indicates that article 14.5 is no restriction to higher courts pronouncing a heavier sentence in second instance $^{162}$. Belgium and Luxembourg made similar reservations, indicating that article 14.5 does not provide for another instance after an acquittal in first instance.

The obligation to provide compensation for the miscarriage of justice in article 14.6 met with a number of reservations ${ }^{163}$. Guyana, Malta, and Trinidad and Tobago indicate that while supporting the principle they are at present not in the position to implement the provision, because of financial constraints. Austra$\mathrm{lia}^{164}$ and Ireland indicate that rather then drafting legislation to deal with these cases, they will be dealt with in administrative procedures. In a similar vein New Zealand reserves the right to consider its system of ex gratia payments as satisfying the requirements of the Covenant. The United States interprets the provision as requiring the existence of an effective and enforceable mechanism through which a person may obtain compensation, subject to reasonable requirements of domestic law.

The ne bis in idem rule in article 14.7 met with a variety of reservations ${ }^{165}$. Without further explanations, Denmark, Norway, Korea, and Sweden indicate their reservation to the provision, with a view to domestic legislation. Austria, Iceland, and the Netherlands mention the existence of the possibility to reopen, resume or review a case. Finland indicates that under certain circumstances a change for the worse is possible under its domestic system, whereas the United States limits the protection to judgments of acquittal rendered by a court of the same governmental unit. This would not seem to prevent prosecution for the same case in two different states ${ }^{100}$.

- article 15 -

Article 15 contains the nullum crimen sine lege rule, as well as provisions on the imposition of lighter penalties in cases of a change in the law ${ }^{167}$. It appears in the list of non-derogable rights in article 4.2 of the Covenant, yet five States issued reservations and declarations in this respect. Italy indicates that the rule in

160. Nowak, op.cit. par.69 at 281.

161. France states that it considers the rule in article 14.5 to be "a principle to which the law may make limited exceptions."

162. McGoldrick, op.cit. par.10.21 at 411 .

163. McGoldrick, op.cit. at 412; Nowak, op.cit. at 281-284.

164. Triggs, op.cit. at 297.

165. McGoldrick, op.cit. at 412-413; Nowak, op.cit. at 285-286.

166. Henkin, op.cit. at 23-24.

167. Nowak, op.cit. at 292-294. 
the latter part of article 15.1 is held to be applicable in cases in progress. excluding possible benefit for convicts. Trinidad and Tobago shares the Italian point of view, whereas the United States is stricter, indicating that the law in force at the time of the crime will be applied ${ }^{168}$. Germany is more lenient indicating that the previous law may remain applicable to certain crimes committed hefore the change in legislation.

Argentina issued an understanding concerning article 15.2, indicating that it will be applied subject to Argentine constitutional lawis".

\section{- article 17 -}

The prohibition of interference with privacy, family, home and correspondence can be found in article $17^{1 \%}$. Before withdrawing its reservation to article 17 some ten years after it was made ${ }^{171}$. Australia was the only state to have made a reservation which indicated that it reserved the right to limit the protection in the interests of national security, public safety, the economic well-being of the country, the protection of public health or morals and the protection of the rights and freedoms of others ${ }^{17}$.

\section{- article 18 -}

Mexico is the only state to have issued an interpretative statement concerning article 18, which is the non-derogable right of freedom of thought, conscience and religion ${ }^{173}$. It indicates that it considers the limitation clauses concerning public religious acts and the professional education of ministers in the Mexican Constitution to be in conformity with the limitation clause in article 18.3. Whether this is a correct interpretation remains to be seen, as paragraph 3 uses two distinct criteria: prescribed by law, and necessary for the protection of the goals listed in the provision.

- article 19 -

Article 19 deals with the freedom of opinion and expression, and five States made general reservations to the provision. Austria, Belgium, France, and Germany indicate that they will apply the articles 19,21 and $22^{174}$ of the Covenant in conformity with articles $10^{175}, 11^{176}$ and $16^{177}$ of the European

168. Flinterman/Rieter, NJCM Bull., 966.

169. As a consequence of a strange omission, the Argentine understanding does not appear in CCPR/C/2/Rev.3, and can only be found in ST/LEG/SER.E/11.

170. Nowak, op.cit. at 306-310, General Comment 16/32.

171. Though CCPR/C/2/Rev.3 indicates that the reservation is withdrawn at p.5 (referring to section $C$ of the document), a notice of withdrawal of this particular reservation cannot be found in section C (at p.35). It is consequently unclear whether the reservation to article 17 has indeed been withdrawn.

172. Triggs, op.cit. at 298.

173. Nowak, op.cit. at 343-345.

174. Germany also indicates the relevance of article 2.1 of the Covenant.

175. Belgium and France.

176. Belgium and France. 
Convention for the Protection of Human Rights and Fundamental Freedoms. Malta indicates that it will maintain its constitutional restrictions on the freedom of speech for public officers, and reserves the right not to apply the provision in as much as it is not compatible with domestic legislation implementing article 16 of the European Convention.

With respect to the second paragraph of article $19^{178}$, Australia ${ }^{179}$, Ireland, Luxembourg, and the Netherlands made reservations dealing with the regulation and licensing of radio and television broadcasting, whereas France made a reservation in this respect to the provision as a whole ${ }^{180}$. Australia indicates that the object of licensing is to provide "the best possible broadcasting services", a goal clearly not mentioned in paragraph 3 of the same provision. Luxembourg and the Netherlands also mention a licensing system for film companies and cinema's respectively.

The issue of licensing is dealt with by Italy in respect of article $19.3^{181}$. India indicates that article 19.3 is to be applied in conformity with the Indian Constitution, and the United States formulated a similar reservation indicating that the requirements and constraints in the Constitution prevail over article $19.3^{182}$.

- article 20 -

Article 20 is the much discussed prohibition of propaganda for war. The reservations to article 20 in general stress the fact that the provision will be considered to be compatible with articles $18,19,21$ and $22^{183}$ of the same Covenant, and with article 18, 19 and 20 of the Universal Declaration on Human Rights ${ }^{184}$. Apart from the fact that is logically necessary for the Covenant to be construed as non-contradictory, such an interpretation also follows from article 31 of the Vienna Convention on the Law of Treaties. Additionally a number of States indicates that it is not their intention to implement the provision through legislation ${ }^{185}$.

In respect of article $20.1^{186}$, the majority of the reserving states indicate that they do not intend to legislate along the lines of this provision, and stress the possible contlict between this provision and the rules on freedom of expression ${ }^{187}$. France indicates that it interprets "war" as war in contravention of

177.(...continued)

177. Austria. France and Germany.

178. McGoldrick op.cit. at 464; Nowak, op.cit at 362-363 and General Comment 10/19 par.2.

179. A reservation withdrawn in 1984; Triggs, op.cit. 298.

180. The reservation was withdrawn in 1988 .

181. Cf. Nowak, op.cit at 378.

182. Craig, op.cit. at 880 .

183. Australia, Belgium, Luxembourg, Malta and the United Kingdom.

184. Belgium and Luxembourg.

185. Australia, Belgium, Luxembourg, Malta, New Zealand, United Kingdom and United States.

186. Higgins, MLR at 15-16 and 17; McGoldrick, op.cit. at 481-483; Meron, op.cit. at 118-119; Nowak, op.cit. at 385-387 and General Comment $11 / 19$.

187. Belgium, Denmark, Finland, Iceland, Ireland, Luxembourg, Malta, Netheriands, Norway, Sweden, Switzerland 
international law, thereby apparently indicating that propaganda for the few remaining categories of lawful warfare is legitimate under article $20.1^{188}$.

With respect to article 20.2 , the obligation to penalize incitement to discrimination $^{189}$, Switzerland indicates that legislation will be forthcoming with the ratification of the Convention on the Elimination of Racial Discrimination. This is obviously a temporary reservation, including a unilateral obligation to withdraw the reservation in due course.

\section{- article 21 -}

The reservations of Austria, Belgium, France, and Germany to article 21 and the right of peaceful assembly have been dealt with under article 19. They all focus on the relevance of the articles 10,11 and 16 of the European Convention for Human Rights and Fundamental Freedoms.

India refers to the compatibility of article 19 of its Constitution with article 21 of the Covenant; whether this is a formal compatibility or a matter of substance remains unclear.

Trinidad and Tobago reserves the right to impose lawful and or reasonable restrictions with respect to the right of assembly. The formulation "lawful and or reasonable" is problematic, as the provision itself requires both, and restricts the notion of "reasonable" to a limited number of eases ${ }^{100}$.

- article 22 -

Article 22 is the provision on freedom of association. Apart from the reservations of Austria, Belgium, France, and Germany dealt with above, as well as the similar reservation of India referring to article 19 of its Constitution, a number of states refer to their national legislation. Malta and New Zealand both indicate that existing legislation may not be in conformity with the provision, whereas the Republic of Korea understands its national legislation and Constitution to be in conformity with the Covenant on this point. Algeria interprets the provision as making the law the framework of action for the State with respect to the right to organize. This is a contentious interpretation, as far as the provision goes a legal basis is a requirement for restricting the right which is a much more liberal system than the one proposed by Algeria.

In a reservation concerning article 22.2 Japan indicates that it includes firemen in the categories of professional groups in respect of which the freedom of association may be restricted ${ }^{191}$.

- article 23 -

A number of reservations deal with the Covenant's provision on family rights. In a general reservation Israel reserves the right to apply the religious law of the

188. (it. the Netherlands expressing a similar line of thought in the consideration of the second periodical report, CCPR/C/SR.863, par. 49.

189. McGoldrick op.cit. at 483-484: Nowak op.cit. at 388-391.

10). Nowak op.cit. at $400-402$.

191. Nowak, op.cit at $424-426$ 
parties in matters concerning the family and the personal status. In a superfluous declaration concerning the second paragraph Belgium indicates that it has the power to regulate the exercise of the right to marry.

In respect of article 23.3 the United Kingdom reserve the right not to apply the provision in a small number of customary marriages in the Solomon Islands ${ }^{192}$.

Through a reservation Algeria safeguards the validity of domestic legislation concerning the rights and responsibilities of spouses. Ireland indicates that the right to obtain a dissolution of marriage is not accepted ${ }^{193}$, and the Republic of Korea merely excludes this provision. The United Kingdom made a reservation concerning the first sentence of article 23.4, indicating that there may be inequalities arising from the law of domicile ${ }^{194}$.

\section{- article 24 -}

This provision deals with the protection of children ${ }^{195}$. Australia made a reservation indicating that this provision, together with article $2.1,25$ and 26 of the Covenant, is without prejudice to Australian legislation concerning positive action $^{196}$. The reservation has subsequently been withdrawn.

The United Kingdom reserved its right to enact legislation in the field of nationality based upon the criterion of sufficient connection with the United Kingdom, in respect of paragraph 3 dealing with the right to nationality for children ${ }^{197}$.

- article 25 -

Article 25 of the Covenant covers issues such as the right to vote and the right to participation in politics and public service. Australia ${ }^{198}$ made a general reservation indicating that these rights may be restricted in the case of persons convicted of serious crimes ${ }^{199}$. Restrictions of this kind would in all likelihood fall within the notion of "reasonable restrictions" in the opening phrase of the provision. The Belgian reservation concerning succession to the throne has been dealt with supra.

Mexico reserves the right to continue to apply article 130 of its Constitution to the effect that ministers of religion may not vote or take part in political organisations ${ }^{200}$. Switzerland indicates that article 25.b will not prevent the possibility under cantonal and local law that particular elections do not take place

192. Nowak, op.cit. at 443-444.

193. Nowak,op.cit. at $439-440$.

194. Nowak, op.cit. at $445-449$.

195. In 1989 the United Nations adopted the Convention on the Rights of the Child, which entered into force on 2 September 1900.

196. Triggs, op.cit. at $302-304$.

197. Nowak, op.cit. at $463-465$; General Comment $17 / 35$ par.8

198. Triggs, op.cit. at 299.

199. While indicating in section $\mathrm{B}$ that this reservation is withdrawn, similar information cannot be found in section $\mathrm{C}$ of CCPR/C/2/Rev.3.

200. Nowak, op.cit at 488. 
in a secret ballot ${ }^{201}$. The United Kingdom reserves the right not to apply article 25.b in respect of an Executive or Legislative Council in Hong Kong and article 25.c in respect of jury service in the Isle of Man. In a withdrawn reservation the Netherlands excluded the application of article 25.c in the Netherlands Antilles.

- article 26 -

Article 26 is the general non-discrimination provision. Australia indicates that it considers the law concerning persons convicted of serious criminal offenses to be consistent with article 26 of the Covenant. Austria indicates that differential treatment of nationals and aliens is permissible under article 26 as well as under article 1.2 CERD. The reservation of Trinidad and Tobago amounts to legitimizing the distinction between nationals and aliens as far as landownership is concerned. In an understanding the United States indicate that article 26 does not prohibit distinctions, based upon the categories mentioned, that are rationally related to a legitimate governmental objective.

In its reservation concerning article 26 , Switzerland limits the scope of this provision to the rights protected in the Covenant ${ }^{202}$, in an apparent reaction to the Committee decisions ${ }^{303}$ about the provisions.

- article 27 -

The rights of persons belonging to minorities are protected in article 27 of the Covenant ${ }^{204}$. Referring to article 2 of the French Constitution, France indicates that it will not apply the Covenant's provision on minority rights. In a reaction, Germany proposed to understand this reservation as implying that the rights are already guaranteed in the French Constitution ${ }^{205}$.

- article 47 -

With respect to the provision on the right of people to enjoy and utilize their natural wealth and resources ${ }^{206}$, the United States declared that this right may only be exercised in accordance with international law. The apparent aim of the

201. Nowak, op.cit.at 481 .

202. C. Nowak, op.cit. at 499-500: 503-504.

203. See: Méssage sur l'adhesion de la Suisse aux deux Pactes internationaux de 1966 rélatifs aux droits de l'homme et une modifiction de la loi féderale d'organisation judiciaire (91.004), dd.30 January 1991: at 12.

Switzerland refers to the recent practice of the Human Rights Committee and its interpretation of article 26 as an independent right (ef. General Comment 19). It is indicated that Switzerland considers article 26, comparable to article 14 of the European Convention, as an accessory right.

Cf. Views in Cases S.W.M.Broeks v. Netherlands (case No.172/1984), in: CCPR/C/OP/2, 196; and F.H.Zwaan-de Vries v. Netherlands (case No.182/1984), in: CCPR/C/$\mathrm{OP} / 2$ at 209.

204. Nowak, op.cit. at 513-539.

205. Graefrath, op.cit. at 70 ; reinfored in the initial report by France, CCPR/C/22/Add.2, p.40.

206. Nowak, op.cit. at $673-674$. 
declaration is to maintain the United States' position with respect to compensation for nationalization of foreign property. The issue of nationalization is intimately linked with natural resources, and the whole discussion about prompt, adequate and effective compensation, as opposed to adequate compensation ${ }^{207}$. This is also reflected in the information sent to Congress ${ }^{\text {xis }}$.

- article 48 -

Article 48 is the Covenant's participation clause, to which communist states have traditionally made reservations on the grounds that the formulation used is contrary to the principle of sovereign equality as participation is restricted to States members of the United Nations or the specialized agencies. Other motives for the reservations are the fact that all States should have the right to become parties to multilateral treaties governing matters of general interest (Czechoslovakia) or the principle of the universality of international treaties and the democratization of international relations (Guinea). A remarkable statement is the one by Hungary, which indicates that it considers the participation clause to be incompatible with the objectives and purposes of the Covenant. The reserving states are Afghanistan (reservation to both articles 48.1 and 3), Byelorussian SSR (Belarus), Bulgaria (reservation to both articles 48.1 and 3), Czechoslovak SR (Czech and Slovak Federal Republic), German Democratic Republic, Guinea, Hungary, Mongolia, Romania, USSR (Russian Federation), Syrian Arab Republic, Ukraine SSR (Ukraine), and Viet Nam.

Though not specifically related to article 48 as such, a number of Arab states indicated that they objected to establishing treaty-relations with Israel. These political reservations need not be discussed extensively ${ }^{\text {not }}$.

Though not specifically related to article 48 , the reservation of the United Kingdom concerning the impossibility to implement the Covenant in Southern Rhodesia needs to be mentioned. At the time of ratification, in 1976, Rhodesia was technically still a British colony $y^{210}$

- article 50 -

Article 50 of the Covenant emphasizes the Covenant's validity in the component parts of federal States. Australia and the United States are the only federal states to have made reservations in respect of article 2.2 and 50, dealt with supra ${ }^{211}$.

\subsubsection{Declarations and reservations relating to the Optional Protocol}

- article 1 -

208. International Covenant on Civil and Political Rights, Ixplanation of Proposed Reservations. Declarations and Understandings etc., at 13-14.

209. Reservations by Iraq. Libya, Syria and Yemen.

210. S.A.de Smith. Constitutional and Administrative Law, Harmondsworth. 3rd.ed. repr. 1978. at 642 .

211. See the discussion reflected at article 2 (CPR supra. 
Article I OP establishes the Committee's competence to receive individual communications. France, Malta ${ }^{212}$, and the Russian Federation have made declarations concerning article 1 , amounting to a restriction on the Committee's power based on the moment of entry into force of the Optional Protocof ${ }^{13}$. France and Malta restrict the Committee's competence to "acts, omissions, developments or events occurring after the date (of entry into force, EL)" as well as "a decision relating to acts, omissions, developments or events occurring after the date"; whereas Russia indicates that the Committee's competence is restricted to "situations or events occurring after the date", which is clearly more restrictive than the French and Maltese declarations are.

From the point of view of the law of treaties there is no problem with reiterating that the Committee's competence in the field of individual communications only begins after the entry into force of the Optional Protocol, which is after all a legal instrument technically distinct from the Covenant. From that angle the declarations state the obvious: that the Optional Protocol cannot cover cases that occurred prior to its entry into force.

However, every State Party to the Optional Protocol must be a party to the Covenant, as indicated in article $1 \mathrm{OP}^{214}$. The French accession to the Optional Protocol took place more than three years after its accession to the Covenant ${ }^{21}$, and Russia ${ }^{216}$ had been a party to the Covenant for eighteen years before acceding to the Optional Protocol. Both declarations intend to exclude the power of the Committee to consider individual communications about cases occurring in the period after the entry into force of the Covenant but prior to the entry into force of the Optional Protocol ${ }^{-17}$. Given the fact that hoth France and Russia were bound by the Covenant in that interim period, the declaration is peculiar, and suggest to a certain extent had faith on the part of both States. In terms of article 19.c VCLT, one might say that these reservations to the Optional Protocol are possibly contrary to the object and purpose of the Covenant.

212. Malta aceded to the Covenant and the Optional Protocol on the same day, 13 September 1990. The Maltese declaration. which is a carbon copy of the French text, will not be dealt with explicitly.

213. The French declaration reads:"France interprets article 1 of the Protocol as giving to the Committee the competence to receive and consider communications from individuals subject to the jurisdiction of the French Republic who claim to be victims of a violation by the Republic of any of the rights set forth in the Covenant which result either from acts, omissions, developments or events occurring after the date on which the Protocol entered into force for the Republic, or from a decision relating to acts, omissions, developments or events after that date."

214. On this issue see par.1.2.2 supra.

215. France acceded to the Covenant on 4-11-1980; and acceded to the Optional Protocol on 17-2-1984.

216. Russia ratified the Covenant on 16-10-1973, and acceded to the Optional Protocol on 110-1991.

217. V.Coussirat-Coustère, L'adhésion de la France au Protocole Facultatif se rapportant au Pacte International relatif aux Droits Civils et Politiques, in: XXIX AFDI 1983, 510-532 at 517. 
Before ratification of the Optional Protocol, the only form of supervision States Parties have to participate in is the reporting procedure under article $40 \mathrm{CCPR}$. Theoretically this covers the whole of the domestic implementation of the Covenant, yet it is know to be a very imprecise and vague procedure. It is quite possible that deficiencies in the implementation may escape the Committee's attention. The reporting procedure will seldom lead to a definite decision that a particular situation is not in accordance with the Covenant. This is distinctly different in the procedure under the Optional Protocol, in which a well-founded complaint may lead to an authoritative view of the Committee that a certain situation is below Covenant standards. By indicating an explicit reluctance to submit prior practice to the Optional Protocol procedure, the authors of the declarations cast doubt on their implementation of the Covenant in the period preceding ratification of the Protocol.

- article 5 -

A number of European States have made a similar reservation in respect of article 5.2, a provision dealing with facts the Committee has to ascertain prior to dealing with the individual communication. The paragraph requires the Committee to establish that the matter is not being examined under another international procedure, and the declarations and understandings indicate that the Committee is also to establish that the matter has not already been examined under another international procedure. This is what Denmark, France, Iceland, Ireland, Italy, Luxembourg. Malta, Norway, Poland, Spain, and Sweden indicate. Austria merely states that the Committee should ascertain that same case has not been dealt with by the European Commission of Human Rights, thereby presenting a more flexible reservation ${ }^{218}$. The reservations all deal with the possible coincidence of various international human rights procedures ${ }^{219}$. Within the Council of Europe it was recommended that the States Parties would all make reservations to the effect that the European Convention procedures would prevail ${ }^{200}$.

The declaration of the Soviet Union is somewhat surprising as it repeats the obvious: the substantive content of article 5.2 subparagraphs a and b. It is possible that the Soviet Union had the same restrictions as the ones mentioned above in mind, this is however not mentioned in the understanding ${ }^{221}$.

218. For instance procedures such as ECOSOC Res.1503(XLVIII), article 14 CERD, article $22 \mathrm{CAT}$ are not excluded under this formulation.

219. Discussing the issue of parallel procedures, Coussirat-Coustère, op.cit. at 516-528.

220. Coussirat-Coustère, op.cit. at 523. See: 13 Yb ECHR 1970, 70-77; and about this P.van Dijk, G.J.H.van Hoof, De Europese Conventic in theorie en praktijk, 2nd Rev.Ed., Nijmegen 1982.

It should be noted, however that not all member States of the Council of Europe followed this recommendation, Portugal and the Netherlands did not make that particular reservation.

221. The Russian understanding reads: The Soviet Union also proceeds from the understanding that the Committee shall not consider any communication unless it has been ascertained that the same matter is not being examined under another procedure of 
- article 7 -

France is the only state to have made a declaration concerning article 7 of the Optional Protocol and the reference to GA Resolution 1514 (XV) contained therein. It merely states that the acceptance of the Optional Protocol does not imply a change in its position concerning this particular Resolution.

\subsubsection{Declarations and Reservations to the Second Optional Protocol aiming at the Abolition of the Death Penalty}

- article 5 -

Spain is the only state to have made a reservation to the Second Optional Protocol so far. It reserves the right to apply the death penalty in exceptional and extremely serious cases such as provided for in its domestic Military Criminal Code in wartime. No texts of the relevant laws appear in the information compiled by the Office for Legal Affairs, it must be assumed that the information was communicated to the Secretary-General, who sent it to the Human Rights Committee 222 .

\section{REACTIONS OF THE STATES PARTIES}

\subsection{Objections}

So far $^{223}$ only eight States ${ }^{24}$ have objected to substantive reservations made by other States Parties ${ }^{225}$.

The Indian reservation concerning article 1 of the Covenant met with objections from France, Germany and the Netherlands. France indicates that the reservation attaches conditions to the right to self-determination not provided by the Charter. Germany states that the Indian interpretation of the right in the Charter is contrary to the clear language of the provision, and is moreover incompatible with the object and purpose of the Covenant. The Netherlands refers to the formulation of the right to self-determination in the Covenant and to the Declaration on Principles of International Law concerning the Friendly Relations and Co-operation among States $^{226}$ as an authoritative statement of the law con-

\section{1.(..continued)}

international investigation or settement and that the individual in question has exhausted all available domestic remedies."

Clearly the necessary formulation of "is not being examined or has not been cxamined" [emphasis added, EL] is absent.

222. This assumption is based on article $2.2 \mathrm{SOP}$. and CCPR/C/2/Rev.3.

223. CCPR/C/2/Rev.3: Nowak, op.cit. par.23 at p.xxiv.

224. Suy. op.cit. at 947.

225. This is excluding the traditional objection by Argentina to the United Kingdom's declaration on the territorial extension of the Covenant to the Falkland Islands/Malvinas Islands. The United Kingdom reacted with a declaration indicating that it is fully entitled to make such a declaration of territorial extension.

226. GA Res. 2625 (XXV). 
cerned; and states that attempts to limit the right to self-determination would seriously weaken its universally acceptable character. Here again the objecting States do so beyond the time-limit set in the Vienna Convention ${ }^{227}$.

Both Germany and the Netherlands responded to the reservation concerning article 4.2 made by Trinidad and Tobago. Germany and the Netherlands use an identical formulation, stating that it follows from the text and history of the Covenant that the reservation is incompatible with the object and purpose of the Covenant ${ }^{228}$. Yet, neither state explicitly refers to the fact that article 4.2 is the provision dealing with non-derogable rights.

Both Belgium and the Netherlands ${ }^{229}$ objected to a reservation made by the Congo regarding article 11, the prohibition of imprisonment on the grounds of inability to fulfil a contractual obligation ${ }^{230}$. The Belgian objection is a longwinded exposé about the fact that the reservation is not necessary in respect of Congolese law, and, being aimed at a non-derogable right, is highly undesirable. The wish is expressed that the reservation be withdrawn ${ }^{231}$.

Four States ${ }^{32}$ objected to the reservation concerning the reservations made by the Republic of Korea relating to articles 14.5, 14.7 and 22 of the Covenant. Germany issued an observation relating to the reservation concerning article 22 . the provision on freedom of association. It states that the declaration made by Korea is interpreted as not restricting the obligations under article 22 by referring to the domestic legal system. Given the fact that the Korean declaration is explicitly labelled a reservation, one wonders why Germany took this line of action. It should be noted that Korea is under no obligation to respond to this benevolent interpretation of its reservation. Czechoslovakia indicates that it considers the reservations concerning articles $14.5,14.7$ and 22 incompatible with the object and purpose of the Covenant, adding that the Korean approach is contrary to the principle of international law that one may not invoke its internal law as a justification for a failure to perform a treaty. The Netherlands raises a

227. India acceded to the Covenant on 10 April 1979; France objected on 4 November 1980, Germany on 15 August 1980 and the Netherlands on 12 June 1980.

228. Trinidad and Tobago acceded on 21 December 1978: Germany objected on 21 April 1982 (more than three years later). the Netherlands objected on 12 June 1980 (one and a half years later).

229. Through a strange omission the Netherlands objection does not appear in CCPR/C/2/Rev.3: ST/LEG/SER.E/11 mentions that the Netherlands made an objection identical to the Belgian objection.

230. Nowak, op.cit. par.23 at p.xxiv and par.11 at p.2015.

231. The "non-paper" by the Netherlands Ministry of Foreign Affairs indieates that as a result of the objection (dd.6 November 1984), the Permanent Representative of Congo in New York indicated on 11 January 1985, that Congo had decided to withdraw the reservation.

In spite of this statement, the reservation has not been formally withdrawn according to UN documents.

232. All of them reacted after the end of the twelve month time-limit set by article 20.5 VCLT. The Republic of Korea aeceded on 10 April 1990: Germany reacted on 24 May 1991. the United Kingdom on 25 May 1991, Crechoslovakia on 7 June 1991 and the Netherlands on 10 June 1991. 
similar objection to this reservation, indicating that the reservations are contrary to the object and purpose of the Covenant. The United Kingdom issued a declaration in which it is stated that there is not sufficient indication of the effect of the reservation ${ }^{233}$. Consequently, it reserves the right to respond in the future ${ }^{234}$.

Germany, the Netherlands and Portugal objected to the Algerian declaration concerning article 23.4, the obligation to ensure equality in marriage. The interpretative declaration reads that Algeria interprets the provision as "..in no way impairing the essential foundations of the Algerian legal system." Given the fact that no further explanation concerning these essentials is provided, the scope of the declaration is fairly vague. In its objection Germany indicates that it understands Algeria as not intending to restrict the obligation to ensure equality of rights and responsibilities of spouses as to marriage, during marriage and at its dissolution. It should be noted that within the procedure of objecting to reservations, there is no way of finding out whether this German assumption is correct, unless Algeria clarifies its position. It is however not obliged to do so. The Netherlands states that the declaration must be considered to be a reservation, and says that it follows from the text and history of the provision that the reservation is contrary to object and purpose of the Covenant. Portugal takes a similar point of view and finds the Algerian declaration to be a reservation incompatible with the purposes and object of the Covenant. Both the Netherlands and Portugal indicate that their objections will not preclude entry into force, but as the objections were received too late that would probably not have been possible anyway ${ }^{235}$.

The Netherlands issued a non-committal statement concerning a number of reservations made by Australia. It indicates that the reservations regarding article $\mathbf{2}$ and 50, the federal clause, is only acceptable if it does not impair the obligation to implement the Covenant in all the component parts of the State ${ }^{236}$. With respect to the reservations concerning article 10 and concerning Convicted

233. The United Kingdom declaration reads:

The Government of the United Kingdom have noted the statement formulated by the Government of the Republic of Korea on accession, under the title "RESERVATIONS". They are not however able to take a position on these purported reservations in the absence of a sufficient indication of their intended effect, in accordance with the terms of the Vienna Convention on the Law of Treaties and the practice of the Parties to the Covenant. Pending receipt of such an indication, the Government of the United Kingdom reserve their rights under the Covenant in their entirety."

234. It remains to be seen whether it is at all possible to reserve such a right, given the fact that this imprecise reaction of the United Kingdon was received after the end of the time-limit set in article 20.5 VCLT. The Republic of Korea ratified on 10 April 1990, the United Kingdom's declaration was issued on 25 May 1991.

235. Algeria ratified on 12 September 1989; Germany issued a declaration on 25 October 1990; the Netherlands objected on 18 March 1991 and Portugal on 26 September 1990. All these reactions are clearly beyond the twelve month time-limit set by article 20.5 VCLT.

236. Nowak, op.cit. at 683. 
Persons, the Netherlands indicates that it cannot determine the effect of these reservations, and asks for a further clarification by Australia $^{237}$.

Germany in a peculiar reaction to the French reservation concerning article 27, indicated that it understood the reservation to mean that the individual rights protected by article 27 were guaranteed under the French Constitution. The legal nature of this statement ${ }^{238}$ is unclear, and the German assumption seems to be rather far-fetched. In particular, the assumption that the rights excluded by the reservation are covered by the Constitution is not entirely credible. Moreover, France is under no obligation to respond to the German statement, and consequently it is not known if the German interpretation is correct.

The reservations to the Covenant have seen the creation of a pseudo-objection, a statement in which the author State indicates that is cannot evaluate the impact of a particular statement, and consequently requests additional information as to the effect of a particular reservation. It is hard to establish the legal nature of these statements, and the obligations, if any, following from them. In particular, there would not seem to be an obligation on the part of the reserving State to provide information. It also unclear whether it would still be possible to object if the information were not provided or proved to be unsatisfactory. Moreover, if the reserving State were to provide such information, there is no rule on the dissemination of the additional information. This might be exchanged in bilateral contacts between the reserving State and the objecting State; though it would be equally valuable for the other States Parties, if not for the Committee.

\subsection{State Party meetings}

So $\mathrm{far}^{239}$ the matter of reservations and interpretative declarations to the CCPR has only been discussed once in a meeting of the States Parties, held bi-annually on the basis of articles 30.4 and 32 of the Covenant. In one of the earlier meetings Sweden raised the issues of reservations to non-derogable rights ${ }^{300}$,

237. The Netherlands statement reads:

"The Kingdom is not able to evaluate the implications of the first part of the reservation regarding article 10 on its merits, since Australia has given no further explanation on the laws and lawful arrangements, as referred to in the text of the reservation. In expectation of further clarification by Australia, the Kingdom for the present reserves the right to raise objections at a later stage."

"The Kingdom finds it difficult. for the same reasons as mentioned in its commentary on the reservation regarding article 10 , to accept the declaration by Australia that it reserves the right not to seck amendment of laws now in force in Australia relating to the rights of persons who have been convicted of serious criminal offences. The Kingdom expresses the hope that it will be possible to gain a more detailed insight into the laws now in force in Australia, in order to facilitate a definitive opinion on the extent of this reservation."

238. The statement appears in the category "Notes" (ST/LEG/SER.E/11, 153).

239. CCPR/SP/37, dd.3-8-1992; CCPR/C/SR.15, dd.19-9-1990.

240. CCPR/SP/SR.5, par.25-27 (Sweden). 
under the agenda-item "other matters". This led to a discussion in which a number of States Parties indicated that the election of the Human Rights Committee was the only task of the meeting. It should not discuss any questions of substance 241 .

It has been suggested that the matter of reservations be put on the agenda ${ }^{242}$, and it might be that there would be more willingness to discuss this in the meeting of States Parties at present. Yet, the issue of reservations does not appear to have had great importance for the States Parties in general.

\subsection{Withdrawal of reservations}

So far six states have been able to withdraw their reservations to the Covenant.

Australia announced the withdrawal of all of its reservations with the exception of reservations to articles 10.2.a; 10.2.b; 10.3(second sentence); 14.6 and article 20 , some four years after the ratification of the Covenant. In actual fact, four reservations were withdrawn, relating to articles $17,19,25$ and the reservation relating to Convicted Persons. The reservation referring to the federal clause in article 50 juncto article 2 was reformulated as a positive obligation stressing that the implementation of the Covenant would take place in accordance with the division of power within the domestic legal system ${ }^{243}$. The statement is now labelled a declaration, and could not be a reservation on the basis of the point in time at which it was issued. Consequently half of the Australian reservations were maintained after the withdrawal. The Netherlands objections to the Australian reservations does seem to have had some impact, the statement on the implementation of the Covenant in a federal State was re-formulated ${ }^{244}$.

Finland managed to withdraw reservations twice. In March 1985, almost ten years after ratification, it revoked the reservations to article 13 and article 14.1 as a consequence of the amendments in domestic legislation. For similar reasons the reservations concerning article 9.3 and article 14.3.d have been withdrawn in 1990. This means that at present only three of the original seven reservations remain in force.

In 1988 France withdrew it reservation relating to article 19 and the monopoly in the French national broadcasting system. In 1983, five years after ratification, the Netherlands withdrew their reservation excluding the application of article 25.c to the Netherlands Antilles, and in 1979 Norway withdrew its reservation to article 6.4. Korea withdrew its reservation to article 23.4 within a year after accession, and here again the objections do not seem to have had any influence, the objections were aimed at the Korean reservations that have been maintained.

242. Flinterman, Rieter, NJCM Bull, at 969.

243. Nowak, op.cit. at 683; Triggs, op.cit. at 292-294.

244. Cf. "non-paper", at 3-5. 


\subsection{Reporting Procedure, article 40 CCPR}

The Covenant has entered into force in March 1976, and a number of States have already had the opportunity to report a few times. The Covenant indicates in article 40.1 that States Parties are obliged to submit a report within one year after the entry into force for the State in question, and after that whenever the Committee so requests. In the Human Rights Committee's decision on periodicity ${ }^{245}$, the Committee indicated that it expects reports every five years. In the following, we shall consider the way in which the Human Rights Committee treated substantive reservations in the reporting procedure.

\section{ALGERIA}

The Algerian Government interprets article 1, which is common to the two Covenants, as in no case impairing the inalienable right of all peoples to self-determination and to control over their natural wealth and resources.

It further considers that the maintenance of the state of dependence of certain territories referred to in article 1, paragraph 3, of the two Covenants and in article 14 of the Covenant on Economic, Social and Cultural Rights is contrary to the purposes and principles of the United Nations, to the Charter of the Organization and to the Declaration on the Granting of Independence to Colonial Countries and peoples (General Assembly Resolution 1514 (XV)).

The Algerian Government interprets the provisions of article 8 of the Covenant on Economic, Social and Cultural Rights and article 22 of the Covenant on Civil and Political Rights as making the law the framework for action by the State with respect to the organization and exercise of the right to organize.

The Algerian Government interprets the provisions of article 23 paragraph 4, of the Covenant on Civil and Political Rights regarding the rights and responsibilities of spouses as to marriage, during marriage and at its dissolution as in no case impairing the essential foundations of the Algerian legal system.

Algeria's first periodical report was due in september 1990, it gives an extensive description of the legal aspects of the implementation of the Covenant ${ }^{24}$. With respect to article 22 CCPR the report presents an outline of Algerian legislation dealing with the legal position of associations. No mention is made of the interpretative declaration concerning this provision, nor is the declaration with respect to article $23.4 \mathrm{CCPR}$ mentioned. The Committee was very concerned with the consequences of political upheaval in Algeria, and the declarations are barely dealt with ${ }^{247}$.

\section{ARGENTINA}

The Argentine Government states that the application of the second part of article 15 of the International Covenant on Civil and Political Rights shall be subject tot the principle laid down in article 18 of the Argentine National Constitution. 
The initial report by Argentina ${ }^{248}$ indicates that articles 18 and $31^{249}$ of its Constitution, dealing with the nullum crimen sine lege principle as well as with the application of treaties within the domestic legal order, have led to the reservation concerning article 15.2 . The report states that the "general principles of law recognized by civilized nations" do not constitute a law authorizing judgement and sentence ${ }^{250}$. Committee-member Pocar indicated that the Argentine reservation was hard to understand, as it dealt with an imperative rule of international law $^{251}$. The Argentine representative did not reply to this remark $^{252}$. And Committee-member Higgins indicated that in her view the reservation was in fact an interpretative declaration ${ }^{253}$.

\section{AUSTRALIA}

Articles 2 and 50 [withdrawn]

Australia advises that, the people having united as one people in a Federal Commonwealth under the Crown, it has a federal constitutional system. It accepts that the provisions of the Covenant extend to all parts of Australia as a federal State without any limitations or exceptions. It enters a general reservation that article 2, paragraphs 2 and 3 , and article 50 shall be given effect consistently with and subject to the provisions in article 2, paragraph 2.

Under article 2, paragraph 2, steps to adopt measures necessary to give effect to the rights recognized in the Covenant are to be taken in accordance with each State Party's Constitutional processes which, in the case of Australia, are the processes of a federation in which legislative, executive and judicial powers to give effect to the rights recognized in the Covenant are distributed among the federal (Commonwealth) authorities and the authorities of the constituent States.

In particular, in relation to the Australian States the implementation of those provisions of the Covenant over whose subject matter the federal authorities exercise legislative, executive and judicial jurisdiction will be a matter for those authorities; and where a provision has both federal and state aspects, its implementation will accordingly be a matter for the respective constitutionally appropriate authorities (for the purpose of implementation, the Northern Territory will be regarded as a constituent State).

To this end, the Australian Government has been in consultation with the responsible State and Territory ministers with the object of developing cooperative arrangements to coordinate and facilitate the implementation of the Covenant.

Article 10

Australia accepts the principle stated in paragraph 1 of article 10 and the general principles of the other paragraphs of that article, but makes the reservation that these and other provisions of the Covenant are without prejudice to laws and lawful arrangements, of the type now in force in Australia, for the preservation of custodial discipline in penal establishments.

In relation to paragraph 2 (a) the principle of segregation is accepted as an objective to be achieved progressively. In relation to paragraph 2 (b) and 3 (second sentence) the obligation to segregate is accepted only to the extent that such segregation is considered by the responsible authorities to be beneficial to the juveniles or adults concerned.

Article 14

248.

CCPR/C/45/Add.2, par.172-176.

249. It should be noted that this provision is not referred to in the reservation.

250. CCPR/C/45/Add.2, par.176.

251. CCPR/C/SR.952, par.55 (Pocar).

252. CCPR/C/SR.955, passim.

253. CCPR/C/SR.956, par.11 (Higgins). 
Australia accepts paragraph 3 (b) on the understanding that the reference to adequate facilities does not require provision to prisoners of all the facilities available to a prisoners's legal representative.

Australia accepts the requirement in paragraph 3 (d) that everyone is entitled to be tried in his presence, but reserves the right to exclude an accused person where his conduct makes it impossible for the trial to proceed.

Australia interprets paragraph 3 (d) of article 14 as consistent with the operation of schemes of legal assistance in which the person assisted is required to make a contribution towards the cost of the defence related to his capacity to pay and determine according to law, or in which assistance is granted in respect of other than indictable offenses, only after having regard to all relevant matters.

Australia makes the reservation that the provision of compensation for miscarriage of justice in the circumstances contemplated in paragraph 6 of article 14 may be by administrative procedures rather than pursuant to specific legal provisions.

Article 17 [withdrawn]

Australia accepts the principles stated in article 17 without prejudice to the right to enact and administer laws which, in so far as they authorize action which impinges on a person's privacy, family, home or correspondence, are necessary in a democratic society in the interests of national security, public safety, the economic well-being of the country, the protection of public health or morals or the protection of the rights and freedoms of others.

Article 19 [withdrawn]

Australia interprets paragraph 2 of article 19 as being compatible with the regulation of radio and television broadcasting in the public interest with the object of providing the best possible broadeasting services to the Australian people.

Article 20

Australia interprets the rights provided for by articles 19,21 and 22 as consistent with article 20; accordingly, the Commonwealth and the constituent states, having legislated with respect to the subject matter of the article in matters of practical concern in the interest of public order (ordre public), the right is reserved not to introduce any further legislative provisions on these matters.

Article 25 [withdrawn]

The reference in paragraph (b) of article 25 to "universal and equal suffrage", is accepted without prejudice to law which provide that factors such as regional interest may be taken into account in defining electoral divisions, or which establish franchises for municipal and other local government elections related to the sources of revenue and the functions of such government.

Convicted persons [withdrawn]

Australia declares that laws now in force in Australia relating to the rights of persons who have been convicted of serious criminal offenses are generally consistent with the requirements of article 14, 18, 19,25, 26 and reserves the right not to seek amendment of such laws.

Discrimination and distinction [withdrawn]

The provisions of articles 2, paragraph 1, and 24, paragraph 1.25 and 26 relating to discrimination and distinction between persons shall be without prejudice to laws designed to achieve for the members of some class or classes of persons equal enjoyment of the rights defined in the Covenant. Australia accepts article 26 on the basis that the object of the provision is to confirm the right of each person to equal treatment in the application of the law.

Declaration $^{24.4}$

Australia has a federal constitutional system in which legislative, executive and judicial powers are shared or distributed between the Commonwealth and the constituent 
States. The implementation of the treaty throughout Australia will be eflected by the Commonwealth, State and Territory authorities having regard to their respective constitutional powers and arrangements concerning their excrcisc.

In its initial report ${ }^{2 s 5}$, Australia interprets its position with respect to articles 2 and 50 in a manner distinct from the reservation made. It states that the Covenant extends to all parts of Australia, stressing that implementation is a complex matter in a federal State ${ }^{-36}$, and indicates how the federation is reviewing the conformity of legislation with the Covenant ${ }^{257}$. It elaborates on the background of the article 10 reservation, stressing the need for disciplinary measures in prison $^{258}$. Australia states that the separation of the accused from the convicted is a problem in sparsely populated regions of the country. A similar motivation is provided for the separation of juveniles, in some cases separation would lead to solitary confinement which is not considered to be beneficial at all ${ }^{599}$. With respect to the reservation concerning article 14.3.h, the report indicates that this was a reaction to a recent decision of the US Supreme Court ${ }^{2(x)}$. Australia feels that the reservation concerning article 14.3.d and the right to be tried in one's presence, is somewhat obvious, but the report indicates that it was made for safety's sake ${ }^{2(61}$. The second reservation relating to article $14.3 . \mathrm{J}$ is intended to safeguard the means testing in the provision of legal aid ${ }^{60}$. Compensation for miscarriages of justice is provided through administrative procedures, as the reservation to article 14.6 indicates, rather than through legislation. Australia's reservation to article 17 and the protection of privacy, can be traced back to uncertainty about the use of the word "arbitrary" in paragraph I of the provision ${ }^{263}$. The reservation concerning article 19.2 of the Covenant is similar to other reservations in that field, and the same goes for the reservation conceming articles 19,21 and 22 of the Covenant ${ }^{20}$. With respect to the article 25 reservation, it is indicated that under certain circumstances people may he disqualified from voting, whereas other groups of people may also be excluded from the right to vote in local elections. The report underlines that the reservation concerning article 26 excludes the obligation to provided legislative protection against discrimination, and to stress the legitimacy of affirmative action programmes. Finally, it is indicated that the main reason for the reservation concerning convicted persons lies in the fact that at present Australian jurisdictions differ in the restrictions imposed on convicts.

256. CCPR/C/14/Add.1, par.64.

257. CCPR/C/14/Add.1, par.67.

258. CCPR/C/14/Add.1, par.203-204.

259. CCPR/C/14/Add.1, par.205-208.

260. CCPR/C/14/Add.1, par.256-257.

261. CCPR/C/14/Add.1, par.267-269.

262. CCPR/C/14/Add.1, par.276.

263. CCPR/C/14/Add.1, par.316-319.

264. It is indicated that the reservation is similar to the one made concerning article 4.a CERD. 
During the Committee discussion $5^{205}$ concern is expressed about the number of reservations made, and about the impact of the reservation in respect of articles 2.2, 3 and 50. There is uncertainty about the meaning of the declaration as a whole, and of the third paragraph as such. Committee members seemed to feel that the labelling of the statement as a reservation, and its content were contradictory. Or, as one member put it, if Australia meant to indicate that implementation would be in accordance with its federal system the reservation was superfluous; whereas if the intention were to exclude responsibility for the implementation by the federal States that would be incompatible with the Covenant. It appears that the labelling "general reservation" was meant to indicate that the aim would still be conformity with treaty obligations, but by then semantics had a hold on the discussion ${ }^{266}$. Ultimately the Australian representative indicated that his country had probably been overcautious in the formulation of its reservations, and stressed that Australia had deemed it desirable to draw the attention to the arrangements concerning the implementation of the Covenant in a federal State ${ }^{267}$.

A small number of members focuses on other substantive issues, such as the relation between General Comment 9/16 and the reservation concerning article 10.2. b and $10.3^{268}$, the need to protect affirmative action by means of a reservation to article $26^{269}$ and the need for making a reservation to article $14^{2 \pi}$. Other issues dealt with were the reference to the economic well-being in the reservation to article $17^{271}$, the mandatory nature of article $20 \mathrm{CCPR}^{272}$, and the means testing in the reservation to article $25 . \mathrm{b}^{273}$.

The second periodical report of Australia indicates the withdrawal in 1984 of the majority of the reservations and declarations ${ }^{274}$. Australia by then maintained the reservations concerning articles 10,14 and 20 of the Covenant. Indicating that "[I]n a federation, implementation of the provisions of the Covenant is a matter of some complexity. ", Australia reformulated its statement on the implications of a federal structure in respect of the implementation of the Covenant ${ }^{275}$. The report then goes on to elaborate on the three remaining reservations. In respect of the reservation concerning the segregation of juvenile delinquents from

265. 17th Session, October 1982.

266. CCPR/C/SR.401 par.12 (Evans), par.29 (Tamopolsky): CCPR/C/SR.402 par.11, 15, 19 (Prado Vallejo), par. 28 (Movchan); par.37 (Ermacora); CCPR/C/SR.403 par.3 (Opsahl). par.11 (Graefrath), par.37-38 (Tomuschat); CCPR/C/SR 407 par. 3-4 (Australia): CCPR/C/SR.408 par.32-36 (ultimate confusion).

267. CCPR/C/SR.407, par.3-4 (Australia).

268. CCPR/C/SR.401 par.24 (Bouziri).

269. CCPR/C/SR.401, par.30 (Tamopolsky).

270. CCPR/C/SR.401, par.41 (Tarnopolsky).

271. CCPR/C/SR.402, par.22 (Prado Vallejo).

272. CCPR/C/SR.402, par.23 (Prado Vallejo).

273. CCPR/C/SR.403, par.25-26 (AI Douri).

274. CCPR/C/42/Add.2, par.59-60.

275. It should be noted that this statement is necessarily a mere interpretative declaration, whatever its content. In 1984 Australia could not have made a reservation, as it had ratified in 1980 . 
adults and of accused persons from the convicted (article 10.2.a, 10.2.b and 10.3 ) it is stated that the reservation originates in, on the one hand, changing views about the best way to punish criminal offenses and on the other hand the problems created by the size of the country ${ }^{276}$; while it is recognized that the separation of accused from the convicted is recognized as an objective to be achieved gradually. The report indicates that the reservation to article 14.6 is in substance covered by the availability of administrative procedures to obtain compensation for miscarriage of justice. With reference to the reservation concerning article 20 of the Covenant, it is indicated that a similar reservation has been made in respect of article 4.a CERD, and that the reservation purports to protect the freedom of expression. The imprecision of the formulation in article 20, the prohibition of "propaganda for war" is criticized.

Discussions with the Australian representative focuses on the need for the article 14 reservation. The questions deal with the administrative procedure concerning compensation for miscarriage of justice, and the question whether the Covenant explicitly provides for a written legal instrument in this case ${ }^{277}$. The withdrawal of the reservation concerning articles 2 and 50 of the Covenant (federal reservation) is discussed, the representative making a mistake by labelling the new declaration a reservation; and correcting it the next day, indicating that it is a statement ${ }^{278}$. The reservation concerning article 20 is discussed ${ }^{279}$, and the withdrawal of the statement with respect to article 25.b which had only been an interpretative declaration and Australia did not want to suggest that it did not give its unqualified support to the provision ${ }^{280}$.

\section{AUSTRIA}

1. Article 12, paragraph 4, of the Covenant will be applied provided that it will not affect the Act of 3 April 1919, State Law Gazette No.209, concerning the Expulsion and the Transfer of Property of the House of Habsburg-Lorraine as amended by the Act of 30 October 1919. State Law Gazette No.501, the Federal Constitutional Act of 25 July, Federal Law Gazette No.292, and the Federal Constitutional Act of 28 January 1928, Federal Law Gazette No.Of, read in conjunction with the Federal Constitutional act of 4 July 1963, Federal Law Gazette No.172.

2. Article 9 and article 14 of the Covenant will be applied provided that legal regulations governing the proceedings and measures of deprivation of liberty as provided for in the Administrative Procedure Acts and in the Financial Penal Act remain pernissible within the framework of the judicial review by the Federal Administrative Court or the Federal Constitutional Court as provided by the Austrian Federal Constitution.

3. Article 10 , paragraph 3 , of the Covenant will be applied provided that legal regulations allowing for juvenile prisoners to be detained together with adults under 25 years of age who give no reason for concern as to their possible detrimental influence on the juvenile prisoner remain permissible.

277. CCPR/C/SR.806, par.30 (Higgins); CCPR/C/SR.808, pars.23 (Chanet), 33 (El Shafei); CCPR/C/SR.809, par.59 (Chanet).

278. CCPR/C/SR.807, par.8 (Australia); CCPR/C/SR.809, par.13-14 (Australia).

279. CCPR/C/SR.807, par.9, 13 (Australia); CCPR/C/SR.809, par.51 (Higgins).

280. CCPR/C/SR.809, pars.11,12 (Australia). 
4. Article 14 of the Covenant will be applied provided that the principles governing the publicity of trials as set forth in article 90 of the Federal Constitutional Law as amended in 1929 are in no way prejudiced and that:

a) Paragraph 3, subparagraph (d) is not in conflict with legal regulations which stipulate that an accused person who disturbs the orderly conduct of the trial or whose presence would impede the questioning of another accused person, of a witness or of an expert can be excluded from participation in the trail;

b) Paragraph 5 is not in conflict with legal regulations which stipulate that after an acquittal or a lighter sentence passed by a court of the first instance, a higher tribunal may pronounce conviction or a heavier sentence for the same offence, while they exclude the convicted person's right to have such conviction or heavier sentence reviewed by a still higher tribunal:

c) Paragraph 7 is not in conflict with legal regulations which allow proceedings that led up to a person's final conviction or acquittal to be reopened.

5. Articles $19,21,22$ in connection with article 2, paragraph 1 , of the Covenant will be applied provided that they are not in conflict with legal restrictions as provided in article 16 of the European Convention for the Protection of Human Rights and Fundamental Freedoms.

6. Article 26 is understood to mean that it does not exclude different treatment of Austrian nationals and aliens, as is also permissible under article 1, paragraph 2, of the International Convention on the Elimination of All Forms of Racial Discrimination.

The first Austrian report deals with the reservation concerning article $9^{281}$. The report elaborates on the application of the segregation principle in article 10.3 of the Covenant, explaining that the reservation protects a system in which minors are imprisoned together with delinquents up to the age of 25 years, and states that the reservation safeguards the existing Austrian prison system $^{282}$. In respect of the reservation concerning article 14.1 and the publicity of the trial and the judgement, it appears that the reservation rests on the wish to maintain a slightly stricter system in Austria. Restrictions on the right to be tried in one's presence are motivated by the possibility under Austrian law to expel the accused from the court room in case of disturbing of the proceedings ${ }^{283}$. The reservation concerning article 14.5 appears to deal with a rule of procedural law in which a higher Court may impose a sentence after an acquittal in first instance, this being a decisive verdict against which appeals are not possible ${ }^{284}$. The consideration leading to the reservation conceming article 14.7 has been that the possibility to review a case should new information come to light is contrary to the ne bis in idem principle ${ }^{285}$. The reservation to article 19 is motivated by the necessity of having a tool to restrict the political activities and similar meetings of foreigners if the need should arise ${ }^{386}$.

In the Committee's consideration of the Austrian report, a number of issues are dealt with. On the basis of detailed knowledge about the Austrian Constitutional system, Committee-member Graefrath criticizes the different approach used on 
the ratification of the European Convention on Human Rights on the one hand and the ratification of the CCPR and ESCR on the other hand. The different position of the latter documents under Austrian law appeared to have led to a number of reservations ${ }^{387}$. The representatives of Austria do not respond to this remark. The exclusion of domestic administrative procedures under articles 9 and 14 is dealt with frequently. It is suggested that this reservation is incompatible with the Covenant, and asked whether the whole body of administrative law is considered to be outside of the scope of the Covenant ${ }^{288}$. In reply to these remarks, Austria elaborates on its system of administrative and juridical procedure, indicating that under certain circumstances an administrative body has the authority to deprive a person of its liberty ${ }^{289}$. Committee-member Opsahl wonders how the reservation to article 9 must be seen in relation to the guarantee of effective remedies in article $2.3^{200}$. In respect of the reservation to article 10 , it is asked who will decide whether harmful influence must be feared ${ }^{291}$, and Austria indicates that the reservation is in keeping with the spirit of the Covenant $t^{292}$. The Committee members have the impression that a number of reservation are based on outdated laws, and the withdrawal of the reservations concerning articles 14.3.d, 14.5 and 14.7 is suggested to Austria. In respect of these suggestions, Austria indicates that it might consider withdrawing the reservation to article 14.3.d, states that there are good reasons for retaining the reservation to article 14.5 , and indicates that the reservation to article 14.7 is in most cases to the advantage of the accused.

The second periodical report by Austria ${ }^{293}$ begins with an historical overview of the constitutional system, and then moves on to a discussion of the provisions of the Covenant. The information about the implementation does not specifically refer to the interpretative declarations and reservations made.

The Committee almost unanimously voices concern about the large number of reservations formulated too generally ${ }^{294}$ and it is suggested that Austria considers withdrawing reservations, and making them more specific ${ }^{295}$.

Initially Austria replies that its reservations are based on concern about the conformity of national legislation on the European Convention on Human Rights with the Covenant, whereas the reservation to the OP was meant to preclude

287. CCPR/C/SR.412, par.12, 13, 14(Gracfrath): CCPR/C/SR.413, par.18(Al Douri).

288. CCPR/C/SR.412, par.17(Graefrath).

289. CCPR/C/SR.416, par.6-8(Austria).

290. CCPR/C/SR.412, par.43(Opsahl).

291. CCPR/C/SR.412, par.4(Herdocia Ortega); CCPR/C/SR.413, par.4 (Bouziri).

292. CCPR/C/SR.416, par.33.

293. CCPR/C/51/Add.2.

294. CCPR/C/SR.1098, par.18 (Ando), 21 (El Shafei), 25 (Lallah), 31 (Myullerson), 33 (Aguilar Urbina), 39 (Prado Vallejo).

295. CCPR/C/SR.1098, 39 (Prado Vallejo).

This raises the interesting question whether States have the right to reconsider and reformulate reservations after ratifying the Covenant. Reservations may only be made at ratification, yet from the perspective of the progressive development of human rights protection formulating a less restrictive reservation should be favoured. 
discussions about parallel procedures under the ECHR and the CCPR ${ }^{206}$. In the discussion about article 1, and in reply to the Committee's question concerning the possible withdrawal of these reservations ${ }^{297}$, Austria takes the unusual step of asking for the assurance by the Committee that the reservation was not necessary, in which case it would be withdrawn ${ }^{208}$. The Committee decided to postpone answering the Austrian question whether legislation was in conformity with the Covenant ${ }^{299}$.

The matter of the Austrian reservations to article 14.5 and 14.7, and the Committee's competence to make comments such as the one requested by Austria is dealt with in the forty-fifth session ${ }^{300}$. It appears that the Working Group ex article 40 CCPR had not been able to reach a conclusion with respect to the question whether or not the Committee could refer to the reservations in its concluding remarks after the consideration of a report ${ }^{301}$; and it is suggested that alternatively, a general comment on the issue of reservations might be prepared ${ }^{302}$.

The discussion in the Human Rights Committee is a clear example of the confusion surrounding the issue of reservations to the Covenant. A number of Committee-members stress that the States Parties had the competence to react to reservations by way of objections, and that the Committee had no authority in this respect. While it was acceptable that individual members might express their opinions orally, an explicit view of the Committee as a whole was not acceptable ${ }^{303}$. It was supposed that this was different under the Optional Protocol, when the Committee was specifically asked to pronounce upon the impact of reservations $\mathrm{s}^{304}$.

The majority of the Committee do not doubt that the States Parties are competent to react to reservations, but see a distinct role for the Committee itself ${ }^{305}$. As Higgins puts it: "The classic position that reservations to treaties were a matter

296. CCPR/C/SR.1098, par.56-57.

297. CCPR/C/SR.1099, par.64.

298. CCPR/C/SR.1099, par.68 reads:"As for the question (d) concerning Austria's reservations in connection with article 14 of the Covenant, he explained that those reservations were explained essentially by the principle that a person could not be tried twice for the same offence. Since criminal proceedings were invariably of a two-tier nature, could it really be said that article 14 (5), had been violated if a person received a more severe sentence by a court of second instance? it had simply been out of caution that the Austrian authorities had entered a reservation in ratifying the Covenant and could envisage withdrawing it if the Committec or any oller United Nations body provided them with the necessary assurances in that conncction."

299. CC.PR/C/SR.1100, par.16.

300. CCPR/C/SR.1167; see also A.Woltjer, VN Verdragen inzake de Rechten van de Mens in: 18 NJCM Bull.1993 183-202 at 198.

301. CCPR/C/SR.1167, par.49 (Pocar).

302. CCPR/C/SR.1167, par.50 (Pocar).

303. CCPR/C/SR.1167, par.53 (Ndiaye), par.54 (Chanet). par.55 (El Shafei), par.62 (Prado Vallejo).

304. CCPR/C/SR.1167, par.53 and par.60 (Ndiaye).

305. CCPR/C/SR.1167, par.51 (Higgins), par.56 (Wennergren), par.57 (Myullerson). par.6364 (Herndl), par.65-67 (Higgins), par.73-76 (Higgins). 
of State sovereignty did not work for human rights treaties, in which States mutually agreed to give certain rights to individuals. The reality was that, for the most part, States did not recognize their mutuality of interests in the field of human rights and failed to monitor reservations. The Committee should surely not take the conservative view that a State party should make whatever reservation it chose and that the Committee would do nothing if the Committee did not take up the general question of reservations to the Covenant, no one else would do so. ${ }^{n 306}$, thereby clearly indicating the specific and supplementary role of a supervisory organ.

While the Working Group had suggested either to formulate a general comment or an answer to the Austrian request ${ }^{307}$, there is general consent about taking up the issue of reservations as a matter to be dealt with in a general comment ${ }^{308}$. The question about whether or not to reply to Austria is troubled by doubts about the seriousness of the request ${ }^{309}$, and is more seriously hampered by the fact that the Committee does not want to pronounce in general on the reservations made. Such a pronouncement would require an in depth study of Austrian ${ }^{l a w^{310}}$. The Working Group had established that the law referred to was indeed incompatible, and that the reservations were necessary for Austria ${ }^{311}$. It was thus decided that Austria would receive a message that the Committee was unable to pronounce on the compatibility of the reservations, "a polite way of refusing to answer ${ }^{\text {3112 }}$.

The way in which the Committee had dealt with the specific request by Austria, calls for some remarks. It would appear that, although there is no unanimity, the majority of the Human Rights Committee does agree that the Committee has a role to play with respect to the reservations. The precise nature of this role, and in particular whether it would consist of a full review of the compatibility of reservations or merely of marginally reviewing the compatibility, is not very clear.

One could, at first sight, be disappointed that the Human Rights Committee declines to explicitly answer the Austrian request. This, it appears, would have been an opportunity for guidance with respect to compatibility. Yet, Committee member Ando raises the interesting issue ${ }^{3 / 3}$ that if Austria were to change its legislation, the Committee might be partially responsible. It might be added to this observation that, if the Committee would have accepted the Working Group's view that the reservations were necessary. it would have been responsible for Austria's upholding incompatible reservations. This would clearly have put the

306. CCPR/C/SR.1167, par.67 (Higgins).

307. CCPR/C/SR.1167, par.49-50 (Pocar).

308. CCPR/C/SR.1167, par.80-81.

309. CCPR/C/SR.1167, par.54 (Chanet), par.66 (Higgins), par.68 (Chanet), par.74 (Dimitrijevic), par.78 (Myullerson).

310. CCPR/C/SR.1167, par.69 (Chanet), par.72 (Prado Vallejo), par.74 (Dimitrijevic), par.77 (El Shafei), par.84 (Higgins).

311. CCPR/C/SR.1167, par.83 (Pocar).

312. CCPR/C/SR.1167, par.89 (Dimitrijevic).

313. CCPR/C/SR.1167, par.59 (Ando). 
Human Rights Committee in a peculiar position. Looking back the Committee was trapped between either agreeing with Austria, which it could not do on the basis of the views of the Working Group, or declining to answer as it did, which conveys a sense of lack of determination. It is likely that the preparation of the general comment will lead to a further clarification of the position of the Human Rights Committee, hopefully leading to an improvement in its possibilities to contribute to the withdrawal of incompatible reservations.

\section{BARBADOS}

The Govemment of Barbados states that it reserves the right not to apply in full, the guarantee of free legal assistance in accordance with paragraphs 3 (d) of article 14 of the Covenant, since, while accepting the principles contained in the same paragraph, the problems of implementation are such that full application cannot be guaranteed at present.

The reservation concerning article 14.3.d is not dealt with in the initial report of Barbados ${ }^{3 / 4}$, yet the Committee asks if Barbados intends to provide for free legal assistance in the future ${ }^{315}$. Committee-member Ermacora asked whether the death penalty could be imposed on persons below 18 years of age, and if so why Barbados had not made a reservation to article 6.5 of the Covenant ${ }^{316}$.

The Barbadian representative indicated that he did not know what the legal position was about the death penalty for minors under the age of 18 . In reply to a question, it was indicated that legal aid was available to persons charged with a number of specific offenses, and the Government were considering widening the scope of legal aid ${ }^{317}$.

In the second periodical report the reservation is dealt with by providing a list of criminal and civil matters for which free legal aid is available ${ }^{318}$, following changes in the Community Legal Services Act 1981-33. In the consideration of the report the Barbadian representative indicates that he is unaware of the position of his government as to the withdrawal of the reservation in view of the change in legislation ${ }^{3 / 9}$.

In the discussions about the second periodical report of Barbados, the question is asked why Barbados did not make a reservation in view of the discrepancy between its rules on the death penalty for minors, and the Covenant's provisions in article $6.5^{330}$. The representative states that he will raise the matter with his Government ${ }^{321}$. 


\section{BELGIUM}

Reservations

1. With respect to articles 2, 3 and 25 , the Belgian Government makes a reservation, in that under the Belgian Constitution the royal powers may be exercised only by males. With respect to the exercise of the functions of the regency, the said articles shall both preclude the application of the constitutional rules as interpreted by the Belgian State.

2. The Belgian Government considers that the provisions of article 10 , paragraph 2 (a), under which accused persons shall, save in exceptional circumstances, be segregated from the convicted persons is to be interpreted in conformity with the principle, already embodied in the standard minimum rules, for the treatment of prisoners [resolution (73) 5 of the Committee of Ministers of the Council of Europe of 19 January 1973], that untried prisoners shall not be put in contact with convicted prisoners against their will [rules 7 (b) and $85(1)$ ]. If they so request accused persons may be allowed to take part with convicted persons in certain communal activities.

3. The Belgian Government considers that the provisions of article 10 paragraph 3. under which juvenile offenders shall be segregated from adults and be accorded treatment appropriate to their age and legal status refers exclusively to the judicial measures provided for under the regime for the protection of young persons. As regards other juvenile ordinary-law offenders, the Belgian Government intends to reserve the option to adopt measures that may be more flexible and be designed precisely in the interest of the persons concerned.

4. With respect to article 14, the Belgian Government considers that the last part of paragraph 1 of the article appears to give States the option of providing or not providing for certain derogations from the principle that judgements shall be made public. Accordingly, the Belgian constitutional principle that there shall be no exceptions to the public pronouncements of judgements is in conformity with that provision. paragraph 5 of the article shall not apply to persons who, under Belgian law, are convicted and sentenced at second instance following appeal against their acquittal of first instance or who, under Belgian law, are brought directly before a higher tribunal such as the Court of Cassation, the Appeals Court or the Assize Court.

5. Articles 19,21 and 22 shall be applied by the Belgian Ciovernment in the context of the provisions and the restrictions set forth or authorised in articles 10 and 11 of the Convention for the Protection of Human Rights and Fundamental Freedoms of 4 november 1950 , by the said Convention.

Declarations

6. The Belgian Government declares that it does not consider itself obligated to enact legislation in the field covered by article 20 , paragraph 1 , an that article 20 as a whole shall be applied taking into account the rights to freedom of thought and religion, freedom of opinion and freedom of assembly and association proclaimed in articles 18 , 19.21 and 22 of the Covenant.

7. The Belgian Government declares that it interprets article 23, paragraph 2. as meaning that the right of persons of marriageable age to marry and to found a family presupposes not only that national law shall prescribe the marriageable age but that it may also regulate the excreise of that right.

The Belgian initial report ${ }^{322}$ discusses the reservation excluding women from rights to the throne ${ }^{33}$. The report elaborates on the practice underlying its

322. CCPR/C/31/Add.3.

323. In respect of article 3 of the Covenant there is also mentioned another reservation to that provision. which was withdrawn in 1978. This is confusing. and probably deals with reservations at signature. Belgium only ratified the Covenant in 1983, and could therefore not withdraw reservations in 1978. 
reservation to article 10.2.a, indicating that the segregation between accused and convicted persons is not complete, but offering a list of distinctions that is used in prison practice ${ }^{324}$. With respect to the reservation concerning article 10.3 , which is mentioned in the report as an interpretative declaration, it is indicated that while a strict separation is not practised the system intends to identify the needs of the juvenile prisoners ${ }^{325}$. While passing over the reservation to article 14.1 (latter part), the report cites two domestic cases in which article 14.5 was invoked, but declared inapplicable on the basis of the Belgian reservation ${ }^{326}$. In respect of the interpretative declaration to article 20 , the report mentions a law incriminating racism and xenophobia and refers to the Belgian report under the CERD $^{327}$. The reservation in respect of article 19,21 and 22 as well as the interpretative declaration to article 23 are not discussed in the report.

The Committee asks about the Belgian reservation dealing with the right to succession and the Belgian representative indicates that the relevant legislation is likely to be changed ${ }^{328}$. The issue of the relation between the European Convention on Human Rights and the Covenant is discussed in respect of the reservation to articles 19,21 and 22; however the Belgian representatives do not clarify this issue to the Committe $e^{329}$. The question what cases are within the ambit of the reservation to article 14.5 is not answered ${ }^{330}$, but the Belgian representatives do indicate that the prison regime with respect to juveniles (article 10.3) had been the subject of a judgement by the European Court of Human Rights, that might lead to legislative changes $^{331}$. The Committee calls upon Belgium to withdraw its reservations ${ }^{332}$, and a member of the Committee is of the opinion that by failing to legislate along the lines of article 20 of the Covenant, Belgium is in breach of its obligations ${ }^{333}$.

The second Belgian report does not mention the reservation concerning succession to the throne, which has officially not yet been withdrawn ${ }^{334}$. The paragraph about article 10 mentions the reservation concerning juvenile offenders (article 10.3) but omits a discussion of the reservation with respect to article 10.2. $\mathrm{a}^{335}$. With respect to article 14 the report mentions that decisions of the European Court of Human Rights have increased the kinds of judgements that need to be made public ${ }^{336}$.

324. CCPR/C/31/Add.3, paras.178-181.

325. CCPR/C/31/Add.3, par. 186-190.

326. CCPR/C/31/Add.3, p.52-53 under (P).

327. CCPR/C/31/Add.3, par.284-286.

328. CCPR/C/SR.815, par.24 (Cooray): CCPR/C/SR.821 (Belgium), par.35.

329. CCPR/C/SR.815, par.30 (EI Shafei); CCPR/C/SR./822. par.47 (Movchan).

330. CCPR/C/SR.816, par.31 (Pocar).

331. CCPR/C/SR.821, par.60 (Belgium).

332. CCPR/C/SR.816, par.36 (Movchan).

333. CCPR/C/SR.822, par.47 (Movchan).

334. ST/LEG/SER.E/11.

335. CCPR/C/57/Add.3, par.119.

336. CCPR/C/57/Add.3, par. 155. 
In reply to questions from the Committee, the Belgian representative indicated that changes in the Protection of Young Persons Act 1965 had taken place, apparently with consequences for the scope of article $10.3 \mathrm{CCPR}^{337}$. Later on in the discussion, Committee member Ndiaye asked whether the monarchy in Belgium had implications for equal access to public office ${ }^{338}$. The Belgian representative did not believe that this was the case. Reservations with respect to articles 2, 3, and 25 CCPR were not mentioned. Various members of the Committee suggest the withdrawal of unnecessary reservations such as the reservations to articles 10 and $14.5^{339}$

\section{CONGO}

The Government of the Peoples's Republic of the Congo declares that it does not consider itself bound by the provisions of article 11 .

Article 11 of the International Covenant on Civil and Political Rights is quite incompatible with the articles $386 \mathrm{ff}$. of the Congolese Code of Civil, Commercial, Administrative and Financial Procedure, derived from Act 51/83 of 21 April 1983. Under those provisions, in matters of private law, decisions or orders emanating from conciliation proceedings may be enforced through imprisonment for debt when other means of enforcement have failed, when the amount due exceeds 20,000 CFA francs and when the debtor, between 16 and 60 years of age makes himself insolvent in bad faith.

The initial report by Congo did not mention its reservation to the non-derogable right contained in article 11 of the Covenant ${ }^{340}$. One Committee-member asks whether Congo had considered amending the legislation and withdrawing the reservation, as it was not consistent with the protection of human rights as a whole ${ }^{341}$; and another member wonders about the impact of the reservation taking into account that inflation could increase the scope of the provision ${ }^{342}$. No explicit reference is made to article 11 being a non-derogable right.

The Congolese representative does not address the matter of the reservation to article 11 in his reply, and neither does the Committee ${ }^{343}$.

\section{DENMARK}

1. The Government of Denmark makes a reservation in respect of article 10, paragraph 3. second sentence. In Danish practice, considerable efforts are made to ensure appropriate age distribution of convicts serving sentences of imprisonment, but it is considered valuable to maintain possibilities of flexible arrangements.

2.(a) Article 14. paragraph 1. shall not be binding on Denmark in respect of public hearings. In Danish law, the right to exclude the press and the public from trials may go beyond what is permissible under this Covenant, and the Government of Dennark finds that this right should not be restricted.

(b) Articles 14, paragraphs 5 and 7, shall not be binding on Denmark.

337. CCPR/C/SR.1143, par.16 (Belgium).

338. CCPR/C/SR.1143, par57 (Ndiaye).

339. CCPR/C/SR.1143, par.63 (Ando), par.68 (Hernd), par.70 (Serrano Caldera).

340. CC.PR/C/36/Add.2.

341. CCPR/C/SR.732, par.25 (Pocar).

342. CCPR/C/SR.732, par. 59 (Dimitrijevic).

343. CCPR/C/SR.736. 
The Danish Administration of Justice Act contains detailed provisions regulating the matters dealt with in these two paragraphs. In some cases, Danish legislation is less restrictive than the Covenant (e.g. a verdict returned by a jury on the question of guilt cannot be reviewed by a higher tribunal, cf.para.5); in other cases, Danish legislation is more restrictive than the Covenant (e.g. with respect to resumption of a criminal case in which the accused party was acquitted, cf.para.7).

3. Reservation is further made to article 20, paragraph 1. This reservation is in accordance with the vote cast by Denmark in the sixteenth session of the General Assembly of the United Nations in 1961 when the Danish delegation, referring to the preceding article concerning the freedom of expression, voted against the prohibition against propaganda for war.

The initial report by Denmark is strikingly brief, and does not mention any of the reservations made ${ }^{344}$. The additional report does not cover articles 8 to 16 , and the majority of Danish reservations fall within part II of the Covenant, and merely mentions the reservations to article 20.1 succinctly ${ }^{345}$. In the discussions about both reports it is indicated that reservations had been made in case of discrepancies between the Covenant and the Danish legal situation ${ }^{346}$. As early as the third session of the Committee the issue of the reservations to article 20.1 is mentioned ${ }^{347}$, without an in depth discussion of article 20 supposedly restricting the freedom of opinion. The Danish reply merely mentions article $20.2^{348}$.

A subsequent additional report ${ }^{349}$ contains the section on articles 8-16, particularly relevant in the case of reservations. The report indicates that reservations have been made to article $10.3^{3.5}$ articles 14.5 and $14.7^{351}$, and states that though a reservation has been made to article 14.1, the domestic rules are in essentials in consonance with the provision" ${ }^{1352}$. In its discussion about this additional report, there is some concern about the Danish reservation to article $10.3^{353}$. Denmark indicates that the reservation seeks to safeguard experiments in this field ${ }^{354}$. It is indicated that the reservation concerning article 14.1 was necessary because Danish law provided better protection to witnesses ${ }^{355}$. The reservations to articles 14.5 and 14.7 are not dealt with in the discussion.

The second periodical report of Denmark ${ }^{336}$ mentions an approach differing from the system of segregation of prisoners, as underlined in article 10.3 in the Covenant, which appears to be the reason for the reservation to that provi-

344.

345.

346.

347.

348.

349.

350.

351.

352.

353.

354.

355.

356. 
sion ${ }^{357}$. In his introduction, the Danish representative indicated that Denmark had made reservations to articles $10.3,14.1,14.7$ and 20.1 , thereby omitting the reservation to article 14.5. The Committee focuses on the reservations to article 14.1 and to article 14.5 and 14.7. With respect to article 14.1 and the exclusion of the press and public from trials, Denmark is asked to indicate in what kind of circumstances the reservation would apply, and if these are not circumstances already covered by the provision itself ${ }^{\text {ss }}$. Denmark indicates that the reservation was made out of uncertainty about the meaning of "where publicity would prejudice the interests of justice" in article $14.1^{359}$. The reservation is meant to protect minors, the interests of the witnesses or the privacy of the co-defendant $^{\text {thet }}$.

One remarkable incident was the discussion about the Danısh reservation to article 14.4. Committee-member El Shafei wonders about the merits of the Danish reservation to article 14.4 and the non-segregation of juvenile offenders, probably confusing article 14.4 and article $10.3^{361}$. The Danish representative answers that the Danish government still considers it preferable to treat juvenile offenders in the same institutions as adult offenders, explicitly referring to article $14.4^{362}$. It should be noted that article 14.4 does not deal with the issue of juvenile offenders, and that Denmark never even made a reservation to article 14.4. Consequently, El Shafei and the Danish representative are discussing a nonexisting reservation, even if the subject matter is covered by another Danish reservation.

The Conmitte is concerned about the reservation to article 14.7 and wonders about its necessity. The Danish representative indicates that the reservation is a consequence of the fact that Danish legislation differs from the Covenant on this point. The reservation to article 14.5 appeared to be related to appeals after a verdict rendered by a jury when review was restricted to specific grounds ${ }^{367}$. In the discussion about the Danish reservation to article 20.1, it is indicated that article 20.2 is indeed incorporated into Danish lawist.

\section{FINLAND}

1. [withdrawn] With respect to article 9, paragraph 3. of the Covenant. Finland declares that according to the present Finnish legislation the Administrative authorities may take decisions concerning arrest or imprisonment, in which event the case is taken up for decision in court only after a certain time lapse.

2. With respect to article 10, paragraph $2(\mathrm{~b})$ and 3 , of the Covenant. Finland declares that although juvenile offenders are, as a rule, segregated from adults, it does not deem

357.

CCPR/C/37/Add.5, par. 61 .

358. CC.PR/C/SR.778, par.25, 48(Higgins); par.51 (Movchan).

359. CCPR/C/SR.778, par.38 (Denmark).

360. CCPR/C/SR.778, par.49; CCPR/C/SR.779, par.53 (Denmark).

361. CCPR/C/SR.778, par.26 (El Shafei).

362. CCPR/C/SR.778, par.38 (Denmark).

363. CCPR/C/SR.778, par.25 (Higgins), par.37 (Denmark); CCPR/C/SR.779, par.50 (Dimitrijevic).

364. CCPR/C/SR.778, par.26 (El Shafei), par.39 (Denmark) par.45-46 (Movchan): CCPR/C/SR.780. par.32 (Denmark). 
appropriate to adopt an absolute prohibition not allowing for more flexible arrangements.

3. [withdrawn] With respect to article 13 of the Covenant, Finland declares that the article does not correspond to the present Finnish legislation regarding an alien's right to be heard or lodge a complaint in respect of a decision concerning his expulsion.

4. [withdrawn] With respect to article 14, paragraph 1, of the Covenant, Finland declares that under Finnish law a sentence can be declared secret if its publication would be an affront to morals or endanger national security.

5. [withdrawn] With respect to article 14, paragraph 3 (d) of the Covenant, Finland declares that the contents of this paragraph do not correspond to the present legislation inasmuch as it is a question of the defendant's absolute right to have legal assistance already at the stage of preliminary investigations.

6. With respect to article 14, paragraph 7, of the Covenant, Finland declares that it is going to pursue its present practice, according to which a sentence can be changed to the detriment of the convicted person, if it is established that a member or an official of the court, the prosecutor or the legal counsel have through criminal or fraudulous activities obtained the acquittal of the defendant or a substantially more lenient penalty, or if false evidence has been presented with the same effect, and according to which an aggravated criminal case may be taken up for reconsideration if within a year until then unknown evidence is presented, which would have led to conviction or a substantially more severe penalty,

7. With respect to article 20, paragraph 1, of the Covenant. Finland declares that it will not apply the provisions of this paragraph, this being compatible with the standpoint Finland already expressed at the 16th United Nations General Assembly by voting against the prohibition of might endanger the freedom of expression referred in article 19 of the Covenant."

The initial report by Finland indicates that during the ratification process Finnish legislation was scrutinized with a view to tracing differences between the Covenant and the legislation. This led to the conclusion that in a number of cases Finnish legislation was considered to reveal discrepancies in respect of the Covenant, in which cases reservations were made ${ }^{365}$. The report indicated that Finland intends to change its legislation and bring it into conformity with the Covenant, the reservations will then be withdrawn. Following this introductory explanation, the report lists the seven reservations made, illustrating the differences between the Covenant's system and the Finnish system. This presentation has the advantage of being very understandable and accessible, moreover by stressing that Finland is maintaining a reservation "for the present", it implies the acceptance of the desirability of future withdrawal of reservations.

In his introduction the Finnish representative indicates that the differences between Finnish law and the Covenant are mainly matters of structure rather than content $^{366}$. The approach to making reservations is praised by a Committeemember, stating that reservations are to be preferred over ratifications that will not be fully implemented ${ }^{367}$. In its discussion of the report the question is asked why Finland did not make a reservation to article 25 on the exercise of political

365. CCPR/C/1/Add.10; the Finnish supplementary report CCPR/C/1/Add.32 does not contain information about reservations.

366. CCPR/C/SR.170, par.6 (Finland).

367. CCPR/C/SR.171, par.12 (Dieye). 
rights by aliens. This question is prompted by the observation that the Finnish situation is below Covenant standards and could only be justified by a reserva$\operatorname{tion}^{368}$. With respect to article 14.7 it is asked whether the application of procedures already available in the Finnish system, the reservation could be overcome $^{369}$. The discussion about the reservation to article 20 , dealing with the prohibition of propaganda for war did not reach any serious conclusions $\mathrm{s}^{370}$.

The second periodical report by Finland simply repeats the paragraph about reservation in the supplementary report, repeating its intention to withdraw the reservations once the legislation had been amended ${ }^{371}$. The report indicates that the reservations to articles 13 and 14.1 had been withdrawn, while legislative changes concerning the reservations to articles 9.3 and 14.3.d are pending. The reservation to articles 10.2. b and 10.3 are considered to have been superfluous from the beginning. This last remark is intriguing, as it is uncertain what the consequences of this determination by the author state are.

In its discussion of the Finnish report, the Committee expressed its interest in learning the reservation to article 9.3 was to be withdrawn, and the Finnish representative indicated that draft legislation relating to the pre-trial arrests was pending ${ }^{372}$. The Committee was equally interested in the withdrawal of the reservations to article 14.3.d and 14.7; and the representative indicated that after a change in legislation the relevant reservations would be withdrawn. Furthermore the Finnish representative indicated that in spite of his suggestions, the Government had decided not to withdraw the reservation to article $20.1^{373}$

The third periodical report by Finland mentions the reservations to articles 10.2.b and $10.3^{374}$, and indicates that the reservations in respect of articles 14.1 and 14.3 (public trial) as well as article 14.3.d (legal counsel) have been withdrawn $\mathrm{n}^{375}$. The possibility of withdrawing the reservation to article 14.7 is being discussed $^{376}$. The report repeats that concern about the freedom of expression leading to the reservation to article $20.1^{377}$

In his presentation to the HRC, the Finnish representative indicated that new legislation made it possible to withdraw the reservation to article 14.3. $\mathrm{d}^{378}$. The Committee inquired about the withdrawal of the reservation to article 14.7, and Finland answered that this matter had been raised before, particularly because Finland had agreed with the principle. It would not withdraw the reservation for the present, as its legislation was in conformity with the non bis in idem principle

368. CCPR/C/SR.170, par.40(Tomuschat).

369. CCPR/C/SR.170, par.64(Hanga).

370. CCPR/C/SR.171, par.40(Movchan).

371. CCPR/C/32/Add.7.

372. CCPR/C/SR.643, par.14(Cooray), 16(Higgins), 19(Finland); CCPR/C/SR.644, par.37(Opsahl).

373. CCPR/C/SR.646, par.34-35(Finland).

374. CCPR/C/58/Add.5, par.66.

375. CCPR/C/58/Add.5, par.82-84.

376. CCPR/C/58/Add.5, par.85.

377. CCPR/C/58/Add.5, par.108-109.

378. CCPR/C/SR.1014, par.13 (Finland). 
in article $14.7^{379}$. A Committee member refers to the discussion of the reservation to article 20 , and wonders why it had been maintained ${ }^{380}$. It appears that a prohibition on incitement to war against Finland is included in the draft Penal Code $^{381}$, that might lead to a withdrawal once the legislation is adopted.

\section{FRANCE}

1. The Government of the Republic considers that, in accordance with Article 103 of the Charter of the United Nations, in case of conflict between its obligations under the Covenant and its obligations under the Charter (especially Articles 1 and 2 thereof), its obligations under the Charter will prevail.

2. The Government of the Republic enters the following reservation concerning article 4, paragraph 1: firstly, the circumstances enumerated in article 16 of the Constitution in respect of its implementation, in article 1 of the Act of 3 April 1978 and in the Act of 9 August 1849 in respect of the declaration of a state of siege, in article 1 of Act No. 55385 of 3 April 1955 in respect of the declaration of a state of emergency and which enable these instruments to be implemented, are to be understood as meeting the purpose of article 4 of the Covenant; and, secondly, for the purpose of interpreting and implementing article 16 of the Constitution of the French Republic, the terms "to the extent strictly required by the exigencies of the situation" cannot limit the power of the President of the Republic to take measures required to circumstances.

3. The Government of the Republic enters a reservation concerning articles 9 and 14 to the effect that these articles cannot impede enforcement of the rules pertaining to the disciplinary régime in the armies.

4. The Government of the Republic declares that article 13 cannot derogate from chapter IV of Order No. $45-2658$ of 2 November 1945 concerning the entry into, and sojourn in, France of aliens, nor from the other instruments concerning the expulsion of aliens in force in those parts of the territory of the Republic in which the Order of 2 November 1945 does not apply.

5. The Government of the Republic interprets article 14. paragraph 5, as stating a general principle to which the law may make limited exceptions, for example, in the case of certain offenses subject to the initial and final adjudication of a police court and criminal offenses. However, an appeal against a final decision may be made to the Court of Cassation which rules on the legality of the decision concerned.

6. The Government of the Republic declares that articles 19,21 and 22 of the Covenant will be implemented in accordance with articles 10.11 and 16 of the European Convention for the Protection of Human Rights and Fundamental Freedoms of 4 November 1950.

7. The Government of the Republic declares that the term "war". appearing in article 20 , paragraph 1 , is to be understood to mean war in contravention of international law and considers, in any case, that French legislation in this matter is adequate.

8. In the light of article 2 of the Constitution of the French Republic. the French Government declares that article 27 is not applicable so far as the republic is concerned.

The initial report of France elaborates on the reservations made, and puts them in the perspective of existing French legislation ${ }^{382}$. While dealing with the majority of the French reservations and declarations, a reference to the reservation to article 19 and the broadcasting monopoly, as well as a reference to the reserva- 
tion concerning article 20.1 are absent. Without mentioning the declaration concerning the non-applicability of article 27 , it is stated that there are no minorities in France.

The Committee proves to be very much interested in the reservation to article 27 . It is indicated that France must have misunderstood the provision, and it is suggested that rather than focusing on specific groups, the Covenant uses a de facto approach ${ }^{383}$. Other matters of concern to the Committee are the reservation to article $4.1^{384}$, and the declaration concerning articles 19,21 and $22^{385}$. Individual members also mention the reservations to articles $13^{386}, 14.5^{387}$, $19^{388}$ and $20^{389}$.

In his reply the French representative emphasizes that France does not feel obliged to withdraw the reservation to article 4.1 , indicating that it is only dealing with the first paragraph of the provision, and is legitimate under the VCLT $^{390}$. In the matter of the existence of minorities in France, and in particular the reservation to article 27, a difference of opinion about the concept minority appeared to exist between the State and the Committee. It was indicated that different communities all enjoyed rights that gave them the opportunity to maintain their identity. France stresses that such rights follow from being a citizen, and are not related to membership of a legally protected minority. To take it even further, France was uneasy about the concept "minority", and felt that article 27 did contradict article 26 of the same Covenant. Furthermore France referred to the declaration by the Federal Republic of Germany which accepted the French reservation because the rights protected in that provision were fully protected under the French Constitution ${ }^{39}$. In answering to a question about the reservation to article 20 , it is indicated that the reservation finds its legal basis in article 51 of the UN Charter, which takes precedence over the Covenant ${ }^{392}$.

The French supplementary report ${ }^{303}$ is rather succinct, and merely refers to the legislation related to the implementation of the Covenant. It does not refer to any of the reservations made,, and it is discussed together with the second periodical report. This repeats verbatim the texts about reservations in the initial report ${ }^{394}$.

383. CCPR/C/SR.440, par.65 (Tamopolsky), CCPR/C/SR.441, par.19 (Dimitrijevic), par.30 (Tomuschat), par.52 (Al Douri), par.55 (Movchan).

384. CCPR/C/SR.440, par.55 (Tarnopolsky); CCPR/C/SR.441, par.35 (Graefrath).

385. CCPR/C.SR.441, par.41(AI Douri), par.55(Movchan).

386. CCPR/C/SR.440, par.60(Tarnopolsky).

387. CCPR/C/SR.441, par.28(Tomuschat).

388. CCPR/C/SR.440, par.64(Tarnopolsky).

389. CCPR/C/SR.441, par.55(Movchan).

390. CCPR/C/SR.445, par.32(France); see Graefrath, op.cit. at 70.

391. CCPR/C/SR.445, pars.77-83(France), see supra par.2.1.

392. CCPR/C/SR.445, par.72 (France). It should be noted that the formulation of the French reservation to article 20 mentions "war in contravention of international law", thereby leaving the possibility of propaganda for wars in self-defense (article $51 \mathrm{UN}$ Charter) open.

393. CCPR/C/22/Add.4.

394. CCPR/C/46/Add.2. 
It is a striking example of the advantages of the computer age: the only editorial changes are a different lay-out of the paragraphs, the text itself is completely identical.

In the subsequent discussion a Committee member asked about the reservation to article 27, and the denied existence of minorities in France. The question in particular refers to the compatibility of such an approach with articles 2.1 and 26 of the Covenant, and the position of languages other than French ${ }^{395}$. The French answer focuses on cultural identity and the use of regional languages, and indicates that the community bears the main responsibility for maintaining regional cultures ${ }^{396}$. This does not satisfy a number of Committee-members, who indicate that the reservation to article 27 reinforces the idea that the protection of minorities is only necessary in a non-democratic country, which is incorrect ${ }^{397}$. The French representative indicates that with changes in the legislation, the reservation to article 19 in respect of the broadcasting system had been withdrawn. The reservation concerning articles 19,21, 22 of the Covenant and their relation with provisions of the ECHR is merely meant to ensure that France will fulfil its obligations under both instruments. In particular there was concern about the possibility to restrict the exercise of the right of assembly for members of the Armed Forces ${ }^{398}$.

\section{GAMBIA}

"For financial reasons, free legal assistance for accused persons is limited in our constitution to persons charged with capital offenses only. The Government of the Gambia therefore wishes to enter a reservation in respect of article 14(3)d of the Covenant in question."

Gambia made a reservation to one provision only, and neither the initial repor ${ }^{399}$ nor the supplementary report ${ }^{400}$ refers to the reservation made.

The HRC did not deal explicitly with the reservation, but a member of the Committee suggested that Gambia would call upon the Bar to provide free legal assistance ${ }^{401}$. In his reply the representative of Gambia indicated that the reason for making the reservation had been the small size of the bar, which led to the inability to provide legal aid at all times ${ }^{402}$.

396. CCPR/C/SR.803, par.36-38 (France).

397. CCPR/C/SR.803, par.42(Higgins), par.46(Dimitrijevic).

398. CCPR/C/SR.803, par.9-12 (France).

399. CCPR/C/10/Add.7.

400. CCPR/C/10/Add. 12 .

401. CCPR/C/SR.501, par.35(Bouziri).

402. CCPR/C/SR.506, par.12 (Gambia). The second periodical report of Gambia was due in 1985, but has not been received yet. See $A / 47 / 40$, at 187 . 


\section{GERMANY ${ }^{403}$}

"1. Articles 19, 21 and 22 in conjunction with Article 2(1) of the Covenant shall be applied within the scope of Article 16 of the Convention of 4 November 1950 for the Protection of Human Rights and Fundamental Freedoms.

"2. Article 14(3)(d) of the Covenant shall be applied in such manner that it is for the court to decide whether an accused person held in custody has to appear in person at the hearing before the court of review (Revisionsgericht).

3. Article 14(5) of the Covenant shall be applied in such manner that:

(a) A further appeal does not have to be instituted in all cases solely on the grounds the accused person - having been acquitted by the lower court - was convicted for the first time in the proceedings concerned by the appellate court.

(b) In the case of criminal offenses of minor gravity the review by a higher tribunal of a decision not imposing imprisonment does not have to be admitted in all cases.

"4. Article 15(1) of the Covenant shall be applied in such manner that when provision is made by law for the imposition of a lighter penalty the hitherto applicable law may for certain exceptional categories of cases remain applicable to criminal offenses committed before the law was amended."

The first German report indicates that the existence of a different domestic rule concerning the presence of an accused during the trial before the Court of Appeal (related to a procedure dealing specifically with questions of law, rather than questions of fact) was the reason for making a reservation to article 14.3. $\mathrm{d}^{504}$. A similar situation appears to exist in respect of the right to appeal that is not necessarily restricted to persons having been convicted in an earlier instance, which explains the German reservation to article $14.5^{\text {t05 }}$. The report furthermore indicates that political activities of aliens may be restricted on the basis of the reservation to articles 19,21 and 22 in accordance with article $16 \mathrm{ECHR}^{406}$. The Committee questions whether the European Convention in fact permits such a far reaching restriction as has been entered by Germany ${ }^{407}$.

In the discussion about the initial report of the Federal Republic of Germany in the fourth session, neither the Committee ${ }^{408}$, nor Germany ${ }^{409}$ raise the issue of the reservations made, except by implication.

In the second periodic report of Germany the discussion of article 14.3.d focuses on the orderly conduct of the proceeding, and the reservation made in respect of the provision is not mentioned ${ }^{410}$. The report merely deals with the"selfinflicted incapacity ${ }^{n}$ to stand trial. With respect to the reservation to article 15.1 the report indicates that the reason for making the reservation has been that a part of a group of offenders that could not be tried at the same time should not benefit from a change in the law that could not be beneficial to the other offenders. The

403. These are the reservations made by the Federal Republic of Germany at ratification on 17 December 1973. The former German Democratic Republic, which ratified on 8 November 1973, only made a reservation in respect of article 48.1 .

404. CCPR/C/1/Add. 18 , p. 18.

405. CCPR/C/1/Add.18, p.21.

406. CCPR/C/1/Add.18, p.27, 28.

407. CCPR/C/SR.94, par.13 (Prado Vallejo).

408. CCPR/C/SR.92-94.

409. CCPR/C/SR.95.

410. CCPR/C/28/Add.6, par.112-113. 
report furthermore indicates that no use had been made of the reservation ${ }^{41}$. The reservations made by Germany have not been dealt with in the discussion about the second periodical report ${ }^{412}$.

The section on the implementation of article 14 and 15 in the third periodical report of Germany elaborates on the changes in the relevant legal measures, without mentioning the reservations made ${ }^{4 / 3}$. Questions are not raised in the discussion about article 14 of the Covenant $t^{414}$

\section{GUYANA}

In respect of sub-paragraph (d) of paragraph 3 of article 14

"While the Government of the Republic of Guyana accept the principle of Legal Aid in all appropriate criminal proceedings, is working towards that end and at present apply it in certain defined cases, the problems of implementation of a comprehensive Legal Aid Scheme are such that full application cannot be guaranteed at this time."

In respect of paragraph 6 of article 14

"While the Government of the Republic of Guyana accept the principle of compensation for wrongful imprisonment, it is not possible at this time to implement such a principle."

The initial report of Guyana is rather brief, and merely lists the provisions of Guyanese law corresponding to the rules in the Covenant ${ }^{415}$. No reference to the reservations is to be found.

The reservations are not dealt with during the consideration of the report and the Committee appears to be unaware of their existence ${ }^{416}$.

\section{ICELAND}

1. Article 8, paragraph 3(a), in so far as it affects the provisions of Icelandic law which provide that a person who is not the main provider of his family may be sentenced to a term at a labour facility in satisfaction of arrears in support payments for his child or children.

2. Article 10, paragraph 2(b), and paragraph 3, second sentence, with respect to the separation of juvenile prisoners form adults. Icelandic law in principle provides for such separation but it is not considered appropriate to aceept an obligation in the absolute form called for in the provisions of the Covenant.

3. Article 13, to the extent that it is inconsistent with the Icelandic legal provisions in force relating to the right of aliens to object to a decision on their expulsion.

4. Article 14, paragraph 7, with respect to the resumption of cases which have already been tried. The Icelandic law of procedure has detailed provisions on this matter which it is not considered appropriate to revise.

5. Article 20 , paragraph 1 , with reference to the fact that a prohibition against propaganda for war could limit the freedom of expression. This reservation is consistent with the position of Iceland at the General Assembly at its 16th session.

Other provisions of the Covenant shall be inviolably observed.

411. C.CPR/C/28/Add.6, par.122-123.

412. CCPR/C/SR.664-666.

413. CCPR/C/52/Add.3, p.24-28.

414. CCPR/C/SR.964, par.51-53.

415. CCPR/C/4/Add.6.

416. CCPR/C/SR.353-354. The second periodical report of Guyana was due in 1987, but it has not been received yet. See $A / 47 / 40$, at 189 . 
The first Icelandic report ${ }^{417}$ indicates that though Iceland made a reservation to article 8.3.a, this reservation is not strictly necessary as these rules of Icelandic law fall within the scope of article 8.c.iv, and moreover these laws are not used at present. The reservation with respect to articles 10.2.b and 10.3 was made because of the absolute nature of the obligations, though Icelandic law in general accepts the principle underlying these provisions ${ }^{418}$. The report merely repeats the formulation of the reservation concerning article 13, and elaborates in more detail on the reason for the reservation concerning article 14.7 and the possibility to retry a case ${ }^{419}$. It is indicated that article 20.1 is considered to be contrary to the freedom of expression ${ }^{430}$.

In its discussion of the Icelandic report, the Committee comments on the necessity of a reservation to article 20 of the Covenant ${ }^{421}$, and the Icelandic representative indicates that in spite of the affront about the horrors of propaganda for war, the concern for the freedom of expression prevailed ${ }^{422}$. It was suggested that Iceland consider withdrawing its reservations relating to articles 8 and $13^{423}$, and information was requested on the reservation to articles 10.2.b and $10.3^{424}$. The Icelandic representative indicated that the withdrawal of reservations was being considered, but would take time ${ }^{425}$.

\section{INDIA}

I. With reference to $[\ldots]$ article $I$ of the International Covenant on Civil and Political Rights, the Government of the Republic of India declares that the words "the right of self-determination" appearing [in that article] apply only to the peoples under foreign domination and that these words do not apply to sovereign independent States or to a section of a people or nation - which is the essence of national integrity.

II. With reference to article 9 of the International Covenant on Civil and Political Rights, the Government of the Republic of India takes the position that the provisions of the article shall not be applied as to be in consonance with the provisions of the clauses (3) to (7) of article 22 of the Constitution of India. Further, under the Indian legal system, there is no enforceable right to compensation for persons claiming to be the victim of unlawful arrest or detention against the State.

III. With respect to article 13 of the International Covenant on Civil and Political Rights, the Government of the Republic of India reserves the right to apply its law relating to foreigners.

IV. With reference to $[\ldots]$ articles 12, 19, paragraphs 3, 21, 22 of the International Covenant on Civil and Political Rights, the Government of the Republic of India declares that the provisions of the said articles shall be so applicd as to be in conformity with the provisions of article 19 of the Constitution of India.

417. CCPR/C/10/Add.4, par.36.

418. CCPR/C/10/Add.4, par.39.

419. CCPR/C/10/Add.4, pars.44, 49.

420. CC.PR/C/10/Add.4, par.58.

421. CCPR/C/SR.391, par.44 (Prado Vallejo), 49 (Movchan). CCPR/C/SR.392 par.72 (Tomuschat).

422. CCPR/C/SR.395, par.31 (Iceland).

423. CCPR/C/SR.391, par.45 (Prado Vallejo).

424. CCPR/C/SR.392, par.58 (AI Douri).

425. CCPR/C/SR.395, par.34 (Iceland). The second periodic report of Iceland was due in 1987, it has not been received yet. See $\mathrm{A} / 47 / 40$, at 190 . 
The first report by India elaborates on the reasons underlying its contentious reservation to article 1 of the Covenant. It is indicated that India supports the right of self-determination for people under colonial domination, and that the right to self-determination is supposed to co-exist with the principle of sovereign equality ${ }^{23}$. With respect to the reservation to article 13 it is indicated that the Government may order an alien to leave the country, but a recourse to court is available ${ }^{427}$. The Indian report elaborates on articles 21 and 22 of the Constitution in respect of article 9 CCPR, and mentions the declarations concerning the absence of a right to claim compensation for unlawful arrest ${ }^{43}$.

The Committee proves to be very concerned about the declaration in respect of article 1 of the Covenant. The gist of the Committee's questions is that there is a need for clarification about the reasons underlying the declaration, and a number of Committee-members wonder whether the intention has been to deny the right to self-determination to a particular groups within India ${ }^{439}$. In his reply the Indian representative indicated that it was his country's understanding that the declaration concerning article 1 was in conformity with "the principles of international law concerning friendly relations and co-operation among States in accordance with the Charter of the United Nations, according to which the right of self-determination in the international context applied only to dependent Territories and peoples ${ }^{m 430}$. The Committee also inquire about the need to make a reservation to article 13, and wish to know the difference between the rules in the Covenant and the domestic rules ${ }^{41}$. The Indian representative indicated that aliens did not have political rights in India and that the reservation specifically related to issues such as registration, passports and entry and stay within the country ${ }^{432}$. In reply to questions about the reservation concerning article 9, a certain amount of confusion arose ${ }^{433}$.

The second periodic report by India states that it adheres to the principle of selfdetermination in coexistence with the principle of sovereign equality, which serves as an explanation for the reservation to article $1^{434}$. With respect to article 9, the earlier report is repeated with a small number of changes in the text. It now includes a remark by a Committee-member on awards by the Supreme Court contrary to the reservation to article $9^{435}$. The reservation to article 13 does not deprive foreigners of protection against human rights viol-

427. CCPR/C/10/Add.8, par.71-73.

428. CCPR/C/10/Add.8, par.60.

429. CCPR/C/SR.494, par.6 (Tomuschat), par.32 (Scrrano Caldera), par.41 (Cooray). par. 54 (Bouziri).

430. CCPR/C/SR.498, par.6 (India).

431. CCPR/C/SR.493, par.36 (Prado Valiejo); CCPR/C/SR.494, par.62 (Opsahl).

432. CCPR/C/SR.498, par.12.

433. CCPR/C/SR.498, par.15 (India), par.34 (Tomuschat), par.36 (India).

434. CCPR/C/37/Add.13, par.10-11.

435. C.PR/C/37/Add.13, par.54-56. 
ations ${ }^{436}$. With respect to article 12 it is indicated that article 19.6 of the Constitution seeks to safeguard the interests of the general public ${ }^{437}$.

The Committee remains concerned about the reservations made ${ }^{438}$ and questions are asked about the way in which India perceives the relationship between the Covenant and domestic legislation. It is felt that India intends to interpret the Covenant in conformity with its legislation, rather than the other way around ${ }^{439}$. There is also concern about the meaning of the reservation to article 1 , and its application in a multi-ethnic society ${ }^{440}$. The reply to the questions about article 1 is quite clear, the representative indicates that: "[B]y definition a group of people within sovereign territory could not break away and form a nation". This was also stressed in the report which made it clear that the right to self-determination only applied to those outside of India, living under foreign domination ${ }^{44}$. The question about the precedence of the Covenant is not completely clarified in the discussion. After an extensive exchange of views on the state of emergency ${ }^{442}$, the representative makes it clear that this area had been covered by the reservation referring to articles 22,23 and 24 of the Constitution, which was a reservation excluding further discussions ${ }^{43}$. In rebuttal Committeemember Higgins underlines that the availability of domestic legislation does not necessarily guarantee compliance with the Covenant $t^{144}$. In the conclusion of its discussion of the report by India, the Committee expresses concern that the reservations lead to a situation in which article 4 would cease to have a function ${ }^{445}$. There is concern that the reservations preclude the implementation of the Covenant and their withdrawal is urged $\mathrm{d}^{446}$. The Indian representative indicates that reservations were essentially a political issue ${ }^{47}$.

\section{IRELAND}

"Article 6, paragraph 5

Pending the introduction of further legislation to give full effect to the provisions of paragraph 5 of article 6 , should a case arise which is not covered by the provisions of existing law. the Government of Ireland will have regard to its obligations under the Covenant in the exercise of its power to advise commutation of the sentence of death.

Article 10. paragraph 2

436.

CCPR/C/37/Add.13, par.70

437. CCPR/C/37/Add.13, par.69.

438. CCPR/C/SR.1039, par.24 (Chanet), CCPR/C/SR.1042, par.3 (Ando), par.7 (Chanet), par.11 (Wennergren).

439. CCPR/C/SR.1039, par.38(Higgins), par.41 (Aguilar), par.45(Sadi).

440. CCPR/C/SR.1039, par.30(El Shafei), par.33(Mullerson), par.43(Aguilar).

441. CCPR/C/SR.1040, par.4-5.

442. CCPR/C/SR.1040, par.21-28 passim.

443. CCPR/C/SR.1041, par.3 (India).

444. CCPR/C/SR.1041, par.61 (Higgins).

445. CCPR/C/SR.1042, par.7 (Chanet), par.14 (Higgins).

446. CCPR/C/SR.1042, par.3 (Ando), par.11 (Wennergren), par.16 (Aguilar), par.19 (Mavrommatis), par.21 (Lallah); par.28 (Serrano Caldera), par.30 (Herndl).

447. CCPR/C/SR.1042, par.32(India). 
Ireland accepts the principles referred to in paragraph 2 of article 10 and implements them as far as practically possible. It reserves the right to regard full implementation of these principles as objectives to be achieved progressively.

Article 14

Ireland reserves the right to have minor offenses against military law dealt with summarily in accordance with current procedures, which may not, in all respects, conform to the requirements of article 14 of the Covenant.

Ireland makes the reservation that the provision of compensation for the miscarriage of justice in the circumstances contemplated in paragraph 6 of article 14 may be by administrative procedures rather than pursuant to specific legal provisions.

Article 19, paragraph 2

Ireland reserves the right to confer a monopoly on or require the licensing of broadcasting enterprises.

\section{Article 20, paragraph 1}

Ireland accepts the principle in paragraph 1 of article $\mathbf{2 0}$ and implements it as far as it is practicable. Having regard to the difficulties in formulating a specific offence capable of adjudication and national level in such a form as to reflect the general principles of law recognised by the community of nations as well as the right to freedom of expression, Ireland reserves the right to postpone consideration of the possibility of introducing some legislative addition to, or variation of, existing law until time as it may consider that such is necessary for the attainment of the objective of paragraph 1 of article 20.

Article 23, paragraph 4

Ireland accepts the obligations of paragraph 4 of article 23 on the understanding that the provision does not imply any right to obtain a dissolution of marriage."

Ireland ratified in December 1989, and the introduction to the Irish report indicates that since ratification the death penalty had been abolished, leading to the withdrawal of the reservation to article $6.5 \mathrm{CCPR}^{448}$. The report clearly states the reservations made to articles 10.2, 14.6 and 20.1, without elaborating on the reasons for such reservations. The reservation about the licensing of broadcasting enterprises (article 19.2) is however followed by a discussion of the licensing system. With respect to the reservation concerning article 23.4 the report indicates that it is based on article 41.3.2 of the Constitution and the prohibition of divorce contained therein. Up until 1992, the Committee had not dealt with the Irish initial report.

\section{ISRAEL}

"With reference to Article 23 of the Covenant, and any other provision thereof to which the present reservation may be relevant. matters of personal status are governed in Israel by the religious law of the parties concerned.

"To the extent that such law is inconsistent with its obligations under the Covenant. Israel reserves the right to apply that law."

Israel ratified in October 1991, at the time of writing its initial report was not yet due for submission to the Human Rights Committee. 


\section{ITALY}

\section{Article 9, paragraph 5}

The Italian Republic, considering that the expression "unlawful arrest or detention" contained in article 9, paragraph 5 , could give rise to differences of interpretation, declares that it interprets the aforementioned expression as referring exclusively to cases of arrest or detention contrary to the provisions of article 9, paragraph 1.

Article 12. paragraph 4

Article 12, paragraph 4, shall be without prejudice to the application of transitional provision XIII of the Italian Constitution, respecting prohibition of the entry into and sojourn in the national territory of certain members of the House of Savoy.

Article 14, paragraph 3

The provisions of article 14, paragraph 3(d), are deemed to be compatible with existing Italian provisions governing trial of the accused in his presence and determining the cases in which the accused may present his own defence and those in which legal assistance is required.

Article 14. paragraph 5

Article 14, paragraph 5 , shall be without prejudice to the application of existing Italian provisions which, in accordance with the Constitution of the Italian Republic, govern the conduct, at one level only, of proceedings instituted before the Constitutional Court in respect of charges brought against the President of the Republic and its Ministers.

Article 15. paragraph 1

With reference to article 15 , paragraph 1 , last sentence: "If, subsequent to the commission of the offence, provisions is made by law for the imposition of a lighter penalty, the offender shall benefit thereby", the Italian Republic deems this provision to apply exclusively to cases in progress.

Consequently, a person who has already been convicted by a final decision shall not benefit from any provision made by law, subsequent to that decision, for the imposition of a lighter penalty.

Article 19, paragraph 3

The provisions of article 19, paragraph 3, are interpreted as being compatible with the existing licensing system for national radio and television and with the restrictions laid down by law for local radio and television companies and for stations relaying foreign programmes.

The initial report by Italy indicates that it made a reservation to article $5 \mathrm{OP}^{449}$, and discusses each of the reservation made. The reservation concerning article 9.5 was made to underline specifically that Italy considered this a rule related to article 9.1 , while the text does not emphasize this ${ }^{4.5}$. The report merely mentions the reservation to article 12.4 in respect of the former rulers of Italy, and it is indicated that the reservation to article 14.3 reflects the rule of Italian law that in spite of absence of the accused a trial may proceed if the defence counsel is present ${ }^{451}$. The explanation about the reservation to article 14.5 refers to criminal procedures against the president and the ministers to be held before the Constitutional Court, when no appeal will be available ${ }^{452}$. The reservation to article 15.1 seeks to prevent the impact of a change in the law during current 
proceedings ${ }^{43}$. It is indicated that the reservation to article 19.3 seeks to legitimize the licensing of local broadcasting operations in Italy ${ }^{454}$.

The Committee was concerned about the Italian rules concerning compensation for judicial error, it was indicated that article 9.5 has a broader scope than Italian law ${ }^{455}$; and the question arose as to whether the House of Savoy constituted a threat to the republic, their banning being covered by a reservation to article $12.4^{456}$. There is also concern about restrictions on public hearings, guaranteed in article $14.3^{457}$.

With respect to the declaration relating to article 9.5, the Italian representative indicated that the declaration was made in order to underline that this provision was interpreted as referring to article 9.1, and, moreover, stated that it was possible to invoke article 9.5 in a request of compensation for unlawful detention, which fitted in the Italian system of compensation for damages ${ }^{48}$. With respect to the position of the House of Savoy the representative did not answer the question and merely referred to a similar reservations made by Austria ${ }^{459}$.

The second Italian report ${ }^{460}$ provides information on an article-by article basis. No information is provided on the reservations made. The Committee wishes to know whether the many reservations needed to be maintained. In particular, questions are asked about the restrictions on the right to entry for the House of Savoy ${ }^{461}$, to which it is replied that a change in the Constitution would be necessary to withdraw the reservation ${ }^{462}$, and about the reservation to article $19^{463}$. It was indicated that this reservation might be withdrawn in future ${ }^{464}$. Questions were asked about the reservations concerning articles $9.5^{4.5}$ and $14.3^{406}$. The Italian representative indicated that the latter was not really a reservation ${ }^{467}$.

JAPAN

".the Government of Japan declares that members...of the police referred to in...paragraph 2 of article 22 of the International Covenant on Civil and Political Rights be interpreted to include fire service personnel of Japan."

453. CCPR/C/6/Add.4, par.70.

454. CCPR/C/6/Add 4 , par.82.

455. CCPR/C/SR.258, par.28 (Koulishev), par.59 (Bouziri).

456. CCPR/C/SR.258, par.44 (Prado Vallejo).

457. CCPR/C/SR.258, par.61 (Bouziri).

458. CCPR/C/SR.261, par.17

459. CCPR/C/SR.261, par.13 (Italy).

460. CCPR/C/37/Add.9.

461. CCPR/C/SR.908, par.25 (Chanet).

462. CCPR/C/SR.908, par.48(Italy).

463. CCPR/C/SR.908, par.25 (Chanet).

464. CCPR/C/SR.908, par.49(Italy).

465. CCPR/C/SR.910, par.44 (Chanet).

466. CCPR/C/SR.911, par.17 (Higgins).

467. CCPR/C/SR.911, par. 20 (Italy). 
The Japanese initial report does not mention its reservation to article 22 of the Covenant, and the issue is not brought up in the discussion with the Committee either ${ }^{468}$. A discussion of the reservation is equally absent in the second periodical report and the consideration thereof by the Committe $e^{4(6)}$.

\section{LUXEMBOURG}

"(a) The Government of Luxembourg considers that article 10, paragraph 3, which provides that juvenile offenders shall be segregated from adults and accorded treatment appropriate to their age and legal status, refers solely to the legal measures incorporated in the system for the protection of minors, which is the subject of the Luxembourg youth welfare act. With regard to other juvenile offenders falling within the sphere of ordinary law, the Government of Luxembourg wishes to retain the option of adopting measures that might be more flexible and be designed to serve the interests of the persons concerned."

"(b) The Government of Luxembourg declares that it is implementing article 14 , paragraph 5 , since that paragraph does not conflict with the relevant Luxembourg legal statutes, which provide that, following an acquittal or a conviction by a court of first instance, a higher tribunal may deliver a sentence, confirm the sentence passed or impose a harsher penalty for the same crime. However, the tribunal's decision does not give the person declared guilty on appeal the right to appeal that conviction to a higher appellate jurisdiction."

The Government of Luxembourg further declares that article 14, paragraph 3, shall not apply to persons who, under Luxembourg law, are remanded directly to a higher court or brought before the Assize Court.

"(c) The Government of Luxembourg accepts the provision in article 19, paragraph 2 , provided that it does not preclude it from requiring broadcasting. television and film companies to be licensed."

"(d) The Government of Luxembourg declares that it does not consider itself obligated to adopt legislation in the field covered by article 20 . paragraph 1 , and that article 20 as a whole will be implemented taking into account the rights to freedom of thought, religion, opinion, assembly and association laid down in articles 18,19 and 20 of the Universal Declaration of Human Rights and reaffirmed in articles 18, 19, 21 and 22 of the Covenant."

The initial report by Luxembourg is rather brief in its description of the background of the reservations made. It refers to the interpretative declaration made in respect of article $10.3^{47}$. It appears that the declaration relating to article 14.3 and 14.5 is made to provide for the situation in which particular persons, such as judges, are brought before the Assize Court in the first instance. Luxembourg indicated that legislation was pending to change this procedure ${ }^{471}$. The reservation to article 20.1 is merely mentioned in the report ${ }^{42}$.

The Committee wonders about the necessity to make a reservation to article 10.3 of the Covenant, and it appears from the answer by the representative that the

468. CCPR/C/10/Add.1; CCPR/C/SR 319, 320, 324.

469. CCPR/C/42/Add .4; CCPR/C/SR.827-831.

470. CCPR/C/31/Add.2, par.46.

471. CCPR/C/31/Add.2, par.63.

472. CCPR/C/31/Add.2, par.82. 
problem was one of different opinions about the educational value of segrega$\operatorname{tion}^{473}$. Luxembourg is praised for its intention to change the legislation that led to the reservation to article $14.5^{474}$, and there is a discussion about the reservation concerning article 20.1 of the Covenant $\mathrm{t}^{75}$.

\section{MALTA}

1. Article 13 - The Government of Malta endorses the principles laid down in article 13. However, in the present circumstances it cannot comply entirely with the provisions of this article;

2. Article 14(2) - The Government of Malta declares that it interprets paragraph 2 of article $\mathbf{1 4}$ of the Covenant in the sense that it does not preclude any particular law from imposing upon any person charged under such law the burden of proving particular facts;

3. Article 14(6) - While the Government of Malta accepts the principle of compensation for wrongful imprisonment, it is not possible at this time to implement such a principle in accordance with article 14, paragraph 6 , of the Covenant:

4. Article 19 - The Government of Malta desiring to avoid any uncertainty as regards the application of article 19 of the Covenant declares that the Constitution of Malta allows such restrictions to be imposed upon public officers in regard to their freedom of expression as are reasonably justifiable in a democratic society. The Code of Conduct for public officers in Malta precludes them from taking an active part in political discussions or other political activity during working hours or on the premises.

The Government of Malta also reserves the right not to apply article 19 to the extent that this may be fully compatible with Act 1 of 1987 entitled "An act to regulate the limitations on the political activities of aliens, and this in accordance with Article 16 of the Convention of Rome (1950) for the protection of Human Rights and Fundamental Freedoms or with Section 4l(2)(a)(ii) of the Constitution of Malta;

5. Article 20 - The Government of Malta interprets article 20 consistently with the rights conferred by Articles 19 and 21 of the Covenant but reserves the right not to introduce any legislation for the purposes of article 20;

6. Article 22 - The Government of Malta reserves the right not to apply article 22 to the extent that existing legislative measures may not be fully compatible with this article.

Malta acceded in September 1990, at the time of writing its initial report had not yet been received by the Human Rights Committee ${ }^{476}$.

\section{MEXICO}

Interpretative statements:

Article 9, paragraph 5

Under the Political Constitution of the United Mexican States and the relevant implementing legislation, every individual enjoys the guarantees relating to penal matters embodied therein. and consequently no person may be unlawfully arrested or detained. However, if by reason of false accusation or complaint any individual suffers

473. CCPR/C/SR.628, par.37 (Movchan); CCPR/C/SR.629, par.23 (Higgins); CCPR/C/SR 632, par.15 (Luxembourg).

474. CCPR/C/SR.629, par.14 (Tomuschat); CCPR/C/SR.632, par.18 (Luxembourg).

475. CCPR/C/SR.628, par.28 (Prado Vallejo), par.40 (Movchan); CCPR/C/SR.632, par.24 (Luxembourg), par.39 (Ndiaye). The second periodic report of Luxembourg has been received, but has not yet been considered. See $\mathrm{A} / 47 / 40$, at 198 .

476. See $\mathrm{A} / 47 / 40$, p. 185 . 
an infringement of this basic right, he has, inter alia, under the provisions of the appropriate laws, an enforceable right to just compensation.

Article 18

Under the Political Constitution of the United Mexican States, every person is free to profess his preferred religious belief and to practice its ceremonies, rites and religious acts, with the limitation, with regard to public religious acts, that they must be performed in places of worship and, with regard to education, that studies carried out in establishments designed for the professional education of ministers of religion are not officially recognized. The Government of Mexico believes that these limitations are included among those established in paragraph 3 of this article.

Reservations:

Article 13

The Government of Mexico makes a reservation to this article, in view of the present text of article 33 of the Political Constitution of the United Mexican States.

Article 25, subparagraph (b)

The Government of Mexico also makes a reservation to this provision, since article 130 of the Political Constitution of the United Mexican States provides that ministers of religion shall have neither an active nor a passive vote, nor the right to form associations for political purposes.

The initial report by Mexico mentions the reservations and declarations made at the ratification of the Covenant. The interpretation of article 9.5 is repeated, although formulated slightly differently ${ }^{477}$. With respect to article 13 of the Covenant, the report reveals the content of article 33 of the Mexican Constitution dealing with the right of the Executive to expel foreigners without prior notice of previous legal action ${ }^{478}$. The report repeats the declaration concerning article 18 , and the constitutional practice in Mexico, and reiterates the reservation concerning article $25 . \mathrm{b}$ and the political rights of the clergy $y^{479}$.

The discussions in the Committee focus mainly on the relations between the State and the Church, and the system laid down in the Mexican Constitution and the declarations made. Committee-members indicate that they are strongly opposed to such far-reaching restrictions on the right to religion, as seem to follow from article 130 of the Mexican Constitution and are underlined by the declarations concerning articles 18 and $25 . \mathrm{b}$ of the Covenant $t^{4 \times 0}$. Mexico indicates that the concern of the Committee has been transmitted to the Government, and states that ministers have all the human rights Mexicans have. Article 130 is merely a provision leading to a complete separation of the church and the State ${ }^{481}$. The Committee is equally concerned with the reservation concerning article 13 of the Covenant, and the reference to article 33 of the Mexican Constitution, and wonders whether Mexico is unfamiliar with the work of the Third Committee (of the General Assembly) on the human rights of aliens. It is suggested that Mexico

477. CCPR/C/22/Add.1, par.22; this might be due to differences in the translation of the declaration and the report from Spanish to English.

478. CCPR/C/22/Add.1, par.29.

479. CCPR/C/22/Add.1, par.40, par.47.

480. CCPR/C/SR.387, par.17 (Tomuschat), par.38 (Evans), par.62 (Bouziri).

481. CCPR/C/SR.404, par.65-68 (Mexico). 
might consider amending its Constitution in order to withdraw the reservation $^{482}$. In its reaction Mexico indicates that it does not see any necessity to review legislation in the light of GA Resolution 36/165, which it had supported.

After repeating the declaration concerning article 9.5, the second periodic report gives a lengthy elaboration on the historical background of article 33 of the Mexican Constitution leading to the conclusion that this provision has never encroached upon any human right and is meant to defend and preserve the sovereignty of the nation ${ }^{483}$. With respect to the reservation to article $25 . \mathrm{b}$ of the Covenant, the report indicates that article 130 of the Constitution has a similar historical background ${ }^{484}$. The report reinforces the declaration concerning article 18.3 by stating that Mexican rules on public worship are in conformity with the declaration on the Elimination of All Forms of Intolerance and of Discrimination based on Religions or Belief ${ }^{\text {ts. }}$.

In its discussion with Mexico, the Committee expresses surprise about historical reasons for maintaining the reservation to article 25.b, and suggest that legislation might be improved in this respect. A wish for an informal follow-up to the dialogue on this matter is expressed ${ }^{486}$. The other issue mentioned briefly in the discussion with Mexico is the reservation to article 13, which is unnecessary in the eyes of Committee-Member Chanet, as the relevant provision of Mexican law is only used when compelling reasons of national security so indicate $e^{487}$. This is a remarkable statement, as this restrictive use is itself not indicated in the Mexican report. The Mexican representative reiterated the position with regard to article 18 and article 24 of the Mexican Constitution ${ }^{48}$. The Committee questions the compatibility of article 24 of the Constitution with the right to freedom of religion ${ }^{489}$.

\section{NETHERLANDS}

Reservations

Article 10

The Kingdom of the Netherlands subseribes to the principle set eut in paragraph 1 of this article. but it takes the view that ideas about the treatment of prisuners are so liable to change that it does not wish to be bound by the obligations set out in paragraph 2 and paragraph 3 (second sentence) of this article.

Article 12. paragraph 1

"The Kingdom of the Netherlands regards the Netherlands and the Netherlands Antilles as scparate territories of a State for the purpose of this provision.

Article 12. paragraphs 2 and 4

483. CCPR/C/46/Add.3, par.255-262.

484. CCPR/C/46/Add.3, par.372. 
The Kingdom of the Netherlands regards the Netherlands and the Netherlands Antilles as separate countries for the purpose of these provisions.

Article 14, paragraph 3(d)

The Kingdom of the Netherlands reserves the statutory option of removing a person charged with a criminal offence from the courtroom in the interests of the proper conduct of the proceedings.

Article 14, paragraph 5

"The Kingdom of the Netherlands reserves the statutory power of the Supreme Court of the Netherlands to have sole jurisdiction to try certain categories of persons charged with serious offenses committed in the discharge of a public office.

Article 14, paragraph 7

"The Kingdom of the Netherlands accepts this provision only in sofar as no obligations arise from it further to those set out in article 68 of the Criminal Code of the Netherlands and article 70 of the Criminal Code of the Netherlands Antilles as they now apply. They read:

"1. Except in cases where court decisions are eligible for review, no person may be prosecuted again for an offence in respect of which a court in the Netherlands or the Netherlands Antilles has delivered an irrevocable judgement.

"2. If the judgement has been delivered by some other court, the same person may not be prosecuted for the same offence in the case of (I) acquittal or withdrawal of proceedings or (II) conviction followed by complete execution. remission or lapse of the sentence.

Article 19, paragraph 2

The Kingdom of the Netherlands accepts the provision with the proviso that it shall not prevent the Kingdom from requiring the licensing of broadeasting, television or cinema enterprises.

Article 20, paragraph 1

"The Kingdom of the Netherlands does not accept the obligation set out in this provision in the case of the Netherlands."

Article 25 (c) [withdrawn]

The Kingdom of the Netherlands does not accept this provision in the case of the Netherlands Antilles.

Explanation

"[The Kingdom of the Netherlands] clarifies that although the reservations [...] are partly of an interpretational nature, [it] has preferred reservations to interpretational declarations in all cases, since if the latter form were used doubt might arise concerning whether the text of the Covenant allows for the interpretation put upon it. By using the reservation form the Kingdom of the Netherlands wishes to ensure in all cases that the relevant obligations arising out of the Covenant will not apply to the Kingdom, or will apply only in the way indicated.

The initial report by the Netherlands indicates that a different opinion exists as to the wisdom of implementing the rule in articles 10.2.b and 10.3. The report indicates that there is an increasing awareness that there should be a selection on the basis of personality criteria rather than on the basis of age ${ }^{400}$. With respect to the reservations concerning article 12.1, 12.2 and 12.4 it is indicated that the Netherlands Antilles and the Netherlands are separate countries with differing regulations as to admission and residence ${ }^{491}$. The reservation to article 14.3.d 
refers to a number of exceptions to the rule about trial in his presence ${ }^{492}$. The reservation to article 14.5 protects the special procedure possible before the Supreme Court for a small group of Government officials ${ }^{493}$, and the reservation to article 14.7 seeks to maintain the domestic rules on ne bis in idem $^{444}$. Both the Netherlands report and the report by the Netherlands Antilles indicate that there is uncertainty about the reference in article 14.7 to the ne bis in idem rule in its domestic or international application. While the reservation to article 19.2 is not dealt with in the report, it does underline that the reservation to article 20.1 is necessary because the implementation of this provision might run contrary to the freedom of expression ${ }^{495}$

There are some striking differences between the Netherlands report and the report of the Netherlands Antilles. The Antilles indicate that the reservation to article 10.2.b and 10.3 does not apply on its territory, and that the accused and the convicted are separated as are the juveniles and the adults ${ }^{4 *}$. The explanation about the reservations to article $12.1,12.2$ and 12.4 is substantially the same as the Netherlands explanation. The Antilles' report merely indicates reservations to articles 14.3. $\mathrm{d}^{497}$ and 14.7; apparently forgetting the reservation to article 14.5 and the sole jurisdiction of the Supreme Court. After mentioning the reservation to article 19.2. the report indicates that the reservation concerning article 20.1 has been made in respect of the Antilles, who were at the time preparing a Bill to include the prohibition in the Criminal Code.

Both reports are dealt with together by the Committee. In the introduction the Netherlands representative points out that in spite of the reservations made by other States Parties to the European Convention, the Netherlands had not made a reservation to article 5 of the Optional Protocol ${ }^{448}$. A certain amount of confusion arises because of the structure of the Kingdom and the relation between the component parts, as well as the fact that a reservation to article 25.c has been entered on behalf of the Antilles ${ }^{499}$. The matter of the reservation to article 20.1 was brought up by a number of Committee members, but the representative upholds the Netherlands point of view ${ }^{500}$. Furthermore there is discussion about the reservation to article 10.2.a and the comment to that by the Dutch section of the International Commission of Jurists ${ }^{501}$; it is indicated that the reservation to article 14.3.d is superfluous as the rules intended to be protected by the reservation would be acceptable under the Covenant anyway ${ }^{502}$. The Netherlands

493. CCPR/C/10/Add.3, p.23.

494. CCPR/C/10/Add.3, p.23.

495. CCPR/C/10/Add.3, p.27.

496. CCPR/C/10/Add.5, p.7.

497. Mentioning a reservation to article 14.3.e as the report does on p.9 must be a mistake.

498. CCPR/C/SR.321, par.10; referring to the reservations to article $5 \mathrm{OP}$.

499. CC.PR/C/SR.322, par.27 (Hanga); CCPR/C/SR.325, par.3 (Netherlands).

500. CCPR/C/SR.321, par.27 (Movchan), par50 (Gracfrath); CCPR/C/SR.322, par.5 (Sadi), par.73 (Tomuschat); SR.325, par.35 (Netherlands).

501. CCPR/C/SR.321, par.38 (Opsahl).

502. CCPR/C/SR.322, par.71 (Tomuschat). 
clarified the group of people falling within the scope of the reservation to article $14.5^{503}$.

The second periodical report by the Netherlands does not refer to any of the reservations made ${ }^{504}$.

The Committee calls for the withdrawal of the reservations to article 10 , but notes at the same time that there might be harmful effects following from isolation $^{505}$. It is noteworthy that the reply of the Netherlands representative stresses the need for prison capacity as one of the reasons for maintaining the reservation, and gives the different opinion on the merits of separation as a secondary reason ${ }^{\text {sox }}$. The capacity issue is new, it had not been raised in the earlier discussion. Few words are spent on the reservation to article 20, which is maintained by the Netherlands ${ }^{507}$. At the conclusion of the discussion a Committee member indicates that a withdrawal of all reservations would be very welcome ${ }^{508}$.

\section{NEW ZEALAND}

\section{Reservations}

"The Government of New Zealand reserves the right not to apply article $10(2)(\mathrm{b})$ or article $10(3)$ in circumstances where the shortage of suitable facilities makes the mixing of juveniles and adults unavoidable; and further reserves the right not to apply article 10(3) where the interests of other juveniles in an establishment require the removal of a particular juvenile offender or where mixing is considered to be of benefit to the persons concerned.

"The Government of New Zealand reserves the right not to apply article 14(6) to the extent that it is not satisfied by the existing system for $c x$ gratia payments to persons who suffer as a result of a miscarriage of justice.

"The Government of New Zealand having legislated in the areas of the advocacy of national and racial hatred and the exiting of hostility or ill will against any group of persons, and having regard to the right of freedom of speech, reserves the right not to introduce further legislation with regard to article 20.

"The Government of New Zealand reserves the right not to apply article 22 as it relates to trade unions to the extent that existing legislative measures, enacted to ensure effective trade union representation and encourage orderly industrial relations, may not be fully compatible with that article."

Although the reservations of New Zealand do not refer to this, the ratification of New Zealand is also on behalf of its dependent territories Niue, Tokelau and the Cook Islands. On each of these territories separate reports are submitted, which makes the New Zealand reports rather bulky.

503. CCPR/C/SR.325, par.25 (Netherlands).

504. CCPR/C/42/Add.6. The second periodic report by the Netherlands Antilles was due in 1986, but has not been received yet. See $A / 47 / 40$, at 189 .

505. CCPR/C/SR.862, par.51 (Ando), par.54 (Dimitrijevic); CCPR/C/SR.864, par.23 (Chanet).

506. CCPR/C/SR.863, par.3 (Netherlands).

507. CCPR/C/SR.863, par.49 (Netherlands).

508. CCPR/C/SR.864, par.23 (Chanet). 
The initial report by New Zealand mentions that apart from the issues covered by reservations, the Covenant is fully implemented ${ }^{500}$. It is indicated that the reservation to articles $10.2 \mathrm{~b}$ and 10.3 is motivated by the shortage of suitable facilities to separate juveniles from adults ${ }^{510}$. In respect of article 14.6 it is indicated that the matter of compensation for miscarriages of justice has no legal basis, but is settled on the basis of ex gratia payments ${ }^{511}$. The reservation in respect of article 20 is merely mentioned in the report, without further explanation $^{512}$. The reports on Niue ${ }^{513}$, on Tokelau ${ }^{5 / 4}$ and on the Cook Islands ${ }^{515}$ all refer to the same reservation to article 20 . The report on Cook Islands also mentions the reservation to article 14.6 and the provision of ex gratia payments in such cases $^{516}$.

A great number of Committee members proved to be concerned about the reservation made in respect of article $20^{517}$, but New Zealand indicates that there is at present no problem with propaganda for war, and it may reconsider its position if the need should arise ${ }^{518}$. With respect to the reservations to articles 10.2.b and 10.3 the question is asked whether the reservation rests on necessity or on considerations of desirability, and the representative answers that both elements played a role in making the reservation ${ }^{519}$. Another question relates to the need to make a reservation to article 14.6 , if a practice of ex gratia payments exits. Here it is indicated that there is no formal obligation to do $\mathrm{so}^{530}$. In general there is concern that not all the reservations are justified ${ }^{521}$.

The initial report on the Cook Islands had been submitted later, and is consequently considered in a different session ${ }^{522}$. There is some discussion about the implementation of article 22 of the Covenant, although it is noted that New Zealand entered a reservation in that respect and was therefor not bound by the provision ${ }^{523}$.

The matter of the reservation to article 22 of the Covenant and the rights of trade union representation is mentioned in the second period report by New Zea-

509. CCPR/C/10/Add.6, par.5.

510. CCPR/C/10/Add.6, par.133, par.142.

511. CCPR/C/10/Add.6, par.201.

512. CCPR/C/10/Add.6, par.255.

513. CCPR/C/10/Add 10 , par.1 at p.16.

514. CCPR/C/10/Add.11, par.l at p.16.

515. CCPR/C/10/Add.13, par.118 at p.22.

516. CCPR/C/10/Add.13, par.95 at p.18.

517. CCPR/C/SR 481, par.30 (Movchan); CCPR/C/SR 482, par.27 (Prado Vallejo), par.41 (Graefrath), par.46 (Al Douri).

518. CCPR/C/SR.487, par.47 (New Zealand).

519. CCPR/C/SR.482, par.46 (AI Douri); CCPR/C/SR.487, par.43 (New Zealand).

520. CCPR/C/SR.482, par.46 (AI Douri); CCPR/C/SR.487, par.47 (New Zealand).

521. CCPR/C/SR.481, par.37 (Bouziri).

522. CCPR/C/10/Add.13.

523. CCPR/C/SR.582, par.59 (Serrano Caldera), par.60 (Mavrommatis), par.62 (Tomuschat). 
land ${ }^{524}$. The reservations are not mentioned in the reports of $\mathrm{Niue}^{525}$ and Tokelau ${ }^{526}$.

In the Committee discussions the question is asked whether New Zealand is considering withdrawing its reservations, and the reply is that no need is felt to do so in general, but that the reservation to article 14 is being reconsidered at the moment ${ }^{527}$. New Zealand elaborates on the content of the legislation in respect of article 10.2.b and the relevant reservation ${ }^{328}$. When asked about article 20 , New Zealand indicated that it did not intend to withdraw that reservation ${ }^{529}$. Perhaps more interesting is the beginning of a discussion about the reservation to article 22, and the question if New Zealand could not withdraw the reservation in view of its new legislation on labour relations. The representative indicates that these questions will be answered in writing ${ }^{530}$.

\section{NORWAY}

[Subject to] reservations to article 10, paragraph 2(b) and paragraph 3 "with regard to the obligation to keep accused juvenile persons and juvenile offenders segregated from adults $^{n}$ and to article 14, paragraph 5 and 7 and to article 20, paragraph 1.

The initial report by Norway indicates that the reservation in respect of article 10.2.b and 10.3 has been made on practical grounds, together with a certain amount of doubt about the advisability of keeping young offenders strictly separated from adult offenders ${ }^{531}$. The reservation concerning article 14.5 is based on doubt as to the acceptability of certain domestic procedures excluding the right to review in particular cases ${ }^{532}$. The reservation to article 14.7 has a similar background, there are possibilities under Norwegian law to resume a case to the disadvantage of a person ${ }^{533}$. Although Norway tried to legislate in accordance with article 20.1, the report indicates that the law to that effect was rejected by parliament ${ }^{334}$.

In the discussion with Norway, questions were asked about the reservations to articles 14.5 and 14.7 , it was indicated that the reservation to article $14.7 \mathrm{might}$ not be necessary, and it was suggested that the law be changed in order to withdraw the reservation ${ }^{335}$. Apart from mentioning a difference of opinion

524. CCPR/37/Add.8, par.129. The second periodic report of the Cook Istands was due in 1985, but has not been received yet. See $\mathrm{A} / 47 / 40$ at 187 .

525. CCPR/C/37/Add.11.

526. CCPR/C/37/Add.12.

527. CCPR/C/SR.888, par.25 (Chanet); par.56 (New Zealand).

528. CCPR/C/SR.889, par.53 (New Zealand).

529. CCPR/C/SR.890, par.37 (Ndiaye), par.48 (New Zealand).

530. CCPR/C/SR.890, par.54 (Chanet), par.58 (New Zealand); CCPR/C/SR.891, par.15 (Chanet).

531. CCPR/C/1/Add.S, p.5.

532. CCPR/C/1/Add.S, p.6.

533. CCPR/C/1/Add.S. p.6.

534. CCPR/C/1/Add.S, p.8

535. CCPR/C/SR.77, par.6 (Graefrath), par.20 (Koulishev). 
about the aim of article $10.3^{536}$, there is general concern about the reservation to article 20 , and it was suggested the bill prohibiting war propaganda be reintroduced to parliament again ${ }^{537}$. A noteworthy question deals with a clarification of the Norwegian reservation to the Optional Protocol ${ }^{538}$.

The Norwegian reply is rather brief, the representative takes note of the remark that the goal of articles 10.2.b and 10.3 had only been to prevent mixing adults and juveniles without taking due account of age ${ }^{539}$. The questions concerning article 14 would be answered in writing and Norway felt that there was no reason for withdrawing the reservation to article 20 at present ${ }^{500}$.

In an apparent reaction to the discussion with the Committee, the Norwegian interim report gives ample information about the reason for making the reservation to articles 10.2.b and 10.3, and indicates that there is a certain amount of scepticism on the part of the Ministry of Justice in respect of total segregation $^{\text {s4l. }}$. The Norwegian report reiterates the position with respect to the implementation of articles 14.5 and $14.7^{542}$, and does not discuss article 20. In respect of the Optional Protocol and the Norwegian reservation thereto, it is indicated that the reservation does not preclude the application of article 5.3.a $\mathrm{OP}^{543}$.

In the discussion about the interim report it is again stressed that non-separation is considered to be beneficial, and the Committee indicates that is would like to see information supporting this point of view ${ }^{544}$. A debate takes place between the Norwegian representative and Committee-member Evans on the consequences of the re-opening of a trial under Norwegian law protected by the Norwegian reservation to article 14.7), in relation to the ne bis in idem rule ${ }^{545}$.

The second periodic report by Norway merely indicates that, although the Criminal Procedures Act had been changed, the system remained very much the same as the one originally protected by the reservation to article 14.5 and article $14.7^{\mathrm{sat}}$.

In the discussion the question was raised why a number of reservations are still maintained $d^{547}$. The Norwegian representative elaborated upon the fact that

536. CCPR/C/SR.77, par.6 (Graeirath).

537. CCPR/C/SR.77, par.7 (Graefrath), par.22 (Koulishev), par.31 (Hanga).

538. CCPR/C/SR.77, par.43 (Tamopolsky).

539. CCPR/C/SR.79, par.18 (Norway).

540. CCPR/C/SR.79, par.21 and par.25 (Norway).

541. CCPR/C/1/Add.52, p.4-5.

542. CCPR/C/1/Add 52 , p.11-12.

543. CCPR/C/1/Add.52, p.25.

544. CCPR/C/SR.301, par.29 (Norway), par.32 (Sadi).

545. CCPR/C/SR.302, par.1,4,6 (Norway); par.3,5 (Evans).

546. CCPR/C/42/Add.5, par.78, 80.

547. CCPR/C/SR.844, par.36 (Movchan). The definition used by Movchan is remarkable because of the focus on the substance of international obligations:"A reservation meant the exercise of the sovereign right of a State to restrict its obligations under an international instrument because it was unable to implement them. 
implementing the obligation under article 20.1 of the Covenant would not be acceptable in the Norwegian society, which explains why the reservation will not be withdrawn ${ }^{548}$. The reservations to article 14.5 and 14.7 might be reconsidered in view of the Committee"s General Guidelines, and Norway indicated it was looking forward to a further dialogue $e^{s 99}$.

\section{REPUBLIC OF KOREA}

The Government of the Republic of Korea [declares] that the provisions of paragraphs 5 and 7 of article 14, article 22, article 23.4 [withdrawn] of the Covenant shall be so applied as to be in conformity with the provisions of the local laws including the Constitution of the Republic of Korea.

Korea ratified in April 1990, its initial report was considered by the Human Rights Committee in 1992. The introduction to the report of Korea mentions reservations to articles 14.5 and $22 \mathrm{CCPR}$ as well as the withdrawal of reservations to article $23.4 \mathrm{CCPR}^{550}$. It is remarkable that the reservation to article 14.7 is not mentioned there, but only further below.

The report indicates that the reservation to article 14.5 CCPR is prompted by article 110.4 of the Constitution and article 543 of the Military Court Act dealing with the absence of a right to appeal in military trials ${ }^{551}$. It indicates that the reservation to article 14.7 refers to a rule that a sentence in Korea, for a crime for which a sentence has also been imposed abroad, might be mitigated ${ }^{552}$. Article 33.2 of the Constitution, which limits the liberty to join a trade union for civil servants is the reason for the reservation to article $22^{553}$.

In his introduction the representative indicates that the reservations only sought to maintain limitations prescribed in the relevant domestic laws, but they did not represent a derogation from basic principles in the Covenant ${ }^{554}$. Committeemember Aguilar Urbina asks about the imposition of the death penalty by military courts, the only case falling outside of the scope of the reservation to article $14.5^{535}$, and some Committee members express the wish that Korea would withdraw its reservations, in particular the reservation to article 14.5 which was an essential provision with respect to the right to appea $\left.\right|^{536}$.

In its reply to questions by the Committee about the status of women, the representative indicates that Korea is considering an amendment to its nationality laws which might lead to a withdrawal of its reservation to the Women's Conven-

548. CCPR/C/SR.846, par.20,21 (Nonway).

549. CCPR/C/SR.846, par.26 (Norway).

550. C.CPR/C/68/Add.1, par.6.

551. CCPR/C/68?Add.1, par.211.

552. CCPR/C/68/Add.1, par.214.

553. CCPR/C/68/Add.1, par.265 c.

554. CCPR/C/SR.1150, par.7 (Korea).

555. CCPR/C/SR.1150, par.51 (Aguilar Urbina).

556. CCPR/C/SR.1150, par.73 (Sadi); SR.1151, par.14 (Prado Vallejo). 
tion $^{557}$. With respect to the question of the absence of the right of appeal in military courts, it is explained that this did not apply to death sentences, in which case appeal was compulsory ${ }^{558}$. Committee-member Higgins indicated that she was pleased to hear about the possible withdrawal of reservations to the Covenant, which had however not been announced by Korea ${ }^{559}$.

\section{SWEDEN}

Sweden reserves the right not to apply the provisions of article 10, paragraph 3 , with regard to the obligation to segregate juvenile offenders from adults, the provisions of article 14 , paragraph 7 , and the provisions of article 20 , paragraph 1 , of the Covenant.

The Swedish initial report mentions the reservation made to article 10.3 and states that as a rule juvenile offenders are separated from adults, but that criminological methods suggest that exceptions should be possible ${ }^{560}$. The report indicates that the reservation to article 14.7 was made in order to protect certain cases in which under Swedish law a case might be retried to the detriment of the convicted person ${ }^{561}$. In respect of the reservation to article 20.1 it is indicated that the reservation seeks to prevent a conflict between the freedom of expression and the prohibition of war propaganda ${ }^{562}$.

A number of Committee-members questioned all the Swedish reservations ${ }^{563}$, in particular stressing the reservation to article 20.1 of the Covenant ${ }^{564}$.

The supplementary report by Sweden provides little additional information on the reservations made, and demonstrates a distinct irritation on the part of Sweden $^{565}$ concerning the Committee's consideration of its reservations.

The discussion of the Swedish report is rather brief, it is suggested that Sweden withdraws its reservations ${ }^{566}$. The Swedish reply is that such an intention does

557.

CCPR/C/SR.1154, par.22 (Korea).

This is a perfect, although probably not deliberate, example of constructive approaches to the coherence of human rights instruments, discussed in Chapter 3, par.2.3 supra. The Korean reservation to article 9 CEDAW has so far not been withdrawn.

558. CCPR/C/SR.1154, par.37.

559. CCPR/C/SR.1154, par.51 (Higgins).

560. CCPR/C/1/Add.9, p.11-12.

561. CCPR/C/1/Add. 9 , p. 18.

562. CCPR/C/1/Add.9, p.26.

563. CCPR/C/SR.52, par.12-15 (Movchan), par.31 (Hanga), par.35 (Koulishev).

564. CCPR/C/SR.52, par.15 (Movehan), par.31 (Hanga), par.35 (Koulishev).

565. The report recalls that reservations have been made on points where the Swedish legislation did not comply with the Covenant; see CCPR/C/1/Add.42, p.3.

The report then continues:"It should be recalled in this connection that, according to international law, reservations have the effect of modifying provisions of an international instrument to the extent provided for the reservations, subject to objections by other Contracting Partics.The objections were raised against the Swedish reservations to the Covenant and, consequently, the reservations have their full legal validity. Since the provisions in respect of which Sweden has made reservations are not binding on Sweden, the Swedish Government does not find it necessary to provide further information in regard to these provisions."

566. CCPR/C/SR.188, par.7 (Prado Vallejo). 
not exist, as the reservations refer to provisions that were not totally acceptable to Sweden ${ }^{567}$.

The second periodical report by Sweden does not mention the reservations at all $^{568}$. The Committee again raises the issue of the withdrawal of the reservation to article 14.7, and the fact that the reservation covers a rare exception to the rule in article $14.7^{569}$. In its reply, Sweden indicates that its domestic situation is in general in conformity with the provision, and that the exception in the reservation was perhaps formulated in rather terse language, giving a wrong impression of its scope ${ }^{570}$. The ongoing discussion about reservations to article 20.1 is picked up again, with a Committee member wondering " $[\mathrm{H}]$ ow long would Sweden continues to contest the provisions of the Covenant? When would it stop derogating from them?"571. Sweden did not explicitly react to this misrepresentation of the reservation, and merely stated that it would maintain the reservation as the implementation of the provision would be contrary to the protection of the freedom of expression ${ }^{57}$.

The third periodic report by Sweden ${ }^{573}$ observed again that the reservation concerning article 10.3 had been made for the benefit of juvenile offenders, although Sweden endorsed the principle underlying the provision ${ }^{574}$. A similar explanation is provided for the reservation to article 14.7. Sweden does agree with the principle but an exception is necessary to maintain the credibility of the system $^{575}$. It was indicated that the opinions on article 20.1 have not changed $^{576}$.

The Committee barely discussed the Swedish reservations, only the reservation to article 14.7 was brought up. There was some concern about the protection against double jeopardy ${ }^{577}$ and Sweden explained that the credibility of the system was not the only reason for reopening a case, insufficient evidence at the time could be another reason ${ }^{578}$.

\section{SWITZERLAND}

a) Reservation concerning articie 10, paragraph 2 (b):

The separation of aceused juvenile persons from adults is not unconditionally guaranteed.

b) Reservations concerning article 12, paragraph I:

567. CCPR/C/SR.188, par.15 (Sweden).

568. CCPR/C/32/Add $6,8,12$.

569. CCPR/C/SR.637, par.13 (Cooray).

570. CCPR/C/SR.637, par.25 (Sweden).

571. CCPR/C/SR.638, par.27 (Movchan).

572. CCPR/C/SR.638, par.24, 33 (Sweden).

573. CCPR/C/58/Add.7.

574. CCPR/C/58/Add.7. par.104.

575. CCPR/C/58/Add.7. par.201.

576. CCPR/C/58/Add.7, par.244.

577. CCPR/C/SR.1044, par. 36 (Lallah), par.37 (Wako).

578. CCPR/C/SR.1044, par.38 (Sweden). 
The right to liberty of movement and freedom to choose one's residence is applicable subject to the federal laws on aliens, which provide that residence and establishment permits shall be valid only for the canton which issues them.

c) reservations concerning article 14 , paragraph 1 :

The principle of a public hearing is not applicable to proceedings which involve a dispute relating to civil rights and obligations or to merits of the prosecution's case in a criminal matter, these, in accordance with cantonal laws, are held before an administrative authority. The principle that any judgement rendered shall be made public is adhered to without prejudice to the cantonal laws on civil and criminal procedure, which provide that a judgement shall not be rendered at a public hearing, but shall be transmitted to the parties in writing.

The guarantee of a fair trial has as its sole purpose, where disputes relating to civil rights and obligations are concerned, to ensure final judicial review of the acts or obligations of public authorities which have a bearing on such rights or obligations. The Term "final judicial review" means a judicial examination which is limited to the application of the law, such as a review by a Court of Cassation.

d) Reservation concerning article 14, paragraph 3, sub-paragraphs d) and f):

The guarantee of free legal assistance assigned by the court and of the free assistance of an interpreter does not definitively exempt the beneficiary from defraying the resulting costs.

e) Reservation concerning article 14, paragraph 5:

The reservations applies to the federal laws on the organization of criminal justice, which provide for an exception to the right of anyone convicted of a crime to have his conviction and sentence reviewed by a higher tribunal, where the person concerned is tried in the first instance by the highest tribunal.

f) Reservation concerning article 20:

Switzerland reserves the right not to adopt measures to ban propaganda for war, which is prohibited by article 20 , paragraph 1 .

Switzerland reserves the right to adopt a eriminal procedure which will take into account the requirements of article 20, paragraph 2, on the occasion of its fortheoming accession to the 1966 International Convention on the Elimination of All Forms of Racial Discrimination.

g) Reservations concerning article 25 , subparagraph b):

The present provision shall be applied without prejudice to the cantonal and communal laws. which provide for or permit elections within assemblies to be held by a means other than secret ballot.

h) Reservation concerning articie 26

The equality of all persons before the law and their entitlement without any discrimination to the equal protection of the law shall be guaranted only in connection with other rights contained in the present Covenant.

As Switzerland ratified in June 1992, its initial report would only be due in 1993.

\section{TRINIDAD AND TOBAGO}

(i) The Government of the Republic of Trinidad and Tobago reserves the right not to apply in full the provision of paragraph 2 of article 4 of the Covenant since section 7(3) of its Constitution enables Parliament to enact legislation even though it is inconsistent with sections (4) and (5) of the said Constitution;

(ii) Where at any time there is a lack of suitable prison facilities, the Government of the Republic of Trinidad and Tobago reserves the right not to apply article $10(2)(b)$ and $10(3)$ so far as those provisions require juveniles who are detained to be accommodated separately from adults;

(iii) The Government of the Republic of Trinidad and Tobago reserves the right not to apply paragraph 2 of article 12 in view of the statutory provisions requiring persons intending to travel abroad to furnish tax clearance certificates; 
(iv) The Government of the Republic of Trinidad and Tobago reserves the right not to apply paragraph 5 of article 14 in view of the fact that section 43 of its Supreme Court of Judicature Act No. 12 of 1962 does not confer on a person convicted on indictment an unqualified right of appeal and that in particular cases, appeal to the Court of Appeal can only be done with the leave of the Court of Appeal itself or of the Privy Council:

(v) While the Government of the Republic of Trinidad and Tobago accepts the principle of compensation for wrongful imprisonment, it is not possible at this time to implement such a principle in accordance with paragraph 6 of article 14 of the Covenant;

(vi) With reference to the last sentence of paragraph 1 of article 15 "If, subsequent to the commission of the offence, provision is made by law for the imposition of a lighter penalty, the offender shall benefit thereby", the Government of the Republic of Trinidad and Tobago deems this provision to apply exclusively to cases in progress. Consequently, a person who has already been convicted by a final decision shall not benefit from any provision made by law, subsequent to that decision, for the imposition of a lighter penalty;

(vii) The Government of the Republic of Trinidad and Tobago reserves the right to impose lawful and or reasonable restrictions with respect to the right of assembly under article 21 of the Covenant;

(viii) The Government of the Republic of Trinidad and Tobago reserves the right not to apply the provision of article 26 of the Covenant in so far as it applies to the holding of property in Trinidad and Tobago, in view of the fact that licences may be granted to or withheld from aliens under the Aliens Landholding Act of Trinidad and Tobago.

The first report by Trinidad and Tobago does not refer to the extensive number of reservations made ${ }^{579}$. The Committee in its discussion stresses the issue of the reservation to article 4.2 made by Trinidad and Tobago. The fact that the Constitution does not exclude the application of article 4.2 in times of emergency is mentioned $d^{\mathrm{s} D}$. The representative is told that the provision is at the core of the Covenant and the reservation is a serious inconsistency with the objectives and purposes of treaty law ${ }^{581}$. The representative indicated that she would take the matter back to the Ministry in Port of Spain ${ }^{52}$.

The second report by Trinidad and Tobago does not inention the reservations $e^{e i t h e r}{ }^{53}$. In her introduction the representative stated that the Government had not given consideration to withdrawing the reservation to article 4.2 , but that Parliament could legislate contrary to the Constitution under a particular section of the Constitution ${ }^{84}$. She indicated that human rights issues might be dealt with in the forthcoming review of the Constitution ${ }^{5.5}$. The Committee, and in particular Committee-members Higgins, are greatly concerned with the reservation to article $4.2^{586}$. It is indicated that certain provisions of the Covenant

58.0. CCPR/C/SR 551, par.2 (Opsahl).

581. CCPR/C/SR.555, par.l (Tomuschat).

582. CC.PR/C/SR.555, par.2 (Trinidad and Tobago).

583. CC.PR/C/37/Add.7.

584. CCPR/C/SR.764, par.13 (Trinidad and Tobago).

585. CCPR/C/SR.765, par.15 (Trinidad and Tobago).

586. CCPR/C/SR.765, par.16-18 (Higgins), par.20 (Cooray), par.22 (Lallah). 
cannot be derogated from, which is why the Netherlands justifiably objected to the reservation. The reservation is a unusable weapon against disorder, which is incompatible with the Covenant ${ }^{587}$.

The Committee also deals with the reservation concerning article 12.2 of the Covenant and the need to fumish tax clearance certificates. Trinidad and Tobago is told that a reservation is not necessary in this respect as such rules would ordinarily be covered by article 12.3 , it is suggested that the reservation be withdrawn ${ }^{588}$.

\section{UNITED KINGDOM}

Upon ratification:

"Firstly the Government of the United Kingdom maintain their declaration in respect of article 1 made at the time of signature of the Covenant. [Upon signature: "the Government of the United Kingdom declare their understanding that, by virtue of Article 103 of the Charter of the United Nations, in the event of any conflict between their obligations under Article 1 of the Covenant and their obligations under the Charter (in particular, under Articles 1, 2 and 73 thereof) their obligations under the Charter shall prevail.]

"The Government of the United Kingdom reserve the right to apply to members of and persons serving with the armed forces of the Crown and to persons lawfully detained in penal establishments of whatever character such laws and procedures as they may from time to time deem to be necessary for the preservation of service and custodial discipline and their acceptance of the provisions of the Covenant is subject to such restrictions as may for these purposes from time to time be authorised by law.

"Where at any time there is a lack of suitable prison facilities or where the mixing of adults and juveniles is deemed to be mutually beneficial, the Government of the United Kingdom reserve the right not to apply article $10(2)(b)$ and $10(3)$, so far as those provisions require juveniles who are detained to be accommodated separately form adults, and not to apply article 10(2)(a) in Gibraltar, Montserrat and the Turks and Caicos Islands in so far as it requires segregation of accused and convicted persons.

"The Government of the United Kingdom reserve the right not to apply article 11 in Jersey.

The Government of the United Kingdom reserve the right to interpret the provisions of article 12(1) relating to the territory of a State as applying separately to each of the territories comprising the United Kingdom and its dependencies.

"The Government of the United Kingdom reserve the right to continue to apply such immigration legislation governing entry into, stay in and departure from the United Kingdom as they may deem necessary from time to time and. accordingly. their acceptance of article 12(4) and of the other provisions of the Covenant is subject to the provisions of any such legislation as regards persons not at the time having the right under the law of the United Kingdom to enter and remain in the United Kingdom. The United Kingdom also reserves a similar right in regard to each of its dependent territories.

The Government of the United Kingdom reserve the right not to apply article 13 in Hong Kong in so far as it confers a right of review of a decision to deport an alien and a right to be represented for this purpose before the competent authority.

The Government of the United Kingdom reserve the right not to apply or not to apply in full the guarantee of free legal assistance in sub-paragraph (d) of paragraph 3 of article 14 in so far as the shortage of legal practitioners renders the application of his 
guarantee impossible in the British Virgin Islands, the Cayman Islands, the Falkland Islands, the Gilbert Islands, the Pitcairn Islands Group, St. Helena and Dependencies and Tuvalu.

The Government of the United Kingdom interpret article 20 consistently with the rights conferred by articles 19 and 21 of the Covenant and having legislated in matters of practical concern in the interests of public order (ordre public) reserve the right not to introduce any further legislation. The United Kingdom also reserve a similar right in regard to each of its dependent territories.

"The Government of the United Kingdom reserve the right to postpone the application of paragraph 3 of article 23 in regard to a small number of customary marriages in the Solomon Islands.

"The Government of the United Kingdom reserve the right to enact such nationality legislation as they may deem necessary from time to time to reserve the acquisition and possession of citizenship under such legislation to those having sulficient connection with the United Kingdom or any of its dependent territories and accordingly their acceptance of article 24(3) and of the other provisions of the Covenant is subject to the provisions of any such legislation.

The Government of the United Kingdom reserve the right not to apply sub-paragraph (b) of article 25 in so far as it may require the establishment of an elected Executive or Legislative Council in Hong Kong and sub-paragraph (c) of article 25 in so far as it relates to jury service in the Isle of Man.

"Lastly, the Government of the United Kingdom declare that the provisions of the Covenant shall not apply to Southern Rhodesia unless and until they inform the Secretary-General of the United Nations that they are in a position to ensure that the obligations imposed by the Covenant in respect of that territory can be fully implemented."

The reservations and declarations made by the United Kingdom are remarkably extensive. The reports by the United Kingdom on the implementation of the Covenant in the United Kingdom, in the dependent territories and the dependencies of the Crown are voluminous and bulky. Given the fact that a difference exists between the ratification for the United Kingdom itself and the ratification for the dependent territories, a certain amount of confusion necessarily arises. In the following we will first deal with the reports from the United Kingdom, and then with the reports from the dependent territories.

\section{UNITED KINGDOM}

The first report by the United Kingdom states the reasons behind the reservation to article 1 of the Covenant ${ }^{589}$, and indicates that the regime provided for in article 10.2. b and 10.3 of the Covenant is considered to be neither desirable in general, nor practical ${ }^{500}$. The report illustrates that the background to the reservation to articles 12.1 and 12.4 is the Immigration Act 71 which regulates the lawful entry of persons from the dependencies into the United Kingdom, as well as regulating of immigration control $^{591}$. In respect of article 20 it is 
indicated that the United Kingdom does not feel the need to legislate in accordance with this provision ${ }^{592}$.

In the Committee-discussions the number of reservations is mentioned ${ }^{503}$, and a certain extent of confusion exists about the dependencies and the reservations made in their respect ${ }^{594}$. Most important issue discussed is the imprecision of the reservation focusing on the "preservation of the service and the custodial discipline", does it refer to article 7 , to articles 2 and $3^{595}$ ? Another issue dealt with are the reservations about articles 12.1 and $12.4^{596}$. Some remarks are made about the reservation to article $20^{597}$; and the need for a reservation to article 1 is questioned ${ }^{598}$.

The United Kingdom representative admits that the reservation concerning article 1 is perhaps over cautious ${ }^{599}$. Talking about the "discipline" reservation the representative merely indicates that is it within the scope of article $2^{6 x 0}$. The status of the dependencies is explained, as well as the system of the Immigration Act $71^{601}$. It is stated that the reason for making a reservation concerning article 20 were the difficulties with possible legislation to implement the provision $^{\mathrm{t} 02}$.

The additional report by the United Kingdom ${ }^{603}$ answers the questions raised by the Committee in greater detail. Information is provided on the implementation of article $12^{604}$ without mentioning the reservation made. In the discussion about the additional report, reservations are not mentioned ${ }^{\text {tos. }}$.

The second periodical report by the United Kingdom merely refers to the reservation concerning article $12.4^{606}$. The report indicates that legislation concerning juvenile offenders has been changed, although the reservation made concerning articles $10.2 . \mathrm{b}$ and 10.3 is not mentioned ${ }^{617}$. Changes in legislation relevant to the implementation of article 12.4 are mentioned ${ }^{20 x}$, as well as related changes in nationality legislation relevant to article $24.3^{(x) 9}$.

592. CCPR/C/1/Add.17, p.23.

593. CCPR/C/SR.69, par.44 (Prado Vallejo); CCPR/C/SR.70, par.1 (Koulishev)

594. CCPR/C/SR.69, par.12 (Gracfrath), par.97 (Ganji); CCPR/C/SR.70, par.1 (Koulishev).

595. CCPR/C/SR.69, par.13 (Graefrath), and par.51 (Hanga).

596. CCPR/C/SR.69, par.13 (Graefrath), par.65 (Movchan), par.90 (Tomuschat).

597. CCPR/C/SR.69 par.48(Prado Vallejo); CCPR/C/SR.70, par.7 (Koulishev).

598. CCPR/C/SR.70, par.3 (Koulishev).

599. CCPR/C/SR.70, par.3 (Koulishev): par.18 (United Kingdom); cf. CCPR/C/SR.164, par.66 (United Kingdom).

600. CCPR/C/SR.70, par.22 (United Kingdom).

601. CCPR/C/SR.70, par. 19 and 43 (United Kingdom).

602. CCPR/C/SR.70, par.49 (United Kingdom).

603. C.CPR/C/1/Add.35.

604. CCPR/C/1/Add.35, par.33-36.

605. CCPR/C/SR.147-149.

606. CCPR/C/32/Add.5, par. 53.

607. CCPR/C/32/Add.5, par.40-48.

608. CCPR/C/32/Add.5, par.51-53.

609. CCPR/C/32/Add.5, par.99-102 idem. 
In its discussion with the United Kingdom, the reservation concerning article 1 of the Covenant is raised again, and the representative admits (again) that the reservation is superfluous ${ }^{610}$. The question whether the United Kingdom would like to consider withdrawing the reservation is however not answered. With respect to the reservation concerning article 12.4 it is indicated that its aim is the protection of the domestic labour market, which explains the distinctions made between men and women in the Immigration Act $71^{611}$. Though the Committee-members have different opinions about the origins of the people the reservation intends to exclude from the right of immigration ${ }^{612}$, a more important question is the one brought up by Committee member Cooray. He wonders whether the Immigration Act ' 71 and its distinguishing on the basis of sex are acceptable in the light of articles $2.1,3$ and 26 of the Covenant ${ }^{613}$. In his reply the United Kingdom representative states that "apart from the distinction drawn between men and women for certain purposes", immigration control was consistent with the Covenant. At this point in the discussion, one would have expected the Committee to be more vigilant and strict towards this State Party. Why was the reservation to article 12.4 which also had an impact on articles 2.1, 3 and 26 accepted, without an express reservation to that effect? With respect to questions about the reservation concerning article 20 , it was indicated that there was no intention to withdraw the reservation and to develop the required legislation ${ }^{614}$.

\section{UNITED KINGDOM DEPENDENT TERRITORIES \& DEPENDENCIES OF THE CROWN}

The first reports by the United Kingdom about the implementation of the Covenant in the dependent territories ${ }^{615}$ and in the dependencies of the Crown ${ }^{616}$ are brief, and merely list the situation in respect of a particular provision, without discussing the situation or the backgrounds in greater detail. The report on the dependent territories indicates that the Court of Appeals in the British Virgin Islands may assign a solicitor and/or a counsel to an appellant who has been sentenced to death, in spite of the reservation to article 14.3. $\mathrm{d}^{617}$. With respect to the Cayman Islands it was indicated that the building of a new prison facility would make it possible to withdraw the reservation concerning article $10.3^{618}$. The reservation on behalf of the Cayman Islands in respect of article 12.4 was mentioned and it was indicated that in spite of the reservation to article 14.3.d there was a possibility for ex gratia payments by the Executive Council ${ }^{619}$.

610. CCPR/C/SR.594, par.43 (Wako), par.50 (United Kingdom).

611. CCPR/C/SR.595, par.4 (United Kingdom).

612. Lallah (CCPR/C/SR.595, par.10) mentions the Indian subcontinent, whereas Cooray states that the goal is people from East Africa (CCPR/C/SR.595, par.15).

613. CCPR/C/SR.595, par.15.

614. CCPR/C/SR.595, par.39 (Movchan); CCPR/C/SR.597, par.42 (United Kingdom).

615. CCPR/C/1/Add.37

616. CCPR/C/1/Add.39

617. CCPR/C/1/Add.37, par.78 p.32.

618. CCPR/C/1/Add.37, par.15 at p.43-44.

619. CCPR/C/1/Add.37, par.17, par.19 at p.44. 
With respect to the Falkland Islands the report merely indicated that a reservation has been made to article $20^{630}$. The report referred to the reservation to article 14.3.d in respect of the Gilbert Islands and indicated that professional legal practitioners were absent from the island ${ }^{621}$. With respect to Hong Kong, it was indicated that a reservation has been made to article $13^{622}$, and explained that although a reservation had been made in respect of article 20 , it was possible to prosecute if the propaganda for war led to public disorder ${ }^{623}$. The reservation to article 25 and the rights to free elections was mentioned, indicating that the circumstances in Hong Kong are special and precluded progress towards an elected Government ${ }^{624}$. The report also mentions the reservation to article 20 in respect of St.Helena ${ }^{625}$.

In view of the multitude of different domestic situations presented by the United Kingdom in its report, the Committee was unable to devote in depth attention to all the different dependent territories. It was asked what the reasons were behind the reservations to article 12.4, 14.3.d and 20 on behalf of the Cayman Islands ${ }^{626}$. Similar questions were asked about the reservations to articles 13 and 25 on behalf of Hong Kong ${ }^{627}$.

The report about the dependencies of the Crown merely indicates that reservations have been made in respect of articles 11,12 (extension of the Immigration Act 71 ) and 20 in respect of Jersey ${ }^{628}$. The reservation to article 20 is also mentioned in respect of Guernsey ${ }^{629}$. And with respect to the Isle of Man, it was indicated that a reservation has been made to article 25.c of the Covenant, covering the inability of women to be liable for jury service ${ }^{600}$.

The initial report for the dependencies of the Crown is discussed together with the additional (initial) report of the United Kingdom, leading to a confusing exchange of views. Confusion about the structure of the United Kingdom prevails $^{631}$, and the reservations made in respect of Jersey and the Isle of Man were not discussed.

The second report on the implementation of the Covenant in the dependent territories ${ }^{632}$, was structured around the questions that arose in the previous discussions with the Committee. While this may have the merits of being very much to the point, it is at the expense of presenting an over-all picture of the implementation. 
The report indicates in respect of the Cayman Islands that the United Kingdom had made the reservation to article 12.4 applicable to all the dependent territories ${ }^{633}$. The reservation to article 14.3.d was reiterated, and the same was true for the reservation to article $20^{634}$. With respect to the Falkland Islands, the reservation to article 20 was again explained, indicating that the Falklands did not have the population or the resources to wage a war $^{635}$. It might be stressed that this is not what article 20 seeks to prohibit. The report explains the implementation of articles 10.2.a and 10.2.b in Gibraltar and indicates that a reservation has been made in respect of article 10.2. $\mathrm{a}^{636}$. The explanation about the reservation to article 13 in respect of Hong Kong is rather brief and merely suggests rereading the earlier report ${ }^{637}$. A similarly bleak approach is taken with respect to the reservation to article 25 on behalf of Hong Kong ${ }^{638}$.

In its discussion of the report the Committee proves to be very concerned about the situation in Hong Kong, and in particular the reservations concerning articles 13 and $25^{639}$. Although the United Kingdom sets out to explain the particular situation of Hong Kong and the possible consequences of the agreement reached with China ${ }^{6 * 0}$, the discussion turns sour when a Committee-member asks about the reasons for making a reservation to article $13^{641}$. There is also some discussion about the reservation to article 12.1 and 12.4, and the functioning of appeal procedures in the expulsion system ${ }^{\mathrm{s} 42}$. In respect of article $25 . \mathrm{b}$ and the reservation thereto, it was asked if the United Kingdom was not acting contrary to its own commitments in a 1984 Green Paper on the electoral situation in Hong Kong, and should not withdraw its reservation to that provision. The representative of the United Kingdom replied that this reservation might be reviewed before the transfer of Hong Kong in $1997^{643}$.

633.

634. CCPR/C/32/Add.14, par.24 at p.27; par.29 at p.28.

635.

636.

637.

638.

639.

640.

641.

642.

643.

CCPR/C/32/Add.14, par.20 at p.26.

CCPR/C/32/Add.14, par.32 at p.36

CCPR/C/32/Add.14, par.26 at p.53.

CCPR/C/32/Add.14, par.143 at p.93.

CCPR/C/32/Add.14, par. 157 at p.99. Shafei).

CCPR/C/SR.856, par.5, par.8. reservation to article 13 of the Covenant.

$[\ldots]$

[...] problem of protection of human rights..." par.26 (United Kingdom)

CCPR/C/SR.857, par.81 (El Shafei), par.83 (United Kingdom).

CCFR/C/SR.855, par.36 (Lallah). CCPR/C/SR.857, par.19 (Ziclinski), par.81 (EI

The discussion (CCPR/C/SR.857) is striking because of the difference of opinions:

"Par. 19. Mr.Zielinski asked what were the material reasons for the United Kingdom's

Par.21 Mr.Fearn (United Kingdom), said that. as he understood it. Governments were not required to set out the reasons for any reservations they had made. Their obligation was, rather, to explain how they implemented the provisions that they had accepted.

Par.23 Mr.Zielinksi said that while it was true that it was not the Committee's function to consider the reasons underlying the reservations, one of its tasks was to consider the

CCPR/C/SR.857, par.20 (Dimitrijevic), par.22 (United Kingdom), par.24 (Dimitrijevic), 
The third periodic report by the United Kingdom ${ }^{644}$ is a joint report on the dependencies of the Crown, the dependent territories as well as the United Kingdom itself, supplemented with two addenda containing additional information $^{645}$. The report mentions changes in legislation relevant to the implementation of article $12^{646}$. Apart from implicit references, no reservations are mentioned in all three parts of the report.

The Committee proved to be surprisingly strict with the United Kingdom. Apart from concern about the future application of the Covenant to Hong Kong, they were irritated by the absence of legislation implementing the Covenant, and by the consistent refusal to ratify the Optional Protocol. The Committee explicitly asked if the United Kingdom intended to withdraw the reservations ${ }^{647}$, in view of the period of time that had passed since ratification. In reply the United Kingdom indicated that the reservations were kept under review, and that the reservation to article 25.e concerning the Isle of Man would soon be withdrawn $^{648}$. The Committee stressed the need to reconsider the reservations ${ }^{649}$ and wished to know if the reservation to article 1 excluded the right to selfdetermination ${ }^{650}$.

The representative indicated that he would convey the Human Rights Committee's concern to his Government, adding that the United Kingdom was usually very cautious in making reservations ${ }^{651}$. It was furthermore indicated that the declaration concerning article 1 was merely an understanding to the extent that the Charter would prevail in cases of conflict, and was not a reservation at all 652 .

\section{UNITED STATES}

\section{Reservations}

1) That article 20 does not authorize or require legislation or other action by the United States that would restrict the right of free speech and association protected by the Constitution and laws of the United States.

2) That the United states reserves the right, subject to its Constitutional constraints, to impose capital punishment on any person (other than a pregnant woman) duly convicted under existing legislation or future laws permitting the imposition of capital punishment, including such punishment for crimes committed by persons below eighteen years of age.

3) That the United states considers itself bound by article 7 to the extent that 'cruel, inhuman or degrading treatment or punishment' means the cruel and unusual treatment or punishment prohibited by the Fifth. Eighth and/or Fourteenth amendment to the Constitution of the United States.

644. CCPR/C/58/Add.6.

645. CCPR/C/58/Add.11; Add.12.

646. CCPR/C/58/Add.6, par.175.

647. CCPR/C/SR.1045, par.14 (Chairman).

648. CCPR/C/SR.1045, par.15 (United Kingdom).

649. CCPR/C/SR.1045, par.21(Chanet), par.38(Ando), par.45(Mavrommatis), par.51(Sadi); CCPR/C/SR.1046, par.11(Prado Vallejo), par.28(Herndl).

650. CCPR/C/SR.1045, par.21 (Chanet); CCPR/C/SR.1046, par.14 (Wako).

651. CCPR/C/SR.1046, par.38 (United Kingdom).

652. CCPR/C/SR.1046, par.40 (United Kingdom). 
4) That because U.S. law generally applies to an offender the penalty in force at the time the offense was committed, the United States does not adhere to the third clause do paragraph 1 of article 15.

5) That the policy and practice of the United States are generally in compliance with and support of the Covenant's provisions regarding the treatment of juveniles in the criminal justice system. Nevertheless, the United States reserved the right, in exceptional circumstances, to treat juveniles as adults, notwithstanding paragraphs 2 (b) and 3 of article 10 and paragraph 4 of article 14. The United States further reserves to these provisions with respect to states with respect to individuals who volunteer for military service prior to age 18.

Understandings

1) That the Constitution and the laws of the United States guarantee all persons equal protection of the law and provide extensive protection against discrimination. The United States understands distinctions based upon race, colour, sex, language, religion, political or other opinion, national or social origin, property, birth or any other status as those terms are used in article 2, paragraph 1 and article 26 - to be permitted when such distinctions are, at minimum, rationally related to a legitimate governmental objective. The United States further understands the prohibition in paragraph 1 of article 4 upon discrimination, in time of public emergency, based "solely" on the status of race, colour, sex, language, religion or social origin, not to bar distinctions that may have a disproportionate effect upon persons of a particular status.

2) That the United States understands the right to compensation referred to in articles 9 (5) and 14 (6) to require the provision of effective and enforceable mechanisms by which a victim of an unlawful arrest or detention or a miscarriage of justice may seek and, where justified obtain compensation from either the responsible individual or the appropriate govemmental entity. Entitlements to compensation maybe subject to reasonable requirements of domestic law.

3) That the United States understands the reference to "exceptional circumstances" in paragraph 2 (a) of article 10 to permit the imprisonment of an accused person with convicted persons where appropriate in light of an individual's overall dangerousness, and to permit accused persons to waive their right to segregation from convicted person. The United States further understands that paragraph 3 of article 10 does not diminish the goals of punishment, deterrence and incapacitation as additional legitimate purposes for a penitentiary system.

4) That the United states understands that subparagraphs 3 (b) and (d) of article 14 do not require the provisions of a criminal defendant's counsel of choice when the defendant is provided with court-appointed counsel on grounds of indigence, when the defendant is financially able to retain alternative counsel. or when imprisonment is not imposed. The United States further understands that paragraph 3 (e) does not prohibit a requirement that the defendant make a showing that any witness whose attendance he seeks to compel is necessary for his defense. The United States understands the prohibition upon double jeopardy in paragraph 7 to apply only when the judgement of acquittal has been rendered by a court of the same governmental unit, whether the Federal Government or a constituent unit, as is seeking a new trial for the same case.

5) That the United States understands that this covenant shall be implemented by the Federal Government to the extent that it exercises legislative jurisdiction over the matters covered therein, and otherwise by the state and local governments; to the extent that state and local governments exercise jurisdiction over such matters, the federal Government shall take measures appropriate to the federal system to the end that the competent authorities of the state or local governments may take appropriate measures for thee fulfilment of the Covenant.

$\underline{\text { Declarations }}$

1) That the United States declares that the provisions of article 1 through 27 of the Covenant are not self-executing. 
2) That it is the views of the United States that States Party to the Covenant should wherever possible refrain from imposing any restrictions or limitations on the exercise of the rights recognized and protected by the Covenant, even when such restrictions and limitations on the are permissible under the terms of the Covenant. For the United States, article 5, paragraph 2 which provides that fundamental human rights existing in any State Party may not be diminished on the pretext that the Covenant recognizes them to a lesser extent, has particular relevance to article 19, paragraph 3 which would permit certain restrictions on the freedom of expression. The United States declares that it will continue to adhere to the requirements and constraints of its Constitution in respect all such restrictions and limitations.

3) That the United States declares that the right referred to in article 47 may be exercised only in accordance with intemational law.

As the United States had ratified in 1992, the initial report would be due in 1993.

\section{VENEZUELA}

Article 60, paragraph 5, of the Constitution of the Republic of Venezuela establishes that: "No person shall be convicted in a criminal trial unless he has first been personally notified of the charges and heard in the manner prescribed by law. Persons accused of an offence against the res publica may be tried in absentia. with the guarantees and in the manner prescribed by law". Venezuela is making this reservation because article 14, paragraph 3(d), of the Covenant makes no provision for persons accused of an offence against the res publica to be tried in absenia.

The initial report by Venezuela is peculiar inasmuch as it presents an overview of the domestic legislation within the scope of the Covenant. Under article 14, the report refers to article 60.5 of the Constitution mentioned in the reservation ${ }^{653}$.

In discussing the Venezuelan report, the HRC indicates that information about the purpose of article 60.5 of the Constitution would be welcome ${ }^{6.54}$. The Venezuelan representative does however not clarify this provision ${ }^{65}$.

The additional report by Venezuela ${ }^{656}$ is a long-winded exposé about its constitutional law, which does not clarify the reservation referring to article 60.5 of the Constitution. During the twenty-third session, the Venezuelan representative answered questions raised by the Committee during the consideration of the initial report $^{657}$. It was indicated that a new law had been enacted following questions by the Committee about this issue. The 1982 Organic Law on the Protection of Public Property gave a legal basis for referring to offenders in article 60.5 of the Constitution $^{658}$. 


\subsection{Individual Complaints, the Optional Protocol}

Under the Optional Protocol a number of cases involving reservations have come up. In the following a chronological presentation of the relevant material is given, with an emphasis on the questions concerning reservations.

\section{A.M. v. Denmark ${ }^{659}$}

The case of A.M. is the first one in which the reservation concerning article 5.2.a OP appears. The plaintiff is a Pakistani complaining about an expulsion order, following a prison sentence on the grounds of bodily injuries with death as a result. The plaintiff had submitted the same matter to the European Commission, which had declared the matter inadmissible being manifestly ill-founded. The HRC notices that Denmark had made a reservation concerning article 5.2.a, and decides that the case is inadmissible.

In an Individual Opinion, Committee member Graefrath comes to a different conclusion. In his opinion the case is inadmissible on the grounds of article $3 \mathrm{OP}$, the matter is not covered by any of the provisions of the Covenant. He disagrees with the majority interpretation of the Danish reservation. Graefrath feels that an application that has been declared inadmissible in Strasbourg falls outside of the scope of the reservation. The Committee is not precluded from considering the application because the European Commission did not consider the substance of the complaint. Following the reasoning of the majority opinion would lead to a situation in which the conditions for admissibility under the European Convention would overrule the provisions of the Optional Protocol ${ }^{600}$. Graefrath's point is well taken; as a consequence of the majority's interpretation the Committee relies on the work of a supervisory body under a different Convention ${ }^{(\infty 1}$.

\section{Duilio Fanali v. Italy ${ }^{662}$.}

Fanali was a retired general in the Italian air force, who had been sentenced on corruption charges following the Lockheed scandal. His case was tried jointly with those of a number of members of Government as part of a larger criminal suit. Consequently the trial took place before the Constitutional Court which is the single court with authority in matters involving the President or the Ministers. No appeals are allowed against decisions of this Court in first instance.

659. No.121/1982 (CCPR/C/OP/1, 32); Decision on Admissibility 23 July 1982.

660. The Individual Opinion reads:"If the Committee interprets the reservation in such a way that it would be excluded from considering a communication when a complaint referring to the same facts has been declared inadmissible under the procedure of the European Convention, the effect would be that any complaint that has been declared inadmissible under that procedure could later on not be considered by the Human Rights Committee, despite the fact that the conditions for admissibility of communications are set out in a separate international instrument and are different from those under the Optional Protocol."

601. McGoldrick, op.cit. at 184-185.

662. No.75/1980 (CCPR/C/OP/2, 99); Views 31 March 1983. 
Fanali claimed that his right to review by a higher tribunal under article $\mathbf{1 4 . 5}$ CCPR had been violated as he did not fall within the scope of the reservation which was specifically meant for the President and the Ministers. Italy put forth that the matter had already been submitted to the European Commission on Human Rights by Fanali's co-defendants, thereby relying on a reservation to article 5.2.a OP. Furthermore it invoked the reservation concerning article 14.5.

The HRC states that with respect to article 5.2.a OP, the same matter must be understood as "the same claim concerning the same individual, submitted by him or someone else who has standing to act on his behalf before the other international body ${ }^{n 663}$. The Committee then follows the Italian reservation to article 14.5 , indicating that there is no doubt as to the international validity of the reservation. Fanali's claim that he does not belong to either of the categories mentioned in the reservation is rejected on the basis of its formulation ${ }^{644}$. The "existing Italian provisions ... in accordance with the Constitution" legitimize the joining of the cases of Fanali with those of the Government members, who are tried in first instance by the Constitutional Cour ${ }^{665}$. Consequently the Italian reservation is applicable to Fanali, and the Committee is of the view that no violation of the Covenant took place.

The case is a rare example of the scope reservations may have. Through an unfortunate coincidence, Fanali found himself to be within the ambit of the reservation as a consequence of its confluence with Italian Criminal Procedure.

\section{O.F. v. Norway ${ }^{666}$.}

The case of O.F. concerns the alleged violation of certain rights under article 14.3 of the Covenant. After the exhaustion of local remedies O.F. submitted the matter to the European Commission on Human Rights prior to submitting the matter to the Human Rights Committee. The submission under the European Convention had been too tardy, and O.F. had informed by the secretariat of the European Commission that his case would not be considered, as it was not received within the six months of the date of the exhaustion of local remedies $^{\phi 6}$.

In its reply to the Human Rights Committee Norway indicates that it had made a reservation to article 5.2.a OP to the effect that the European procedure would preclude the procedure under the Optional Protocol. It states that as the matter had not been dealt with in Strasbourg ratione temporis, it would not rely on the

663. No.75/1980, par.7.2.

664. The reservation reads:"Article 14, paragraph 5, shall be without prejudice to the application of existing Italian provisions which, in accordance with the Constitution of the Italian Republic, govern the conduct, at one level only, of proceedings instituted before the Constitutional Court in respect of charges brought against the President of the Republic and Ministers."

665. No. $\quad$ N5/1980, par.11.7-11.8

666. No.158/1983 (CCPR/C/OP/2, 44); Decision on Admissibility 26 October 1984.

667. Article 26 ECHR. 
reservation. As far as Norway is concerned, the case has not been examined within the meaning of article 5.2.a OP. The HRC concurs with the State Party's opinion that the reservation does not apply in this case. The case is declared inadmissible for other reasons ${ }^{668}$.

\section{V.Ø. v. Norway ${ }^{669}$.}

The case of V.Ø. is about the rights of a father after divorce. The father had submitted an application to the European Commission on Human Rights which had decided that the application was inadmissible. The detailed decision on admissibility held that the allegations were manifestly ill-founded on all accounts ${ }^{670}$. In his submission to the HRC, V.Ø. indicated that the provisions of the Covenant were better suited to protect his rights than the provisions of the European Convention invoked in his submission to the European Commission.

In its reply Norway argued that it had made a reservation to article 5.2.a OP concerning the same matter being considered under another international procedure. It indicated that the European Commission had examined the substance of the complaint, and that consequently the reservation was applicable in this case $^{671}$. The HRC agreed, and stressed that "the same matter" regards identical parties, complaints and facts. Consequently the Norwegian reservation led to the decision that the complaint was inadmissible ${ }^{62}$.

\section{S.R. v. France ${ }^{673}$}

This case is about a teacher of both French and Breton in conflict with the educational authorities. It is the first in a long list of Breton cases in which article 27 CCPR (amongst others) is invoked. The importance of the Breton cases is that they show the development in the HRC's approach to a declaration.

The claim is about the creation of a full-time position (instead of a part-time position) as a teacher of Breton which was not achieved, and about a transfer from the Academy at Versailles to the Academy at Lille without the consent of the claimant.

As the plaintiff was unable to indicate which judicial steps, if any, he had taken in order to exhaust the local remedies, the case was dismissed by the Human Rights Committee on the basis of article 5.2.b OP.

\section{Carl Henrik Blom v. Sweden ${ }^{674}$}

The case of Carl Henrik Blom is about government support for pupils of private schools under State supervision. Blom claimed that the denial of such grants,

668. MeGoldrick, op.cit. at 185.

669. No.168/1984 (CCPR/C/OP/2, 48): Decision on Admissibility 17 July 1985.

670. No.168/1984 par.2.4.

671. No.168/1984, par.4.2.

672. MeGoldrick, op.cit. at 185.

673. No.243/1987 (A/43/40, 263-265); Decision on Admissibility 5 November 1987.

674. No.191/1985 (CCPR/C/OP/2, 216); Views 4 April 1988. 
because of the fact that the Rudolf Steiner school he attended was not under State supervision, was a violation of his rights under the Covenant.

In its reply Sweden indicated that two other pupils of the same school had brought an application before the European Commission which had been declared inadmissible; thereby apparently invoking its reservation to article 5.2.a OP ${ }^{675}$. Blom informs the HRC that the case before the European Commission was a distinct one, related to granting free textbooks to pupils in private schools. The Committee agrees with Blom, and repeats that the "same matter" must be understood as including: "the same claim concerning the same individual, submitted by him or someone else who has standing to act on his behalf before the other international body". Consequently the Swedish reservation did not apply.

\section{C.L.D v. France ${ }^{676}$ (1st communication)}

The case of C.L.D. is another Breton case, it deals with various refusals on the part of administrative officials to use the Breton language instead of French. C.L.D. complains about the refusal by the Postal Administration, as well as the fiscal authorities to use Breton, invoking amongst others article 27 CCPR.

In an initial reaction the Committee asked C.L.D. to provide information on the exhaustion of local remedies, and it turns out that apart from a number of letters no procedural steps have been taken. Consequently the majority of the Committee decided that the communication was inadmissible because of the non-fulfilment of the conditions in article 5.2.b OP.

In a joint Individual Opinion, Committee-members Dimitrijevic, Higgins, Mavrommatis, Pocar and Wennergren also concluded that the communication was inadmissible, but disagreed with the majority as to the grounds for inadmissibility. In their view the matters complained about were beyond the competence of the Committee ratione materiae. The rights referred to were not protected, consequently the communication was inadmissible under article $3 \mathrm{OP}^{677}$, and the issue of exhaustion of local remedies did not need to be dealt with. The five Committee-members explicitly stated that there was no need to discuss the character of the French declaration concerning article $27 \mathrm{CCPR}^{678}$, but would apparently like to do so. They indicated that should the issue arise, the Committee would have to consider whether the statement was a reservation or a mere

675. No.191/1985, par.5.6, the text does not explicitly mention the Swedish reservation.

676. No.228/1987 (A/43/40, 252-257): Decision on Admissibility 18 July 1988.

677. The authors of the individual opinion venomously write: None of the articles cited by the author, including article 27 , even potentially provide the entitlement to receive postal cheques or to have acknowledgement of one's address in one's mother tongue."; Individual Opinion, par.4.

678. The declaration reads: "In the light of article 2 of the Constitution of the French Republic, the French Government declares that article 27 is not applicable so far as the Republic is concerned." 
interpretation. The clarity of the Individual Opinion could easily be read as an invitation for communications dealing with the French declaration ${ }^{679}$.

In a separate Individual Opinion Committee-member Ndiaye disagrees with both the majority opinion and the joint individual opinion. In his view the decision about admissibility includes a primae facie examination of the submission in relation to the rights guaranteed in the Covenant and the treaty obligation of the State involved. This would have led to the conclusion that the violations claimed do not correspond to rights under article 27 of the Covenant ${ }^{680}$. The author of the Individual Opinion understands the statement to be an obvious reservation, based on an internal law of fundamental importance ${ }^{681}$. As a result of that France is not bound by article 27, and submissions invoking article 27 against France are inadmissible. Ndiaye indicates that the French "reservation" to article 27 is the principle ground for inadmissibility, the fact that the rights claimed are not protected by the Covenant is a subsequent ground for inadmissibility.

\section{J.B. and H.K. v. France ${ }^{682}$}

The case of J.B and H.K. is about two Bretons who allegedly spray-painted road signs in Brittany in a campaign aimed at obtaining bilingual road signs. When taken to Court they did not receive the services of an interpreter, as the Tribunal found them able to understand French. The plaintiffs invoke article 27 CCPR. They indicate that they have not pursued the exhaustion of local remedies because

679. The 5th paragraph of the Individual Opinion reads: "... Nor is it necessary to examine whether the declaration of the Government of France made upon accession to the Covenant is to be interpreted as a reservation or as a declaration simpliciter. [...] Declarations do not have the same legal effect as reservations. In any case where the jurisdiction turned on the effect of a declaration, it would be necessary to see whether the statement of the country concerned was in fact, regardless of its nomenclature, a reservation as to the Committee's jurisdiction or a declaration of interpretation by the State Party. This is not such a case and no view is offered here as to the legal effect of the French declaration regarding article 27."

Cf. Nowak, op.cit. at xxiv-kxv.

680. Nowak, op.cit. at xxiv, par.24.

681. Here the Individual Opinion refers to article 46 VCLT; the provision reads:

"1. A State may not invoke the fact that its consent to be bound by a treaty has been expressed in violation of a provision of its internal law regarding the competence to conclude treaties as invalidating its consent unless that violation was manifest and concerned a rule of its internal law of fundamental importance.

2. A violation is manifest if it would be objectively evident to any State conducting itself in the matter in accordance with normal practice and in good faith."

In view of the text of article 46 VCLT, the author of the Individual Opinion must clearly have misinterpreted it when referring to this provision in respect of article 27 C.CPR. Article 46 deals with the competence to express consent to be bound, and the consequences if consent to be bound has been expressed contrary to domestic rules on the issue. Clearly there is no discussion about a French accession in violation of its domestic rules.

See about article 46 VCLT: Sinclair, op.cit. at 160-171.

682. No.324 and 325/1988 (A/44/40, 303-304); Decision on Admissibility 25 October 1988. 
that would have been absolutely futile, given the fact that the Tribunal in Rennes systematically refuses to hear cases in Breton.

This approach by the applicants is criticized by the Committee, who indicate that the pursuit of the available remedies cannot be deemed a priori futile, and that mere doubts about the success of such remedies do not render them ineffective. Consequently the complaint is inadmissible on the ground of article 5.2.b.OP.

\section{R.M. v. Finland ${ }^{683}$}

The plaintiff has been convicted on a charge of smuggling hashish, and complains about the non-availability of legal assistance during the preliminary investigations in his case. In its reply to the Committee, Finland indicates that it made a reservation concerning article 14.3.d CCPR, the provision about legal assistance.

The Committee takes note of the Finnish reservation, and decides that the communication is inadmissible ${ }^{6 \% 4}$.

\section{R.T. v. France ${ }^{685}$}

In this Breton case, the issue is the treatment of a Breton teacher who complains that his right to teach his native language is denied, a right supposed to be protected under article 27 CCPR. It is indicated that the educational administration registered him as a teacher of English and Armenian, but failed to acknowledge Breton. It appears that the plaintiff did not submit his case to an administrative tribunal, and merely exchanged letters with various officials.

France objects to admissibility on the grounds of the non-exhaustion of local remedies, and because of the fact that the complaint is "incompatible with the Covenant". In that respect it indicates that it made a declaration concerning article 27. The plaintiff comments that France made a mere declaration, as opposed to a reservation.

In its decision on the admissibility the Committee indicates that it will take three steps: first of all the question in article 5.2.a OP, then article $3 \mathrm{OP}$, and finally the question in article 5.2.b OP. This order appears to be a reaction to the confusion in the C.L.D. ease. However, in spite of indicating the steps to be taken the Committee does not abide by the rules it sets itself. After dealing with article 5.2.a, it mentions that it will not be necessary to pronounce on the French declaration concerning article 27 (this is the article 3 OP question) as the author has not exhausted the domestic remedies. Consequently the communication is inadmissible.

683. No.301/1988 (A/44/40, 300-302); Decision on Admissibility 23 March 1989.

684. It should be noted that the Finnish reservation concerning article 14.3.d, that lead to this decision on inadmissibility in this case in March 1989. was withdraw by Finland in July 1990.

685. No.262/1987 (A/44/40, 277-281); Decision on Admissibility 30 March 1989. 


\section{Ibrahima Gueye et al. v. France ${ }^{686}$}

The case of Ibrahima Gueye et al. concerns the pension rights of some 742 retired Senegalese members of the French Army. Though initially treated exactly like retired French members of the Army, France introduced legislation that differentiated between the pensions of retired French and Senegalese army personnel in 1974 and again in 1981. The authors claim that this is a violation of article 26 of the Covenant.

France indicates that the claim is inadmissible, because pension rights are not protected under the Covenant (article $3 \mathrm{OP}$ ), and adds that it made a reservation ratione temporis concerning article $1 \mathrm{OP}$. It states that the facts of the case all took place before the French accession to the Optional Protocol and can therefore not be complained about. The authors indicate that negotiations about the issue had still been going on in 1984, at the time of the French accession. The Committee then decided that the communication was admissible, referring to its interpretation of "violation" in article $1 \mathrm{OP}$ as including "an alleged violation of human rights said to have taken place prior to entry into force of the Covenant for a State party, unless it is a violation that continues after that date or has effects which themselves constitute a violation of the Covenant after that date. ${ }^{n 687}$ While stating that it did not have authority to deal with violations prior to the French accession to the Protocol, it declared the communication admissible with a view to consider violations after accession.

In its View, the Committee concluded that there had indeed been a violation of article 26 CCPR, qualifying the distinction made between people with a similar professional background in the army, but with different nationalities following the Senegalese independence as "discrimination on any ground such as.. other status". Given the services rendered in the past by French as well as Senegalese army personnel there is no reasonable and objective criterion to distinguish between them in respect of pension rights.

It should be noted that the Committe does not devote much attention to the French temporal reservation, apart from mentioning it in respect of the admissibility. It would appear that in spite of the reservation, the whole issue is justiciable under the Covenant even if the relevant legislation dates from long before French obligations under the Covenant or the Protocol. The French reservation does not seem to have had the intended effect. The Committee's interpretation of "violation" in article I OP appears to overrule the reservation, though the Committee devotes some formal consideration to the matter.

\section{T.K. v. France ${ }^{6 \times 8}$ and M.K. v. France ${ }^{6 \times 0}$}

The case of T.K. is about a Breton legal entity applying in Breton for a license, and the problems arising from the fact that Breton is not an official language in French Courts. M.K. complains about the refusal of the tax authorities to use his 
address in Breton, and also complains about the fact that his daughter does not enjoy an education in Breton. Both T.K. and M.K. did communicate with the judicial authorities (in Breton), but their communications were not received or registered because they were not written in the French language. France indicated that neither T.K. and his association, nor M.K. exhausted the local remedies, and that the claims were incompatible with the Covenant because France made a reservation $^{60}$ concerning article 27 CCPR. Yet, the plaintiffs stressed that France itself indicated that the "article 27 reservation" was a mere declaration $^{691}$.

Both communications were dealt with by the Committee on the same day, leading to a similar decision on (in)admissibility, with the same Individual Opinions attached. In both decisions the Committee did not explicitly decide whether or not domestic remedies had been exhausted. It raised the issue of whether remedies in French, rather then Breton, could be considered unavailable or ineffective. The Committee noticed that the authors of the complaints were proficient in French, and could therefore have pursued their case in that language.

The Committee then goes on to decide whether the French declaration concerning article 27 prevents it from examining the complaint. Referring to article 2.1.d VCLT which does not distinguish between the labelling of the statement, but focuses on the intentions of the author State, the Committee had decided that the declaration was in fact a reservation ${ }^{692}$. Supportive arguments are found in the first and second periodical reports of France which explained the reasons behind the reservation ${ }^{693}$. The Committee then proceeded to declare the communication inadmissible on the grounds of articles 2 and 5.2.b OP.

Two Individual Opinions were attached to the decisions on admissibility in the cases of T.K and M.K. The Individual Opinion of Committee-member Wennergren focuses on the issue of the availability of effective remedies, knowing that French case law does not allow the use of any other language than French in Court. Finding that the available remedies cannot be considered effective remedies, Wennergren concludes that the communication should have been declared admissible.

The Individual Opinion of Committee-member Higgins is proof of a better insight into the Law of Treaties aspects of the French declaration, and provides a satisfactory solution. While agreeing that both cases are inadmissible on the grounds of non-exhaustion of local remedies (she mentions again that no harm

690. It should be noted that France itself labels the declaration a "reservation" in the reply to the Committee on the matter of admissibility.

691. See par. 7. of the Decision on Admissibility.

692. The view reads:"In the present ease, the statement entered by the French Government upon accession to the Covenant is clear: it seeks to exclude the application of article 27 to France and emphasizes the exclusion semantically with the words "is not applicable".

693. Contrary to the Committee's opinion. one could consider this a case of a particularly successful manipulation of the Committee's insights. If France could reinforce the dubious nature of its "reservation", or change the nature of its interpretation by explaining the background in its periodical reports, that would be contrary to the rule that reservations can only be made at ratification, cf. article 19 VCLT opening phrase. 
would be done to the Breton cause if the procedure were conducted in French), Higgins strongly disagrees with the majority opinion. It is quite clear that as France itself made the distinction between reservations and declarations, it did so deliberately and should therefore bear the consequences. Article 2.1.d VCLT is of no relevance here, it cannot serve to turn declarations into reservations ${ }^{604}$. Consequently, as the declaration is merely an interpretation, the final interpretation of the French declaration is to be made by the Committee rather then by France. Higgins' Individual Opinion is interesting because it clearly echoes the Belilos approach of distinguishing between the legal effects of interpretative declarations and reservations, when a State Party has made both ${ }^{695}$.

\section{Dominique Guesdon v. France ${ }^{(\%)}$}

Dominique Guesdon is a Breton alleged to have spray-painted road signs in the fight for bilingual road signs, facts which took place in April 1984 whereas France became a party to the Optional Protocol in May 1984.

Guesdon claims that he was convicted in the absence of any proof, at the hearing he introduced twelve Breton-speaking witnesses on his behalf, but their testimonies were not accepted, nor were they granted the assistance of an interpreter. Consequently the witnesses were not heard. This led to a violation of the right to a fair hearing (in article $14 \mathrm{CCPR}$ ), as well as a violation of minority rights in article 27 CCPR, according to the plaintiff.

The Human Rights Committee asked the plaintiff whether he spoke and understood French and was assured that he did. The State indicated that if the plaintiff was a victim of a violation of article 14.1 CCPR, this was his own fault because of his unwillingness to speak French, and indicated that the right to an interpreter is limited to those accused who have insufficient mastery of the French language. With respect to article 27 CCPR the State mentions that it has made a "reservation ${ }^{m(28)}$, according to France the concept of an ethnic, religious or linguistic community is irrelevant as this concept is not recognized under its Constitution. Counsel for the applicant agrees that France had made a "declaration", but indicated that within France opinions about minority rights were changing.

The Human Rights Committee had not dealt with article 27 in its decision on admissibility. In the submission of the State in the second stage of the procedure, the fundamental question was about the right to speak Breton as a matter of personal preference (as advocated by the applicant) or the right to an interpreter

694. The Individual Opinion reads:"To note, by reference to article 2 (1)(d) of the Vienna Convention, that it does not matter how a reservation is phrased or named, cannot serve to turn these interpretative declarations into reservations. Their content is clearly that of declaration. Further, the French notification shows that deliberately different language was selected to serve different legal purposes. There is no reason to suppose that the contrasting use, in different paragraphs, of the phrase "resenvation" and "declaration" was not entirely deliberate, with its legal consequences well anderstood by the Govemment of the Republic."

695. See Chapter 3, par.4.1.2 supra.

696. No.219/1986 (A/45/40, 61-68): Views 25 July 1990.

697. These are French quotation marks (EL). 
only in case of a lack of understanding of the French language (as advanced by the State).

The View by the Committee ultimately relies on the scope and meaning of article 14 CCPR, rather than on the meaning of article 27. Thus the matter revolves around the ability of Guesdon to speak French, and the fact that the right to an interpreter is limited to those who do not understand the official language. "If the court is certain,.., that the accused is sufficiently proficient in the court's language, it is not required to ascertain whether it would be preferable for the accused to express himself in a language other that the court language. "French law does not give everyone the right to speak their language of preference; there has thus not been a violation of a right protected under the Covenant.

\section{Hervé Barzhig v. France}

Barzhig was charged with defacing 21 road signs, and requested permission to speak Breton in court. This was rejected, and he was heard in French both in first instance as well as in appeal.

France claims the applicant did not exhaust local remedies as he could have lodged an appeal against the decision not to allow Breton in court. Moreover the State claims that "criminal procedures are an inappropriate venue for expressing demands linked to the promotion of the use of regional languages. The sole purpose of criminal proceedings is to establish the guilt or the innocence of the accused". The judge had the power to order the assistance of an interpreter, but had great discretion in doing so. France furthermore reiterates that it had made a reservation with respect to article 27 CCPR.

In dealing with the issues raised by the application, the Human Rights Committee specifically dealt with the rights protected under article 14 CCPR, stressing that neither Barzhig nor his witness had been unable to understand French. The Committee then repeated its earlier position that French law did not give everyone the right to speak the language of their preference in court.

\section{Yves Cadoret and Hervé le Bihan v. France ${ }^{(2)}$}

Both applicants had been charged with vandalizing three road signs, and had not been allowed to speak Breton before the criminal tribunal, and neither had their witnesses been allowed to do so. They alleged that no domestic remedies were available, as Breton was not accepted within the French judicial system at all.

The claim is about articles 14 and 19 CCPR, and the fact that the denial of the right to use Breton is a discrimination on the basis of language (article 27 CCPR). France indicated that domestic remedies had not been exhausted, and that criminal proceedings were not the place to discuss the use of regional languages.

The Human Rights Committee repeated its earlier view that the use of one language in court did not violate the principle of equality of arms in the article 14 
CCPR, and the fact that French law did not authorize the use of other languages in court was not a violation of the Covenant.

\section{G.B. v. France $e^{700}$}

The plaintiff was charged with spray-painting road sign in Brittany, and was sentenced (together with Hervé Barzhig and S.G.) to a suspended sentence and a fine. Testimony in Breton had not been accepted. None of the sentences had been subject to amnesty, and the plaintiff felt that the suspended sentence was merely meant to prevent her from entering the civil service.

France indicates that domestic remedies had not been exhausted, that the violations had not been substantiated and that it had made a reservation to article $\mathbf{2 7}$ CCPR. The Committee considers the claim inadmissible on the grounds that G.B. has failed to substantiate her complaint and that the reservation to article 27 would have prevented the Committee from dealing with an alleged violation of that provision anyway.

In her separate opinion, Higgins stresses that she does not agree with the interpretation of the French declaration as a reservation, and does not think that the declaration could prevent the Committee from dealing with a complaint about article 27 . Yet the facts do not give a prima facie indication that article 27 CCPR had been violated.

\section{S.G. v. France ${ }^{701}$}

The applicant was arrested on charges of defacing several road signs, and sentenced to a suspended sentence together with Hervé Barzhig and G. B. He was employed by the French postal service, and his employer supposedly harassed him after the incident. He was the subject of a disciplinary investigation, in which it was proposed to suspend him from his post for six months. After reactions from the public, the disciplinary committee gave him a suspended sentence of six days suspension.

France contends that local remedies have not been exhausted, that defacing road signs is not a matter of the freedom of speech; and that it had made a reservation to article 27 CCPR. The Committee finds the claim to be unsubstantiated, and indicates that the declaration to article 27 is tantamount to a reservation.

In a separate opinion, Committee member Higgins repeated her view in the cases of T.K and M.K. v. France ${ }^{72}$ that it was incorrect to accept the declaration with respect to article 27 CCPR to be a reservation. The Committee would in her opinion not be precluded from considering complaints about violations of article 27. There is however no substantiation in the complaint that article 27 has been violated. Individual Opinion by Higgins.

701. No. 347/1988 (A/47/40, 354-358); Decision on Admissibility 1 November 1991 , with Individual Opinion by Higgins.

702. No.220/1987 and 222/1987, dealt with supra. 


\section{C.L.D. v. France ${ }^{703}$ (2nd communication)}

The applicant ${ }^{704}$ was fined for refusing to pay parking tickets, and was refused the use of the Breton language when the matter was dealt with in court. He then conducted his own defense, but was found guilty.

In its Decision on Admissibility the Committee established that the claim of a violation of the rights protected under articles 2, 3, 14, 26 and 27 had not been substantiated. Moreover the Committee reiterated its point of view that the French declaration was tantamount to a reservation, and would thus preclude the Committee from dealing with the alleged violation of article 27 CCPR.

\section{R.L.M. v. France ${ }^{705}$}

The plaintiff was a teacher of Breton at the Academy of Nantes, who claimed that the Rectorate of the Academy has discouraged and obstructed the teaching of Breton. His action is based upon personal grievances in the shape of the obstruction of his career, and freedom of choice with respect to the fields of specialization. He had not appealed the decision, as he claimed that no remedies had been available.

France contends that the author of the complaint had not exhausted local remedies, and that the complaints were about the general issue of the discrimination of Breton which should not be the subject of an Optional Protocol case. Contrary to the allegation of the plaintiff, remedies would have been available.

The Committee indicates that the claim has not been substantiated, that France had made a reservation to article 27 CCPR, and that all available remedies had not been exhausted. Thus the complaint was inadmissible.

\section{CONCLUSIONS}

\subsection{The reservations}

The Covenant on Civil and Political Rights does not contain a reservations clause in spite of the fact that this had been contemplated during the drafting. Consequently the "object and purpose" rule should be applied to the reservations to the Covenant. This instantly raises the question as to what the content of "object and purpose" would be, what are the core obligations from which derogation is not allowed. Suggestions for such core obligations are the nondiscrimination rule, and the non derogable rights. The rule that the Covenant be implemented in the domestic legal system is also frequently mentioned in this respect. 
With the extensive practice that has been considered in the foregoing, a number of general remarks can be made about the reservations made, and about the attitudes of their authors.

Reservations have been made with respect to non-derogable rights ${ }^{706}$, and every reservation is one too many in this respect. Although not each and every reservation to a non-derogable right has a similarly detrimental impact on the implementation of the Covenant, as a matter of principle such reservations are highly undesirable.

A number of almost identical reservations have been made. Given the fact that most of these have been discussed by the author states and the Committee in the reporting procedure, one could assume that since the reservations have not been withdrawn, they indicate a difference of opinion about the desirability of a particular rule, or the wisdom of implementing it. In a number of cases, reservations are the obvious reaction to majority drafting and the concessions this entails. Differences of opinion between the individual States Party and the original drafters are not unusual reasons for making reservations, or for maintaining reservations. A number of reservations frequently made will be briefly indicated below.

A reservation to article 10.2.b and $10.3 \mathrm{CCPR}$ is frequently made by western European states, who explain this reservation on the grounds that contemporary insights into the best way to treat prisoners, and in particular the question whether separation of accused and convicted and the separation of juveniles and adults, differ from the Covenant's rules. While the Committee consistently asked about the policy underlying such reservations, the gist of the issue appeared to be one of different points of view. The Committee's vigilance did not lead to a change of position. A question arising from this debate is whether the rights in the Covenant, such as the separation issue in articles 10.2.b. and 10.3 CCPR, are absolute rights or whether they may be influenced by developments in science and society. This is a serious issue, as the reserving states clearly indicate that their goal (not the means) is the same as the goal underlying the Covenant's provisions.

Though it has never been suggested that these provisions belong to the object and purpose of the Covenant, the test would be to discuss the validity of the assumptions underlying the choices made in the Covenant and the choices made by the reserving States. This would however be an unusually flexible approach.

Another reservation that is constantly discussed without leading to a change in position on either side is the matter of article 20 CCPR. The States that have made reservations in this respect are maintaining the prevalence of freedom of expression over the prohibition of war propaganda. In spite of the fact that some Committee members ${ }^{707}$ have never failed to ask questions about these reserva-

706. Article 4: Israel, France (twice). Trinidad and Tobago, and the United States; article 6: Norway [withdrawn], Ireland, United States; article 7: United States; article 11: Congo, United Kingdom (Jersey); article 15: Argentina, Italy, Germany, Trinidad and Tobago, United States; article 18: Mexico.

707. Committee member Movchan has been notably active in this respect. 
tions, it seems to have been completely pointless, as no reserving State changed its views in order to withdraw the reservation and provide the necessary legislation. The issue here is not about the undesirability of war-propaganda, but about a conflict between the provisions in the Covenant that has not been solved satisfactorily during the drafting.

\subsection{The role of States}

As the authors of reservations, States frequently purport to safeguard their domestic legislation against any changes that might be necessary as a consequence of expressing consent to be bound by the Covenant. As there is no obligation to explain the reasons for making reservations, there is little certainty in this field. It may be assumed that apart from reluctance to bring legislation into conformity with the Covenant, there is in a number of cases a distinct difference of opinion on the wisdom of a particular rule. The best example of this is the pointless discussion about the reservations to article $20 \mathrm{CCPR}$, which are clearly the result of a difference of opinion.

It is also useful to look at the attitudes of States towards reservations in the course of time. Although a distinct amount of irritation about interference with the reservations sometimes arises ${ }^{78}$, this does not amount to an overall reluctance to discuss reservations, either with the Committee or with other States.

Yet it must be emphasized that relatively few states have been able to formally withdraw reservations. So far only six states have been able to withdraw a total of twelve reservations. Not only is the number not particularly impressive, it should be noted that a number of States do agree with the Committee, that their reservations are superfluous ${ }^{709}$, but in spite of that fail to formalize such statements by withdrawing the reservations officially.

A similarly disappointing picture must be drawn in respect of the objections, eight States objected to reservation made by a total of five (possibly seven ${ }^{710}$ ) States. This might be interpreted as meaning either that the reservations do not have such a detrimental impact that a great number of States made the effort to object, or it might be the consequence of a complete lack of interest on the part of the other States Parties, to be traced back to the absence of reciprocity in the implementation of the Covenant.

708. Cf. CCPR/C/1/Add.42, p.3 (Sweden); CCPR/C/SR.857 (United Kingdom before the Committec).

709. Or other States may say so, ef. the objection by Beigium and the Netherlands to the reservation to article 11 by Congo, expressly indicating that the reservation was not necessary in view of Congolese law.

710. The pseudo objections by the Netherlands and Germany to reservations by Australia and France respectively, see supra par.2.1. 


\subsection{The role of the Human Rights Committee}

Some confusion has surrounded the authority of the HRC to deal with reservations. Whereas some have argued that the Committee could pronounce on the validity of reservations (that is, admissibility in VCLT terms), others have repeatedly stressed that reservations are a mere fact for the Committee to take into account.

The right position would seem to be the following. Under general international law, it is for the States Parties to accept reservations, or if necessary object to the reservations. The Committee has no role to play in this respect. Yet, when it comes to the application of the Covenant, and the impact that reservations may have in this respect the Committee is fully entitled, if not obliged, to interpret the reservation. It goes without saying that the "object and purpose" of the Covenant will be the guideline for the Committee.

Moreover, it would seem to follow from the Committee's role as a guardian of the Covenant that it is fully entitled to ask the States Parties to reconsider their reservations with a view to withdrawal. States have every right to be irritated, and to disclaim the authority of the Committee to ask such questions, but it would seem to be completely in keeping with the Committee's tasks under the Covenant that it should monitor not only the implementation but also the declarations influencing that implementation.

For the purpose of clarity the role of the Committee in the reporting procedure and under the Optional Protocol will be discussed separately. As will be seen, the discussions in both procedure about reservations and their impact differs significantly.

\subsubsection{Reservations in the reporting procedure}

Discussions about the reservations under the reporting procedure of article 40 of the Covenant are distinctly monotonous, to the point of boredom. Looking at the Committee's practice, three phases can be distinguished. The consideration of the initial report left much to be desired in general, and the Committee paid little attention to the reservations made. Attention slightly improved in the consideration of the second periodic reports, but this did not lead to particularly fundamental discussions. On the whole the Committee had little insight into the reservations made, and did not know the rules on reservations.

The outlook for scrutinizing reservations seems somewhat better with the method developed by the Committee for discussing the third periodic reports. In the approach focusing on a set of articles, questions are explicitly asked about the reservations made. This has led to more in depth discussions, and also led to more refusals of representatives to discuss reservations. The only advantage in this last respect is the fact that states have sometimes been made to clarify their position explicitly, which may in turn give the HRC the opportunity to narrow down the scope of a particular reservation.

Interpretative declarations are identical to reservations, at least that sometimes seems to be the opinion of the Committee. This may be the result of a lack of knowledge on the part of Committee members, and it appears to have been used 
by States who claim that their interpretative declaration was (and had always been) a reservation. Some reflection on the applicability of the distinguishing rule as developed by the European Commission on Human Rights in the Belilos case $^{711}$, might help to narrow down the number and scope of the exceptions States create.

Another thing to be noticed is the fact that in spite of the discussions about reservations to non-derogable rights, the HRC has not achieved the withdrawal of any of those reservations made. Given the fact that there is little discussion about the core character of non-derogable rights, this must be seen as a distinct failure of the Committee.

\subsubsection{Reservations under the Optional Protocol}

With its characteristics of a legal, almost judicial procedure the occurrence of reservations in cases under the Optional Protocol can best be discussed in the order in which the procedure is structured.

To begin with, only genuine reservations could prevent the Committee from considering an individual complaint. Reservations to the Protocol itself, restricting the availability of that procedure, as well as reservations to the Covenant excluding provisions that are invoked by the claimant, must be dealt with in the admissibility phase. The earlier cases about the reservations to article 5.2.a OP are an example of the former, even if Graefrath $^{712}$ is right in asserting that the applicability of a reservation to the Optional Protocol when a case has been declared inadmissible under the European Convention, would be interpreting the reservation to extensively.

This implies the necessity to consider, in the admissibility stage, whether or not a State can indeed rely upon a particular statement which it presents as a reservation. To begin with, there will be a prima facie test as to the scope of the reservation, is it reasonable to assume that the complaint invokes a right excluded through the functioning of the reservation. In case of uncertainty about the scope: of the reservation, and its impact on the situation of the plaintiff, there is reason to declare the complaint admissible and investigate the scope of the reservation in the merits-stage. The cases of Ibrahima Gueye ${ }^{113}$ (uncertainty about the scope of the reservation ratione temporis) and of Duilio Fanali ${ }^{714}$ (uncertainty about the scope of the reservation ratione personae) are an indication that the Committee is following this line.

In the decision on admissibility article 2.1.d VCLT plays a role. In view of that provision, there is no certainty as to the legal effect of an "interpretative declaration". It might, or might not be a reservation. Consequently, when an interpretative declaration has been made with respect to a right invoked in a procedure under the Optional Protocol, this would seem to oblige the HRC to determine in 
the admissibility stage what legal effect it considers the declaration to have. Thus the admissibility stage is the moment to decide upon the legal effect of interpretative declarations in a "Belilos situation". Should the communication deal with a matter falling within the scope of an interpretative declaration, when the State party has made both declarations and reservations, it will be for the Committee to indicate clearly that the declaration cannot go under the guise of reservation, and consequently does not prevent the Committee from dealing with the matter.

With its focus on individual cases, rather then the more general matter of implementation, the Optional Protocol leaves some room for case-law engineering. The surprisingly long list of cases under the Optional Protocol regarding the rights of Bretons as a minority in France and their rights under article 27 CCPR, to which France had made an interpretative declaration, clearly demonstrates two issues.

France had made both interpretative declarations and reservations when ratifying the Covenant, thus a provision to which an interpretation had been attached led to a "Belilos" situation. In its consideration of the Breton cases under the OP, the HRC demonstrated a notable lack of insight into the law on reservations. The nature of declarations leads to confusion and disparity amidst the Committee. The reference in the majority opinion in the cases of M.K. and T.K. v. France ${ }^{715}$ to article 2.1.d VCLT is uncalled for, "if a state makes reservations and interpretative declarations at the same time, an interpretative declaration will only exceptionally be able to be equated with a reservation ${ }^{m 716}$. The Belilos theory of distinguishing would lead to the burden of proof that the declaration was a reservation resting on France. The Committee however, was satisfied that France itself had indicated that the declaration was in fact a reservation, in a previous periodic report. Consequently France managed to change the legal effect of its declaration years after ratification, and the Human Rights Committee facilitated that.

On the other hand, there has been a striking lack of procedural ingenuity in all the Breton cases. Being more stubhom than smart, the Bretons stumbled over the barrier of the non-exhaustion of local remedies in article 2 OP all the time. While this may have been an excusable problem in the initial cases, the same domestic remedies issue in the following cases prevented the discussion of the French declaration as a matter of substance. The Bretons clearly irritated the Committee by suggesting that they could not take legal action in the French language, and frequently complained about rights that are not protected under the Covenant. This lack of strategy on the part of the Bretons is regrettable because. with the developments under the ECHR and the Belilos theory of distinction, a situation existed in which the Committee could have followed this line, thereby ignoring the fact that France considered its statement to be a reservation ${ }^{717}$. It is my

716. Belilos report para.102.

717. This is clearly a possibility in the first case of C.L.D. v. France, Communication $228 / 1987$. 
impression that the Committee could have been persuaded to distinguish, if the Bretons had not consistently failed to exhaust local remedies, and had presented complaints that would have challenged the Committee to give the declaration concerning article 27 thorough consideration. This did not happen, and the cases of G.B. and S.G. indicate that the acceptance of the French declaration as a reservation has become standard case law of the HRC. Thus ending all hope for the advancement of the Breton case through the Optional Protocol.

The admissibility stage is the crucial moment in dealing with reservations under the Optional Protocol, and important choices need to made in that phase of the procedure. By being precise about the potential scope of a reservation, and thereby selecting between the "reservations" that do and do not prevent the Committee from looking at an individual complaint, it will be possible to give the Covenant the widest possible impact.

\subsection{Prospects}

Prospects to reduce the impact of reservations and interpretative declarations on the Covenant are not all that gloomy. There are few indications that states will want to withdraw large numbers of reservations in the near future. However, it is beyond doubt that the Committee could improve its grip on the reservations issue, by drafting a General Comment on Reservations ${ }^{718}$ and by improving the discussion of reservations when the periodic reports are considered. To further enhance their success in this field, it would be worthwhile analyzing the remarks, suggestions and perhaps promises made by state representatives during the consideration of earlier reports. If the consistency of the Committee's approach could be improved, the Committee would be on solid ground when it recalls earlier commitments by the reserving States. However, such a project could only be undertaken if the servicing of the Committee were improved.

Prospects for restricting the impact of reservations under the Optional Protocol are not particularly good. It would appear that reservations are dealt with in a formal way, and that they thus preclude a consideration of the substance by the Committee. Perhaps some room for imaginative case-law exists where it concems interpretative declarations, but in that respect it must be stressed that such cases should be presented with greater care than has happened up until now. (Poear). 


\section{RESERVATIONS TO THE CONVENTION ON THE ELIMIN- ATION OF ALL FORMS OF DISCRIMINATION AGAINST WOMEN}

\section{INTRODUCTION TO THE CONVENTION}

\subsection{Content of the Convention ${ }^{1}$}

The Convention on the Elimination of All Forms of Discrimination Against Women was adopted by the General Assembly on 18 December 1979', and was opened for ratification on $1 \mathrm{March} 1980^{3}$. It entered into force on 3 September 1981, when twenty states had ratified the Convention ${ }^{4}$.

The Convention consists of six parts, dealing with substantive law (parts 1-4), supervision (part 5) and final clauses (part 6). It begins by recalling that, in spite of various instruments proclaiming the equality of men and women, extensive discrimination against women continues to exist. The long-winded preamble also mentions the New International Economic Order, and the importance of strengthening international peace and security.

The first part of the Convention (articles 1-6) lays down fundamental rules. Article 1 defines discrimination against women as "any distinction, exclusion or restriction made on the basis of sex which has the effect or purpose of impairing or nullifying the recognition, enjoyment or exercise by women, irrespective of their marital status, on a basis of equality of men and women, of human rights and fundamental freedoms in the political, economic, social, cultural, civil or any

1. Unfortunately so far no detailed commentary on the Convention has been published. Nor has the Committee "..developed a detailed jurisprudence of the substantive articles of the Convention.." of. Byrnes, The Work of the Committee, at 46. The travane of the Women's Convention are published as Guide to the Travaler Priparatoires of the United Nations Convention on the Elimination of All Forms of Diserimination against Women: L.A.Rehof: Dordrecht, 1993.

2. GA Res.34/180, 18 December 1979.

3. On the origins of the Convention:N.Burrows, The 1979 Convention on the Elimination of All Forms of Diserimination against Women, in:32 NILR 1985, 419-460 at 419-421; R.J.Cook. Reservations to the Convention on the Elimination of Discrimination Against Women, in:30 VJIL. 1990, 643-716 at 663-678 (hereafter: Cook. Women's Convention): J.Delbrück, Die Konvention der Vereinten Nationen zur Beseitigung jeder Form der Diskriminierung der Frau von 1979 im Kontext der Bemühungen um einen völkerrechtlichen Schutz der Menschenrechte. in: Staatsrecht, Volkerrecht. Europarecht (festschrift Schlochauer). Berlin 1981. 247-270 at 252-254; Th. Meron. Human Rights Law-making in the United Nations, Oxford 1986, at 53-57; E.Oeser. Neue Etappe in Kampf fur die Gleichberechtigung und Forderung der Frauen (hereafter: Neue Etappe), in: Geschriften und Informationen des DDR-Komitees für Menschenrechte 1982, 43-57 at 43-46 and 49-50.

4. Article 27.1 CEDAW. 
other field." This part furthermore contains the complementary obligation for the States Parties to incorporate the principle of equal treatment in their legislation, and to modify existing discriminatory legislation. Adopting temporary measures aimed at accelerating de facto equality of men and women is possible. States undertake to modify customary practices based on ideas of inferiority or superiority of either of the sexes.

The second part of the Convention deals with the right to participate in public and political life. It also provides for equal treatment in nationality law, including the nationality of children.

Economic, social and cultural rights are dealt with in part three. It contains provisions on education, including the obligation to eliminate stereotypes in educational materials. Discrimination in employment, in health care and other areas of economic and social life are dealt with. Article 14 pays attention to the situation of women in rural areas, and stresses the need for equal participation in development planning and access to relevant training and education.

Part four of the Convention consists of provisions on equality before the law, and on equal treatment in matters of family law.

The fifth part of the Convention contains the supervisory system. A Committee on the Elimination of Discrimination against Women is established, consisting of twenty-three experts in the field of women's rights. The States Parties undertake to report to the Committee on the measures adopted to implement the Convention and on the progress made, in the year following ratification and then every four years and whenever the Committee so requests. The Committee meets for two weeks every year.

And finally the Convention contains in part six the final clauses, dealing amongst others with revision, with the entry into force and with reservations.

The Convention covers a wide range of women's rights, including civil and political rights, economic and social rights as well as human rights related to development. The preamble reaches beyond the usual scope of a preamble, and seems to indicate that women's rights are related to international political goals. The provisions are formulated in rather vague terms and may prove to be not specific enough for a meaningful interpretation. The Convention reaches into the private sphere, and given the scope and nature of women's discrimination this seems a logical approach". However, implementation of the Convention in the private sphere may be considerably more difficult than implementation between the states and the individuals under its jurisdiction. The CEDAW's supervisory werkelijke betekenis van het Vrouwenverdrag (hereafter: Het kussen van een kikker), in: Nemesis 1991.2, 5-17 at 14-15: D.Sullivan. Gender equality and religious freedom: toward a framework for conflict resolution. in: 24 JILP 1992. 795-856 at 799; S.C.Zearfoss. Note. The Convention for the Elimination of All Forms of Discrimination against Women: Radical, Reasonable, or Reactionary? in: 12 Mich.llL 1991, 903-942 at 907-909; 917-920. 
system, consisting of a reporting obligation only, is minimal and seriously undermines the strength of the Convention's provisions.

\subsection{The law applicable to reservations}

The dispute settlement procedure provided in article 29.1 contains the option of referring a dispute unilaterally to arbitration, and if this is not successful, unilateral referral to the International Court of Justice. Reservations may be made to this provision under article 29.2. This provision will not be dealt with in what follows.

According to article 28.2 CEDAW a reservation incompatible with the object and purpose shall not be permitted. During the drafting of the Women's Convention the issue of reservations has been discussed in relation to the universality integrity dilemma. Initial views were that reservations were not permitted (Philippines), or that reservations were a sovereign right and could therefore not be restricted (Eastern Europe). It was suggested by Finland that partial ratification could be a measure to accommodate the obligations under the Convention. In the same line of thought, Sweden suggested later on in the drafting debates that a limited number of reservations might be allowed, valid for a short period of time, by way of a transitional measure. The United Kingdom suggested that the solution be sought along the lines of article 19 VCLT, and a number of States felt that a reservations clause was not necessary in view of the adequacy of the rules laid down in the Vienna Convention. Denmark submitted a proposal for a reservations clause identical to article $20 \mathrm{CERD}^{7}$, which was heavily criticized by Japan ${ }^{8}$.

Ultimately, in the final stages of the drafting process the Danish draft lost much of its substance because of the repeated views that the Vienna Convention provided adequate rules. This lead to the formulation of article 28 as it now stands. Reading the drafting records some fifteen years later, one cannot but be struck by the shadow the Vienna Convention cast over the debate. The delegates clearly operated on the assumption that the Vienna Convention provided adequate solutions for the universality - integrity dilemma they perceived. Since then, the history of the Women's Convention has proved them to have been wrong. Enhancing the Effectiveness of the Prohibition of Discrimination against Women, in: $\& 4$ AJIL 1990, 213-217; and M.Wadstein, Implementation of the UN Convention on the Elimination of All Forms of Discrimination Against Women, in: SIM Newsletter 1988, 5-21 at 19-21; Zearfoss, op.cit. at 922-924.

7. For a discussion of article 20 CERD see Chapter 4, par.1.2 supra.

8. About the drafting of article 28 CEDAW: Cook, Women's Convention at 673-678; Rehof, Travaux at 234-237: and the UN documents mentioned.

9. Burrows, op.cit. at 460 says: "The possibility of reservations may make it an attractive instrument which would enable some States who would not otherwise be able to do so to ratify the Convention." 
Article 28 CEDAW reads:

"1. The Secretary-General of the United Nations shall receive and circulate to all States the text of the reservations made by states at the time of ratification or accession.

2. A reservation incompatible with the object and purpose of the present Convention shall not be permitted.

3. Reservations may be withdrawn at any time by notification to this effect addressed to the Secretary-General of the United Nations who shall then inform all states thereof. Such notification shall take effect on the date on which it is received."

One might read article 28.2 CEDAW as a provision referred to in article 20.1 VCLT $^{10}$. Article 28.2 indicates which reservations are expressly authorized by the Convention, namely the ones compatible with its object and purpose. This implies a priori acceptance of all reservations fulfilling the compatibility requirement of article 28.2. No objections can be raised, as such reservations have been accepted prior to opening the Convention for ratification.

States are supposed to make compatible reservations, and will indeed usually maintain that their reservations are compatible. The system of a priori acceptance leads to a situation in which (incompatible) reservations are accepted at the very moment of ratification. A consequence of article 20.1 VCLT is that States Parties give away their authority to determine the compatibility of each individual reservation, on the assumption that contracting States will not ignore article 19.b VCLT. It does not leave room for objections and leads to the instant acceptance of a reservation". Moreover, the depository is supposed to monitor "article 19.b provisions". In this particular case the Secretary-General of the UN acting as depositary would have to judge the compatibility of the reservations, which is understandably a delicate matter.

Disagreement about the compatibility of the reservation is in this situation a problem of treaty interpretation. The determination of compatibility may have to take place within the dispute settlement procedure of article 29 CEDAW. The purpose of the interpretation could either be to determine whether or not the reservation is compatible, and if not to determine what would be the consequences; or to interpret the reservation so that its impact does not extend beyond the object and purpose of the Convention. Yet, the dispute settlement procedure may not be available, as a large number of states have made reservations to article 29.1.

10. Article 20.1 VCLT reads:"A reservation expressly authorized by a treaty does not require any subsequent acceptance by the other contracting States unless the treaty so provides."

11. Article 19.b reads:"A State may..... formulate a reservation unless:

b) the treaty provides that only specified reservations. which do not include the reservation in question, may be made .." 
In practice article 28.2 CEDAW has been understood to refer to article 19.c VCLT $^{12}$. When the question arose in the Committee as to who was to monitor article 28.2, and in particular whether the Committee itself had the competence to do $\mathrm{so}^{13}$, the Office for Legal Affairs of the UN Secretariat held the provision to belong to the article 19.c VCLT system ${ }^{14}$. It must be assumed that the literal similarity between both provisions led to this interpretation. Monitoring whether or not reservations are compatible would be a delicate task for the UN Secretariat acting as depository. As this would be the only other alternative, it makes this an acceptable solution.

Both article 19.c VCLT and 28.2 CEDAW mention "object and purpose" as a yardstick for reservations, and in the Vienna Convention system the States Parties are considered to be the guardians of the Convention's "object and purpose". Although reservations incompatible with object and purpose may not be formulated according to article 19.c, they need (theoretically) to be accepted. States may object to reservations or otherwise, in accordance with article 20.4 and 20.5 VCLT, the reservation will be (tacitly) accepted 12 months after ratification. While objections may not have a substantial impact on the treaty relations, they are an opportunity to voice disapproval of certain reservations, thereby possibly influencing the interpretation given to a reservation by the Committee. If the opportunity to object is not used, one might however wonder whether there is any relevant distinction between the tacit acceptance of article 20.5 and the a priori acceptance of article 20.1 VCLT.

12. As stated by Czechoslovakia in A/41/608/Adud.1:"This provision of the Convention (referring to article 28.1, EL) only confirms the general rule of the law of treaties concerning reservations that is stated in article 19 of the 1969 Vienna Convention on the Law of Treaties." Cf. B.Graefrath. Menschenrechte und internationale Kooperation, Berlin 1988, at $69-70$.

13. E.Oeser, Legal questions in the Committee on the Elimination of Discrimination Against Women (hereafter: Legal questions), in: 14 Bulletin of the GDR Committee for Human Rights 1988, 86-99, at 93-95.

14. A/39/45 Volume II Annex II, Legal opinion submitted by the Treaty Section of the Office of Legal Affairs of the United Nations Secretariat upon an Inquiry by the Committee concerning the implementation of article 28 of the Convention on the Elimination of All Forms of Discrimination against Women.

Rather than discussing the substance of the matter, the Treaty Section deals with the procedural aspects of determining the incompatibility.

The opinion reads, inter alia:

"a).. the Convention on the Elimination of All Forms of Discrimination against Women does not offer any specific criterion of incompatibility (the Treaty Section is far too demanding at this point, there are little or no examples of treaties explicitly indicating the content of a compatibility criterion. EL) ...a question of interpretation of the Convention is involved here."

"b) Assuming a dispute arose with regard to the interpretation of article 28 of the Convention, article 29 thereof would become applicable .."

"c) The depository.. does not have the power to interpret the Convention..."

"d)..the functions of the Committee (on the Elimination of All Forms of Discrimination Against Women) do not appear to include a determination of the compatibility of reservations..". 
Article 28.2 does indeed not contain a specific criterion as to what the "object and purpose" of the Women's convention are ${ }^{15}$. Looking at theory and practice, a number of suggestions as to the core obligations have been made. Cook suggests that the object and purpose of the Convention is that the states parties move progressively towards elimination of discrimination, and that consequently reservations that threaten the achievement of this goal are contrary to the object and purpose ${ }^{16}$.

The Committee itself has indicated during its discussions with the States that it considers articles $2^{17}, 9$ and $16^{18}$ to be provisions essential to the object and purpose of the Convention.

In its reply to the survey by the Secretary General ${ }^{19}$, Canada suggested that reservations to general provisions such as articles 1, 2, 3 and 24 were prohibited, as well as reservations to particularly crucial provisions such as article 15 . Other criteria in order to establish incompatibility would be whether a significant aspect of national life was involved, or whether the reservation aimed at a complete provision or at specific elements of the provision. The latter criteria seem to outline modalities of incompatibility, whereas the first two criteria provided more insight into the substantial content of the "object and purpose" of the Convention, as viewed by Canada.

Looking at the practice of the four States that have objected most frequently (Germany, Mexico, the Netherlands and Sweden), their objections seem to specifically aim at reservations to articles $2,9,11,15$ and $16^{20}$.

Authors writing about the Convention have suggested a number of rules that could be considered core obligations under the Conventions. Writing elsewhere about the way to determine compatibility, Cook suggests that it be measured by quantitative and qualitative factors, and indicates that "object and purpose" are related to the situation in the reserving States rather than to one singular objective norm $^{21}$. She writes that the Women's Convention "mandates relative assessment of reservations for the purpose of legal determination of compatibility ${ }^{m 2}$. This approach necessarily leads to a relative system. However, Cook also mentions a number of provisions that have the character of core rights, such as article 2 and

15. H.Charlesworth, C.Chinkin. S.Wright, Feminist approaches 10 international law, in: 85 AIL 1991. 613-645, at 632-633: Zearfoss, op.cit, at 924-925.

16. Cook. Women's Convention at (AS8.

17. See discussion of the initial reports by Bangladesh and Egypt, par.3.1 infra.

18. See discussion about the initial report by the Republic of Korea. par.3.1 infra.

19. To be discussed in par. 2.4.1 infra.

20. For a discussion of the objections see par.2.1 infra.

21. Cook. Women's Convention at 680 . writes:"To propose that compatibility is specific to the circumstances of individual countries, and that with such features as a large differential literacy rate between men and women or with many households headed by women are different from other countries, suggests that legal determination of compatibility arises not from the object and purpose of the convention per se, but from the specific applications of treaty provisions to individual countries. In other words compatibility may seem determinable not as a function of interpretation of the treaty as a whole. but from socio-political measurements of effects of reservations on women."

2. Cook. Women's Convention at 681 . 
the obligation therein to eliminate discrimination of women without delay. Other rights within the ambit of "object and purpose" are, in the opinion of Cook, the entrance into military service under article $7^{23}$, article 9 , article 11 , article 15 and article 16. In discussing the reservations referring to Sharia law, Jacobs suggests that articles 2, 9 and 16 are core obligations ${ }^{24}$. I would personally like to suggest that articles 2 and 5 are essential obligations outlining the goals of the Convention. On the basis of the notion that protection against the most detrimental restrictions to the elimination of discrimination ${ }^{25}$ are necessary; articles 9 (nationality), 11 (employment), 15 (equality before the law) and 16 (equality in family law) would also seem to be core-obligations.

On the whole there would seem to be a communis opinio on the core value of articles $2,9,11,15$ and 16 . While article 2 presents the goals of the Convention in a nutshell, the other articles deal with discrimination in the fields of nationality, labour, equality before the law and equality in family matters. It may be suggested that these are the fields in which discrimination is most detrimental to the achievement of women's equal rights.

\subsection{Reservations and declarations}

Up until now ${ }^{26} 120$ states have ratified Convention. Of these 81 ratified without reservations $^{27}, 23$ made reservations in accordance with article 29 (the dispute settlement procedure) $)^{28}$, and 27 made reservations to substantive provisions or other declarations. The reservations relating to the dispute settlement procedure will not be dealt with in depth. In the following the focus will be on the reservations and declarations made to the Convention's substantive provisions.

- preamble -

France, and the Federal Republic of Germany have made interpretative declarations concerning the 11 th paragraph ${ }^{29}$ of the preamble ${ }^{30}$. France indi-

23. Cook, Women's Convention at 692, writes:"[W]omen have few prospects of equality with men where they are legally excluded from military careers or advancement." The present author does not agree with this point of view.

24. M.Jacobs, Onder Voorbehoud, In: Nemesis 1993, 81-87, at 81-82.

25. See for a discussion of ways to determine the content of object and purpose, Chapter 3 , par.2.I supra.

26. ST/LEG/SER.E/11, 31 December 1992.

27. Or have withdrawn their reservations to this date.

28. 8 reservations to this provision have been withdrawn.

29. It reads:"Affirming that the strengthening of international peace and security, relaxation of international tension, mutual co-operation among all States irrespective of their social and economic systems, general and complete disarmament, and in particular nuctear disarmament under strict and effective international control, the affirmation of the principles of justice, equality and mutual benefit in relations among countries and the realization of the right of peoples under alien and colonial domination and foreign occupation to self-determination and independence, as well as respect for national sovereignty and territorial integrity, will promote social progress and development and

(continued...) 
cates that it contains debatable elements, whereas the FRG states that it "would be unable to recognize as legally valid" the formulation of the right to selfdetermination in the 11th paragraph. These declarations both seek to maintain a different interpretation of the principle of self-determination than the one laid down in the preamble. The Netherlands objected to both the 10th and the 11th paragraph, indicating that it feels that it is undesirable to include these political considerations into the preamble. Moreover they were not related to the achievement of total equality between men and women.

Although the preamble is an integral part of the treaty, it is not legally binding $^{31}$. The preamble is merely an introduction to the treaty. Thus, even if the declarations are aimed at restricting the interpretation of the right to self-determination, they do not exclude or modify the legal effects of any provision of the treaty, and can thus not be considered reservations.

- general reservations -

Although as a rule reservations of a general nature are prohibited, because of the uncertainty they bring for the co-contractants both Malawi and Libya ${ }^{32}$ made such reservations ${ }^{33}$.

Malawi, in a reservation withdrawn in 1991, upheld traditional customs and practices rather than the Convention in cases of conflict ${ }^{34}$. While the reservation seemed to be aimed at article 5.2 CEDAW, the modification of social and cultural patterns of conduct, it in fact encompassed discrimination in all spheres of society. Without wanting to ridicule the importance of Malawian customs and practices, these would almost everywhere be the foundation of discrimination against women. As Cook quite rightly says: "reservations made on grounds of culture are suspect ${ }^{\text {"3s. }}$. If anything the reservation was incompatible with the aim of the Convention, and made Malawi's adherence to the Convention ambiguous.

\section{9.(...continued)}

as a consequence will contribute to the attainment of full equality between men and women.

30. Criticizing the preamble: Burrows, op.cit. at 423-424: Delbruick op.cit. at 255; Meron, op.cit. at 58-59. Advocating the linking of women's rights to other international political questions: Oeser. Neue Etappe, at 46.

31. Cr. anticle 2.1.d VCLT.

32. Libyan reservation invoking Sharia law to be dealt with in par.3.1 infra.

33. See about the specificity rule Chapter 3. par.2.1.2 supra.

34. The Malawian reservation read: "Owing to the decp-rooted nature of some traditional customs and practices of Malawians, the Government of the Republic of Malawi shall not for the time being, consider itself bound by such of the provisions of the Convention as require immediate eradication of such traditional customs and practices."

35. Byrnes. The Work of the Committec at 53: Cook. Women's Convention at 689; similarly: R.J.Cook, Etnische culturen en vrouwendiscriminatic (hereafter: Etnische culturen); in: 3 Nemesis 1987, 49-55 at 50-52; and the anonymous quote "When men are oppressed, it is a tragedy; when women are oppressed, it is their culture." 
- article 1 -

The United Kingdom, also on behalf of various dependent territories, has made rather extensive declarations concerning article 1 , the definition of women's discrimination ${ }^{36}$.

Firstly there is a reservation to the extent that the phrase "irrespective of their marital status ${ }^{\text {n37 }}$ does not prohibit discrimination between single and married persons, but merely prohibits discrimination between married men and married women.

The second reservation relating to article 1 deals amongst other things with succession to the throne, peerage and affairs of religious denominations ${ }^{38}$. Cutting it into pieces, it contains four different reservations.

As far as the reservation deals with succession to the throne, it is necessary to determine which of the rights laid down in the Convention are involved. Without wanting to ponder on specific aspects of royal succession, the reservation obviously restricts the application of article 7 , equality in the participation in political and public life ${ }^{39}$. It should he noted that other states wanting to uphold male priority in royal succession opt for the much more restricted approach of making a reservation to article $7^{+0}$. It is difficult to see the point of bringing up this issue in relation to the definition of women's discrimination.

As concerns the succession to, or possession and enjoyment of the peerage, titles of honour, social precedence or armorial bearings it is again hard to determine to which of the rights formulated in the Convention they exactly relate. These traditions seem to have an impact on the enjoyment of a variety of rights, such as the right to hold public office (article 7), and the right of equality before the law

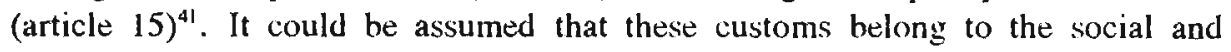
cultural patterns of conduct of men and women that article 5 seeks to eliminate, although not everyone will accept that they are hased on "the idea of the inferior-

36. About the definition of discrimination against women in the Convention see: Cook, Women's Convention at 667-670; Lijnzaad. Het kussen van een kikker at 6-7; Meron, Human Rights Law-making at 59-63; Zearfoss, op.cit at 907-909 and 917-920.

37. On this element of the definition see the Canadian answer in A/41/608 at 5 : "It is understood that the term "discrimination against women" means any practice or act which distinguishes women from other citizens because of their sex and/or marital status in such a way as to prevent them from fully realizing their human rights and fundamental freedoms in all areas of national life." C.. article 23.b CEDAW, and Burrows, op.cit. at 426.

38. The reservations reads:" .the United Kingdom's ratification is subject to the understanding that none of its obligations under the Convention shall be treated as extending to the succession to, or possession and enjoyment of, the Throne, the peerage, titles of honour, social precedence or armorial bearings, or as extending to the affairs of religious denominations or orders or to the admission into or service in the Armed Forces of the Crown."

39. Cook, Etnische culturen at 52; Cook, Women's Convention at 680 discussing this as a symbolic qualitatively limited reservation.

40. Cf. reservations to article 7 by Belgium, Luxembourg and Spain, dealt with infra.

41. Or perhaps even article 16.1.h CEDAW. 
ity or superiority of either of the sexes or on stereotyped roles for men and women".

As far as the affairs of religious denominations are concerned, the reservation poses interesting questions. Making a reservation excluding the applicability of the Convention in affairs between private persons (if one may qualify the affairs of religious denominations as such) seems to indicate on the contrary that the United Kingdom is of the opinion that, in the absence of such a reservation, the provision would be applicable. Conventions are usually supposed to contain obligations binding upon the states parties, and in the case of human rights treaties, obligations between States and persons under their jurisdiction. The Women's Convention has an even wider scope, it claims applicability between private persons ${ }^{42}$. The United Kingdom may have felt the need to reserve its position as far as the affairs of its State Church are concerned. At this point in time it seems highly unlikely that a state church in Europe would be taken to be a state organ, for whose compliance with the Convention a state party would be responsible ${ }^{43}$.

The final part of the reservation related to article 1 deals with the admission into, or service in the Armed Forces of the Crown. It is not clear what is actually covered by this reservation, whether it seeks to exclude combat duties. Assuming that these are meant, the actual reservation is again much narrower and should have been directed at a specific provision. One might wonder if women should not rather have the freedom to decide for themselves on the safety risks involved in military careers ${ }^{44}$.

- article 2 -

Article 2 CEDAW contains a variety of obligations to eliminate discrimination in the legislative sphere ${ }^{45}$. Bangladesh excludes the application of article 2 because the provision is in conflict with Sharia law. Egypt indicates that it will comply with the provision provided that this does not run counter to Sharia law, and Iraq mentions the equivalent rights of women under Sharia law with respect to article $2^{46}$.

42. Lijnzaad. Het kussen van een kikker at 12-15: General Recommendation 19 (Eleventh Session). Expressing a contrary opinion: Delbrück, op.cit. at $260-261$.

43. A.Krishnaswami, Study of discrimination in the matter of religious rights and practices, New York 1960 [E/CN.4/Sub.2/200/Rev.1] at 49:"Where there is an Established Church, the relationship between the State and that Church is usually so intimate that the political organs of the State are clothed with the power to decide questions relating to faith, doctrine and ritual, including rules for the management of religious affairs. But this does not mean that public authorities can intervene at will in the management of religious affairs. ..... In addition, today, in a large number of countries having an Established Church, the State concedes considerable autonomy to clected church bodies in several fields, including not only day-to-day administration but also the organization of the church."

44. Comparable reservations have been made with respect to article 7 by Austria, Germany and Thailand.

45. Wadstein, op.cit. at 10.

46. See infra for a discussion of reservations related to Sharia law. 
On behalf of the Cook Islands, New Zealand entered a reservation implying the right not to apply articles 2.f and 5.a in view of the inheritance of chiefly titles. This is supposedly comparable with the British reservation to article 1, discussed supra ${ }^{47}$.

The United Kingdom and a number of dependent territories entered a longwinded reservations related to articles 2.f and 2.g dealing with the fact that the UK is constantly reviewing its legislation related to the elimination of discrimination against women. The reservation is initially self-applauding, as nothing in the Convention restricts a state's freedom to review its own legislation, as far as it ameliorates the position of women ${ }^{48}$. But there is a snake in the grass, as the reservation ends by stating that the legislative changes would be dependent on economic considerations ${ }^{49}$. The subordination of legislative changes to economic policy completely ignores the object and purpose of the Convention ${ }^{50}$. Article 2 is one of the few provisions formulated as an absolute obligation, using the expression "all appropriate means and without delay", leaving no room for gradual implementation depending on economic circumstances.

The reservation states, also in respect of article 2.f and 2.g, that the United Kingdom will continue to apply national legislation as far as sexual offenses or prostitution are concemed ${ }^{51}$. If national legislation is not discriminatory, no reservation is needed. However, there may be difference in the treatment of male and female prostitutes, which is prohibited by the Convention on the grounds of article 1 , as well as article $2 . \mathrm{g}$ and $\mathrm{h}$. It is noteworthy that the United Kingdom brings up the issue of prostitution in relation to article 2, dealing with legislative measures to eliminate discrimination, rather than article 6 which explicitly deals with the suppression of prostitution ${ }^{12}$.

-article 4 -

The United Kingdom states with regard to article 4 of the CEDAW, temporary measures aimed at accelerating de facto equality, states that it intends to understand article 1 in terms of this provision and thus is not obliged to repeal laws providing for women to be treated favourably.

47. Cook, Women's Convention, at 688-689.

48. Cf.article 23.a CEDAW.

49. The reservation reads:" .. by keeping under review such of its laws and regulations as may still embody significant differences in treatment between men and women with a view to making changes to those laws and regulations when to do so would be compatible with essential and overriding considerations of economic policy." (my emphasis, EL).

50. Cr.Y.Klerk, Working paper on Article 2(2) and article 3 of the International Covenant on Economic, Social and Cultural Rights, in: 9 HRQ 1987, 250-273, and similarly L.Lijnzaad. Teleurstellende vrijheid, de positie van vrouwen in post-communistisch Polen, in: Nemesis 1993, 15-23 at 19.

51. It reads:" With regard to paragraphs $(f)$ and $(\mathrm{g})$ of this Article (article 2, EL) the United Kingdon reserves the right to continue to apply its law relating to sexual offenses and prostitution; this reservation will apply equally to any future law which may modify or replace it."

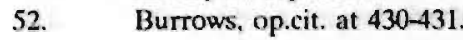


- article 5 -

Article 5 CEDAW deals with the elimination of prejudices and the proper understanding of the role of parents. In relation to article 5.b, France made an interpretative declaration, explaining that "family education" means public education concerning the family, adding that this should be applied in line with article $17 \mathrm{CCPR}$ and article $8 \mathrm{ECHR}$. As both provisions deal with the right to privacy, one might question whether the French declaration is not in fact a reservation. This depends upon the operational scope of article 5 , which is at present not very clear ${ }^{33}$.

The reservation by France to article 5.b and 16.1.d deals with the joint exercise of parental authority. These are provisions on the common responsibility of men and women in the upbringing and development of their children(article 5.b) and the same rights and responsibilities as parents, irrespective of their marital status in matters relating to their children(article 16.1.d), in both cases stressing that the interests of the children are the primordial consideration. France states that joint parental authority can not be deduced from the Convention in cases which French national legislation provides for single parent authority. It is doubtful whether the Convention has a mandatory system of joint parental authority, it does not literally say so. The idea of a common responsibility, and the same rights and responsibilities as a parent do not seem to contradict the possibility of single parent authority in cases where this is to the benefit of the child. Bearing the interests of the child in mind the distribution of parental authority should however not be discriminatory for women, measured by the standard laid down in article 1 CEDAW. The nature of the French declaration will in fact depend on the criteria involved in the attribution of parental authority in French domestic legislation. If the interests of the child and equal opportunities for women to obtain single parental authority are guaranteed, the statement is an interpretative declaration rather than a reservation ${ }^{54}$.

- article 7 -

Belgium, Luxembourg and Spain have made a reservation to article $7 . b$, dealing with the participation in the formulation of government policy and the right to hold public office 5 . They seek to maintain a male priority system in the succession to the throne ${ }^{56}$. The Convention cannot be considered to change basic constitutional rules, like the ones on succession to the throne in monarchies, for the internal organization of a state belongs to the "domaine réservé". Leaving

53. About article 5 CEDAW:Cook, Women's Convention at 669; Lijnzaad, Het kussen van een kikker at 7. General Recommendations 3 (sixth session, 1987) and 6 (seventh session, 1988) do not contain specific guidelines for the implementation of article 5.

54. C. the "distinguishing" approach of the European Commission on Human Rights in the Belilos case, discussed in Chapter 3, par.4.1.2 supra.

55. Cook, Ethnische culturen at 52: Cook, Women's Convention at 680, 692-693; Sullivan, op.cit. note 64 at 822.

56. Cf. supra the United Kingdom reservation to article 1, and the New Zealand (Cook Islands) reservation to articles $2 . f$ and $5 . a$. 
aside the question of object and purpose of the treaty in relation to succession, the reservations will, in practice, only be disadvantageous to a very small number of women. Moreover, looking at everyday political practice, there is little difference between states explicitly stating that their hereditary head of state will always be a man, and states who through their electoral system have so far never been able to appoint a woman.

In a reservation withdrawn in 1984 , France had reserved the right to apply article 7 in conformity with a provision of its electoral code with respect to disqualifications for persons who had obtained the French nationality. The other major group of reservations dealing with article 7 concerns restricting the entry of women in armed forces. Without mentioning the relevant provision New Zealand together with Niue and the Cook Islands entered a reservation dealing with the recruitment and service in the Armed Force as far as it concerns situations of armed conflict, and law enforcement forces in situations involving violence or the threat of violence. Explicitly mentioning article 7.b the Federal Republic of Germany states that its Constitution prohibits women rendering service involving the use of arms. And Austria restricts the service of women in armed forces to the limits established in national legislation. Thailand formulated a strikingly vague reservation in respect of articles 7 and 10 CEDAW. It reserves its right to apply national legislation where it concerns national security, maintenance of public order and service or employment in the military or paramilitary force ${ }^{57}$. The reservation literally encompasses not only the whole of article 7 but also the whole of the rather extensive article 10, and stretches beyond the requirements of precision.

The link between these reservations and the rights laid down in the Convention is article 7.b where it reads:".. to hold public office and perform all public functions at all levels of government ${ }^{n 58}$. If one could consider participation in the armed forces a public function, the next question would then be whether this restriction runs contrary to the object and purpose of the Convention. The fact that military positions sometimes carry a lot of prestige and add to the dignity of the official, makes the unavailability of these positions for women discriminatory. It has been said that as the military sometimes take over political power, the reservation thus deprives women of the essential right of participation in government policy and must therefore be considered contrary to object and purpose ${ }^{59}$.

57. The Thai reservation discussed in par.3.1 infra.

58. Ci. the United Kingdom's reservation to article 1 in respect of the Armed Fores of the Crown.

59. Cook, Women's Convention at 692-693, and idem. Ethnische culturen at 52:"Men hoeft alleen maar de frequentie op te merken waarmee hoge militaire officieren politieke macht verwerven, om te begijpen hoe een dergelijke discriminatie van vrouwen hen kan uitsluiten van volledige deelname aan invloedrijke sferen van het politieke en openbare leven". [One only has to notice the frequent seizure of political power by high-ranking military officers to understand how such discrimination of women excludes them from complete participation in influential spheres of political and public life.]. Criticizing Cook's point of view: L.Lijnzaad, Voorbehouden bij Vrouwenverdrag (he reafter:Voortehouden), 4 Nemesis $1988,105-111$, note 15 at 110. 
This seems a false argument, for situations of military coups d'etat cannot be the standard used to measure political influence of women. As far as these reservations must be understood to imply protection of women (whether or not inspired by their procreative function) one might wonder whether such protection is not in fact paternalistic, contrary to the spirit of the Convention ${ }^{60}$.

Israel made a reservation dealing with the fact that women can in a number of cases not be appointed judges in religious courts. The relation with article 7.b is probably that such courts have a public function.

- article 9 -

Article 9 of the Convention deals with equality in matters of nationality, paragraph 1 proclaiming equal rights of men and women, and the second paragraph providing for equality with respect to the nationality of children ${ }^{61}$.

Both Iraq and the Republic of Korea indicate that they will not be bound by article 9, without elaborating on the reasons why. France in its reservation declares that the application of its national legislation is not precluded by article 9, while the United Kingdom states that, although its Nationality Act does not allow any discrimination against women, it reserves the right to apply certain temporary or transitional provisions that may be still in force. Ireland had made a reservations, withdrawn in 1986, to the effect that it would continue to apply its legislation on the acquisition of citizenship through marriage. With regard to article 9.1, Turkey stresses that its nationality law is not in conflict with the Convention. The reasoning provided in the reservation is striking: "the intent of those provisions regulating acquisition of citizenship through marriage (articles $5.1,15$ and 17 of the Turkish law on Nationality, EL) is to prevent statelessness". It seems to imply that the idea behind article 9 CEDAW is the prevention of statelessness, which is a misconception, not only has this never been the aim, limiting statelessness has in practice been always been discriminatory towards women $^{62}$.

States have organized their nationality laws according to simple principles, in which the nationality of men (be it as husband or father) is of primordial importance. There has been a tendency to promote single nationality couples, that ean be discerned in treaties banning bipatridy and statelessness ${ }^{63}$. This proved to be

60. On maternity protection as a legitimate ground for unequal treatment (articles 4.2, 11.1.f and 11.2.d CEDAW) see Burrows, op.cit. at 428: Meron. op.cit. at 73 and Wadstein, op.cit.at 16.

61. Cook. Women's Convention at 693-696: Wadstein. op.cit. at 9, stresses the fact that article 9 prescribes that States "shall grant women equal right with men".

62. Cook, Women's Convention at 696 discussing relevant case law under the CCPR and the ACHR.

G.R.de Groot, Gelijkheid van man en vrouw in het nationaliteitsrecht, Preadvies Nederlandse Vereniging voor Rechtsvergelijking No.25. Deventer 1977 at 68-69.

63. Convention on the Nationality of Married Women. New York 20 February 1957; Convention on the Reduction of Statelessness, New York 30 August 1961; Convention on the reduction of cases of multiple nationality and military obligations in case of

(continued...) 
discriminatory towards women because of the weight attached to the nationality of the husband and father, which implies relying on the stereotypes that article 5 CEDAW seeks to eradicate. It does not seem possible to reconcile the aim of the single nationality family with the aims of the Convention. States will thus have to determine which of the rules prevails and renounce either of the treaties.

The real bone of contention is the issue of equality in respect to the nationality of children, laid down in article 9.2. Recent authors on nationality law have so far scarcely discussed this provision ${ }^{64}$, at best merely mentioned that it is an innovating rule ${ }^{65}$.

Cyprus indicates that it will repeal its reservation concerning article 9.2 once the relevant law is amended. Jamaica and Jordan simply state that they don't not consider themselves bound by the provision. Thailand, in a reservation withdrawn in 1991, and Tunisia reserved their obligations under article 9.2 with a view to national legislation. Egypt bases its reservation on the fact that as two nationalities may be prejudicial to the future of the child, children acquire their father's nationality. Moreover women, on marrying an alien, commonly agree to their children having their father's nationality, and this does not infringe on the equality between men and women. As with the Turkish reservation before, it should be underlined that the object of the Convention has not been to restrict bipatridy.

As far as article 9.2 is concerned, the question is not only what the practical consequences of this provision will be $e^{66}$, but whether equal treatment in relation to the nationality of offspring is of such importance that it is essential to the Convention's object and purpose. Here in particular, object and purpose demonstrate their inaccuracy as a yardstick. While the rule laid down in article 9.2 is well balanced and follows logically from the Convention's notion of equality, it raises the question of the acceptability of reservations on the fringe of the object and purpose of a treaty.

- article 10 -

The elimination of discrimination in education implies not only equal access to the same education, but also demands the elimination of stereotypes in educational material. Equal opportunities in education are vital for achieving the Convention's aim, and this rather extensive provision is of great importance.

\section{3.(...continued)}

multiple nationality, Strasbourg 6 May 1963.

G.R. de Groot, Gelijkheid van man en vrouw, at 67-93.

64. G.R. de Groot, Staatsangehörigkeitsrecht im wandel, 's Gravenhage, 1988 at 29; M. Tratnik, Het nationaliteitsrecht in de Oosteuropese landen, Deventer, 1989 at 45.

65. Burrows, op.cit. at 434; M.-H.Marescaux, Nationalité et Statut Personnel dans les instruments internationaux des Nations Unies, in: M.Verwilghen, Nationalité et Statut Personnel, Bruxelles, 1984; $15-72$ at 64-65; H.U.Jessurun d'Oliveira, Nationaliteit, in: Internationaal Recht en Vrouwen, Zwolle, 1987, 279-291 at 287.

66.

Burrows, op.cit. at 434 ; d'Oliveira, op.cit. at 287. 
Two states have so far made reservations in respect to article 10. Thailand made a reservation dealing with national security, public order and the military" The reservation could have been a simple national legislation reservation, had it not been referring to the link between security interests and the right to education in article 10, which makes the scope of the reservation very uncertain. An explanation could be that student revolts have created internal political problems.

The United Kingdom in its reservation ${ }^{68}$ refers to the obligation to guarantee parental choice in education ${ }^{69}$, and the liberty to establish educational institutions $^{\text {To }}$. It is unlikely that the Convention would restrict the rights mentioned, and a reservation may not be necessary. The British declaration is however formulated as a reservation, and indicates a priority between different human rights instruments.

Another reservation of the United Kingdom concerns article 10.c. It underlines that the central Government has a limited ability to influence educational methods, as many aspects of teaching are within local control ${ }^{71}$. Furthermore the reservation excludes the obligation to solely encourage co-education. Whether the Convention contains such a strict obligation is uncertain, as the article reads: "...by encouraging coeducation and other types of education which will help to achieve this aim (that is, the aim of eliminating any stereotyped concept of the roles of men and women at all levels and in all forms of education) ${ }^{n 7}$. In view of recent discussions on the advantages of separate education as a way of strengthening the self-confidence of girls, the interpretation of article 10.c ought not be too restrictive.

- article 11 -

Article 11 deals with equal treatment in the field of employment. The first paragraph contains general rules, the second one deals with the prohibition of discrimination on grounds of marriage and maternity, whereas the third paragraph contains the obligation to periodically review protective legislation.

Amongst the reservations dealing with article 11, there are a good many dealing with the protection of women. Wadstein's analysis on the issue of protection seems quite correct:" $(W)$ ith reference to the need to 'protect motherhood', States

67. The reservation reads:" In all matters which concern national security, maintenance of public order and service or employment in the military and paramilitary forces, the Royal Thai Government reserves its right to apply the provisions of the Convention on the Elimination of all Forms of Discrimination against Women. in particular articles 7 and 10 , only within the limits established by national laws. regulations and practices."

68. The lay-out of ST/LEG/SER.E/11 almost hides the reservation 10 arlicle 10 . While the numbers of the articles are underlined in the other reservations made by the United Kingdom, this is missing as concerns article 10. Although one does not know if this is a precise transcription of the British original, no doubt some editing on the part of the Secretariat could have improved the legibility of the document.

69. As laid down in article 2 of the First Protocol to the ECHR and article 13.3 CESCR.

70. As laid down in article 13.4 CESCR.

71. On the same problem see Meron, op.cit. at 69-71.

72. Burrows, op.cit. at 437; Meron, op.cit. at 70. 
Parties still uphold protective legislation stipulating that women are not allowed to work at night...- - or to carry out dangerous and unhealthy work in certain branches of the economy ... Such protection ... reflects gender-stereotyping and implies overemphasis on the reproductive role of women. ${ }^{n 73}$

The United Kingdom declares that the content of 11.1.a must be taken to be the same as that of article 6 of the Covenant on Economic, Social and Cultural Rights. With regard to the right of equal remuneration Canada, in a declaration withdrawn in 1992, stated its national practice, and indicated that the object and purpose of article 11.1.d are a guideline for the further development of policy on the issue.

Probably the most blunt reservation to article 11 has been made by Mauritius, which simply states that it does not consider itself bound by provisions 11.1.b (the right to the same employment opportunities) and 11.1.d (the right to equal remuneration for work of equal value). In view of the object and purpose of the Convention, the compatibility of the reservation of Mauritius is highly questionable. A similar reservation to article 11.1.b by Thailand has been withdrawn in 1991.

Night work by women, and protective legislation are mentioned by Austria and Thailand in relation to article 11. Both refer to the prevalence of their national legislation $^{74}$. Malta's reservation to article 11 specifically deals with maternity protection, mentioning article 4.2 CEDAW and the health and safety of women and the human foetus.

Ireland in its reservation equates the content of the articles 11.1.b, $\mathrm{c}$ and $\mathrm{d}$ with its national legislation to implement the European Community standards on equal opportunities. Although the reservation seems to indicate the priority of one treaty over another ${ }^{75}$, it is a plain and simple reservation favouring national legislation. Another Irish reservation with respect to article 11.1, withdrawn in 1986, also referred to national legislation on the rights of married women in social security schemes.

The United Kingdom made a long-winded reservation in relation to article 11. It deals with protection, and in particular favours ILO Convention 45 (Convention concerning the employment of women on underground work in mines of all kinds) to articles 11.1 and 4.2 of the Convention ${ }^{76}$. Then the reservation deals with national legislation, not only legislation in force but also future legislation that will be compatible with the Convention. The problem with this reservation is not so much that the United Kingdom indicates that it will maintain current

73. Wadstein, op.cit. at 16. Cf. N.Kaufman Hevener, An Analysis of Giender Based Treaty Law: Contemporary Developments in Historical Perspective, in: 8 HRQ 1986, 70-88 at 73, 82-86; Cook, Women's Convention at 696-698; Meron, op.cit. at 73-77 and the "Note on the Question of Compatibility between the UN Convention on the Elimination of All Forms of Discrimination against Women and Certain ILO Conventions on the Protection of Women" in: 68 ILO Official Bulletin 1985. Ser.A, no.1, 40-42.

74. Hevener, op.cit. at 71 .

75. Cf. article 23.b CEDAW.

76. Hevener, op.cit. at 71. 
legislation, but the pretentious claim that future legislation will be compatible with the Convention ${ }^{77}$. Of course, any State Party to the Convention must be expected to legislate in conformity with the Convention, but who is to decide on the compatibility of legislation? One could argue that this is within the competence of the Committee, at any rate a reservation is not a carte blanche for future legislation. A similar reservation referring to ILO Convention 45 had been made by New Zealand, and it was withdrawn in 1989 .

The second paragraph of article 11 contains in sub-section b, a provision that urges states to take measure to ensure paid maternity leave. Both Australia and New Zealand reserve the right not to apply this provision, Australia explicitly indicating in which parts of the country paid maternity leave is available, thereby restricting its reservation.

The United Kingdom in respect to article 11.2 states that it reserves the right to apply any non-discriminatory requirement for a qualifying period of employment or insurance. As article 11.2 deals with the specific situation of women, matters such as pregnancy, maternity and the combination of family obligations with work responsibilities, it is hard to see how a qualifying period could be applied in a non-discriminatory way. The reservation seems to run contrary to the Convention's notion of equality ${ }^{78}$.

\section{- article 13 -}

This article provides for the elimination of discrimination in different areas of economic and social life, and involves matters like family benefits, bank loans as well as recreational activities.

Ireland indicates that it is considering whether additional legislation governing access to financial credits is necessary, and makes a reservation for the time being. Article 13 requests gradual implementation and the Irish reservation indicates that it has a temporary character. Another Irish reservation dealing with article 13.a and national legislation on social welfare benefits had been withdrawn in 1986.

The United Kingdom seems to reserve discriminatory tax legislation, at least as far as the reservation is concerned, the taxation of married women appears to be completely dependent on their husbands taxation, not only in respect to the assessment, but also in relation to the right to appeal ${ }^{79}$. This last element would

77. It reads (twice):"This reservation will apply equally to any future legislation which may modify or replace such legislation.... on the understanding that the terms of such legislation will be compatible with the United Kingdon's obligations under the Convention."

78. Cf. article 5.b CEDAW.

79. Although the technicalities of British tax legislation are beyond the scope of this thesis, it is illustrative to repeat parts of the reservation :"... to continue to apply the income tax and capital gains tax legislation which:

i) deems for income tax purposes the income of a married women living with her husband ... to be her husband's income and not to be her income (...); and

(continued...) 
seem to be an implicit reservation to article 15.2 CEDAW, the right to be treated equally in all stages of procedure in courts and tribunals ${ }^{80}$. It is noteworthy that the reservation does not even try to uphold the varnish of equality ${ }^{81}$. Malta made similar reservations to article 13: it reserves the right to apply discriminatory tax legislation in which the income of married women is deemed to be the income of her husband; and it reserved the right to apply discriminatory social security legislation which makes benefits payable to the husband as head of the household.

Moreover, Malta made a reservation in respect of articles 13,15 and 16 that it would be applying present family and property law until changes in that field had been concluded.

\section{- article 14 -}

The problems of rural women are dealt with in article $14^{82}$. It has been said that in particular the second paragraph of the article contains programmatic provisions, so that it will be hard to determine whether or not a state fulfils its obligations.

France is the only state to have made interpretative declarations with respect to this provision. The first one deals with article 14.2.c, and holds that women who qualify have independent rights within the framework of social security. This would seem to be precisely the Convention's requirement, although it seems somewhat strange to bring this up in relation with article 14, article 11.1.e being the general rule on social security. The second declaration deals with the fact that the services mentioned in article 14.2.h (the enjoyment of adequate living conditions) need not be free of charge. There is indeed no such implication in the provision, it merely deals with the elimination of discrimination in the enjoyment of these living conditions.

- article 15 -

Equality before the law is for certain one of the most vital provisions of the Convention. Apart from this, article 15 also deals with the right to an identical

79.(...continued)

ii) requires tax in respect of such income and of chargeable gains accruing to such a married woman to be assessed on her husband (...) and consequently (...) restricts to her husband the right to appeal against any such assessment and to be heard or to be represented at the hearing of such appeal;

iii) ...

The fact that the reservation so specifically refers to gender and marital status(cf. article 1 CEDAW) as a decisive element in tax legislation implies that this is a case of direct discrimination.

80. Discussing this same issue in the Lindsay v. United Kingdom case before the European Commission on Human Rights (9 Eur.H.R.Rep. 1986, 55), R.J.Cook, International Human Rights Law Concerning Women: Case Notes and Comments, in: 23 VaJTL 1990, 779-818, at $808-809$.

81. Wadstein, op.cit. at 18.

82. Burrows, op.cit at 446-448, Delbrück, op.cit. at 260. Hevener, op.cit. at $75-76$. 
legal capacity, the prohibition of contracts restricting women's legal capacity as well as the right to movement and the right to choose residence and domicile ${ }^{83}$. In an interpretative declaration the United Kingdom states that it understands "legal capacity" as referring merely to the existence of a separate and distinct legal personality. As this seems to be the ordinary meaning of the term ${ }^{84}$, one fails to see the necessity of this declaration.

Belgium in its reservation to articles 15.2 and 3, refers to an interim law providing as a transitional rule that couples could choose to maintain their prior (and discriminatory) marriage contracts. France made a reservation with respect to articles 15.2 and 15.3, which was withdrawn in 1986 when the discriminatory legislation had been amended.

Thailand, in a reservation withdrawn in 1991, simply stated that it did not consider itself bound by article 15.3, the prohibition of contracts restricting the legal capacity of women. Although there is no obligation to motivate reservations, this statement demonstrates complete indifference to woman's rights, and would seem to be distinctly in conflict with the object and purpose of the Convention. The reservation by Ireland dealing with article 15.3 states that it would not supplement existing legislation already according identical legal capacity to women to give effect to this provision. The idea is apparently that legislation in accordance with article 15.2 (legal capacity) renders article 15.3 superfluous. It would seem correct that if states are obliged to afford identical legal capacity to women, private parties can a fortiori not restrict legal capacity.

The United Kingdom, on the other hand restricts article 15.3 by stating that only the discriminatory part of the contract, and not the entire contract, would be void. Although there may be some merit in this approach from the point of view of the law of contracts, there is on the other hand much to be said for complete nullity such as the Convention provides for. It does justice to the fundamental nature of the right to legal capacity.

The Convention's rule on movement and the right to choose a residence in article 15.4 CEDAW has not had a favourable reception ${ }^{85}$. Brazil, Jordan, Tunisia and Turkey all exclude the provision. Ireland made a reservation which was withdrawn in 1986, after the amendment of the relevant legislation. The Brazilian and Jordanian reservations are not motivated, whereas Tunisia and Turkey state that the provision is not compatible with national legislation ${ }^{86}$. A question

83. Cook, Women's Convention at 699-702: Sullivan, op.cit. at 845 .

84. Cf. article 31 VCLT.

85. Wadstein, op.cit. at 19.

86. The Tunisian reservation contains the rather ambiguous formulation "[I]n accordance with the provisions of the Vienna Convention on the Law of Treaties, the Tunisian Government emphasizes that the requirements of article 15.4 .... must not be interpreted in a manner which conflicts with the provisions of the Personal Status Code..".

The provisions of the Vienna Convention to which the reservation refers are somewhat misty. It might be that Tunisia purported to deliver an "instrument which was made by one or more parties in connection with the conclusion of the treaty" as mentioned in article $31.2 . b$ of the Vienna Convention, thereby providing a context for the interpreta-

(continued...) 
arising in this respect would be the link between article 15.4 CEDAW and article 12.1 CCPR, also dealing with freedom of movement and the right to choose a residence $^{87}$.

- article 16 -

The extensive provision on matters relating to marriage, family relations and in general the personal status of women has been the object of many reservations $^{28}$. Treaty provisions determining the personal life of women, and consequently the life of men, are threatening which may explain the large amount of reservations ${ }^{89}$.

The United Kingdom remarks that it does not regard the interests of the child as directly relevant to the elimination of discrimination of women, and indicates that the interests of the child do not have the same impact in matters of adoption as in matters of custody ${ }^{90}$. The British statement need not be considered a reservation, for the object of the provision was not to lay down rules with an eye to promoting child welfare. However a future clash between women's rights and children's rights, embodied in the Convention and the Convention on the Rights of the Child may be possible ${ }^{91}$. Israel indicates in its reservation that the laws of various religious groups do not conform with the provisions of article 16 . Thailand merely indicates that it does not consider itself bound by article 16 .

One of the very basic rights is embodied in article 16.1.a, the right to enter into marriage. Brazil, without further explaining the reasons why, expressed its

\section{6.(...continued)}

tion of this provision in the Tunisian situation. If that was the intention, the Tunisian approach is bound to fail as the ordinary meaning of article 15.4 CEDAW within its context, given the object and purpose of the CEDAW can be established beyond doubt, in accordance with article 31.1 VCLT.

87. Brazil. Jordan and Tunisia are all parties to the CCPR and ought to have made a similar reservation in respect to the CC.PR provision, as it reads "[E]veryone (this includes women, EL) lawfully within the territory of a State". However, no such reservations have been made. It is hard to understand that the more general provision article 12.1 CCPR is compatible with national legislation, whereas the more specific rule of article 15.4 CEDAW is not.

88. Fourteen states have made reservations to article 16, of these reservations seven (two withdrawn) aim at article 16.1.c (responsibilities and rights during marriage and at its dissolution), six (two withdrawn) deal with article 16.1.d (rights and responsibilities as parents), five (one withdrawn) deal with article 16.1.f (guardianship) and eight reservations are aimed at article 16.1.g (personal rights as husband and wife).

89. Burrows, op.cit. at $450-452$ presenting the background of this provision and predicting some of the problems that were to arise: Cook, Women's Convention at 669-670; 702706; S.Wright, Human rights and Women's rights: an Analysis of the United Nations Convention on the Elimination of all Forms of Discrimination against Women, in: Human rights in the twenty-first century: A Global Challenge, K.E.Mahoney and P.Mahoney eds., Dordrecht 1993, 75-88 at 82-85.

90. The reservation reads:"and declares in this connection that the legislation of the United Kingdom regulating adoption, while giving a principal position to the promotion of the children's welfare, does not give to the child's interests the same paramount place as in issues concerning custody over children."

91. GA Res.44/25, 20 November 1989. 
reservation conceming this provision. It should be noted that the Convention distinguishes between the right to enter into marriage in sub-paragraph a, and the right to choose a spouse and to enter into marriage with free and full consent in sub-paragraph b. It is noteworthy that Brazil has recently become a party to the CCPR, which in articles 23.2 and 3 provides for the right to marry provided that man and woman are of marriageable age, to found a family and to enter into marriage with free and full consent.

The obligation to ensure the same rights and responsibilities during marriage and upon its dissolution, provided in article 16.1.c, has been excluded by various states. Without any explanation Brazil, Jordan, the Republic of Korea and Tunisia merely indicate their reservation to this provision. Korea has since then withdrawn its reservation, as has France as a consequence of changes in legislation. Turkey indicates the prevalence of national legislation (the Turkish Civil Code), whereas Bangladesh does the same stating that the provision conflicts with Sharia law.

Article 16.1.c CEDAW is matched by article 23.4 CCPR. Tunisia, is a party to both the CCPR and the Convention, yet it never made a reservation in respect of article 23.4 CCPR.

The equality of rights between parents, irrespective of their marital status is dealt with in article 16.1.d, and here again Jordan, the Republic of Korea and Tunisia made reservations without a clarification as to the necessity of the reservations. Korea withdrew its reservation in 1991. Turkey again states that the provision is not compatible with its Civil Code. Both France and Ireland delve deeper into the substance of the provision. Ireland links article 16.1.d and 16.1.f on the point of children born out of wedlock, and declares as its understanding that the Convention does not necessitate legislative action to accord equal rights to men in respect of these children. This interpretation seems in line with the object of the Convention, the burden of single-parent families usually resting on the mother's shoulders. France makes a reservation in view of its national legislation, stating that article 16.1.d does not preclude the application of article 383 of its Civil Code ${ }^{92}$. The advantage of this particular reference to national legislation, in comparison with the Turkish reservation, is the precision with which the reserving state restricts the scope of its reservation. The reservation was withdrawn in 1986

Article 16.1.e deals in a very general way with equal access to family planning. Malta indicates that it will not understand this provision as imposing an obligation to legalize abortion. The Maltese reservation is over-cautious, as the Women's Convention is generally considered not to contain a right to abortion.

Although the Convention provides for equality with regard to guardianship, trusteeship and the adoption of children in article 16.1.f, this is subject to the 
interests of the children". Again neither the Republic of Korea nor Tunisia elaborate on the necessity of their reservation, whereas Turkey refers to the incompatibility of the provision with national legislation. Korea withdrew its reservation in 1991. Bangladesh states that it will not be bound by article 16.1.f because of its incompatibility with Sharia law.

Article 16.1.g provides for the equality between husband and wife with regard to personal rights. Brazil, Jordan, Mauritius and the Republic of Korea do not elaborate on their reservation to this provision, whereas Tunisia and Turkey prefer to uphold their national legislation. Both France and Luxembourg reserve their position as regards the right to choose a family name, mentioned in article 16.1. $\mathrm{g}^{\text {at }}$.

The provision on equality between both spouses in the administration of property, as laid down in article 16.1.h, has led to reservations by Brazil and Tunisia. The latter indicate that the provision must not conflict with the provisions of national legislation on the acquisition of property through marriage. A reservation by France dealing with national legislation and article 16.1.h was withdrawn in 1986.

The United Kingdom formulated a rather broad reservation in respect of article 16.1 as a whole, but it would seem that the reservation actually refers at subparagraph $h$. The reservation reads: " $\ldots$ shall not be treated as either limiting the freedom of a person to dispose of his property as he wishes or as giving a person a right to property the subject of such a limitation". Here, as before, the lack of information on the Convention and its drafting history make it hard to sketch the possible impact of the reservation.

- Reservations invoking Sharia law -

A subject that deserves separate attention are the reservations referring to the overriding importance of Sharia law. Islamic law is often considered to be discriminatory towards women per se and so far it has been hard to reconcile the cause of women's rights with Islamic law ${ }^{95}$. The Committee has made an abortive attempt in 1987-1988 to initiate a study into the rights of women under Islamic law, but this idea has not had a favourable reception, to say the least ${ }^{\text {to }}$.

Four states explicitly invoke Sharia law in their reservations, whereas the reservations of two other states seem based on the codification of Sharia as domestic family law ${ }^{97}$. The Libyan reservation is sweeping and far-reaching, it

93. Cf.the United Kingdom's declaration with respect to article 16.

94. The Luxembourg reservation is formulated confusingly:"The application of paragraph 1 (g) of article 16 of the Convention shall not affect the right to choose the family name of children."

95. Byrnes, The Work of the Committee at 53-54; Cook, Etnische culturen at 52-53; Jacobs, op.cit. at 81-84; Lijnzaad, Voorbehouden at 107; Sullivan, op.cit. at 834-848.

96. Byrnes, The Work of the Committee at 54-55; Clark, op.eit. at 287-288; Jacobs, op.cit. at 85.

97. Reservations by Tunisia and Turkey. 
completely submits accession to the Convention to Sharia law ${ }^{98}$. The reservations of Egypt $^{99}$, Iraq ${ }^{100}$ and Bangladesh ${ }^{101}$ mention the provisions that conflict with Sharia law. It is noteworthy that the reservations differ and that these states hold different opinions on the compatibility of the various provisions with Sharia law $^{102}$. Iraq simply states that it will not be bound by article $2 . \mathrm{f}$ and $2 . \mathrm{g}$, without providing any reasons for the reservation.

The very least a reserving state should do is indicate with precision which provisions of the Convention are affected by its reservation ${ }^{103}$. It can after all not expect its co-contractants to have a full insight into its national (religious) laws. The construction used by Bangladesh, Egypt and Iraq in their reservations, mentioning not only the prevalence of sharia law but also the articles of the Convention to which the reservations apply, is thus preferable to the generality of

98. The Libyan acceded "subject to the general reservation that such accession cannot conflict with the laws on personal status derived from Islamic Sharia."

99. The Egyptian reservation reads:

General reservation on article 2

The Arab Republic of Egypt is willing to comply with the content of this article, provided that such compliance does not run counter to the Islamic Sharia.

In respect of article 16

Reservation to the text of article 16 concerning the equality of men and women in all matters relating to marriage and family relations during the marriage and upon its dissolution, without prejudice to the Islamic Sharia's provisions whereby women are accorded rights equivalent to those of their spouses so as to ensure a just balance between them. This is out of respect for the sacrosanct nature of the firm religious beliefs which govern marital relations in Egypt and which may not be called in question and in view of the fact that one of the most important bases of these relations is an equivalency of rights and duties so as to ensure complementarity which guarantees true equality between the spouses. The provisions of the Sharia lay down that the husband shall pay bridal money to the wife and maintain her fully and shall also make a payment to her upon divore. whereas the wife retains full rights over her property and is not obliged to spend anything on her keep. The Sharia therefore restricts the wife's rights to divorce by making it contingent upon a judges ruling whereas no such restriction is laid down in the case of the husband.

Two other reservations dealing with articles 9 and 19 do not mention Sharia.

100. The Iraqi reservation reads:

"Approval of and accession to this Convention shall not mean that the Republic of Iraq is bound by the provisions of article 2. paragraphs $(f)$ and $(\mathrm{g})$, of article 9, paragraphs 1 and 2, nor of article 16 of the Convention. The reservation to this last-mentioned article shall be without prejudice to the provisions of the Islamic Shariah according women rights equivalent to the rights of their spouses so as to ensure a just balance between them."

101. The Bangladeshi reservation reads:

"The Government of the People's Republic of Bangladesh does not consider as binding upon itself the provisions of article 2, 13(a) and 16.1(c) and (f) as, they conflict with Sharia law based on Holy Quran and Sunna."

102. Bangladesh mentions article 2, 13.a, 16.1.c and f; Egypt mentions article 2 and 16; Iraq only mentions article 16 ; cf. Clark op.cit. at 300 .

103. Byrnes, The Work of the Committee at 53; Clark, op.cit. at 310-312; Cook, Women's Convention at 655 and supra Chapter 3, par.2.1.2 on the specificity requirement. 
the Libyan statement, or the vagueness of the Tunisian and Turkish referrals to national legislation.

The reservations invoking sharia law appear to be detrimental to the Convention's goal of eliminating discrimination, and at the same time they entail problems related to freedom of religion (and religious law) as well as the question of cultural relativism in respect of human rights ${ }^{104}$. There are different ways of looking at the problem and some will be explored here. Basically one could distinguish between an approach based on the law of treaties, which has the advantage of avoiding the delicate subject of cultural relativity, and an approach based on human rights law, which may raise questions of conflict of rights. In the following various lines of argument will be presented.

\subsubsection{Pacta sunt servanda}

From the point of view of the law of treaties, the obligation to respect the object and purpose of the Convention is not necessarily a notion alien to islamic law. The prohibition of incompatible reservations as laid down in article 28.2 CEDAW and article 19.c VCLT, is the logical correlate of pacta sum ser$v a n d a^{105}$. There is no doubt that islamic states are bound by this prohibition. As Arzt explains, the principle of 'siyar' in islamic international law is the equivalent of the pacta sumt servanda rule $e^{106}$.

Making reservations is based on treaty interpretation, and anticipating the consequences of ratification. Should the States Parties have understood the meaning of the provisions, and have they been able to foresee domestic problems? If the provisions themselves are not clear, has their content been clear during the drafting? Whether this is the case can only be established on the basis of the travaux préparatoires.

If the implication of the Convention and its provisions was clear prior to ratification, and there is no reason to suspect otherwise, the states must have understood that they would not only literally be bound by the Convention because of their ratification, but that it also entailed the obligation not to undermine its object and purpose. In other words, if the conflicts between Sharia and the Convention were foreseeable, the islamic states ought to have refrained from ratifying, as they knew they would not be able to fulfil the obligations contained therein. This is a logical line of argument based upon the principle of good faith. Yet, it has the disadvantage of giving up the quest for universality in the form of global adherence.

104. Cook, Etnische culturen at 53: Jacobs, op.cit. at 84-85; L.Lijnzaad. Het maken en breken van internationaal recht voor vrouwen (hereafter: Maken en Breken), Nemesis 1993.6, 211-214.

105. See for a discussion of article 19.c VCLT Chapter 2, par.3.1.2 and par.4.3 supra.

106. D.E.Arzt, The application of International Human Rights Law in Islamic States, in:12 HRQ 1990, 202-230, at 212-213; Jacobs, op.cit. at 83. 


\subsubsection{National legislation}

Another way of looking at these reservations would be to say that they belong to the major category of reservations purporting to uphold national legislation ${ }^{107}$. Islamic Sharia law is to be understood as national legislation. This does justice to the rule that an islamic state must comply with, and maintain the divine law, as states must in general comply with domestic law ${ }^{108}$. The difference between the four States explicitly mentioning Sharia, and Turkey and Tunisia mentioning their personal status legislation, thus disappears.

Islamic countries are no longer singled out and their reservations are treated as a standard type of reservation. This approach is less prejudicial and might remove the emphasis on the religious background of the reservation. It does however not solve the compatibility question. As such, reservations indicating the prevalence of national legislation are very undesirable because national law does not in general have priority over international law ${ }^{109}$. Reliance on domestic law over international law leads to insecurity for the co-contractants, and is contrary to the progressive development of the international protection of human rights.

\subsubsection{Conflicting human rights}

An approach based on human rights law will lead to the conclusion that reservations invoking Sharia law point to conflicting norms. In particular, there would seem to be a conflict between freedom of religion and the equality rule. As Meron indicates, there are two main areas of conflict, namely the legal status of women under religious law and religious practices concerning marriage and the family ${ }^{110}$. Although he suggests a balancing of interests, the example given is not particularly convincing and reveals a distinct gender bias. The focal point for Meron seems to be whether discrimination hampers women's ability to function in society ${ }^{\prime \prime \prime}$.

Regretfully Meron misunderstands the nature of women's discrimination and the fact that its persistence depends if anything on the structure of the family ${ }^{112}$.

107. Lijnzaad, Voorbehouden at 107; Sullivan, op.cit. at 807.

108. Jacobs, op.cit. at 82-83; Clark, op.cit. at 317 .

109. For a discussion of reservations giving prevalence to national legislation see Chapter 3 . par.2.1.1 supra.

110. Meron, op.cit. at 77-80 and 155-160.

111. Meron, op.cit. at 159:". the interests in preserving the privacy of the family and respecting. in so far as is possible without eviscerating the Convention, religious freedom suggests that a balancing of the interests involved should be attempted. Thus, religious practices within the family which have relatively less significance for women's ability to function as full human bcings in society [my emphasis, EL] might be permitted even though those practices perpetuate stereotyped roles, while practices which impair women's ability to exercise their rights and foreclose opportunities to function outside stereotyped roles (...) must not be allowed." Idem at 62-63.

112. Similarly the criticism by Zearfoss, op.cit. at 917-920. At 918-919 she writes:"Yet, if one cannot legislate against an abusive practice because there is a religious tradition behind it, the ability to deal with discriminatory abuses is radically weakened. If the international convention is meant to address human rights abuses against women is fettered by 
The impact of religiously inspired discrimination within the family is by no means of lesser importance than overt discrimination in society. Rather, there is a causal connection between discrimination in the private sphere and the existence of formalized discrimination in public life.

It would appear that, although balancing seems a reasonable approach, it will in practice be hard to find an equilibrium that is not prejudicial to the position of women. Given the fundamental character of freedom of religion and the equality rule it is neither possible nor acceptable to determine in general which of both has priority ${ }^{113}$.

The ways in which the problem has been dealt with here, merely serve as an explanation, but do not provide solutions. Sharia being religious law makes it all the more understandable that States are reluctant to object.

\section{REACTIONS OF THE STATES PARTIES}

\subsection{Objections}

The sometimes far-reaching and detrimental reservations to substantive provisions have met with only a few objections ${ }^{114}$. As the reservations are circulated by the depository of the Convention, all States Parties are able to consider the reservation and possibly formulate a reaction in the shape of an objection. In fact, seven States objected. Denmark, Norway, and Finland objected to the reservation by Libya. The Federal Republic of Germany, Mexico, the Netherlands and Sweden objected to a great number of reservations ${ }^{115}$. These four States showed perseverance and consistency in their objections.

A general pattern of objections can be discerned. All four states objected to reservations by Bangladesh ${ }^{116}$, Egypt $^{117}$, Iraq ${ }^{118}$, Jamaica ${ }^{119}$, Libya ${ }^{120}$,

\section{2.(...continued)}

concern over religious rights, its potential effectiveness vis-à-vis women will be diminished. .... it is inappropriate to require that the balancing of women's rights and religious rights undertaken by the Women's Convention, or to suggest that guarantees of women's rights must accommodate religious rights instead of the other way around."

113. Sullivan, op.cit. at 821-823.

114. Painting a too optimistic picture, Oeser, Legal questions, at 95:" This matter (reservations, EL)... aroused the interest of a number of States Parties to the Convention. More and more objections to certain reservations made by other States Parties to the Convention were being received."

115. Portugal and Saint Lucia used the inquiry about reservations to the CEDAW by the Secretary General $(A / 41 / 608)$ to object to a variety of reservations. Both States had been parties to the CEDAW for some time by then (Portugal ratified on 30 July 1980 , Saint Lucia on 8 October 1982: their statements date respectively from 11 August 1986 and 18 June 1986) and should have objected according to the rules laid down in articles 20.5 and 23.1 of the Vienna Convention. Their objections were superfluous remarks in the Secretary General's survey.

116. Reservations to articles 2, 13.a. 16.1.c and f. 
Malawi $^{121}$, Mauritius ${ }^{122}$, the Republic of Korea ${ }^{123}$ and Thailand ${ }^{124}$. Some of the objections are shared by only two of the above mentioned states, the Federal Republic, the Netherlands and Sweden objected to reservations by Brazil $^{125}$ and Tunisia ${ }^{126}$, whereas Sweden en Mexico objected to the reservations of New Zealand on behalf of the Cook Islands ${ }^{127}$ and West-Germany, the Netherlands and Mexico objected to the reservations by Turkey ${ }^{128}$. Mexico is the only state objecting to the reservation made by Cyprus ${ }^{129}$. However it should be stressed that a number of objections were made beyond the time-limit set by article 20.5 VCLT $^{130}$.

It is important to look at the motivation states provide with their objections. The Federal Republic stresses that the reservations objected to are incompatible with the object and purpose of the Convention and in particular contrary to article 28.2. It states that the reservations may not be invoked "in support of a legal practice which does not pay due regard to the legal status afforded to women and children in the Federal Republic in conformity with the articles mentioned." This part of the objection seems to exclude the reciprocity reservations would otherwise have had in accordance with article 21 VCLT, and also restricts the territorial impact of the reservations made ${ }^{131}$.

Mexico in its objections links the invalidity of the reservations to other obligations incumbent on the reserving states. The reserving states face the reproach of acting inconsistently with regard to the non-discrimination obligation as laid down in article 1.3 of the United Nations Charter, articles 2.1 and 3 CCPR and articles

117.(...continued)

117. Reservations to articles 9.2 and 16.

118. Reservation to articles $2 . f$ and g. 9, 16.

119. Reservation to article 9.2.

120. General reservation with respect to prevalence of Sharia in personal status law.

121. Reservation in respect of traditional customs. The Mexican objection is merely a communication. It reads: The Government of the United Mexican States hopes that the process of eradication of traditional customs and practices referred 10 in the first reservation of the Republic of Malawi will not be so protracted as to impair fulfilment of the purpose and intent of the Convention."

The formulation is much weaker than the formulation of the other Mexican abjections, and indeed it might be doubted whether this was an objection at all. The UN Secretariat listed the statement in the 'notes' section of ST/LEG/SER.E/11.

C. Clark, op.cit. note 115 at 299.

122. Reservations to article $11.1 \mathrm{~b}$ and d, 16.1.g.

123. Reservations to article 9 and 16.1.c, $d, f$ and $g$.

124. Reservations to articles 9.2, 15.3 and 16. The Federal Republic of Germany also objected to the Thai reservations concerning articles 7. 10. and 11.1.b CEDAW.

125. Reservations to articles 15.4, 16.1.a, $c, g$ and $h$.

126. Reservations to article $9.2,15.4$ and 16.

127. Reservations to articles 2.f and 5.a.

128. Reservations to articles 15.2 and $4 ; 16.1 . c, d, f$, and $g$.

129. The Mexican objection seems rather rash, as the reservation to article 9.2 indicates that it will be withdrawn once the relevant law is amended.

130. Discussing the objections, Clark, op.cit. at 298-302; about the twelve months rule at $312-$ 314.

131. Cr. Clark, op.cit. at 319. 
2.2 and 3 ESCR as well as the Universal Declaration of Human Rights binding on the basis of customary international law ${ }^{132}$. The advantage of the Mexican objection is that the conduct of states in international treaty relations is measured by standards they themselves set when ratifying prior treaties ${ }^{133}$. On the other hand, the Mexican objection is rather broad and does not distinguish between reservations contrary to object and purpose, and reservations on the fringe of object and purpose ${ }^{134}$. It is after all conceivable that there are reservations that, while restricting the Convention's sometimes very detailed anti-discrimination provisions, do not undermine the core obligations of Convention.

The Swedish objection is of a more legalistic nature ${ }^{135}$. While the matter of inconsistency with other human rights obligations is mentioned in much the same way as Mexico did, the objection furthermore elaborates on the logical and legal necessity of upholding the Convention's object and purpose ${ }^{136}$. The objection holds that incompatible reservations undermine the credibility of treaty law, as well as casting doubt on the intentions of the reserving state. This re-articulation of the obligations following from object and purpose may serve to strengthen provisions like article 19.c VCLT and article 28.2 CEDAW.

132. The objection reads:"The Government of the United Mexican States has studied the reservations made by ..., and had concluded that they should be considered invalid in the light of article 28 , paragraph 2 of the Convention, because they are incompatible with its object and purpose.

Indeed, these reservations, if implemented, would inevitably result in discrimination against women on the basis of sex. which is contrary to all the articles of the Convention. The principle of equal rights of men and women and non-discrimination on the basis of sex, which are embodied in the second preambular paragraph and article 1, paragraph 3 of the Charter of the United Nations, to which .. is a signatory, and in articie 2 and 16 of the Universal Declaration of Human Rights of 1948, were previously accepted by the Government of ... when it acceded, on ..., to the International Covenant on Civil and Political Rights and the International Covenant on Economic, Social and Cultural Rights. The above principles were stated in article 2, paragraph 1 and article 3 of the former Covenant and in article 2, paragraph 2, and article 3 of the latter. Consequently, it is inconsistent with these contractual obligations previously assumed by ... for its Government now to claim that it has reservations, on the same subject, about the 1979 Convention."

133. See supra Chapter 3, par.2.3, The interpretation of human rights instruments: coexistence and coherence.

134. A case in point would be provisions like article 9.2 (equality in respect of nationality of children) or article 16.1.g (equality in respect of the right to a family name).

135. Wright, op.cit. at 85 remarks that the objections do not refer to the impartance of article 16 CEDAW as crucial to women in general.

136. The objection reads:" .. the reason why reservations incompatible with the object and purpose of a treaty are not acceptable is precisely that otherwise they would render a basic international obligation of a contractual nature meaningless. Incompatible reservations, .., do not only cast doubt on the commitments of the reserving states to the objects and purposes of this Convention, but moreover, contribute to undermine the basis of international contractual law. It is the common interest of states that treaties to which they have chosen to become parties also are respected, as to object and purpose, by other parties." Cf. Clark, op.cit. at 319 . 
Another group of objections has political overtones, rather than concern for the Convention's content ${ }^{137}$. Thus token objections to West-Germany's ratification in respect of West-Berlin, as well as the United Kingdom's ratification in respect of the Falkland Islands were made by respectively the Soviet Union and Argentina. The Iraqi reservation that it will neither recognize Israel, nor establish treaty relations with that State, met with an Israeli objection. As far as Israel is concerned, the fact that the Iraqi reservation has an explicit political character implies that it is contrary to the object and purpose of the treaty. This reasoning is hard to follow, the Israeli objection seems to restrict the right only to enter into treaty relations if a State explicitly wants to do so, in a most dramatic way. It is unlikely that striving for global adherence is as intimately related to the object and purpose of the Convention as Israel pretends. The objection is a curiosity in every respect, as Israel which had not yet ratified the Convention, maintained that Iraq had acted contrary to the Convention's object and pur$\operatorname{pose}^{138}$.

\subsection{State Party meetings ${ }^{139}$}

The States Parties to the Convention meet every two year and have dealt with reservations on two occasions ${ }^{100}$.

For the third meeting, in February 1986, Canada asked for a "General exchange of views on the question of reservations" to be put on the agenda ${ }^{141}$. It is interesting that the State requesting the inclusion of this agenda item did not express its concern with reservations in any other way, for instance by objecting ${ }^{142}$. The States Parties were concerned that some of the reservations made

137. The UN Secretariat choose not to include these political objections in the objections' section of the ST/LEG/SER.E/11 document. it merely presents them in the 'notes' section. Although this might be explained by the limited impact of these political objections, it is not for the Secretariat to anticipate this in the editing of the document.

138. Israel objected on 12 December 1986. and ratified on 3 October 1991. Other than political motivation, the objection could only be explained by a sweeping interpretation of articles 18.1 and 20.5 VCLT.

139. Byrnes, The Work of the Committee nt.197 at 55; Cook, Women's Convention, at 708; Oeser, Legal questions, op.cit. at 95-96.

140. Unfortunately the Summary Records of the Mecting of the States Parties are not published, in accordance with the "Rules of Procedure of the Meeting of States Parties to the Convention on the Elimination of All Forms of Discrimination Against Women", CEDAW/SP/4, Annex II, dd.3-6-1982. This is hardly remedied by the publication of a document entitled "Decisions adopted.." which is a mere summary of decisions, not reflecting the issues in the discussion between the States Parties.

141. CEDAW/SP/8/Add.1; Clark, op.cit. at 283 .

142. In view of the lengthy reply by Canada on the question of incompatible reservations in A/41/608, the absence of objections is striking. Failure to object within 12 months implies acceptance of the reservation in accordance with article 20.5 VCLT.

It is, conceivable that Canada had concluded that objections could not be of any use given the Vienna Convention system on objections as well as the object of human rights treaties. Indeed the Canadian reply reads:"..the most productive approach to the

(continued...) 
could be incompatible with article $28.2^{143}$ and requested the Secretary-General of the United Nations to seek the views of the States Parties on this matter and to report upon the issue to the General Assembly ${ }^{144}$.

The matter was dealt with again in the fourth meeting of the States Parties in March $1988^{145}$, which lead to a meagre declaration in which previous decisions are recalled, and is taken note of the discussions on the issue in the General Assembly as well as in the Economic and Social Council ${ }^{146}$. This decision was the end of the attention of the States Parties meeting for reservations, as neither the summary report of the fifth meeting ${ }^{147}$, nor the sixth meeting ${ }^{148}$ contain any reference to the question of reservations.

A remarkable point to be mentioned is that the obligation for the SecretaryGeneral in article 28.1 CEDAW to receive and circulate all the reservations to all States, is at present being covered by issuing the list of reservations, declarations, objections and withdrawals as a States Parties document ${ }^{149}$. This seems to suggest that the reservations are primarily of importance to the States Parties, which is theoretically indeed the case. However, similar documents relating to other human rights instruments are issued as Committee documents, which seems much more in line with the role Committees have in monitoring the scope of reservations. Issuing the reservations as a Committee document is not necessarily in conflict with article 28.1 , the Secretary-General may be considered to have fulfilled this duty by publishing the bulky book "Multilateral Treaties Deposited With the Secretary-General" ${ }^{150}$.

\subsection{Withdrawal of reservations}

Fifteen States have so far already been able to withdraw reservations. Eight States withdrew their reservations to article 29.1 of the Convention, the provision on compulsory dispute-settlement by the International Court of Justice. As these reservations have not been elaborated on previously, this withdrawal will not be

142.(...continued)

question of incompatible reservations would be a multifaceted one: through discussions between States; through considerations at meetings of States Parties and at meetings of the Committee on the Elimination of Discrimination against Women (CEDAW), all with a view to arriving at a better understanding of the Convention." Apparently objections are, as far as Canada is concerned, not effective.

143. Although understandable, this formulation is contradictory because it is a double negation.

144. CEDAW/SP/10, the introductory paragraphs of UN doc.A/41/608 present the backgrounds.

145. CEDAW/SP/11; see Clark, op.cit. at 288.

146. CEDAW/SP/14.

147. CEDAW/SP/17.

148. CEDAW/SP/1992/4.

149. Cr. CEDAW/SP/13; CEDAW/SP/1992/2.

150. ST/LEG/SER.E/.., published annually. 
dealt with in depth. However, the extension of compulsory dispute settlement must be considered a positive development.

Canada, France, Ireland, Malawi, New Zealand, the Republic of Korea and Thailand decided to withdraw reservations to substantial provisions of the Convention. France first withdrew its reservation to article $7^{15 t}$, as new legislation had changed the law which had earlier necessitated the reservation. Two years later ${ }^{152}$, France withdrew its reservations to articles 15.2 and 3 , and 16.1.c and h, also because of changes in domestic legislation. It is noteworthy that when making the reservation France had not indicated its intention to change existing legislation, the reservations merely refer to national legislation not in conformity with the Convention. But apparently the reservations were considered temporary measures necessary to gain time so as to implement changes in legislation.

The withdrawal of the Irish reservations to articles 9.2, 15, 11.1 and 13.a was also a consequence of changes in legislation ${ }^{153}$. In formulating its reservations, Ireland had already indicated their temporary nature ${ }^{154}$. Thus when the necessary legislative changes had taken place, the country withdrew its reservations.

The withdrawal of the reservation by New Zealand, also on behalf of the Cook Islands and Niue is related to the denunciation of ILO Convention 45 (Employment of Women in Underground Work in Mines of all Kinds). This ended a peculiar situation in which New Zealand's reservation referred to Convention 45 which it had already renounced ${ }^{155}$.

In 1991, three States withdrew reservations. Malawi withdrew its much criticized reservation dealing with traditional customs. The republic of Korea withdrew it reservation to articles 16.1.c, 16.1.d and 16.1.f; whereas Thailand withdrew reservations to articles $11.1 . \mathrm{b}$ and 15.3 . Within a year later Thailand withdrew the reservation to article 9.2 . It should be noted that objections had been made to the reservations by Malawi, the Republic of Korea, Thailand and New Zealand. Also in 1992, Canada informed the Secretary General of the withdrawal of its declaration concerning article 11.1.d

151. The reservation was withdrawn on 26 March 1984. France had ratified the CEDAW on 14 December 1983.

152. The withdrawal took place on 21 July 1990.

153. The withdrawal took place on 19 December 1986, Ireland had acceded to the Convention on 23 December 1985.

154. The temporariness of the reservations was formulated as "[P]ending the proposed amendment to the law relating to citizenship, which is in an advanced stage.." (article 9.1) and "pending the coming into force of the Social Welfare (Amendment)(No.2) Act, 1985.." (articles 11.1 and 13.a).

155. New Zealand ratified the CEDAW on 10 January 1985, renounced ILO Convention 45 before 31 December 1987, and withdrew its reservation on 13 January 1989. C.. International Labour Conference, 75th Session 1988, List of Ratifications of Conventions (as at 31 December 1987), Report III (Part 5), at 36. 


\subsection{Consultations in other forums}

As mentioned above, the States Parties refrained from dealing in depth with the problem as other United Nations organs had already paid attention to reservations to the Convention.

\subsubsection{The Secretary General's survey}

In 1986 the General Assembly dealt with the report by the Secretary General, compiled at the request of the third meeting of the States Parties to the Convention $^{156}$. Complying with the request, the views of the States Parties on reservations that could be considered to fall within the scope of article 28.2 were invited. Of the 87 States parties at the time, 17 replied. Their reactions focus on various questions surrounding reservations to human rights treaties ${ }^{157}$. Some of the reservations have a limited significance ${ }^{158}$, or are based on an incorrect interpretation of the Convention ${ }^{159}$, but Sweden wams that a bundle of minor reservations may have an accumulative effect ${ }^{160}$.

The major issue is of course the object and purpose of the Convention, which is not defined in the Convention itself. A conclusive explanation of the object and purpose of the Convention by the States Parties could have been hoped for, but alas. Some states use the petitio principii that the goal of the Convention is the elimination of all forms of discrimination against women ${ }^{161}$ when explaining the essence of the Convention.

Both Canada ${ }^{162}$ and Spain ${ }^{163}$ elaborate on the content of the 'object and purpose' and the Canadian view in particular seems well-considered. It lists four factors that are decisive in determining the compatibility of a reservation:

- whether the reservation is made to a general provision, such as the articles $1,2,3$ and 24 CEDAW.

- the reservation deals with a particularly crucial aspect of equality, for example article 15 CEDAW.

- the reservation affects women in a significant facet of national life.

- whether or not the reservation involves the complete provision or is restricted to specific elements of the provision. ${ }^{164}$

156. (EDAW/SP/10; about the survey: Clark, op.cit, at 284-285.

157. $A / 41 / 608$ and $A / 41 / 608 /$ Add.l.

Clark. op.cit. at 284-285: Oeser. Legal yuestions, at 97 mentiuns the (iDR reaction to the Secretary General's questions, which surprisingly is not incorporated in the above mentioned documents.

158. A/41/608. Japan at 9.

159. A/41/G08. Denmark at 7 .

160. $A / 41 / 618$. Sweden at 14 .

101. $N / 41 / 608$. Canada at 5 and $\mathrm{A} / 41 / 6018 / \mathrm{Add} .1$. Czechoslowikia at 2.

162. $A / 41 / 608$. Canada at 6 .

163. $\quad A / 41 /(1) 8$. Spain at 13.

1(H. A/ $41 / 608$. Canada at 6. 
The Canadian point is well taken, it has the advantage of separating essential norms from detailed provisions on the fringe of the Convention's object and purpose.

States give two reasons for the importance of preserving the Convention's object and purpose. There is the 'legalistic' argument that undermining the object and purpose of the Convention casts doubt on the State Party's intentions, and moreover frustrates the law of treaties ${ }^{165}$. Denmark and Sweden quite aptly state that there is no reason to apply less stringent treaty law requirements to a convention against discrimination against women, than to other international treaties $^{\mathrm{i} * 6}$.

There is also a more 'substantive' argument, namely that the rules laid down in the Convention are basically a repetition of principles already enshrined in other documents ${ }^{167}$. In other words, making a reservation to such provisions in the Convention does not change these other obligations.

The fact that some of the obligations contained in the Convention can be implemented progressively has led to a group of transitional reservations. Japan finds this acceptable in view of the different levels of development ${ }^{168}$. Turkey stresses that the Convention is a dynamic process to attain a common ideal ${ }^{169}$, Sweden states that these reservations should not have been necessary ${ }^{170}$, and Denmark emphasizes the need for rapid implementation ${ }^{171}$.

As far as the reservations referring to national legislation are concerned, they are not a case for much concern. Spain believes that national legislation must be assumed to be in conformity with the Convention ${ }^{172}$, and Turkey stresses that these reservations are 'of a practical nature and mindful of the social and administratice order ${ }^{\prime 173}$. Saint Lucia argues that the reservations invoking national legislation may conflict with the laws of other States Parties ${ }^{174}$, and that reservations are only acceptable if the dispute settlement provision of article 29.1 CEDAW is accepted ${ }^{175}$.

The States seem to agree that it is beyond the power of the Committee to proclaim the incompatibility of a reservation in any way. Yet, whether the incompatibility of a reservation would compel States Parties to object is another

165. $\mathrm{A} / 41 / 608$, Federal Repullic of Germany at 8 . Sweden at 15

166. A/41/608, Denmark at 7 , Sweden at 15

167. A/41/608, Canada at 5 ; Mexico at 10 , and $A / 41 / 6018 / A d d .1$. C wihostovatia at 2 .

168. A/41/608. Japan at 9 : and elaborating on the issue of onmparative cumpliance Conk, op.cit. at $680-683$.

169. A $/ 41 / 608$, Turkey at 16 .

170. $A / 41 / 608$. Sweden at 15 .

171. A/41/608, Denmark at 7 .

172. A/41/608. Spain at 12.

173. Needless to say the elimination of discrimination against women is not necessarily practical, nor is the maintenance of social and administrative order necessarily without discriminatory implications.

174. This is very hard to imagine in as much as human rights ireatics are referred to.

175. A/41/608. Saint Lucia at 12 . 
matter. Mexico and Sweden say so, and the Federal Republic of Germany implies it by stating that it is not in a position to accept those reservations ${ }^{176}$. As Sweden puts it: "It is tempting for States to accede to "high status conventions" such as the Convention on the Elimination of All Forms of Discrimination against Women. But if they do so and at the same time make a number of reservations, or one incompatible reservations, other States should object to such a misapplication."

Not only do States explain their point of view on the incompatibility issue, they also suggest ways of remedying the problem. There seems to be consensus on the need to encourage states to withdraw their reservations ${ }^{177}$. Assuming that states make reservations because they are not thoroughly aware of the obligations implied in the Convention's provisions, Canada suggest that the Committee should speedily embark on making general recommendations, as provided in article 21.1 of the Convention, to elaborate on the obligations contained in the substantive provisions. Guidelines are in particular necessary for article $9,11,15$ and 16, which are the object of many of the reservations. Another option, as suggested by Sweden, would be to review article 28.2 , in accordance with article 26.1 of the CEDAW, so as to either indicate provisions to which reservations are prohibited or provide for a system comparable to the CERD system ${ }^{178}$.

Two states ${ }^{179}$ mistakenly use the inquiry by the Secretary General as an opportunity to object to a wide range of reservations, but to no avail, as objections have to fulfil the requirements of the Vienna Convention. And the most surprising statement is that of France, which explicitly indicates that there are no problems as "..none of these reservations seem to be incompatible with the object and purpose of the Convention ${ }^{n 180}$.

\subsubsection{Discussions in the Third Committee (General Assembly)}

On the basis of article 21 CEDAW, the Committee reports annually to the General Assembly of the United Nations. The Third Committee of the General Assembly then deals with the report and attaches its conclusions in the form of a resolution ${ }^{|8|}$. The matter of reservations has also been dealt with.

During the fortieth Session (1985) a few states expressed an opinion on reservations to the Women's Convention. Both Norway ${ }^{182}$ and Finland ${ }^{183}$ indicated their concern and said that the reservations were incompatible. Mexico ${ }^{184}$ shared this concern. This led to the adoption of a Resolution requesting the

176. A/41/608, Federal Republic of Germany at 8; Mexico at $10 ;$ Sweden at 14.

177. A/41/608, Canada at 7; Denmark at 8; Sweden at 15.

178. About article 20.2 CERD see Chapter 4, par.1.2 supra; similarly Clark, op.cit. at 298.

179. Portugal and Saint Lucia.

180. A/41/608 at 8 .

181. On the Third Committee:D.W.Bowett, The Law of International Institutions, London, 1982, 4th Ed. at 54-56.

182. A/C.3/40/SR.25, par.21.

183. A/C.3/40/SR.26, par.6.

184. A/C.3/40/SR.34, par.7. 
Secretary General to compile the views of the States Parties on the issue of reservations ${ }^{185}$.

The Secretary General's survey of the views of States on the issue of reservations was published in 1986. Consequently States were better informed on the matter, and during the forty-first session, reservations were dealt with again. A large number of States expressed their concern about the reservations made ${ }^{186}$, and it is suggested that States do not fully understand the nature of the obligations contained in the Convention ${ }^{187}$. Although the Convention's supervisory Committee has a role to play in respect of the reservations, it is by no means empowered to make a final judgment on the validity of reservations ${ }^{188}$. Nor can the Third Committee deal with the legality of the reservations ${ }^{189}$. Japan and Austria express the view that countries making a sincere effort should not be discouraged from participation ${ }^{190}$ and Egypt states that it would not have been able to ratify the Convention had it not been possible to make reservations ${ }^{191}$. It is suggested that states should reconsider their reservations with a view to withdrawal ${ }^{192}$.

1987 is the year of the Convention Committee's rather unfortunate steps concerning women's rights in Islam ${ }^{193}$. This is reflected in the discussions in the Third Committee in which the connection between reservations and Islamic law arises. Certain countries repeat their concern ${ }^{194}$ and indicate that the matter will be dealt with by the States Parties at their 1988 meeting ${ }^{195}$.

The Islamic states participate in the discussion with vigour, saying amongst others that the Committee had made inappropriate, presumptuous and biased observations on the subject of women and Islamic law ${ }^{19}$. Iraq as well as Egypt stressed the sovereign right of States to choose their political, economic and social system without the interference of others ${ }^{197}$. Both Indonesia and Tunisia take a moderate stance on the matter, saying that the reservations and the

185. Ecosoc RES.1986/4.

186. Ausiralia, A/C.3/41/SR.24, par.17; Congo, A/C.3/41/SR.27, par.15; Greece, A/C.3/41/SR.27, par.38: Burundi, A/C.3/41/SR.29, par.53; Nicaragua, A/C.3/41/SR.30, par.29.

Burundi's participation in the discussion and its concern about the reservations are quite surprising. Burundi was at the time not a party to the Convention, it ratified in 1992.

187. Sweden, A/C.3/41/SR.25, par.103; Burundi, A/C.3/41/SR.29, par.53.

188. Australia, A/C.3/41/SR.24, par.17.

189. Venezuela, A/C.3/41/SR.25, par.98.

190. Japan, A/C.3/41/SR.25, par 106; Austria, A/C.3/41/SR.28, par.47.

191. Egypt, A/C.3/41/SR.29, par.36.

192. Sweden, A/C.3/41/SR.25, par.103; Yugoslavia, A/C.3/41/SR.26, par.21.

193. Byrnes, The Work of the Committee at 54-55; Clark, op.cit. at 283-284.

194. Sweden, A/C.3/42/SR.25, par.33; Yugoslavia, A/C.3/42/SR.26, par.28 and Greece, A/C.3/42/SR.28, par.31.

195. China, A/C.3/42/SR.26, par.19 and Yugoslavia par.28.

196. Bangladesh, A/C.3/42/SR.22, par.43.

197. Egypt, A/C.3/42/SR.26, par.9; Iraq, A/C.3/42/SR.29, par.29 and Turkey, A/C.3/42/SR.30 , par.12. 
discussion thereof would help the Committee to find ways and means of adapting the Convention so that it became an acceptable instrument ${ }^{19 \%}$.

The expenses of the Committee and the quality of the servicing are the main item dealt with in the 1988 session of the Third Committee. By then, Finland, on behalf of the Nordic countries, is the only one mentioning the issue of reservations ${ }^{199}$, the issue had apparently lost momentum.

\subsubsection{A role for the International Court of Justice?}

A possible solution for the problem of incompatible reservations to the Women's Convention has been the suggestion to put the issue before the International Court of Justice. The first, and perhaps the most logical way to do this would be to raise the question of compatibility as a problem of interpretation and application under article $29 \mathrm{CEDAW}^{200}$. In that particular case, an issue would be brought before the Court by two States Parties to the Convention who differ as regards the compatibility of a reservation made by one of them. This would hypothetically be a situation in which a reserving State responds to an objection stressing the incompatibility of its reservation. Not only is this unusual, it is very unlikely that this situation would arise. The fact that the objecting states have never indicated that treaty-relations were absent, leads to a lack of interest on the part of reserving States to contradict the views of an objecting State that the reservation is contrary to "object and purpose". Moreover, a substantial number of States have made reservations to article 29 , which restricts the possibility of using this provision as a way to a judicial settlement of the question of incompatibility.

Another development in the discussion has been the suggestion to put the same question before the Court, in the shape of a request for an Advisory Opinion. The way to an Advisory Opinion would be either via the Commission on the Status of Women to the Economic and Social Council that has the authority to request an Advisory Opinion ${ }^{\text {s1 }}$, or via the Subcommission on the Prevention of Discrimination and Protection of Minorities, and the Commission on Human Rights to ECOSOC. A number of authors ${ }^{202}$ have advocated this solution but, to my mind, is a dangerous development that must be discouraged ${ }^{\mathbf{m}}$.

Drawing a parallel with the advisory jurisdiction of the Inter-American Court under article $64 \mathrm{ACHR}^{204}$, Cook suggests that the advisory jurisdiction of the

198. Indonesia, A/C.3/42/SR.24, par.43: Tunisia, A/C.3/42/SR.25, par 14 .

It is noteworthy that though Indonesia as an islamic country speaks out against the Committee's approach to the "women's rights and Islam issue", it did not itself make any substantive reservations to the CEDAW.

199. A/C.3/43/SR.27, par.50.

200. Byrnes, The Work of the Committee at 55-56; Cook, Women's Convention, at 709; Lijnzaad, Voorbehouden at 108.

201. Article 96.2 Charter jo. GA Res.89(1), 11 December 1946.

202. Cook, Women's Convention at 710-712: Jacobs, op.cit. at 86.

203. Lijnzaad, Maken en breken at 212-214.

204. For a discussion see Chapter 3, par.4.2 supra. 
International Court of Justice will lead to similarly positive solutions ${ }^{205}$. It should however be kept in mind that the task of the American Court is explicitly laid down in the American Convention and is explicitly related to the interpretation of the ACHR and other human rights instruments. This is a singular situation which is in no way comparable to the advisory competence of the ICJ. Cook suggests that the whole issue of an Advisory Opinion is only a matter of the political will to use the available procedure to clarify the object and purpose of the Convention.

To my mind, she disregards the fundamental question whether or not this is a wise strategy. The possibility of asking an Advisory Opinion should not be used if an analysis beforehand would lead to the conclusion that this is a risky path. My impression is that this would be the case. In answering the question how to apply the contemporary rules on reservations, and in particular the object and purpose rule, to human rights instruments, the International Court will not use an approach fundamentally different from the contemporary law of treaties. Why would the Court apply other rules than the existing ones in which States are the sole judges of object and purpose, a system in which incompatible reservations can be accepted. Even if much depends on the way in which the request for an Advisory Opinion will be formulated, the Court will not be very explicit about the substantive content of "object and purpose" of the Convention. If the request were specifically to deal with the compatibility of sharia reservations the prospects would be even more grim. In conclusion, I fail to see why the Court would be more flexible that the Office for Legal Affairs ${ }^{206}$ with respect to determining compatibility.

The danger is that a conservative and restrictive interpretation of article 28 CEDAW will be more detrimental to the achievement of the Convention's goals than leaving the matter undecided, as it is now. Such an Opinion would ruin the acquis of the Women's Convention, and limit the cautious steps that the Committee has been taking, and may take in the future. In fact, if an Opinion were given, stressing the VCLT system in which States individually determine compatibility, this would be a great set back for the way in which the supervisory bodies in the field of treaty-based human rights protection are "getting a grip" on the reservations, hesitant though this may be. No Advisory Opinion is better than a conservative Opinion. As long as the odds are that the outcome of such a request might be detrimental to the achievement of the goals of the Convention, the whole idea had better be dropped.

206. For the advice to the CERD Committee see UN Juridical Yearbook 1976, (ST/LEG/SER.C/14) at 219-221, discussed in Chapter 4, par.1.2 supra; for the advice to the CEDAW Committee see A/39/45 Volume II Annex II, discussed par.1.2 supra. 


\section{PRACTICE OF THE COMMITTEE}

The Committee on the Elimination of All Forms of Discrimination against Women is the only supervisory committee to have dealt with the issue of reservations by means of General Recommendation $5^{307}$.

In 1987, in General Recommendation $4^{208}$, the Committee expressed its concern about the significant number of reservations that appeared to be incompatible with the object and purpose of the Convention. It welcomed the decision of the States Parties to consider the reservations at their next meeting, and it suggested that the reserving States consider a withdrawal of the reservations. As we have see supra, the discussions about reservations in the meeting of the States Parties did not lead to any significant steps ${ }^{309}$.

In the eleventh session, Recommendation 20 was issued ${ }^{10}$. It recommended that in connection with the World Conference on Human Rights in 1993, States Parties should raise the question of the validity and legal effects of reservations to the Women's Convention in relation to reservations to other human rights instruments; suggested a reconsideration of reservations with a view to strengthening the implementation of human rights instruments; and suggested considering the introduction of a procedure on reservation comparable to that of other human rights instruments.

General Recommendation 20 is a remarkable document because it outlines the issues that are of primary importance with respect to reservations, in the eyes of the Committee. The explicit link between the reservations to the Women's Convention and to other human rights instruments is a step towards an integrated approach based upon the assumption that States should not have conflicting human rights obligations, and seems based upon the coherence of human rights law. I am less impressed in respect of the introduction of a procedure on reservations comparable to other human rights treaties. In general it would seem that so far, few adequate procedures to deal with (supposedly) incompatible reservations have been designed. Indeed it is not to be hoped that the Committee was actually pointing at a procedure comparable to article 20 CERD, as had been suggested in earlier discussions ${ }^{21}$.

\subsection{Reporting procedure, article 18 CEDAW}

\section{AUSTRALIA}

\section{Reservations}

The Government of Australia states that maternity leave pay is provided in respect of most women employed by the Commonwealth Government and the Government of New South Wales and Victoria. Unpaid maternity leave is provided in respect of all other women employed in the State of New South Wales and elsewhere to women

207. Article 21 CEDAW.

208. General Recommendation 4, sixth session 1987.

209. See par.2.2 supra.

210. General Recommendation 20, eleventh session 1992.

211. Cf. the suggestion by Sweden in the Secretary General's survey. see par. 2.4.1 supra. 
employed under Federal and some State industrial awards. Social Security benefits subject to income tests are available to women who are sole parents.

"The Government of Australia advises that it is not at present in a position to take the measures required by article $11(2)$ to introduce maternity leave with pay or with comparable social benefits throughout Australia.

"The Government of Australia advises that it does not accept the application of the Convention in so far as it would require alteration of Defence Force policy which excludes women from combat and combat-related duties. The Government of Australia is reviewing this policy so as to more closely define "combat" and "combat-related duties."

\section{Declaration}

"Australia has a Federal Constitutional System in which Legislative, Executive and Judicial Powers are shared or distributed between the Commonwealth and the Constituent States. The implementation of the Treaty throughout Australia will be effected by the Commonwealth State and Territory Authorities having regard to their respective constitutional powers and arrangements concerning their exercise."

The Australian initial report sums up the reservations made ${ }^{212}$. The reservation with respect to the provision on paid maternity leave is elaborated upon, and the availability of unpaid maternity leave as well as the relevant legislation in the different Australian states is indicated.

In her introduction the representative repeats Australia's position with respect to maternity leave, and indicates that progress has been made in women's participation in the Defence force ${ }^{213}$. The Committee wonders whether the federal structure is the main obstacle to withdrawing the reservation to article 11 , and asks if the reservation does not in fact endorse the absence of paid maternity leave in the private sector ${ }^{214}$. Another member of the Committee asks if the reservation to article 11.2.b is an indirect way of population control ${ }^{215}$.

In reply, the representative elaborates on the consequences of the Australian federal system, and indicates that a complaint procedure was available in cases in which it was thought that unpaid maternity leave was discriminatory ${ }^{216}$. The country would consider withdrawal in the future, and the reservation was at any rate not a means of population control ${ }^{217}$.

The second periodic report by Australia was due in 1988 and was received in 1992. Consequently the report was not considered in the eleventh session of the Committee. The report ${ }^{218}$ elaborated upon the reasons for maintaining the reservation with respect to article 11.2.b and the right to paid maternity leave. It is indicated that Australia had also declined to ratify ILO Convention 103 on Maternity Protection (Revised) 1952, which a government body had considered to

212. CEDAW/C/5/Add.40.

213. CEDAW/C/SR.114, par.15 (Australia).

214. CEDAW/C/SR.114.

215. CEDAW/C/SR.114, par.84 (Ukeje).

216. CEDAW/C/SR.118, par.73, 81, 82 and 139.

217. About the Australian report: A.C.Byrnes, Australia and the Convention on Discrimination against Women, in: 62 ALJ 1988, 478-479; Zearfoss, op.cit. at 921.

218. CEDAW/C/AUL/2. 
be unsuitable for ratification, because inter alia, of the potential cost implications $^{219}$. Australia had ratified ILO Convention 156 on Equal Employment Opportunities. Entitlements to paid maternity leave varied greatly and were absent in a number of States. Studies were being undertaken on the feasibility of introducing paid maternity leave.

The third report was due in 1992 , but has not yet been submitted ${ }^{230}$.

\section{AUSTRIA}

"Austria reserves its right to apply the provision of article 7(b), as far as service in the armed forces is concerned, and the provision of article 11 , as far as night work of women and special protection of working women is concerned, within the limits established by national legislation."

In its initial report, Austria mentions its reservations to articles 7 and $11^{221}$. It states that the reservation with respect to night work for women was inspired by ILO Conventions 4 (Night work by Women) and 89 (Night work by Women in Industry), and that it is within the scope of article 11.2.d of the Convention which deals with pregnancy protection.

The Committee inquired about the necessity to make the reservation concerning women in the armed forces, and asked if the reservation could be withdrawn ${ }^{222}$. They wonder whether the prohibition on night work would not hamper the employment opportunities of women.

In its reply, Austria urges the Committee to leave the reservations alone ${ }^{223}$. In fact it does not feel obliged under article 18 of the Convention to report on the provisions to which it reserved its position. This fierce standpoint is mitigated by the fact that Austria itself does explicitly mention the reservations made. In the following, Austria argues that while women are employed in administrative functions in the military, there are objectively justifiable reason for the reservation. And as concerns night work of women, the Committee would surely not demand that Austria renounce a convention drafted under the aegis of an international organization related to the United Nations.

\section{BANGLADESH}

The Government of the People's Republic of Bangladesh does not consider as binding upon itself the provisions of articles 2, 13(a) and $16.1(c)$ and (f) as they conflict with Sharia law based on Holy Quran and Sunna."

In its initial report Bangladesh indicates that it implements article 13 with the exclusion of paragraph a, and article 16 paragraphs $1 . c$ and $\mathrm{f}^{24}$. It implements

220. CEDAW/C/1993/2.

221. CEDAW/C/5/Add.17.

222. CEDAW/C/SR.S1.

223. CEDAW/C/SR.55.

224. CEDAW/C/5/Add.34. 
article 3 bearing in mind its reservation to article 2 , which approach seems to extend the scope of the original reservation.

It is especially the reservation to article 2 that the Committee is concerned about $^{225}$. Committee members ask not only for the reservation to be withdrawn, but indicate that a reservation to such a vital provision casts doubt on Bangladesh's adherence to the Convention. Moreover, the fact that equality is laid down in the Constitution makes the Committee wonder why a reservation is necessary. Finally it is suggested that Bangladesh indicates what the exact problems are with the implementation of article 2 CEDAW, so that the Committee will gain some insight in the scope of the reservation.

The Bangladeshi representative indicates that she understood the Committee to have held that there were no differences between the Bangladesh Constitution and the Convention, and states that the reservation will not stand in the way of the improvement of the status of women in her country ${ }^{226}$.

The second periodic report of Bangladesh was dealt with in the twelfth session in $1993^{227}$.

\section{BELGIUM}

\section{Article 7}

The application of article 7 shall not affect the validity of the provisions of the Constitution as laid down in article 60 , which reserves for men the exercise or royal powers, and in article 58, which reserves for the sons of the King or. where there are none, for Belgian princes of the branch of the royal family in line to the throne, the function of $c x$ officio senators as from the age of 18 years, with entitlement to vote as from the age of 25 years.

Article 15 . paragraphs 2 and 3

The application of article 15 , paragraphs 2 and 3 , shall not affect the validity of the interim provisions enacted for couples married before the entry into force of the Act of 14 July 1976 concerning the reciprocal rights and duties of husbands and wives and their marriage contracts, in cases where, in accordance with the option available to them under the Act, they have declared that they are maintaining in toto their prior marriage contracts.

In its initial report Belgium wholeheartedly acknowledges the discrimination against female members of the royal family due to its Constitution and the reservation to article $7^{238}$.

A Committee member inquires about the extent of Royal powers and the impact of the reservation, and another member wants to know how the female members of the Royal Family feel about the reservation ${ }^{329}$.

225. CEDAW/C.SR.96, par.63 (Guan Minquian), GA (Wadstein). G8 (Forde), 76 (Oeser), 79 (Ilic), 83 (Pilataxi de Arenas), 84 (Akamatsu), 86 (Laiou-Antoniou). 89 (El-Tallawy), 93 (Salema), 96 (Ukeje), 99 (Evatt), 101 (Caron).

226. CEDAW/C/SR.99, par.9 (Bangladesh); about the discussion on the report of Bangladesh sec Clark, op.cit. at 287-288.

227. CEDAW/C/13/Add 30 .

228. CEDAW/C/S/Add.S3.

229. CEDAW/C/SR.143, par.19 (Akamatsu), par.57 (Pilataxi de Arenas). 
No answer is given to this last question, the representative merely states that the reservations to article 15.2 and 3 have elapsed whereas the reservation to article 7 involving hereditary royal powers remains.

The second periodic report of Belgium was due in 1990, but had not been received by the end of $1992^{230}$.

\section{BRAZIL}

The Government of the Federative Republic of Brazil hereby expresses its reservations to article 15, paragraph 4 and to article 16, paragraphs 1 (a), (g) and (h) of the Convention on the Elimination of All Forms of Discrimination Against Women.

The initial report by Brazil was due in 1985; and the second periodic report in 1989. So far no reports have been received by the Committe $e^{23 !}$.

\section{CANADA}

\section{Statement}

"The Government of Canada states that the competent legislative authorities within Canada have addressed the concept of equal pay referred to in article 11 (1) (d) by legislation which requires the establishment of rates of remuneration without discrimination on the basis of sex. The competent legislative authorities within Canada will continue to implement the object and purpose of article 11 (1) (d) and to that end have developed, and where appropriate will continue to develop, additional legislative and other measures. "[withdrawn 28-5-1992]

Canada's initial report elaborates on the existing situation with respect to equal pay. It gives an empirical overview of the situation, but does not mention relevant legislation, nor does it explain the need for the declaration ${ }^{232}$. In his introduction the representative indicates that the right to equal remuneration was laid down in legislation at various levels. The Canadian statement indicated that it would make a continuous effort to implement article 11.1.d through legislative and other measures ${ }^{333}$.

Committee members are interested in the precise content of Canada's efforts with respect to equal pay ${ }^{34}$. The answer of the representative is not particularly enlightening, as it deals with the concepts of equal pay for work of comparable value, work of equal value and equivalent work ${ }^{235}$.

The second periodic report of Canada contains information gathered per province and territory ${ }^{236}$. The general section indicated that a difference in earnings between men and women continued to exist, without specitically mentioning the equal pay issue ${ }^{337}$. Some of the provinces and territories mention relevant

$\begin{array}{ll}\text { 230. } & \text { CEDAW/C/1993/2. } \\ \text { 231. } & \text { CEDAW/C/1993/2. } \\ \text { 232. } & \text { CEDAW/C/5/Add.16. } \\ \text { 233. } & \text { CEDAW/C/SR.48, par.30 (Canada). } \\ \text { 234. } & \text { CEDAW/C/SR.48, par.61 (Wadstein), } 71 \text { (Peytcheva), } 75 \text { (Biryukova). } \\ \text { 235. } & \text { CEDAW/C/SR.54, par.62 (Canada). } \\ \text { 236. } & \text { CEDAW/C/13/Add.11/ Part I; and Part II. } \\ \text { 237. } & \text { CEDAW/C/13/Add.11/Part I, par.129-132. }\end{array}$


legislation and policies dealing with the issue of equal pay, but not all of them ${ }^{238}$.

In her introduction, the Canadian representative mentions that several provinces had adopted new legislation with respect to equal pay for work of equal value $^{239}$. While questions are asked about equal pay ${ }^{240}$, the matter of the reservation is not dealt with.

The third periodic report of Canada was submitted after the withdrawal of the declaration concerning article 11.1. $\mathrm{d}^{24}$. As with the previous reports, no mention of the declaration can be found, and it is unclear why Canada withdrew the declaration.

\section{CYPRUS}

The Government of the Republic of Cyprus wishes to enter a reservation concerning the granting to women of equal rights with men with respect to the nationality of their children, mentioned in article 9 paragraph 2 of the Convention.

This reservation is to be withdrawn upon amendment of the relevant law.

The initial report by Cyprus was due in 1986 and the second periodic report in 1990. By the end of 1992 neither had been received ${ }^{2-4}$ ?

\section{EGYPT}

\section{In respect of article 9}

Reservation to the text of article 9, paragraph 2, concerning the granting to women of equal rights with men with respect to the nationality of their children, without prejudice to the acquisition by a child born of a marriage of the nationality of his father. This is in order to prevent a child's acquisition of two nationalities where his parents are of different nationalities, since this may be prejudicial to his future. It is clear that the child's acquisition of his father's nationality is the procedure most suitable for the child and that this does not infringe upon the principle of equality between men and women, since it is customary for a woman to agree, upon marrying an alien, that her children shall be of the father's nationality.

In respect of article 16

Reservation of the text of article 16 concerning the equality of men and women in all matters relating to marriage and family relations during the marriage and upon its dissolution, without prejudice to the islamic Sharia's provisions whereby women are accorded rights equivalent to those of their spouses so as to ensure a just balance between them. This is out of respect for the sacrosanct nature of the firm religious beliefs which govern marital relations in Egypt and which may not be called in question and in view of the fact that one of the most important bases of these relations is an equivalency of rights and duties so as to ensure complementarity which guarantees true equality between the spouses. The provisions of the Sharia lay down that the husband shall pay bridal money to the wife and maintain her fully and shall also make a payment

238. CEDAW/C/13/Add.11/Part I, par.246 (Manitoba), par.285-288 (New Brunswick), par.410 (Ontario); par.516-517 (Québec); par.602 (Northwest Territories); par.652-654 (Yukon).

239. CEDAW/C/SR.167, par.43-49 (Canada).

240. CEDAW/C/SR.167, par.85 (Evatt).

241. $\mathrm{CEDAW} / \mathrm{C} / \mathrm{CAN} / 3$.

242. CEDAW/C/1993/2. 
to her upon divorce, whereas the wife retains full rights over her property and is not obliged to spend anything on her keep. The Sharia therefore restricts the wife's rights to divorce by making it contingent on a judge's ruling, whereas no such restriction is laid down in the case of her husband.

General reservation on article 2

The Arab Republic of Egypt is willing to comply with the content of this article, provided that such compliance does not run counter to the Islamic Sharia.

The Egyptian reservations were the first ones to be dealt with by the Committee $^{243}$. Egypt had mentioned in its report the reservations to article 9, 16 and 29 , apparently omitting its sweeping reservation to article 2 . The report said that the practice related to the nationality of children (article 9.2) did not affect the principle of equality, and stated that the reservation concerning article 16 had been inspired by religious law which provided for "real equality" rather than formal equality ${ }^{24}$.

Although one of the Committee members considers it commendable that Egypt ratified despite the reservations made ${ }^{245}$, other members are rather concerned about the reservations. The issue of equivalence and harmony (Egypt's statement on "real equality") as opposed to formal equality points to a conceptual prob${ }^{1 e m^{246}}$. It is suggested that Egypt should withdraw the reservations, or at least provide insight into the question which legal system (domestic law, sharia or the Convention) prevails. The focal points of the discussion are the reservations to article 9 and 16. Only one Committee member notices that the reservation to article 2, which is not covered in the report, touches on the very heart of the Convention ${ }^{247}$.

The representative of Egypt consequently elaborates on the background of the reservations to articles 9 and $16^{248}$. It appears that the Convention is nothing new, as Sharia law already guaranteed equal rights to women. She attempts to give an overview of rules of islamic law within the scope of the Convention. Understandably this is a fragmentary picture as her remarks are mainly a reaction to the questions of the Committee members. The precise impact of Sharia law on the Convention remains, at any rate, obscure.

Egypt's second periodic report qualifies the reservation to article 9 with respect to the nationality of children ${ }^{249}$. The explanation on the development of Personal law in Egypt is closely related to the reservation to article 16 although the report does not elaborate on the reservation itself.

In his introduction to the second report, the Egyptian representative stresses the differences in the possibilities to attain de iure and de facto equality. The latter is

243. CEDAW/C/5/Add.10; CEDAW/C/5/Add.10/Amend.1.

244. CEDAW/C/5/Add.10 at 3.

245. CEDAW/C/SR.35, par.26 (llic).

246. Cook, Etnische culturen at 50-52; Sullivan op.cit. at 843-845 and Jacobs, op.cit. at 82-83.

247. CEDAW/C/SR.35, par.13 (Nordenfelt); SR.39 par.15 (Nordenfelt).

248. CEDAW/C/SR.39, par.17 (Egypt).

249. CEDAW/C/13/Add.2. 
difficult, given the prominence of group identity, and cultural and religious ${ }^{l a w} w^{250}$. States have a sovereign right to enter reservations and it reflects their honesty if they do. It was better to accede with reservations than not to accede at all, and Egypt's reservations were due to factors such as its heritage, religion and legal system ${ }^{251}$. The reservation with respect to article 9.2 was currently under discussion. Discussing article 2 CEDAW, the representative states that this provision is in conformity with Egyptian law $w^{252}$. This is a remarkable statement, not only does it turn the issue of conformity upside down (national legislation should be in conformity with the convention, after all), it also appears to make the reservation to article 2 superfluous. The representative does not mention the reservation to article 16.

In their response Committee-members welcome the reconsideration of the reservation to article $9^{253}$ but regret the continued existence of the reservations to articles 2 and $16^{254}$. Committee member Tallawy suggests that as Egyptian law excluded discrimination, the reservation to article 2 should not exist; whereas the reservation to article 16 could be withdrawn as there was no conflict with Islamic law ${ }^{255}$. Committee member Diallo Soumare indicated that men had interpreted the Islamic doctrine incorrectly leading to the oppression of women in the name of Islam ${ }^{256}$. In his reply the Egyptian representative does not address the issue of reservations ${ }^{257}$.

The third periodic report of Egypt was due in 1990, but had not been received by the end of $1992^{258}$.

\section{FRANCE}

\section{Declarations}

The Government of the French Republic declares that the preamble to the Convention in particular the eleventh preambular paragraph - contains debatable elements which are definitely out of place in this text.

The Government of the French Republic declares that the term "family education" in article 5 (b) of the Convention must be interpreted as meaning public education concerning the family and that, in any event, article 5 will be applied subject to respect for article 17 of the International Covenant on Civil and Political Rights and article 8 of the European Convention for the Protection of Human Rights and Fundamental Freedoms.

The Government of the French Republic declares that no provision of the Convention must be interpreted as prevailing over provisions of French legislation which are more favourable to women than to men.

250. CEDAW/C/SR.164, par.41-44 (Egypt).

251. CEDAW/C/SR.164, par.47-48 (Egypt).

252. CEDAW/C/SR.164, par.49 (Egypt).

253.

254.

255. 
$\underline{\text { Reservations }}$

Article 5(b) and 16.1(d)

1) The Government of the French Republic declares that article $5(\mathrm{~b})$ and article 16, paragraph 1(d), must not be interpreted as implying joint exercise of parental authority in situations in which French legislation allows of such exercise by only one parent.

2) The Government of the French Republic declares that article 16, paragraph 1(d), of the Convention must not preclude the application of article 383 of the Civil Code. [withdrawn 21-7-1986].

\section{Article 7}

The Government of the French Republic declares that article 7 must not preclude the application of the second paragraph of article LO 128 of the electoral code [withdrawn 26-3-1984]

Article 14

1. The Government of the French Republic declares that article 14, paragraph 2(c), should be interpreted as guaranteeing that women who fulfil the conditions relating to family or employment required by French legislation for personal participation shall acquire their own rights within the framework of social security.

2. The Government of the French Republic declares that article 14, paragraph 2(h), of the Convention should not be interpreted as implying the actual provision, free of charge, of the services mentioned in that paragraph.

Article 15.2 and 15.3; article 16.1(c). 1(h)

The Government of the French Republic declares that article 15 paragraphs 2 and 3 , and article 16 paragraphs $1(\mathrm{c})$ and $1(\mathrm{~h})$, of the Convention must not preclude the application of the provisions of Book Three, Part V, chapter Il of the Civil Code [withdrawn 21-7-1986]

Article $16.1(\mathrm{~g})$

The Government of the French Republic enters a reservation concerning the right to choose a family name mentioned in article 16 , paragraph $\mathrm{l}(\mathrm{g})$, of the Convention.

In its initial report France merely mentions the reservations it withdrew ${ }^{259}$.

The Committee welcomes the withdrawal of reservations but is at the same time eager to know when the remaining reservations will be withdrawn ${ }^{260}$. They inquire whether a discussion concerning withdrawal is taking place in the Government ${ }^{261}$, and wonder about the remaining reservations which are supposed to uphold legislation favourable to women, an aim already covered by article 4 of the Convention ${ }^{262}$.

France in its reply states that the reservations to articles 14.2.c and h, 16.1.d and $5 . b$ are technical reservations, which are being reconsidered in the light of draft legislation concerning parental authority. The reservation to article 16.1.g was under review and the reservation to article 29 was of secondary importance ${ }^{263}$. The second periodic report of France ${ }^{264}$ was discussed in the Committee's twelfth session in 1993. The report mentions the reservations that were with-

259. CEDAW/C/5/Add.33, CEDAW/C/5/Add.33/Amend.1.

260. CEDAW/C/SR.93, par.37 (Caron), 42 (Escobar), 43 (Evalt), 47 (Forde); SR.94, par.31 (Akamatsu).

261. CEDAW/C/SR.94 par.31.

262. CEDAW/C/SR.93 par.52.

263. CEDAW/C/SR.95, pars.4-7 (France): about the French constitutional reservations see Clark, op.cit. at 311-312.

264. CEDAW/C/FRA/2. 
drawn, as well as the remaining reservations ${ }^{265}$. It does not provide much background information on the reasons for making reservations. The reservations concerning articles 14.2.c and 14.2.h are labelled "technical reservations". With respect to article 14, the report elaborates on the different legal forms in which women farmers may organize their work ${ }^{266}$. It is indicated that the retention of the mother's primacy with respect to parental authority over children born out of wedlock is the reason for maintaining the reservation to article 16.1.d. The report quotes an opinion poll revealing that the transmission of the fathers name was widely accepted, by way of reason for the reservation to article 16.1.g.

\section{GERMANY ${ }^{267}$}

\section{Declaration}

The right of peoples to self-determination, as enshrined in the Charter of the United Nations and in the International Covenants of 19 December 1966, applies to all peoples and not only to those living "under alien and colonial domination and foreign occupation". All peoples thus have the inalienable right freely to determine their political status and freely to pursue their economic, social and cultural development. The Federal Republic of Germany would be unable to recognize as legally valid an interpretation of the right to self-determination which contradicts the unequivocal wording of the Charter of the United Nations and of the two International Covenants of 19 December 1966 on Civil and Political Rights and on Economic, Social and Cultural Rights. It will interpret the 1lth paragraph of the Preamble accordingly.

Reservation

Article 7 (b) will not be applied to the extent that it contradicts the second sentence of Article 12.a (4) of the Basic Law of the Federal Republic of Germany. Pursuant to this provision of the Constitution, women may on no account render service involving the use of arms.

The initial report by the Federal Republic of Germany merely repeats its reservation to article 7 with respect to the use of arms by women ${ }^{208}$. Although the German representative does not mention the reservation in the introduction, Committee members ask whether Germany intends to withdraw the reservation $^{269}$. In her reply the representative stated that the reservation was based upon a prohibition in the Basic Law that women could under no circumstances bear arms. This provision was supported by the majority of women, and it did not constitute a limitation to the equality principle ${ }^{2 \pi}$.

The second periodic report of Germany was due in 1990, but had not been received by the end of $1992^{27}$.

265. CEDAW/C/FRA/2, par.52-53.

266. CEDAW/C/FRA/2/Rev.1 at 89.

267. These are the reservations originally made by the Federal Republic of Germany; the reservations by the German Democratic Republic dealt with article 29.1, see CE. $\mathrm{DAW} / \mathrm{SP} / 13$.

268. CEDAW/C/5/Add.59 at 29; CEDAW/C/5/Add.59/Amend.1.

269. CEDAW/C/SR/152, par.16 (Pilataxi de Arenas), par.17 (Diallo Soumare), par.21 (Novikova).

270. CEDAW/C/SR.157, par.55 (Germany).

271. CEDAW/C/1993/2. 


\section{IRAQ}

1. Approval of and accession to this Convention to this Convention shall not mean that the republic of Iraq is bound by the provisions of article 2, paragraphs (f) and (g), of article 9, paragraphs 1 and 2 , nor of article 16 of the Convention. The reservation to this last-mentioned article shall be without prejudice to the provisions of the Islamic Shariah according women rights equivalent to the rights of their spouses so as to ensure a just balance between them.

2. This approval in no way implies recognition of or entry into any relations with Israel.

Iraq's initial report ${ }^{272}$ was scheduled to be reviewed in the Committee's twelfth session in 1993. The report indicates that the reservations to articles 2.f and 2.g have been made because it believes that the goals laid down in these provisions will be attained gradually, and legislative shocks are undesirable ${ }^{273}$. The reservation to article 9 has its roots in the consideration that one-nationality families and non-dual nationalities contribute to the unity of the family ${ }^{274}$. With respect tot article 16 the reservation is motivated by Iraq's commitment to its cultural and jurisprudential heritage as embodied in Islamic Sharia, and by the concern that Iraq meets its obligations both under the convention and islamic $\mathrm{law}^{275}$.

Iraq's second periodic report was due in 1991, but has not yet been submitted.

\section{IRELAND}

\section{Article 9.1}

Pending the proposed amendment to the law relating to citizenship, which is in an advanced stage, Ireland reserves the right to retain the provisions in its existing law concerning the acquisition of citizenship upon marriage. [withdrawn 19-12-1986]

Articles 13.(b) and (c)

The question of supplementing the guarantee of equality contained in the Irish Constitution which special legislation governing access to financial credit and other services and recreational activities, where these are provided by private persons, organisations or enterprises is under consideration. For the time being Ireland reserves the right to regard its existing law and measures in this area as appropriate for the attainment in Ireland of the objectives of the Convention.

\section{Article 15.3}

With regard to paragraph 3 of this article. Ireland reserves the right not to supplement the existing provisions in Irish law which accord women a legal capacity identical to that of men with further legislation governing the validity of any contract or other private instrument freely entered into by a woman.

\section{Article 15.4}

With regard to paragraph 4 of this article. Ireland observes the equal rights of women relating to the free movement of persons and the freedom to choose their residence; pending the proposed amendment of the law of domicile, which is in an advanced stage, it reserves the right to retain the existing law. [withdrawn 19-12-1986]

\section{Articles 16.1(d) and (f)}

Ireland is of the view that the attainment in Ireland of the objectives of the Convention does not necessitate the extension to men of rights identical to those accorded by law to 
women in respect of the guardianship, adoption and custody of children born out of wedlock and reserves the right to implement the Convention subject to that understanding.

Articles 11.1 and $13(\mathrm{a})$

Ireland reserves the right to regard the Anti-Discrimination (Pay) Act, 1974 and the Employment Equality Act 1977 and other measures taken in implementation of the European Economic Community standards concerning employment opportunities and pay as sufficient implementation of articles $11,1(b),(c)$ and (d).

Ireland reserves the right for the time being to maintain provisions of Irish legislation in the area of social security which are more favourable to women than men (...).

Articles 11.1 and 13(a)

$\ldots$ and pending the coming into force of the Social Welfare (Amendment)(No.2) Act 1985, to apply special condition to the entitlement of married women to certain social security schemes. [withdraw 19-12-1986]

The initial report of Ireland deals extensively with the reservations made, including the reservations already withdrawn ${ }^{276}$. Ireland is congratulated on its prompt withdrawal of reservations, and is urged to withdraw the remaining ones as well.

The reply of the Irish representative is quite extensive. He states that articles 13. $b$ and $c$ are already guaranteed under the Constitution, whereas the reservation to article 15 seems to be more like an interpretative declaration and the Government may consider withdrawing it. This is not the case with the reservations concerning article 16 , it is not intended to withdraw these. Finally the matter of wage discrimination (a reservation to articles 11. and 13.a) may also be reconsidered $^{277}$.

Ireland's second periodic report was due in 1991, but had not been received by the end of $1992^{278}$.

\section{ISRAEL}

"1. The State of Israel hereby expresses its reservation with regard to article $7(b)$ of the Convention concerning the appointment of women to serve as judges of religious courts where this is prohibited by the laws of any of the religious communities in Israel. Otherwise, the said article is fully implemented in Isracl, in view of the fact that women take a prominent part in all aspect of public life.

"2. The State of Israel hereby expresses its reservation with regard to article 16 of the Convention, to the extent that the laws on personal status which are binding on the various religious communities in Israel do not conform with the provisions of that article."

Israel's initial report was due in 1992 , but has not yet been received ${ }^{279}$.

\section{JAMAICA}

The Government of Jamaica does not consider itself bound by the provisions of article 9. paragraph 2, of the Convention. 
The initial report of Jamaica indicates that nationality law is not in conformity with the Convention, but that legislation to change this, and withdraw the reservation to article 9.2 , is on the way ${ }^{230}$.

Apart from urging Jamaica to withdraw its reservation to article 9.2, a member of the Committee wonders whether the Government used the reservation as a way of regulating population growth ${ }^{281}$. The representative does not answer this particular question, stating neutrally that Jamaica is committed to make the necessary changes ${ }^{282}$.

Jamaica's second periodic report was due in 1989 , but had not been received by the Committee by the end of $1992^{283}$.

\section{JORDAN}

1. Reservation with respect to article 9, paragraph 2;

2. Reservation with respect to article 15 , paragraph 4 (a wife's residence with her husband);

3. A reservation to the wording of article 16, paragraph (1) (c), relating to the rights arising upon the dissolution of marriage with regard to maintenance and compensation;

4. A reservation to the wording of article 16, paragraph (1) (d) and (g).

As Jordan ratified in 1992, its initial report would only be due in 1993.

\section{LIBYAN ARAB JAMAHIRIYA}

Subject to the general reservation that such accession cannot conflict with the laws on personal status derived from the Islamic Sharia.

The initial report of Libya has been received by the Committee but has not been considered yet ${ }^{284}$. In spite of the statement that the Holy Quran considers both sexes as equal in rights, the reports contains references to notoriously different rights, in particular with respect to articles 2,11 , and 16 CEDAW. The reservation is however not mentioned in either report.

\section{LUXEMBOURG}

(a) The application of article 7 shall not affect the validity of the article of our Constitution concerning the hereditary transmission of the crown of the Grand Duchy of Luxembourg in accordance with the family compact of the house of Nassau of 30 June 1783. maintained by article 71 of the Treaty of Vienna of 9 June 1815 and expressly maintained by article 1 of the Treaty of London of 11 May 1867.

(b) The application of paragraph 1 (g) of article 16 of the Convention shall not affect the right to choose the family name of children.

The initial report by Luxembourg was due in 1990 but had not been received by the end of $1992^{285}$. 


\section{MALAWI}

Owing to the deep-rooted nature of some traditional customs and practices of Malawians, the Government of the Republic of Malawi shall not for the time being, consider itself bound by such of the provisions of the Convention as require immediate eradication of such traditional customs and practices. [withdrawn 24-10-1991]

The Malawi initial report clarifies its reservation dealing with traditional customs and practices. The reservation is apparently a transient declaration, Malawi indicates that it intends to withdraw it in due time and thinks that the necessary changes will be an evolutionary process ${ }^{286}$. The reservation does not indicate the provisions it deals with but the report clarifies this, addressing the reservation when reporting on articles 2, 5 and 16 in relation to polygamous marriages. Malawi uses the opportunity to reflect on the Mexican declaration to its reserva$\operatorname{tion}^{287}$.

The representative of Malawi indicated in her introduction that the reservations had been withdrawn and that legislation had been amended accordingly ${ }^{288}$. Malawi is congratulated by different members of the Committee on the withdrawal of its reservation ${ }^{289}$. In reply to a question whether the withdrawal of the reservation also meant that the elimination of the practices referred to, the representative indicates that this is not the case. The government had decided to play a conscious role in ensuring their speedy elimination ${ }^{200}$.

The second periodic report of Malawi was due in 1992, but had not been recieved by the end of the year ${ }^{291}$.

\section{MALTA}

\section{Article 11}

The Government of Malta interprets paragraph 1 of article II, in the light of provisions of paragraph 2 of article 4 , as not precluding prohibitions, restrictions, or conditions on the employment of women in certain areas, or the work done by them, where this is considered necessary or desirable to protect the health and safety of women or the human foetus, including such prohibitions, restrictions or conditions imposed in conseguence of other international obligations of Malta.

Article 13

(i) The Government of Malta reserves the right, notwithstanding anything in the Convention. to continue to apply its tax legislation which deems, in certain circumstances, the income of a married woman to be the income of her husband and taxable as such.

(ii) The Government of Malta reserves the right to continue to apply its social security legislation which in certain circumstances makes certain benefits payable to the head of the household which is, by such legislation, presumed to be the husband. on 23 January 1990, whereas ST/LEG/SER.E/11 lists 24 October 1991 (almost two years later) as the date of withdrawal.

289. CEDAW/C/SR. 154, par.17 (Evatt). 19 (Diallo Soumare), 22 (Ukejc); 26 (Corti).

290. CEDAW/C/SR.158, par.52 (Malawi).

291. CEDAW/C/1993/2. 
Articles 13,15, 16

While the Government of Malta is committed to remove, in as far as possible, all aspects of family and property law which may be considered as discriminatory to females, it reserves the right to continue to apply present legislation in that regard until such time as the law is reformed and during such transitory period until those laws are completely superseded.

\title{
Article 16
}

The Government of Malta does not consider itself bound by sub-paragraph (e) of paragraph (1) of Article 16 in so far as the same may be interpreted as imposing an obligation on Malta to legalise abortion.

Malta's initial report was due in 1992, but it had not yet been received by the end of that year ${ }^{292}$.

\section{MAURITIUS}

The Government of Mauritius does not consider itself bound by sub-paragraph (b) and (d) of paragraph 1 of article 11 and sub-paragraph $(\mathrm{g})$ of paragraph 1 of article 16.

By the end of 1992 the combined initial and second report of Mauritius ${ }^{293}$ had been received by the Committee, but had not yet been considered.

The report mentions the reservations to article 11.1.b and 11.1.d without elaborating on the precise situation in which the reservations apply. The reservation to article 16.1.g is not mentioned, and the need for this reservation is not directly apparent in the report.

\section{MEXICO}

\begin{abstract}
Upon signature
Declaration

In signing ad referendum the Convention on the Elimination of All Forms of Discrimination Against Women, which the General Assembly opened for signature by States on 18 December 1979, the Government of the United Mexican States wishes to place on record that it is doing so on the understanding that the provisions of the said Convention, which agree in all essentials with the provisions of Mexican legislation, will be applied in Mexico in accordance with the modalities and procedures prescribed by Mexican legislation and that the granting of material benefits in pursuance of the Convention will be as generous as the resources available to the Mexican State permit.
\end{abstract}

Though the Mexican initial report does not deal with reservations the discussion with the Committee was somewhat confusing ${ }^{294}$. An apparently uninformed member of the Committee asked whether Mexico made any reservation ${ }^{295}$. Given the fact that the Mexican reservation was made upon signature, but not confirmed subsequently, the answer should have been that it did not do $\mathrm{so}^{2 \%}$. 
Yet, the Mexican representative stated that Mexico expressed on ratification that it would implement the Convention in accordance with national legislation ${ }^{297}$. He expressly indicates a reservation dealing with article 10.c (elimination of stereotyped roles in education) because of its financial implications. This reservation must have been mentioned erroneously as it is not on file with the Secretary General of the United Nations, the depositary of the Convention.

The second periodic report by Mexico does not mention the declaration, or the non-existing reservation to article $10 . \mathrm{c}$, although it must be mentioned that the report is not very specific about the implementation of this provision dealing with the elimination of stereotypes in education ${ }^{208}$. The non-existent reservation dealt with before, is not mentioned in the discussions ${ }^{299}$.

The third report mentions a great number of educational plans, but does not adress the issue of stereotypes or a reservation in that respect ${ }^{300}$. It has not yet been considered by the Committee.

\section{NETHERLANDS}

During the preparatory of the present Convention and in the course of debates on it in the General Assembly the position of the Government of the Kingdom of the Netherlands was that it was not desirable to introduce political considerations such as those contained in paragraphs 10 and 11 of the preamble in a legal instrument of this nature. Moreover, the considerations are not directly related to the achievement of total equality between men and women. The Government of the Kingdom of the Netheriands considers that it must recall its objections to the said paragraphs in the preamble at this occasion.

The Netherlands report ${ }^{301}$ has been received by the end of 1992, but had not yet been considered by the Committee. The report merely mentions that initially the Bill on the ratification of the Women's convention contained reservations, but that these were deleted in the later stage of the procedure ${ }^{302}$.

\section{NEW ZEALAND}

The Government of New Zealand, the Government of the Cook Islands and the Government of Niue reserve the right not to apply the provisions of Article 11 (2) (b).

The Government of New Zealand, the Government of the Cook Islands and the Government of Niue reserve the right not to apply the provisions of the Convention in so far as they are inconsistent with policies relating to recruitment into or service in

(a) the Armed Forces which reflect either directly or indirectly the fact that members of such forces are required to serve on armed forces aircraft or vessels and in situations involving armed combat or

(b) the law enforcement forces which reflect either directly or indirectly the fact that members of such forces are required to serve in situations involving violence or threat of violence. 
The Government of the Cook Islands reserves the right not to apply Article 2(f) and Article 5(a) to the extent that the customs governing the inheritance of certain Cook Islands chief titles may be inconsistent with those provisions.

The Government of New Zealand, the Government of the Cook Islands and the Government of Niue reserve the right, to the Convention is inconsistent with the provisions of the Employment of Women on Underground Work in Mines of all Kinds (ILO Convention No 145) which was ratified by the Government of New Zealand on 29 March 1938, to apply the provisions of the latter. [withdrawn 13-1-1989]

A clear listing of reservations is to be found in the initial report of New Zealand ${ }^{303}$. The matter of maternity leave is dealt with, and the government announces changes that will bring about paternity leave. Although this might be a positive development it should be noted that its reservation deals with unpaid maternity leave ${ }^{304}$. The reservation by the Cook Islands concerning the chiefly titles is merely mentioned in the additional report on Niue and the Cook Islands ${ }^{305}$.

While one member of the Committee does not seem to be aware of the reservations made by New Zealand, three other members urge it to withdraw the reservations ${ }^{306}$. Asked when the withdrawal of reservations could be expected, the representative states that this will depend on future legislative changes ${ }^{307}$.

The second periodic report of New Zealand which was due in 1990, had not been received by the end of $1992^{308}$

\section{REPUBLIC OF KOREA}

The Government of the Republic of Korea, having examined the said Convention, hereby ratifies the Convention considering itself not bound by the provisions of Article 9 and sub-paragraph (g) of paragraph 1 of Article 16 of the Convention.

[Reservations to article $16.1(\mathrm{c}), 1(\mathrm{~d})$ and $1(f)$ withdrawn 15-3-1991]

Korea in its initial report merely mentions that the patriarchal system remains in effect, and that, as a consequence, family law still contains some tradition bound provisions ${ }^{309}$.

In their discussion the Committee members stress that article 9 and 16 are essential to the Convention's object and purpose, and the reservations are therefor incompatible ${ }^{30}$. They wonder whether legislative changes are to be expected so that the reservations can be withdrawn ${ }^{31 !}$.

303. CEDAW/C/5/Add.41.

304. Wadstcin, op.cit. at 14.

305. CEDAW/C/5/Add.41/Aniend.1.

306. CEDAW/C/SR.105, pars. 9 (Wadstein), 14 (Guan), 18 (Ukejc).

307. CEDAW/C/SR.109.

308. CEDAW/C/1993/2.

319. CEDAW/C/5/Add.35.

310. CEDAW/C/SR.87, par.22 (Wadstein), 23 (Caron). 25 (Sinegiorgis), 40 (Akamatsu), 48 (Corti), 67 (Gonzalez Martinez), 72 (Evatt), 76 (Veliz de Villavilla).

311. However, see about the intention to withdraw the reservation to article 9 CEDAW in CCPR/C/SR.1154, par.22 (Korea). 
In her reply the representative notices the frequency with which the Committee asked about the reservations ${ }^{32}$. Her Government not only found that the Convention's provisions concerned conflicted with Korean legislation, but considerable social resistance would have to be overcome before legislative changes could take place.

\section{SPAIN}

The ratification of the Convention by Spain shall not affect the constitutional provisions concerning succession to the Spanish crown.

The single reservation by Spain concerning the succession to the throne has not been dealt with in the initial report ${ }^{313}$, but a Committee member points out that withdrawal would be wise as 'discrimination at the level of the Head of State clearly had an influence throughout the entire social system ${ }^{3 / 4}$.

The second periodic report of Spain contains an impressive amount of charts, but does not refer to the reservation dealing with succession to the throne $e^{315}$. In reply to questions raised by the Committee the Spanish representative indicates that the reservation was limited and did not affect the goals of the Convention. Moreover a Constitutional amendment would be necessary to withdraw the reservation. ${ }^{316}$

\section{THAILAND}

\section{Declaration}

The Royal Thai Government wishes to express its understanding that the purposes of the Convention are to eliminate discrimination against women and to accord to every person, men and women alike, equality before the law, and are in accordance with the principles prescribed by the Constitution of the Kingdom of Thailand.

\section{Reservations}

In all matters which concern national security, maintenance of public order and service or employment in the military or paramilitary forces, the Royal Thai Government reserves its right to apply the provisions of the Convention on the Elimination of all Forms of Discrimination against Women, in particular articles 7 and 10, only within the limits established by national laws, regulations and practices.

With regard to article 9, paragraph 2. $[\ldots]$ the Royal Thai government considers that the application of the said provisions shall be subject tot the limits and eriteria established by national law, regulations and practices. [withdrawn 26-10-1992]

[Reservations to article 11, paragraph 1 (b) and article 15.3 withdrawn 25-1-1991]

Thailand in its initial report indicates to which provisions reservations have been made ${ }^{317}$. It remarks that the international principles are subject to national law and practice and ensuring consistency between both will be a constant challenge. The reservation to article 11.1.b has been made because of the "sensitive nature 
of equal opportunities for men and women in regard to employment". As concerns article 16, Thailand not only states that it made a reservation and is consequently not bound by the provision, it also list further so-called anomalies that are being thought about.

In her presentation the Thai representative mentions the reservations, indicating that they should be understood in their socio-cultural, economic and political setting $^{318}$. Mobilization of the public opinion would be needed. She then gives an overview of the seven reservations indicating the contemporary thoughts about them. The reservation to article 7 was motivated by the exclusion of women from the army and from key administrative posts but there was an interest in amending these patriarchal laws. Similarly, there was an interest in changing the situation underlying the reservation to article 9.2 , which was motivated by the paternalistic structure of society and the fear of refugees and illegal immigrants gaining the Thai nationality through marriage. The representative announced the forthcoming withdrawal of the reservations to article 11.1.b and $15.3^{319}$, and clarifies that the reservation to article 16 was being remedied by a step-by-step approach towards the practices incompatible with the Convention. It would appear that the representative was implicitly referring to bigamy in this respect.

The prospect of the withdrawal of the reservations is welcomed by the Committe $^{320}$ and the wish is expressed that the other reservations would also be withdrawn $n^{321}$. The issue of the compatibility of the reservations is raised ${ }^{322}$ and the exact scope of the reservation to article 10 is questioned ${ }^{232}$. Similarly, Committee member Akamatsu expresses concern about the reservations to article 11.1.c, $d$, e, and $f$ that would be maintained by Thailand ${ }^{324}$.

In the reply Thailand indicates that it had chosen to make reservations and wait with their withdrawal until compatibility is achieved $d^{325}$. With respect to the issue of compatibility it is unclear to Thailand who is to determine that: the States or an independent body. The Thai reservations had been accepted by some states but rejected by others. Thailand would appreciate the view of an independent body such as the Committee ${ }^{326}$. The representative then reviews all the reservations once again, and adds that concern for national security played an important

\footnotetext{
318. CEDAW/C/SR.156, par.59-66.

319. This statement was made on 9 February 1990 , the reservations were withdrawn on 25 January 1991, almost a year later.

320. CEDAW/C/SR.156, par.70 (Evatt), 71 (Bernard), 72 (Sinegiorgis); SR.157, par.5 (Akamatsu), 8 (llic), 49 (Akamatsu).

321. CEDAW/C/SR.156, par.71 (Bernard), 73 (Pilataxi de Arenas). 74 (Gonzalez Martinez), 75 (Oeser), 76 (Laoui-Antoniou), 77 (Ukeje), 78 (Schopp-Schilling), 79 (Tallawy); SR.157, par.5 (Akamatsu), 7 (Walla-Tchangai), 10 (Corti).

322. CEDAW/C/SR.156, par.79(Tallawy); SR.157, par.5 (Akamatsu), 50 (Pilataxi de Arenas), 51 (Akamatsu).

323. CEDAW/C/SR.157, par.39 (Akamatsu).

324. CEDAW/C/SR.157, par.42.

325. CEDAW/C/SR.157, par.79-83 (Thailand).

326. CEDAW/C/SR.160, par.81 (Thailand).
} 
role in the formulation of reservations ${ }^{327}$. This last remark prompts reactions from the Committee who fail to see the link between security and women's rights $^{328}$, the representative promises to bring this matter to the attention of the government ${ }^{329}$.

Thailand's second periodic report was due in 1990, but had not been received by the Committee by the end of $1992^{330}$

\section{TUNISIA}

\section{General declaration}

The Tunisian Government declares that it shall not take any organization or legislative decision in conformity with the requirements of this Convention where such a decision would conflict with the provisions of chapter I of the Tunisian Constitution.

Reservation concerning article 9, paragraph 2:

The Tunisian Government expresses its reservation with regard tot the provisions in article 9, paragraph 2 of the Convention, which must not conflict with the provisions of chapter VI of the Tunisian Nationality code.

Reservation concerning article 16, paragraphs (c), (d), (f). (g), and (h):

The Tunisian Government considers itself not bound by article 16, paragraphs (c), (d) and $(f)$ of the Convention and declares that paragraphs $(\mathrm{g})$ and $(\mathrm{h})$ of that article must not conflict with the provisions of the Personal Status Code concerning the granting of family names to children and the acquisition of property through inheritance.

Declaration concerning article 15 , paragraph 4 :

In accordance with the provisions of the Vienna Convention on the Law of Treaties, dated 23 May 1969, the Tunisian Government emphasizes that the requirements of article 15, paragraph 4, of the Convention on the Elimination of All forms of Discrimination against Women, and particularly that part relating to the right of women tot choose their residence and domicile. must not be interpreted in a manner which conflicts with the provisions of the Personal Status code on this subject, as set forth in chapters 23 and 61 of the Code.

The initial report of Tunisia was due in 1986, but had not been received by the end of $1992^{331}$.

\section{TURKEY}

\section{Reservation}

"Reservations of the Government of the Republic of Turkey with regard to the articles of the Convention dealing with family relations which are not completely compatible with the provisions of the Turkish Civil Code, in particular, article 15, paragraphs 2 and 4 , and article 16, paragraphs $1(\mathrm{c}),(\mathrm{d}),(\mathrm{f})$ and $(\mathrm{g}) . "$

Declaration

"Article 9, paragraph 1 of the Convention is not in conflict with the provisions of article 5. paragraph 1 and article 15 and 17 of the Turkish Law on Nationality, relating to the acquisition of citizenship, since the intent of those provisions regulating acquisition of citizenship through marriage is to prevent statelessness."

327. CEDAW/C/SR.160, par.83 (Thailand). Who would have thought that women's rights were a security issue?

328. CEDAW/C/SR.160, par.111 (Gonzalez Martinez), 114 (Schopp-Schilling).

329. CEDAW/C/SR.160, par.116 (Thailand).

330. CEDAW/C/1993/2.

331. CEDAW/C/1993/2. 
The initial report of Turkey is rather succinct about the reservations made. It states that legislation is in conformity with article 9 of the Convention, and the text on articles 15 and 16 seems to suggest the possibility of a rapid withdrawal of the reservations to article $15.2,15.4$ as well as 16.1 .c. The amendment to the Turkish report does mention the reservations to article 15 and 16 , and seeks to clarify their origins in Turkish domestic law $w^{332}$. It is indicated that the reservations to article 15.2, 15.4 and 16.1 would be withdrawn when amending the Civil Law would be completed ${ }^{333}$. Moreover the report indicates that other states have also made reservations to the same provisions; and that Mexico and Germany had objected to the Turkish reservations ${ }^{334}$.

The intended withdrawal of the reservations is confirmed by the representative in the introduction, together with the indication that the withdrawal would take place before the second periodic report would be submitted $d^{335}$.

In their discussion the Committee seeks clarification of the reasons for making the reservations ${ }^{336}$, in relation to Turkey's views on ideal equality as opposed to equality in practice. In particular Committee member Pilataxi de Arenas stresses that a withdrawal of reservations should be based on substantive considerations ${ }^{337}$. A general wish for all the reservations to be withdrawn in expressed.

In her reply the Turkish representative indicates that there is no distinction between mother and father with respect to the nationality of the child (article 9.2 CEDAW $)^{338}$, which seems to make the declaration distinctly redundant. Furthermore it is indicated that the reservations to articles 15 and 16 were studied with a view to withdrawing them before the second periodic report was due.

The second periodic report of Turkey was due in 1991, but had not been received by the end of $1992^{339}$.

\section{UNITED KINGDOM OF GREAT BRITAIN AND NORTHERN IRELAND}

"A. On behalf of the United Kingdom of Great Britain and Northern Ireland:

"(a) The United Kingdom understands the main purpose of the Convention, in the light of the definition contained in Article 1, to be the reduction, in accordance with its terms, of discrimination against women, and does not therefore regard the Convention as imposing any requirement to repeal or modify any existing laws, regulations, customs or practices which provide for women to be treated more favourably than men, whether temporarily or in the longer term; the United Kingdom's undertakings under Article 4, paragraph 1 , and other provisions of the Convention are to be construed accordingly.

"(b) The United Kingdom reserves the right to regard the provisions of the Sex Discrimination Act 1975. the Enployment Protection (Consolidation) Act 1978, the Employment Act 1980, the Sex Discrimination (Northern Ireland) Order 1976, the

332. CEDAW/C/5/Add.46/Amend.1.

333. CEDAW/C/5/Add.46/Amend.1 at 18.

334. CEDAW/C/5/Add.46/Amend.1 at 19.

335. CEDAW/C/SR.161, par. 16 (Turkey).

336. CEDAW/C/SR.161, par.18 (Fenger-Moller), 20 (Oeser), 27 (Gonzalez Martinez), 28 (Schopp-Schilling), 91 (Pilataxi de Arenas), 95 (Gonzalez Martinez).

337. CEDAW/C/SR.161, par.91 (Pilataxi de Arenas).

338. CEDAW/C/SR.165, par.36 (Turkey).

339. CEDAW/C/1993/2; the announced withdrawal of reservations has not taken place either. 
Industrial Relations (No. 2) (Northern Ireland Order 1976, the Industrial Relations (Northern Ireland) Order 1982, the Equal Pay Act 1970 (as amended) and the Equal Pay Act (Northem Ireland) 1970 (as amended), including the exceptions and exemptions contained in any of these Acts and Orders, as constituting appropriate measures for the practical realisation of the objectives of the Convention in the social and economic circumstances of the United Kingdom, and to continue to apply these provisions accordingly; this reservation will apply equally to any future legislation which may modify or replace the above Acts and Orders on the understanding that the terms of such legislation will be compatible with the United Kingdom's obligations under the Convention.

"(c) In the light of the definition contained in Article 1, the United Kingdom's ratification is subject to the understanding that none of its obligations under the Convention shall be treated as extending to the succession to, or possession and enjoyment of, the Throne, the peerage, titles of honour, social precedence or armorial bearings, or as extending to the affairs of religious denominations or orders or to the admission into or service in the Armed Forces of the Crown.

"(d) The United Kingdom reserves the right to continue to apply such immigration legislation governing entry into, stay in, and departure from, the United Kingdom as it may deem necessary from time to time and, accordingly, its acceptance of Article 15 (4) and of the other provisions of the Convention is subject to the provisions of any such legislation as regards persons not at the time having the right under the law of the United Kingdom to enter and remain in the United Kingdom.

"Article 1

With reference to the provisions of the Sex Discrimination Act 1975 and other applicable legislation, the United Kingdom's acceptance of Article 1 is subject to the reservation that the phrase "irrespective of their marital status" shall not be taken to render discriminatory any difference of treatment accorded to single persons as against married persons, so long as there is equality of treatment as between married men and married women and as between single men and single women.

"Article 2

In the light of the substantial progress already achieved in the United Kingdom in promoting the progressive elimination of discrimination against women, the United Kingdom reserves the right, without prejudice to the other reservations made by the United Kingdom, to give effect to paragraphs (f) and (g) by keeping under review such of its laws and regulations as may still embody significant differences in treatment between men and women with a view to making changes to those laws and regulations when to do so would be compatible with essential and overriding considerations of economic policy, in relation to forms of discrimination more precisely prohibited by other provisions of the Convention, the obligations under this Article must (in the case of the United Kingdom) be read in conjunction with the other reservations and declarations made in respect of those provisions including the declarations and reservations of the United Kingdom contained in paragraphs (a) - (d) above.

"With regard to paragraphs $(\mathrm{f})$ and $(\mathrm{g})$ of this Article the United Kingdom reserves the right to continue to apply its law relating to sexual offenses and prostitution; this reservation will apply equally to any future law which may modify or replace it.

"Article 9

The British Nationality Act 1981, $\mathrm{f}$ which was brought into foree with effect from January 1983, is based on principles which do not allow of any discrimination against women within the meaning of Article 1 as regards acquisition, change or retention of their nationality or as regards the nationality of their children. The United Kingdom's acceptance of Article 9 shall not, however, be taken to invalidate the continuation of certain temporary or transitional provisions which will continue in force beyond that date.

The United Kingdom reserves the right to take such steps as may be necessary to comply with its obligations under Article 2 of the First Protocol to the Convention for 
the Protection of Human Rights and Fundamental Freedoms signed at Paris on 20 March 1952 and it obligations under paragraph 3 of Article 13 of the International Covenant on Economic, Social and Cultural Rights opened for signature at New York on 19 December 1966, to the extent that the said provisions preserve the freedom of parental choice in respect of the education of children; and reserves also the right not to take any measures which may conflict with its obligation under paragraph 4 of Article 13 of the said Covenant not to interfere with the liberty of individuals and bodies to establish and direct educational institutions, subject to the observation of certain principles and standards.

"Moreover, the United Kingdom can only accept the obligations under paragraph (c) of Article 10 within the limits of the statutory powers of central Government, in the light of the fact that the teaching curriculum, the provision of textbooks and teaching methods are reserved for local control and are not subject to central Government direction; moreover, the acceptance of the objective of encouraging co-education is without prejudice to the right of the United Kingdom also to encourage other types of education.

\section{"Article 11}

The United Kingdom interprets the "right to work" referred to in paragraph $1(a)$ as a reference to the "right to work" as defined in other human rights instruments to which the United Kingdom is a party, notably Article 6 of the International Covenant on Economic, Social and Cultural Rights of 19 December 1966.

"The United Kingdom interprets paragraph 1 of Article 11, in the light of the provisions of paragraph 2 of Article 4, as not precluding prohibitions, restrictions of conditions on the employment of women in certain areas, or on the work done by them, where this is considered necessary or desirable to protect the health and safety of women or the human foetus, including such prohibitions, restrictions or conditions imposed in consequence of other international obligations of the United Kingdom; the United Kingdom declares that, in the event of a conflict between obligations under the present Convention and its obligations under the Convention concerning the employment of women on underground work in mines of all kinds (ILO Convention No. 45), the provisions of the last mentioned Convention shall prevail.

"The United Kingdom reserves the right to apply all United Kingdom legislation and the rules of pension schemes affecting retirement pensions, survivor's benefits and other benefits in relation to death or retirement (including retirement on grounds of redundancy), whether or not derived from a Social Security scheme.

This reservation will apply equally 10 any future legisiation which may modify or replace such legislation, or the rules of pension schemes, on the understanding that the terms of such legislation will be compatible with the United Kingdom's obligations under the Convention.

"The United Kingdom reserves the right to apply the following provisions of United Kingdom legislation concerning the benefits specified:

a) social security benefits for persons engaged in caring for a severely disabled person under section 37 of the Social Security Act 1975 and section 37 of the Social Security (Northern Ireland) Act 1975;

b) increases of benefits for adult dependants under section 44 to 47,49 and 66 of the Social Security Act 1975 and under sections 44 to 47, 49 and 66 of the Social Security (Northern Ireland) Act 1975;

c) retirement pensions and survivor's benefits under the Social Security Acts 1975 to 1982 and the Social Security (Northern Ircland) Acts 1975 to 1982:

d) family income supplements under the Family Income Supplements Act 1970 and the Family Income Supplements Act (Northern Ireland) Acts 1971.

"This reservation will apply equally to any future legislation which may modify or replace any of the provisions specified in sub-paragraphs (a) to (d) above, on the understand that the terms of such legristation will be compatible with the United Kingdom's obligations under the Convention. 
The United Kingdom reserves the right to apply any non-discriminatory requirement for a qualifying period of employment or insurance for the application of the provisions contained in Article 11(2).

\section{"Article 13}

The United Kingdom reserves the right, notwithstanding the obligations undertaken in Article 13, or any other relevant article of the Convention, to continue to apply the income tax and capital gains tax legislation which:

i) deems for income tax purposes the income of a married woman living with her husband in a year, or part of a year, of assessment to be her husband's income and not to be her income (subject to the right of the husband and the wife to elect jointly that the wife's earned income shall be charged to income tax as if she were a single woman with no other income); and

ii) requires tax in respect of such income and of chargeable gains accruing to such a married woman to be assessed on her husband (subject to the right of either of them to apply for separate assessment) and consequently (if no such application is made) restricts to her husband the right to appeal against any such assessment and to be heard or to be represented at the hearing of any such appeal; and

iii) entitles a man who has his wife living with him, or whose wife is wholly maintained by him, during the year of assessment to a deduction from his total income of an amount larger than that to which an individual in any other case is entitled and entitles and individual whose total income includes any earned income of his wife to have that deduction increased by the amount of that earned income or by an amount specified in the legislation whichever is the less.

"Article 15

In relation to Article 15, paragraph 2, the United Kingdom understands the term "legal capacity" as referring merely to the existence of a separate and distinct legal personality. "In relation to Article 15, paragraph 3, the United Kingdom understands the intention of this provision to be that only those terms or elements of a contract or other private instrument which are discriminatory in the sense described are to be deemed null and void, but not necessarily the contract or instrument as a whole.

"Article 16

As regards sub-paragraph $1(f)$ of Article 16, the United Kingdom does not regard the reference to the paramountcy of the interests of the children as being directly relevant to the elimination of discrimination against women, and declares in this connection that the legislation of the United Kingdom regulating adoption, while giving a principal position to the promotion of the children's welfare, does not give to the child's interests the same paramount place as in issues concerning custody over children.

The United Kingdom's acceptance of paragraph 1 of Article 16 shall not be treated as either limiting the freedom of a person to dispose of his property as he wishes or as giving a person a right to property the subject of such a limitation."

"B. On behalf of the Isle of Man, the British Virgin Islands, the Falkland Islands, South Georgia and the South Sandwich Islands, and the Turks and Caicos Islands:

Same reservations as the one made on behalf of the United Kingdom under paragraphs A(a). (c). and (d) except that in the of case d) it applies to the territories and their laws). J

Article 1

Same reservation as the one made in respect of the United Kingdom except with regard to the absence of a reference to United Kingdom legislation.]

\section{Article 2}

Same reservation as the one made in respect of the United Kingdom except that reference is made to the laws of the territories. and not the laws of the United Kingdom.]

Article 9

[Same reservation as the one made in respect of the United Kingdom]

Article 11 
SSame reservation as those made in respect of the United Kingdom except that a reference is made to the laws of the territories. and not to the laws of the United Kingdom.]

"Also, as far as the territories are concerned, the specific benefits listed and which may be applied under the provisions of these territories' legislation are as follows:

a) social security benefits for persons engaged in caring for a severely disabled person;

b) increases of benefit for adult dependants;

c) retirement pensions and survivors' benefits;

d) family income supplements.

"This reservation will apply equally to any future legislation which may modify or replace any of the provisions specified in sub-paragraphs (a) to (d) above, on the understanding that the terms of such legislation will be compatible with the United Kingdom's obligations under the Convention.

"The United Kingdom reserves the right to apply any non-discriminatory requirement for a qualifying period of employment or insurance for the application of the provisions contained in Article 11(2)."

Article 13,15 and 16

Same reservations as those made on behalf the United Kingdom

The initial report of the United Kingdom repeats most of its reservations without providing further insight into their background ${ }^{3 * 0}$, although with respect to the reservation to article 9 it elaborates on relevant case-law from the European Court of Human Rights. It considers existing UK sex discrimination legislation as constituting appropriate measures for the practical realization of the objectives of the Convention. In discussing the reservation to article 13, concerning discrimination in taxation, there is a certain amount of self-criticism as the United Kingdom indicates that another, less discriminatory system of taxation would also be possible.

In her introduction the United Kingdom representative mentions that a number of reservations had been made which was a sign of how serious the government took the Convention ${ }^{341}$. She indicates that discriminatory tax legislation would be abolished by April 1990 which would enable the United Kingdom to partially withdraw the reservation to article $13^{342}$. It is indicated that certain prohibitions on various kinds of work are being removed, such as in the off-shore industry and in mining, which would lead to the withdrawal of another reservation.

In their reaction the Committee appreciates the intended withdrawal of the reservations $\mathrm{s}^{343}$, but expresses its concern about the large number of reservations made, as well as about their $\operatorname{scope}^{34}$. The Committee inquired about the intention to withdraw the remaining reservations ${ }^{345}$ and the question was raised whether the reservations to the Convention were matched by reservations to the

340. CEDAW/C/S/Add.S2 (25-9-1987).

341. CEDAW/C/SR.155, par.50-53 (United Kingdom)

342. By the end of 1992 no withdrawals by the United Kingdom had been received by the depository (ST/LEG/SER.E/11).

343. CEDAW/C/SR.155, par.59 (Evatt), par.60 (Bernard).

344. CEDAW/C/SR.155, par.59 (Evatt), 69 (Tallawy), 70 (Pilataxi de Arenas), 76 (Oeser), 95 (Escobar), 114 (Guan Minquian).

345. CEDAW/C/SR.155, par.59 (Evalt), 60 (Bernard), 64 (Walla Tchangai), 65 (llic), 66 (Diallo Soumare), 82 (Ukeje), 83 (Gonzalez Martinez), 85 (Sinegiorgis). 
Covenant on Civil and Political Rights ${ }^{346}$. Another issue raised is the fact that some reservations claim the conformity of existing legislation with the Convention. If this is the case, no reservation needed to have been made ${ }^{347}$. It is unclear whether the reservations were not in fact explanations ${ }^{348}$, and the reference to considerations of economic policy in the reservation to article 2 is questioned ${ }^{349}$.

In her reply to the Committee the representative indicates that the reservations had been declarations of the United Kingdom's understanding of the purpose of the Convention. It felt that some of the provisions had been drafted hastily and were rather imprecise, and the reservations indicated that a number of provisions could not be implemented immediately upon ratification ${ }^{350}$. With respect to the question about the coherence of the Convention and the Covenant on Civil and Political Rights it was indicated that the reservations to both instruments differed because of their different scope, and it was again stressed that the Convention was unfortunately not as precise as it might $b^{351}$. On answering questions with respect to prostitution, it is indicated that proposals to make legislation genderneutral were pending. The fact that this could lead to the withdrawal of reservations is however not mentioned ${ }^{352}$.

The second periodic report by the United Kingdom ${ }^{353}$ had not been discussed by the end of 1992. In a paragraph called "Reservations", the report discusses the policy with respect to reservations ${ }^{354}$. The paragraph appears to be a reflection on the discussion with the Committee concerning the initial report. The remark by the representative that the United Kingdom was considering changes in the areas where reservations had been made is repeated, without actually indicating that such reflections had already led to the withdrawal, or even intended withdrawal, of reservations. The reservations concerning tax legislation (article 13 CEDAW), ILO Convention 45 (article 1I.1 CEDAW) and family income supplements legislation (article $11 \mathrm{CEDAW}$ ) are singled out. It is indicated that the United kingdom denounced ILO Convention 45 , and that a conflict, which is what the reservation refers to, will therefore not arise. While the report indicates in each of these three cases that the relevant legislation had been changed, there is no indication that the reservations might be withdrawn ${ }^{355}$. Finally it is repeated that the large number of reservations are merely a reflection of the importance attached to the Convention by the United Kingdom, which will keep the reservation under review. It should be noted that this presentation, in spite of

347. CEDAW/C/SR.155, par.69 (Tallawy).

348. CEDAW/C/SR.155, par.71 (Pilataxi de Arenas).

349. CEDAW/C/SR.155, par.72 (Schopp-Schilling), 77 (Laoiu-Antoniou).

350. CEDAW/C/SR.159, par.2-3 (United Kingdom).

351. CEDAW/C/SR.159, par.5 (United Kingdom).

352. CEDAW/C/SR.159, par.41 (United Kingdom).

353. CEDAW/C/UK/2, CEDAW/C/UK/2/Amend.1.

354. CEDAW/C/UK/2, par.12-17.

355. And indeed, the relevant reservations are still mentioned in ST/LEG/SER.E/11. 
the merits it has by focusing specifically on reservations, only mentions a few of the numerous reservations. It is therefore somewhat deceptive.

Looking at the discussing of the individual provisions in the second periodic report it is noticeable that the report does not discuss the implementation of article 1 CEDAW, and begins with article 2. Given the fact that a number of reservations specifically mention article 1 , this approach is somewhat concealing. A discussion of the reservations to articles $9,10,11,15$ or 16 is absent.

\section{CONCLUSIONS REGARDING RESERVATIONS TO THE CONVENTION}

In an article about reservations to human rights treaties, Shelton has suggested that it is no coincidence that a large number of reservations to human rights treaties are detrimental to the status of women ${ }^{336}$. And indeed, the number of reservations to the Women's Convention is perhaps not really surprising.

Bymes distinguishes four separate problems, namely the nature and scope of the reservations, the permissibility of certain reservations, the manner in which their validity is determined as well as the implications of reservations for the obligations of the States Parties ${ }^{357}$. These elements are of vital importance, yet the list is probably incomplete. From an activist point of view, other important issues would be the withdrawal of reservations as well as the restriction of their impact. These issues will be dealt with in the following, focusing on the role of the States as well as the role of the Committee.

\subsection{The reservations}

An important issue when looking at the reservations is the determination of their scope, and their possible impact on the obligations incumbent on the States Parties. Different groups of reservations can be distinguished.

Some reservations underline the State Party's intention to gradually implement a provision of the Convention ${ }^{38}$. This may be superfluous given the fact that the Convention in many of its provisions already implies gradual implementation. In that case the reserving state merely repeats what is already provided for, and according to article 2.1.d VCLT does not even make a reservation ${ }^{359}$. It however depends on the firmness of the statement, as it may well be that gradual

356. Shelton, op.cit. at 227.

357. Byrnes, The Work of the Committee, at 52.

358. Reservation by Australia in respect of article 11.2 ('not at present'), and concerning combat duties in the armed forces (the Government.. is reviewing this policy'), a reservation by Cyprus in respect of article 9.2 ('shall be withdrawn'), a reservation by Ireland in respect of articles $13 . \mathrm{b}$ and $\mathrm{c}$ ("for the time being'), and the general reservation by Malawi ('for the time being').

359. Article 2.1.d VCLT reads:".. whereby it purports to exclude or to modify the legat effect of certain provisions...". 
implementation is completely excluded, which leads to a genuine reservation. It also depends on the nature of the provision that reservation is attached to, if this is a core provision even a reservation indicating gradual implementation may be incompatible.

Of course the focal point in any discussion about reservations to the Convention is its object and purpose. It must be noticed that though 'object and purpose' has become a catch phrase, it is a negative obligation. The rule is that reservations should not be contrary to the object and purpose of a treaty, there is no obligation for them to be in conformity with object and purpose. This may seem a twist of words but it is not without importance. One of the consequences of object and purpose as a negative obligation is that theoretically there is no need to determine its material content, it is mainly necessary to see whether a reservation is contrary to a but vaguely determined object and purpose.

The value of the prohibition of reservations contrary to object and purpose will depends on the selection made between fringe reservations and more serious ones. Whatever object and purpose is, it they must be assumed to be the raison d'être of the Convention. This implies that it is quite possible that reservations are made that do not touch upon the object and purpose, but remain on the fringe. Although these reservations restrict the legal effect of provisions of the treaty, not every reservation will be as harmful as the reservations contrary to object and purpose. A clear example of an acceptable approach with respect to disparities between national legislation and the Convention were the reservations to article $9.1,11.1,13 . \mathrm{a}$ and 15.4 by Ireland, that indicated that reservations had been made because of these differences, and indeed withdrew the reservations when domestic legislation had been changed.

For practical purposes it is useful to split up the "object and purpose" rule into two separate rules, namely the obligation not to undermine the treaty qua treaty and the obligation not to undermine the content of the treaty. From this perspective the vast amount of reservations to the Convention becomes slightly transparent.

The first rule is the obligation not to obstruct the treaty law side of the Convention. Acting in contravention of general rules of treaty law is contrary to the object and purpose of any treaty. The group of reservations that, because of their impact on the formal aspects of the Convention, are contrary to the object and purpose of the Convention, consists of two different kinds of reservations. Firstly, there are the general reservations that do not indicate the provision at which they are aimed ${ }^{360}$. General and unrestricted reservations entail much uncertainty about the extent to which a State making such reservations will be bound by the obligations contained in the treaty. They are contrary to the very idea of lex scripta, the importance of explicit and written agreements. Apart from 
that, these reservations cast doubt on the State Party's intention to comply with the object and purpose of the Convention.

Secondly, there is a large group of reservations indicating the prevalence of national legislation in favour of the Convention. Here again, States do not provide certainty about their obligations towards their co-contractants. This uncertainty arises because the reserving state may change its national legislation at will, which leads to incertitude about the obligations agreed upon. Reservations emphasizing the predominance of religious law or traditional custom belong to the same category. They leave compliance with the treaty to the reserving State's discretion, it will depend on the obligatory value of other legal and social systems.

The second rule sees to the content of the Convention and prohibits acting contrary to the intended substantive rules. This group of reservations consists of reservations contrary to the object and purpose of the treaty in as much as its content is concerned. As stated above, given the fact that the "object and purpose" rule is formulated as a negative rule there is no obligation, much less an option to determine the object and purpose of the Convention in any objective way. Apart from an authoritative statement by the States Parties or an interpretation on the basis of article 29 CEDAW, it will be up to the Committee to indicate what is and what is not contrary to the object and purpose. Theory and practice indicate that the articles 2, 9, 11, 15 and 16 of the Convention are understood as coreprovisions. Moreover, the exclusion of the Convention's frequent reference to the progressive elimination of discrimination is also widely considered to be incompatible with the very object of the Convention.

\subsection{The role of States}

Looking at the attitude of States towards reservations to the Convention and the impact of reservations on its implementation, one cannot but be struck by the atmosphere of inertia. The States Parties frequently express the intention to withdraw reservations, but usually fail to do $\mathrm{so}^{361}$.

A reason for the small number of objecting states may be the fact that objections have become a feeble weapon in the Vienna Convention-system, and are useless in respect of reservations to human rights treaties ${ }^{362}$. Four states objected frequently to reservations made, and did so with persistence. Yet the withdrawal of reservations objected to by these four states demonstrates a limited success. The reservations withdrawn by Thailand and Korea had been objected to by four states, three states objected to the reservation of Malawi, and two states objected to the reservation of New Zealand. This does not show that objections will

361. For instance the possible withdrawal of the Australian reservation with respect to maternity leave (CEDAW/C/SR.118; CEDAW/C/AUL/20; the Korean reservation to article 9 (CCPR/C/SR.1154, par.22): the Belgian reservation with respect to the exercise of royal powers, mentioned in the press.

362. See Chapter 2, par.3.2.2 supra. 
always lead to withdrawals, but withdrawals may have been influenced by objections. Moreover the four objecting States demonstrated a shared opinion as to the incompatibility of certain reservations. On the other hand it is not too bold to suspect that states have simply not been attentive enough to make objections within the time-limit set by article 20.5 VCLT.

It has been suggested that a distinct element of opportunism plays a role in decisions to object ${ }^{363}$, and attention has been given to the relation between the reserving state and the objecting state. Thus the absence of objections on the part of Mexico to the reservations by Brazil could be explained by their regional relations, which were absent between the other objecting States and Brazil. While political considerations may indeed play a role in deciding to object, it may not be completely fair to denounce an objecting State for the failure to object when the complete failure on the part of other states is much more visible, if not more detrimental.

The difference between the limited number of objections and the explicitness of the replies in the Secretary General's survey is remarkable ${ }^{364}$. Yet, though the survey shows that the responding states have quite strong ideas on the matter of incompatible reservations, all that glitters is not gold. Of the 89 States Parties to the Convention at the time, only 17 States replied. Of these, three replies did not address the precise questions, two states mistakenly used the survey to object to reservations already made, and France stated that it did not consider any of the reservations incompatible with the object and purpose of the Convention. Only eleven States sent a meaningful reply.

The reservations issue was barely dealt with in the bi-annual meeting of the States Parties. They left the matter to be discussed in the General Assembly. That discussion, in the Third Committee, in fact only took place during the forty-first session, in 1986. In the following sessions the States were occupied with other aspects of the Convention, and reservations have received little or no attention.

No doubt the ill-fated approach of the Committee towards the issue of women's rights in Islam, froze the willingness of the States Parties and their options with regard to the Sharia'h reservations. In fact, rather than opening the issue for debate, the atmosphere hardened and the reservations issue became non-negotiable ${ }^{365}$.

364. A/41/608 and $A / 41 / 608 / A d d .1$, dealt with supra par.2.3.I at..

365. Clark, op.cit. at 289. 


\subsection{The role of the Committee on the Elimination of Discrimination against Women}

Given the fact that States are irresolute, the role of the Committee could of great importance. Yet, it would appear that the Committee has so far not been able to get a grip on the reservations issue.

From a practical point of view, some simple improvements may have a positive impact on the reservations issue. For instance, the knowledge of reservations to the Convention ought to increase. The ignorance of Committee-members is sometimes striking ${ }^{36}$. They should have more insight into the reservations made, and also about aspects of the law of treaties, as this lies at the very basis of thorough supervision. Though this is a personal responsibility, the insight of the Committee members could be enhanced by the issue of a yearly update of the document entitled "Reservations, declarations, notifications and objections relating to the Convention on the Elimination of All Forms of Discrimination against Women ${ }^{n 367}$. At the moment this is a States Parties document, clearly it ought to be a Committee document.

The Committee's major task is to consider the reports of States Parties on the implementation of the Convention. The reporting by the States Parties does not always give an adequate presentation of either the reservations made $e^{368}$, or the actual impact of the reservations. It is understandable that States would rather disguise their reservations than explicitly mention them, although a few states set good examples by stating all their reservations at the beginning of their reports ${ }^{369}$.

Fortunately, the nihilist point of view taken by Austria, the idea that reservations need not be reported on, has not caught ${ }^{370}$. The articles 17,18 and 20 CEDAW are the basis of the Committee's authority to deal with the reservations. The obligations to report on reservations would seem to be the mirror image of the Committee's competence. Moreover, article 18.2 explicitly deals with reporting about "..factors and difficulties affecting the degree of fulfilment of obligations under the present Convention."

The "General Guidelines regarding the form and the content of the reports received from States Parties under article 18 of the Convention ${ }^{37 !}$ do not contain rules as to whether and how states should report on their reservations, it focuses basically on information conceming domestic implementation. It would be useful to amend the Guidelines and add a rule on indicating the reservations

366. CEDAW/C/SR.13 par.16; CEDAW/C/SR.135 par.83, 85.

367. CEDAW/SP/1992/2; 1 November 1991.

368. Cf.the second periodical report of the United Kingdom, CEDAW/C/UK/2, discussed supra at...

369. CEDAW/C/5/Add.40 (Australia). CEDAW/C/5/Add.41 (New Zealand), CEDAW/C/5/Add.SI (Thailand), CEDAW/C/S/Add.S2 (United Kingdom).

370. CEDAW/C/SR.55, and supra para.3.1.

371. CEDAW/C/7 (11-8-1983), on the Guidelines see: Wadstein, op.cit. at 7-8. 
made $^{37}$ as well as a guideline providing that the reservation should be dealt with when reporting on the individual provisions of the Convention ${ }^{373}$. This would force States to reconsider their reservations each time a report is drafted, and at the same time provide the Committee with more detailed information.

The Committee is the only supervisory organ that dealt with the question of reservations by way of general recommendations. As such it is interesting that this path has been chosen, but too little has been achieved it seems. The general recommendations contain suggestions for the reserving State, and it would seem that a stricter approach might require a more specific approach to the way in which States report about the reservations made, and about the reasons for maintaining the reservations. This could be included in a general comment on the structure of periodic reports, but could also be included in the guidelines on reporting.

A better knowledge of the reservations as well as stricter guidelines may improve the Committee's handling of the reservation issue, but this will probably not be enough. As Byrnes quite aptly states, ultimately "the important questions are tactical ones: how to encourage the withdrawal of existing reservations, limit the number and extent of new ones and monitor closely the impact of those presently in force. ${ }^{374}$ Much will depend on the way in which the problem will be dealt with.

Reservations are clearly a matter of concern to the Committee, at least they are frequently mentioned. It is within the competence of the Committee, as laid down in articles 17, 18 and 20 , to discuss the reservations made. This is a general competence, and consequently the Committee can legitimately inquire about the Convention, including the provisions to which reservations have been made. Moreover, such questioning is a way of stimulating the progressive implementation of the Convention by the reserving states. Committee members appear particularly conscious of article 28.2, and their questioning revolves around the compatibility issue. The incompatibility of reservations is suggested in discussions with the States Parties ${ }^{375}$.

The withdrawal of reservations is frequently suggested, so often that it seems a mere formality ${ }^{376}$. States will in general reply that the matter is under consideration, and the Committee would only seem to achieve its goals by repeating the question when considering successive reports by the same State.

372. This could be incorporated into Part I sub a), which requires States to report on the "actual, general, social, economic, political and legal framework", to which reservations no doubt belong.

373. This could be incorporated into Part II sul a), which deals with "[T]he constitutional, legislative and administrative provisions..".

374. Byrnes, op.cit. at $\mathbf{5 2 .}$

375. CEDAW/C/SR.35 par.13; SR.39 par.15; SR.87 passim; SR.96 passim.

376. CEDAW/C/SR.35; SR.51; SR.93 and 94; SR.96; SR.105; SR.135. 
Too much emphasis on the prohibition in article 28.2 may not be wise. Obviously, "object and purpose" are not the same as literally every single provision of the Convention. The provision does not prohibit reservations in general, it merely prohibits the ones contrary to core obligations. It might be suggested that the Committee would sketch some outlines, and indicate which are obligations are the Convention's raison d'être. The Committee appears to be concerned about articles 9,15 and 16 , while the reservations to article 2 are surprisingly not in the focus of the attention ${ }^{377}$.

Discussions of the reservations need not be restricted to the compatibility issue, but may also deal with other aspects of reservations, including reservations to non-core obligations. It should be remembered that a great number of seemingly unimportant reservations by one State can have an equally devastating impact on the integrity of the Convention.

In the course of time Committee members have engaged in more profound questioning, exploring other ways of getting a grip on the issue of reservations. Rather than mentioning the incompatibility of reservations or requesting their withdrawal, the Committee seems to have embarked on a constructive dialogue with the States Parties ${ }^{378}$. The strategy, if there is one, would seem to consist of two elements: a more profound approach to withdrawal and an attempt to narrow broadly formulated reservations.

Rather than demanding that a reservation be withdrawn, the Committee has sometimes sought to find out what kept the State from withdrawing its reserva$t^{t i o n}{ }^{379}$. An approach aimed at gradual withdrawal of reservations would seem to be in harmony with the Convention's notion of gradual implementation. Moreover, it has the advantage of increasing insight into the origins of the reservation, and forces the reserving state to report on the progress made in the implementation of the Convention.

A similar line of argument holds true for the group of broad reservations ${ }^{300}$. These reservations leave the author state great freedom to interpret their own reservation. The Committee has shown a tendency to ask reserving states to be explicit about their actual reservation, thus narrowing the scope of the reserva$\operatorname{tion}^{381}$. The requirement, in article 23.4 VCLT, of a formulation in writing for the withdrawal of a reservation, would seem to be rebutted by the fact that such

377. Such as reservations made by Bangladesh. Egypt, and Iraq.

378. Byrnes, The Work of the Committee at $52-53$ is much more positive about the Committee's performance in the field of reservations. I doubt if whether "the Committee has consistently encouraged the States to review and withdraw their reservations".

379. For example, the discussion of the reports by Austria (CEDAW/C/SR.51); France (CEDAW/C/SR.93,94); Korea (CEDAW/C/SR.91); Turkey (CEDAW/C/SR.161); United Kingdom (CEDAW/C/SR.155).

380. Byrnes, The Work of the Committee at 53.

381. cf. CEDAW/C/SR.96 par.99 at 15 (Evatt):".. suggested that the Bangladesh Government study the terms of article 2 further with a view to including in future reports its comments on the legislative or other structures which, in its view, prevented it from fully implementing article $2 . "$ 
statements are public and are moreover published in the Committee's summary records. It must be assumed that States who publicly restrict the scope of their reservations, for instance in the discussions with the Committee, thus unilaterally limit the scope of their reservation in a legally binding way.

Only occasionally has the Committee asked about the compatibility of reservations when compared to the obligations under other human rights instruments382. As has been explained before, I feel that this is a avenue which might provide better opportunities for monitoring the reservations; and it could thus be suggested to the Committee that this is a strategy to be explored and elaborated upon in the future $\mathrm{e}^{383}$.

In sum, the Committee may be hesitantly on the way to developing ways of reducing the substantial impact of reservations. It should be kept in mind that this is a judgment based on the Committee's performance with respect to the initial reports. The second periodic reports should give the Committee ample opportunity to improve its dealing with reservations to the Convention. Yet if anyone, apart from the States Parties, has the opportunity to do anything about the problem it is the Committee and much will depend on its perseverance.

\subsection{Prospects}

The responses to the survey, the few objections, the few withdrawals and the attitude of the States Parties as well as the discussions in the Third Committee paint an equally gloomy picture of the prospects of the Convention. Bymes has indicated that so far the Committee's approach consists of four element $\mathrm{s}^{384}$. Although the task of the Committee is by no means an easy one, it would seem that the Committee might try and venture other avenues so as to limit the impact of the reservations. It may find ways of doing its very necessary work by using international law in a creative way. To Byrnes' list could be added elements based on the law of treaties, as a way of strengthening the supervision and reducing the impact of reservations. The Committee has not yet reached the limits of legal imagination.

382. C. the questions by Committee-members lic and Gonzalez Martinez (CEDAW/C/SR. 155, par.65 and 83) to the United Kingdom with respect to reservations to CEDAW and their coherence with obligations under the CCPR.

383. See supra Chapter 3, par.2.3, The interpretation of human rights instruments: coexistence and coherence.

384. Byrnes, The Work of the Committee at 52-53:"As well as questioning States on the extent to which women enjoy equality in the areas covered by reservations and exhorting them to withdraw reservations the Committee considers unnecessary, the CEDAW (that is the Committee, EL) has consistently encouraged States to review and withdraw their reservations. The Committee has also sought to determine how reservations to individual articles undermine a State Party's ability to fulfil the obligations it has accepted under other articles of the Convention, while endeavouring to establish the practical impact of broad sweeping reservations on the implementation of individual articles of the Convention". 
At present two suggestions are at hand that might be tumed to the Convention's advantage. First of all there is the possibility mentioned in article 23.b CEDAW, the availability of better protection in other international conventions. As has been pointed out States occasionally follow an inconsistent policy when making reservations. In such cases, when provisions more conducive to the achievernent of equality are available elsewhere, article 23.b provides an opportunity for ignoring the reservation made, albeit not expressis verbis. In that case the Committee will assume that the State intended to act in consistence with prior obligations, thus limiting the effect of the reservation ${ }^{385}$.

A further strategy would be to put more emphasis on general rules of inteinational law. States are presumed to act in accordance with international law when concluding international agreements. This entails obligations such as the duty to be explicit about obligations and the prohibition to unilaterally alter pacta. As demonstrated above, this could restrict the impact of excessively broad resef vations, and reservations invoking domestic law.

In conclusion it might be said that the reporting procedure and the monitoring of the implementation of the Convention by the Committee are not without ptospects, but very much will depend on the Committee's ability to act flexible and creatively. As indicated, the Committee has opportunities to improve its grip on the reservations within the limits of international law. 


\section{RESERVATIONS TO THE CONVENTION AGAINST TORTURE AND OTHER CRUEL, INHUMAN OR DEGRADING TREATMENT OR PUNISHMENT}

\section{INTRODUCTION TO THE CONVENTION AGAINST TORTURE}

\subsection{Content of the Convention}

The Convention against Torture and other Cruel, Inhuman or Degrading Treatment or Punishment, (henceforth: CAT) was adopted by Resolution 39/46 of the General Assembly of the United Nations on 10 December 1984'. It was opened for signature on 4 February 1985, and entered into force on 26 June 1987 when twenty States ratified the Convention ${ }^{2}$. The Convention consists of three parts, dealing with substantive law (part I), supervision (part II), and final clauses (part III).

In Part I torture is defined in article $\mathrm{I}^{3}$ as any act by which severe pain or suffering, whether physical or mental, is intentionally inflicted on a person for such purposes as obtaining from him or a third person information or a confession, punishing him for an act he or a third person has committed, or intimidating or coercing him or a third person, or for any reason based on discrimination of any kind, when such pain or suffering is inflicted by or at the instigation of or with the consent or acquiescence of a public official or other person acting in an official capacity'. It should be noted that the Convention does not give a definition of 'other cruel, inhuman or degrading treatment or punishment'4. States are obliged to take measures to prevent torture, and neither exceptional circumstances nor superior orders can serve as justification for torture. Torture shall be a criminal offence, and the Convention lays down rules of penal law and extradition law to that effect, the most important of which is universal jurisdiction for

1. GA Res. 39/46. On the origins of the Convention see: J.H.Burgers and H.Danelius, The United Nations Convention against Torture, Dordrecht,1988. 5-110; Z.Haquani, La Convention des Nations Unies contre la Torture, in:90 RGDIP 1986, 127-170 at 131-139; N.Lerner, The U.N.Convention on Torture, in:16 IsrYbHR 1986, 126-142 at 127-129; R.Marx, Die Konvention der Vereinte Nationen gegen Folter und andere grausame, unmenschliche oder erniedrigende Behandlung oder Strafe, in:18 ZfRechtspolitik 1986, 81-85 at 81-82; M.E.Tardu. The United Nations Convention against Torture and other Cruel Inhuman or Degrading Treatment or Punishment, in:56 Nordic JIL 1987, 303-321 passim.

2. Article 27.1 CAT.

3. Burgers and Danelius, op.cit. at 122 point out that article 1 CAT gives a description of torture rather than a legal definition.

4. Haquani, op.cit. at 141; J.Donnelly. The emerging international regime against torture, in:33 NILR 1986, 1-23 at 2-3; Lerner, op.cit. at 131; Marx. op.cit. at 82 and Tardu op.cit. at $309-311$. 
acts of torture. The Convention furthermore contains rules aimed at prevention of torture, such as the duty to educate and inform law-enforcement personnel and to systematically review interrogation rules. Alleged victims of torture have a right of complaint, and the legal system of a State Party should provide for compensation for victims of torture.

Part II sets up the Convention's implementation system, which is by and large based on the systems created by the Convention against Racial Discrimination and the Convention on Civil and Political Rights. There is a Committee against Torture (hereinafter: the Committee) consisting of ten independent experts. The expenses of Committe members ${ }^{5}$ as well as the expenses incurred in connection with meetings of the States Parties and the Committe itself will be the responsibility of the States Parties, according to articles 17.7. and 18.56. This is an unusual system compared to other UN human rights instruments. The work of the Human Rights Committee and the Committee on the Elimination of Discrimination against Women is completely financed by the United Nations, whereas the expenses of the members of the Committee on the Elimination of Racial Discrimination are bome by the States Parties, and the remainder is paid for by the UN. It must be assumed that the United Nations financial problems have led to this regulation of the costs of the supervision of the Convention?

States Parties shall submit a report to the Committee on the measures taken to implement the Convention (article 19). Article 21 provides for interstate complaints in an optional procedure, which has entered into force in accordance with paragraph $2^{8}$. The individual complaints procedure of article 22 is also optional, and has entered into force in accordance with article 22. $8^{9}$. A new and innovative procedure in the Convention is the Committee's option to start a confidential inquiry once it receives reliable intormation containing well-founded indications that torture is systematically practised in the territory of a State Party (article 20). While this provision appears to be mandatory, it is possible to opt out according to article 28 , which indicates that reservations may be made ${ }^{10}$.

5. cf. article 8.6 CERD.

6. On the issue of expenses of the Committee see: Burgers and Danelius, op.cit. at 154-155 (art.17.7) and 156 (art.18.5); M.Coccia, A Controversial Declaration on the UN Convention against Torture (hereafter: Controversial Declaration), in: 1 EJIL 1990, 314327 at 317; L.Lijnzaad, Nederlands bezwaar bij DDR-voorbehoud ten aanzien van VNFolteringverdrag (hereafter: Nederlands bezwaar), in:14 NJCM 1989, 504-509 at 505; M.Mohr. The German Democratic Republic's Declaration on the Anti- Torture convention and its consequences: an Attempt at Evaluation, in: 1 EJIL 1990, 328-335 at 328-331.

7. Tardu op.cit at 316 .

8. By the end of 1992 (ST/LEG/SER.E/11, 31-12-1992) 30 States had recognized the Committee's competence in this field.

9. By the end of 1992 (ST/LEG/SER.E/11, 31-12-1992) 29 States had recognized the Committee's competence in this field.

10. By the end of 1992 (ST/LEG/SER.E/11, 31-12-1992) 11 States had made reservations according to article 28.1, thus excluding article 20; four States have already withdrawn these reservations. 
Part III contains the final clauses. It deals with ratification, entry into force, amendments, dispute-settlement and denunciation. There is no general reservations clause, but in articles 28.2 and 30.3 the Convention explicitly mentions the possibility of making reservations to specified provisions.

The general opinion of the Convention seems to be that although the substantive provisions are satisfactory, the Convention lacks strength in the sphere of implementation. Criticism has especially been directed at the fact that reporting is the only compulsory supervision procedure, while both interstate complaints and individual complaints procedures are optional, and the confidential inquiry procedure can be opted out of ${ }^{1 !}$.

\subsection{The law applicable to reservations}

Mentioning reservations in two instances, articles 28.2 and 30.3, the Convention contains a dual system of law applicable to reservations. Firstly there are the rules of the Convention itself. Article 28 indicates the option of declaring that a State does not recognize the Committee's competence as laid down in article 20, the confidential inquiry based on indications that torture is systematically practised. According to the second paragraph of article 28 the reservation to article 20 can be withdrawn by simply notifying the Secretary-General of the United Nations. Article 30 deals with dispute settlement and provides for a procedure in which a conflict about interpretation or application may be unilaterally submitted to arbitration, and, if no agreement can be reached within six months, may be referred to the International Court of Justice by one of the Parties. Paragraph 2 provides for reservations and indicates that such a reservation will apply reciprocally. Paragraph 3 states that reservations may be withdrawn at any time by simple notification.

The Convention thus only provides explicit rules on reservations relating to articles 20 jo. 28 and article 30 . With respect to those provisions the rules are clear, but what about reservations to other rules in the Convention? As the Convention does not mention that these reservations are the only reservations that may be made, it would appear that the system as laid down in article 19.b VCLT is not applicable ${ }^{12}$. This leads to the applicability of article 19.c VCLT, and its

11. Haquani, op.cit. at 130:"Le résultat obtenu est relativement satisfaisant pour ce qui concerne les mesures de protections préconisées, mais timide quant aux moyens de contrôle prévus pour son application sur le plan international."; and Marx, op.cit. at 84:"Angesichts des erheblichen Defizits an effektiven Bestimmungen des Kontrollverfahrens ist von einem Inkrafttreten der Konvention gegen Folter ohne hin kaum ein Fortschritt in der Entwicklung des Folterschutzes zu erwarten."

12. According to article $19 . \mathrm{b}$ the treaty should indicate that only specified reservations may be made.

But compare the views expressed by Committee-member Voyame who suggests in CAT/C/SR.40, par.36-38 (reservations by Chile) and in CAT/C/SR.126, par.53 (reservations by New Zealand) that article $19 . \mathrm{b}$ VCLT is applicable. 
notion of "object and purpose" being the guiding principle with respect to reservations to the Convention ${ }^{13}$.

A subsequent question would then be what the "object and purpose" is, as a concrete yardstick is necessary to apply this criterion. In establishing "object and purpose" it is necessary to keep in mind that the prohibition of torture is a rule of ius cogens. It is a pre-existing rule, and it would make little sense to consider it part of the core-obligation under the Convention. The importance of the Convention is that it facilitates the prosecution and extradition of the offenders who committed torture, and creates an international supervisory mechanism to enforce the pre-existing prohibition of torture. From this perspective it is easy to see that the GDR's reservation was contrary to the object and purpose of the Convention, as it sought to undermine what can actually be considered to be the contribution the Convention made to existing human rights law ${ }^{14}$.

\subsection{Reservations and declarations}

Thus far $^{15} 71$ States have ratified the Convention. Of these 48 ratified without making reservations ${ }^{16}, 9$ states ratified with a reservation to article 20 and 9 states made reservations to $30^{17}$. As the Convention explicitly allows reservations to articles 20 and 30 , these will not further be dealt with. The other reservations and declarations dealing with substantive rights and the supervisory system will be discussed below.

\section{- article 1 -}

Article 1 CAT defines torture. Both Luxembourg and the Netherlands have made declarations interpreting "lawful sanctions" mentioned in article 1 CAT as requiring lawfulness not only under national law but also under international law. Burgers and Danelius state that the second sentence of the first paragraph of article 1 is, and has been controversial during the drafting ${ }^{18}$. The requirement of lawful sanctions might imply lawful merely according to national law, but could also mean in accordance with both national and international law. Even if the meaning of this provision was not agreed upon during the drafting of the Convention, Marx ${ }^{19}$ seems to be right in arguing that "lawful sanctions" must imply

13. For a detailed analysis of article 19.c VCL.T see Chapter 2. par.3.1.2 supra.

14. Coccia, Controversial Declaration, at 320-325: and G.Gornig. M.Ney. Die Erklärungen der DDR zur UN-Antifolterkonvention aus völkerrechtlicher Sicht, in: 43 Juristenzeitung 1988. 1048-1053 at 1050-1051: expressing a contrary opinion: Mohr, op.cit. at 332-333.

15. ST/LEG/SER.E/11, 31-12-1992.

16. Although Austria, Ecuador, Luxembourg and the Netherlands ratified making interpretative declarations relating to articles 5 and 15 (Austria), article 5(Ecuador) and article 1(Luxembourg and the Netherlands). See below for an analysis of these declarations.

17. Two State have withdrawn a reservation to article 20; seven States have withdrawn reservations to article 30 C.AT.

18. Burgers and Danelius, op.cit. at 121-122.

19. Marx, op.cit. at 84. 
compatibility with both international and national law. His reasoning is based on the guarantee provided in paragraph 2 of article 1 , and on the duty to interpret a treaty in accordance with its object and purpose, as laid down in article 31 of the Vienna Convention ${ }^{30}$. In view of this, the Luxembourg and Netherlands declarations are interpretative declarations, merely aimed at clarifying the provision. They repeat what is already laid down in the treaty itself and in the law of treaties in general.

In a declaration Chile states that it will apply the Inter-American Convention to Prevent and Punish Torture in cases where its provisions are incompatible with those of the Convention. At first sight it is very unlikely that two conventions aimed at combating torture could contain provisions incompatible with one another. And even if they did, the Convention provides in article 1.2 that the international instrument or national legislation that gives the individual the better protection will prevail .

The Chilean declaration lays down a different priority rule: the per se application of the Inter-American Convention regardless of the quality of protection afforded in the Convention. Thus the declaration is in fact a reservation to article 1.2.

- article 2 -

Article 2.3 prohibits invoking a superior order as a justification for torture. This rule of law, based on principle IV of the so-called Nuremberg principles ${ }^{21}$ is by now so self-evident that authors on the Convention devote little attention to this provision ${ }^{22}$. Chile stated in a reservation, subsequently withdrawn ${ }^{23}$, that it would only apply article 2.3 if the order aiming at acts referred to in article 1 , was not insisted upon by the superior officer when challenged. The reservations read:

"To article 2, paragraph 3, in so far as it modifies the principle of 'obedience upon reiteration' contained in Chilean domestic law. The Government of Chile will apply the provisions of that international norm to subordinate personnel governed by the Code of Military Justice, provided that the order patently intended to lead to perpetration of the acts referred to in article 1 is not insisted on by the superior officer after being challenged by his subordinate."

In other words, if the subordinate questions the order and the superior officer withdraws it, but the act of torture is still perpetrated, Chile would apply article 2.3. The Chilean reservation is problematic, both theoretically and from the point of view of the prohibition of torture. First of all it implied that Chilean subordinates are self-confident and assertive and do have some basic insight into the prohibition of torture. These are the people that might be expected to challenge an "order patently intended to lead to perpetration of the acts referred to in article 1". One wonders why Chile assumed that subordinates challenging torture, not

20. Arguing similarly Tardu, op.cit. at $307-309$.

21. The Principles of Law recognized in the Charter of the Nuremberg Tribunal and in the Judgment of that Tribunal, GA Res.95/1.

22. Burgers and Danelius, op.cit. at 124: Tardu, op.cit. at 311-312.

23. Reservation withdrawn on 7 September $19 \%$. 
insisted on by superior officers, would still commit this offence. Not only is this an unusual assumption, it is also questionable whether this would be a situation of superior order. If the superior officer does not insist, article 2.3 by its own terms seems inapplicable. Thus the Chilean reservation appeared to extend article 2.3 to situations going well beyond the ordinary meaning of the rule.

At the same time the Chilean reservation excluded article 2.3 CAT in situations for which it was drafted. The reservation read: "... will apply the provisions... provided that the order...is not insisted on by the superior officer"[my italics, EL]. On the contrary, if the order was insisted upon when challenged, Chile would not apply article 2.3. It would appear that in that case a superior order could be invoked as justification.

Apart from these problems the reservation posed various other questions. What is exactly meant by "obedience upon reiteration", and what about (para-) military or police personnel not governed by the Code of Military Justice? It hardly needs stressing that this reservation ran contrary to the object and purpose of the Convention for it intends to modify the Chilean duty to incriminate torture in national law. Thus the reservation is contrary to prevalent customary law, it met with many objections and was withdrawn within two years.

- article 3 -

Article $3 \mathrm{CAT}$ contains the prohibition on expelling, returning or extraditing a person to a country where there is reason to believe that this person might be in danger of being tortured. This provision is based on article 33 of the Convention relating to the Status of Refugees ${ }^{24}$, and influenced by case law within the framework of the European Convention on Human Rights ${ }^{25}$. It should be noted that the wording of article 3 is especially precise, requiring "...substantial grounds for believing that a person would be in danger of being subjected to torture.." Obviously it will depend on the facts of a case whether such a danger exists ${ }^{26}$. Chile however made a reservation to this provision stating that it is discretionary and subjective.

In a declaration the Federal Republic of Germany indicates that it considers that the Convention exclusively establishes State obligations in respect of article 3, and that moreover German legislation is in accordance with the Convention. The earlier part of the declaration is perhaps surprising given the fact that the provision specifically reads "No State shall..". The gist of the declaration seems to be that an individual will not be able to rely upon article 3 CAT in case of an extradition.

- article 5 -

Article 5 deals with establishing jurisdiction. States Parties shall establish jurisdiction when the offenses are committed in territory under their jurisdiction

24. Tardu, op.cit. at 313.

25. Burgers and Danelius, op.eit. at 125.

26. Burgers and Danelius, op.cit. at 127. 
(article 5.1.a), when the alleged offender is a national (article 5.1.b) or when the victim is a national if the State considers that appropriate (article 5.1.c). Austria declared that it would only establish jurisdiction on the grounds of article 5. 1.c if prosecution on grounds of articles 5.1.a or 5.1.b was not to be expected. As article 5.1 contains no obligation to establish jurisdiction, but reminds states of the possibility to do $\mathrm{so}^{27}$, the Austrian declaration is not a reservation. Whether it is an interpretative declaration remains to be seen as its aim is not to clarify the provision but rather to indicate if and when Austria will avail itself of jurisdiction based on article 5.1.c.

Ecuador made a declaration stating that it would not extradite its nationals. The declaration implies that a State wanting to establish jurisdiction on the grounds of articles 5.1.a or 5.1.c would not be able to obtain the extradition of an alleged offender of Ecuadoran nationality present in Ecuador. Likewise article 8 CAT, containing provisions about torture as an extraditable offence, will not be applicable with respect to Ecuadoran nationals. The declaration does not exclude or modify Ecuador's obligations under the Convention, as the Convention contains a system in which states either establish jurisdiction and prosecute, or extradite $^{28}$. Since according to the Ecuadoran declaration the option of extradition of nationals does not exist, it will be obliged to establish jurisdiction according to articles 5.1 and $5.2^{29}$.

- article 8 -

Article 8 makes torture, attempts to commit torture and complicity or participation in torture extraditable offenses. The declaration of Ecuador in respect of article 8 has been dealt with supra.

- article 14 -

Article 14 deals with the right to compensation for acts of torture. New Zealand declared that it reserved the right to award compensation at the discretion of the Attorney-General. As the provision speaks of an enforceable right to compensation, this must be understood as a reservation.

- article 15 -

The inadmissibility of evidence resulting from torture is dealt with in article 15 CAT.

Austria states that it will regard article 15 CAT as the legal basis for the exclusion of evidence resulting from torture. Some authors ${ }^{30}$ think that article 15 requires a change in national procedural legislation, but basically international

27. Burgers and Danelius, op.cit. at 132; it reads:" if the State considers it appropriate".

28. Burgers and Danelius, op.cit. at 131:".the present Convention is also based on the principle "aut dedere aut punire"; in other words, the country where the suspected offender happens to be shall either extradite him for the purpose of prosecution or proceed against him on the basis of its own criminal law."

29. Burgers and Danelius, op.cit. at 132-133.

30. Donnelly, op.cit. at 4; Tardu, op.cit. at 314. 
law contains no rules as to how states should fulfil their treaty obligations. The Austrian declaration, although addressed at the other states parties, deals with the domestic application of article 15. It implies that Austria is not going to change its procedural law, for it considers article 15 to be directly applicable. As such, the declaration provides the states parties with useful, although superfluous, information. Thus it is neither an interpretative declaration nor a reservation.

- articles 17 and 18 -

The articles 17 and 18 lay down the financing of the supervision of the Convention.

The German Democratic Republic made a declaration relating to articles 17.7 and 18.5 when ratifying the Convention, which was withdrawn within three years. Although the dissolution of the GDR has resolved the problems created by this reservation it was such a singular reservation that it will be dealt with, in spite of its disappearance.

The GDR's reservation read:

The German Democratic Republic declares that it will bear its share only of those expenses in accordance with article 17. paragraph 7 and article 18, paragraph 5 of the convention arising from activities under the competence of the Committee as recognized by the German Democratic Republic."

Articles 17 and $18 \mathrm{CAT}$ indicate that the expenses for supervision will be paid for by the states parties to the Convention. In its declaration East Germany stated that it would only bear its share of the expenses for activities of the Committee as recognized by the GDR. It is important to note that the GDR had not made declarations according to article 21 (Inter-State complaints) nor to article 22 (Individual complaints), and had excluded the Committee's competence to hold a confidential inquiry based on article 20 through a reservation in accordance with to article 28. The only supervisory procedure binding on the GDR was the reporting procedure according to article 19 . Apparently the GDR intended to pay only its share of the expenses incurred in this procedure.

As has been discussed above, the supervision of the Convention will vary according to the declarations and reservations made by a State Party. In spite of the fact that States Parties may choose to submit to supervisory procedures other than reporting, this has not lead to a system in which the financial contributions for the work of the Committee depend on the choices made by the individual States. The provisions about the expenses are formulated in clear and unambiguous language, and leave no doubt about the fact that all States Parties should be responsible for all the expenses incurred ${ }^{31}$.

Moreover, in a very general way, reference could be made to the Advisory Opinion on Certain Expenses of the United Nations ${ }^{32}$. Although this Opinion

31. Cr. article 31.1 VCLT: "ordinary meaning to be given to the terns of the treaty".

32. Certain Expenses of the United Nations (Article 17 paragraph 2 of the Charter) Advisory Opinion 20 July 1962; ICJ Rep. 1962. 151-181. 
deals with questions relating to the financing of UN Peace Keeping operations, there is a certain similarity between this problem and the GDR's reservations. The functioning of the Committee is a collective interest, whatever supervisory procedure is used. Similarly, peacekeeping is a collective action under the Charter, based upon the authority of the General Assembly. In discussing article 17.2 Charter $^{33}$, the Court concluded that, as the Charter does not qualify "expenses", this means all the expenses ${ }^{34}$. Discussing the expenses in the context of the Charter, the Court does not find any other limitation of the meaning of article 17.2 Charter either.

The close resemblance between article 17.2 Charter and articles 17.1 and 18.5 CAT is striking. In the latter case the Convention merely mentions "expenses" without qualifying the origins of the expenses. By omitting a reference to the relation between the expenses and the supervisory procedures selected, it stands to reason that the Advisory Opinion could be applied by analogy $y^{35}$. Consequently, "the expenses of the Committee" are the amounts paid out to defray the costs of carrying out the purposes of the Committee, that is executing its supervisory task $^{36}$.

As the declaration intended to restrict the GDR's obligations under the Convention, it definitely was a reservation ${ }^{37}$. In fact, the GDR publicly acknowledged this during the first meeting of the States Parties ${ }^{38}$. It must be emphasized that as a result of the GDR's reservation a great deal of confusion could arise concerning the financing of the Convention. The reservation is a rupture in a system in which it is assumed that the collective of States Parties paid for all the expenses ${ }^{39}$. A system such as the one proposed in the East-German reservation would involve some complicated arithmetic ${ }^{40}$.

33. Article 17.2 Charter reads:"The expenses of the Organization shall be borne by the Members as apportioned by the General Assembly".

34. The Advisory Opinion reads: "Since no such qualification is expressed in the text of the Charter, it could be read in. only if such qualification must necessarily be implied from the provisions of the Charter as a whole. or from some particular provision thereof which makes it unavoidable to do so in order to give effect to the Charter": ICJ Rep. 1962 at 159.

35. This view will clearly be unacceptable to Mohr, who argues op.cit. at 333, that "under customary law -which is ultimately reflected in the German Democratic Republic's declaration - a state need be responsible only for the costs accepted by it".

36. Cf. Advisory Opinion, ICJ Rep.1962 at 179.

37. Coccia, Controversial Declaration, at 318-319; Gornig/Ney, op.cit. at 1050.

38. CAT/SP/SR.1 para.59, the GDR representative speaks of "the reservation by the German Democratic Republic to the effect that it would not fund the activities with which it was not in agreement..".However, Mohr, op.cit. at 330-331, suggest that it is a mere interpretative declaration as it repeats an understanding of these provisions expressed during the drafting.

39. CAT/SP/4 and CAT/SP/SR.1 para.54:".proportionately on the basis of the United Nations scale of assessment..", and see Burgers and Danelius, op.cit. at 112-113.

40. About the problems with the assessment of the contributions as a consequence of the GDR's declaration see: Coccia. Controversial Declaration at 325-327, Edwards, op.cit. at 391-393: Gomig/Ney op.cil. at 1052: Lijnzaad. Nederlands bezwaar at 507-508. 


\subsection{Objections}

The Convention against Torture is remarkable for the number of objections made, and the fact that the objections appear to have led to the withdrawal of reservations. As this has not occurred under the other instruments we have considered, it is useful to look at these objections in greater detail. An explanation of the surprising amount of objections might be the fact that, whereas States may not take an interest in a variety of detailed reservations to the other human rights treaties, they are indeed concerned about torture. The seriousness of the acts that the Convention seeks to prohibit may prompt a more active objections policy. The objections focus on both contentious reservations, the reservation by Chile to articles 2.3 and 3 CAT and the German Democratic Republic's reservation concerning articles 17.7 and 18.5 .

On the other hand, a cynic might suggest that neither Chile not the German Democratic Republic were States of great importance at the time of the objections. Thus States could object without the objections having any serious consequences for their international relations. Moreover, with respect to the GDR's reservation, States had a clear interest in the assessment of the Committee's expenses.

Sixteen States have objected to the GDR's reservation concerning the financing of the Committee's work ${ }^{41}$. The objections differ a lot, and show a wide variety of reasons for objecting. Four different reactions can be distinguished ${ }^{42}$. Italy, Greece and Spain based their objections on the fact that the GDR's reservation is contrary to article 19.b VCLT ${ }^{43}$. In view of the drafting history of the provision, it must be considered a misinterpretation of article 19.b VCLT to assume that the Convention would not allow other reservations than the ones specified in the Convention itself, as it does not explicitly say $\mathrm{so}^{44}$.

A second group of States plainly states that the reservation is unacceptable, without clarifying the legal aspects of their position ${ }^{45}$. States are not obliged to

41. The United Kingdom made a declaration which cannot be considered an objection.

42. Edwards, op.cit. at 384-385.

43. Coccia, Controversial Declaration at 315,320 ; Mohr, op.cit. at 332 ; similarly suggesting the applicability of article 19.b VCLT Meron, Humanitarian norms at 23.

44. See Chapter 2, par.3.1.1 supra on the implications of article 19.b VCLT; and para.1.2 supra on the law applicable to reservations to the CAT.

45. Austria:"..cannot alter or modify, in any respect, the obligations arising from the Convention for all the States Parties thereto.."

Denmark:"..the said declaration has no legal basis in the Convention or in international treaty law."

Netherlands:"..it would also affect the obligations of the other States Parties which would have to pay additionally in order to ensure the proper functioning of the Committee against 'Torture. For this reason the reservation is not acceptable.."

(continued...) 
provide reasons for the reservations they make, or for the objections, but these are somewhat peculiar ${ }^{46}$. The Austrian contention is strange in view of the fact that reservations by their very nature alter or modify obligations arising from a treaty, as indicated amongst others by article 2.1.d VCLT. One wonders what is meant by the assumption by Denmark that there is no legal basis for the GDR's reservation in the Convention, as reservations to these provisions are not prohibited. The Norwegian statement, also adhered to by Finland, that the reservation is without legal effect can only be understood if Norway is of the opinion that reservations contrary to object and purpose of the treaty are void ${ }^{47}$. The Netherlands consideration that the East-German reservation will increase the financial obligations for other States Parties seems to be based on down-to-earth bookkeepers' logic ${ }^{48}$.

A third group of States consider the reservation contrary to article 19.c, or formulate their objection in similar terms ${ }^{49}$. These objections rely on the rule laid down in article 19.c VCLT, the prohibition of reservations incompatible with the object and purpose of the treaty.

Finally there is the peculiar declaration made by the United Kingdom ${ }^{50}$. It reads:

"... It does not regard the said declaration of the German Democratic Republic as affecting in any way the obligations of the German Democratic Republic as a State Party to the Convention (including the obligations to meet its share of the expenses of the Committee on Torture as apportioned by the first meeting of the States Parties held on 26 November 1987 or any subsequent such meetings) and do not accordingly raise objections to it. It reserves the rights of the United Kingdom in their entirety in the event that the said declaration should at any future time be claimed to affect the obligations of the German Democratic Republic as aforesaid".

Although the declaration expressly states that it is not an objection, it appears to be a conditional objection. In fact the declaration bears a striking resemblance to what has been said before about interpretative declarations that might be converted into reservations $s^{5 !}$. The United Kingdom declaration is complicated to say the least. It assumes that the GDR's reservation has no implications for the GDR's obligations under the Convention. However, would this be the case, then

\section{5. (...continued)}

Norway:".eannot accept this declaration entered by the German Democratic Republic. The Government of Norway considers that any such declaration is without legal effect, and cannot in any manner diminish the obligation of a government to contribute to the costs of the Committee.."

46. See Chapter 2, par.3.2.2 supra.

47. See Chapter 2, par.3.1.2 supra.

48. Lijnzaad, Nederlands Bezwaar, at 507-508.

49. Canada and Sweden specifically indicate that the reservations are contrary to art.19.c, whereas Australia. France. New Zealand and Portugal mention "object and purpose", Luxembourg "purpose and goal" and Switzerland "purpose and aims".

50. Cf. Coccia, Controversial Declaration, note 9 at $316,318$.

51. See Chapter 2. par.5. 
they claim the right to reconsider their position. This creates uncertainty about the treaty relations hetween the United Kingdom and the GDR until the United Kingdom determines its position. On the other hand, it could follow from article 20.5 VCLT that the United Kingdom has accepted the reservation tacitly after a year of silence. It all depends on the interpretation of the declaration. Obviously, the United Kingdom has not been able to determine whether it dealt with a reservation or a (non-binding) declaration. It therefore made this ambivalent declaration, implying a more or less conditional objection.

It should be noted that two States objected within a year after the reservation was entered by the GDR, and another six States objected within a year of their own ratification. This implies that seven States objected, hut were outside the timelimit set by article $20.5 \mathrm{VCLT}^{52}$. This did not lead to problems, as none of the States precluded the convention's entry into force on the basis of their objections.

Seven States explicitly indicate that although they objected, the Convention would enter into force between them and the $\mathrm{GDR}^{53}$. According to article 20.4.b VCLT it is not necessary to state this, and it may safely be assumed that the Convention will enter into force between all the objecting States and the GDR. The interesting question remains as to what is actually going to enter into force. What is the legal regime created by the mishmash of the CAT, the GDR reservation and the objections?

The reservation has not only modified the GDR's obligations according to articles 17.7 and 18.5, but has thoroughly changed financial obligations of all States Parties. The reservation will modify the Convention between states accepting the reservation and the GDR. This implies that neither the GDR nor the accepting state will be obliged vis-à-vis one another to contribute towards the Committee's expenses to any further extent than the procedures binding on such a State Party, which follows from article 21.1 VCLT. Between objecting states ${ }^{54}$ not opposing entry into force of the Convention and the GDR, articles 17.7 and 18.5 do not apply according to article 21.3 VCLT. Thus, although the Convention enters into force there will not be any obligation whatsoever between these states to contribute to the expenses of the Committee against Torture. In the relations between the other states parties, whether they accept the GDR's reservation or not, the Convention will enter into force with the obligation to pay for all the Committee's expenses irrespective of the supervisory mechanisms binding on the State Party, which follows from article 21.2 VCLT. To summarize: the reservation and the objections have led to triangular system of financial obligations ${ }^{55}$. There is no doubt that this could lead to a complex discussion when estimating the Committee's budget and apportioning each State Party's share.

52. Austria, Canada, Denmark. Norway, Spain and Switzerland reacted ton late.

53. Denmark, France, Greece. Luxembourg, New Zealand, Portugal and Switzerland.

54. As the GDR ratified on 9-12-1989) these can now, atcording to article 20.5 of the Vienna Convention only be states that express oljections at ratification.

55. On this issue:Lijnzaad, Nederlands bezwaar, at 507-508; Gornig/Ney. op.cit. at 1052. 
Another issue also requires attention. Basically reservations and objections only modify or restrict the obligations of States Parties vis-à-vis one another. Indeed it says so in article 21.2 VCLT: no inter se modification between the other States Parties. But looking at the budgetary problem facing the Committee against Torture it would appear that in this case there are going to be modifications in the obligations facing the other States Parties. For whatever their treaty obligations based on the reciprocity of the reservation, there will be an increase of obligations for the simple reason that the functioning of the Committee would otherwise be hampered. The GDR's reservations not only modify the GDR's position, but at the same time necessitate the other States Parties assuming obligations beyond the ones laid down in the Convention or following from treaty law in general. This peculiar consequence is pointed out by both Austria and the Netherlands in their objections ${ }^{56}$.

Thus the GDR's reservation undermines the validity of the assumption laid down in article 21.2 VCLT. The problem is not so much whether article 21.2 is an imperative rule of treaty law, but the reservation is peculiar in undermining the assumption underlying an established rule of the law on reservations. The articles 17.7 and 18.5 CAT lay down the financial basis for the functioning of the Committee against Torture. These are not obligations between the States Parties and the Committee but, between the States Parties as a collective obligation. Providing for the expenses of the Committee is a responsibility bearing on the collective of States Parties to the Convention, which is more or less indicated by the way in which both provisions are formulated ("States Parties shall be responsible.."). The functioning of the Committee is a collective interest, and this implies that in case one of the members of the collective limits its contribution, the other members will have to increase their contributions so as to maintain supervision by the Committee. Although from the point of view of the law of treaties they are not obliged to do so, they will be inclined to provide additional funds that make up for the restriction affecting the community interest. This is based on policy considerations rather than legal obligations.

The concept of the functioning of the Committee as a collective interest is based upon the existence of the supervisory system which is in itself a core element of the Convention ${ }^{57}$. The fact that the financing of the Committee is a collective obligation does unfortunately not imply that reservations could be ignored, as the

56. Austria:"..cannot alter or modify, in any respect, the obligations arising from that Convention for all States Partics thereto."|my italics, EL]

Netherlands:".it would also affect the obligations of the other States Parties which would have to pay additionally in order to ensure the proper functioning on the Committee against Torture."[my italies, EL]

57. Coccia, Controversial Declaration. at 322-324; Gornig/Ney, op.cit. at 1051. 
Netherlands and Norway seem to assume ${ }^{58}$. The law of treaties is inflexible, a reservation does modify the obligations of the reserving state.

An even greater number of States objected to the reservation by Chile on the issue of superior order. Fourteen states indicated that they considered the Chilean reservations to articles 2.3 and 3 CAT incompatible with the object and purpose of the Convention, but added that the objection would not preclude entry into force of the Convention between Chile and the objecting State ${ }^{59}$. The other six states that object also indicate incompatibility as the ground for their objections but add different consequences. The United Kingdom indicates it is unable to accept the reservation, Bulgaria considers itself not bound by the reservation, Czechoslovakia states the reservation is invalid, Canada considers it inadmissible, and Austria and Australia indicate that the reservation cannot alter the obligations under the Convention.

The group of objecting States shows an increased variety of objectors. Apart from the European Communities ${ }^{60}$, the Nordic countries, Australia, New Zealand and Canada; Eastern European States express objections to substantive reservations, which is by all means a novelty. Without wanting to deny the right of objecting to any State, it might be suggested that the objections by Turkey are somewhat unexpected, and may be more of a reaction to the discussions about the Turkish conditional acceptance of article 25 ECHR, similarly including a "privileged" position for the military"

\subsection{State Party meetings}

The first meeting of the States Parties was held in Geneva on 26 November $1987^{62}$. It dealt with the election of the Committee and other organizational matters. The responsibility of the States Parties for the financing of the Committee's activities was on the agenda ${ }^{63}$, and it was decided that the expenses should be apportioned on the bases of the UN scale of assessments ${ }^{64}$. The declaration

58. The Netherlands objection:"..Thus, the assessment of the financial contributions of the States Parties to be made under article 17, paragraph 7 and article 18, paragraph 5 , must be drawn up in disregard of the declaration of the German Democratic Republic." The Norwegian objection:".. and cannot in any manner diminish the obligation of a government to contribute to the costs of the Committee against Torture in conformity with the provisions of the Conventions."

59. Similar objections by Denmark, Finland, France. Greece, Italy, Luxembourg, the Netherlands, New Zealand, Norway, Portugal, Spain, Sweden, Switzerland, and Turkey.

60. Belgium. Germany and Ireland had not ratified the Convention and could thus not object.

61. See about the Turkish declaration: S.Tomuschat, Turkey's declaration under article 25 of the European Convention on Human Rights, in: Fortschritt im Bewusstsein der Grund- und Menschenrechte (Festschrift Ermacora), Keht 1988, 119-139.

62. CAT/SP/1; Coccia, Controversial Declaration, at 317; Lijnzaad, Nederlands bezwaar, at 506-507.

63. $\mathrm{CAT} / \mathrm{SP} / 4$

64. CAT/SP/SR.1 par.54-55; about the assessment see Mohr, op.cit. at 331-332.. 
by the GDR was brought up at the meeting, and various representatives spoke on their government's views. According to Sweden the Convention provided no grounds for restricting the joint responsibility of States Parties for the Committee's expenses ${ }^{65}$, Canada found the declaration to be inconsistent with the spirit of the Convention ${ }^{66}$, whereas Switzerland thought it not to be in accordance with the intent of the Convention ${ }^{67}$. The GDR, acknowledging that the declaration was a reservation ${ }^{68}$, maintained that it was in conformity with the Convention.

The issue of the GDR reservation was not discussed at all during the second meeting of the States Parties in $1989^{\circ}$. The estimates provided by the Secretary General did not take into account the reservation, even though the Committee was already dealing with individual complaints at that time ${ }^{70}$. A reason for not taking into account the reservation might have been the fact that the GDR had paid more than it was due to for the period 1987-1989, and had in fact built up a credit against its 1990 assessment.

By the time of the third meeting of the States Parties, the GDR had withdrawn its reservation, and soon afterwards acceded to the federal Republic of Germany. In 1992 a Conference of the States Parties was held to discuss the initiative of Australia to change the financing of the Committee through an amendment to articles 17.7 and 18.5 CAT, which would lead to funding from UN resources upon terms and conditions to be decided upon by the General Assembly ${ }^{71}$.

\subsection{Withdrawal of reservations}

Within the relatively short existence of the Convention against Torture a remarkable number of reservations have been withdrawn. Not only did the reservations by Chile and the GDR disappear ${ }^{22}$, other reservations restricting supervisory procedures were also withdrawn.

With respect to the withdrawal of the confusing reservation by the GDR, it might be suggested that not only the number of objections, and the insistence of the Committee have contributed; but the changes in the political situation in the GDR prior to its dissolution may also have led to a change of mind for the responsible politicians.

The withdrawal of the Chilean reservation should also be attributed to political changes in the country, where a civilian government was just coming to

65. CAT/SP/SR.1 para.56.

66. CAT/SP/SR.1 para.57

67. CAT/SP/SR 1 para.58.

68. CAT/SP/SR.1 para.59:"..in his view the reservation by the German Democratic Republic..".

69. CAT/SP/SR.2.

70. $\mathrm{CAT} / \mathrm{SP} / 8$, at $5-8$.

71. CAT/SP/12:13.

72. All the German Democratic Republic's reservation has been withdrawn, and declarations under articles 21 and 22 CAT had been made on 13 September 1990, before the dissolution of that State. 
power $^{73}$, and apparently wanted to change its human rights record. In particular it may be relevant that the reservation seemed to aim specifically at the position of the military involved in torture practices ${ }^{74}$.

Though somewhat less visible, the withdrawal of two reservations to article 20 $\mathrm{CAT}^{75}$, and of seven reservations under article $30 \mathrm{CAT}^{76}$ should be mentioned, as these withdrawals contributed to expanding the Convention's supervisory system.

\subsection{Other consultations}

When discussing the progress of international human rights law in the Third Committee of the General Assembly, several representatives mentioned the GDR's reservation. Speaking on behalf of the Nordic countries in 1987, the representative of Norway expressed the hope that the State concerned would reconsider its declaration ${ }^{77}$. In a general way the representative of Canada expressed her government's concern that reservations might run contrary to the objective and intention of a Convention, be it in respect of substance or financing ${ }^{78}$.

\section{PRACTICE OF THE COMMITTEE AGAINST TORTURE}

\subsection{Reporting procedure, article 19 CAT}

\section{AUSTRIA}

"1. Austria will establish its jurisdiction in accordance with article 5 of the Convention irrespective of the laws applying to the place where the offence occurred, but in respect of paragraph I(c) only if prosecution by a State having jurisdiction under paragraph 1(a) or paragraph $1(b)$ is not to be expected.

"2. Austria regards article 15 as the legal basis for the inadmissibility provided for therein of the use of statements which are established to have been made as a result of torture."

In its second session the Committee had before it the report of Austria which mentions the declarations made ${ }^{79}$. A Committee member asked why Austria made the reservations, as the articles referred to are in fact applied ${ }^{\text {so }}$. The

73. Aylwin won the elections on 14 December 1989; and was sworn in on 10 March 1990.

74. L.J.LeBlane, Reservations to Human Rights Treaties (hereafter: Reservations), Paper prepared for the Thirty-Fourth Annual Convention of the International Studies Association. March 23-27, 1993 Acapulco Mexico, at 23-24.

75. Withdrawals by Hungary and USSR.

76. Withdrawals by Bulgaria, Byelorussian SSR, Czechoslovakia, Guatemala, Hungary, Ukrainian SSR and USSR.

77. $A / C .3 / 42 / S R .42$ par. 14 .

78. A/C. $3 / 42 / \mathrm{SR} .43$ par. 10.

79. CAT/C/5/Add.10 para.25 (article 5) and para.49 (article 15).

80. CAT/C/SR.18 para.13 (Gil Lavedra). 
Austrian reply is in both cases that the statement is interpretative. The Austrian representative elaborated on the domestic legal backgrounds of the statement concerning article $5^{81}$, and as regards the declaration regarding article 15 it established the inadmissibility of evidence obtained under torture as a legal principle directly applicable by criminal courts ${ }^{82}$.

A supplementary report was due in 1992 but has not yet been received.

\section{CHILE}

To article 2, paragraph 3 , in so far as it modifies the principle of "obedience upon reiteration" contained in Chilean domestic law. The Government of Chile will apply the provisions of that international norm to subordinate personnel governed by the Code of Military Justice, provided that the order patently intended to lead to perpetration of the acts referred to in article 1 is not insisted on by the superior officer after being challenged by his subordinate."[withdrawn 7 September 1990]

"Article 3, by reason of the discretionary and subjective nature of the terms in which it is drafted." [withdrawn 7 September 1990]

The Government of Chile declares that in its relations with American States that are Parties to the Inter-American Convention to Prevent and Punish Torture, it will apply that Convention in cases were its provisions are incompatible with those of the present Convention."

The initial report by Chile mentions the reservations made in the introduction and than elaborates on the reasons underlying the reservations ${ }^{83}$. The report indicates that in general Chilean legislation is in keeping with the rule in article 2.3 CAT. The duty of obedience only applies when the order is lawful, but it must be understood that it is not simple to apply such notions in real life. Subordinates may question the legality of an order, but if the order is maintained the obligation of obedience will prevail. However this will exempt the subordinate from criminal responsibility ${ }^{84}$. Similarly the report elaborates on the content of the reservation to article $3 \mathrm{CAT}$, Chilean legislation is in general in conformity with the spirit of the provision ${ }^{8 .}$.

In its discussion of the initial report the Committee is highly critical about the reservations made. Committee members ask about the factual situations that would fall under the scope of the reservations to article 2.3 $\mathrm{CAT}^{86}$; and wonder what is meant by the phrase that article 3 was drafted in a discretionary and subjective manner ${ }^{87}$. It is suggested that the reservations be withdrawn ${ }^{88}$, and that the three reservations are incompatible ${ }^{89}$.

In its reply Chile indicates that the reservations had been made for reasons of substance, for procedural reasons, and because of the replacement of the Govern-

81. CAT/C/SR.19 para.7-8 (Austria).

82. CAT/C/SR.19 pars.15 (Austria)

83. $\quad$ CAT/C/7/Add.2.

84. CAT/C/7/Add.2; par.54-61.

85. CAT/C/7/Add.2, par.62-74.

86. CAT/C/SR.40, par.10 (Burns): par.26 (Khitrin), par.30 (Mikhailov).

87. CAT/C/SR.40, par.11 (Burns); par.31 (Mikhailov). par.38 (Voyame).

88. CAT/C/SR.40, par.27 (Khitrin).

89. CAT/C/SR.40, par.36-38 (Voyame). 
ment at the time. Reservations were not final and could be withdrawn ${ }^{\infty}$. The representative then explains the principle of considered obedience in Chilean law ${ }^{91}$, and states that the reservation to article 3 was made because it is improper to pass judgement on the internal affairs of a State ${ }^{92}$. The prevalence of the Inter-American Convention was based upon a regional agreement to that effect but it was a hypothetical case ${ }^{93}$.

In their reactions, Committee members in particular welcome the remark that reservations can be withdrawn ${ }^{94}$.

It had been agreed that Chile would submit an additional report within a year, and in that period the change of government took place, as well as the withdrawal of the reservation ${ }^{95}$. The additional report, submitted by the new democratic government of Chile, is unusual to say the least ${ }^{\text {th }}$. It gives an historical overview of the torture practices of the Pinochet regime, and discusses the inaccuracies of the earlier report in a paragraph called "Main falsehoods". Moreover the arguments provided earlier to justify the reservations made are heavily criticized. The Committee reacted positively to the changes in Chile, including the withdrawal of the reservations ${ }^{97}$. On the request of the Committee additional information is provided with respect to the implementation of articles 2.3 and 3 $\mathrm{CAT}^{98}$. While it seems implied in the Chilean statement that all reservations had been withdrawn, it would appear that the reservation dealing with the co-existence of the Inter-American convention and the CAT was not withdrawn".

\section{ECUADOR}

Ecuador declares that, in accordance with the provisions of article 42 of its Political Constitution, it will not permit extradition of its nationals.

The initial report by Ecuador was rather brief ${ }^{100}$, and the State was consequently asked to provide more and more detailed information. The two additional reports do not deal with the declaration made referring to the Constitution ${ }^{101}$, even if one of the reports contains an explanation of the relevant provision ${ }^{102}$. The questions raised by the Committee merely deal with an explanation of the constitutional provision, rather than discussing it as a possible reservation ${ }^{103}$.

90. CAT/C/SR.41, par.5 and par.44 (Chile).

91. CAT/C/SR.41, par.6 (Chile).

92. CAT/C/SR.41, par.7 (Chile).

93. CAT/C/SR.41, par.8 (Chile).

94. CAT/C/SR.41, par.36 (Khitrin), par.39 (Voyame).

95. $\mathrm{CAT} / \mathrm{C} / 7 / \mathrm{Add} .9$.

96. CAT/C/SR.77 par.21 (Diaz. Palacios).

97. CAT/C/SR.77, par.30 (Burns), par.33 (Chanet).

98. CAT/C/SR.77, par.33 (Chanet); CAT/C/SR.78, par.7-8 (Chile).

99. ST/LEG/SER.E/11 at 182.

100. CAT/C/7/Add. 7 and CAT/C/SR.61

101. CAT/C/7/Add.11; CAT/C/7/Add.13.

102. CAT/C/7/Add.13 at 16-17 about article 42 of the Political Constitution.

103. CAT/C/SR.90/Add.1 par.20 (Ecuador). 


\section{FEDERAL REPUBLIC OF GERMANY}

Article 3

This provision prohibits the transfer of a person directly to a State where this person is exposed to a concrete danger of being subjected to torture. In the opinion of the Federal Republic of Germany, article 3 as well as the other provisions of the Convention exclusively establish State obligations that are met by the Federal Republic of Germany in conformity with the provisions of its domestic law which is in accordance with the Convention.

The German report does not specifically mention the declaration made with respect to article 3 in relation to German extradition legislation. It does however contain an extensive elaboration about the relevant legislation ${ }^{104}$, and the issue is briefly referred to by the German representative in his introduction ${ }^{105}$.

\section{GERMAN DEMOCRATIC REPUBLIC}

"The German Democratic Republic declares that it will bear its share only of those expenses in accordance with article 17. paragraph 7 and article 18, paragraph 5 of the convention arising from activities under the competence of the Committee as recognized by the German Democratic Republic."[withdrawn 13 September 1990]

The initial report by the German Democratic Republic is rather brief and merely deals with the substantive provisions of the Convention, and thus the implementation of articles 2 to 16 is discussed ${ }^{106}$. The issue of the reservations made is equally absent from the discussion of the Committee ${ }^{107}$.

Given the far-reaching nature of the reservations, it is striking that they are not mentioned. An explanation might be that the Provision Guidelines on reporting $^{108}$ did not explicitly refer to the issue of reservations and deliberately focused on the domestic situation. On the other hand, reservations could be dealt with under the rather general heading "Information of a general nature".

\section{LUXEMBOURG}

Interpretative declaration

Article 1

The Grand Duchy of Luxembourg hereby declares that the only "lawful sanctions" that it recognizes within the meaning of article 1, paragraph 1, of the Convention are those which are accepted by both national law and international law.

The initial report of Luxembourg explains that the declaration had been made to stress that this would be the right interpretation of the provision ${ }^{1(2)}$, which is not defined expressis verbis in the Convention itself. In response a Committee

104. CAT/C/12/Add.1, par.36-44.

105. CAT/C/SR.128, par 10 (Germany).

106. CAT/C/5/Add.13.

107. CAT/C/SR.30, CAT/C/SR.31.

108. Provisional guidelines regarding the form and content of initial reports to be submitted by States parties under article 19 of the Convention; see: $A / 43 / 46$ at $43-44$.

109. CAT/C/5/Add.29, par.8. 
member raised the issue how Luxembourg struck a balance between international and internal law ${ }^{110}$, but the matter was not dealt with any further.

\section{NETHERLANDS}

Interpretative declaration with respect to article 1:

"It is the understanding of the Government of the Kingdom of the Netherlands that the term "lawful sanctions" in article 1, paragraph 1, must be understood as referring to those sanctions which are lawful not only under national law but also under international law."

The declaration is mentioned in the initial report by the Netherlands ${ }^{111}$, but a Committee member mentions that the point of view expressed would seem to go without saying ${ }^{112}$. She also asks why the Netherlands did not enter a reservation with respect to article 5.1.c CAT, as the report indicates that this provision would not be implemented by the Netherlands. The Netherlands reply that it was felt that the provision provided the opportunity to establish jurisdiction if appropriate, which was not the case ${ }^{113}$. The declaration was not discussed when the Committee dealt with the reports of the Netherlands Antilles and Aruba ${ }^{1 / 4}$.

\section{NEW ZEALAND}

"The Government of New Zealand reserves the right to award compensation to torture victims referred to in article 14 of the Convention Against Torture only at the discretion of the Altorney-General of New Zealand."

The initial report of New Zealand gives an elaborate presentation of the domestic system with respect to the settlement of claims for compensation for personal injury and indicates how the compensation issue covered by the reservation has been dealt with in order to fit into the existing system ${ }^{115}$.

In their discussion of the report of New Zealand, Committee members frequently ask what is precisely meant by the phrase "at the discretion of the Attorney General"116. It is also suggested that the reservation is incompatible because of the fact that the Convention indicated which specified reservations might be made ${ }^{177}$.

New Zealand replies that the rule of object and purpose applied and that New Zealand had not acted contrary to that rule ${ }^{118}$. However, the Committee in its conclusions on the report specifically mentions the reservation to article $14 \mathrm{CAT}$,

110. CAT/C/SR.107, par.16 (Sorensen).

111. CAT/C/9/Add.1, par.6.

112. CAT/C/SR.46, par.88 (Chanet).

113. CAT/C/SR.47, par.57 (Netherlands).

114. CAT/C/9/Add.2: CAT/C/9/Add.3; CAT/C/SR.63-64.

115. $\mathrm{CAT} / \mathrm{C} / 12 / \mathrm{Add} .2$ at $35-37$.

116. CAT/C/SR.126, par.25 (EI Ibrashi), par.34 (Gil Lavedra), par.40 (Sorensen), par.53 (Voyame).

117. CAT/C/SR.126, par.53 (Voyame), assuming that the Convention against Torture uses the article 19.6 VCLT system.

118. CAT/C/SR.127, par.3 (New Zealand). 
and suggests that New Zealand will review its reservations to ensure full compliance with the Convention ${ }^{119}$.

\subsection{Individual complaints, article 22 CAT}

The individual complaints dealt with by the Committee against Torture so far have not touched upon the issue of reservations. The majority of claims were made against non-reserving States. A claim against Austria in which article 15 CAT was invoked, was declared inadmissible under article 22.5. a CAT ${ }^{120}$.

\section{CONCLUSIONS REGARDING THE RESERVATIONS TO THE CONVENTION AGAINST TORTURE}

In giving an opinion about the reservations to the Convention, one could easily be tempted to agree that reservations have only been a marginal problem. Looking back at the genesis of the "object and purpose" notion, I have earlier argued that this concept was influenced by the single-mindedness of the Genocide convention $^{121}$. The clear goal of the Genocide Convention explains why "object and purpose" became the yardstick with respect to compatibility. The limited number of reservations, and indeed the large number of objections can probably be explained by the fact that the Convention against Torture is an instrument codifying a rule of ius cogens, thereby being a treaty with a "single purpose" comparable to the Genocide Convention.

\subsection{The reservations}

Looking at the limited number of reservations that have been made to the Convention against Torture, the reservations of Chile and the GDR call for special attention.

The Chilean reservations to articles 2.3 and 3 did undermine core provisions of the Convention. Not only was the reservation rather complex, if not contradictory, it ran against the prohibition of relying on superior orders as an excuse for torture. It is however doubtful whether there would have been any other way to improve the quality of protection against torture in Chile other than the withdrawal of the reservations by the author State.

The reservation entered by the GDR regarding the financing of the work of the Committee against Torture has no parallel in human rights law. From the point of view of treaty law it raises number of intriguing questions about the treaty relations established on the basis of this reservation. Considering the Committee's financial fundament a collective obligation clarifies why the reservation would, in

120. W.J. v. Austria; Communication 5/1990, Decision on Admissibility 20 November 1990 (A/46/46 at 73-74).

121. About the single-mindedness of the Genocide Convention see Chapter 3, par.2 supra. 
spite of article 21.2 VCLT, also lead to a change of the relations, and indeed financial obligations, between the other states parties.

Other reservations have a more limited effect and frequently indicate which option a state has chosen in case the Convention opens the possibility for different ways of implementation.

\subsection{The role of States}

The wide variety of objections made to the GDR's reservation shows that States are at a loss with the rules of the law of treaties. It is striking that two states refer to a provision of the Vienna Convention (articles 19.b) that is clearly not applicable. Other objections demonstrate the inadequacy of article 19.c VCLT as a yardstick, assuming that reservations contrary to object and purpose should be ignored. And the objections correctly stating a breach of article 19.c merely prove the impotence of the objecting states for lack of other possibilities of action. The fact that states are not at ease with objections as an instrument of treaty law shines through the various formulations. And it must be admitted, even though states object they do not seem to achieve anything at all.

It is remarkable that the issue of the financing of the Committee that the GDR's reservations dealt with, has not explicitly been on the agenda of the States Parties. It must be assumed that this organ would specifically be interested in the issue, but it has barely been mentioned. On the other hand, this may be the consequence of the wise step not to take the reservation into account when producing the list with the contributions due by the States Parties. This could have been a risky approach, because the GDR could legitimately bring up its position with respect to the financing of the two procedures it had not accepted. However, it never did.

There have been equally impressive numbers of objections to the Chilean reservation. A total of twenty States objected to the reservation, three more than to the GDR's reservation. By and large the objecting States indicate that the reservations are incompatible and therefore invalid, although no one excludes entry into force. This would seem to indicate that the States that earlier referred to article 19.b VCLT in their objections, had by then come to the conclusion that article 19.c VCLT was the relevant provision.

In spite of the objections, the only thing that could really change anything about the incompatible reservations would be their withdrawal. And indeed the two, most notorious reservations have been withdrawn, the GDR's reservation was withdrawn a few days before the accession of the German Democratic Republic to the Federal Republic of Germany ${ }^{122}$. Chile's reservation was withdrawn within two years after it had been made. It has been argued that both these

122. The reservations were withdrawn on 13 September 1990; the German Democratic Republic ceased to exist on 3 October 1990. 
withdrawals are the direct consequences of a change in the political situation in the reserving State ${ }^{123}$. Be this as it may, taking this as the only explanation would seem to ignore that the objections may have had any effect. Again, this does not mean that the objections lead to the withdrawals, but they may have influence the decision to withdraw.

\subsection{The role of the Committee against Torture}

Given the fact that very few far-reaching reservations have been made, there would not seem to be a lot of analytical remarks to be made about the practice of the Committee. Yet a few remarks must be made.

In its discussion about the reservations of Chile, the Committee is, as it should be, rather critical. Given the nature of the reservations this was to be expected. Yet, it is to be regretted that the discussion of the declaration by Ecuador was not very thorough: in particular, the Committee might have been expected to raise the question of whether the declaration should be read as a reservation. The discussion, later on, of the New Zealand reservation with respect to compensation is an example of more agile way of questioning: the Committee wanted to know what the precise extent of the reservation was, and suggested that the reservation be withdrawn. Clearly, the Committee had to find a way to address the issue of reservations and declarations at the beginning of its work. In the discussion with New Zealand the question of the compatibility of the reservation was asked, and it would be useful if the Committee would retain the liberty to inquire into the compatibility of a reservation. Even if Committee-member Voyame remains of the opinion that article 19.b VCLT is applicable with respect to reservations to the Convention against Torture ${ }^{124}$.

The fact that the GDR's report did not even mention its far-reaching reservations, indicates the need to require reporting about reservations in the "Guidelines on reporting". The absence of a reference to reservations may be understandable, given the fact that the emphasis is on substantive provisions. Yet the financial reservations potentially posed a great threat to the Convention and should at least be mentioned in the report.

Another interesting development is the fact that Committee-member Chanet asks a state party (the Netherlands) why it did not make a reservation ${ }^{125}$. While restricting the amount of reservations is in general desirable, Chanet's approach seems to be inspired by the desire to be clear about the obligations accepted under the Convention. As the state suggested that it had liberty in establishing jurisdiction, which is a misinterpretation of the Convention, there is a point in this line of questioning. 


\subsection{Prospects}

Since the withdrawal of the Chilean reservation and the withdrawal of the GDR's declarations with respect to the financing of the Committee the issue of reservations to the Convention against Torture has lost much of its urgency. 
PART IV CONCLUSIONS 


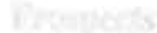

78 19.9

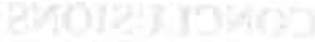




\section{RESTORING THE RUINS, CONCLUDING REMARKS}

In the, by now almost forgotten, socialist theory of international law, and its version of the law of treaties in particular, it has been suggested that reservations represented the interests of the ruling class in the reserving State'. Nowadays socialist legal doctrine has slipped into oblivion, and is not considered a relevant doctrine in the theory of international law anymore. In this case, however, I would like to suggest that Gubin's view is a particularly useful insight that may clarify a number of reservations made. In general it could be suggested that in a number of states, the political elite takes care of its own interests when in power. This does not necessarily have to coincide with the interests of human rights protection. The interests of males as society's privileged class may, for instance, account for the majority of the reservations to the Women's Convention. In fact, Shelton suggests that it is no coincidence that when looking at the substantive scope of the reservations to human rights treaties, the most fundamental ones aim at the least respected groups in society, such as aliens, prisoners and women ${ }^{2}$. To put it cynically, reservations are used to kick the weakest out of the system of human rights protection. Looking at it from this point of view, demonstrates that the reservations issue is not only a question of the adequate functioning of human rights law, but it also underlines that distinct moral issues are involved.

When discussing reservations one of the first questions is whose problem they are. Looking at the large number of reservations made, one would suspect that they are no problem at all, at any rate few objections were made, and few reservations have been withdrawn. We might be looking at a hypothetical problem, in which very few people other than the author take an interest. I have however never felt that this was a mere technical problem of international law, but rather a hidden impediment to the full implementation of human rights instruments. If this book has focused the attention on the importance of the problem, and has illustrated its origins, that will hopefully be a step on the path to a reduction of the detrimental impact of reservations. Given the multifarious aspects of this subject, before embarking on a discussion of the results of this enquiry into the law on reservations, the remark must be that there is doubtlessly more to be said than is possible at present. Issues such as the possibilities of developing the law of treaties into a set of rules that will facilitate the creation of

1. Gubin as quoted by Göttling. op.cit. at 15:".. zeigt nicht die verschiedene Lösungsmöglichkeiten für das problem von widerstreitenden Interessen der vertragswilligen Staaten, sondern erklärt die Entstehung der Vorbehalte politisch im sinne des marxistischleninistische Ideologie mit der Entstehung der Interessengegensảtze der Staaten".

And Schweisfurth, op.cit. at 258:"Wie ein internationaler Vertrag im ganzen, so diene auch ein Vorbehalt jeweils direkt oder indirekt den Interessen der herrschenden Klasse des den Vorbehalt erklärenden Staates. Nach den Vorstellungen des sowjetischen Theorie sind die Vorbehalte kapitalistischer Staaten meist ein Ausdruck der zwischen diesen Staaten bestehenden Widersprüche und Machtkämpfe." 
international rules stressing the common interest, rather than the individual and reciprocal interest of States; or a further investigation of ways to strengthen the role of the supervisory organs in the field of human rights law, present themselves. In that respect this study has merely highlighted disparities arising with respect to a very specific issue, the question of reservations to human rights treaties.

There is a growing interest in the problem of reservations to human rights treaties. Reservations to the Women's Convention put the issue on the international agenda, the reservations by the German Democratic Republic and by Chile to the Convention against Torture triggered a large number of objections, and as a consequence of questions by Austria the Human Rights Committee is at present considering a general comment with respect to reservations. The 1993 World Conference on Human Rights dealt with the issue of reservations ${ }^{3}$, and it is to be hoped that all these events are the beginning of genuine concern and ensuing action with respect to reservations to human right instruments.

\section{SOME ESSENTIAL ISSUES}

Prior to embarking on a detailed critique of the rules of law and the practice with respect to human rights treaties, it is useful to consider a number of rather general, yet essential issues that influence the practice, and thereby also influence possible solutions to the problem of incompatible reservations.

\subsection{The universality debate}

From the point of view of human rights protection, a fundamental issue is the dilemma between the integrity of human rights obligations and the universality of such obligations. The emphasis on the integrity of human rights obligations stresses the interdependence of the obligations, thereby implying that a pick-andchoose system undermines the authority of commitments in the field of human rights, and leads to a lower standard of protection. The issue at stake is the quality of protection, even if this would be at the expense of the universal scope of the obligations. The universality perspective, on the other hand, stresses the importance of a world-wide commitment to human rights, even if this implies allowing for certain differences between the States. The important goal is for all states to be bound, if necessary at the expense of the level of protection.

Universality and integrity are important goals, but seem to be interrelated in a unfriendly balance, in which achieving the one is necessarily at the expense of the other. Taking universality and integrity to be abstract values will not lead to greater insight into ways in which the problems concerning incompatible reservations may be solved. 
The fact should be taken into account that the implementation of a human rights instrument will take place at the domestic level, which may in itself influence the integral application of the treaty. The precise impact of reservations will not be exactly visible, the consequences of the limitation of the obligations under the human rights instrument will be hidden by domestic legislation. Even if no reservations were made, the universal adherence to a treaty might still detract attention from the fact that the universal rules may be substantially less universal when implemented at national level.

With respect to universality it should be kept in mind, that while adhering to the goals of universality a great number of different views exist as to what is precisely meant by universality. The aim of universality has great promotional value, and this aspect may have monopolized the discussion. However, uncertainty about the actual meaning of universality has turned it into a notion that is somewhat manipulative.

While it is tempting to look at universality in a purely arithmetical way, this might be very delusive as there is the risk of losing sight of fundamental flaws in human rights protection behind abstract figures. On the basis of the numbers of ratifications in relation to the reservations made, it could be assumed that reservations are a reasonable option to increase ratification. The fact that an impressive number of States have ratified the four human rights instruments discussed in the foregoing would seem to illustrate that reservations may be a practicable tool to facilitate ratification. Yet, this approach clearly ignores the scope of reservations and their impact on the human rights protection.

\subsection{The lack of correlation between the law of treaties and human rights law}

Throughout this book two different angles have been used to study the problem of reservations, the law of treaties perspective and the human rights law perspective. As has transpired, there is a general problem of correlation between the law of treaties and human rights law. Both fields of international law have a different orientation, and a different structure. It may not be possible to solve these structural problems within the near future, yet it is important to be aware of this as one of the origins of the problem of reservations to human rights treaties.

The general assumption is that the law of treaties purely regards the creation of rules of international law as laid down in treaties. It governs the creation of lex scripta, its rules are merely instrumental and thereby supposedly neutral. The law of treaties does have no other aim than facilitating the creation of lex scripta. The law of treaties developed as customary law, based upon intemational practice, and is nothing more than the States found necessary to create. As such, it does not have any inherent aspirations of its own. 
When the law of treaties was codified by the Vienna Conference, the bulk of the rules were traditional rules, and only a few rules were progressive development of the law of treaties. The rules on reservations in the Vienna Convention were partially based upon the Court's Advisory Opinion on the Genocide Convention, and partially based upon the exigencies of treaty-making in a rapidly expanding world. The twelve month rule for the acceptance of reservations in article 20.5 VCLT is a clear example of this tendency. One might have suspected that the latter consideration would have led to a law of treaties that is sufficiently flexible, if not agile, to include the needs and necessities of present day law making, for instance within the United Nations. Yet, while the Vienna Convention appears to live up to the needs of multilateral treaty-making, it in fact does not. The concept of a multilateral treaty used by the Vienna Convention is not based upon genuinely multilateral relations, but upon a bundle of bi-lateral relations that add up to being a multilateral treaty. A basically bilateral system is used to realize multilateral interests. As Higgins describes it, the core problem is that the law of treaties is inappropriate for solving the new challenges in international law, the aim of creating obligations other than strictly reciprocal obligations 5 .

A clear example of the inability of the present law of treaties to cope with the fundamentally different relations springing from a multilateral treaty are the problems created by the GDR's reservations to the Torture Convention's financing. The German Democratic Republic intended to restrict its obligation to contribute to financing the work of the Committee to those supervisory procedures that it had accepted. These reservations entered into force, even though a substantial number of objections were made. As has been demonstrated, the result of the reservations would have been a confusing bundle of financial obligations, in which as a result of the reservation the obligations of the other States Parties would probably have been increased. It is a rare example that clearly demonstrates the inadequacy of the rules, in particular with respect to building a universal system of human rights protection.

The fact that the law of treaties does not provide for the creation of genuinely multilateral instruments and still uses largely the method that was developed with respect to reciprocal treaties is misleading; it gives us a wrong idea about the balance of obligations between the contracting States. While it may not be possible to change the Vienna Convention or adapt the law of treaties to the changing needs of the international legislative process, it is a necessity that will have to be kept in mind for future developments in the law of treaties. Unless a mechanism is developed that adequately addresses the common interest of the international community rather than the reciprocal interest of States, or the consequences of the indifference of States, there will not be fundamental changes in this field.

A second, and related issue is the way in which international law functions, and the importance of interest as a mechanism stimulating compliance. One has to 
realize that the law of treaties is still very much geared towards a traditional, some would say old-fashioned, model of implementation. The fulfilment of international obligations largely depends on the benefits a state expects. Implementation is encouraged by co-contracting states who emphasize fulfilment of obligations, because this is in their interest. The interrelation of rights and obligations for all parties to a treaty is thus a mechanism that enhances the fulfilment of obligations. Substantive reciprocity provides the necessary dynamics for implementation monitored by the States Parties themselves.

As we have seen the States Parties to a human rights treaty have an interest in the fulfilment of obligations under such a treaty, but this may be a mere legal interest. The absence of interrelated obligations leads to a declining interest in the implementation of a treaty, treaty relations underlying human rights obligations are to a certain extent a legal construction, rather than an realistic and genuine obligation. Human rights obligations have to be implemented between the States Parties and the individuals under their jurisdiction, whereas a "traditional" treaty leads to obligations carried out at the international level. This leads to a lack of interest in the implementation of an instrument, and in particular a lack of interest in (objecting to) reservations. The absence of the do ut des mechanism thus explains the small number of objections and withdrawals. There does not appear to be an incentive to push a reserving State to withdraw its reservations by objecting.

Another consequence of the absence of a vital balance between the obligations of the States Parties is the appearance of declarations of an uncertain nature. Opaque declarations are made that might be reservations, but might also not be reservations. Similarly, vague declarations are made with respect to reservations which might or might not be objections ${ }^{7}$. This lack of clarity is, to my mind, the consequence of the absence of interest on the part of the other States Parties. In view of this indifference, it does not matter much how a reservation is formulated, neither does it matter that there is little certainty about the exact legal effect of such statements. Certainty about the legal effect is important when actual interests are at stake, it matters little when theoretical interests, such as the interests of States Parties to a human rights treaty in the correct implementation of the instrument by other States, are the core of the obligation.

A third problem is related to the dynamic nature of human rights law. Not only has there been a continuous increase in human rights documents since the second

6. In a discussion about the United Kingdom's initial report to the CEDAW Committee (CEDAW/C/6/Add.52). the representative indicated that the reservation (it was explicitly labelled "reservations" by the United Kingdom) was meant as an explanation(CEDAW/C/SR.159), probably implying that the legal effect would be that of an interpretative declaration.

7. See the statements (objections?) with an uncertain legal effect by the Netherlands to the Australian reservation to the CCPR and by Germany to the French reservation to the CCPR, discussed supra at Chapter 5, par.2.1: and the United Kingdom to the GDR reservation to the CAT, discussed supra at Chapter 7. par.2.1. 
World War, within the scope of the different treaties there is also an inherent tendency to expand and refine the protection offered by an instrument. This takes place through the practice of the supervisory Committees under the reporting procedure, and in the case of the HRC, also under the Optional Protocol. The general comments formulated by the Committees are also an important means of clarifying and refining the protection afforded by a human rights instrument.

These dynamic tendencies lead to some interesting questions with respect to reservations. Subsequent interpretation by a supervisory Committee may turn an interpretative declaration into a reservation, when the interpretation is not accepted by the Committee. On the other hand, an interpretative declaration may become extinct when the interpretation is accepted. The issue is more complicated when States ratifying some time after the entry into force. through their reservations maintain an interpretation that has not been accepted by the Committee in an earlier comment ${ }^{8}$. This poses the question whether reservations could and should be used to hamper the progressive development of human rights law, or whether States ratifying at a later date could opt out of the aciguis. It is again a consequence of the differences between the law of treaties which is relatively static, and the dynamic potential of human rights law.

\subsection{Reservations are not necessarily "wrong"}

In discussing the issue of reservations to human rights treaties, one has to realize that reservations may be inevitable to a certain extent. Even if the emphasis in this book has been on incompatible reservations, thereby creating the impression that reservations are always wrong, it should be stressed that in a number of cases reservations are a necessary and acceptable accommodation mechanism.

Reservations are to a certain extent the price to be paid for the drafting of human rights instruments in the United Nations, the price for striving for universality. The fact that much of the drafting takes places on the basis of consensus makes it clear that occasionally States may not want to disagree with the final result, in spite of disagreeing about a particular provision. Reservations are a reaction to drafting based upon the political wishes of the majority, and reservations are then an understandable solution. Somewhat differently, states may use reservations to redress imprecise drafting, when for political reasons the compromise formulation is ambiguous and a State Party wants to limit the extent of its obligations explicitly.

Another reason for making reservations may be to indicate in what way problems of conflicting rights will be solved. These may be conflicting international obligations, or conflicts between national and international law. As compared to other fields of international law, the national dimension is of great importance with respect to human rights. This may again be a reason for the large number of reservations that have been made. They shield the national situation against the

8. Cf. the reservations by the United States and Switzerland with respect to article 26 CCPR, discussed in Chapter 5, par.1.3 supra. 
exigencies of human rights law. It can have distinct advantages for the reserving State to indicate this, rather than being silent about it, in which case supervisory organs might be tempted to interfere. Thus some States claim that reservations reflect honesty, suggesting that it is uncalled for to be treated as though they were breaching their obligations under a treaty. The question is whether the scope of this "honesty" should have had a far-reaching impact on the protection guaranteed under the human rights instrument.

Human rights instruments deal with a variety of rights, which should lead to a more or less uniform human rights protection around the world, in spite of the fact that the situation in the ratifying states differs to a great extent. The variety in human rights situations, societies, cultures and economic situations between the States Parties to a human rights instrument may illustrate the need for some differentiation in the obligations undertaken. On the other hand the question would be how far such considerations should restrict the impact of a treaty. In particular with respect to the supposed cultural relativity of human rights, there is reason to suspect that limitations on human rights based upon notions of culture and religion may have an adverse effect for particular groups in society ${ }^{10}$.

Thus, while reservations may be an acceptable and practical accommodation mechanism, each time a determination will have to be made as to whether the reservation is a simple accommodation, or has a much wider scope. These are precisely the margins that will have to be judged using the "object and purpose" criterium. As much as honesty is to be praised, it will still be limited by what is permissible under the compatibility rule, which by its nature distinguishes between core and non-core obligations. Accommodation is acceptable with respect to non-core obligations, but it is not with respect to core obligations.

\section{THE GENOCIDE CASE IN RETROSPECT}

As has been described before, I am of the opinion that the Advisory Opinion in the Genocide case is, in retrospect, rather unfortunate. The clarity with which the majority proclaimed "object and purpose" as a yardstick, made it look too simple ${ }^{11}$. "Object and purpose" was to be the magic formula that would sort out all possible problems with respect to reservations. To my mind the ingenuity with which the majority sought to combine the different requirements of integrity and universality has blinded lawyers to the disadvantages of the criterion. While the "object and purpose" rule may have appeared to bridge the gap between the formal law of treaties and the focus on substantive rights in human rights law, the

9. Cf. the statements by Egypt (CEDAW/C/SR.164) and the United Kingdom (CEDAW)C/SR 155) in their discussions with the CEDAW Committec.

10. See about cultural relativity: R.E.Howard, Cultural Absolutism and the Nostalgia for Community, in: 15 HRQ 1993, 315-338; Jacobs, op.cit. at 81-87; and Lijnzaad, Maken en Breken, at 211-214.

11. The Advisory Opinion reads: The object and purpose of the Convention thus limit both the freedom of making reservations and that of objecting to them"; ICJ Rep.1951 at 24. 
notion never had that effect. "Object and purpose" is a multi-purpose rule, a catch phrase. It is as self-evident as it is opaque.

It is interesting to note that, when re-reading the joint dissent in the Genocide case the majority of the problems dealt with before have been predicted. The dissenting judges underlined that it would be hard to establish the "object and purpose", and that an individual determination of "object and purpose" by the States Parties would lead to confusion. Their conclusion that the "object and purpose" rule designed by their colleagues was not a reliable means of solving the problems ${ }^{12}$, is still valid today when looking at the problems that have arisen in practice as discussed in the previous chapters.

On the other hand, finding that the joint dissent was written with more foresight and vision than the majority opinion, does not mean that I would rather adhere to the solution chosen by the jointly dissenting judges. Not only do I feel that the emphasis on the integrity of the treaty would be unduly restrictive. While the majority opinion is quite unfortunate in retrospect, neither of the dissenting opinions is acceptable from the point for view of combining the notions of integrity and universality of human rights law. Looking back, this may be analyzed as the result of a Court that stuck to a limited opinion on what international law could achieve in the field of treaty-based human rights protection. The views expressed seem to suggest that few other possibilities for solving the problem of reservations are available, other than the ones suggested by the judges. This however should be understood as a view at the time of the Opinion, and the situation has changed since then. The development of supervision since the nineteen fifties has brought perspectives that were not available at the moment of the Genocide case.

The fact that none of the three opinions in the Genocide case gives adequate solutions illustrates, with hindsight, the complexity of the problem of reservations to human rights treaties, and the sheer impossibility of combining universality and integrity through the law of treaties. It would seem that there is no perfect solution, feasible solutions should be looked for.

\section{THE VIENNA CONVENTION RULES}

After these general remarks, we will have a look at the provisions of the Vienna Convention that are directly related to the issue of reservations to human rights treaties. An article-by-article overview will highlight the major difficulties.

12. The joint dissent, ICJ Rep. 1951 at 46, reads: "We regret, therefore, that we do not find in the new rule [that is the "object and purpose" rule. EL] that has been proposed any reliable means of solving the problems to which reservations to this convention have given and may continue to give rise, nor any means that are likely to produce final and consistent results". 
- article 2.1.d -

Commonly understood to be the definition of 'reservation' (it is in fact just a paragraph in the provision on "use of terms" in the Vienna Convention) this provision has led to a certain amount of inflation. The original idea was that the provision would provide guidance in case the status of a declaration was uncertain. In practice the focus on the substance of the declaration, emphasized by the "however phrased or named" formula has got a hold of the rule. This has led to almost ignoring the labelling of a statement by the reserving State itself. Rather than being a tool for distinguishing in cases of doubt, the rule in article 2.1.d has become the guiding principle itself.

The Opinion of the European Commission on Human Rights in the Belilos case, stressing that the original distinction made by the reserving State should determine the legal effect of interpretative declarations, seems to have found little acclaim. The importance of this case should be highlighted, especially so because of the increasing number of interpretative declarations. It provides a general rule to distinguish between the legal effects of reservations and interpretative declarations. The Commission's Opinion stressed the responsibility that States have for being clear about the intended legal effect of their declaration or reservation. The Opinion is a warning against the inflatory use of article 2.1.d VCLT, but the warning does not seem to have been heard.

\section{- article 19 -}

Few remarks are necessary to underline the problems created by article 19.c and the "object and purpose" rule laid down therein, as this has been the essential question in the foregoing. Within the law of treaties with its overriding formal character, the rule is unusual because of its emphasis on substance. It is that aspect through which a connection between the law of treaties and human rights law could have been established.

An obligation implied in the object and purpose rule is that it necessarily leads to distinguishing between the core and the non-core obligations in the treaty. If reservations contrary to the object and purpose are prohibited, this implies that reservations not detrimental to object ad purpose are permitted. This process of distinguishing is necessary if article 19.c VCLT is to have any meaning at all, yet it is a process that appears to be complicated and occasionally subjective. This will in particular be the case when distinguishing between core and non-core human rights. Thus far, there has been little theory as to how this process should take place, and it is indeed a matter to which further study should be devoted.

No formal mechanisms of protecting "object and purpose" are available to ensure that the obligation be fulfilled. "Object and purpose" is a rule without safeguards. This does not necessarily mean that the rule would therefore not be a rule of international law. Enforcement is in general not one of the stronger aspects of international law. If the "object and purpose" rule is a weak rule, a solution could be to look for mechanisms that might stimulate abiding by the rule. This would mean looking for elements that might increase the interest the States Parties have in the reservations made, turning it from a theoretical interest into an actual interest. It must be admitted that this is to a large extent a theoretical 
construction, as it is hard to see how this could be done. In general it might well be that the stewardship required by the object and purpose rule is based upon an image of the functioning of the international legal practice that is not in conformity with its present nature.

It should be noted though, that article 19.c VCLT itself is not the problem, rather the failure to formulate more precise reservations clauses as suggested under articles 19.a and 19.b is the original problem. It seems hardly feasible to include mechanisms monitoring object and purpose into the existing system, unless the supervisory organs take up this task. Thus, the choice should be to turn to a down-to-earth mechanism for the admissibility of reservations, for instance a system suggested by article 19.a and 19.b of the Vienna Convention. Preventing problems caused by the application of article 19.c should take place during the drafting. If clauses like article 19.a and 19.b VCLT were used more frequently, the "object and purpose" could stay the residual solution it was meant to be, and be interpreted for use in a particular treaty through either an explicit prohibition or an explicit allowance of certain reservations.

- article 20.4.a -

This provision clearly demonstrates that the Vienna Convention considers treaties to be a bundle of bilateral relations and operates on the assumption that this is what is meant by a multilateral treaty. The provision indicates the basically reciprocal relations resulting from the ratification.

- article 20.4.b -

The limited effect of objections is laid down in this provision. Objections no longer prevent a State from becoming a party to a treaty, and rarely stimulate the withdrawal of reservations. With hindsight, it could be suggested that the limited number of objections might be the direct consequence of the futility of objections, as indicated by article 20.4.b. If a reservation is totally unacceptable, it will not only be necessary to object, but the exclusion of treaty relations will only take place when this is explicitly indicated. This is why the Vienna Convention is said to favour reservations.

On the other hand, as I have argued in chapter two, this two-fold reaction to unacceptable reservations may be beneficial when it concerns human rights treaties. As demonstrated, the system distinguishes between approval of a reservation and the establishment of treaty relations. The issue of disapproval could be dealt with by objecting to a reservation. Whether a reservation is considered to be so detrimental that treaty relations should be excluded is a separate issue. With respect to human rights treaties, States may want to take the first step, and may express objections to underline the incompatibility of a reservation. However, given the absence of a direct interest to the objecting state, and in view of the importance of bringing reserving States into a Convention's 
supervisory mechanism, there will be little reason to exclude treaty relations, which makes the second step unnecessary ${ }^{13}$.

- article 20.5 -

With some cynicism, one might say that this provision has been a great success. The method of tacit acceptance has made the establishment of treaty relations on the basis of reservations much easier, and has greatly contributed to facilitating the increase in membership to treaties. It is also through this provision that States acquiesce in the existence of incompatible reservations. Tacit acceptance does not look like acceptance, but technically it is.

The time limit set for the tacit acceptance, and consequently the limit within which objections should be made, may be too short. Frequently objecting states express their objections after the twelve months period; being too late to prevent them taking effect should they want $t^{14}$. Taking into account the time required for the processing of reservations in a Ministry of Foreign Affairs, the time involved in deciding whether or not to object and subsequently formulating the objection, twelve months may just not be long enough.

\section{- article 21 -}

This provision may again be said to highlight the Vienna Convention's bilateral approach to reservations. Reservations modify the relations between reserving and accepting States. Because the majority of reservations are accepted under article 20.5 , the result will ultimately be general acceptance.

Some uncertainty remained about the difference between article 21.1.a and 21.3 about the different legal effects of an accepted reservation and a reservation objected to. Given the nature of human rights instruments this is of little relevance, as these provisions focus on substantially reciprocal obligations, which are by and large absent in human rights instruments.

\section{- article 22 -}

Article 22 provides a simple procedure for the withdrawal of reservations and objections. It is hard to see how the Vienna Convention could have facilitated withdrawal more than it does. In fact the liberal rule with respect to withdrawal underlines that, with the limited number of reservations to the treaties under consideration being withdrawn, the failure does not lie within the structure of the law of treaties but rather with the absence of a stimulus for withdrawal.

13. Imbert, Les Réserves at 153.

14. Objections to reservations to the Convention against Torture made by Austria, Canada, Denmark, Norway, Spain and Sweden were received after the twelve months period, see Chapter 7, par.2.1 supra. 
4.

In this paragraph we shall discuss the possibilities of reducing the Jetrimental impact of reservations to existing human rights treaties, in particular with respect to the ones discussed in the foregoing. Bymes is probably right in writing that "ultimately the important questions are tactical ones"15. As far as future practice on the basis of existing human rights conventions is concerned, suggestions would have to fit into the existing system, as it is unlikely that substantial changes would be take place. New additional protocols may have some promotional effect, but it is unlikely that fundamentally different rules could be created having an ex post facto influence on the reservations already made.

The main actors in this field are the States Parties and the supervisory Committees. My suggestions will indicate the opportunities both have to favourably influence the reduction of reservations to human rights instruments. Though from a formal point of view, it is first of all the obligation of States Parties to react to incompatible reservations, there are reasons to also take into account the complementary authority of the supervisory Committees to undertake action with respect to reservations.

\subsection{Role of the States Parties}

As far as States Parties are concerned, the message is simple: they should not make reservations, should object to reservations contrary to object and purpose, and should withdraw the reservations made ${ }^{16}$. While this is a too simplistic picture painted of solutions to the problem, it is to my mind first and foremost the task of the States Parties to prevent the existence of incompatible reservations that hamper the implementation of human rights conventions. The problem is attributable to the reserving States as well as to the negligence of the other States Parties.

With respect to the object and purpose rule, it must be repeated that the rule is only applicable in case a treaty does not contain a reservations clause. Ideally a treaty should contain a reservations clause specifying what is, and what is not acceptable.

The object and purpose rule is a rule of customary law, it is a rule with its foundation in the general principle of good faith. With its emphasis of the substantive aspects of reservations, the object and purpose rule should be adequate for considering reservations to human rights treaties. Monitoring of the

15. Bymes, The work of the Committee, at 52.

16. Vienna Declaration and Programme of Action (A/Conf.157/23) Part II, A par.S reads: The World Conference on Human Rights encourages States to consider limiting the extent of any reservations they lodge to international human rights instruments, formulate any reservations as precisely and narrowly as possible, ensure that non is incompatible with the object and purpose of the relevant treaty and regularly review any reservations with a view to withdrawing them." 
rule should however be improved. As indicated earlier, not only the reserving states are to blame for the detrimental impact, to my mind the accepting States are equally responsible for the existence of such reservations. Admittedly the Vienna Convention favours the acceptance of reservations through its system of tacit acceptance, but acceptance is merely a presumption that can be rebutted, if States act within the time-limit indicated by article 20.5 VCLT. It would appear that States rarely understand their role as a State Party as implying an active stewardship of the treaty, which may include objecting to incompatible reservations. While it has been suggested that objections largely depend upon political expediency ${ }^{17}$, it would seem that this has not been of great importance to the objecting States. A number of States do take an active approach and object, but this seems to be restricted to a regionally limited number of States ${ }^{18}$. Through political contacts awareness could be raised as to the possibility and desirability to consider each and every reservation from the point of view of object and purpose, and if need be, to object to incompatible reservations. It should be stressed that objections, while appearing to be unfriendly acts, are in fact nothing other than the expression of legitimate concern about the quality of the international legal order.

17. Jacobs, op.cit. at 85.

18. An overview of the States that objected to reservations to the four Conventions:

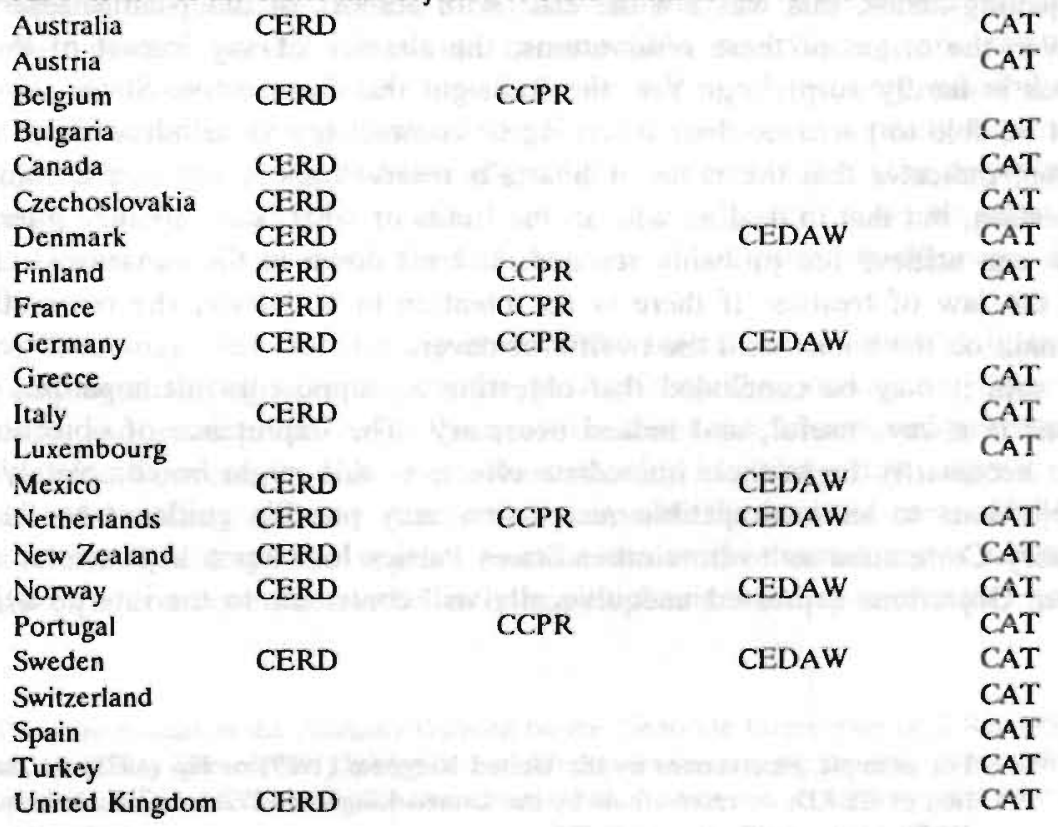


With respect to withdrawals, it has been noticed that States rarely withdraw their reservations. Reservations once made are hard to get rid of ${ }^{19}$. Here again, persuasion might be necessary to stress that adherence to the integral treaty is the standard, and reservations are a sub-optimal situation. A change of opinion on the acceptability of reservations is necessary, re-emphasizing the necessity to withdraw.

On the other hand a change may have been taking place in recent years, in which it appears that States object more frequently, and in which it looks as though a number of reserving States have on the basis of these objections reconsidered their reservations and have withdrawn them. This tendency is most notable with respect to the Convention against Torture and the Women's Convention.

As regards the two most striking reservations to the Convention against Torture, the reservation concerning the financing of the Committee made by the GDR, and the reservations by Chile with respect to superior order as a justification for torture, the impressive number of sixteen and twenty objections respectively have been made. The objections are somewhat selective, there does seem to be little regional variety in the group of objecting States. The objections seem to have been successful: the East German reservation was withdrawn within three and a half year after it was made, and the Chilean reservations were withdrawn within two years. On the other hand, political changes in both states may have been responsible for these withdrawals.

A similar tendency is visible with respect to the Women's Convention. Malawi, New Zealand, Thailand and the Republic of Korea managed to withdraw their reservations, to which a number of objections had been made. However, the objections have not had any impact whatsoever on the reservations invoking Sharia'h law. Whereas a number of states may have been persuaded by the objecting states, this was not the case with authors of the Islamic reservations. Given the origin of these reservations, the absence of any impact of the objections is hardly surprising. Yet, the foresight that even active States Parties will not be able to persuade their reserving co-contractants to withdraw these reservations, indicates that the issue of Sharia'h reservations is not just a complicated question, but that in dealing with it, the limits of what contemporary international law can achieve are probably reached. It boils down to the consensual character of the law of treaties: if there is no intention to withdraw, the reservation will remain on the books until the twelfth of never.

In sum it may be concluded that objecting to supposedly incompatible reservations is always useful, and indeed necessary. The importance of objections does not necessarily lie in their immediate effect, as this might be completely absent. Objections to an incompatible reservation may provide guidance to the supervisory Committee as to how other States Parties look upon a particular reservation. Objections expressed unequivocally will contribute to the interpretation of a

19. For example, reservations by the United Kingdom (1969) or Fiji (1973) on the ratification of CERD; or reservations by the United Kingdom (1976) or Trinidad and Tobago (1978) on the ratification of C.C.PR. 
reservation. Moreover, it is not beyond imagination that objections will eventually persuade the reserving State to withdraw its reservation. On the other hand, there is little certainty whether such a withdrawal does indeed lead to the granting of human rights that had previously been excluded, it is conceivable that withdrawals will be influenced by political considerations, rather than humanitarian considerations.

Within the framework of individual treaties there are also some options States may use to reduce the detrimental impact of reservations. To begin with, the meetings of the States Parties, held bi-annually primarily to elect the Committee members, might be used to address the reservations issue in more depth. The advantage is that the meeting of the States Parties is an existing forum whose members must be expected to take an interest in the treaty. These meetings are a regular forum in which the States Parties could expand their purely formal interest in the election of the Committee towards a more genuine stewardship of the treaty. It could be a forum to express concern about reservations made, and for consultations with the reserving States. With respect to the Women's Convention this has been initiated by Sweden, but without great impact. It is obvious that states should have a genuine intention to discuss reservations, especially the reserving states, if this is to have any effect at all.

Another possibility for States to take action with respect to reservations would be to put a dispute concerning the compatibility of a particular reservation before the International Court of Justice, on the basis of dispute settlement provisions in human rights treaties. Theoretically this is possible if States disagree about the compatibility. However, there are a number of reasons why the merits of such an approach should be questioned. First of all it is hard to see how such a dispute should arise in the present situation. Incompatible reservations are tacitly accepted on the basis of article 20.5 VCLT. To my mind the only possibility would be the rather hypothetical case in which a State objects to a reservation on the grounds of incompatibility, and this objection is contradicted by the reserving State arguing that the reservation is indeed compatible. Up until now, no reserving state has ever sought to rebut the accusation of incompatibility expressed in an objection.

It has also been suggested that the expertise of the International Court of Justice could be employed through the request for an Advisory Opinion on the issue of compatibility, and more precisely on the question about the "object and purpose" of the Women's Convention. However attractive, this is a dangerous suggestion that should not be taken up ${ }^{20}$. An Advisory Opinion on the issue of compatibility may be too detached from the regular practice under the human rights instruments, and as a consequence not be in line with the increasing awareness, and 
hopefully also increasing agility, of the supervisory Committees to dealing with reservations. Moreover, given the Vienna Convention rules on reservations, it is highly likely that the Court would ratify the existing practice. The contemporary rules are clear, incompatible reservations can be accepted, and there is little reason to suppose that the Court should feel otherwise. From that point of view an Advisory Opinion can do more harm than good.

\subsection{Role of the supervisory Committees}

Theoretically the role of the supervisory organs is residual as States should act upon article 19.c VCLT, yet they may in practice be the primary actors with respect to reservations.

The position of supervisory organs in the UN system is quite different from the position of the supervisory organs under the European Convention and the American Convention. The organs under both regional instruments have a distinct authority to deal with reservations, be it with respect to individual complaints or in Advisory Opinions. The rather far-reaching influence on reservations that is possible in those systems, is understandable in view of the fact that the legal order created by the regional human rights instruments is tighter and more coherent than it could be on world-level. Thus, though it is useful to look at the way in which reservations are dealt with under regional instruments, the situation is not fully comparable.

The practice of supervisory Committees with respect to reservations has not been impressive, to say the least. Members of the supervisory organs have always been reluctant to affirm their authority to deal with reservations, and to elaborate on the scope of this authority.

As to how this competence to discuss reservations could be established, various methods have been used. Looking for expert advice, the CERD Committee turned to the Director of the UN Division on Human Rights, who explained, after consultation with the Office for Legal Affairs, that the Committee had no authority to deal with the compatibility question as this was the authority of the States Parties ${ }^{21}$. An almost identical question was put to the Office for Legal Affairs by the CEDAW Committee, and the reply was identical: the Committee had no authority to deal with the matter of compatihility ${ }^{22}$. Apart from the fact that the Office for Legal Affairs is perhaps not a very liberal legal advisor, this also shows that this question should not he discussed explicitly.

Some Committee members have dealt with the issue, arguing persuasively that indeed the Committees have a role to play. In an early discussion about the British reservations to the Convention on the Elimination of Racial Discrimination, Committee-member Kapteyn stressed that there was a distinct competence relating to the determination of the scope of a reservation. Apparently annoyed 
by the British reluctance to accept a role for the supervisory Committee, he says that the United Kingdom's interpretation that the exclusive right to determine the scope of the obligation ${ }^{3}{ }^{3}$ rested with each State party, was both dangerous and disturbing, and, moreover, would be true only if the United Kingdom had made a formal reservation and not just an interpretative statement. In the absence of a formal reservation, it rested with the Committee rather than the United Kingdom Government to determine whether or not a State party, was fulfilling its obligations under article 4. Unless and until the interpretation of the scope of those obligations had been the subject of a decision by the International Court of Justice under article 22 of the Convention or of an advisory opinion of the Court requested by the General Assembly, the Commirtee, as the guardian of the Convention, was fully comperent to interpret and apply the Convention. In so doing, the Committee had the duty to allow States parties a measure of discretion so as to enable them to take into account their legal and cultural traditions... ${ }^{24}$. A number of years later, HRC-member Higgins reinforces the view expressed by Kapteyn in a clear statement when discussing the Austrian questions about the possible withdrawal of reservations. The frustration about the lack of action on the part of the States Parties to act as guardian for the human rights instruments they themselves created, shines through in her remark that although the Committee theoretically has a secondary role in this respect, it is in practice the only actor that can deal with the issue of reservations. She says: "The classic position that reservations to treaties were a matter of State sovereignty did not work for human rights treaties, in which States mutually agreed to give certain rights to individuals. The reality was that, for the most part, States did not recognize their mutuality of interests in the field of human rights and failed to monitor reservations. The Committee should surely not take the conservative view that a State party should make whatever reservation it chose and that the Committee would do nothing if the Committee did not take up the general question of reservations to the Covenant, no one else would do so. "s. therehy clearly indicating the specific and supplementary role of a supervisory organ.

The Committees should not be as indifferent to the question of reservations to the extent that they have been in the past, and ought to take these examples as a starting point for strengthening their position in the reservations debate. In the course of their work, more attention should and could, be paid to the reservations made, and the impact the reservations have on the implementation of a convention. This is a role that is based upon the authority of the supervisory organ to monitor the implementation of the convention. The Committes represent the common interest of the international community, and are endowed with an implicit authority to interpret the human rights treaties. Their task is to enhance the implementation of the convention within all ratifying States. The basis of this task is the integral treaty. I would think that this is legitimate authority deriving 
from the treaty itself, and complementary to the role States play when accepting the reservation, or objecting to it. Looking at the inertia displayed by the States Parties in reacting to incompatible reservations, a more proactive approach by the Committees must be advocated.

\subsubsection{The reporting procedure}

In discussing the possibilities supervisory Committees have to discuss reservations and restrict their detrimental impact one should keep in mind that this will be limited by the very nature of the reporting procedure. This process of supervision, common to all four conventions dealt with, has its disadvantages. There is an impressive backlog of reports not yet considered and an equally impressive list of reports not yet received. Supervision is thus hardly ever based upon up-to-date information. Moreover, the discussion with the government representative can have major flaws. In practice the representative does not necessarily answer all questions, replies are frequently based upon pick-and-choose. Consequently questions about reservations may be put to the State, but need not be answered $^{26}$.

As I see it, the supervisory organs have two important tasks with respect to reservations. First of all, the Committees would be excellently qualified to identify the potential scope of an interpretative declaration, thereby determining the legal effect of such a declaration in accordance with article 2.1.d VCLT. Similarly, they are in a position to distinguish between reservations and interpretative declarations, following the rule laid down in the Belilos opinion of the European Commission on Human Rights. While these are steps to identify the legal effect of a particular statement, the second important task for a supervisory organ is to monitor the scope of a reservation in practice. In particular, this would seem to be an obligation following from the general nature of the reporting procedure, seen together with the implied authority of the supervisory organs to deal with reservations. A Committee should monitor if State practice remains within the scope of the reservation, and is not extending the legal effect of their reservation. Reservations should be interpreted narrowly. The "object and purpose" rule when applied to human rights instruments is another forceful argument for a restrictive interpretation of reservations.

It is advisable to discuss reservations as matters related to the implementation of the substantive provisions of a treaty. Focusing on the substantive implications of reservations is an approach in line with the substantive focus of the "object and purpose" criterion. In order to get a grip on the reservations made, a Committee should ask for clarification about the reasons for reservations, and invite States to

26. For example questions by the CERD Committee to the United Kingdom with respect to its fourth report (CERD/C/SR.348, par.49; SR.349, par.8-19), with respect to the combined tenth and eleventh report (CERD/C/SR.907, par.32 and par.53-60; SR.908, par.1-33); or questions by the Human Rights Committee to Austria with respect to its initial report (CCPR/C/SR.412. par.12-14: SR.413, par.18). 
motivate the reservations made ${ }^{27}$. For example, without explicitly raising the question of whether or not it had any authority, the Human Rights Committee has, in a number of cases, raised the issue of compatibility in the discussions about the periodic reports ${ }^{28}$. Thus reservations are an issue included in the discussions, and the States Parties have rarely questioned this approach, or the Committee's authority to raise the issue of reservations in this manner.

The transition of reservations from a mere formal indication of a provision excluded, to an insight in the substance and scope of the reservation is a necessary step to facilitate supervision. In order to turn the clarification of the precise scope of the reservation into a structural step in the reporting procedure, the Committees should therefore encourage such clarity by including, in their guidelines on periodic reporting, the rule that reports should specify what reservations (and interpretative declarations) have been made, how the reservations influence the implementation of the obligations and why it was necessary to make these reservations. This would be a simple rule that has the advantage of keeping the Committee informed, and at the same time may lead to a reconsideration of the reservations made by the reserving state when compiling the report. The recent practice of the supervisory organs shows an increasing interest in the matter of reservations. States are already being questioned about their reservations during the discussions with a Committee. Consequently, such an explicit requirement would be a logical development. This rule would formalize the moment at which information is to be provided. From this perspective, the rule would not change the existing practice very much.

On the basis of additional information about the reservations the Committees might try to expand the constructive dialogue with the reserving State, so as to seek solutions that may facilitate withdrawal of the reservation. This would perhaps be a novel approach, but a proactive attitude seems necessary if there is a genuine wish to reduce the detrimental impact of reservations to human rights treaties.

The constructive dialogue between the State and the Committee would be enhanced if the Committee would have information about the reservations made, as well as a plan about how to discuss the reservations issue, making sure that the States does indeed reply to the Committee's concern. Obviously such information is available in such bulky book as "Multilateral treaties deposited with the

27. For example questions by the Human Rights Committee to Austria (CCPR/C/SR.412, SR.413); questions by the Women's Committee to Bangladesh (CEDAW/C/SR.96) and to Thailand (CEDAW/C/SR.156).

However, States can be reluctant to answer, see for instance the discussion between the Human Rights Committee and the United Kingdom (CCPR/C/SR.857).

28. For example, with respect to the Australian reservation to articles $2.2,3$ and 50 (CCPR/C/SR.401; SR.402); the reservation by Trinidad and Tobago to article 4.2 (CCPR/C/SR.555). However, the information is inconclusive, see for instance the discussion about the Austrian reservations (CCPR/C/SR.1167), and the Committee's reluctance to pronounce on the compatibility issue. 
Secretary General ${ }^{29 n}$, published annually by the United Nations, but it could hardly be called accessible information, and moreover it indicates little about the impact a reservation will have on the domestic protection of human rights.

If increased attention for reservations during the discussions about the periodic reports is to have any effect, is the lack of continuity that has transpired in the practice considered in the previous chapters, needs to be addressed. It is striking that States may suggest withdrawal of a reservation in one session and remain completely silent about the withdrawal when the next report is discussed ${ }^{30}$. The legal effect of the clarifications provided by the representative of the state in the discussion with the Committee about the periodic reports must be clarified. This is relevant when representatives indicate that their State will reconsider the necessity of maintaining a particular reservation, and particularly relevant when a representative predicts the withdrawal of a reservation when legislation has been changed. The question must be raised whether these remarks could in any way bind the State of the representative.

In answering this question, the starting point should be that the representative acts on the authority of the state, and thus speaks in an official capacity ${ }^{31}$. It must be assumed that the discussions about the periodic reports have an ulterior goal, other than merely fulfilling the formal reporting obligation under the convention. The reporting system was set up to monitor the implementation of the obligations, and the constructive dialogue conducted with the state representatives serves this end. Thus, if a representative indicates that in future his state will extend its implementation, by withdrawing a reservation, this is not merely relevant information for the supervisory Committee. It may in fact be a unilateral obligation to withdraw the reservation in due course, based upon the intention expressed by the representative to the Committee. To see it otherwise, by considering the remark about withdrawal a mere suggestion would seem to

29. ST/LEG/SER.E/11.

30. For example the withdrawal of the Australian reservation to article 4 CERD, as promised in the discussion about the first Australian report (CERD/C/SR.330, SR.335), or the withdrawal of the Belgian reservation to articles 2,3 and 25 CCPR (also to article 7 CEDAW) as indicated in CCPR/C/SR.821, par.35, and completely non-existent in CCPR/C/SR.1143, par.57.

Another example of an intention to withdraw is the statement by Korea on its reservation to article 9 CEDAW, as mentioned to the Human Rights Committee (CCPR/C/SR.1154, par.22). It is highly unlikely that this commitment will be noticed by the Women's Committee.

31. Sometimes there is reason to doubt this. Cf.the much quoted remark by the Philippine representative at the consideration of the first report on the Women's Convention, stating that "their (women's. EL) best weapon was the way in which they dealt with Philippine men. For that reason, there was no women's liberation movement, because if they became involved in that type of confrontation. women would never obtain from men what they had been able to obtain from them in the past (CEDAW/C/SR33, par.13)". 
devour the reporting procedure of all significance with respect to the implementation of a convention ${ }^{32}$.

While a failing memory may be attributed to political considerations of a State representative, such a deficient memory should not hamper the work of a supervisory organ. It seems necessary that the continuity of the questioning and thereby the consistency of the reporting procedure are improved. Though this is foremost a task of the individual members of the supervisory organs, it stands to reason that the UN Secretariat, servicing the supervisory Committees, has a distinct role to play in this respect ${ }^{33}$. Improving the institutional memory of the Committee would, I suspect, contribute to a tighter grip on the reservations issue.

The potential criticism to a more pro-active approach is that reserving states will claim, and indeed have claimed, that they were fully entitled to make reservations, and that the reservations have been accepted. In other words, the Committee should not interfere. The point to be made is that the Committee is not assuming the authority to judge upon the validity, much less the compatibility, of a reservation. It is acting as the guardian of the integral treaty, and as such it has a task in promoting the integral acceptance of a treaty. Full insight into the reasons for making reservations, and for maintaining them, could lead to a fruitful discussion with the withdrawal of the reservation as the ulterior aim.

\subsubsection{The individual complaints procedure}

With respect to the Optional Protocol to the CCPR, and the individual complaints brought under articles $14 \mathrm{CERD}$ or article $22 \mathrm{CAT}$, it should be noted that it is possible to deal in greater detail with reservations under these procedures, than in the reporting procedure. The focus can be on the precise impact of reservations in individual cases, which may thus also provide relevant information to be used in the reporting procedure.

The Human Rights Committee is the only supervisory organ to have dealt with reservations in individual complaints so far. The Optional Protocol gives the Human Rights Committee the possibility to restrict the scope of a reservation on the basis of the object and purpose rule, used as an interpretation rule. The Human Rights Committee should be monitoring whether the proposed scope of a reservation is not greater than could legitimately be assumed on the basis of the reservation made. Its practice might serve as a guideline for dealing with reservations under article $14 \mathrm{CERD}$, article $22 \mathrm{CAT}$ or a possible Optional Protocol to the Women's Convention.

However, the way in which the Human Rights Committee has handled reservations and interpretative declarations under the Optional Protocol has not been very convincing so far. In order to be able to act with agility under the Optional Protocol, it is necessary that the HRC has a clear idea as to how and when a reservation or interpretative declaration should be dealt with in the procedure. In 
order to restrict the effect of reservations it is essential to understand if and how the reservations will restrict the scope of protection. Looking at the two stages in an individual complaints procedure the following would seem to be the right approach.

In the admissibility stage all clearly defined reservations will lead to non-admissibility if the plaintiff is relying on a provision that has been reserved. These would in general be reservations that are formulated precisely, and clearly indicate their scope. In case a state only made interpretative declarations, there should be a marginal test to see whether the declaration could, within reason, fall within the scope of article 2.1.d VCLT. If this is the case, and the declaration should be understood as being a reservation, this would also lead to inadmissibility of the complaint.

However, if a State has made both reservations and declarations, the Belilos situation, and a plaintiff relies on a provision with respect to which a declaration has been made, there is no reason to declare such a complaint inadmissible. In a Belilos situation the possibility that the interpretative declaration is indeed a reservation does not exist, which invalidates this argument as a reason for inadmissibility ${ }^{34}$.

The misinterpretation of the French declaration with respect to article 27 CCPR as a reservation has led to inadmissibility in the numerous Breton cases, whereas the Committee should in my opinion have been more precise and should have applied the distinguishing approach. The way in which the Committee dealt with the French interpretative declaration, allowed France to subjectively label its declaration a reservation, whereas the Committee was in fact the one called upon to establish objectively what the legal effect of the statement was. Understanding the declaration as a mere interpretative declaration would probably have led to the conclusion that the rights claimed by the Bretons (the language of roadsigns, giro-cheques in Breton) were not protected under the Covenant, but that is a different matter.

If there is any doubt about the compatibility of a particular reservation, this would also be a valid reason not to dismiss a case, and look at it in greater detail in the merits stage. Or, to put it differently: the Committee should declare such a complaint admissible on the assumption that the State never meant to act contrary to international law, which assumptions merits an in depth consideration in the second stage ${ }^{35}$. The discussion would then be about the scope of the reservation, which as we have seen is in practice a matter to be dealt with in the admissibility stage.

Reservations of which the scope could not be established prima facie are dealt with in the merits stage. As we have seen, the case of Diulio Fanali ${ }^{36}$ is an example of uncertainty of the scope of the Italian reservation ratione personae,

34. Cf. the Individual Opinion of Committee-member Higgins in cases 220/1987 (T.K. v France) and 222/1987 (M.K. v. France).

35. See about "object and purposen as a rule for interpretation Chapter 2, par.4 supra.

36. See Chapter 5, par.3.2 supra. 
whereas the case of Ibrahima Gueye $e^{37}$ is an example of uncertainty about the scope of the French reservation ratione temporis; both cases were decided in the stage of the merits.

While the Optional Protocol could be a useful method to challenge the validity of interpretative declarations as reservations, or to question the scope of reservations, this all depends on the procedural ingenuity of the claimants. To my mind the cases of the Breton were badly handled, which may have had an impact reaching further than merely the question of the French "interpretative declaration" to article 27 CCPR. The declaration has, with the consent of the Committee, become an established reservation. Thus, while there is a theoretical possibility for the supervisory organs to reduce the scope of reservations and declarations in the individual complaints procedure, this requires a great deal of agility and insight into the law of treaties aspects of the matter.

\subsection{The application of the "object and purpose" rule}

The interpretation of reservations instantly brings up the question of what the object and purpose of a particular human rights treaty is. The "object and purpose" notion can only play a meaningful role if an attempt is made to make its content operational. "Object and purpose" must be a rule with substance in order to be of any use. It is necessary to determine the substantive content of the rule. Apart from the role that legal scholars might play in this respect, it would seem that the supervisory organs would be in the best position to undertake steps to make "object and purpose" operational with respect to human rights treaties.

As I see it, it is necessary to distinguish between all the obligations in a convention and the core obligations, in order to be able to apply the object and purpose rule. This is in itself an approach which is somewhat unusual in human rights law, and for which no tools exist. In the third chapter some tentative suggestions are made for approaches that might be used in this process of distinguishing. It has been suggested that the relevance of human rights law, and its functioning within the domestic legal order could be a yardstick; that general requirements of the law of treaties such as the precision of obligations and the acceptance of obligations by a federal state might be a criterion; furthermore fundamental rules of human rights law, such as non-derogable rights and the non-discrimination rule could be used in determining the core character of an obligation. Finally it was suggested that considerations concerning the ways and means of implementing human rights obligations could play a role in this respect. Apart from these four categories that might facilitate distinguishing between core and non-core obligations it should be noticed that a number of other reservations are also prohibited, albeit not under the object and purpose rule. The inadmissibility of reservations contrary to ius cogens, or contrary to the Charter of the United Nations is not based upon the law of treaties, but follows from general international law. 
Another avenue that should be explored by the supervisory Committees is that of the relevance of co-existing human rights instruments. An increasing number of human rights instruments contains rights covered by different instruments, and, in a number of cases, reservations have been made with respect to a right in one treaty whereas a similar right under another treaty has been accepted without reservation. This, it seems to me, is relevant information for the supervisory organs. On the basis of their expert knowledge, the obvious question to ask would be how a reservation should be understood given the fact that the right had not been restricted under another instrument; or vice versa how a right would be implemented given the fact that a reservation had been made under another instrument. In using the coherence approach the underlying assumption is that it is contrary to the "object and purpose" of any human rights treaty to limit the scope of another human rights treaty through the use of reservations. The International Bill of Rights must be understood as a coherent and integral system of human rights law. Coherence is also the gist of provisions underlining the priority of the rule affording the best protection ${ }^{38}$. The strength of an approach based upon the coherence of human rights law lies in the fact that reservations will be judged by the standards set by the reserving States themselves ${ }^{39}$. These are fairly obvious questions, based upon the assumption that States should ideally have non-conflicting international obligations. Though there is no explicit rule to that effect, it does not seem far fetched to look upon international human rights law as a coherent set of rules. On the basis of that coherence, some penetrating questions might be asked of reserving States that happen to have incongruent treaty obligations. As indicated earlier this is an approach that may be particularly useful with respect to the reservations to the Women's Convention.

Focusing on the "object and purpose rule", it would seem that a more extensive interpretation of this rule is needed. While article 19.c VCLT is merely known as an obligation to be kept when making a reservation, it can also be read as a presumption and consequently function as a rule used for the interpretation of reservations. Using the presumption that a reservation is compatible with object and purpose will lead to a restrictive interpretation of the scope of the reservation.

38. Such as article 5.2 CCPR or article 23 CEDAW.

39. Cf. the Mexican objections to reservations to the Women's Convention, which elaborates on other related human rights provisions, and concludes:"Consequently, it is inconsistent with these contractual obligations previously assumed by ... for its Government now to claim that it has reservations, on the same subject about the 1979 Convention." And similarly, remarks by CEDAW Committee-member llic in respect of the initial report by the United Kingdom: "She would be interested to know whether the United Kingdom Government had entered reservations to the corresponding articles of the International Covenant on Civil and Political Rights. If so, she wished to know whether the contem of the resenvations to the International Covenant was the same and, if not, why not." (CEDAW/C/SR.155. par.65). 
With respect to future human rights instruments, the most obvious advise is that a reservations clause should be included. This is nothing new, the same suggestion was made by the General Assembly when discussing reservations to the Genocide Convention, and it is included in General Assembly Resolution 598(VI). The foregoing overview of reservations to four UN treaties suggests that a reservations clause could have prevented the detrimental impact of reservations. In particular, it is striking that although there was an awareness that it was necessary to include a reservations clause into the Covenant on Civil and Political Rights, this eventually did not materialize ${ }^{*}$. The problems that might be overcome by not having long discussions about a reservations clause, are likely to come back like a boomerang once a treaty without a reservations clause is ratified with reservations. Thus a reservations clause is necessary.

Reservations clauses such as article 20 CERD need not be copied, as practice has proved that this has not been of much use in practice. The flaw in this provision is the fact that there is an assumption that States will be active, and will indeed object to reservations contrary to object and purpose. Had this been the case, then the provision might have worked, but it appears that the assumption about the activity of States was wrong to begin with. Moreover the fact that the norm in article $20 \mathrm{CERD}$, is a relative norm, implying an ever increasing number of necessary objections with the increase of the number of States Parties. The reservations rule in article 28 CEDAW has not been a success either, as it copied a system that was designed by the Court in the Genocide case, and codified in the Vienna Convention without actually wondering whether this was a rule that would adequately protect the object and purpose of the Women's Convention. In sum, if a future convention would be drafted along the model of the treaties studied, that is with a similar supervisory structure, the rule on reservations should be different from the ones discussed above.

After thoroughly criticizing the existing rules on reservations to human rights treaties, it may be expected from the author that she would present a suggestion as to how a reservations clause should look like. Given the absence of a tight supervisory structure, similar to the supervision under the European Convention or the American Convention, the reservations clause should be simple enough to be monitored by the depository. This means that the States Parties will have to indicate which provisions are core obligations to be protected by the reservations clause, as only an explicit indication makes it possible for the depository to monitor reservations. A further requirement, to my mind, should be that reservations are restricted to matters of existing legislation conflicting with the standards set in the human rights instrument. This should in itself narrow the ambit of the reservation. And finally, I suggest that reservations will in future be considered 
temporary exceptions from the validity of treaty provisions. Reservations once made remain on the books, and a way to change their continued existence may be to see reservations as a temporary step. In other words, if a State would like to maintain a reservation after an initial period of time, it will have to take action on a regular basis as the reservation will otherwise lapse.

A reservations clause could be formulated like this:

A.1 - Reservations to article(s) *** are prohibited.

- At the time of signing, ratifying, or acceding, any State may declare that it does not consider itself bound by article(s) ***.

or

A.2 - Reservations are only permitred to article(s) ***.

B - At the time of signing, ratifying, or acceding, any State may declare that it does not consider itself bound by articles of this Convention other than article(s) ***** only.

- Any State may only make a reservation (in accordance with the foregoing paragraph), to the extent that a law in force is not in conformity with a provision of the Convention.

C - Any reservation shall contain a brief statement of the law concerned.

D - Reservations shall have limited validiry

- Reservations shall be valid for the duration of (five) years.

E - Extension of the validity of a reservation shall take place by express notification to the depository, three months before the end of the (five) years period at the latest.

Paragraph A (A.I or A.2). As indicated before, a reservations clause containing a precise yardstick as to the acceptability of reservations is to be preferred over a vague provision (such as a rule pointing to object and purpose) or no rules at all. Thus the rule drawn up in basically modelled on article 19.a and 19.b VCLT. To my mind both options could be used.

When listing the provisions to which reservations are allowed, or when listing the provisions to which reservations are explicitly forbidden, States are supposed to take into account the object and purpose of the treaty. It may be suggested that at least the non-derogable rights, if the treaty would contain such rights, and the provisions that establish the supervisory mechanism will be safeguarded by a reservations clause.

Paragraphs $B$ and $C$. These two provisions are modelled on the rule laid down in article 64 ECHR, in which the scope of reservations is restricted to deficiencies of existing law, in comparison with the standard set by the European Convention. The complementary obligation to provide information on the law that prevents full adherence to the treaty has been of vital importance in case-law with respect to reservations under the European Convention. 
It has been suggested that the importance of factual information, as stressed by article $64 \mathrm{ECHR}$, is directly related to the importance of individual complaints in the European system. Be this as it may, this information would seem to have a wider importance. With its focus on human rights in the domestic situation, such information is equally necessary for the supervisory organs at world-level. Information about legislation related to reservations will give the supervisory organs more possibilities of getting a grip on the issue. With such background information the constructive dialogue between States and supervisory organ may lead to a more proactive approach of the Committee, in suggesting solutions leading to the withdrawal of the reservations. In time the supervisory organ may focus its attention on the factual situation behind the legal situation, and wonder if new legislation could be enacted in order to withdraw the reservation.

Paragraphs $\boldsymbol{D}$ and $\boldsymbol{E}$. One of the disadvantages of the European system has been that once a reservation is on the books, it hardly ever disappears. This is in general also the case with respect to UN human rights treaties, although the periodic discussions with the States Parties provide a possibility to stress the need for the withdrawal of a reservation. Yet, withdrawals are rare, and even when States admit that there is no need to maintain a particular reservation, they remain on the books for failure of the States parties concerned to withdraw.

The (sunset) provision I envisage has the advantage of being simplistic, and probably useful. It is based on the assumption that a reservation has a limited validity, which will give the reserving State the opportunity to change its domestic legislation in the meantime. It should be noticed that the advocates of reservations, saying that reservations will bring the reserving State within the ambit of the treaty which will eventually lead to a withdrawal of the reservation, argue on the basis of the same assumption. The validity of the reservation can be extended, or renewed so to say, by notifying the depository of the extension of the validity. Thus, if no extended validity is notified, the reservation will be extinct.

This rule bears a similarity with the system of denunciation of ILO Conventions, in which States may only denounce a Convention after the expiration of ten years, and if no denunciation is notified it will be bound for another ten years. In my proposal, no notification means the disappearance of the reservation. This mechanism is more or less comparable with article 20.5 VCLT, and the rule of tacit acceptance formulated therein, which as we know has been extremely successful (sic). The indifference and inertia of States with respect to reservations is striking, and the rule formulated under $E$ may turn this into an advantage.

6. PROSPECTS FOR THE FUTURE

Originally, at the very beginning of the study that was to lead to this book, I had the impression that the gist of the problem of reservations to human rights treaties was the fact that incompatible reservations ought not to be made, or should be withdrawn as soon as possible. Some of the reservations ruin the potential impact of treaty at the very moment of ratification, which is undesirable 
by any means. It hardly needs stressing that this is still my opinion, but looking back it was also too simplistic a view.

At the conclusion of this book, it would seem that there are more means of restricting the detrimental impact of reservations than I initially thought. Restoring the ruins created by the incompatible reservations is possible to a certain extent, but it will largely depend on the agility of the supervisory organs dealing with reservations. I am not talking about a formal authority for the Committees to decide upon compatibility, but about the ways in which to restrict the impact of reservations in the ongoing human rights debate, as takes place with respect to the four instruments discussed.

A synthesis between the fundamentally different aims and structure of the law of treaties and human rights law is hard to construct, and this would propably be a very ambitious goal. At the end of this book, I would like to suggest that taking reservations to human rights treaties to be temporary measures rather than a formal and final element in the consent to be bound by a particular treaty, opens the way to finding proactive strategies of dealing with reservations. The issue of reservations should be taken up in the dynamic process of human rights evaluation, in which the safeguarding of human rights is continually improved. In order to be able to respond in a coherent and successful way to reservations made to UN human rights treaties two things are of primordial importance: the general rule of the "object and purpose" should be interpreted within the scope of the individual human rights treaty. In order to turn it into an operational rule, it is necessary to understand its substantive content. Moreover, the role of the supervisory Committees should be expanded; rather than merely monitoring the implementation of the human rights instruments, they should more actively pursue their implicit role as the guardians of a convention.

While it may look as though incompatible reservations will definitely ruin the potential impact of a human rights instrument, I have come to the conclusion that there are mechanisms available within the human rights system to limit the impact of reservations. Tools to restore such ruins do exist, and it is about time that this work began. 


\section{SELECTED BIBLIOGRAPHY}

LIST OF CASE LAW 


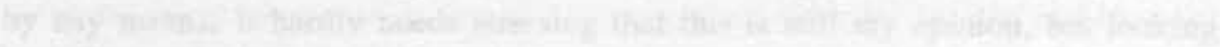

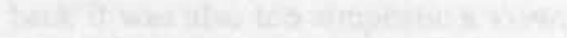

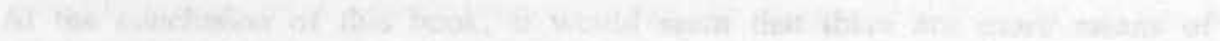

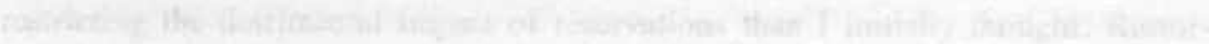

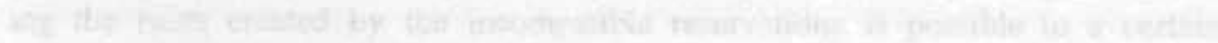

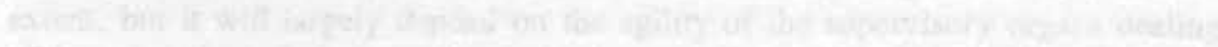

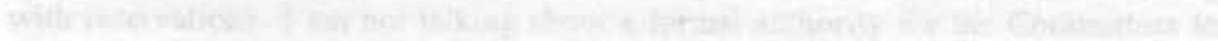

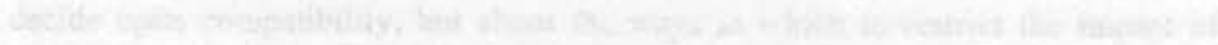

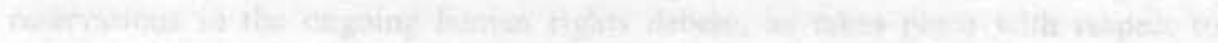

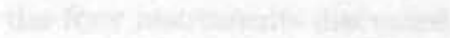

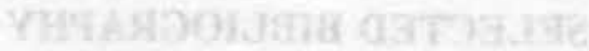

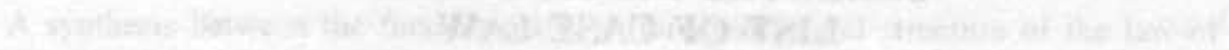

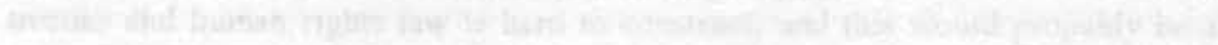

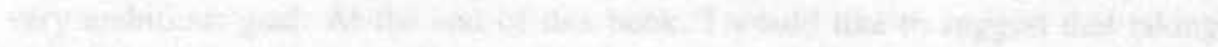

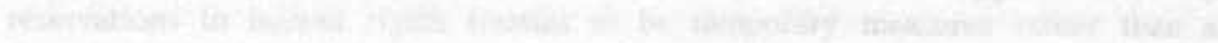

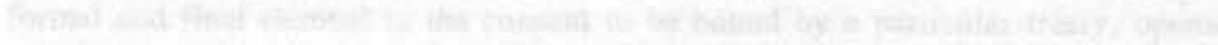
How

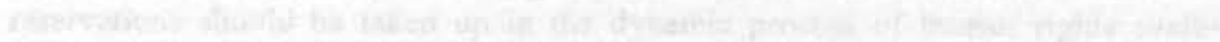

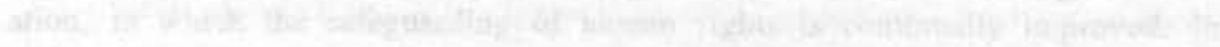

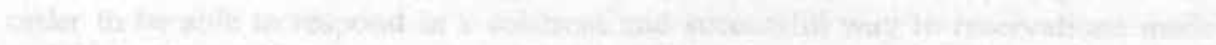

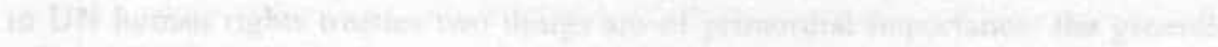

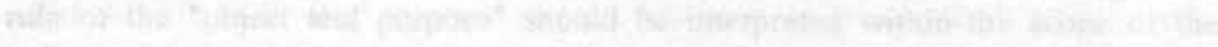

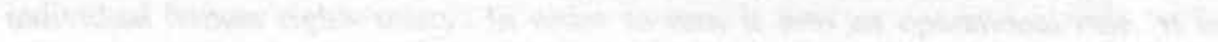

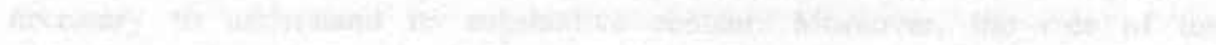

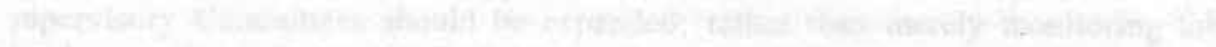

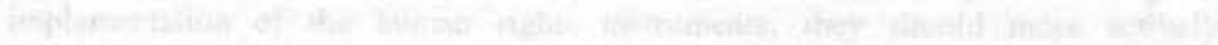

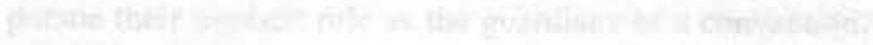

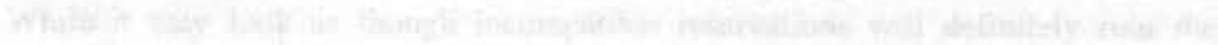

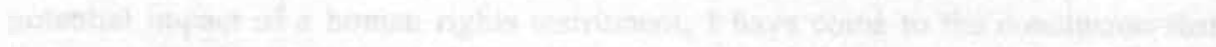

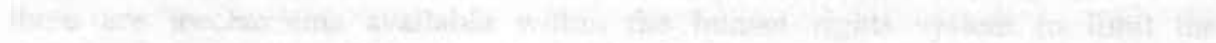

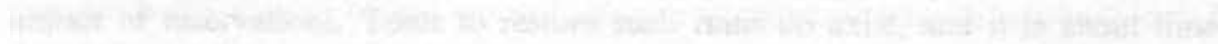

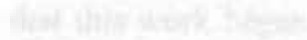




\section{SELECTED BIBLIOGRAPHY}

P.Alston, The United Nations and the elliptical notion of the universality of human rights, in: Is Universality in jeopardy? United Nations Department of Public Information, New York 1987, 51-65.

D.E.Arz, The application of International Human Rights Law in Islamic States, in: 12 HRQ 1990, 202-230.

P.R.Baehr, Toepassing van universele mensenrechtennormen, in: 40 Internationale Spectator $1986,85-92$.

M.Bertrand, Universality, in: Is Universality in jeopardy? United Nations Department of Public Information, New York 1987, 21-33.

R.L.Bindschedler, Vorbehalt, in: K.Strupp, H.J.Schlochauer (eds.), Wörterbuch des Volkerrechts, Vol.III, Berlin 1962.

A.Bleckmann, Die Nichtrückwirkung völkerrechtlicher Verträge, in: 33 ZAöRV 1973, 38-55.

M.J.Bossuyt, Guide to the "Travaux Préparatoires" of the International Covenant on Civil and Political Rights, Dordrecht 1987.

H.J.Bourguignon, The Belilos Case: New Light on Reservations to Multilateral Treaties, in: 29 VJIL 1989, 347-386.

Th. C.van Boven, Politisation et droits de l'homme, in: Les organisations internationales entre l'innovation et la stagnation, N.Jéquier, F.Muheim (eds.), Lausanne $1985,125-138$.

D.W.Bowetr, The Law of International Institutions, 4th ed. London 1982.

D.W.Bowett, Reservations to non-restricted multilateral treaties, in: 48 BYIL 1976/77, 67-92.

D.Breillat, L'abolition mondiale de la peine de mort. A propos de $2 \mathrm{e}$ Protocole facultatif se rappportant au Pacte internationale relatif aux droits civils et politiques, visant a abolir la peine de mort, in: RSCDPC 1991, 261-278.

I.Brownlie, General Principles of International Law, 4th ed. Oxford 1990.

T.Buergenthal, The advisory practice of the Inter-american Human Rights Court, in: 79 AJIL 1985, 1-27.

T.Buergenthal, Implementing the UN Racial Convention, in: 12 TILJ 1977, 187221.

J.H.Burgers, H.Danelius, The United Nations Convention against Torture, Dordrecht 1988, 5-110.

N.Burrows, The 1979 Convention on the Elimination of All Forms of Discrimination against Women, in: 32 NILR 1985, 419-460.

A.C.Byrnes, Australia and the Convention on Discrimination against Women, in: 62 ALJ 1988, 478-479.

A.Byrnes, The "Other" Human Rights Treaty Body: The Work of the Committee on the Elimination of Discrimination Against Women, in: 14 YaleJIL 1989, 1-67.

A. Cassese, International Law in a Divided World, Oxford 1988.

A.Cassese, A new reservations clause (Article 20 of the United Nations Convention on the Elimination of All Forms of Racial Discrimination), in: Recueil 
d'études de droit international en hommage à Paul Guggenheim, Geneve 1968, 266-304.

H.Charlesworth, C.Chinkin and S.Wright, Feminist approaches to international law, in: 85 AJIL 1991, 613-645.

B. Clark, The Vienna Convention regime and the convention on discrimination against women, in: 85 AJIL 1991, 281-321.

M. Coccia, A Controversial Declaration on the UN Convention against Torture, in: 1 EJIL 1990, 314-327.

M.Coccia, Reservations to multilateral treaties on human rights, in: 15 CalWILJ 1985, 1-51.

R.J.Cook, Etnische culturen en vrouwendiscriminatie; in: Nemesis 1987, 49-55.

R.J.Cook, International human rights law concerning women: case notes and comments, in: 23 VaJTL 1990, 779-818.

R.J.Cook, Reservations to the Convention on the Elimination of Discrimination Against Women, in: 30 VJIL 1990, 643-716.

V.Coussirat-Coustere, L'adhésion de la France au Protocole Facultatif se rapportant au Pacte International relatif aux Droits Civils et Politiques, in: XXIX AFDI 1983, 510-532.

M.D.Craig, The International Covenant on Civil and Political Rights and United States Law: Department of State Proposals for preserving the Status Quo, in: 19 HarvILJ 1978, 845-886.

K.Das, Measures of implementation of the International Convention on the Elimination of All Forms of Racial Discrimination with special reference to the provisions concerning reports from States Parties to the Convention, in: 4 RDH 1971, 213-263.

E.Decaux, La réciprocité en droit international, Paris 1980.

J.Dehaussy, Le problème de la classification des traités et le projet de convention établi par la Commission du Droit International, in: Recueil d'études de droit international en hommage à Paul Guggenheim, Geneve 1968, 305-326.

J.Delbrück, Die Konvention der Vereinten Nationen zur Beseitigung jeder Form der Diskriminierung der Frau von 1979 im Kontext der Bemühungen um einen völkerrechtlichen Schutz der Menschenrechte, in: Staatsrecht, Volkerrecht, Europarecht (festschrift Schlochauer), Berlin 1981, 247-270.

O.Deleau, Les Positions Françaises à la Conference de Vienne sur le Droit des Traités, in: 15 AFDI 1969, 7-23.

J.Donnelly, The ernerging international regime against torture, in: 33 NILR 1986, 1-23.

M.Driessen, J.Parlevliet, Internationale Escapades (Opinie), in: 63 NJB 1988, 357.

R.J.Dupuy, L'universalité des droits de I'homme, in: Studi in onore di Giuseppe Sperduti, Milano 1984, 541-556.

P.van Dijk, G.J.H.van Hoof, De Europese Conventie in Theorie en Praktijk, Nijmegen 1982.

R.W.Edwards, Reservations to treaties, in: 10 MichJIL 1989, 362-405. 
T.O.Elias, The Modern Law of Treaties, Leiden 1974.

C.Ferguson, International Convention on the Elimination of All Forms of Racial Discrimination, in: U.S.Ratification of the Human Rights Treaties, with or without reservations? R.Lillich ed., Charlottesville 1981, 41-46.

G.Fitzmaurice, The General Principles of International Law considered from the standpoint of the rule of law, in: 92 RdC 1957 II, 5-222.

G.C.Firzmaurice, The law and procedure of the International Court of Justice 1951-1954, in: 33 BYIL 1957, 203-293.

C.Flinterman, E.Rieter; Nederland en de Amerikaanse voorbehouden bij het Internationaal verdrag inzake Burger- en Politieke Rechten, in: 17 NJCM Bull.1992, 961-970.

C.Flinterman, E.Rieter, De Verenigde Staten en het BUPO Verdrag: de rol van Nederland, in: 67 NJB 1992, 935-936.

J.A.Frowein, W.Peukert, Europaische Menschenrechtskonvention (EMRK Kommentar), Kehl 1985.

J.A.Frowein, Reservations to the European Convention on Human Rights, in: Protecting Human Rights: the European Dimension; F.Matscher, H.Petzold (eds.), Köln 1988, 193-200.

L.L.Fuller, The morality of law, rev.ed. New Haven 1969.

G.Gaja, Reservations to treaties and the newly independent States, in: IYIL 1975, 52-68.

G.Gaja, Unruly treaty reservations, in: Le Droit International à l'heure de sa codification (Etudes en I'honneur de Roberto Ago) Vol.I, Milano 1987, 305-330.

J.K.Gamble, Reservations to multilateral treaties: a macroscopic view of state practice, in: 74 AJIL 1980, 372-394.

H.Golsong, Les Réserves aux Instruments Internationaux pour la Protection des Droits de l'Homme, in: Les Clauses Echappatoires en matière d'Instruments Internationaux relatifs aux Droits de l'Homme, Bruxelles 1982, 23-42.

J.L.Gomez del Prado, United Nations Conventions on Human Rights: The Practice of the Human Rights Committee and the Committee on the Elimination of Racial Discrimination in Dealing with Reporting Obligations of States Parties, in: 7 HRQ 1985, 492-513.

G.Gornig, M.Ney, Die Erklarungen der DDR zur UN-Antifolterkonvention aus vőlkerrechtlicher Sicht, in: 43 Juristenzeitung 1988, 1048-1053.

E. Görtling, Vorbehalte zu internationalen Verträgen in der sowjetischen Völkerrechtstheorie und Vertragspraxis, Hamburg 1967.

B. Graefrath, Menschenrechten und internationale Kooperation, Berlin 1988.

G.R.de Groot, Gelijkheid van man en vrouw in het nationaliteitsrecht, Preadvies Nederlandse Vereniging voor Rechtsvergelijking No.25, Deventer 1977.

G.R.de Groot, Staatsangehörigkeitsrecht im wandel, 's Gravenhage 1988.

H.Gros Espiell, The evolving concept of human rights, in: Human rights, thirty years after the Universal Declaration, B.G.Ramcharan(ed.), The Hague 1979, 4165. 
V.F. Gubin, The Soviet Union and Reservations to multilateral treaties(summary), in: SYbIL 1959, 141-143.

P.Guggenheim, Traité de droit international public Tome I, 2ieme ed.aug. Genève 1967.

Z. Haquani, La Convention des Nations Unies contre la Torture, in: 90 RGDIP 1986, 127-170.

J.F.Hartman, Working paper for the Committee of Experts on the Article 4 Derogation Provision, in: 7 HRQ 1985, 89-131.

L. Henkin, The Covenant on Civil and Political Rights, in: U.S. Ratification of the Human Rights Treaties, R.B.Lillich (ed.) Charlottesville 1981, 20-26.

R.Higgins, Derogations under Human Rights Treaties, in: 48 BYIL 1976/77, 281-320.

R. Higgins, The United Nations still a force for Peace, in: 52 MLR 1989, 1-21.

K.Holloway, Modern trends in treaty law, London 1967.

K. Holloway, Les réserves dans les traités internationaux, Paris 1958.

G.J.H. van Hoof, Rethinking the Sources of International Law, IJsselstein 1983.

F.Horn, Reservations and Interpretative Declarations to Multilateral Treaties, Amsterdam 1988.

R.E.Howard, Cultural absolutism and the Nostalgia for Community, in: 15 HRQ 1993, 315-338.

P. H. Imbert, Reservations and human rights conventions, in: 6 HRR 1981, 28-60.

P.H.Imbert, Les Réserves à la Convention Européenne des Droits de l'Hornme devant la Commission de Strasbourg, in: 87 RGDIP 1983, 580-625.

P. H.Imbert, Les réserves aux traités multilatéraux, Paris 1979.

M.Jacobs, Onder Voorbehoud, In: Nemesis 1993, 81-87.

H.U.Jessurun d'Oliveira, Nationaliteit, in: Internationaal Recht en Vrouwen, Zwolle, 1987, 279-291.

M.T.Kamminga, Inter-state accountability for violations of human rights, Leiden 1990.

D. Kappeler, Les réserves dans les traités internationaux, Bâle 1958.

N.Kaufinan Hevener, An Analysis of Gender Based Treaty Law: Contemporary Developments in Historical Perspective, in: 8 HRQ 1986, 70-88.

H.Kelsen, Principles of international law, R.W.Tucker(ed.), 2nd ed. New York 1966.

M. Khadjenouri, Réserves dans les traités internationaux, Genève 1953.

Y.Klerk, Working paper on Article 2(2) and article 3 of the International Covenant on Economic, Social and Cultural Rights, in: 9 HRQ 1987, 250-273.

J.K.Koh, Reservations to Multilateral Treaties: How International Legal Doctrine Reflects World Vision, in: 23 HarvILJ 1982/83, 71-116.

P. Kooijmans, Preadvies voor de Emancipatieraad, 17 March 1988.

A.Krishnaswami, Study of discrimination in the matter of religious rights and practices, New York 1960 [E/CN.4/Sub.2/200/Rev.1]. 
R.Kühner, Die "auslegende Erklärung" der Schweiz zu Art.6 Abs.3 lit.e der Europäischen Menschenrechtskonvention, in: 43 ZAöRV 1983, 829-833.

R.Kühner, Vorbehalte und auslegende Erklärungen zur Europäischen Menschenrechtskonvention, in: 42 ZAöRV 1982, 58-92.

R.Kühner, Vorbehalte zu multilateralen völkerrechtlichen Verträge, Berlin 1986.

L.Kühnhardt, Die Universalität der Menschenrechte, München 1987.

M.Lachs, Some Thoughts on the Role of Good Faith in International Law, in: Declarations on principles, Liber amicorum Röling, Leyden 1977, 47-55.

H.Laurerpacht, Restrictive interpretation and the principle of effectiveness in the interpretation of treaties, in: 26 BYIL 1949, 48-85.

L.J.LeBlanc, Reservations to Human Rights Treaties, Paper prepared for the Thirty-Fourth Annual Convention of the International Studies Association, March 23-27, 1993 Acapulco Mexico.

L.J.LeBlanc, The United States and the Genocide Convention, Durham 1991.

N.Lerner, The U.N. Convention on the Elimination of all Forms of Racial Discrimination, Alphen aan den Rijn 1980.

N.Lerner, The U.N.Convention on Torture, in: 16 IsrYbHR 1986, 126-142.

L.Lijnzaad, Het kussen van een kikker, de werkelijke betekenis van het Vrouwenverdrag, in: Nemesis 1991, 5-17.

L.Lijmzaad, Het maken en breken van internationaal recht voor vrouwen, in: Nemesis 1993, 211-214.

L.Lijnzaad, Nederlands bezwaar bij DDR-voorbehoud ten aanzien van VN-Folteringverdrag, in: 14 NJCM Bull.1989, 504-509.

L.Lijnzaad, Paradoxale universaliteit, of de beperkingen van het verdragenrecht, in: Universaliteit van mensenrechten, fundamenteel en controversieel, Th.van Boven, C. Flinterman (eds.) Leiden 1992; 7-17.

L.Lijnzaad, Teleurstellende vrijheid, de positie van vrouwen in post-communistisch Polen, in: Nemesis 1993, 15-23.

L.Lijnzaad, Voorbehouden bij Vrouwenverdrag, in: Nemesis 1988, 105-111.

C.Logan Piper, Reservations to multilateral treaties: the goal of universality, in: 71 lowaLR 1985, 295-322.

I.l.Lukashuk, The principle pacta sunt servanda and the nature of obligation under international law, in: 83 AJIL 1989, 513-518.

R.StJ.Macdonald, Reservations under the European Convention of Human Rights, in: 21 RBDI 1988, 429-450.

D.Mahalic, J.Gambee Mahalic, The Limitation Provisions in the International Convention on the Elimination of All Forms of Racial Discrimination, in: 9 HRQ 1987, 74-101.

I.Maier (ed.), Europaischer Menschenrechtsschutz, Heidelberg 1982.

M.-H.Marescaux, Nationalité et Statut Personnel dans les instruments internationaux des Nations Unies, in: M.Verwilghen, Nationalité et Statut Personnel, Bruxelles 1984; 15-72. 
R.Marx, Die Konvention der Vereinte Nationen gegen Folter und andere grausame, unmenschliche oder emiedrigende Behandlung oder Strafe, in: 18 ZfRechtspolitik 1986, 81-85.

D.McGoldrick, The Human Rights Committee, Its Role in the Development of the International Covenant on Civil and Political Rights, Oxford 1991.

A.D.McNair, The functions and differing legal character of treaties, in: 11 BYIL 1930, 100-118.

A.D.MCNair, The Law of Treaties, Oxford, 1961.

D.M.McRae, The legal effects of interpretative declarations, in: 50 BYIL 1978, 155-173.

Th.Meron, Enhancing the Effectiveness of the Prohibition of Discrimination against Women, in: 84 AJIL 1990, 213-217.

Th.Meron, On a hierarchy of International Human Rights, in: 80 AJL 1986, 123.

Th.Meron, Human rights and humanitarian norms, Oxford 1989.

Th.Meron, Human Rights Law-making in the United Nations, Oxford 1986.

M.Mohr, The German Democratic Republic's Declaration on the Anti-Torture convention and its consequences: an Attempt at Evaluation, in: 1 EJIL 1990, 328-335.

R.A.Mullerson, Sources of international law: new tendencies in soviet thinking, in: 83 AJIL 1989, 494-512.

G.J.Naldi, The prohibition of the death penalty in international law, in: 38 NILR 1991, 373-384.

G.E.do Nascimento e Silva, Le facteur temps et les traités; 154 RdC 1977 1, 215298.

N.L.Nathanson, E.Schwelb, The United States and the United Nations Treaty on Racial Discrimination, Washington 1975.

M. Nowak, UNO Pakt bürgerliche und politische Rechte und Fakultativprotokoll, CCPR Kommentar, Kehl 1989.

E. Oeser, Legal questions in the Committee on the Elimination of Discrimination against women, in: 14 Bull. GDR Cttee. Human Rts. 1988, 86-98.

E.Oeser, Neue Etappe im Kampf fur die Gleichberechtigung und Forderung der Frauen, in: Geschriften und Informationen des DDR-Komitees für Menschenrechte $1982,43-57$.

L. Oppenheim, International law, a treatise, H.Lauterpacht(ed.), 8th ed. Oxford 1967.

K.J.Partsch, Elimination of Racial Discrimination in the Enjoyment of Civil and Political Rights, in:14 TJIL 1979, 191-250.

K.J.Partsch, Die Konvention zur Beseitigung der Rassendiskriminierung, in: Vereinte Nationen 1971, 1-8 and 46-53.

K.J.Partsch, Die Strafbarkeit der Rassendiskriminierung nach dem Internationalen Abkommen und die Verwirklichung der Verpflichtungen in nationalen Strafrechtsordnungen, in: GYbIL 1977, 119-138. 
V.Pechota, The Development of the Covenant on Civil and Political Rights, in: The International Bill of Rights, L.Henkin ed., New York 1981, 32-71.

L.A.Rehof, Guide to the Travaux Préparatoires of the United Nations Convention on the Elimination of All Forms of Discrimination against Women; Dordrecht 1993.

W.M.Reisman, Responses to Crimes of Discrimination and Genocide: An Appraisal of the Convention on the Elimination of Racial Discrimination; in: 1 Denver JILP 1971, 29-64.

P.Reuter, Droit International Public, Paris 1976, 5ième ed.rev.

S.Rosenne, Bilateralism and Community Interest in the Codified Law of Treaties, in: Transnational Law in a changing society, W.Friedmann cs.(eds.), New York 1972, 202-227.

S. Rosenne, Developments in the Law of Treaties 1945-1986, Cambridge 1989.

S.Rosenne, The Temporal Application of the Vienna Convention on the Law of Treaties, in: 4 CornellILJ 1970, 1-24.

J.M.Ruda, Reservations to treaties, in: 146 RdC 1975 III, 95-218.

K. Sachariew, State responsibility for multilateral treaty violations: identifying the "injured State" and its legal status; in: 35 NILR 1988, 273-289.

O. Schachter, The obligation to give effect to the Covenant on Civil and Political Rights, in: 73 AJIL 1979, 402-405.

O.Schachter, The Obligation to Implement the Covenant in Domestic Law, in: L. Henkin, The International Bill of Rights, the Covenant on Civil and Political Rights, New York 1981, 311-331.

O.Schachter, M.Nawaz, J.Fried, Towards wider acceptance of UN treaties, a UNITAR study, New York 1971.

R. Schmidt, Zu einigen Aspekten der Vereinigung beider jemenitischer Staaten, in: 19 Asien, Afrika, Lateinamerika 1991, 293-304.

G.Schwarzenberger, The fundamental principles of international law; in: 87 RdC 1955 I, 195-383.

G.Schwarzenberger, International Law, 3rd Ed.London, 1957.

Th. Schweisfurth, Der internationale Vertrag in der modernen sowjetischen Völkerrechtstheorie, Köln 1968.

E.Schwelb, The International Covenants on Human Rights, in: A.Eide, A.Schou (eds.), International Protection of Human Rights, Stockholm 1968.

E.Schwelb, The International Convention on the Elimination of All Forms of Racial Discrimination, in: 15 ICLQ 1966, 996-1068.

E.Schwelb, The Law of Treaties and Human rights, in: 16 AdV 1973, 1-27.

D.Shelton, State Practice on Reservations to Human Rights Treaties, in: CHRY 1983, 205-234.

S.A.de Smirh, Constitutional and Administrative Law, Harmondsworth 1978.

B.Simma, Das Reziprozitätselement im Zustandekommen völkerrechtlicher Verträge, Berlin 1972.

I.Sinclair, The Vienna Convention on the Law of Treaties, 2nd ed. Manchester 1984. 
M. Soerensen, Manual of public international law, C.Parry(ed.), London 1968.

D. Sullivan, Gender equality and religious freedom: toward a framework for conflict resolution, in: 24 JILP 1992, 795-856.

E.Suy, Droit de traités et droits de l'homme, in: Völkerrecht als Rechtsordnung, Internationale Gerichtsbarkeit, Menschenrechte (Festschrift fur Hermann Mosler) Berlin 1983, 935-947.

R. Szafarz, Reservations to multilateral treaties, in: 3 PYIL 1970, 293-316.

A.N.Talalajew, Das Recht der internationalen Verträge, Berlin 1977.

M.E.Tardu, The United Nations Convention against Torture and other Cruel Inhuman or Degrading Treatment or Punishment, in: 56 Nordic JIL 1987, 303-321.

G. Teboul, Remarques sur les Réserves aux Conventions de Codification, in: 86 RGDIP 1982, 679-717.

C.Tomuschat, Turkey's declaration under article 25 of the European Convention on Human Rights, in: Fortschritt im Bewusstsein der Grund- und Menschenrechte (Festschrift Ermacora), Kehl 1988, 119-139.

C.Tomuschat, Is Universality of Human Rights Standards an Outdated and Utopian Concept?, in: Das Europa der Zweiten Generation (Gedächtnisschrift für Chr. Sässe), Kehl 1981, 585-609.

M.Tramik, Het nationaliteitsrecht in de Oosteuropese landen, Deventer, 1989.

G.Triggs, Australia's ratification of the International Covenant on Civil and Political Rights: Endorsement or Repudiation?, in: 31 ICLQ 1982, 278-306.

J.M.van der Velde, De reaktie van de Zwitserse regering op het Belilos arrest, in: 13 NJCM Bull.1988, 597-601.

J.M.van der Velde, Voorbehouden ten aanzien van de ECRM, in: 12 NJCM Bull. 1987, 353-365.

J.M. van der Velde, Zwitserse interpretative verklaring en artikel 64 EVRM, in: 13 NJCM Bull. 1988, 464-481.

A.Verdross, B.Simma, Universelles Volkerrecht, Theorie und Praxis, 3.Aufl. Berlin 1984.

M. Virally, Le principe de réciprocité en droit international contemporain, in: 122 RdC 1967 III, 5-67.

B. Wagner, L. Wildhaber, Der Fall Temeltasch und die auslegenden Erklärungen der Schweiz, in: 10 EuGRZ 1983, 145-149.

M. Wadstein, Implementation of the UN Convention on the Elimination of All Forms of Discrimination Against Women, in: SIM Newsletter 1988, 5-21.

J.A.Walkate, The Human Rights Committee and Public Emergencies, in: 9 YJWPO 1982, 133-146.

J.H.J.de Wildr, Het Internationaal Verdrag inzake de uitbanning van alle vormen van Discriminatie van Vrouwen, in: 41 Ars Aequi 1992, 259-266.

A.Woltjer, VN Verdragen inzake de Rechten van de Mens in: 18 NJCM Bull. 1993 183-202. 
S. Wright, Human rights and Women's rights: an Analysis of the United Nations Convention on the Elimination of all Forms of Discrimination against Women, in: Human rights in the twenty-first century: A Global Challenge, K.E.Mahoney and P.Mahoney (eds.), Dordrecht 1993, 75-88.

M.K. Yasseen, L'interpretation des traités d'apres la Convention de Vienne sur le droit des traités, in: 151 RdC 1976 III, 9-114.

S.C.Zearfoss, Note, The Convention for the Elimination of All Forms of Discrimination against Women: Radical, Reasonable, or Reactionary? in: 12 MichJIL 1991, 903-942. 


\section{LIST OF CASE LAW}

\section{International Court of Justice}

Reservations to the Convention on the Prevention and Punishment of the Crime of Genocide, Advisory Opinion 28 May 1951; ICJ Rep. 1951.

Fisheries case (United Kingdom v. Norway), 18 December 1951; ICJ Rep. 1951.

Certain expenses of the United Nations (article 17 paragraph 2 of the Charter) Advisory Opinion 20 July 1962; ICJ Rep. 1962.

North Sea Continental Shelf cases (Federal Republic of Germany v. Denmark; Federal Republic of Germany v. the Netherlands), 20 February 1969; ICJ Rep. 1969.

Barcelona Traction, Light and Power Company (Belgium v. Spain), 5 February 1970; ICJ Rep. 1970.

Legal consequences of the continued presence of South Africa in Namibia (Southwest Africa) notwithstanding Security Council Resolution 276 (1970), Advisory Opinion 21 June 1971; ICJ Rep. 1971.

Nuclear Tests case (Australiá v. France; New Zealand v. France), 20 December 1974; ICI Rep. 1974.

Case concerning military and paramilitary activities in and against Nicaragua (Nicaragua v. United States of America), 26 November 1984; ICJ Rep. 1984.

\section{Arbitral Awards}

Islands of Palmas (Netherlands v. United States of America) Permanent Court of Justice 4 April 1928; 2 RIAA 1949.

Delimination of the Continental Shelf (United Kingdom of Great Britain and Northern Ireland and the French Republic), 30 June 1977; 54 ILR 1979.

\section{European Convention case-law}

Austria v. Italy, European Commission on Human Rights, 11 January 1961; 4 European Yearbook on Human Rights 1961.

Ringeisen case, European Court of Human Rights, 16 July 1971; ECHR Series A, Vol.13. 
Temeltasch v. Switzerland, European Commission of Human Rights 5 May 1982; D\&R 31 (1983).

Albert \& Le Compte, European Court of Human Rights, 10 February 1983; ECHR Series A, Vol.58.

Belilos v. Switzerland, European Commission of Human Rights 8 July 1985; D\&R 44 (1985).

Belilos v. Switzerland, European Court of Human Rights, 29 April 1988; ECHR Series A, Vol.132.

\section{American Convention case-law}

The Effect of Reservations on the Entry into force of the American Convention on Human Rights (Articles 74 and 75), Advisory Opinion, 24 September 1982.

Restrictions to the Death Penalty (Articles 4(2) and 4(4)) Advisory Opinion, 8 September 1983. 
(15:54:

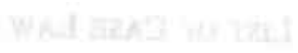

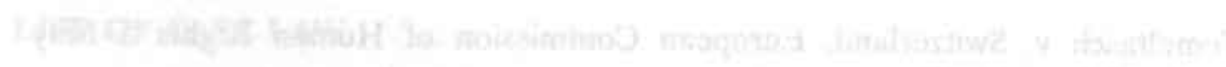

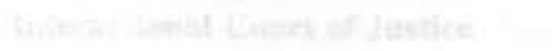

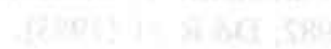

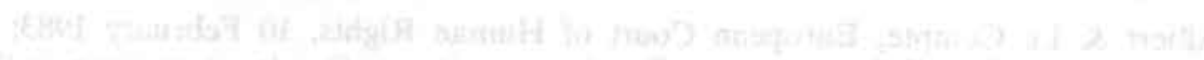

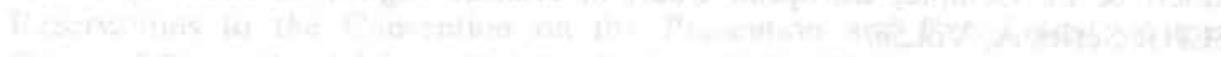

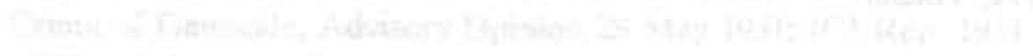

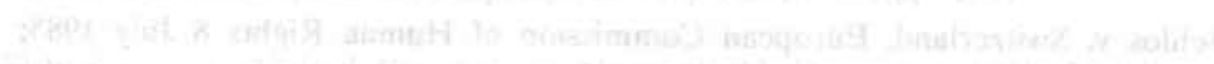

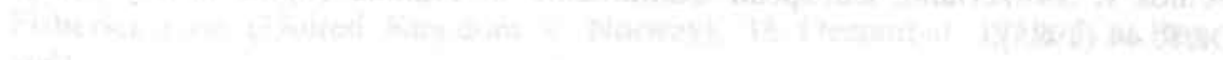
$\cos 2$

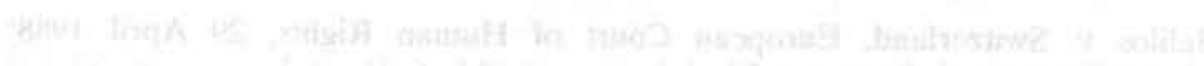

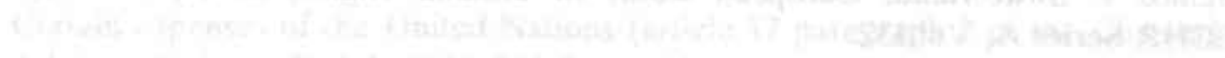

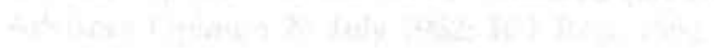

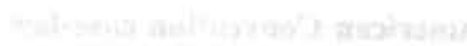

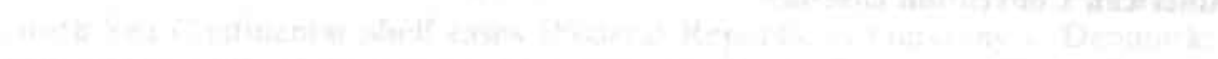

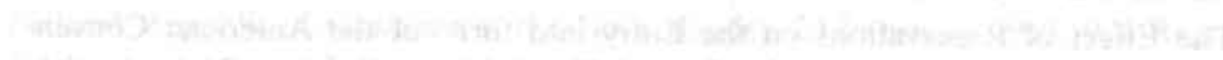

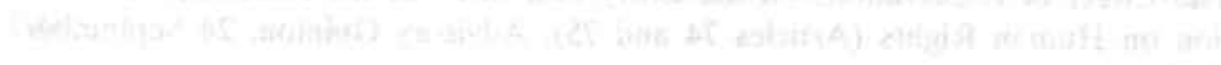

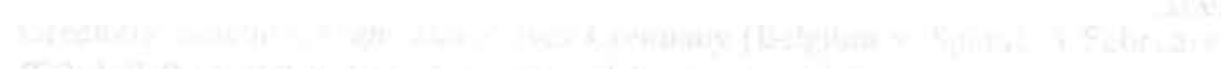

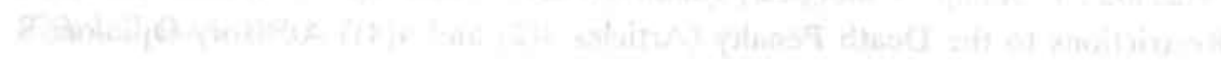

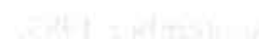

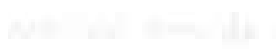
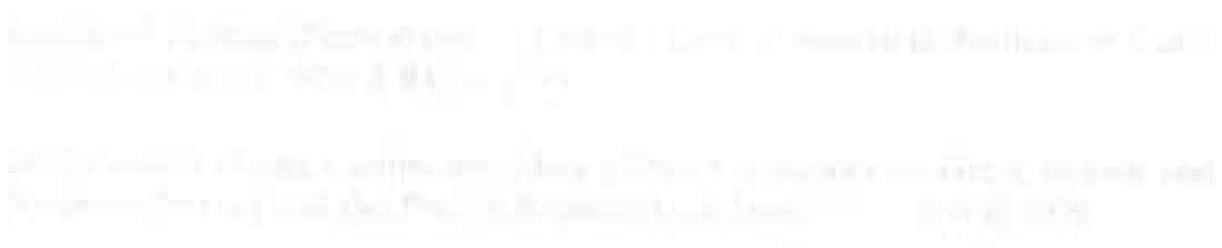

1.

(1)

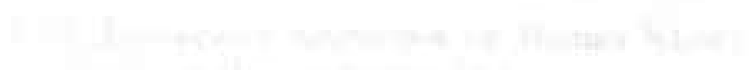

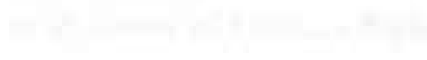

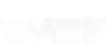




\section{Voorbehouden bij VN mensenrechtenverdragen: ratificeren en ruïneren?}

\section{Inleiding deel I}

Dit boek stelt het maken van voorbehouden bij mensenrechtenverdragen, tot stand gekomen binnen de Verenigde Naties, ter discussie. De vraag is hoe het internationale recht reageert op het schijnbaar tegenstrijdige gedrag van staten, die bij het ratificeren van een verdrag tegelijkertijd de gelding van een deel van het verdrag uitsluiten. Ratificatie van een verdrag gaat gepaard met het uitsluiten van de gelding van een of meer bepalingen voor de voorbehoudende staat.

Voorbehouden treffen vaak vitale bepalingen, zoals de Arabische Republiek Jemen die de gelding van grondrechten als godsdienstvrijheid, en het recht te huwen uitsloot bij de ratificatie in 1989 van het Rassendiscriminatieverdrag. Dat is op z'n minst raadselachtig gedrag, omdat het Rassendiscriminatieverdrag beoogt mensenrechten zonder onderscheid naar ras te garanderen. Blijkbaar is dat in Noord Jemen niet het geval. Een vergelijkbaar probleem doet zich voor bij het voorbehoud van Bangladesh bij het Vrouwenverdrag, waarin deze staat te kennen geeft het verdrag overeenkomstig het Islamitisch Sharia recht uit te voeren. Dat leidt direct tot de vraag in hoeverre het verdrag vrouwen in Bangladesh zal kunnen beschermen tegen vrouwendiscriminatie.

Dit zijn slechts twee voorbeelden die het probleem illustreren: het ratificeren van een mensenrechtenverdrag suggereert een verbetering in de bescherming van de rechten van burgers, maar vergaande voorbehouden doen daar aan af. In gewoon Nederlands gezegd: kan dat zo maar? Daar gaat het hier om.

In dit boek komt het probleem van de voorbehouden op twee verschillende manieren aan de orde. Allereerst wordt in de hoofdstukken twee en drie gekeken naar de theoretische, technisch-juridische kant van de zaak. Daarna volgt in de hoofdstukken vier tot en met zeven een analyse van de praktijk van vier $\mathrm{VN}$ mensenrechtenverdragen.

\section{Het theoretisch kader, deel II}

\section{Het recht met betrekking tot voorbehouden}

De oorsprong van het moderne recht met betrekking tot voorbehouden is te vinden in het Advies van het Internationaal Gerechtshof over voorbehouden bij het Genocide verdrag uit 1951. Aan het Hof werd de vraag voorgelegd of het niet aanvaarden door de overige partijen van een voorbehoud van een ratificerende staat er toe kon leiden dat die laatste staat in relatie tot sommige staten partij bij het Genocide verdrag werd, maar niet in relatie tot de staten die bezwaar hadden gemaakt tegen het voorbehoud. De uitspraak van het Hof komt er op neer dat bij het beoordelen van de rechtmatigheid van een voorbehoud, en bij het overwegen van een bezwaar "doel en strekking" van het verdrag de maatstaf moeten zijn. Hoewel het Hof z'n antwoord op de vraag 
nadrukkelijk beperkt tot de Genocide Conventie, heeft deze uitspraak grote gevolgen gehad.

"Doel en strekking" als maatstaf voor het maken van voorbehouden is sindsdien gezien als de algemeen geldende regel. $\mathrm{Zo}_{\mathrm{o}}$ is dat nooit bedoeld door het Hof naar ik meen, en bovendien wordt daarmee over het hoofd gezien dat de vanzelfsprekendheid van deze regel ook te danken is aan het heldere "doel en strekking" van het Genocide verdrag. Dit verdrag bestrijdt één probleem, in de latere mensenrechtenverdragen komt een groot aantal problemen aan de orde, waardoor de onduidelijkheid van "doel en strekking" als onderscheidend criterium spoedig zichtbaar wordt.

De regels met betrekking tot voorbehouden in het Verdragenverdrag worden besproken ${ }^{41}$. Artikel 2 lid 1 onder $\mathrm{d}$ geeft aan dat onder een voorbehoud wordt verstaan "een eenzijdige verklaring, ongeacht haar bewoording of haar benaming afgelegd door een Staat wanneer hij een verdrag ondertekent, bekrachtigt, aanvaardt of goedkeurt of daartoe toetreedt, waarbij hij te kennen geeft het rechtsgevolg van zekere bepalingen in hun toepassing met betrekking tot deze Staat uit te sluiten of te wijzigen." Hieruit blijkt dat het beoogde rechtsgevolg van een verklaring bepaalt of er sprake is van een voorbehoud, ongeacht het etiket dat daaraan hangt. Met deze formulering is bedoeld de onduidelijkheid rond de zogeheten interpretatieve verklaringen te weg te nemen. In de praktijk wordt, onder het mom van interpretatie door verdragspartijen, een beperkende uitleg aan een verdrag te geven. Als de intentie van zo'n verklaring is de reikwijdte van het verdrag te beperken, is er blijkens artikel 2.1.d dus sprake van een voorbehoud. Omdat dergelijke verklaringen geen voorbehouden heten is het andere staten evenwel vaak niet duidelijk dat hierop eventueel door middel van een formeel bezwaar zou moeten worden gereageerd.

Het verdragenrecht kent drie verschillende regimes ten aanzien van voorbehouden waarvan artikel 19.c, bedoeld voor verdragen die zelf geen specifieke bepalingen kennen, grote problemen oplevert. Artikel 19.c geeft de regel uit het Genocide Advies weer dat voorbehouden niet mogen strijden met "doel en strekking" van het verdrag. Dit is een regel die door verdragspartijen zelf gehandhaafd moet worden. Daartoe geeft artikel 20.5 staten de termijn van éen jaar om bezwaar te maken tegen een voorbehoud. Het maken van bezwaar heeft in dit systeem slechts tot gevolg dat geen verdragsrelaties worden aangegaan als de bezwaar makende staat de wens daartoe uitdrukkelijk te kennen geeft aldus artikel 20.4.b. Het geen-bericht-goed-bericht systeem in artikel 20.5 stimuleert de universele gelding van verdragen door zo min mogelijk beperkingen te verbinden aan de gebondenheid van de voorbehoudende staat. Nadeel is dat de regel dat een voorbehoud niet mag strijden met "doel en strekking" van het verdrag door de verdragspartijen gehandhaafd moet 
worden, wat niet diruct een gedegen garantie is, temeer niet daar artikel 20.5 de stilzwijgende aanvaarding van voorbehouden als hoofdregel ziet.

Verder wordt ingegaan op de theoretische achtergrond van de "doel en strekking" regel. Daarbij komt de relatie met het beginsel van de goede trouw in verdragsrelaties aan de orde en wordt de vraag gesteld hoe deze regel zich verhoudt tot het principe ex injuria non oritur ius. Er wordt uitgebreid stilgestaan bij reciprociteit als drijvende kracht in het verdragenrecht, en de rol die reciprociteit speelt bij voorbehouden. Tenslotte komen in dit hoofdstuk vragen over de inter-temporele toepassing van het verdragenrecht aan de orde.

\section{Voorbehouden bij mensenrechtenverdragen}

Hoewel in dit boek de staten die voorbehouden maken doorgaans optreden in de rol van snoodaard, wil dat niet zeggen dat voorbehouden onder alle omstandigheden verwerpelijk zijn. Bij voorbehouden is het afwijken van het verdrag expliciet, en doorgaans rechtmatig. Staten die zonder voorbehouden ratificeren maar het verdrag niet implementeren gedragen zich minstens even onjuist, al zal dat minder zichtbaar zijn.

In dit derde hoofdstuk staat de vraag centraal hoe "doel en strekking" van een mensenrechtenverdrag bepaald kan worden. Staten geven zelden aan wat de kern is van het instrument dat tot stand gekomen is, en in dit hoofdstuk wordt nagegaan hoe "doel en strekking" van een mensenrechtenverdrag te definiëren. Uitgangspunt is dat dit criterium een onderscheid tussen alle normen van het verdrag en de kernbepalingen beoogd. Om die reden is een uitleg waarin "doel en strekking" met de gehele normatieve inhoud van het verdrag wordt vereenzelvigd niet acceptabel, evenmin als de minimalistische lezing dat slechts de regels van ius cogens en bepalingen die tevens in het Handvest van de Verenigde Naties te vinden zijn door de "doel en strekking" regel zullen worden beschermd.

Bestudering van dit onderwerp leidt tot het voorstellen van een viertal invalshoeken die relevant zijn bij het maken van onderscheid tussen kernbepalingen die op grond van de "doel en strekking" regel beschermd worden, en de overige bepalingen waar dat niet voor geldt. Het belang van de codificatie van de rechten van de mens kan mijns inziens worden gezien als een van de relevante invalshoeken bij de bepaling van "doel en strekking". Dit betekent een beperking van het beroep op voorrang voor nationale wetgeving, en grenzen aan het beperken van de supervisiemechanismen. Omdat het hier gaat om mensenrechtenbescherming op verdragsbasis, komt ook aan de verdragsvorm relevantie toe: voorbehouden behoren essentiële regels van het verdragenrecht, zoals de duidelijkheid van verdragsverplichtingen en de gelding van het verdrag op alle niveaus in een bondsstaat, niet te ondermijnen. In relatie tot de inhoud van een mensenrechtenverdrag wordt stil gestaan bij de betekenis van zogeheten non-derogable rights en van het non-discriminatie beginsel als maatstaven ter bepalingen van "doel en strekking". Als vierde punt komen de uitvoeringsmodaliteiten aan de orde, zoals het verschil tussen resultaatsverplichtingen en 
inspanningsverplichtingen, en de betekenis van travaux préparatoires bij een dynamische rechtsgebied zoals de rechten van de mens dat zijn.

Na deze poging om "doel en strekking" van een mensenrechten verdrag te schetsen wordt ingegaan op de mogelijkheden om op deze regel toe te zien. Van belang voor de toezichthoudende comités is te beseffen dat "doel en strekking" niet slechts een regel is geadresseerd aan staten die voorbehouden maken, doch dat deze regel ook kan functioneren als een interpretatieregel. Het komt er dan op neer dat staten verondersteld worden géén met "doel en strekking strijdige voorbehouden te hebben gemaakt. Deze veronderstelling van goede trouw houdt de mogelijkheid in een voorbehoud zeer restrictief uit te leggen, doel-en-strekking conform te interpreteren. Deze uitleg van artikel 19.c kan van groot praktisch belang zijn voor de toezichthoudende comités.

Ten onrechte wordt er in de literatuur weinig aandacht besteed aan de onderlinge samenhang tussen de verschillende mensenrechtenverdragen. Het feit dat deze verdragen vaak parallelle bepalingen bevatten, kan van groot belang zijn bij het beperken van de reikwijdte van voorbehouden. Staten zijn dikwijls niet bijzonder consistent in het maken van voorbehouden en beperken een recht in het ene verdrag door middel van een voorbehoud, terwijl inhoudelijk dezelfde bepaling in een ander verdrag niet geclausuleerd is. Voor de toezichthoudende comités kan dit een uitgangspunt zijn voor een discussie met de voorbehoudende staat op basis van de veronderstelling dat staten coherente verdragsverplichtingen hebben. Dat betekent concreet dat een gewraakt voorbehoud, dat niet overeenstemt met inhoudelijke overeenkomende verplichtingen onder een ander verdrag, op basis van de regel dat aan de beste bescherming van de rechten van de mens de voorrang toekomt, naar de achtergrond verdwijnt. Verondersteld mag worden dat door een dergelijke aanpak door de comités het negatieve effect van een aantal voorbehouden beperkt kan worden.

Bij de ontwikkeling van de rechten van de mens speelt het streven naar universele gelding een belangrijke rol. In het Advies over het Genocideverdrag was de kwestie van universaliteit en integriteit ook aan de orde. Het gaat hierbij om het idee dat het verstandig is voorbehouden te aanvaarden opdat de kring van verdragspartijen zo groot mogelijk zal zijn en dus ook de reikwijdte van de bescherming die een verdrag beoogt te bieden zo groot mogelijk zal zijn; of juist anderzijds vast te houden aan het integrale verdrag en het hoge niveau van bescherming daarin. $\mathrm{Bij}$ het benadrukken van universaliteit is de beperking van de bescherming door middel van voorbehouden in zeker zin de prijs voor de universele gelding van het verdrag.

Hoe juist het streven naar universele gelding van mensenrechtenverdragen op zichzelf ook mag zijn, een blik op de getallen is onthullend. Het uitermate liberale beleid met betrekking tot voorbehouden heeft er niet toe geleid dat de vier verdragen waar de aandacht naar is uitgegaan ook inderdaad universeel geratificeerd zijn. Het is, met ander woorden twijfelachtig of met inhoudelijke concessies, inderdaad een grotere participatie bewerkstelligd wordt. 
Ook wordt in dit hoofdstuk kort gekeken naar de regels en de praktijk met betrekking tot voorbehouden bij twee regionale mensenrechten verdragen: het Europese Verdrag voor de Rechten van de Mens $^{42}$ en het Inter-Amerikaans Verdrag voor de Rechten van de Mens ${ }^{43}$.

Binnen het kader van het EVRM wordt aandacht besteed aan de uitspraken in de Temeltasch en Belilos zaken. Met name de uitspraak van de Commissie in de Belilos zaak is mijns inziens van groot belang voor het beoordelen van het rechtskarakter van interpretatieve verklaringen. In aanvulling op de definitie in artikel 2 lid 1 onder d Verdragenverdrag is de Commissie van oordeel dat in het geval een staat zowel voorbehouden als interpretatieve verklaringen heeft gemaakt, er in het algemeen van uit mag worden gegaan dat dit onderscheid verbindend is. Deze uitspraak is in feite een herhaling van de regel dat niet geinterpreteerd behoeft te worden wat duidelijk is. Deze uitspraak kan een aanknopingspunt zijn bij de schifting tussen de voorbehouden en interpretatieve verklaringen waaraan (lang na hun formulering) door de betrokken staat het karakter van een voorbehoud wordt toegedicht.

Twee Inter-Amerikaanse zaken met betrekking tot voorbehouden worden besproken. De eerste zaak over de gevolgen van voorbehouden wijst op de wenselijkheid de inwerkingtreding van een verdrag waarbij voorbehouden zijn gemaakt, niet uit te stellen voor de voorbehoudende staat tot na het verstrijken van de één-jaars termijn waarin bezwaren kunnen worden gemaakt, als het betreffende voorbehoud compatibel is. De zaak over de doodstraf in Guatemala handelt over voorbehouden bij non-derogable rights. Interpretatie van de bepaling getroffen door het voorbehoud leidt tot de vaststelling dat het doel van de bepaling de beperking van de doodstraf is, terwijl het voorbehoud de doodstraf uitbreidt. De relevante bepaling is een non-derogable right, wat volgens het Hof in principe betekent dat het voorbehoud strijdt met "doel en strekking".

\section{Het onderzoek van de praktijk, deel III}

Hierna volgt een omvangrijk onderzoek naar de praktijk onder vier verschillende mensenrechtenverdragen die in het kader van de Verenigde Naties tot stand zijn gekomen: het Rassendiscriminatieverdrag, het Verdrag inzake Burgerrechten en Politieke Rechten, het Vrouwenverdrag en het Folteringenverdrag. De keus is op deze verdragen gevallen omdat het VN verdragen zijn en universaliteit van de bescherming van de rechten van de mens het centrale onderzoeksthema van de projectgroep mensenrechten van de Rijksuniversiteit Limburg is. De vier verdragen zijn aan de hand van een standaard schema geanalyseerd, wat een vergelijking mogelijk maakt. Een ander voordeel van deze standarisering is dat praktijk onder het ene verdrag gebruikt zouden kunnen worden onder het andere verdrag. Dit is overigens ook een van de conclusies van dit proefschrift: er wordt door de toezichthoudende organen veel 
te weinig gebruik gemaakt van de ervaringen en ontwikkelingen tussen de mensenrechtenverdragen onderling, terwijl dat juist voor wat betreft het bestrijden van verstrekkende voorbehouden van groot belang zou kunnen zijn.

\section{Voorbehouden bij het Rassendiscriminatieverdrag ${ }^{44}$}

Het Rassendiscriminatieverdrag is het oudste verdrag dat in dit boek aan de orde komt. In 1965 tot stand gekomen bevat het een bepaling met betrekking tot voorbehouden: artikel 20 bepaalt dat er geen voorbehouden gemaakt mogen worden in strijd met "doel en strekking" van het verdrag. Aan de hand van bezwaren van tweederde van de verdragspartijen die drie maanden de tijd hebben om hun bezwaar te uiten, wordt deze incompatibiliteit vastgesteld. In het geval tweederde van de verdragspartijen bezwaar maakt, kan de voorbehoudende staat het voorbehoud aanpassen dan wel intrekken, of besluiten in het geheel geen partij worden.

Op het eerste gezicht is dit een bruikbare regel: het verdrag formuleert zelf een regime dat van toepassing zal zijn op de voorbehouden. Bij nader beschouwing is het oordeel minder positief: de regel hanteert een relatief getalscriterium en een tijdlimiet die beide het kritiekloos aanvaarden van voorbehouden in de hand werken. De termijn van drie maanden lijkt vooral geschreven voor imaginaire ministeries van Buitenlandse Zaken die alle prioriteit kunnen geven aan een voorbehoud bij het Rassendiscriminatieverdrag. Zelfs de termijn van Eén jaar uit artikel 20.5 Verdragenverdrag blijkt, ter vergelijking, in de praktijk regelmatig overschreden te worden. Belangrijker is dat de tweederde meerderheid een relatief criterium is: het absolute aantal staten dat bezwaar moet maken opdat incompatibiliteit wordt vastgesteld neemt toe naarmate het aantal verdragspartijen groeit. Gezien de geringe animo die er in het algemeen bestaat om bezwaar te maken leidt dit tot de slotsom dat de procedure van artikel 20 in de praktijk weinig kan betekenen. En inderdaad bleek dit nog onlangs het geval met een verstrekkend voorbehoud van Jemen, dat bij gebrek aan voldoende bezwaren verondersteld moet worden compatibel te zijn.

\section{Voorbehouden bij het Verdrag inzake Burgerrechten en Politieke Rechten ${ }^{45}$}

Dit algemene mensenrechtenverdrag kent geen specilieke bepaling met betrekking tot voorbehouden. Het (eerste) Facultatieve Protocol met betrekking tot het individueel klachtrecht evenmin. Daarom zal de regeling van artikel 19.c Verdragenverdrag van toepassing zijn. Gesuggereerd wordt dat deze regel met name non-derogable rights en het non-discriminatiebeginsel zal beschermen. Ook het uitgangspunt dat het verdrag in de nationale rechtsorde geïmplementeerd moet worden mag tot "doel en strekking" gerekend worden.

Het tweede Facultatieve Protocol ter uitbanning van de doodstraf kent in artikel 2 een bepaling over voorbehouden, waardoor ten aanzien van dit

44. Internationaal Verdrag inzake de Uitbanning van Alle Vormen van Rassendiscriminatie, 7 maart 1966; Trb.1967, 48.

45. Internationaal Verdrag inzake Burgerrechten en Politieke Rechten, 19 december 1966; Trb.1978. 177. 
Protocol artikel 19.b Verdragenverdrag van toepassing is. Waarschijnlijk onbewust zegt artikel 6.2, dat eerst stelt dat artikel 1.1 van het tweede Protocol een non-derogable right is, tegelijkertijd dat voorbehouden toelaatbaar zijn. Dit betekent dat in dit geval een voorbehoud bij een non-derogable right mogelijk is, wat onwenselijk geacht moet worden.

Van het individueel klachtrecht onder het facultatieve Protocol is uitgebreid gebruik gemaakt. In dat verband kwamen voorbehouden en ook interpretatieve verklaringen aan de orde. Een analyse van de zaken waarin het Mensenrechtencomité zich over voorbehouden boog, wijst uit dat teveel wordt uitgegaan van de visie van de voorbehoudende staat met voorbijgaan aan de mogelijkheid dat het comité zelf een oordeel velt over het rechtsgevolg van een bepaalde verklaring. Met name in de Bretonse zaken geeft het comité blijk van een gebrekkig inzicht in het verdragenrecht en de Belilos jurisprudentie. Bepleit wordt een helder onderscheid te maken tussen welke vragen in de ontvankelijksfase, en welke vragen bij de inhoudelijke bespreking aan de orde moeten komen. Concreet betekent dat de suggestie dat het Mensenrechtencomité nauwkeuriger zou moeten handelen in gevallen waarin voorbehouden aan de orde zijn. In de ontvankelijkheidsfase zouden slechts duidelijke voorbehouden tot niet-ontvankelijk verklaring kunnen leiden. Voorbehouden met een onduidelijke reikwijdte (naar tijd, persoon of inhoud) behoren in de volgende fase aan de orde te komen. Interpretatieve verklaringen kunnen in geval er door dezelfde staat tevens voorbehouden zijn gemaakt (een Belilos situatie) evenmin tot niet-ontvankelijkheid leiden.

\section{Voorbehouden bij het Vrouwenverdrag ${ }^{\text {to }}$}

Bezorgdheid over de verstrekkende gevolgen van voorbehouden bij het Vrouwenverdrag heeft aan de basis van dit proefschrift gelegen. Het in 1982 tot stand gekomen verdrag trad betrekkelijk snel in werking, en een indrukwekkend aantal staten ratificeerde. Het aantal voorbehouden is even indrukwekkend, sterker nog het lijkt alsof er weinig overblijft van het beschermingsbereik van het verdrag als de inhoud van de voorbehouden in ogenschouw wordt genomen.

Het meest in het oog springende probleem zijn de voorbehouden die verwijzen naar de voorrang van Islamitische Sharia recht. Drie mogelijke juridische argumentaties worden aangevoerd om een antwoord te geven op deze verstrekkende voorbehouden: een verwijzing naar de regel pacta sunt servanda en het contractsbegrip in het Islamitisch recht; het verbod om met een beroep op nationaal recht voorbij te gaan aan internationaal recht; en het probleem van de botsende grondrechten, in dit geval de vrijheid van godsdienst en cultuur in conflict met het recht op vrijwaring van vrouwendiscriminatie.

Het grote aantal verstrekkende voorbehouden heeft in de literatuur tot discussie geleid over de wijze waarop dit probleem opgelost zou moeten 
worden. Het is, indachtig het Verdragenverdrag, niet aan het comité zich uit te spreken over de compatibiliteit. Op verzoek van verdragspartijen heeft de Secretaris Generaal de visies van staten over het probleem van de voorbehouden geïnventariseerd. Het onderwerp heeft een tijdje op de agenda van de bijeenkomst van de verdragspartijen gestaan, wat weinig opleverde. De gedachte de vraag over de compatibiliteit voor te leggen aan het Internationaal Gerechtshof moet als gevaarlijk van de hand gewezen worden. Bepleit wordt dat het comité het verbod in strijd met "doel en strekking" te handelen opvat als interpretatieregel wat tot een restrictieve uitleg van vergaande voorbehouden moet leiden. Ook moet het comité zich meer bewust zijn van de mogelijkheid terug te grijpen op eerdere discussies met verdragspartijen, en aldus benadrukken dat de toezegging voorbehouden in te zullen trekken verplichtingen schept.

\section{Voorbehouden bij het Folteringenverdrag ${ }^{47}$}

Van de bestudeerde verdragen is het Folteringenverdrag het meest recent in werking getreden. Met het Oostduitse voorbehoud ten aanzien van de financiering van de supervisiemethoden, kwam een aantal problemen van groot theoretisch belang aan het licht. Door de beperking van de betalingsverplichting in de vorm van een voorbehoud, rees de vraagt of dit niet tegelijkertijd tot een uitbreiding van de verplichtingen voor de overige verdragspartijen zou leiden, wat niet alleen ongewenst is maar theoretisch ook onmogelijk is. Het Oostduitse financieringsvoorbehoud was een opmerkelijk voorbeeld van een van de weinige gevallen waarin de verdragsverplichtingen onder een mensenrechtenverdrag in elkaar grijpen in tegenstelling tot de doorgaans afwezige materiële reciprociteit.

Het Oostduitse voorbehoud, maar ook een verstrekkend Chileens voorbehoud leidden tot ongekend veel bezwaren, wat aangeeft dat bezwaren nog niet een definitief vergeten instrument van het verdragenrecht zijn.

\section{Slotopmerkingen, deel IV}

\section{Het herstellen van de ruïnes}

In het slothoofdstuk wordt aangegeven hoe om te gaan met de voorbehouden opdat die een beperkt negatief effect hebben. Allereerst wordt teruggeblikt op een aantal essentiële vragen. Zo komen opnieuw de kwestie van de universaliteit, en het feit dat voorbehouden niet onder alle omstandigheden verwerpelijk zijn aan de orde.

Het onderzoek heeft uitgewezen dat een belangrijke oorzaak van het probleem ligt in de gebrekkige correlatie tussen het verdragenrecht en de mensenrechten. Beide rechtsgebieden functioneren op basis van verschillende normatieve systemen, en ook de mechanismen die naleving stimuleren zijn fundamenteel

47. Verdrag tegen Foltering en andere wrede, onmenselijke of onterende behandeling of bestraffing, 10 december 1984; Trb.1985,69. 
verschillend. Eigen belang als essentiële stimulans voor de handhaving van de "doel en strekking" regel door verdragspartijen ontbreekt vaak bij mensenrechtenverdragen waar de voorbehouden vooral de burgers in de voorbehoudende staat zullen treffen. Niet alleen is het maken van bezwaar daardoor minder opportuun, ook de praktische betekenis van een bezwaar, zelfs als dat wederzijdse gebondheid uit zou sluiten, is gering.

Ook de aansluiting tussen het dynamische rechtsgebied van de rechten van de mens, in dit verband met name de interpretaties, Algemene Commentaren en uitspraken in de individuele klachtenprocedures, en het statische verdragenrecht is problematisch. Onlangs kwam dat duidelijk naar voren bij de ratificatie van het Verdrag inzake Burgerrechten en Politieke Rechten door Zwitserland en de Verenigde Staten, die door middel van voorbehouden het acquis van het verdrag beogen uit te sluiten. Dit leidt tot puzzels die vooral aantonen dat het verdragenrecht een verlegenheidsoplossing is ter verwerkelijking van de rechten van de mens.

Terugkijkend op de Genocide zaak valt op hoe zeer het minderheidsadvies van de vier rechters de toekomstige problemen met het vaststellen van "doel en strekking" juist heeft voorzien. Mijn indruk is dat de relatief simpele vraag in de Genocide zaak, en het ingenieuze antwoord van het Hof daarop, lange tijd hebben verhuld dat het "doel en strekking" criterium even vanzelfsprekend als vaag is. Het geeft in elk geval niet het antwoord op de actuele vragen.

Ten aanzien van de beide hoofdrolspelers staten en toezichthoudende comités moet gesteld worden dat deze beide een verantwoordelijkheid hebben voor het beperken van de ondermijnende gevolgen van voorbehouden. De bevoegdheden van staten berust op het verdragenrecht, en het is aan diezelfde staten om deugdelijk voorbehoudsclausules op te nemen. Er van uitgaande dat artikel 19.c een regeling is voor die gevallen waarin verdragspartijen niet zelf voorzien in een regeling, is het duidelijk dat een heldere bepaling in het verdrag zelf de voorkeur verdient. Aan het slot van dit boek wordt een bepaling geformuleerd voor toekomstige mensenrechtenverdragen, die er van uit gaat dat voorbehouden in principe tijdelijke uitzonderingen op de gelding van het verdrag zijn. Door de gelding van het voorbehoud in de tijd te begrenzen tenzij een staat uitdrukkelijk voortdurende gelding voor een vervolg periode wenst, kan wellicht een afname van het aantal voorbehouden bereikt worden.

Ten aanzien van de rol van toezichthoudende comités is duidelijk dat zij veel meer zouden kunnen doen dan tot nu toe gebeurt. Door het verbeteren van de continuïteit in de rapportageprocedure kan voortgebouwd worden op eerder toezeggingen van staten. Uitgangspunt zou moeten zijn dat de opmerkingen van de vertegenwoordiger van de staat verplichtend zijn, en aan de staat toegerekend kunnen worden. Ook het onderwerp van de parallelle verplichtingen onder de verschillende verdragen zou krachtdadiger ter hand moeten worden genomen. Een overzicht van de verplichtingen en de gemaakte voorbehouden kan op eenvoudige wijze als geheugensteun voor de toezichthoudende comités functioneren. Ook het gebruik van de "doel en strekking" regel als 
interpretatieregel bij het bepalen van de reikwijdte van voorbehouden kan in principe een positief effect hebben.'

Hoewel het uitgangspunt van dit onderzoek een sombere kijk op de mogelijkheden ter beperking van de voorbehouden binnen het verdragenrecht was, kom ik tot de conclusie dat er methoden en strategieën bestaan die binnen de grenzen van het geldende recht het ondermijnende effect van voorbehouden kunnen beperken. Wat mij betreft valt er genoeg te doen. 


\section{CURRICULUM VITAE}

Liesbeth Lijnzaad werd op 2 oktober 1960 te Rotterdam geboren. $\mathrm{Zij}$ behaalde in 1979 het VWO diploma aan het Bonhoeffer College te Castricum. Vervolgens studeerde ze rechten aan de Universiteit van Amsterdam. In 1985 studeerde zij af in de internationaal-rechtelijke studierichting. In 1986 nam zij deel aan de Tweede Fase opleiding Internationaal en Europees Recht van het T.M.C.Asser Instituut, gevolgd door het voltooien van de studie Nederlands recht in 1987.

In 1986 trad zij in dienst van de Rijksuniversiteit Limburg, en werkte daar aanvankelijk als assistente in opleiding, en vanaf 1990 als universitair docente internationaal publiekrecht. Sinds enkele maanden is zij assistent Juridisch Adviseur bij het Ministerie van Buitenlandse Zaken. 
Ratify and Ruin?

by Liesbeth Lijnzaad

This book deals with the problems created by reservations to four UN Human Rights Treaties: the Convention on the Elimination of Racial Discrimination; the International Covenant on Civil and Political Rights; the Convention on the Elimination of Discrimination Against Women; and the Convention Against Torture and Other Cruel, Inhuman or Degrading Treatment. The focus of the study is the concepts and mechanisms in international law that are relevant as regards reservations to Human Rights Treaties, as well as the role of States and the possibilities supervisory committees have to monitor their impact. UN Human Rights instruments are studied because little information exists on the impact of reservations thereto, in contrast with reservations to regional Human Rights instruments.

After the introduction, the second chapter begins with the Genocide case, and the development of the law on reservations since then is discussed. The Vienna Convention rules on reservations are dealt with, as well as the impact of reciprocity as a dynamic force underlying treaties with respect to the reservation issue.

The third chapter deals with theoretical aspects of reservations to Human Rights Treaties. The reasons for making such reservations are discussed, along with the quantitative impact which they have.

In the second part of the book the four. Human Rights Treaties themselves are studied on the basis of a standardized scheme.

The final chapter considers the possibilities for States and supervisory organs to reduce the detrimental impact of reservations within the existing framework. Proposals for better provisions on reservations are made. 